UNIVERSIDAD NACIONAL DE LA PLATA

FACULTAD DE HUMANIDADES Y CIENCIAS DE LA EdUCACIÓN SECRETARÍA DE POSGRADO

\title{
Itinerarios de Althusser en Argentina: marxismo, comunismo, psicoanálisis (1965-1976)
}

\author{
Marcelo Starcenbaum \\ Tesis para optar por el grado de Doctor en Historia \\ Director: Aníbal Viguera (UNLP) \\ Codirector: Jorge Cernadas (UBA/UNGS/UNLP)
}

La Plata, Diciembre de 2016 


\section{Índice}

Introducción

Capítulo 1. Althusser en Argentina: cuestiones de orden teórico y metodológico............................................................................... 22

1.1. El althusserianismo como objeto político-intelectual

1.2. Althusser y sus mediadores latinoamericanos: Régis Debray y Marta Harnecker

1.3. Entre La Habana y Santiago de Chile: itinerarios de Althusser en América Latina 1.4. Althusser en Argentina: de los relatos canónicos a las indagaciones contemporáneas

1.5. Historia intelectual y recepción de ideas

Capítulo 2. De la desestalinización a la lucha armada: Althusser y los comunistas argentinos.

2.1. Introducción

2.2. La necesidad de la teoría: lucha política y lucha teórica en la recuperación revolucionaria del PCA

2.3. Insurrección o guerrilla: el marxismo althusseriano y el debate acerca de la lucha armada

2.4. Organigramas para la revolución: althusserianismo y lucha armada en el nacimiento del PCR

2.5. El giro maoísta: antirrevisionismo y antialthusserianismo en el PCR

2.6. En defensa del marxismo-leninismo: los intelectuales comunistas y la modernización del marxismo

2.7. La teoría enloquecida: el maoísmo francés visto por los comunistas argentinos

2.8. Las ambivalencias del Marx estructural: lecturas de Althusser en Cuadernos de Cultura

2.9. Contra la finalización del marxismo: Abel García Barceló y las lecturas de Althusser en la década de 1970

2.10. A modo de cierre

Capítulo 3. Entre el estructuralismo y el maoísmo: el Althusser de Los Libros. 


\subsection{Introducción}

3.2. El paradigma estructural: crítica y crítica de la crítica

3.3. El dispositivo althusseriano: sociología, ciencia, filosofía, política

3.4. ¿Qué es el estructuralismo? Difusión y control de un programa renovador de las ciencias humanas

3.5. Una crítica política de la cultura: Mao y Althusser

3.6. El aparato ideológico escolar: ideología y educación en Argentina

3.7. La interferencia cultural: del Gramsci althusseriano al potencial de la cultura popular

3.8. A modo de cierre

Capítulo 4. Más allá del principio de exclusión: el Althusser de Pasado y

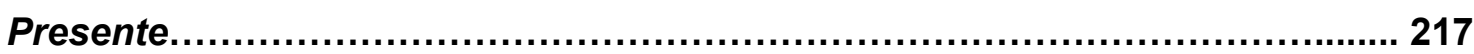

4.1. Introducción

4.2. Althusser y Gramsci en América Latina: límites de una historización

4.3. La reflexión del hombre sobre el hombre: un marxismo humanista e historicista para la cultura argentina

4.4. Las tensiones de la modernización: marxismo y estructuralismo

4.5. Los cuadernos althusserianos

4.5.1. La parcialidad del pensador francés: primeras lecturas de Althusser

4.5.2. ¿Gramscianos vergonzantes? Althusser y las posibilidades de una lectura renovada de Gramsci

4.5.3. Gramsci o Althusser, una falsa disyuntiva. El debate en torno al concepto de formación económico-social

4.5.4. La revolución que tuvo lugar: Nicos Poulantzas entre el historicismo y el estructuralismo

4.6. Partir de la fábrica: intelectuales y partido en la conformación de una fuerza revolucionaria

4.7. Una diferencia necesaria: estado, política e ideología entre Gramsci y Althusser

4.8. A modo de cierre

Capítulo 5. Entre Lacan y el freudomarxismo: el Althusser de los psicoanalistas argentinos. 280

5.1. Introducción

5.2. 1965 , annus mirabilis 
5.3. El momento fenomenológico: marxismo, fenomenología y estructuralismo en los tempranos 1960

5.4. El desplazamiento estructural: entre el saber marxista y la práctica teórica

5.5. Leer a Freud: marxismo, estructuralismo y psicoanálisis

5.6. La mediación althusseriana: lecturas de Lacan en la década de 1970

5.7. La veta freudomarxista: marxismo y psicoanálisis en la crisis de la APA

5.8. Althusser sin Lacan: la singularidad de una lectura

5.9. Entre el lacanismo y el freudomarxismo: el Althusser de Gregorio Baremblitt

5.10. Un marxismo sin sujeto: el antialthusserianismo de León Rozitchner

5.11. Althusser con Lacan: disputas en torno a una apropiación

5.12. A modo de cierre

Capítulo 6. Hacia la fundación científica de la psicología: Carlos Sastre y Roberto Harari lectores de Althusser.

6.1. Introducción

6.2. Un pensamiento falso: la polémica Carlos Sastre-Hernán Kesselman

6.3. El despertar de un sueño: Althusser contra la psicología de la conducta, el hombre alienado y la antipsiquiatría

6.4. La psicología, red ideológica: ciencia e ideología en la conformación de un campo profesional

6.5. Confusiones epistemológicas: las polémicas de Roberto Harari con Juana Danis, Hernán Kesselman y Antonio Caparrós

6.6. Realismo, abstracción y formalismo: crítica de la psicología de la conducta y fundación científica de la disciplina

6.7. Althusser en la villa: ideología y reproducción en comunidades marginales

6.8. A modo de cierre

Consideraciones finales

Apéndice de imágenes.

Bibliografía 


\section{Siglas utilizadas}

AIE

API

APA

CC

CNRR

CTERA

ENS

FAL

FAP

FAR

FJC

FREJULI

GAN

IMEC

OSPAAL

PCA

PCF

$\mathrm{PCl}$

PCR

PCCh

PRT

RCPCh

SFP

SMATA

UMSNH

UNAM

VC
Aparato Ideológico de Estado

Asociación Psicoanalítica Internacional

Asociación Psicoanalítica Argentina

Comité Central

Comité Nacional de Recuperación Revolucionaria

Confederación de Trabajadores de la Educación de la

República Argentina

École Normale Supérieure

Fuerzas Argentinas de Liberación

Fuerzas Armadas Peronistas

Fuerzas Armadas Revolucionarias

Federación Juvenil Comunista

Frente Justicialista de Liberación

Gran Acuerdo Nacional

Institut Mémoires de l'édition contemporaine

Organización de Solidaridad de los pueblos de Africa y

América Latina

Partido Comunista Argentino

Partido Comunista Francés

Partido Comunista Italiano

Partido Comunista Revolucionario

Partido Comunista Chino

Partido Revolucionario de los Trabajadores

Revolución Cultural Proletaria China

Sociedad Francesa de Psicoanálisis

Sindicato de Mecánicos y Afines del Transporte de la

República Argentina

Universidad Michoacana de San Nicolás de Hidalgo

Universidad Nacional Autónoma de México

Vanguardia Comunista 


\section{Índice del Apéndice de imágenes}

Imagen 1: Tapa de García Barceló, Abel. Hegel y la dialéctica científica de Marx. Buenos Aires, Centro de Estudios Marxistas-Leninistas Victorio Codovilla, 1971.

Imagen 2: Diagrama inserto en García Barceló, Abel. Hegel y la dialéctica científica de Marx. Buenos Aires, Centro de Estudios Marxistas-Leninistas Victorio Codovilla, 1971.

Imagen 3: Diagrama inserto en García Barceló, Abel. Hegel y la dialéctica científica. Buenos Aires, Centro de Estudios Marxistas-Leninistas Victorio Codovilla, 1971.

Imagen 4: Tapa del número 4 de Los Libros. Un mes de publicaciones en Argentina y el mundo (octubre de 1969).

Imagen 5: Tapa del número 25 de Los Libros. Para una crítica política de la cultura (marzo de 1972).

Imagen 6: Tapa del número 31 de Los Libros. Para una crítica política de la cultura (agosto-septiembre de 1973).

Imagen 7: Tapa del número 36 de Los Libros. Para una crítica política de la cultura (agosto de 1974).

Imagen 8: Tapa del Cuaderno de Pasado y Presente número 4; Althusser, Louis. La filosofía como arma de la revolución. Córdoba, Pasado y Presente, 1968.

Imagen 9: Tapa del Cuaderno de Pasado y Presente número 48; Poulantzas, Nicos. Hegemonía y dominación en el Estado moderno. Córdoba, Pasado y Presente, 1973.

Imagen 10: Tapa de Masotta, Oscar. Introducción a la lectura de Jacques Lacan. Buenos Aires, Proteo, 1970. 
Imagen 11: Tapa de Masotta, Oscar. Ensayos lacanianos. Barcelona, Anagrama, 1976.

Imagen 12: Tapa de Baremblitt, Gregorio y otros. El concepto de realidad en psicoanálisis. Buenos Aires, Socioanálisis, 1974.

Imagen 13: Tapa de Rozitchner, León. Freud y los límites del individualismo burgués. Buenos Aires, Siglo XXI, 1972.

Imagen 14: Tapa de Sastre, Carlos. La psicología, red ideológica. Buenos Aires, Tiempo Contemporáneo, 1975.

Imagen 15: Tapa de Harari, Roberto (comp.). Teoría y técnica psicológica de comunidades marginales. Buenos Aires, Nueva Visión, 1974. 


\section{Sobre las citas y las traducciones}

A menos que se indique lo contrario, todas las traducciones son nuestras. A los fines de facilitar la lectura, hemos optado por reproducir en primer lugar la versión castellana de los pasajes citados. A continuación de cada traducción o en nota al pie, según corresponda, reproducimos el texto en su idioma original.

A menos que se indique lo contrario, las citas son fieles del texto original. Con excepción de algunos resaltados nuestros, que se encuentran debidamente señalados, los subrayados, las negritas, las cursivas y las mayúsculas pertenecen a las versiones originales de los textos. 


\section{Agradecimientos}

La realización de esta tesis hubiese resultado imposible de no contar con la ayuda de un conjunto de personas e instituciones que contribuyeron de distintos modos a lo largo de estos años.

Ana Julia Ramírez estuvo en los inicios alentando el camino de la investigación y brindando consejos que resultaron fundamentales para la delimitación del objeto de estudio. Aníbal Viguera y Jorge Cernadas en su calidad de directores contribuyeron con lecturas y consejos a lo largo de todo el recorrido que culminó con la presentación de la tesis.

EI CONICET me otorgó una beca doctoral que me permitió dedicarme exclusivamente a la elaboración de este trabajo. La Facultad de Humanidades y Ciencias de la Educación de la Universidad Nacional de La Plata me brindó condiciones de trabajo inmejorables para las tareas de investigación.

Silvia Sigal, Hugo Vezzetti y Adrián Gorelik realizaron comentarios sugerentes sobre distintos pasajes de la tesis. Carlos Astarita formuló comentarios y sugerencias al plan de tesis presentado en el Doctorado en Historia. Adrián Celentano y Néstor Arrúa leyeron y discutieron diversas partes de la tesis. Alberto Pérez, Hernán Sorgentini, Enrique Garguin y los equipos de los proyectos de investigación de los que he participado realizaron comentarios a versiones previas de algunos capítulos. Miguel Valderrama, Gerardo Muñoz, Sergio Villalobos-Ruminott y Oscar Ariel Cabezas fueron interlocutores a lo largo de todos estos años.

Quisiera agradecer a los amigos con los que compartimos el interés por Althusser: Marcelo Rodríguez, Zeto Bórquez, Natalia Romé, Carolina Collazo, Pedro Karczmarczyk, Roque Farrán, Gonzalo Barciela, Vittorio Morfino y Warren Montag. También a los amigos con los que compartimos el interés por el marxismo latinoamericano: Jaime Ortega, Víctor Hugo Pacheco, Guillermo Ricca, Gavin Arnall y Bruno Bosteels. 
A los amigos del $\mathrm{CeDInCl}$, en cuyos encuentros y publicaciones pude difundir y discutir avances de la tesis. Me gustaría agradecer especialmente a Horacio Tarcus, Adriana Petra, Martín Bergel y Laura Fernández Cordero por sus lecturas y consejos.

Algunos avances de la tesis fueron discutidos en el Ateneo de Historia de la Psicología de la Facultad de Psicología de la Universidad de Buenos Aires. Agradezco a Luciano García y Mauro Vallejo la invitación y los comentarios. El Taller de Historia Intelectual de la Universidad de Quilmes y la Universidad de Córdoba también fue un espacio en el que pude presentar avances. Agradezco a Luis García los comentarios realizados en aquella ocasión.

Al Doctorado en Historia de la Facultad de Humanidades y Ciencias de la Educación. Quisiera agradecer especialmente a su director, Fernando Barba, y a sus secretarias, Catalina Curciarello, Paula Salguero y Paula Román.

A las bibliotecas en las que consulté material a lo largo de estos años, así como a su personal: Biblioteca de la Facultad de Humanidades y Ciencias de la Educación de la Universidad Nacional de La Plata, Biblioteca Pública de la Universidad Nacional de La Plata, Centro de Documentación e Investigación de la Cultura de Izquierdas, Biblioteca Central de la Universidad Nacional Autónoma de México, Biblioteca Pública de la Universidad Michoacana San Nicolás de Hidalgo y Princeton University Library.

Me gustaría agradecer especialmente a las personas implicadas en la tesis que accedieron a conversar sobre el tema: Saúl Karsz, Gregorio Baremblitt, Miguel Matrajt, Santiago Funes, Fernanda Navarro, Hugo Sáez Arreceygor y Roberto Follari. La mayoría de ellos también leyeron partes de la tesis y realizaron devoluciones sugerentes.

A los amigos de la carrera de Historia: Leandro Sessa, Juan Carnagui, Lucía Abbattista, Fernanda Tocho y Christian Casco. A los compañeros del Centro de Investigaciones Sociohistóricas. A los compañeros de las cátedras Introducción a la Historia de la Facultad de Humanidades e Historia Socioeconómica Argentina y Latinoamericana de la Facultad de Trabajo Social. 
A mis padres, Gabriel y Mabel, y a mi hermana, Melina, por estar siempre. No alcanzan las palabras para agradecerle a Leila, por su paciencia, acompañamiento, lecturas y consejos. Finalmente, a mis hijos, Lara y Elías, que son lo más importante. 


\section{Introducción}

Al calor de inquietudes más militantes que académicas, comencé hace unos diez años a interesarme por la presencia de Louis Althusser en la izquierda argentina de los años 1960 y 1970. Un esquema interpretativo que descasaba sobre el otorgamiento de un valor diferencial al pensamiento marxista latinoamericano no podía volver sino sospecho aquel episodio de la historia intelectual de nuestro país. Originado en un contexto diferente al latinoamericano y bajo impulsos políticos y teóricos que nada tenían que ver con los de nuestra región, el althusserianismo no habría hecho más que distorsionar la autenticidad del marxismo latinoamericano y reforzar la dependencia cultural con el centro intelectual mundial. Como veremos más adelante, las pocas referencias existentes acerca de la recepción del filósofo francés en nuestro país no hacían más que reforzar esta hipótesis. En esta dirección, los primeros trabajos realizados privilegiaron los espacios y los sujetos que habían hecho del althusserianismo un objeto de refutación. Fuimos configurando una imagen de la presencia de Althusser en Argentina en la que enfatizaba su tolerancia intelectual a la vez que se destacaba su intolerancia política.

Esta imagen se fue modificando a medida que el tema se convertía en objeto de investigación y la reconstrucción se volvía cada vez exhaustiva. Una aproximación abarcativa de las discusiones que formaron parte de la coyuntura teórica y política de nuestro país en aquellos años nos fue devolviendo un panorama mucho más complejo que el que se suponíamos al comienzo de la investigación. Junto a los sujetos y las instancias reactivas al althusserianismo, nos fuimos topando con un conjunto de experiencias en las cuales diversos aspectos de dicho pensamiento resultaron claves en su desarrollo. De la misma manera, aquellas refutaciones de las ideas de Althusser comenzaron a ser consideradas en su singularidad y a partir de sus condicionamientos contextuales. No debe dejar de señalarse que esta complejización estuvo acompañada por una aproximación al problema desde los marcos de la historia 
intelectual y la recepción de ideas. Las variables analíticas proporcionadas por este campo de investigación nos permitió dotar de una valoración positiva a las apropiaciones de Althusser realizadas en un contexto distinto al de origen, a la vez que descartar por esquemáticas y simplistas la hipótesis de la autenticidad del pensamiento latinoamericano y la concepción de la lectura de una obra extranjera como mero acto de dependencia cultural.

De esta manera pudimos constatar que entre la segunda mitad de la década de 1960 y la primera mitad de la 1970, el althusserianismo constituyó el soporte teórico de procesos transformadores acaecidos en el interior de la cultura de izquierda y la cultura psicoanalítica argentinas. Por tanto, nos propusimos precisar las articulaciones entre diferentes elementos pertenecientes a la corriente althusseriana y experiencias desarrolladas en el interior de los mencionados espacios. Nos interesamos por delimitar la especificidad de la articulación que se produjo en el interior de la cultura de izquierda argentina entre los elementos característicos de la relectura althusseriana de la tradición marxista -como el énfasis en la cientificidad del marxismo, los conceptos de práctica teórica y sobredeterminación y la prioridad otorgada al análisis de la formación económico social- y el proceso de radicalización de la política comunista que derivó tanto en la ruptura del PCA como en el surgimiento y consolidación de las organizaciones políticas y culturales de la nueva izquierda argentina. El trabajo sobre la cultura psicoanalítica argentina se dirigió a establecer las características de las mediaciones generadas entre las particularidades del abordaje althusseriano del psicoanálisis -como el énfasis del inconsciente como objeto del psicoanálisis, el programa de lectura sintomal y la propuesta de una lectura científica de Freud- y el surgimiento de la tradición lacaniana local, la consolidación de una corriente freudomarxista y la formulación de una nueva psicología científica.

Esta reconstrucción nos reveló una trama de lectores que hicieron del althusserianismo un insumo que les permitió recolocarse política y teóricamente en los espacios a los que pertenecían. Decimos trama porque si bien las lecturas de Althusser se desarrollaron en la especificidad de dichas 
instancias, veremos que hay nombres que son transversales a ellas. A intelectuales que realizaron apropiaciones políticas de Althusser los veremos luego desempeñándose como comentaristas del filósofo francés en publicaciones político-culturales. A intelectuales que escribieron artículos sobre Althusser en esas publicaciones los veremos luego desempeñarse como maestros de psicoanalistas que llevaron a cabo apropiaciones de Althusser en sus campos respectivos. A intelectuales que editaron a Althusser en castellano los veremos entablar discusiones con las implicaciones políticas de su obra. Es decir, que lejos de llevarse a cabo a través de un grupo con contornos definidos, la recepción argentina de Althusser tuvo como protagonistas a un conjunto de intelectuales situados en campos bien delimitados pero entre los cuales existían relaciones de tipo colaborativas, formativas y políticas.

La delimitación de esta red de lectores nos enfrentó con un escenario que trastocaba ciertas representaciones tanto del campo intelectual argentino como del propio objeto de estudio. En relación al primero, el abordaje de la historia intelectual argentina de los años sesentas y setentas desde una mirada interesada en los itinerarios de Althusser ha puesto de relieve un conjunto de intelectuales cuya labor ha sido escasamente atendida. No hay aquí ni mérito de nuestra parte ni mala intención por parte de otras investigaciones sobre la época. Los contornos de un momento histórico son delineados a partir de las preguntas que guían la reconstrucción. En este caso, una pregunta pocas veces formuladas -¿quiénes fueron los lectores de Althusser en Argentina?nos devolvió una franja intelectual pocas veces visitada. Si bien nuestra tesis atiende los itinerarios de los intelectuales que han ocupado la mayor parte de las investigaciones sobre la época, tales como José Aricó y Oscar Masotta, también se detiene en los recorridos de otros desatendidos o desconocidos, tales como el psicoanalista Gregorio Baremblitt o los psicólogos Carlos Sastre y Roberto Harari. La apertura a esta trama de lectores nos condujo a una relativización del rol de ciertos intelectuales a los cuales se suele asociar la recepción de Althusser en Argentina. Por un lado, porque nos permitió constatar canales de difusión del pensamiento althusseriano más solapados que los tradicionales. Una parte considerable del ingreso de Althusser en 
Argentina se produjo a través de la actividad de grupos de estudios y la formación en espacios militantes. La reconstrucción orientada, no sólo a la difusión sino también a los efectos de Althusser, nos condujo a valorar el trabajo de intelectuales que fueron menos visibles en la época y que no se convirtieron en referentes consagrados en las décadas posteriores. En este sentido, si bien la tesis se detiene en las lecturas desarrolladas por Emilio de Ípola y Eliseo Verón, también atiende la productividad de Althusser en los itinerarios de intelectuales menores, tales como los filósofos comunistas Mauricio Malamud y Raúl Sciarreta.

El recorrido que proponemos articula una dimensión contextual y otra cronológica. Por un lado, los itinerarios de Althusser en Argentina son analizados a partir de experiencias en cuyo seno la recepción del filósofo francés tuvo un carácter relevante. La elección de dicho criterio obedece al hecho de que, tal como ha indicado Stanley Fish, los actos de lectura singulares se desarrollan en el marco de comunidades interpretativas, las cuales establecen los sentidos a través de los cuales aquel acto se lleva a cabo $^{1}$. Es por ello que si bien delimitaremos apropiaciones de Althusser desarrolladas por lectores particulares, los códigos y los intereses a través de los cuales aquellas operan son compartidas por una comunidad más amplia de lectores. Por otra parte, el recorrido realizado por estas distintas experiencias contempla la historicidad de las apropiaciones de Althusser. El cruce de las particularidades de las lecturas con el momento histórico en el cual éstas son realizadas se nos presenta como necesario por dos razones. En primer lugar, porque el althusserianismo atravesó en aquellos años un conjunto de torsiones y desplazamiento significativos. Por ejemplo, constataremos que mientras a fines de los años sesentas las apropiaciones girarán en torno a la relación que el marxismo o el psicoanálisis establecían con el paradigma estructural, durante la primera mitad de los setenta las lecturas están centradas en el problema de la ideología. En segundo término, porque la recepción argentina de Althusser se acompasó con el ritmo cambiante de la coyuntura intelectual y

\footnotetext{
${ }^{1}$ Fish, Stanley. Is there a text in this class? The authority of interpretative communities. Massachusetts, Harvard University Press, 1982.
} 
política de nuestro país. Así analizaremos, por ejemplo, que mientras en los últimos años de la década de 1960 el althusserianismo estará imbricado con las disputas políticas e institucionales del PCA y la APA, en los primeros años de la de 1970 se articulará con elaboraciones sistemáticas más centradas en las problemáticas teóricas.

Mencionemos finalmente algunas cuestiones referidas a la circunscripción del objeto. En primer lugar, debemos explicitar que el recorrido propuesto no agota todas las instancias de recepción de Althusser en Argentina. La delimitación de los espacios pertenecientes a la cultura de izquierda y psicoanalítica obedece a que en dichos campos el althusserianismo permeó durante un tiempo considerable las discusiones en ellos desarrolladas y acompañó la problematización y reformulación de las intervenciones específicas. Este recorte, sin embargo, no es exhaustivo. Alhusser circuló en otros campos, tales como el de las ciencias de la educación o la epistemología. Si bien no ingresamos de lleno en estas recepciones, veremos que algunas discusiones mantenidas en estos campos estuvieron conectadas con aquellas que aquí reconstruimos.

También es posible constatar otras recepciones de Althusser en los espacios en los que sí nos concentramos. Sin embargo, estas lecturas son puntuales o se encuentran irremediablemente perdidas. Entre las primeras, podemos mencionar apelaciones a Althusser por parte de Carlos Olmedo en los documentos fundacionales de las $\mathrm{FAR}^{2} \mathrm{o}$ en el llamado Proceso de Homogeneización Política Compulsiva impulsado por Raimundo Villaflor y Jorge Cafatti en las $\mathrm{FAP}^{3}$. Entre las segundas, por ejemplo, los testimonios militantes dan cuenta que en 1970 el sociólogo Daniel Hopen habría

\footnotetext{
${ }^{2}$ Ver González Canosa, Mora. "Políticas de construcción del peronismo. El discurso de las FAR en los albores de la década del setenta en Argentina". Tempo \& Argumento. Vol, 7, N¹4, 2015, pp. 180-216.

${ }^{3}$ Ver Luvecce, Cecilia. Las Fuerzas Armadas Peronistas y el Peronismo de Base. Buenos Aires, Centro Editor de América Latina, 1993, pp. 98-99.
} 
coordinado un seminario sobre Althusser en el que participaron los principales dirigentes del $\mathrm{PRT}^{4}$.

Lo mismo cabe decir de los marcos temporales de nuestra investigación. Si bien algunos análisis nos obligarán a remontarnos hacia fines de la década de 1950 y los primeros años de la de 1960, resulta indudable que el año 1965 constituye un hito en la consolidación del althusserianismo. Ese año fueron publicadas en Francia las dos obras principales de Althusser, Pour Marx y Lire Le Capital. Ese mismo año comenzarán a llegar noticias a nuestro país de la relectura novedosa de Marx que por entonces propiciaba un filósofo comunista en la ENS. En el otro lado de la línea temporal, 1976 marca el quiebre de la gramática política y teórica que prevaleció en la cultura argentina durante los sesentas y la primera mitad de aquella década. Las experiencias políticas e intelectuales con las cuales se imbricó el althusserianismo fueron derrotadas $u$ obligadas a replegarse con el golpe de Estado. Esto no quiere decir que los itinerarios de Althusser en Argentina hubiesen llegado a su fin en aquel año. Al contrario, el althusserianismo siguió siendo, y lo es en la actualidad, una referencia en los debates políticos y teóricos sostenidos por nuestros intelectuales. Sin embargo, el carácter diferencial de los tópicos que atravesaron la cultura argentina en los años sesentas/setentas y en los de la posdictadura transforma a los itinerarios ulteriores de Althusser en el objeto de investigaciones específicas.

La tesis está estructurada en seis capítulos. El primero de ellos es de índole teórico y metodológico. Se plantean los presupuestos que guían nuestra investigación. En primer lugar, nos interesa destacar la importancia que tiene para nuestro trabajo un conjunto de nuevas aproximaciones a Althusser que volvieron a la tradición por él inaugurada un objeto político-intelectual. En segundo lugar, enmarcamos la recepción argentina de Althusser en el fenómeno más amplio de su recepción latinoamericana. Reconstruimos tanto el vínculo establecido por el propio Althusser con la realidad política

\footnotetext{
${ }^{4}$ Ver la entrada correpondiente a Hopen en Tarcus, Horacio (dir.). Diccionario biográfico de la izquierda argentina. De los anarquistas a la "nueva izquierda" (18701976). Buenos Aires, Emecé, 2007, pp. 307-309.
} 
latinoamericana a través de Marta Harnecker y Régis Debray como la difusión de su obra en el resto de los países latinoamericanos. Se discuten también las interpretaciones tradicionales sobre el tema que nos interesa, así como las nuevas indagaciones con las cuales establecemos diálogos productivos. Finalmente explicitamos las variables analíticas provenientes de la historia intelectual y la recepción de ideas a través de las cuales abordamos nuestro objeto de estudio.

El segundo capítulo está dedicado a los itinerarios de Althusser entre los comunistas argentinos. Se delimitan dos grandes problemas. En primer lugar, reconstruimos el carácter productivo que tuvo la difusión de Althusser en la crisis del PCA a mediados de la década de 1960. Nos interesa poner en evidencia la importancia que tendrá el énfasis althusseriano en el trabajo teórico en el diagnóstico de que la crisis del partido no obedecía a causas meramente políticas. Nos concentramos en la experiencia del zaratismo, cuyas formulaciones programáticas articularon althusserianismo y guevarismo. Finalmente analizamos el pasaje en el PCR desde unas concepciones permeadas por el marxismo althusseriano hasta su furibundo antialthusserianismo luego del alineamiento con China. El otro problema delimitado es el de los itinerarios de Althusser entre los intelectuales comunistas que permanecieron en el Partido. Enmarcamos la recepción de Althusser en el posicionamiento defensivo que el comunismo partidario tendrá frente a los procesos de modernización del marxismo. Veremos al respecto que la relación establecida con el althusserianismo será ambivalente. Si bien los comunistas argentinos se mostrarán cautelosos frente al antihumanismo, valorarán a Althusser como un marxista renovador que no cedía ante las tentaciones del idealismo. Reconstruimos finalmente los usos de Althusser realizados por Abel García Barceló en Cuadernos de Cultura a comienzos de la década de 1970.

En el tercer capítulo nos concentramos en la recepción de Atlhusser en la revista Los Libros. Analizamos en primer lugar la circulación del althusserianismo junto a otros desarrollos teóricos en la difusión y discusión propiciada por la revista acerca de la consolidación del paradigma estructural. 
Estamos interesados en mostrar que en los primeros años de la revista el althusserianismo cumplió un rol tanto en la modernización de los instrumentos de la crítica como en la indagación acerca de la especificidad del análisis estructural. Veremos que un conjunto de problemas sociológicos, políticos y epistemológicos serán abordados desde marcos estrictamente althusserianos. Comprenderemos las torsiones operadas en relación a Althusser en la segunda etapa de la revista. Por un lado, sus colaboradores incorporarán el problema de la ideología y el concepto de AIE para analizar problemas de la coyuntura argentina, especialmente el relativo al sistema educativo. Por otro lado, la filiación maoísta de la revista la llevará a formar parte de la querella sobre el althusserianismo y a distanciarse progresivamente de su antiguo referente. Finalmente analizaremos cómo los últimos números de la revista estarán marcados por fuertes críticas a Althusser y un desplazamiento hacia las concepciones gramscianas de la cultura popular.

El cuarto capítulo está dedicado a los itinerarios de Althusser en la experiencia de Pasado y Presente. La existencia de un sentido común acerca de este proceso receptivo hace que partamos de una discusión con la bibliografía existente. Al respecto estamos interesados en matizar la afirmación según la cual los itinerarios de Gramsci y Althusser en Argentina y América Latina habrían sido incompatibles. Un recorrido por las dos etapas de la revista y un conjunto de cuadernos dedicados al pensamiento althusseriano, nos permitirán constatar que por un lado las dimensiones humanistas e historicistas del marxismo sustentado por José Aricó y su grupo volvían hostil a una corriente marxista como la inaugurada por Althusser. Pero también nos permitirá advertir que algunos elementos provenientes de ella serán articulados de distintas maneras con el corpus gramsciano. Analizamos la recepción por parte de la revista de desarrollos teóricos que tensionaban la matriz gramsciana, como el marxismo de Galvano Della Volpe y el estructuralismo de Claude Levi-Strauss. Luego ingresamos a los efectos del althusserianismo en la tarea difusión del marxismo cifrada en los Cuadernos de Pasado y Presente. Nos interesa evidenciar el carácter productivo de Althusser en lo relativo a una corrección de Gramsci, el ingreso del concepto de formación económico-social 
y la valoración de una relectura estructural de Marx. Finalmente veremos que en la segunda etapa de la revista el direccionamiento consejista del marxismo de Pasado y Presente redundará en una posición marcadamente antialthusseriana.

En el quinto capítulo reconstruimos las lecturas de Althusser llevadas a cabo por psicoanalistas argentinos. Proponemos un recorrido por dos experiencias. En primer lugar, analizamos el itinerario de Oscar Masotta con el objetivo de evidenciar los efectos de Althusser en el pasaje desde la fenomenología hacia el estructuralismo y en la recolocación de la obra de Lacan. Atendemos las intervenciones de Masotta entre fines de la década de 1950 y principios de la de 1960 con el afán de constatar los efectos de la fenomenología en una concepción del vínculo entre marxismo y psicoanálisis en términos de asimilación y en la coexistencia entre lacanismo y psicología concreta. La reconstrucción de su encuentro con Althusser nos permitirá dar cuenta de la productividad de la relectura althusseriana de Freud en una crítica a los modos fenomenológicos de compatibilizar marxismo y psicoanálisis y en la recolocación estructural del lacanismo. El otro recorrido es el de los itinerarios de Althusser en los ámbitos psicoanalíticos permeados por el freudomarxismo. En tanto estos espacios tendían a ser hostiles hacia el althusserianismo, nos enfocaremos en la particularidad de las lecturas de aquellos que encontraban en Althusser insumos para tramitar los conflictos políticos e intelectuales derivados de la crisis de la institución psicoanalítica. Al respecto, el itinerario de Gregorio Baremblitt nos permitirá dar cuenta de una lectura de Althusser que tendía a separar sus desarrollos teóricos de los esbozados por el lacanismo. Finalmente daremos cuenta de la singularidad de esta lectura a través del repaso por lecturas freudomarxistas antialthusserianas, como las de León Rozitchner, y posicionamientos althusserolacanianos, como los de Germán García y Miriam Chorne.

El capítulo sexto está dedicado a las lecturas de Atlhusser llevadas a cabo por los psicólogos Carlos Sastre y Roberto Harari. Analizamos un primer momento de sus intervenciones en las cuales el althusserianismo opera como soporte de la crítica tanto de la concepción blegeriana de los vínculos entre 
marxismo y psicoanálisis con la que se habían formado, como de desarrollos contemporáneos tales como la teoría de la alienación y la antipsiquiatría. En segundo lugar examinamos sus producciones de los primeros años de la década de 1970 en las cuales la preocupación se dirige hacia el problema de la fundación científica de la disciplina. Comprenderemos cómo el althusserianismo proporciona elementos que coadyuvan a un esfuerzo por delimitar al inconsciente como objeto de la práctica del psicólogo e inmunizar los ejercicios teóricos desarrollados en el campo frente a las acechanzas de la ideología. Estamos interesados en destacar la productividad del althusserianismo en el esbozo de formulaciones originales, tales como la idea de la psicología como red ideológica en Sastre y los desarrollos sobre los sintagmas ideológicos cristalizados en Harari. Finalmente reconstruimos las singularidades de la recepción de Althusser en el trabajo desarrollado por este último en el tratamiento de la experiencia de las comunidades marginales.

Concluimos la tesis con unas consideraciones finales, en las que proponemos una evaluación en conjunto de los desarrollos de la tesis y un recorrido que da cuenta de los itinerarios de los sujetos estudiados luego del golpe de Estado de 1976.

La tesis cuenta además con un apéndice de imágenes en el que reproducimos tapas de revistas y libros analizados así como algunos cuadros y diagramas a los que referimos en algunos capítulos. Se listan, finalmente, las fuentes y la bibliografía utilizada. 


\section{Capítulo 1}

\section{Althusser en Argentina: cuestiones de orden teórico y metodológico}

\subsection{El althusserianismo como objeto político-intelectual}

En el año 2001, en un texto dedicado a la figura de Althusser incluido en el Dictionnaire Marx Contemporaine editado por Jacques Bidet y Stathis Kouvélakis, François Matheron realizaba una afirmación contundente en relación a las investigaciones sobre el filósofo francés: "el campo de los estudios althusserianos todavía no ha sido constituido" ${ }^{\text {. De }}$ este modo, Matheron sentenciaba que, con excepción de unos pocos trabajos, no existían estudios críticos acerca del lugar de Althusser en la historia del marxismo y en el campo de la filosofía contemporánea. Si bien este diagnóstico se ajustaba a las lecturas sobre Althusser desarrolladas en la década posterior a su muerte, una reedición en el presente de la pregunta acerca de la existencia de dicho campo nos obligaría a formular una respuesta distinta a la de Matheron. Puede afirmarse que desde hace una década asistimos a una recolocación de Althusser como objeto de reflexión en diversos ámbitos del pensamiento contemporáneo. Resurgimiento que se expresa en la cantidad de libros dedicados a distintos aspectos de su pensamiento, la reedición de gran parte de su obra, la publicación de su correspondencia y material inédito, la publicación de dossiers temáticos, la realización de encuentros y coloquios dedicados a su trabajo, y la existencia de revistas dedicadas especialmente a los estudios althusserianos.

\footnotetext{
${ }^{5}$ Matheron, François. "Louis Althusser ou la impure pureté du concept". Jacques Bidet y Stathis Kouvélakis (dirs.). Diccionaire Marx contemporaine. París, Presses Universitaires de France, 2001, p. 369. Existe traducción castellana: "Louis Althusser o la pureza impura del concepto". Demarcaciones. Revista Latinoamericana de Estudios Althusserianos. $\mathrm{N}^{\circ} 1$, Abril 2014, pp. 44-62.
} 
Uno de los efectos más significativos de este movimiento de recolocación ha sido la tendencia a considerar al althusserianismo como un objeto político-intelectual. Si bien el desplazamiento hacia el análisis histórico representa un avance significativo en la comprensión de cualquier tradición intelectual, esta reorientación ha sido especialmente productiva en el caso del althusserianismo. Desde su irrupción a mediados de la década de 1960 hasta los años posteriores a su muerte, Althusser y su obra estuvieron sometidos a un conjunto de operaciones que empujaron al althusserianismo a un terreno más próximo al del juicio político e intelectual que al de la comprensión histórica. La primera de estas operaciones se remonta al surgimiento y desarrollo de la corriente althusseriana. Propiciadora de una relectura polémica de Marx en un contexto en el cual las inflexiones en el corpus marxista implicaban efectos políticos contundentes, la obra de Althusser dio lugar a una de las querellas más importantes de la historia de la izquierda europea de la segunda mitad del siglo XX. Además de la célebre refutación de E.P. Thompson $^{6}$, el althusserianismo fue objeto de impugnaciones desde las tradiciones maoísta ${ }^{7}$ y trotskista ${ }^{8}$, espacios comunistas oficiales ${ }^{9}$ y corrientes marxistas independientes ${ }^{10}{ }^{11}$. Como afirmaba recientemente Warren Montag, Althusser "podría haber presumido que hacia fines de siglo XX se había escrito

\footnotetext{
${ }^{6}$ Thompson, E.P. Miseria de la teoría. Barcelona, Crítica, 1981.

${ }^{7}$ Rancière, Jacques. La lección de Althusser. Buenos Aires, Galerna, 1975; Lisbonne, Bernard. Philosophie marxiste ou philosophie althussérienne. París, Anthropos, 1978.

8 Löwy, Michael. Dialectique et révolution. Essais de sociologie et d'histoire du marxisme. París, Anthropos, 1973; Fougeyrollas, Pierre. Contre Lévi-Strauss, Lacan et Althusser. Trois essais sur l'obscurantisme contemporaine. París, Editions de la Jouquère, 1976; Vincent, Jean Marie et al. Contre Althusser. París, Union Génerale d' Editions, 1974.

${ }^{9}$ Garaudy, Roger. Marxisme du XXe siècle. París, La Palatine, 1966; Sève, Lucien. Marxismo y teoría de la personalidad. Buenos Aires, Amorrortu, 1973; Schaff, Adam. Structuralism and Marxism. Oxford, Pergamon Press, 1974.

${ }^{10}$ Lefebvre, Henri. L' idéologie structuraliste. París, Du Seuil, 1971; Schmidt, Alfred. Historia y estructura. Crítica del estructuralismo marxista. Madrid, Alberto Corazón, 1973; Goldmann, Lucien. Marxismo y ciencias humanas. Buenos Aires, Amorrortu 1975.

${ }^{11}$ Si bien la delimitación precedente es representativa, está lejos de ser exhautiva. Para un panorama de las lecturas antialthusserianas ver Elliott, Gregory. Althusser: The Detour of Theory. Leiden, Brill, 2006, pp. XIII-XXIV.
} 
más en contra de él que sobre ép' ${ }^{\prime 2}$. Particularidad que se evidencia al constatar la cantidad de libros sobre Althusser que llevan la palabra contra en su título. Además de los ya mencionados Contre Althusser de Fougeyrollas y Vincent, pueden citarse el Contra Althusser del brasileño José Arthur Giannotti y el For Marx Against Althusser del estadounidense John O'Neill.

Si bien esta literatura conspiró contra la comprensión histórica de la corriente althusseriana, se le debe conceder su circunscripción a las dimensiones teóricas y políticas. Distinta fue la operación a la que fue sometido Althusser en los años ochentas y noventas, que no adquirió la forma de la impugnación sino la de la represión, y que no tuvo como objeto sus posicionamientos políticos e intelectuales sino los avatares de su vida privada. En este sentido, el asesinato de su esposa en 1980 y los trastornos mentales padecidos hasta su muerte en 1990 fueron esgrimidos como evidencia tanto de la irracionalidad de su pensamiento como de la criminalidad del comunismo. En un contexto en el cual la crisis del socialismo real se conjugaba con un desplazamiento de la intelectualidad crítica hacia posiciones socialdemócratas o abiertamente liberales, el marxismo althusseriano constituyó un objeto privilegiado en la constatación del carácter totalitario de la experiencia comunista. Este tipo de maniobras se desarrollaron especialmente en Francia, tanto por la pertenencia de Althusser a su campo intelectual como por el rol desempeñado por los nouveaux philosophes. Sin embargo, también tuvieron lugar en otros espacios nacionales en los cuales el althusserianismo había sido tenido importancia. En Chile, por ejemplo, la revista Hoy publicó en ocasión de la muerte de Althusser un artículo de Roberto Brodsky titulado "El loco de la familia" ${ }^{13}$. En el caso argentino, fue un artículo de Alvaro Abós publicado en

\footnotetext{
12 "Althusser alone could boast that more had been written against him that about him by the end of the twentieth century", Montag, Warren. Althusser and His Contemporaries. Philosophy's Pertetual War. Durham, Duke University Press, 2013, p. 1.

${ }^{13}$ Agradezco a José Antonio Ramírez haberme señalado y facilitado este material.
} 
1984 en la revista Unidos el que propició vía Althusser el anudamiento entre marxismo, crimen y locura para certificar el fracaso del ciclo revolucionario ${ }^{14}$.

Fueron precisamente los efectos de estas operaciones las que llevaron a Gregory Elliott, autor del primer estudio sistemático sobre Althusser, a optar por un posicionamiento "anti-anti-Althusser" ${ }^{15}$. Es decir, el trabajo de situar históricamente la intervención althusseriana para analizarla en términos teóricos y políticos sólo podía llevarse a cabo suspendiendo el juicio al que habían sido sometidas la figura y la obra de Althusser a lo largo de dos décadas. A fines de los años ochenta, Elliott presentaba como novedosas un conjunto de valoraciones que hoy gozan de cierto consenso: que Althusser es uno de los pensadores marxistas más importantes del siglo $X X$, que su regreso a Marx constituye el ejercicio más importante en la filosofía marxista desde Historia y conciencia de clase de Lukács, que su desarrollo del materialismo histórico es tan productivo como el llevado a cabo por Gramsci en sus Cuadernos de la cárcel y que varios aspectos de su obra aún permanecen vigentes. Si bien este posicionamiento ya no es totalmente necesario, además de conllevar una toma de partido que no constituye nuestro objetivo, subyace a él un impulso historizador que resulta fundamental a los fines de aprehender de manera desprejuiciada los itinerarios de Althusser en la cultura de izquierdas contemporánea. Es en este sentido que Elliott proponía como principal variable de su reconsideración de Althusser el esfuerzo por situarse "más allá de la adulación (el althusserianismo como meridiano del marxismo) y los anatemas (el althusserianismo como apoteosis del stalinismo), características de muchas respuestas al surgimiento y consolidación del filósofo" ${ }^{\prime 16}$. En la misma dirección apuntaba Montag, para quien la productividad de la corriente althusseriana no puede captarse sin referirse a todo lo que hay

\footnotetext{
${ }^{14}$ Cabe destacar que los argumentos de Abós fueron posteriormente respondidos en un artículo de Artemio López publicado en el primer número de la revista Acontecimiento.

${ }^{15}$ Elliott, Gregory. Althusser: The Detour of Theory. op. cit., p. XXI.

16 "beyond the adulation (Althusserianism, meridian of Marxism), and anathemas (Althusserianism, apotheosis of Stalinism), characteristic of many responses to the philosopher's advent and ascendancy", Elliott, Gregory. Althusser: The Detour of Theory. op. cit., p. XVIII.
} 
en ella de histórica. En un sentido análogo a Elliott, destacaba la importancia de aproximarse al althusserianismo desde una perspectiva que se posicione "por fuera del círculo vicioso de la mímesis y el rechazo"17. Desplazamiento que permite situar la intervención de Althusser en el campo de la izquierda contemporánea, un terreno heterogéneo, en constante desarrollo y atravesado por conflictos y divergencias.

La configuración de una mirada centrada en la explicación del surgimiento y desarrollo del althusserianismo ha redundado en una delimitación de las características del contexto en el que dichos fenómenos se desarrollaron. Nos parece ajustada la afirmación de Elliott de que la intervención original de Althusser debe ser entendida a partir de la interrelación de cuatro procesos políticos e intelectuales ${ }^{18}$. En primer lugar, la crisis del movimiento comunista internacional después de Stalin. La relectura de Marx desarrollada por Althusser en la década de 1960 estuvo condicionada por la consolidación de la línea propiciada por Kruschev, centrada en el proceso de desestalinización y la vía pacífica al socialismo, así como por la ruptura sinosoviética, con la consecuente construcción de una nueva referencia revolucionaria. En segundo término, la singular adecuación del PCF al proceso de desestalinización. El itinerario de Althusser como intelectual comunista se desarrolló en seno de un partido que se ajustó lentamente a las directrices kruschevistas y que combatió duramente las tendencias pro-chinas surgidas en sus filas. En tercer lugar, las características de las corrientes marxistas desarrolladas entre fines de la década de 1950 y principios de 1960. El marxismo althusseriano se instituyó a modo de contrapunto de las tendencias humanistas surgidas al calor del proceso desestalinización. Finalmente, la particularidad del escenario intelectual francés de los años sesentas. El anclaje en la teoría marxista desarrollado por Althusser se produjo en una coyuntura teórica en la que se conjugaron la tradición epistemológica francesa con el paradigma estructuralista.

\footnotetext{
17 "outside of the vicious circle of mimicry and rejection", Montag, Warren. Althusser and His Contemporaries. Philosophy's Pertetual War. op. cit., p. 7.

${ }^{18}$ Ibid., p. 1.
} 
Resulta interesante destacar que esta aproximación contextual al althusserianismo no sólo ha logrado transcender las lecturas enjuiciadoras sino que también ha permitido comprender varias de las dimensiones que en ellas se expresan. Una porción significativa de estos trabajos de historización se han dedicado a desentrañar el carácter singular de la intervención althusseriana. La extinción del ciclo histórico del comunismo ha posibilitado el surgimiento de una lectura sobre la relación entre intelectuales y política que se permite la constatación de contradicciones y ambivalencias. Al respecto, el hecho de que el althusserianismo fuera violentamente combatido tanto desde espacios comunistas oficiales como desde la izquierda radicalizada obedece en gran parte a la particularidad del vínculo establecido entre Althusser y el PCF. Dicha particularidad radica en la coexistencia entre la pertenencia al comunismo partidario y el sostenimiento de una teoría que empuja la política comunista hacia fuera de los marcos del partido. Es precisamente esta dimensión de la trayectoria de Althusser una de las que más valoraba Balibar al momento de despedir a su amigo y maestro:

por esa obra interrumpida -más pronto o más tarde toda obra lo
es-, por esas tesis que continúan confiriendo inquietud al
concepto, Althusser es indiscutiblemente filósofo. Por esa
misma obra y esas mismas tesis Althusser es marxista y, más
aún, comunista. Ser al mismo tiempo totalmente filósofo y
totalmente comunista, sin sacrificar, sin subordinar, sin someter
ninguno de los dos términos al otro, en esto consiste la
singularidad intelectual de Althusser, en esto consistió la
apuesta y el riesgo asumido por Althusser ${ }^{19}$

Esta particularidad ya había sido señalada por Perry Anderson en su esbozo de una tipología de las relaciones entre intelectuales y partido en el siglo $X X^{20}$. De acuerdo al marxista inglés, los intelectuales comunistas se enfrentaron a un conjunto de opciones en lo relativo a la vinculación que establecían con el aparato partidario. Una era el abandono de toda adhesión y toda referencia a la política, representada por Adorno. Otra, más recurrente, era la de

${ }^{19}$ Balibar, Étienne. "Adiós”. Escritos por Althusser. Buenos Aires, Nueva Visión, 2004, p. 99.

${ }^{20}$ Anderson, Perry. Consideraciones sobre el marxismo occidental. México D.F., Siglo XXI, 1987. 
desempeñarse como intelectuales independientes por fuera de los marcos del partido. Esta vía, representada por Sartre y Marcuse, dotaba a los intelectuales de una libertad absoluta para sus elaboraciones teóricas pero los desarraigaba políticamente de la clase obrera. Otro camino era el de intelectuales como Althusser y Lukács que habían elegido permanecer dentro de los marcos del partido a condición de aceptar el rigor de su disciplina. Así se mantenía un vínculo con los problemas de la clase obrera nacional y con la tradición leninista. El precio a pagar por dicha pertenencia era el silencio sobre la línea política partidaria. Nadie que no formara parte de la dirección política del partido podía realizar declaraciones independientes sobre los problemas políticos de la coyuntura. Anderson agregaba un detalle que resulta clave para comprender la especificidad de la intervención de Althusser: salvo que estos pronunciamientos se realizaran "en la forma más oracular" ${ }^{21}$. Althusser, al igual que Lukács, habrían sellado un pacto tácito con el partido según el cual guardaban silencio sobre los problemas estrictamente políticos a cambio de que sus elaboraciones teóricas no fueran censuradas. Claro está que para que ello no ocurriese, la teoría no podía enfrentarse abiertamente a la dirección política.

Esta particularidad, que Anderson cifraba en términos de mutua acomodación y coexistencia táctica, ha sido un objeto privilegiado de indagación en las investigaciones contemporáneas sobre Althusser. En términos de Elliott,

\begin{abstract}
para Althusser el Partido era el partido de la clase obrera francesa. Este planteaba (al menos en potencia) la única amenaza real al orden capitalista en Francia; la pertenencia a él era la precondición para algún tipo de relación orgánica con la lucha de clases. Pero el precio a pagar por el carnet del partido y la inmunidad de la teoría era alto: consentimiento -o silencio- sobre las cuestiones políticas ${ }^{22}$
\end{abstract}

\footnotetext{
${ }^{21}$ Ibid., p. 58.

22 "To Althusser, the Party was the party of the French working class. It (potentially) posed the only real threat to the order ofcapital in France; membership of it was thus a precondition of any kind of organic link with the class struggle. But the price to be paid for a party card and for theory's immunity was high: assent -or silence- on political issues". Elliott, Gregory. Althusser: The Detour of Theory. op. cit., p. 52.
} 
En este mismo sentido Matheron ha llamado la atención sobre la pretensión althusseriana de generar efectos políticos a partir de su obra. Es decir, que a diferencia de aquellos intelectuales marxistas que gozaban de libertad en sus pronunciamientos a condición de mantenerse separados del comunismo partidario, en vínculo orgánico con el partido obligaba a Althusser a expresarse políticamente de una manera más tangencial. Según el investigador francés, "la adhesión de Althusser a una verdadera ontología del movimiento obrero y del movimiento comunista internacional, le impedía plantear formalmente el problema esencial de la identificación de los problemas políticos. En estas condiciones, el 'rodeo por la teoría' tomaba en él una forma extremadamente sofisticada"23.

En esta dirección, los compiladores de un reciente volumen dedicado a Althusser enfatizaban el hecho de que las dimensiones teóricas de la obra del francés estaban siempre dirigidas hacia objetivos políticos. Característica que volvía ambivalente su fidelidad al PCF y a su modelo de organización partidaria. De acuerdo a Katja Diefenbach, Sara Farris, Gal Kirn y Peter Thomas, por un lado "las críticas de Althusser a las posiciones economicistas, evolucionistas y revisionistas desde dentro del PCF tuvieron el efecto de convencer a varios jóvenes militantes de que se quedaran en un partido al cual de otra manera hubieran abandonado" 24 . Y por el otro, "sus intervenciones también fueron tomadas como apoyo, aún con contradicciones, para las rupturas con la ortodoxia comunista partidaria, especialmente por aquellas atraídas hacia el maoísmo" 2526.

${ }^{23}$ Matheron, François. "Louis Althusser o la pureza impura del concepto". Demarcaciones. Revista Latinoamericana de Estudios Althusserianos. op. cit., p. 55.

24 "Althusser's criticism of economistic, evolutionist and revisionist positions from withim the PCF had the effect of convincing many Young activists to stay within a party from which they otherwise have departed". Diefenbach, Katja; Farris, Sara; Kirn, Gal; Thomas, Peter. Encountering Althusser. Politics and Materialism in Contemporary Radical Thought. Londres, Bloomsbury, 2012, p. XIV.

25 "his interventions were also taken as providing support, albeit not without contradictions, for breaks with communist party orthodoxy, particularly by those attracted to Maoism", Id.

${ }^{26} \mathrm{La}$ vinculación entre althusserianismo y maoísmo también ha sido en los últimos años objeto de investigaciones académicas, ver Bourg, Julian. "The Red Guards of Paris: French Student Maoism in the 1960's". History of European Ideas. N 4, 2005, 472-490; Robcis, Camille. "China in our Heads: Althusser, Maoism and Structuralism". 
Señalemos finalmente otros dos efectos del pasaje desde una aproximación enjuiciadora del althusserianismo hacia una comprensiva. En primer lugar cabe destacar que esta torsión interpretativa ha permitido una evaluación desprejuiciada acerca de los efectos de la obra de Althusser en diversos campos del saber. Es decir, que una mirada centrada en la constatación de la naturaleza perniciosa de la penetración del althusserianismo en los distintos espacios disciplinares fue dejando lugar a un análisis atento al carácter productivo de este proceso de difusión. De esta manera se pudo reconstruir una amplia trama de desarrollos teóricos e investigaciones concretas que abrevaban en distintas dimensiones de la obra althusseriana. Así se volvieron inteligibles los efectos de Althusser en el campo historiográfico, expresados en los trabajos de Guy Bois, Robert Linhart, Peter Schöttler, Perry Anderson y Gareth Stedman-Jones; en el de la antropología, a través de las investigaciones de Emmanuel Terray y Pierre-Philippe Rey; en el de la teoría política, materializado en las obra de Nicos Poulantzas, Göran Therborn y Ernesto Laclau; en el de la economía, que dio lugar a la escuela de la regulación de Michel Aglietta y Alain Lipietz; en el de la educación, a través de los trabajos de Christian Baudelot y Roger Establet; en el de la teoría literaria, expresados en la obra de Pierre Macherey; y en el de la lingüística, con el trabajo de Michel Pêcheux ${ }^{27}$.

Junto a la reconstrucción de sus efectos, la transformación del althusserianismo como objeto político-intelectual dio lugar a un análisis retrospectivo de los itinerarios del propio corpus althusseriano. Como es sabido, las elaboraciones teóricas de Althusser fueron sometidas por el propio autor a un conjunto de operaciones de rectificación y autocrítica. Desde la corrección de un excesivo estructuralismo a fines de la década de 1960 hasta

Social Text. Vol. 30, № 110, 2012, pp. 51-69; Celentano, Adrián. "Althusser, el maoísmo y la revolución cultural". Políticas de la Memoria. Anuario de investigación e información del CEDINCI. № 15, Verano 2015/2016, pp. 220-226.

${ }^{27}$ Este listado no es exhaustivo, además de ceñirse a las décadas de 1960 y 1970. Ecos del althusserianismo pueden encontrarse, además, en la epistemología, la filosofía del derecho, la estética, los estudios culturales, el feminismo y los film studies. Para un repaso detallado de los campos en los cuales la obra de Althusser tuvo efectos significativos, ver Elliott, Gregory. Althusser: The Detour of Theory. op. cit., pp. 308-311 y Ferretter, Luke. Althusser. Oxford, Routledge, 2005, passim. 
la insólita afirmación de su autobiografía acerca de un escaso conocimiento de Marx al momento de escribir sus principales trabajos, las operaciones a las que Althusser sometió a su obra pasaron a formar parte de la propia querella althusseriana. Certificación de la inviabilidad de su propuesta para algunos, evidencia del abandono de los esquemas marxistas para otros, las sucesivas transformaciones de la obra de Althusser fueron abordadas desde lecturas en las que la toma de partido se imponía a la comprensión histórica. Si bien las investigaciones contemporáneas sobre Althusser no coinciden totalmente en la periodización de su obra, todas ellas comparten la pretensión de analizar en términos históricos las transformaciones experimentadas por el corpus althusseriano. Si dejamos de lado sus escritos tempranos, aquellos enmarcados en el catolicismo y el hegelianismo de izquierda, podemos delimitar cuatro grandes períodos. El primero de ellos, correspondiente a la primera mitad de los años sesentas, que se inicia con los esbozos de un marxismo estructural y que culmina con la publicación de Pour Marx y Lire Le Capital. El segundo, desde los últimos años de la década de 1960 hasta mediados de la de 1970, caracterizado por la denuncia del teoricismo y la definición de la filosofía como lucha de clases en la teoría. Si bien se escapan a los marcos temporales de nuestro trabajo, señalemos que en la segunda mitad de la década de 1970 se lleva a cabo un proceso radical de destrucción de la obra anterior y discusión acerca de la cientificidad del marxismo, y que en la década de 1980 Althusser se desplaza hacia la problemática del materialismo del encuentro.

\subsection{Althusser y sus mediadores latinoamericanos: Régis Debray y Marta Harnecker}

En su reciente reconstrucción de los itinerarios de Foucault en Argentina, Mariana Canavese llamaba la atención sobre la particularidad de un extendido fenómeno de recepción de un autor que nunca visitó nuestro país ni se refirió 
sustancialmente a cuestiones de la región ${ }^{28}$. Difícilmente podría realizarse una afirmación análoga con respecto a la relación de Althusser con América Latina. Si bien nunca visitó los países latinoamericanos, a pesar de las numerosas invitaciones realizadas, Althusser mantuvo durante décadas un vínculo activo con los problemas políticos de la región ${ }^{29}$. Relación condicionada por su militancia comunista, lo que habilitaba unos canales políticos e intelectuales de los que carecieron otros procesos de recepción de autores europeos en América Latina. El vínculo de Althusser con la coyuntura política de la región dio lugar a un conjunto de reflexiones e intervenciones en torno a problemas acuciantes de la izquierda del subcontinente, tales como las desarrolladas alrededor de la política revolucionaria en los años 1960 y las transformaciones de la izquierda en los años 1980.

Si nos concentramos en el vínculo establecido entre Althusser y América Latina en las décadas de 1960 y 1970, puede constatarse que el filósofo francés estaba especialmente interesado en que sus trabajos se publicaran en la región y que sus elaboraciones teóricas circularan entre la militancia del subcontinente. Creemos que gran parte de este interés se debía a que el contexto latinoamericano le ofrecía a Althusser un espacio menos restrictivo de enunciación teórica y política. Si como vimos en el primer apartado de este capítulo, la politicidad de la renovación marxista propuesta por Althusser encontraba en el contexto francés un límite en el anudamiento entre filosofía marxista y comunismo partidario, el relajamiento sufrido por este vínculo en América Latina volvía a la región un terreno más propicio para la inscripción militante de sus postulados. El contexto delineado por la proyección continental de la Revolución cubana, los desencuentros con las identidades políticas populares y el carácter represivo de los regimenes políticos institucionales, empujaron al comunismo partidario de la región a una crisis que fue más profunda que la experimentada por los partidos comunistas europeos y que implicó la pérdida del monopolio sobre la política comunista. Este especial

${ }^{28}$ Canavese, Mariana. Los usos de Foucault en la Argentina. Recepción y circulación desde los años cincuenta hasta nuestros días. Buenos Aires, Siglo XXI, 2015, p. 13.

${ }^{29}$ En la sección "Colloques - Voyages" del Fondo Althusser depositado en el IMEC pueden encontrarse invitaciones cursadas desde Venezuela, Chile y Uruguay; así como proyectos de viajes a México y Brasil. 
interés se materializó en la publicación de textos que en Francia fueron objeto de censura o en la difusión de tesis que para el público europeo recién fueron accesibles muchos años después.

Asimismo, la proyección latinoamericana del althusserianismo ha sido advertida por intelectuales que formaron parte de alguna manera de los itinerarios del althusserianismo en Europa. Este fue el caso de Balibar, quien en su favor destacaba que "algunos militantes de América Latina, en particular, lo consideraron casi como un nuevo Marx" ${ }^{30}$. También el de Rancière, quien en su contra intentaba dejarlo expuesto al afirmar que Althusser se sentía "libre de citar a Mao en prefacios para ediciones latinoamericanas" ${ }^{31}$.

Como ha sido numerosas veces señalado, el vínculo entre Althusser y América Latina ha estado mediado en gran parte por la actividad de dos intelectuales vinculados con los procesos políticos de la región. Uno de ellos ha sido el francés Régis Debray. Estudiante de filosofía en la ENS en los tempranos 1960, Debray había formado parte del grupo de jóvenes congregados alrededor de las enseñanzas de Althusser. Luego de una estadía en la Cuba revolucionaria, publicó dos artículos que lo transformaron en uno de los principales intérpretes del proceso desarrollado en la isla: "Le castrisme: la longue marche de l'Amérique Latine" en la francesa Les Temps Modernes y "América Latina: algunos problemas de estrategia revolucionaria" en la cubana Casa de las Américas ${ }^{32}$. Durante 1965 y 1966 estuvo radicado en Cuba, donde se dedicó a entrevistar a los principales dirigentes revolucionarios y realizar un trabajo de investigación acerca de las particularidades del proceso revolucionario allí desarrollado. Como resultado de dichas tareas y su cada vez mayor involucramiento con la revolución cubana, en 1967 publicó el libro ¿Revolución en la revolución? Este texto, en el cual se reconstruye el proceso revolucionario cubano y se argumenta a favor de la vía armada para la

\footnotetext{
${ }^{30}$ Balibar, Étienne. "Althusser y la Rue d'Ulm”. New Left Review. № 58, 2009, p. 94.

${ }^{31}$ Rancière, Jacques. La lección de Althusser. op. cit., p. 186-187.

${ }^{32}$ Para profundizar la recepción de la revolución cubana en la izquierda francesa, ver Artaraz, Kepa. Cuba y la nueva izquierda. Una relación que marcó los años 60. Buenos Aires, Capital Intelectual, 2011, pp. 155-184.
} 
revolución en América Latina, se vincula de dos maneras con los itinerarios de Althusser en el subcontinente.

En primer lugar, el propio texto era portador de un conjunto de postulados deudores de la obra althusseriana. Si bien los relatos sobre la lucha armada en América Latina han mencionado la existencia de una relación entre los argumentos de Debray y las formulaciones althusserianas, no ha se indagado en la especificidad de dicho vínculo. Una excepción la ha constituido la observación de Oscar Terán acerca del lugar ocupado en el texto por la noción althusseriana de problemática ${ }^{33}$. Efectivamente, a los fines de destacar la novedad de la gramática política inaugurada por la revolución cubana, Debray acudía al concepto utilizado por Althusser para dar cuenta de la coherencia específica de una unidad teórica y el carácter diferencial entre ciencia e ideología:

\begin{abstract}
Para decirlo en lenguaje de filósofo, una cierta problemática ha muerto desde la revolución cubana, es decir una cierta manera de plantear las cuestiones que ordena el sentido de todas las respuestas posibles. $Y$ no son las respuestas las que hay que cambiar, sino las preguntas mismas: esas fracciones o partidos 'marxistas-leninistas' se mueven en el interior de la misma problemática política dominada por la burguesía ${ }^{34}$
\end{abstract}

A través de esta analogía Debray le concedía al proceso revolucionario cubano el mismo tenor que Althusser le otorgaba a la ruptura epistemológica en el seno del pensamiento de Marx. Así como en la obra marxiana podía identificarse una problemática ideológica y una problemática científica, en la izquierda latinoamericana podía delimitarse una concepción política burguesa y otra efectivamente revolucionaria. Si la fundación de la teoría de la historia le había permitido a Marx romper con su conciencia filosófica anterior, la revolución cubana le había permitido a la izquierda del subcontinente quebrar su conciencia política reformista. De esta manera quedaba establecida una

\footnotetext{
${ }^{33}$ Terán, Oscar. "Lectura en dos tiempos". Lucha Armada en la Argentina. N 1, 2004, p. 12.

${ }^{34}$ Debray, Régis. ¿Revolución en la revolución? Buenos Aires, Sandino, 1967, pp. 130-131.
} 
correspondencia entre idealismo en el terreno de la teoría y vía pacífica al socialismo en el campo de la política.

Si bien era significativo, el uso de la noción althusseriana de problemática no agotaba la filiación de Debray en las enseñanzas de su maestro. A nuestro entender, la dimensión más relevante de dicho vínculo lo constituye la importancia otorgada al trabajo teórico en la delimitación de una estrategia revolucionaria. Los argumentos de Debray se dirigían hacia la legitimación de la guerra de guerrillas. De acuerdo a su lectura, las acciones militares llevadas a cabo por grupos guerrilleros permitiría la construcción de una fuerza móvil estratégica que sería el núcleo de un ejército popular y el futuro estado socialista. El reforzamiento de esta línea política encontraba sustento en la desacreditación de las operaciones de aplicación a la realidad latinoamericana de esquemas políticos importados.

Es decir que el error de los grupos de izquierda que actuaban en el subcontinente sin una línea militar coherente y precisa radicaba en el empleo de modelos que habían sido elaborados para otras realidades históricas. De esta manera eran refutados los esquemas de autodefensa armada, propaganda armada y sujeción de la guerrilla al Partido. De acuerdo a Debray, dicho error tenía origen en la ausencia de un conocimiento concreto de una situación concreta. Si bien este postulado remitía a los debates clásicos de la estrategia revolucionaria, la filiación althusseriana le permitía cifrar dicha ausencia en términos de una carencia de "una interpretación científica de la formación social”35. De esta manera, el análisis concreto de situaciones concretas adquiría la forma de una aproximación científica a la sociedad en la complejidad de sus niveles. En este sentido, las organizaciones políticas noguerrileras del subcontinente carecían de "un análisis concreto de los modos de producción en vigor en cada país de América Latina, de las combinaciones existentes entre los diversos modos de producción, de las formas de dominación de un modo de producción sobre los otros" 3637.

\footnotetext{
${ }^{35}$ Ibid., p. 98-99.

${ }^{36}$ Ibid., p. 90.
} 
El otro aspecto relevante del itinerario de ¿Revolución en la revolución? es la participación del propio Althusser en la discusión abierta por el libro. Dicha intervención se produjo a través de una carta a Debray en la que Althusser le realizaba una serie de observaciones sobre el texto. La carta llegó a Roberto Fernández Retamar, director de Casa de las Américas, a través de Jacques Arnault, por entonces corresponsal en La Habana del periódico L'Humanité. De acuerdo a las evocaciones de Fernández Retamar, Althusser pretendía que la carta fuera publicada en Casa de las Américas. Sin embargo, el hecho de que para entonces Debray se encontrara junto a Guevara en Bolivia habría retrasado su publicación. Con Debray ya detenido en territorio boliviano, Fernández Retamar y Althusser habrían decidido en una reunión en París postergar la publicación hasta que aquel fuera liberado ${ }^{38}$. Siguiendo con los recuerdos del cubano, el hecho de que la carta de Althusser fuera un secreto a voces en los ámbitos de la izquierda latinoamericana reactivó la idea de

${ }^{37}$ El texto de Debray fue objeto de refutación por parte del PCA. En 1967, Rodolfo Ghioldi publicó por la editorial partidara Anteo el libro No puede haber revolución en la revolución.

${ }^{38}$ Tal como se desprende de la correspondencia mantenida con su traductora al italiano Franca Madonia, Althusser -como muchos otros- dio por muerto a Debray los primeros días de su detención: "estoy conmocionado por la noticia (no absolutamente confirmada pero por desgracia verosímil) de la muerte de Régis Debray, uno de los más queridos de mis estudiantes, que se había convertido en el confidente y una especie de teórico personal de Fidel en Cuba. Se anuncia su muerte en un combate entre los guerrilleros bolivianos y las 'fuerzas del orden'. Sabía que nada podía impedir su decisión de ir a combatir con los maquis de América Latina. Le había dicho con todos los argumentos posibles que tenía objetivamente cosas mejores para hacer por la causa a la que pretendía servir, pero no lo pude convencer. Veintiséis años" ["je suis bouleversé par la nouvelle (non encore absolument confirmée, mais hélas très vraisemblable) de la mort de Régis Debray, un de mes anciens élèves que j'amais beaucoup, et qui étair devenu le confident et en quelque sorte le théoricien personnel de Fidel à Cuba. On annonce sa mort dans un combat entre les guérrilleros boliviens et les 'forces de l'ordre'. Je savais que rien ne pouvait l'empecher de mettre à exécution sa décision d'aller se battre effectivement dans les maquis d'Amerique latine. Je luis avais dit avec tous les arguments possibles qu'il avait objectivement mieux à faire pour la cause même qu'il voulait servir, mais je n'avais pu le convaincre. Vingt-six ans"], Lettres à Franca (1961-1973). París, Stock/IMEC, 1998, p. 742. Debray permaneció tres años encarcelado y luego fue liberado por gestiones del gobierno francés. 
publicarla, pero la muerte de Guevara habría cancelado definitivamente el proyecto $^{39} 40$.

La intervención de Althusser alrededor del texto de Debray resulta de interés por varias razones. Por un lado, nos permite dar cuenta de cuál era el conocimiento que Althusser tenía de la realidad latinoamericana. En primer lugar, el filósofo francés alegaba cierta ignorancia de las condiciones existentes en América Latina. En segundo término, le comentaba a Debray que lo poco que conocía provenía de los artículos que éste había publicado sobre Cuba, de la prensa francesa (Le Monde y Les Temps Modernes) y de los discursos de Fidel Castro.

Por otro lado, nos permite indagar sobre los modos en los que Althusser había recibido las argumentaciones de Debray. Al respecto se mostraba sumamente crítico ya que para él el texto fallaba en ofrecer una demostración positiva de la validez de la línea guerrillera para América Latina. Es decir que el programa inspirado en la revolución cubana obtenía su legitimidad a través de la refutación de las otras líneas y no de una comprobación de la validez de la guerra de guerrilla a partir de las particularidades de la región. Lo que faltaba en las formulaciones de Debray era, por tanto, una demostración apoyada en un análisis histórico complejo de la realidad latinoamericana: "tu mencionas en alguna parte la necesidad de analizar las condiciones específicas de los modos de producción en América Latina, pero no vas desgraciadamente más lejos de esta mención, y es una lástima, pues allí está el punto absolutamente decisivo"41. La recriminación realizada por Althusser a Debray nos conduce a advertir que ambos convergían en la necesidad de abocarse al estudio de aquellas condiciones específicas. La diferencia radicaba en que para Althusser la lucha política no podía operar como factor retardatario de dicho ejercicio. Es por ello que, adelantándose a una posible respuesta de Debray anclada en las

\footnotetext{
${ }^{39}$ La evocación de Fernández Retamar se encuentra en Casa de las Americas. $\mathrm{N}^{\circ}$ 190, enero-marzo 1993, p. 59.

${ }^{40}$ La carta de Althusser a Debray permaneció inédita hasta la publicación por parte de este último en su libro La critique des armes. París, Du Seuil, 1974. Fue traducida recientemente al castellano por Marcelo Rodríguez, "Carta de Louis Althusser a propósito de ¿Revolución en la revolución? (1967)". Demarcaciones. Revista Latinoamericana de Estudios Althusserianos. N 3, Abril 2015, pp. 57-63.

${ }^{41}$ Ibid., p. 61.
} 
necesidades políticas del presente, Althusser le recodaba que si bien hay exigencias urgentes de la lucha, "es políticamente urgente tomar perspectiva y entregarse a los estudios de los cuales todo depende" 42 .

La historia de la difusión de las tesis althusserianas a través del trabajo de Debray tuvo un último episodio en ocasión de la muerte de Guevara. Fernández Retamar le había solicitado a Althusser un texto sobre dicho episodio para ser publicado junto a otras contribuciones en Casa de las Américas. La nota enviada por Althusser prolongaba los términos de la devolución al libro de Debray. Por un lado, el francés reconocía la ejemplaridad de la militancia revolucionaria de Guevara: "con su vida, el 'Che' nos dejó un admirable ejemplo de conciencia, de voluntad, de coraje y de abnegación revolucionarios. Su muerte llama a todos los revolucionarios a cumplir su deber: la Revolución" ${ }^{43}$. Asimismo, ratificaba la estrategia de lucha armada para política revolucionaria a desarrollarse en la región: “El 'Che' nos deja una definición marxista-leninista de la estrategia general de la lucha de las clases revolucionarias en la América Latina: en su conjunto, la lucha revolucionaria de masas de la América Latina pasa y pasará necesariamente por la lucha armada" $^{44}$. Sin embargo Althusser se remitía a la lucha de Guevara a los fines de puntualizar las necesidades de la izquierda del subcontinente. Su muerte obligaba a los militantes latinoamericanos a trascender el plano de la estrategia general de lucha. Es decir que le cabía a cada fuerza revolucionaria nacional calibrar los modos de aplicación de la estrategia de lucha armada a la formación económico-social en la que operaba. Era esta tarea la que redundaría en la delimitación de las formas de organización, los modos de lucha, los objetivos concretos y las tácticas particulares. Según Althusser, la postergación de los análisis de las especificidades locales conllevaba la inflación del problema del vínculo entre organización militar y organización política en detrimento de la discusión acerca de la relación entre organizaciones político-militares y las masas. La aproximación de Althusser a

\footnotetext{
42 Ibid., p. 63.

${ }^{43}$ Althusser, Louis. "Carta ante la muerte del Che Guevara". Casa de las Americas. N ${ }^{\circ}$ 190, enero-marzo 1993, p. 61.

${ }^{44} / d$.
} 
dicho desbalance culminaba con dos argumentaciones. La primera de ellas tenía el carácter de inferencia. Dado que la situación cubana representaba más una excepción que la norma de la sociedad latinoamericana, la estrategia de lucha armada podría adquirir la forma particular de guerra popular en lugar de la de guerrilla. La segunda tenía un tenor más normativo. La única manera de zanjar la discusión en torno a las formas concretas de lucha era la delimitación de los modos específicos a través de los cuales se presentaba el pueblo en cada formación económico-social: "es preciso saber siempre qué es el pueblo, en cada momento de la lucha, dónde está el pueblo, cómo está constituido, qué quiere, de qué es capaz, etc. De ahí la necesidad vital de análisis concretos de la situación de las clases y de las relaciones de clase"45 46.

La otra persona que resulta clave a los fines de indagar sobre la relación entre Althusser y América Latina es la chilena Marta Harnecker. Harnecker había llegado becada a Francia en 1963, luego de un viaje a Cuba que la había distanciado de su militancia cristiana en la Acción Católica Universitaria de Chile. A través de vínculos con los círculos católicos ligados al PCF, Harnecker y su pareja de entonces Rodrigo Ambrosio, dirigente del Partido Demócrata Cristiano, se contactaron en 1964 con los grupos de estudios que coordinaba Althusser en la ENS ${ }^{47}$. De manera progresiva Harnecker se fue transformando

\footnotetext{
${ }^{45}$ Ibid., p. 63.

${ }^{46}$ Al igual que la carta a Debray, el texto sobre la muerte de Guevara atravesó un conjunto de circunstancias originadas tanto en la coyuntura políica latinoamericana como en la estrategia del propio Althusser. De acuerdo a las evocaciones de Fernández Retamar, Althusser había enviado su artículo una vez que el número de Casa de las Américas sobre la muerte de Guevara ya había entrado a la imprenta. Pero dado que no era el único caso, el texto de Althusser sería publicado en el número siguiente de la revista. Sin embargo, hacia fines de 1967 el cubano recibió una breve nota de Althusser en la que éste le pedía que el texto no fuera publicado. Rezaba esta misiva: "Recibí el último número de Casa [de las Américas]. Si puedes no publicar nada, ni mi carta a Régis ni mi 'página' sobre el 'Che', ello es desde mi punto de vista, la mejor solución. Cuando te digo 'desde mi punto de vista', tengo en cuenta lo que imaginas: intereses generales, los de nuestra causa común", Ibid., p. 64. El texto sobre la muerte del Che y esta última nota fueron publicados por Fernández Retamar en Casa de las Américas recién en 1993.

${ }^{47}$ El mismo día que conoció a Harnecker, Althusser le relataba a Madonia: "Esta mañana vi a una chilena que me escribía 'estimado señor Althuser' y que quiere 'estudiar en el marxismo' con un grupo de brasileños y otros sudamericanos. Se presentó ante mi una especie de campesina: cara angulosa, boca torcida, pero ojos negros, y algo en los dientes y en la voz que ha tocado algo en mi: puede ser la
} 
en una colaboradora cercana del filósofo francés. De este vínculo resultaron dos acontecimientos editoriales claves para la difusión del althusserianismo en América Latina.

El primero de ellos es la traducción al castellano de los dos libros con los cuales Althusser intervenía en el campo marxista francés. Harnecker tradujo Pour Marx, publicado por Siglo XXI México en 1967 bajo el título La revolución teórica de Marx, y una versión reducida de Lire Le Capital, publicada por la misma editorial en 1969 con el título Para leer El Capita/ ${ }^{48}$. Si bien ambas ediciones constituyeron canales privilegiados del ingreso del pensamiento althusseriano en los países latinoamericanos, nos interesa especialmente el primero de ellos dado que allí se conjuga tanto la pretensión de Althusser de difundir su obra como la riqueza que Harnecker encontraba en ella a los fines de delinear una intervención teórica y política para América Latina.

En este sentido resulta clave la introducción realizada por Harnecker a La revolución teórica de Marx. Tal como evocara posteriormente la chilena, la escritura del texto había sido alentada por el propio Althusser y altamente valorada una vez concluida: "había traducido La revolución teórica de Marx y había escrito un prólogo a la versión en español. Es lo primero que escribí en mi vida. Althusser me estimuló muchísimo, me dijo que era muy bueno porque captaba muy bien el espíritu de su pensamiento y lograba explicarlo en una forma muy comprensible" ${ }^{49}$. La introducción justificaba la traducción por el esfuerzo de reflexión sobre los problemas principales del marxismo y el desarrollo de nuevos instrumentos teóricos que contenía su obra. Según

notalgia de no tener su edad, o de no haberla tenido cuando tenía la suya, esa libertad que ella tenía" ["Vu ce matin une chilienne qui m'ecrivait 'estimé M. Althusser' et qui veut, avec toute une bande de brésiliens et autres sud-américains, étudier 'dans le marxisme'. Une sorte de paysanne s'est présentée à moi: visage taillé à la serpe, bouche de travers, mais des yeux noirs, et quelque chose dans les dents (toutes de travers) et dans le voix qui a touché en moi quelque chose: peut-être tout simplement la nostalgie de n'avoir pas son âge, ou de n'avoir pas été, quand j'avais le sien, cette liberté qu'elle avait'], Lettres à Franca (1961-1973). op. cit., p. 574.

48 La versión de Lire Le Capital publicada por Siglo XXI contenía solo las intervenciones de Althusser y Balibar. Dejaba afuera, por tanto, las contribuciones de Establet, Macherey y Rancière. Si bien estos últimos textos fueron posteriormente traducidos, Lire Le Capital nunca fue publicado en castellano en su versión completa.

${ }^{49}$ Castañeda, Antonio y Quiroz, Sergio. "Marxismo y desafíos actuales. Entrevista a Marta Harnecker". Cuadernos de Marxismo. Noviembre de 2000, p. 7. 
Harnecker, el mayor mérito de Althusser era promover un estudio más serio sobre Marx sin caer en una interpretación ética y humanista del marxismo. A su entender, Althusser llevaba a cabo un redescubrimiento de Marx para superar la simplificación que ofrecían los manuales marxistas clásicos -los cuales generaban malentendidos y convertían al marxismo en un dogma- sin por ello volver a las obras tempranas de Marx y a la utilización de conceptos ideológicos no-marxistas.

El texto ingresaba en el debate teórico y político que por entonces estaba generando la relectura de Marx propiciada por Althusser. En este contexto Harnecker aseguraba que las discusiones suscitadas no llegaban a advertir la radicalidad y complejidad de la propuesta althusseriana, ya sea por resistencias ideológicas o por la incomprensión de muchos de sus postulados, lo que llevaba a la mayoría de sus críticos a mantenerse en el terreno de la superficialidad. Igual de significativo resultaba su señalamiento acerca de la importancia la productividad de la obra de Althusser para la militancia revolucionaria de América Latina. En los términos de Harnecker, la innovación althusseriana proporcionaba al lector latinoamericano nuevas herramientas teóricas y habilitaba un espacio desde el cual desarrollar nuevos abordajes de la realidad latinoamericana, así como preparar con garantía científica una transformación revolucionaria de las estructuras sociales:

el autor [Louis Althusser] nos ofrece algunos elementos teóricos fundamentales, y nos señala el terreno en el que podemos producir los que todavía no han sido elaborados para realizar un análisis objetivo, científico, de la coyuntura histórica, turbulenta pero llena de esperanzas, que viven y sufren nuestros pueblos de América Latina, como los de África y Asia, quienes buscan, un poco a ciegas, la vía revolucionaria que les permita salir de su situación de explotación, de hambre y de miseria $^{50}$

El otro acontecimiento editorial que vincula a Althusser con Harnecker es la publicación de Los conceptos elementales del materialismo histórico. Un libro cuya importancia para la formación militante de la izquierda latinoamericana ha

${ }^{50}$ Harnecker, Marta. "Introducción". Louis Althusser. La revolución teórica de Marx. México D.F., Siglo XXI, 1967, p. 4. 
sido inversamente proporcional a la valoración de sus cualidades. Concluido el ciclo revolucionario de los años 1960/1970 y extinguido el impulso estructural del marxismo, el texto de Harnecker pasó a la historia como un ejercicio de esquematización de una relectura de Marx que ya de por sí era esquemática ${ }^{51}$. Como se desprende de las afirmaciones de Rozitchner, gran parte de la mala fama del libro se debe a las consideraciones realizadas por el propio Althusser en su autobiografía. A los fines de dar cuenta del amplio proceso de recepción que habían generado sus días más allá de Francia, Althusser se refería de manera despectiva al texto de Harnecker:

\begin{abstract}
una de mis alumnas, la chilena Marta Harnecker, que vivió en París entre 1960 y 1965, si no me traiciona la memoria, volvió a la América Latina (Cuba) para redactar un pequeño manual de materialismo histórico ¿Se sabe que se publicaron diez millones de ejemplares? No era muy bueno pero sin embargo constituyó -a falta de algo mejor- la única base teórica y política de formación para centenares de millares, sino para decenas de millones de militantes de la América Latina porque era la única obra de su especie en el continente. Ahora bien seguía al plan de la letra, incluso aunque las comprendiese mal a menudo, las ideas que Balibar y yo habíamos propuesto en Para leer El Capita $^{52}$
\end{abstract}

\footnotetext{
${ }^{51}$ La condensación en el libro de Harnecker de los defectos y limitaciones de una generación militante es una operación habitual en las reflexiones intelectuales de la izquierda latinoamericana. Sólo a modo de ejemplo, podemos citar a a Rozitchner, quien en la década de 1990 afirmaba: "Martha Harnecker escribió la Vulgata althusseriana, un pedante catecismo, que Althusser crítica en sus memorias, pero se complace sin embargo por los millones de libros vendidos que le dieron influencia sobre nuestro Tercer Mundo, y lo hicieron conocido. Aunque contribuyeran al fracaso", "La tragedia del althusserianismo teórico". Néstor Kohan. El Capital. Historia y método -Una introducción-. Buenos Aires, Universidad Popular Madres de Plaza de Mayo, 2003, p. 337. O al chileno Ernesto Ottone, quien en su autobiografía asegura: "de todo lo que leí en ese tiempo lo más intragable fue Louis Althusser, con su visión estructuralista y escritura endemoniada. Me salté olímpicamente a la tan leída Marta Harnecker; si de manuales se trataba, los soviéticos bastaban y sobraban", El viaje rojo: un ejercicio de memoria. Santiago, Debate, 2014. Todo esto para no ahondar en los ataques provenientes de intelectuales marcadamente anticomunistas. Por ejemplo, el panfleto neoliberal Manual del perfecto idiota latinoamericano de Plinio Apuleyo Mendoza, Carlos Alberto Montaner y Alvaro Vargas Llosa se refiere al libro como "la gran vulgata marxista publicada en América Latina" y considera a la reedición del libro en la década de 1990 como un "dato que prueba la resistente vitalidad de esta obra (y la heroica terquedad de los marxistas), pese al descalabro de los países comunistas y al descrédito predecible en que cayeron los estudios marxistas a partir de 1989".

${ }^{52}$ Althusser, Louis. El porvenir es largo. Los hechos. Barcelona, Destino, 1992, p. 312.
} 
Una reconstrucción de los itinerarios del libro nos permitirá, sin embargo, dar cuenta de la historicidad del texto así como reponer el rol desempeñado por Althusser en su elaboración y publicación.

Los conceptos elementales del materialismo histórico tuvo su origen en un curso de formación teórica coordinado por Harnecker al cual concurrían latinoamericanos que se encontraban en París. De acuerdo a su testimonio, el curso estaba dirigido a unos quince estudiantes brasileños, mexicanos, chilenos y haitianos, y era sostenido económicamente por el maoísta mexicano Adolfo Orive Bellinger, quien también se encontraba estudiando en París ${ }^{53}$. A la par del desarrollo del curso, Harnecker comenzó a publicar textos pedagógicos sobre marxismo en la revista chilena Punto Final. Del meticuloso trabajo de reconstrucción realizado por José Antonio Ramírez, se desprende que Harnecker publicó treinta y tres artículos entre 1967 y $1969^{54}$. Firmados con el seudónimo de NEVA y publicados con frecuencia quincenal en la sección "Teoría" de la revista, los artículos de Harnecker abordaban los principales problemas de la teoría marxista. Mediada por la lectura althusseriana, la producción de la chilena se detenía en problemas tales como el objeto de El Capital, la relación Hegel-Marx, la categoría de hombre y el problema de la ideología.

Los textos publicados en Punto Final constituyeron la base de Conceptos elementales del materialismo histórico, el cual fue editado por Siglo XXI México en 1968. El libro estaba compuesto por doce capítulos dedicados a los problemas centrales de la teoría marxista (producción, fuerzas productivas, relaciones sociales de producción, estructura económica de la sociedad, infraestructura y superestructura, estructura ideológica, estructura jurídicopolítica, coyuntura política, clases sociales, transición y revolución, y teoría marxista de la historia), una sección de "Textos escogidos" sobre cada uno de los problemas y una "Bibliografía mínima comentada" de los clásicos de la teoría marxista. Cada capítulo contenía, al comienzo, un índice de los temas a

${ }^{53}$ Castañeda, Antonio y Quiroz, Sergio. "Marxismo y desafíos actuales. Entrevista a Marta Harnecker". op. cit., p. 7.

${ }^{54}$ Ramírez, José Antonio. "Marta Harnecker y el marxismo pedagógico. Itinerarios del pensamiento de Marta Harnecker en la Revista Punto Final, Chile 1967-1969". VIII Jornadas de Historia de las Izquierdas - CeDINCI/UNSAM. 2015, pp. 333-342. 
desarrollar a continuación; y al final, un cuestionario con fines pedagógicos, "tanto para los que estudien en forma aislada como para aquellos que utilicen el contenido de este libro en cursos de formación para trabajadores y estudiantes" ${ }^{\prime 25}$, y unos temas de reflexión sobre los aspectos planteados, con el doble objetivo de "mostrar los problemas teóricos que pueden plantearse al estudiar determinados conceptos" e "indicar las posibles aplicaciones de los conceptos teóricos en el análisis de nuestra realidad latinoamericana"56.

Los desarrollos de Harnecker estaban precedidos por una presentación de Althusser preparada especialmente para la publicación del volumen. Allí el francés recomendaba calurosamente la lectura del libro y realizaba una valoración positiva del esfuerzo intelectual realizado por Harnecker. Según su entender, los principales méritos del libro eran sus cualidades pedagógicas, la exposición clara y rigurosa de los conceptos fundamentales de la teoría marxista y la presentación de tesis que realizaban precisiones sobre el pensamiento de los pensadores marxistas clásicos. Althusser explicitaba que la mayor utilidad que se le podía dar al libro era la de la "formación teórica de militantes revolucionarios, ayudarlos a 'analizar concretamente la situación concreta', es decir, la coyuntura de tal o cual país" ${ }^{57}$. Productividad que lo llevaba a ubicar el trabajo de Harnecker, en tanto precedente teórico de las condiciones subjetivas de la Revolución, en la tradición de la Revolución rusa y la Revolución china, dado que en ambos procesos habían existido dirigentes formados en la teoría marxista que habían producido un análisis concreto de una situación concreta.

Igual de significativa resulta la introducción al libro realizada por Harnecker. Allí se anunciaba al lector que el trabajo debía ser enmarcado en la problemática de la formación teórica de la militancia revolucionaria. La autora presentaba las principales bases sobre las que se debería diagramar un programa de formación teórica. A su entender, todo militante revolucionario

\footnotetext{
${ }^{55}$ Harnecker, Marta. Los conceptos elementales del materialismo histórico. México D.F., Siglo XXI, 1968.

${ }^{56}$ Ibid., p. 9.

${ }^{57}$ Althusser, Louis. "Presentación". Marta Harnecker. Los conceptos elementales del materialismo histórico. op. cit., p. 2.
} 
debía formarse en tres aspectos básicos: el estudio de la teoría marxistaleninista, que le proporcionaría los elementos teóricos para pasar de una etapa de romanticismo y voluntarismo a una de realismo y preparación efectiva; la aplicación de la teoría marxista a la realidad concreta de su país, que le ayudaría a identificar características de la formación social a partir de la utilización de los principios generales del marxismo-leninismo; y el estudio de la coyuntura política de su país y a nivel mundial, que contribuiría a la comprensión de la relación existente entre las diversas fuerzas de un país determinado y las fuerzas sociales internacionales. En el marco de este programa, el libro de Harnecker tenía como objetivo ayudar a los militantes revolucionarios a conocer la teoría marxista, en el sentido de proporcionarles los conceptos teóricos necesarios para el conocimiento científico de su realidad concreta.

La relación establecida entre Althusser y Harnecker tuvo un último hito en 1971, al publicarse la sexta edición de Los conceptos elementales del materialismo histórico. Esta nueva edición contenía algunas modificaciones con respecto a la que se publicaba desde 1968, por lo que Harnecker le solicitó a Althusser un nuevo prólogo. El texto en cuestión, "Marxismo y lucha de clases", producía cierto desplazamiento en sus reflexiones teóricas y políticas, al direccionar la discusión alrededor de la teoría marxista hacia el problema de la lucha de clases. Enmarcada en su lectura de Lenin y la definición de la filosofía como lucha de clases en la teoría, esta orientación se articulaba sobre la interpretación de la lucha de clases como eslabón decisivo de la teoría científica de Marx. Movimiento que conllevaba el relevo de una lectura de El Capital en términos de una teoría de la economía política del capitalismo a una teoría de las formas materiales, jurídico-políticas e ideológicas de un modo de producción fundado en la explotación de la fuerza de trabajo asalariada.

A pesar de la importancia de los postulados del texto de Althusser, éste recién fue traducido y publicado en francés varios años después de su inclusión en el libro de Harnecker. Junto a otros textos destacados de la primera mitad 
de la década de 1970, "Marxismo y lucha de clases" integró la compilación Positions publicada por Editions Sociales en $1976^{58} 59$.

\subsection{Entre La Habana y Santiago de Chile: itinerarios de Althusser en América Latina}

El único trabajo preocupado por ofrecer una explicación general del fenómeno de recepción de Althusser en América Latina es un artículo del investigador chileno Miguel Valderrama ${ }^{60}$. Si bien este texto cuenta ya con varios años, contiene un conjunto de líneas interpretativas claves a los fines de dar cuenta del extendido fenómeno de difusión del pensamiento althusseriano en la región. De acuerdo a Valderrama, la importancia política de la lectura de Althusser en el subcontinente radicó en la potencialidad que ella entrañaba para otro tipo de lecturas de Marx y el marxismo. El ingreso de Althusser posibilitó el surgimiento en distintos espacios políticos e intelectuales de un

${ }^{58}$ En una carta fechada en febrero de 1971, Althusser le relataba a Madonia el proceso de escritura del nuevo prólogo: "tengo que escribir dos o tres páginas para la reedición de un pequeño manual de Marta (la chilena de la que te había hablado un día, que tenía una especie de aire campesino, una muchacha alta con cabellos hermosos, y tu me habías dicho algunas palabras que significaban ¿pero por qué no te interesas en ella? Y de hecho esas palabras tuvieron como efecto que, sin interesarme en ella, fuera muy gentil y la ayudara: ella tenía -y tiene- una especie de genio pedagógico, y de regreso ha su país ha escrito un pequeño manual de materialismo histórico que dio la vuelta por América Latina con un pequeño prefacio mío) entonces ella reedita (ies la sexta edición!) su pequeño manual con transformaciones importantes y me pide un nuevo prefacio que dé cuenta de dichas transformaciones" "[j'ai à ecrire deux ou trois pages pour la réédition d'un petit manuel de Marta (cette chilienne dont je t'avais parlé un jour, qui avait une sorte de d'allure paysanne, une grande fille aus très beaux cheveux, et mu m'avais alors dit quelques mots qui signifiaient mais pourquoi ne t'intéresserais-tu pas à elle ? et de fait ces quelques mots avaient eu pour effet que sans m'interesser à elle j'avais été très gentil avec elle et l'avais beaucoup aidée : elle avait -et a- une sorte de génie pédagogique, et rentrée dans son pays elle y a écrit un petit Manuel de matérialisme historique qui a fait le tour de l'America latine avec une petite préface de moi) donc elle réédite (c'est la $6^{\circ}$ édition!) son petit Manuel avec d'important transformations, et me demande une nouvelle préface qui tienne compte de ces transformations]", Lettres à Franca (19611973). op. cit., p. 787.

${ }^{59}$ Era este prólogo al que remitía Rancière en su escrache a Althusser por su cita de Mao.

${ }^{60}$ Valderrama, Miguel. "Althusser y el marxismo latinoamericano. Notas para una genealogía del (post)marxismo en América Latina". Mapocho. Revista de Humanidades y Ciencias Sociales. № 43, 1998, pp. 168-183. 
nuevo tipo de textualidad teórica en la que se articuló un novedoso discurso científico sobre la historia y la sociedad latinoamericanas. Este efecto de novedad generó en los países latinoamericanos una ruptura tanto en el horizonte del marxismo clásico de la III Internacional como en el terreno de las ciencias sociales. Al respecto, Valderrama iluminaba una dimensión relevante de estos efectos de ruptura al enfatizar que el pensamiento de Althusser habilitaba un conjunto de desplazamientos que conllevaban la activación de campos originalmente extraños al marxismo, tales como el psicoanálisis, la lingüística y la semiología.

Ahora bien, los efectos rupturistas del althusserianismo en América Latina sólo pueden ser entendidos a partir de las particularidades de un contexto que se siente interpelado por sus tesis. Al respecto resulta fundamental la afirmación de Valderrama de que la recepción de Althusser en la región está determinada "desde el punto de vista histórico y teórico, por la emergencia significativa de la revolución cubana como acontecimiento disruptor de la normalidad comunicativa impuesta a la izquierda continental por la hegemonía estalinista"61. En este sentido es posible hablar de una convergencia significativa entre la relectura de Marx propiciada por Althusser y la crisis de la racionalidad política revolucionaria experimentada en la región en la década de 1960. Como es sabido, la importancia de la revolución cubana radica en el hecho de que este proceso expresa simultáneamente la apertura histórica al giro revolucionario de América Latina y el punto de articulación de un nuevo discurso crítico dentro del campo del marxismo. En este marco, el althusserianismo penetró en un espacio teórico que se mostraba incapaz de dar respuesta al debate marcado por las problemáticas del desarrollo nacional, las teorías de la revolución y las vías de transición al socialismo.

No resulta sorprendente, por tanto, que Cuba haya constituido uno de los primeros y más significativos espacios receptivos de la obra de Althusser. Como ha destacado Natasha Gómez Velázquez, la atención concitada por la renovación althusseriana entre los intelectuales cubanos hizo que sus textos

${ }^{61}$ Ibid., p. 170. 
fueran tempranamente traducidos y publicados ${ }^{62}$. Pour Marx y Lire Le Capital contaron con ediciones previas a las traducidas por Harnecker y publicadas por Siglo XXI. El primero fue editado con el título de Por Marx en 1966 por Edición Revolucionaria. El segundo fue editado con el título de Leer El Capital el mismo año por la editorial de la Universidad de La Habana. Si bien este trabajo de publicación constituye un elemento destacable por sí mismo, debe mencionarse que la edición cubana de Lire Le Capital incorporó la totalidad de las contribuciones del libro original. A diferencia de la de Siglo XXI, que sólo reproducía los textos de Althusser y Balibar, la publicación cubana incorporó en dos tomos los de Althusser, Balibar, Establet, Macherey y Rancière.

Además de la publicación temprana de las dos principales obras de Althusser, en Cuba se produjo un acontecimiento editorial que es altamente indicativo de la proyección latinoamericana del pensamiento althusseriano. A comienzos de 1966 Casa de las Américas publicó un texto de Althusser que nunca fue publicado en francés. Dicho texto se titulaba "Teoría, práctica teórica y formación teórica. Ideología y lucha ideológica" y se había originado en uno de los momentos de mayor tensión entre Althusser y la dirigencia del PCF ${ }^{63}$. Althusser había preparado el texto para una reunión de filósofos comunistas, pero dado que Althusser no pudo asistir a la reunión, fue leído por su alumno Michel Verret. El texto fue duramente rebatido por Garaudy y Macherey ensayó una defensa de las posiciones althusserianas. En este contexto, Althusser había enviado el texto para su publicación en Cahiers du communisme, la revista teórica del PCF. Al no recibir nunca respuesta de su solicitud, el texto se convirtió en un punto de partida para un conjunto de escritos sobre los principios del marxismo ${ }^{64}$. El vínculo entre Althusser y Fernández Retamar hizo

${ }^{62}$ Gómez Velázquez, Natasha. "El pensamiento althusseriano entre los cubanos: sus primeros acercamientos". Utopía. № 15, marzo 2002.

${ }^{63}$ Para una reconstrucción detallada de este contexto, ver Matheron, François. "Louis Althusser et Argenteuil : de la croisée de chemins au chemin de croix". Les Annales de la Société des Amis de Louis Aragon et Elsa Troilet. N² 2, 2000, pp. 169-198.

${ }^{64}$ Como ha analizado Matheron, el proyecto de Althusser era agrupar estos escritos sobre problemas básicos del marxismo en un un volumen que cumpliera el el rol de manual de formación, "Louis Althusser o la pureza impura del concepto". op. cit. Constación que resulta sumamente interesante en tanto permite matizar las lecturas que tienden a separar las elaboraciones teóricas de Althusser y su divulgación. Como 
que el texto finalmente fuera publicado en la revista cubana ${ }^{65}$. La publicación no sólo tuvo impacto en Cuba, sino que también tuvo un fuerte efecto en círculos políticos e intelectuales de varios países latinoamericanos. Como veremos más adelante, el texto fue incluido en el volumen La filosofía como arma de la revolución publicado por el grupo de Pasado y Presente. De esta manera, una de las vías privilegiadas de ingreso del pensamiento althusseriano en América latina lo constituyó un texto que en Francia no tuvo mayor repercusión que la de los círculos filosóficos del $\mathrm{PCF}^{66}{ }^{67}$.

Junto a los procesos de traducción y publicación de sus textos, el pensamiento althusseriano tuvo un efecto significativo en las intervenciones teóricas y políticas desarrolladas por los intelectuales cubanos. Como ha puesto en evidencia Jaime Ortega, la lectura de Althusser se entroncó con un conjunto de transformaciones desarrolladas en la isla hacia fines de la década

vimos anteriormente, es esta operación a la que fue tradicionalmente sometida el manual escrito por Harnecker.

${ }^{65}$ La correspondencia con Madonia evidencia no sólo que Althusser estaba al tanto de la edición de sus textos en Cuba sino también que seguía atentamente el proceso de publicación: "tuve novedades de Cuba. Mis artículos son traducidos y conocidos por un gran público. Uno de mis antiguos alumnos, que ha pasado mucho tiempo en Cuba y conoce a todo el mundo (incluido Castro), estaba alli para la Navidad. En la prensa oficial se anuncia su participación en tal reunión o conferencia de la siguiente manera: tomará la palabra el camarada Régis Debray, iii alumno de Althusser'!!!" "[j'ai eu des nouvelles de Cuba. Mes articles y sont traduits et connus d'un très large public. Un de mes anciens élèves, qui est déjà allé longuement à Cuba, et y connaît tout le monde (dont Castro), s'y trouvait pour la Noël. Dans la presse officielle on annonçait sa participation à telle ou telle réunion ou conférence sous la forme suivante : prendra la parole le camarade Régis Debray, iii'alumno de Althusser'!!!", Lettres à Franca (19611973). op. cit., p. 663.

${ }^{66}$ Resulta interesante, al respecto, analizar los modos en los cuales este texto es referenciado en la bibliografía europea sobre Althusser y el marxismo occidental. Por ejemplo, Gregory Elliott aclara que el texto no se encuentra publicado en francés, que ha sido publicado por Casa de las Américas y que ha sido incluido en el volumen Philosophy and the Spontaneous Philosophy of the Scientists and Other Essays editado por Verso en 1990, Althusser: The Detour of Theory. op. cit., p. 391. Perry Anderson, por su parte, afirma que el texto está publicado sólo con traducción española y cita únicamente la edición de Pasado y Presente, Consideraciones sobre el marxismo occidental. op. cit., p. 105. Terry Eagleton sólo dice que hay un texto sin publicar de Althusser sobre la ideología, pero se equivoca al fecharlo en 1969, Ideología. Una introducción. Barcelona, Paidós, 2005, p. 200.

${ }^{67}$ En la sección del fondo Althusser dedicada a este texto se encuentra una versión mimeografiada de 47 páginas, una versión con correcciones, un borrador dactilografiado de 65 páginas, una versión dactilografiada de 84 páginas, así como correspondencia mantenida alrededor del texto con Fernández Retamar, el historiador francés Maurice Caveign, el intelectual comunista Léo Figuères y Michel Verret. 
de $1960^{68}$. El althusserianismo interpeló fuertemente a los jóvenes intelectuales que buscaban rebasar las formaciones teóricas del marxismo soviético que predominaban en el espacio cubano. En este sentido ha sido clave el trabajo desarrollado por Fernando Martínez Heredia a través de la revista Pensamiento crítico y el Departamento de Filosofía de la Universidad de La Habana. La investigación desarrollada por Ortega ha destacado dos particularidades del episodio cubano de la recepción de Althusser. La primera es que, al igual que en otros contextos, el pensamiento de Althusser no circuló de manera aislada sino que se imbricó con otras corrientes y tradiciones de pensamiento. En este caso, el althusserianismo fue puesto en diálogo con constelaciones teóricas tales como la tradición martiana, el pensamiento socialista cubano e inclusive la ortodoxia soviética. La segunda radica en el hecho de que la aproximación a la obra de Althusser estuvo mediada por una incorporación crítica de sus postulados y un distanciamiento de aquellas dimensiones que se tornaban intraducibles al contexto revolucionario. Por un lado, las lecturas de Althusser desarrolladas por los intelectuales de Pensamiento crítico habilitaron una discusión acerca de la propia historia del marxismo que complejizaba la sistematizada alrededor de la filosofía marxista-leninista. De la misma manera, estas lecturas permitieron en el Departamento de Filosofía de la Universidad de La Habana un abordaje de la realidad de la isla ya no en términos de modo de producción sino de formación económico-social. Sin embargo, estos procesos receptivos se mostraban marcadamente hostiles hacia ciertos efectos de la crítica althusseriana del humanismo. Del mismo modo, la particularidad del proceso revolucionario desplegado en la isla volvía sospechoso al pensamiento althusseriano debido a la filiación comunista partidaria del filósofo francés ${ }^{69}$.

\footnotetext{
${ }^{68}$ Ortega, Jaime. "Incendiar el océano. Notas sobre la(s) recepción(es) de Althusser en Cuba". De Raíz Diversa. Revista Especializada en Estudios Latinoamericanos. Vol. 2, $\mathrm{N}^{\circ}$ 4, julio-diciembre 2015, pp. 129-153.

${ }^{69}$ Además del trabajo editorial de Fernández Retamar y las lecturas de Martínez Heredia, Althusser estuvo vinculado con Cuba a través de los hermanos Alvarez-Ríos. Por un lado, Roberto, pintor surrealista que vivía en París. En 1962 Althusser escribió un artículo sobre su obra para la revista Les Lettres Françaises, "Devant le surréalisme: Alvarez-Ríos". Por el otro, Renato, quien se desempeñaba como agregado cultural en la embajada cubana en París. De la correspondencia de Althusser con Madonia se desprende que Renato Alvarez Ríos le propuso al francés pasar un año en Cuba hacia 1964: "te quiero decir también que ayer cené con Renato
} 
La recepción de Althusser en México es sin lugar a dudas el fenómeno de difusión de las ideas del filósofo francés que más se ha estudiado. Desde el artículo pionero de Cesáreo Morales ${ }^{70}$ hasta las minuciosas investigaciones de Jaime Ortega $^{71}$, pasando por las reconstrucciones de Santiago Ramírez Castañeda $^{72}$ y las diversas notas publicadas por la prensa ${ }^{73}$, un abanico de interpretaciones han intentado delimitar la especificidad de los itinerarios del althusserianismo en el país del norte. A diferencia de la recepción cubana pero en sintonía con los procesos análogos desarrollados en el resto de los países latinoamericanos, la penetración de Althusser en México tendió a polarizar las lecturas desarrolladas por sus intelectuales. Por el lado de las lecturas críticas, la obra de Althusser encontró un duro contendiente en uno de los principales intelectuales marxistas mexicanos, Adolfo Sánchez Vázquez. Enmarcada en la tradición praxiológica del marxismo, su obra no podía más que chocar con el programa cientifizador del althusserianismo. Enfrentamiento que se agudizó al ser publicada su principal obra Filosofía de la praxis de manera casi simultánea a la llegada de las tesis althusserianas a territorio mexicano. El contrapunto entre Sánchez Vázquez y el althusserianismo alcanzó su punto máximo a fines de la década de 1970 con la publicación de su libro Ciencia y revolución (el

el cubano, quien está en relación con Dorticós por trabajos de documentación teórica, a los cuales me quiere asociar. Hablamos de todo tipo de cosas, tengo que verlo nuevamente, está buscando obras especializadas en la $2^{\circ}$ Internacional. Por suspuesto hablamos de Cuba, iquiere que vaya todo un año! Le dije: sólo dos meses, en el verano" "[je veux te dire aussi que dîné hier soir avec Renato le Cubain, et qui est en rapport avec Dorticos pour des travaux de documentation théorique, auxquels il veut me associer. On a parlé de toutes sortes de choses, je dois le revoir dans quelques instants, il vient chercher des ouvrages spécialisés sur la $2^{\circ}$ Internationale. Bien entendu on a parlé de Cuba... ill voudrait que j'y aille une année entière! Je lui ai dit : l'été, deux mois oul]", Lettres à Franca (1961-1973). op. cit., p. 374.

${ }^{70}$ Morales, Cesáreo. "El althusserismo en México". Dialéctica. № 14-15, 1983-1984, pp. 173-184.

${ }_{71}$ Ortega, Jaime. "El cerebro de la pasión: Althusser en tres revistas mexicanas". Izquierdas. Una mirada histórica desde América Latina. № 25, octubre 2015, pp. 143164 y "De Lecumberri a Lacandona: Louis Althusser y México". Rebelión. Agosto de 2016.

${ }^{72}$ Ramírez Castañeda, Santiago. "Althusser en México”. Guillermo González Rivera y Carlos Torres (comps.). Sociología de la educación: corrientes contemporáneas. México D.F., Centro de Estudios Educativos, 1981, pp. 247-262.

${ }^{73}$ Ochoa Sandy, Gerardo y Beltrán del Río, Pascal. "Louis Althusser en México: la generación del 68 lo hizo suyo por radical y antidogmático". Proceso. 27 de octubre de 1990; Híjar Serrano, Alberto. "Althusser en Morelia". Por esto!. Mayo de 2012. 
marxismo de Althusser), un trabajo dedicado íntegramente a refutar las tesis althusserianas. Trabajo que dio lugar a un intercambio epistolar con Balibar, el cual es reproducido en la segunda edición del libro realizada en 1983.

Sin embargo, una camada de jóvenes intelectuales mexicanos encontró en la obra de Althusser un conjunto de elementos que les permitieron reconfigurar sus intervenciones políticas y teóricas. Dentro de este grupo puede mencionarse a Cesáreo Morales y Alberto Hijar, quienes introdujeron el marxismo althusseriano en sus clases impartidas en la Facultad de Filosofía y Letras de la UNAM; Raúl Olmedo, cuyo seminario sobre El Capital y su libro El anti-método: introducción a la filosofía marxista estuvieron inspirados en los aportes althusserianos; Enrique González Rojo, autor del volumen Para leer a Althusser y protagonista de una polémica con Sánchez Vázquez a propósito de su lectura del filósofo francés; Carlos Pereyra, quien llevó a cabo una incorporación de las tesis althusserianas a las cuales sometió a una corrección inspirada en el marxismo gramsciano y cuyas enseñanzas sobre Althusser se prolongaron en las producciones de sus alumnas Mariflor Aguilar y Corina Yturbe; y César Gálvez, profesor de filosofía que difundió el pensamiento de Althusser en la UMSNH emplazada en la localidad de Morelia ${ }^{74} 75$.

En los marcos del proceso de recepción mexicana de Althusser se produjo a comienzos de la década de 1980 un fenómeno que sólo adquiere relevancia al ser leído de manera retrospectiva. Bajo la dirección de Morales, un estudiante de la UNAM alcanzó su graduación como licenciado en filosofía con una tesis titulada "Filosofía y educación. Prácticas discursivas y prácticas ideológicas. Sujeto y cambio históricos en libros de texto oficiales para la educación primaria en México". El estudiante en cuestión, Rafael Sebastián

\footnotetext{
${ }^{74}$ Sobre Galvez y las lecturas de Althusser en Morelia, ver la presentación de Hugo Sáez Arreceygor a la reedición de un texto póstumo de aquel titulado "Notas para una teoría marxista de la filosofía", "Sobre líneas de demarcación trazadas por César Gálvez". Demarcaciones. Revista Latinoamericana de Estudios Althusserianos. № 1 , abril 2014, pp. 97-101.

75 Junto a estas lecturas, debe destacarse que otra vía privilegiada de ingreso de Althusser en México lo constituyeron los cursos dictados por Balibar en 1978 y 1979 en la Facultad de Economía de la UNAM. Balibar hizo referencia a dichos viajes y a los diálogos entablados con intelectuales mexicanos en la reciente visita a México en ocasión de la celebración de los cincuenta años de Lire Le Capital, ver "El infinito adiós al marxismo". Metapolítica. Septiembre de 2015.
} 
Guillén Vicente, reapareció catorce años más tarde dirigiendo un levantamiento indígena con el nombre de guerra de Subcomandante Marcos. La tesis consistía en un abordaje del sistema educativo mexicano a través de un análisis centrado en la ideología y los AIE. El trabajo estaba estructurado alrededor de cuatro núcleos problemáticos que dan cuenta de su filiación en los esquemas althusserianos: la práctica filosófica, la teoría de las ideologías, los mecanismos ideológicos dominantes y los análisis concretos. El análisis sobre el problema educativo se llevaba a cabo sobre materiales concretos, tales como informes de clases realizados por docentes. Asimismo la tesis intentaba dar cuenta de los efectos ideológicos en la constitución de los sujetos a través de un individuo genérico al cual su autor denominaba Juan Pérez ${ }^{76}$.

Debe mencionarse finalmente el trabajo de difusión de Althusser llevado a cabo por la filósofa mexicana Fernanda Navarro. Navarro había conocido a Althusser en París a comienzos de la década de 1980. Comenzó por entonces un vínculo intelectual que nos permite calibrar la especificidad de los itinerarios althusserianos en América Latina más allá de las décadas de 1960 y 1970. Althusser comenzó a trabajar junto a Navarro alrededor del materialismo aleatorio, tesis que marcará las reflexiones althusserianas de la época. Navarro tuvo acceso a los materiales inéditos de Althusser y mantuvo con el filósofo una relación epistolar que se extendió durante casi toda la década. El vínculo entre ambos filósofos tuvo como resultado el libro Filosofía y marxismo, el cual consistía en una larga entrevista de Navarro a Althusser. La edición de este volumen resulta sumamente significativa, en tanto constituyó la primera sistematización pública de Althusser alrededor del materialismo del encuentro. De este modo, los lectores latinoamericanos conocieron varios años antes que los europeos las transformaciones experimentadas por el althusserianismo luego de su período clásico. Divergencia, cabe destacar, que no obedece a circunstancias azarosas, en tanto la correspondencia mantenida entre ambos

\footnotetext{
${ }^{76}$ Para un análisis detallado de la tesis y una contextualización de su escritura en el escenario intelectual y mexicano de la época, ver Sáez Arreceygor, Hugo. "La tesis de filosofía del sub Marcos: una lectura de Althusser". Pacarina del Sur. Revista de Pensamiento Crítico Latinoamericano. Año 3, № 12, julio-septiembre 2012.
} 
da cuenta del interés de Althusser de que sus formulaciones alrededor del materialismo aleatorio se difundieran entre el público latinoamericano ${ }^{77}$.

Al igual que ocurrió en México con la lectura de Sánchez Vázquez, la recepción de Althusser en Brasil está marcada por un conjunto de reacciones contundentes frente a la penetración de las tesis del filósofo francés. Fenómeno que ha llevado a Michel Löwy a afirmar que el marxismo brasileño representa la principal excepción al entusiasmo latinoamericano por la relectura althhusseriana de Marx $^{78}$. Si bien esta aseveración debe ser matizada, es indudable que entre fines de 1960 y comienzos de 1970 se desarrolló en Brasil una fuerte oleada antialthusseriana, la cual se vuelve comprensible a partir de la marcada filiación gramsciana y lukacsiana de tradición marxista del país. En este marco pueden ser mencionados los trabajos Contra Althusser de José Arthur Giannotti, A situação de Althusser no pensamiento contemporáneo de Norma Bahia Pontes, O marxismo de Louis Althusser de Caio Prado Jr., O estruturalismo e a miséria da razão de Carlos Nelson Coutinho, Sobre Althusser de Luciano Zajdsznajder, Filosofia, ideología e realidade brasileira de Tarcísio Padilha y "Althusserianismo ou marxismo? A propósito do conceito de classes em Poulantzas" de Fernando Henrique Cardoso. Cabe señalar que junto a estos trabajos originales tuvieron una gran circulación las traducciones de obras críticas del althusserianismo como las de Thompson, Glucksmann y Sánchez Vázquez.

Sin embargo, como han rastreado Décio Saes y Luiz Eduardo Motta, la obra de Althusser fue objeto de un conjunto relevante de apropiaciones por parte de la izquierda brasilera ${ }^{79}$. Una lectura en el marco de una experiencia

\footnotetext{
77 Hemos profundizado aldedor de este problema en Starcenbaum, Marcelo. "La filosofía marxista entre Francia y América Latina: una lectura de la correspondencia entre Louis Althusser y Fernanda Navarro". Políticas de la Memoria. Anuario de Investigación del CeDInCl. N 15, Verano 2014/2015, pp. 107-121.

${ }^{78}$ Löwy, Michel. "Notas sobre a recepção crítica ao althusserianismo no Brasil (anos 1960 e 1970)". Elide Rugai Bastos, Marcelo Ridenti y Denis Rolland. Intelectuais: sociedade e política. São Paulo, Cortez, 2003, pp. 213-223.

${ }^{79}$ Saes, Décio. "O impacto da teoría althusseriana da história na vida intelectual brasileira". João Quartim de Moraes (org.). História do marxismo no Brasil. Volume III. Teoria. Interpretações. São Paulo, Editora da UNICAMP, 1998, pp. 11-122; Motta, Luiz Eduardo. "Presentación a 'Carlos Henrique Escobar: “¿Quién tiene miedo de Louis
} 
netamente política puede encontrarse en la experiencia de la organización armada Açao Popular. Se ha señalado al respecto que las tesis althusserianas acompañaron el pasaje de este agrupamiento desde las posiciones del cristianismo de izquierda hacia las del maoísmo ${ }^{80}$.

Cabe destacar asimismo el trabajo de recepción de la obra de Althusser llevada a cabo por el filósofo Carlos Henrique Escobar. Por un lado, Escobar fue el referente de un grupo de intelectuales brasileños que difundieron el althusserianismo desde la revista Tempo Brasileiro. Dentro de este grupo se econtraban Eginardo Pires, Alberto Coelho de Souza, Marco Aurélio Luz, Severino Bezerra Cabral Filho, Manoel Barros da Motta y Manuel Mauricio de Albuquerque. Junto a este trabajo, Escobar publicó cinco libros que se inscribían en el horizonte problemático abierto por la obra de Althusser: Proposições para uma semiologia e uma lingüística en 1973, Epistemologia das ciências hoje en 1975, As ciências e a filosofia en 1975, Discursos, instituições e história en 1975 y Ciência da história e ideología en $1978^{81}$.

Así como la recepción cubana de Althusser estuvo mediada en parte por la obra de Debray, el fenómeno análogo desarrollado en Chile no puede ser comprendido sin la importante labor de Harnecker. Efectivamente, su rol como traductora de las obras de Althusser y su actividad como divulgadora de las tesis althusserianas la volvieron una referencia indispensable en lo relativo a la circulación del filósofo francés en territorio chileno. Sin embargo, el trabajo desarrollado por Marcelo Rodríguez, José Ramírez y Cecilia Cortés ha iluminado algunas zonas de la recepción trasandina de Althusser que se ubican

\footnotetext{
Althusser? (1979)"'. Demarcaciones. Revista Latinoamericana de Estudios Althusserianos. $\mathrm{N}^{\circ} 1$, abril 2014, pp. 113-116.

${ }^{80}$ Un análisis de dicha articulación puede encontrarse en Ridenti, Marcelo. "O romantismo revolucionário da Ação Popular: do cristianismo ao maoísmo". Latin American Studies Association. Chicago, 1998.

${ }^{81}$ Como ha demostrado Néstor Arrúa, el althusserianismo tuvo también en Brasil un fuerte efecto en el campo del trabajo social, enfatizando el carácter científico de la disciplina, destacando el problema de la práctica y cuestionando la figura del experto, ver "El marxismo en clave althusseriana de los trabajadores sociales brasileños en los años setenta". VIII Jornadas de Historia de las Izquierdas - CeDINCI/UNSAM. 2015, pp. 315-332.
} 
más allá de la influencia del trabajo de Harnecker ${ }^{82}$. Por un lado, la lectura de Althusser propició efectos de ruptura tanto con el marxismo soviético, presente en las experiencias de formación de la militancia de izquierda, como con el marxismo neohegeliano, que se articulaba en las obras de importantes filósofos chilenos como Juan Rivano y Fernando Zavala. Por otro lado, el althusserianismo contribuyó a un proceso renovador en el terreno de la enseñanza de la filosofía, dominado hasta entonces por una práctica hermenéutica. Finalmente, el marxismo althusseriano produjo efectos importantes en el campo de la práctica política, impugnando las nociones etapistas y la concepción de la vía pacífica al socialismo.

\subsection{Althusser en Argentina: de los relatos canónicos a las indagaciones contemporáneas}

Como veremos a lo largo de la tesis, la discusión acerca de la singularidad de los itinerarios de Althusser en Argentina formó parte del propio proceso de recepción del filósofo francés en nuestro país. A medida que el pensamiento althusseriano se difundía en distintos espacios políticos e intelectuales, los sujetos implicados en dicho fenómeno fueron elaborando relatos acerca de las particularidades de las lecturas propias y ajenas. Ahora bien, por tratarse de discursos configurados a la par del proceso receptivo, estos relatos se caracterizaron principalmente por la búsqueda de potencialidades y limitaciones en los usos que los intelectuales argentinos realizaban del pensamiento de Althusser.

Si dejamos de lado estas interpretaciones, que están inscriptas en nuestro propio objeto de estudio, podemos afirmar que las primeras reconstrucciones sobre los itinerarios de Althusser en Argentina se desarrollaron en la segunda mitad de la década de 1980. Estos primeros esbozos están delineados por dos aspectos característicos de los marcos en los cuales se inscriben. El primero de ellos es que forman parte de

\footnotetext{
${ }^{82}$ Rodríguez, Marcelo; Ramírez, José; Cortés, Cecilia. "Lecturas de Althusser en Chile (notas preliminares)". Ramal. Revista de filosofía y crítica. № 1, Diciembre 2013, pp. 49.
} 
reconstrucciones más amplias de la vida intelectual y política argentina en la segunda mitad del siglo XX. El segundo es que son realizados por intelectuales que habían sido protagonistas de la recepción de Althusser en las décadas de 1960 y 1970.

Uno de ellos se encuentra en el marco de la reconstrucción de los itinerarios de Gramsci realizado por Aricó en su libro La cola del diablo. Circunscripta a la experiencia de las militancias de izquierda de fines de la década de 1960, la alusión de Aricó a los itinerarios de Althusser está estructurada alrededor de tres hipótesis. La primera está relacionada con un efecto de sutura entre política y cultura. De acuerdo a esta lectura, el althusserianismo habría contribuido a superar la escisión entre las dimensiones cultural y política de la vieja izquierda a través de la reducción de la teoría a una ideología legitimadora de la práctica política. Según Aricó, una generación de militantes habría encontrado en las elaboraciones teóricas de Althusser "la base doctrinaria y política para una acción caracterizada por su extremo voluntarismo" ${ }^{83}$. Leída desde las transformaciones de la izquierda en la década de 1980, la relectura cientifizadora de Marx se presentaba como una reformulación de las matrices clásicas del marxismo-leninismo. De allí que Aricó se centrara en el reforzamiento que el althusserianismo propiciaba de las posiciones vanguardistas. La izquierda argentina habría visto en el marxismo althusseriano la posibilidad de refundar su condición de portadora de una verdad científica en un contexto signado por la crisis del stalinismo y el surgimiento de procesos revolucionarios por fuera de la órbita soviética.

Según el recorrido propuesto por Aricó, la recepción de Althusser habría tenido un efecto contradictorio. Por un lado, el althusserianismo le habría devuelto el prestigio a los aspectos teóricos del marxismo luego de la sospecha que se cernía sobre ellos desde la experiencia stalinista. A través de su anclaje en el estructuralismo, el althusserianimo habría favorecido una inflexión en la tradición marxista centrada en el registro de la teoría. Por otra parte, Althusser habría contribuido a consolidar en sus posiciones ideológicas a las vanguardias

${ }^{83}$ Aricó, José. La cola del diablo. Itinerario de Gramsci en América Latina. Buenos Aires, Siglo XXI, 2005, p. 130. 
desprendidas de los partidos de izquierda tradicionales. Es por ello que una relectura de Marx que se pretendía científica habría terminado ligada al accionar de organizaciones guerrilleras que se creían depositarias de una tarea histórica incumplida. La coronación de la reconstrucción de Aricó evidencia que la constatación de dicha contradicción está realizada principalmente sobre las elaboraciones de Debray: "nadie ignora el papel desempeñado por los escritos de Régis Debray en la formulación de una propuesta estratégica global revolucionaria que fusionaba elementos del 'foquismo' de matriz guevarianocastrista con las ideas de Althusser"84 85 .

El otro esbozo reconstructivo al que nos referimos se encuentra en Nuestros años sesentas de Oscar Terán. Las menciones al lugar de Althusser en la cultura argentina allí realizadas son escuetas, dado que su análisis de la experiencia de la nueva izquierda intelectual se cierra con el golpe de Estado de 1966. Sin embargo el contrapunto que se establece en el libro entre las formaciones marxistas de fines de la década de 1950 y principios de la de 1960 con las que se impondrán en la segunda mitad de los sesentas, así como el hecho de que las primeras lecturas de Althusser en Argentina sean previas al golpe de Onganía, llevan a Terán a pronunciarse acerca de los itinerarios del althusserianismo en nuestro país. Su hipótesis es que la obra de Althusser tuvo dificultades para ingresar en la vida intelectual argentina debido a la fuerte presencia en la nueva izquierda de un voluntarismo humanista revolucionario. Terán llega a dichas afirmaciones luego de haber reconstruido el lugar del hombre y la voluntad en un conjunto de agrupamientos políticos e intelectuales que abrevaban en las tradiciones sartreana y guevarista. Al respecto el libro reconstruye el proceso a través del cual el humanismo historicista de los años cincuenta se encuentra con la noción de revolución de los años sesenta dando lugar a un humanismo optimista que permeará el discurso marxista de la época. Una formación intelectual que propiciaba un rescate del hombre como sujeto soberano y que se esforzaba por tanto en desembarazar al marxismo de

${ }^{84}$ Ibid., p. 131-132.

${ }^{85}$ La alusión de Aricó también incluía una reflexión acerca de la relación entre los itinerarios de Alhusser y Gramsci en Argentina y América Latina. Sin embargo, dado que esa relación es el objeto de nuestro análisis sobre Pasado y Presente, atendemos las afirmaciones de Aricó al comienzo del capítulo dedicado a dicha experiencia. 
sus lastres positivistas reforzando la unidad entre teoría y práctica, no podía más que establecer un vínculo conflictivo con una corriente marxista como la althusseriana.

Terán remitía a Masotta y su movimiento de apertura al estructuralismo, pero también de cautela frente al abandono del compromiso, a los fines de ejemplificar "la encrucijada en la que se hallaron algunos intelectuales de franja crítica de la cultura argentina entre las demandas de lo que entendían era la actualizada adopción de nuevos códigos teóricos y las de una moral pública atraída con fuerza por los deberes de la política" 86 . De acuerdo a su lectura, el estructuralismo habría abierto dos frentes conflictivos entre los intelectuales argentinos. Por un lado, impugnando el antropocentrismo reinante en la cultura de izquierdas de la época. El énfasis en los procesos de sujeción del hombre era difícilmente compatible con la creencia en la capacidad del hombre de transformar su entorno de acuerdo a su voluntad. En este mismo sentido, el estructuralismo centraba su análisis en los mecanismos ideológicos de sujeción a la vez que carecía de una explicación del cambio histórico. Desbalance que tornaba sospechosa a esta tradición en un contexto en el cual existía una fuerte confianza en la capacidad de los seres humanos para organizarse y llevar a cabo transformaciones políticas y sociales.

Si bien las menciones realizadas por Aricó y Terán permiten iluminar algunas vías de ingreso de Althusser en Argentina y ofrecen algunos ejes explicativos para comprender dicho proceso, los recorridos propuestos se nos revelan como limitados en ambos sentidos. Por un lado, porque las instancias seleccionadas están lejos de agotar los canales a través de los cuales el pensamiento althusseriano fue recepcionado en la cultura argentina. Si bien las organizaciones armadas y los intelectuales sartreanos fueron importantes en la difusión y problematización de los aportes althusserianos, estuvieron lejos de ser los únicos sujetos inscriptos en este proceso. Lo mismo cabe decir de las conclusiones analíticas. Si bien se produjeron articulaciones entre el althusserianismo y la lucha armada, así como un rechazo del pensador francés

86 Terán, Oscar. Nuestros años sesentas. La formación de la nueva izquierda intelectual argentina, 1956-1966. Buenos Aires, El Cielo por Asalto, 1993, p. 108. 
por parte de intelectuales pertenecientes a la tradición sartreana, los efectos del pensamiento de Althusser fueron más complejos de lo que se desprende de estos relatos. Por un lado, porque la circunscripción a una sola instancia de recepción conlleva una generalización a partir de procesos singulares. De este modo, si uno atiende la reconstrucción de Aricó, podría concluir que el althusserianismo fue hegemónico en la izquierda argentina. Ahora si solo lee el recorrido de Terán, podría creer que el althusserianismo fue duramente resistido. Por otro lado, porque las lecturas realizadas por aquellos sujetos son absolutizadas, bloqueando la advertencia de matices o de transformaciones en un plano diacrónico. Como veremos más adelante, existieron articulaciones entre althusserianismo y lucha armada que excluyeron explícitamente las formulaciones de Debray. En el mismo sentido, veremos que la tensión de Masotta entre conciencia y estructura se resolverá posteriormente a favor de la última, operando precisamente el althusserianismo como legitimador de una intervención intelectual centrada en la teoría.

Gran parte de estas limitaciones se deben indudablemente al cariz autorreferencial de estos relatos y a las marcas epocales que los delinearon. En este sentido, La cola del diablo y Nuestros años sesentas deben ser captados como reconstrucciones históricas pero también como balances políticos de la experiencia de la nueva izquierda argentina. En tanto lo que allí se trataba de pensar eran las particularidades de un proyecto colectivo que había sido duramente derrotado, las historizaciones allí desplegadas tendieron a superponerse con miradas autocríticas sobre las propias experiencias políticas. De allí que una parte significativa de las reconstrucciones coincidieran con las discusiones por ellos sostenidas en las décadas de 1960 y 1970. Como veremos en el capítulo tercero, los términos de la reconstrucción de los itinerarios del althusserianismo de Nuestros años sesentas coinciden con los de la lectura que Terán hacía de Althusser en 1969. Desde las páginas de Los Libros un joven Terán sartreano y guevarista sospechaba de una relectura de Marx que tendía a sujetar al hombre y no ofrecía una teoría del cambio social ${ }^{87}$.

${ }^{87}$ Ver asimismo cómo una evocación de su encuentro con Althusser replica la reconstrucción ofrecida en Nuestros años sesentas. En 1996 respondía de la siguiente 
Del mismo modo estos relatos reconstruyeron los itinerarios de Althusser en Argentina desde un ángulo en el que se condensaban las transformaciones experimentadas por la izquierda en la década de 1980. El fenómeno que nos interesa estudiar fue aprehendido por una mirada que tendía a detectar los errores de la nueva izquierda y procesarlos en un horizonte político más democrático que revolucionario. De allí la preponderancia que adquiría la cuestión del vanguardismo en Aricó, al cual el althusserianismo habría venido a reforzar, y el problema del voluntarismo en Terán, con la cual el pensamiento de Althusser habría entablado vínculos conflictivos ${ }^{88}$.

Otro momento propicio para la reconstrucción de los itinerarios de Althusser en Argentina lo constituyó la publicación en 1993 de la autobiografía del filósofo francés. En aquel entonces el suplemento cultural del diario Clarín publicó una reseña de El porvenir es largo. Junto a ella se reproducía un artículo del filósofo Dardo Scavino en el que se repasaba los efectos del pensamiento althusseriano entre los intelectuales argentinos. El recorrido propuesto por Scavino contenía un par de señalamientos sugerentes. Por un lado, allí se afirmaba que en la segunda mitad de la década de 1960 un conjunto de intelectuales argentinos se habían dedicado a estudiar y difundir el pensamiento althusseriano. Entre ellos Scavino mencionaba a Sciarreta y Malamud, lo cual resulta relevante dado el que poco interés que estas figuras despertaban en las historizaciones de la izquierda argentina de los años sesentas. Por otro lado, se subrayaba un efecto del althusserianismo en

manera una pregunta acerca de sus lecturas de la década de 1960: "El Capital quedaría para 1965 aproximadamente, bajo la impronta de Pour Marx y Lire Le Capital, aunque para la recepción de Althusser me encontré con un obstáculo epistemológico y otro de diverso tenor: en el primer aspecto, mi posicionamiento 'humanista' frente a los avances del estructuralismo, y en el otro el golpe militar de 1966 (que implicó entre tantas cosas la disolución del grupo de lectura de El Capital que poco antes había empezado a funcionar en el Instituto de Filología)". "Oscar Terán". Alejandro Herrero y Fabián Herrero. Las ideas y sus historiadores. Un fragmento del campo intelectual en los años noventa. Santa $\mathrm{Fe}$, Centro de Publicaciones / Universidad Nacional del Litoral, 1996, p. 155.

${ }^{88}$ Hemos reconstruido la convergencia entre historización y autocrítica en la obra de Terán en Starcenbaum, Marcelo. "Historia, política y responsabilidad. Oscar Terán y la autocrítica entre los intelectuales de izquierda en Argentina". Temas de Nuestra América. Revista de Estudios Latinoamericanos. № 51-52, Julio-diciembre de 2012, 143-160. 
argentina que permitía una interrogación acerca de su recepción en la cultura psicoanalítica. Al respecto Scavino aseguraba que Althusser tenía el efecto de cerrarle el camino a la síntesis entre Marx y Sartre para abrir el de la relación entre Marx y Freud. De esta manera el althusserianismo proporcionaba herramientas para un diálogo entre marxismo y psicoanálisis distinto a los que por entonces ofrecían ejercicios teóricos como los de Reich o Marcuse.

Si bien el repaso de Scavino daba lugar a los efectos productivos del althusserianismo, la mayor parte de su artículo estaba destinado a evidenciar la resistencia que los intelectuales argentinos mostraron frente a la obra de Althusser:

con todo, aquí fue menos importante la existencia de una corriente althusseriana que el impacto de su pensamiento sobre la intelectualidad marxista. Porque, a decir verdad, hacia fines de los sesenta, y para muchos de estos intelectuales, Althusser traía la peste. Esa peste se llamaba 'estructuralismo,89

En sintonía con la reconstrucción realizada por Terán, Scavino destacaba las dificultades del althusserianismo por compatibilizar con una formación intelectual marcada por el existencialismo. Si bien esta dificultad habría sido compartida por todos los autores ligados a la corriente estructuralista, el caso de Althusser habría sido más complejo dada su filiación marxista. El rechazo sufrido por la obra de Althusser habría sido más contundente que el experimentado por la de Levi-Strauss o Lacan. Esto se debía, según Scavino, al desarrollo en la cultura de izquierdas argentina de fines de los cincuenta y principios de los sesentas de un marxismo estructurado alrededor de lecturas de Sartre y el joven Marx. Por ello la intelectualidad marxista argentina no podía sino entablar una relación conflictiva con un pensamiento que trataba con desdén problemas tan caros a ella como la conciencia, la praxis y la alienación.

Habrá que esperar hasta fines de la década de 1990 para contar con una reconstrucción abarcativa de las instancias de recepción del pensamiento althusseriano y un análisis complejo de las particularidades de dicho fenómeno.

${ }^{89}$ Scavino, Dardo. "Louis Althusser: ecos de una polémica. Un pensamiento renovador en la Argentina". Clarín. Suplemento Cultura y Nación. Jueves 4 de marzo de 1993, p. 8. 
Esta tarea fue realizada por Horacio Tarcus en un trabajo que repasaba la historia del marxismo preparado para la Historia crítica de la literatura argentina dirigida por Noé Jitrik ${ }^{90}$. El abordaje que allí se propiciaba resulta significativo dado que la estación althusseriana del marxismo argentino se convertía en un momento específico de la historia intelectual de nuestro país. Es decir, la recepción del Marx estructural tenía, al igual que la del Marx sartreano o el Marx gramsciano, sus propios sujetos y sus propias discusiones. A diferencia de las interpretaciones anteriores, el análisis de Tarcus evitaba la postulación del althusserianismo como mero elemento disruptor o reforzador de tradiciones preexistentes. De este modo, la captación del althusserianismo argentino como un momento en sí mismo permitía comprenderlo a partir de sus particularidades en lugar de juzgarlo a través de elementos externos, ya sea el voluntarismo humanista o el vanguardismo izquierdista.

Si bien escueta, dada la particularidad del texto en el que se enmarcaba, la reconstrucción de Tarcus mencionaba la mayoría de los espacios en los cuales la obra de Althusser había tenido algún efecto. El recorrido se detenía en la importancia que el althusserianismo había tenido en los campos de las ciencias sociales, la teoría literaria y la epistemología, además de la cultura psicoanalítica y la experiencia de la nueva izquierda. Centrándose en este último espacio, Tarcus señalaba que el marxismo althusseriano había sido asimilado principalmente por formaciones políticas de corte guevarista, proceso en el que las formulaciones de Debray tenían un rol destacado, y maoísta, fenómenos que ejemplificaba con la revista Los Libros. Junto a esta identificación, el texto de Tarcus hacía ingresar dos dimensiones de la recepción de Althusser que eran sumamente interesantes. Una de ellas era el vínculo complejo entre el marxismo althusseriano y los intelectuales comunistas. Al respecto, Tarcus hablaba con justeza de Althusser como una vía de aggiornamiento teórico para la antigua ortodoxia comunista. Como veremos en el próximo capítulo, este será el sentido que tendrá la lectura de García Barceló en la primera mitad de la década de 1970. La segunda remite a

90 Tarcus, Horacio. "El corpus marxista". Susana Cella (dir.). Historia crítica de la literatura argentina. Volumen 10. La irrupción de la crítica. Buenos Aires, Emecé, 1999, pp. 465-500. 
la cuestión que aparecía como prioritaria en las reconstrucciones de Terán y Scavino, es decir el vínculo conflictivo entre las formulaciones althusserianas y una intelectualidad formada en la tradición fenomenológica. Fenómeno ejemplificado por Tarcus con la lectura de Rozitchner y el debate entre Masotta, Verón y Sebreli, los cuales trabajaremos en el capítulo quinto.

Junto a la reconstrucción realizada por Tarcus, nuestro trabajo se referencia en el único análisis sistemático de la recepción argentina de Althusser: el libro In the Shadow of Althusser: Culture and Politics in Late Twentieth-Century Argentina de la investigadora estadounidense Anna Popovitch $^{91}$. Este trabajo analiza el lugar ocupado por Althusser en la teorización de los vínculos entre política y cultura por parte de la nueva izquierda en las décadas de 1960 y 1970. La investigación de Popovitch está guiada por el presupuesto de que si bien la intervención althusseriana es un hecho del pasado, la indagación historiográfica acerca de la productividad teórica e intelectual de dicha intervención constituye una tarea tan legítima y necesaria. De esta manera, la reconstrucción realizada por la autora se desenvuelve a través de un esquema que contempla la caracterización del althusserianismo como una tradición político-intelectual situada y el impacto de dicha tradición entre los intelectuales argentinos. El mayor aporte del libro lo constituye, sin lugar a dudas, el análisis del lugar del althusserianismo en lo que la autora denomina la constelación cognitiva de la historia intelectual argentina de las décadas de 1960 y 1970. Es decir, aquella configurada por la radicalización política, la modernización cultural y las dictaduras militares, la que propició una corriente de crítica socio-cultural vinculada a ideologías de izquierda.

Como expresión privilegiada de dicha constelación, la autora analiza la experiencia de la revista Los Libros con el objetivo de delimitar los efectos de la lectura de Althusser entre los intelectuales de la nueva izquierda argentina. En esta dirección, la reconstrucción del proceso de recepción da cuenta, por ejemplo, de la eficacia política de la caracterización de los sindicatos peronistas como AIE. Popovitch demuestra que la utilización de la teoría althusseriana de

${ }^{91}$ Ann Arbor, UMI Dissertation Publishing, 2011. 
la ideología por parte de los intelectuales maoístas tenía un sentido claramente performativo en tanto reforzaba la afinidad política con las experiencias del sindicalismo clasista. Asimismo, la autora analiza el rol del althusserianismo en el proceso de modernización de la crítica literaria. Evidencia, al respecto, que la asunción de posiciones althusserianas redundó en una rearticulación de los vínculos entre crítica y política en un sentido opuesto a las fórmulas canónicas de la estética marxista. A través del repaso de las lecturas de la literatura argentina realizadas por los miembros de la revista, Popovitch da cuenta de los efectos de Althusser en la impugnación de las concepciones humanistas de la literatura, en la deslegitimación de aproximaciones centradas en el autor y en la apertura hacia el análisis de los diversos factores implicados en el proceso de producción literaria.

\subsection{Historia intelectual y recepción de ideas}

Ya constituye un lugar común afirmar que desde hace varias décadas la tradicional historia de las ideas ha sido reemplazada por una mirada sobre los fenómenos intelectuales que trasciende el mero registro del pensamiento. La historia intelectual comenzó a desarrollarse en los años 1980 como una perspectiva que retomaba de manera productiva herramientas pertenecientes a la historia de las ideas, la historia de la filosofía, la historia de las mentalidades y la historia cultural. Esta productiva matriz analítica logró imponerse a los estudios tradicionales que se limitaban a exponer de manera cronológica el sistema de ideas de un autor o de una corriente de pensamiento. En este sentido, los trabajos desarrollados por la historia intelectual se interesan tanto por las obras como por sus autores y el contexto bajo en cual ellas se produjeron. Como afirma François Dosse, esta perspectiva se caracteriza por el rechazo de "la alternativa empobrecedora entre una lectura interna de las obras y una aproximación externa que priorice únicamente las redes de sociabilidad" 
proponiendo en cambio "dar cuenta de las obras, de los recorridos, los itinerarios, más allá de las fronteras disciplinares"92.

Es evidente que al tratarse de un campo de estudios consolidado a lo largo de varias décadas y con desarrollos en las academias de los cinco continentes, no existe una visión unificada sobre los modos en los cuales deben calibrarse las diversas dimensiones inherentes a los fenómenos de producción y circulación de ideas. Nos interesa destacar, sin embargo, que la premisa que nuclea a las diferentes corrientes desarrolladas en los marcos de la historia intelectual es la de la necesidad de atender la multiplicidad de registros implicados en la práctica de los intelectuales. Es precisamente en esta dirección que se han esbozado las formulaciones programáticas de los principales referentes del campo. De acuerdo a Robert Darnton, la historia intelectual conjunta

la historia de las ideas -el estudio del pensamiento sistemático, por lo general en los tratados filosóficos-, la historia intelectual propiamente dicha -el estudio del pensamiento informal, los climas de opinión y los movimientos literarios-, la historia social de las ideas -el estudio de las ideologías y la difusión de la idea- y la historia cultural -la historia de la cultura en el sentido antropológico, incluyendo las ideas del mundo y las mentalités colectivas $^{93}$

En este mismo sentido Pascal Ory y Jean-François Sirinelli se han referido a la historia intelectual como una perspectiva que pretende anudar "arqueología, geografía y genealogía" ${ }^{4}$. Es decir, que está interesada en dar cuenta de la relación existente entre generaciones, preocupada por los lugares y las redes de producción intelectual y atenta a los vínculos que los intelectuales establecen con el pasado. En este mismo sentido Christophe Prochasson ha destacado que la historia intelectual pone en evidencia que "un texto o una

\footnotetext{
92 Dosse, François. La marcha de las ideas. Historia de los intelectuales, historia intelectual. Valencia, Universitat de València, 2007, p. 14.

${ }^{93}$ Darnton, Robert. "Intellectual and Cultural History". Michael G. Kammen. The Past Before Us. Contemporary Historical Writing in the Unites States. Ithaca, Cornell University Press, 1980, p. 337.

${ }^{94}$ Ory, Pascal y Sirinelli, Jean- François. Les Intellectuels en France. De l'affaire Dreyfuss à nos jours. París, Armand Colin, 1986, p. 241.
} 
obra constituyen una creación social, responden a leyes de producción perceptibles y cumplen una función social en un momento dado, el cual determina su 'éxito' o su fracaso" ${ }^{95}$. Por tanto, esta perspectiva evita concentrarse en la genética de las producciones intelectuales o en las condiciones sociales de la elaboración intelectual. Al contrario, integra ambas dimensiones en un marco analítico que permite expresar al mismo tiempo la especificidad de las ideas elaboradas y los condicionamientos que posibilitan dicha elaboración.

El abordaje multidimensional de la producción y difusión de las ideas propiciado por la historia intelectual ha conllevado un conjunto de transformaciones en los modos de aproximarse al fenómeno intelectual. El desplazamiento desde una mirada centrada en la secuencia temporal de las ideas hacia una perspectiva interesada en sus encarnaciones temporales ha redundado en una jerarquización de los sujetos portadores de las ideas. Es por ello que gran parte de la atención de los estudios de historia intelectual se han concentrado tanto en los grandes autores como en aquellos implicados en el proceso de difusión de ideas, tales como editores y traductores. De la misma manera, han atendido tanto a los grandes textos como a los canales de difusión considerados anteriormente menores, tales como la correspondencia y el periodismo. Esta complejización ha posibilitado la legitimación de aproximaciones a ideas que no tuvieron el rasgo de hegemónicas. Tal como afirma Tarcus en su original estudio sobre la recepción argentina de Mariátegui, "más que a las grandes ideas-núcleo de una época, quisimos reconstruir una trama más amplia, tratando de restituir a muchas de ellas su rol de ideas hegemónicas, pero al lado de otras que aparecen como residuales, emergentes o contra hegemónicas" $"$.

Abordados desde lo marcos de la historia intelectual, los fenómenos de recepción de ideas remiten a procesos de producción y difusión intelectual en los cuales intervienen sujetos forjadores y receptores de ideas. Tal como ha

\footnotetext{
${ }^{95}$ Prochasson, Christophe. "Héritages et trahisons: la réception des œuvres". Mil neuf cent. Revue d'histoire intellectuel. Vol. 12, № 1, 1994, p. 5.

${ }^{96}$ Tarcus, Horacio. Mariátegui en Argentina o las políticas culturales de Samuel Glusberg. Buenos Aires, El Cielo por Asalto, 2001, p. 7.
} 
sistematizado Tarcus en su trabajo sobre la recepción de Marx en Argentina, "dentro del proceso global de producción y circulación de las ideas, podemos distinguir no etapas temporales sucesivas sino distintos momentos, a cada uno de los cuales corresponde cierto tipo de intelectuales, eso es, sujetos especificos que desarrollan capacidades y habilidades concretas" ${ }^{\prime \prime}$. De este modo es posible hablar de un momento de producción, en el cual una idea es elaborada en un contexto determinado; uno de difusión, en el cual la idea es puesta a circular a través de un soporte material; uno de recepción, en el cual un sujeto o un grupo ubicados en otro contexto se sienten interpelados por la idea; y uno de apropiación, en el cual la idea es sometida a una lectura. En términos de Pierre Bourdieu, la circulación internacional de las ideas está sometida a un conjunto de factores estructurales que son generadores de malentendidos. Dichos equívocos creadores derivan del hecho de que los textos circulen sin el contexto del cual son producto y sean reinterpretados de acuerdo a las características del contexto de recepción. Tal como ha afirmado en el texto que se ha vuelto canónico para la interpretación de fenómenos de recepción de ideas, "para comprender una obra, es necesario comprender en primer lugar la producción, el campo de producción y la relación entre el campo en el cual ha sido producida y el campo en el cual es recibida o, más precisamente, la relación entre las posiciones del autor y del lector en sus campos respectivos" ${ }^{\prime \prime 8}$.

Los fenómenos de recepción de ideas quiebran la certeza según la cual alcanzaría partir únicamente de la intención de un autor y del contenido de sus significaciones, en tanto la historia intelectual atiende tanto este contenido como las apropiaciones y contrasentidos que generan en aquellos en los que las significaciones son recibidas. En términos de Martin Jay, la riqueza de estos fenómenos obliga a eludir "la falacia de que la originalidad es siempre una virtud evidente por sí misma" y a reconocer en cambio "la enmarañada madeja de las lecturas y las apropiaciones erróneas que caracterizan la circulación de

\footnotetext{
${ }^{97}$ Tarcus, Horacio. Marx en Argentina. Sus primeros lectores obreros, intelectuales y científicos. Buenos Aires, Siglo XXI, 2007, p. 30.

98 Bourdieu, Pierre. "Las condiciones sociales de la circulación de las ideas". Intelectuales, política y poder. Buenos Aires, EUDEBA, 1999, p. 199.
} 
cualquier idea idea o creación cultural que merezca ser estudiada" 99 . El hecho de que la historia de los efectos de un texto sea más una crónica de sucesivas malas interpretaciones que la reproducción perfecta del texto original, implica que la interpretación de un fenómeno de recepción no radique tanto en la recuperación de la intencionalidad original del autor como en la reconstrucción de la productividad de los encuentros entre el texto y sus receptores. Las verdades de un texto comprendido en una historia abarcan tanto las ortodoxias como los contrasentidos y las disidencias. Una particularidad que implica, como afirma Christophe Prochasson, que "el texto se inscriba siempre en un horizonte de expectativas que condiciona la historia de su recepción en su tiempo y en su devenir" ${ }^{100}$. De allí que el trabajo histórico a realizar no consista en valorar si los sujetos leyeron correctamente o incorrectamente a un autor, sino más bien en establecer cómo lo leyeron y por qué lo leyeron.

Con respecto a la singularidad de la lectura, Roger Chartier ha destacado que la producción de sentido operada por un lector está sometida a un conjunto de coacciones. En primer lugar, los efectos de sentido pretendidos por los propios textos a través de los dispositivos de enunciación. En segundo lugar, los desciframientos que dan a leer la obra. Finalmente, las convenciones de interpretación propias de un tiempo o una comunidad ${ }^{101}$. Si bien los estudios de recepción atienden especialmente a los malentendidos generados por la circulación de las ideas entre contextos diferentes, debe enfatizarse el hecho de que la singularidad del texto favorece determinadas recepciones al tiempo que dificulta otras. Como afirma Jay, "la potencialidad para las distorsiones específicas que se producen puede considerarse como latente en el texto

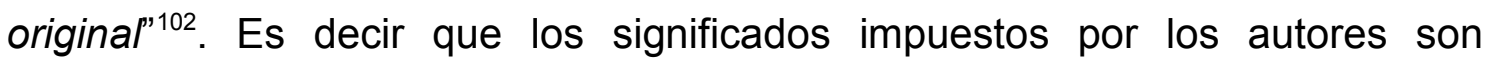
transgredidos por los lectores pero las invenciones se desarrollan sobre un

\footnotetext{
${ }^{99}$ Jay, Martin. Campos de fuerza: entre la historia intelectual y la crítica cultural. Buenos Aires, Paidós, 2003, p. 16.

${ }^{100}$ Prochasson, Christophe. "Héritages et trahisons: la réception des œuvres". op. cit., p. 6.

${ }^{101}$ Chartier, Roger. Escribir las prácticas. Foucault, de Certeau, Marin. Buenos Aires, Manantial, 2006, p. 97.

102 Jay, Martin. "¿Debería la historia intelectual tomar un giro lingüístico? Reflexiones sobre el debate Habermas-Gadamer". Socialismo fin-de-siècle y otros ensayos. Buenos Aires, Nueva Visión, 1990, p. 46.
} 
trasfondo históricamente determinado. Esta particularidad de la lectura ha sido interpretada por Chartier en clave de un juego permanente entre libertades y restricciones:

contra un visión simplista que supone la servidumbre de los lectores respecto de los mensajes inculcados, se recuerda que la recepción es creación, y el consumo, producción. Sin embargo, contra la perspectiva inversa que postula la absoluta libertad de los individuos y la fuerza de una imaginación sin límites, se recuerda que toda creación, toda apropiación, está encerrada en las condiciones de posibilidad históricamente variables y socialmente desiguales. De esta doble evidencia resulta el proyecto fundamental, que cree descubrir cómo, en contextos diversos y mediante prácticas diferentes (escritura literaria, la operación historiográfica, la manera de leer), se establece el paradójico entrecruzamiento de restricciones transgredidas y libertades restringidas ${ }^{103}$

Como afirma Michel de Certeau, el hecho de que la lectura tenga un carácter activo transforma a la lectura en una peregrinación en un sistema impuesto, a través del cual el lector no pretende el sitio del autor, sino que inventa en los textos algo distinto de su intención original dando lugar a la posibilidad de una pluralidad de significaciones ${ }^{104}$.

En tanto proporcionan el horizonte de recepción de un texto, las traducciones constituyen un elemento destacado para los estudios de circulación internacional de ideas. Como ha enfatizado Rainer Rochlitz, la experiencia del traductor no se reduce únicamente al aspecto técnico, sino que, al hacer pasar ideas escritas en y para un contexto específico a otro contexto en el que esas ideas no son totalmente familiares, esa experiencia se dota de una función cultural ${ }^{105}$. En términos de François Cusset, las dificultades inherentes a la traducción imponen al traductor un metadiscurso de justificación, autocrítica o aclaración que tienden a ubicarlo más allá de sus prerrogativas. Es por ello que en los procesos de recepción de ideas el

${ }^{103}$ Chartier, Roger. Cultura escrita, literatura e historia. México D.F., Fondo de Cultura Económica, 1999, pp. 14-15.

${ }^{104}$ De Certeau, Michel. La invención de lo cotidiano. I. Artes de hacer. México D.F., Universidad Iberoamericana-ITESO, 2007, p. 182.

${ }^{105}$ Rochlitz, Rainer. "Traduire les sciences humaines". Raisons Politiques. Etudes de pensée politique. $\mathrm{N}^{\circ}$ 2, Mayo 2001, p. 74. 
traductor trasciende su rol como transliterador para convertirse también en hermeneuta: "la astucia que debe demostrar supone una manera de reemplazar la imposible neutralidad de un simple traspaso semántico por el gesto más voluntario, más afirmativo, de una apropiación"106. En este mismo sentido Chartier ha constatado que a través de las traducciones pueden literalmente crearse autores, siendo precisamente el autor creado y no el del contexto de origen el que concentra la atención de los estudios de recepción de ideas $^{107}$.

Explicitemos finalmente dos consideraciones relativas a los problemas de la historia intelectual y la recepción de ideas que han sido fundamentales al momento de llevar a cabo nuestra investigación. Una de ellas está relacionada con la calibración del vínculo entre ideas y contexto. Como se desprende del repaso realizado, la operativización de una perspectiva analítica que tiende a situar la producción y difusión de ideas en un marco histórico que vuelve a estos fenómenos inteligibles ha tenido un efecto altamente productivo en el campo de la historia intelectual. En este sentido Peter Burke ha destacado a la historia social y cultural de las ideas como una alternaiva efectiva frente a corrientes, como la escuela de Cambridge de John Pocock y la Begriffsgeschichte de Reinhart Koselleck, que tendían a cincunscribir el análisis al registro del pensamiento ${ }^{108}$. Es precisamente la consolidación de esta tercera vía la que permite hablar de un giro contextual a través del cual la mirada de la historia intelectual comenzó a detenerse cada vez más en las circunstancias y las situaciones de la producción y difusión de ideas ${ }^{109}$. Si bien este desplazamiento no acarreaba un desbalance en contra del análisis de las ideas, el giro material que experimenta el campo desde hace ya algunos años ha contribuido a un alejamiento progresivo de los problemas relativos al registro

106 Cusset, François. French Theory. Foucault, Derrida, Deleuze \& Cia y las mutaciones de la vida intelectual en Estados Unidos. Barcelona, Melusina, 2005, p. 101.

${ }^{107}$ Chartier, Roger. Cultura escrita, literatura e historia. op. cit., p. 92.

${ }^{108}$ Burke, Peter. "La historia intelectual en la era del giro cultural". Prismas. Revista de historia intelectual. $\mathrm{N}^{\circ} 11,2007$, pp. 159-160.

${ }^{109}$ Burke, Peter. "Context in Context". Common Knowledge. Vol. 8, № 1, 2002, p. 164. 
del pensamiento ${ }^{110}$. La focalización en dimensiones tales como la cultura impresa, la circulación de libros y las prácticas de consumo han confinado a las ideas a un lugar cada vez más secundario. Dicho solapamiento constituye un movimiento que termina desvirtuando el impulso de apertura hacia la dimensión contextual y material de la producción y difusión de ideas. Como puede verse en las reflexiones de Dominick LaCapra hacia mediados de la década de 1980, la necesidad de atender aquellas dimensiones obedecía al primado de un modo reduccionista de aproximarse a textos complejos. Reducción que adquiría la forma de un acercamiento documental que se conformaba con análisis sinópticos de los contenidos ${ }^{111}$. Creemos al respecto que ciertas tendencias que se advierten en el campo se aproximan peligrosamente a la inversión de aquel movimiento. Es decir, una atención desproporcionada a los condicionamientos contextuales y la materialidad de las ideas que ensombrece las operaciones propias del registro del pensamiento. Es por ello que nuestro recorrido da cuenta de la necesaria inscripción contextual y material de las ideas a la vez que jerarquiza la especificidad de los conceptos y las filiaciones teóricas.

La segunda consideración está vinculada con el peso que tienen actualmente las perspectivas sociológicas en el campo de la historia intelectual. Si bien la propuesta de Bourdieu en lo relativo a la circulación internacional de ideas resulta clave a los fines de comprender la particularidad de los fenómenos de recepción, algunos elementos propios de dicho programa han resultado claramente restrictivos para la historización de las prácticas intelectuales. Anclado en un esquema netamente utilitarista, la perspectiva bourdiana ha tendido a reducir la vida intelectual a intentos por parte de sus integrantes de maximizar su interés de acuerdo a las leyes del campo en el que actuan. De este modo Bourdieu propone al interés y los beneficios como variables analíticas privilegiadas en la aproximación a los fenómenos de circulación de ideas en un contexto diferente al de su origen. Con respecto a la

${ }^{110}$ Sobre el giro material, ver Grafton, Anthony. "La historia de las ideas. Preceptos y prácticas, 1950-2000 y más allá". Prismas. Revista de historia intelectual. № 11, 2007, pp. 123-148.

${ }^{111}$ LaCapra, Dominick. Rethinking Intellectual History: Texts, Contexts, Language. Ithaca, Cornell University Press, 1983, p. 33. 
apropiación de autores, ha afirmado que "el que se apropia, con toda buena fe, de un autor y que se hace de él el introductor, tiene beneficios subjetivos completamente sublimados y sublimes, pero que, sin embargo, son determinantes para comprender que él haga lo que hace" ${ }^{112}$. En relación a la publicación, "hacer publicar lo que amo, es reforzar mi posición en el campo, lo quiera o no, lo sepa o no, y aún si este efecto no cabe en el proyecto de mi acción"113.

En un sentido análogo al movimiento de apertura a la dimensión contextual, la atención prestada a las estrategias de posicionamiento en el campo ha permitido iluminar aspectos que la historia tradicional de las ideas era incapaz de advertir. En el mismo sentido que la consideración realizada anteriormente, el problema radica en la circunscripción de los fenómenos de circulación de ideas a las necesidades de poder de los sujetos implicados en dichos procesos. Como ha destacado Dosse en relación a la aproximación bourdiana de Sartre realizada por Anne Boschetti, "en esta lógica reducida a su única dimensión de maximización de su interés, la vida intelectual se encuentra totalmente desvitalizada, expurgada de todo contenido, simple simulacro ocultando las horribles pasiones de poder en un juego que escapa a todos"114. O como ha sugerido con agudeza Bernard Lahire, "preguntándose demasiado desde dónde 'habla' el otro, se acaba por no oír lo que dice”115.

En sintonía con estas observaciones, si bien nuestro trabajo evita la tentación ingenua de creer que los debates intelectuales están exentos de objetivos relacionados con las posiciones del campo, también descansa sobre la premisa de que la práctica intelectual tiene una particularidad que es irreductible a dichos objetivos. Es por ello que el recorrido propuesto a continuación da cuenta de las operaciones de legitimación y posicionamiento

\footnotetext{
${ }^{112}$ Bourdieu, Pierre. "Las condiciones sociales de la circulación de las ideas". op. cit., p. 162.

${ }^{113}$ Ibid., p, 163.

114 Dosse, François. La marcha de las ideas. Historia de los intelectuales, historia intelectual. op. cit., p. 110.

115 "À trop se demander d'où l'autre 'parle', on finit par ne plus entendre ce qu'il dit", Lahire, Bernard, "Objectivation sociologique, critique sociale et disqualification". Mouvements des idées et des luttes. № 2, noviembre-diciembre de 2002, p. 46.
} 
propias de la recepción de ideas a la vez que preserva el necesario espacio de autonomía de las ideas. 


\section{Capítulo 2}

\section{De la desestalinización a la lucha armada: Althusser y los comunistas argentinos}

\subsection{Introducción}

En este capítulo se recorre la presencia de Althusser en las discusiones teóricas y políticas del comunismo argentino. En primer lugar, reconstruimos el rol significativo jugado por las tesis althusserianas a mediados de la década de 1960 en el contexto de crisis del PCA. Nos detenemos en la importancia otorgada a la articulación entre las tareas políticas y las tareas teóricas y en el privilegio adquirido por el estudio científico de la realidad argentina. Luego analizamos el lugar del althusserianismo en la discusión entre los grupos insurreccionalistas y guerrilleristas que formaban parte de la disidencia comunista. Al respecto nos concentramos en la experiencia del zaratismo, una tendencia que articuló de manera programática el guevarismo con el marxismo althusseriano. Reconstruimos luego el proceso a través del cual la derrota política del zaratismo contribuyó a la atención prestada por el PCR al althusserianismo. Finalmente analizamos la relación entre el alineamiento del PCR con el proceso revolucionario chino y el marcado antialthusserianismo que signó al partido durante la primera mitad de la década de 1970.

En segundo término, atendemos los itinerarios de Althusser entre los intelectuales que permanecieron en el PCA. A los fines de contextualizar esta recepción, nos detenemos en el posicionamiento reactivo de los intelectuales comunistas frente a los fenómenos de modernización del marxismo llevados a acabo a comienzos de la década de 1960. Analizamos luego el posicionamiento de dichos intelectuales frente a los procesos de radicalización política en Argentina y en Francia. Con respecto a esto último, nos concentramos especialmente en los modos a través de los cuales el 
comunismo argentino recepcionó la experiencia de las corrientes maoístas y la relación de Althusser con las mismas. A continuación analizamos las lecturas de la obra de Althusser realizadas en Cuadernos de Cultura en el contexto de la política partidaria de una renovación democrática de la cultura. Finalmente reconstruimos el seguimiento que Abel García Barceló realizó del trabajo de Althusser y sus discípulos durante la primera mitad de la década de 1970.

\subsection{La necesidad de la teoría: lucha política y lucha teórica en la recuperación revolucionaria del PCA}

Las tensiones desarrolladas en el interior de la estructura partidaria entre el CC y sectores mayoritarios de la FJC alcanzaron, hacia 1967, un nivel de confrontación inusitado. Si bien la línea partidaria sufría desde hacía unos años un proceso de creciente deslegitimación entre la militancia juvenil, fue precisamente en aquel año cuando el carácter impugnador de las posiciones del CC comenzó a articularse con formulaciones programáticas. Los textos que operaron a modo de condensadores de los elementos fundamentales de la disidencia partidaria anudaron una revisión crítica del posicionamiento del PCA frente a los procesos políticos locales e internacionales con un incipiente trabajo de sistematización de una línea política paralela a la sostenida por el $\mathrm{CC}^{116}$.

Las condiciones de posibilidad de dicha articulación habían sido establecidas por el golpe militar de 1966. Este acontecimiento era invocado por la FJC como el elemento que obligaba a un proceso de autocrítica y corrección de los errores cometidos por el Partido durante el gobierno de Illia. El derrocamiento del gobierno radical por parte de los sectores tradicionalistas de la derecha argentina y la absoluta pasividad de las masas frente a dicha imposición eran -en el balance realizado por la juventud comunista- indicativos de un progresivo desdibujamiento de las concepciones leninistas con las que el

\footnotetext{
${ }^{116}$ A diferencia con lo que ocurre con la historia del Partido Socialista Argentino, no existen a la fecha reconstrucciones sistemáticas del proceso de crisis y ruptura del PCA. Sobre el creciente malestar en el PCA a comienzos de la década de 1960, ver Tortti, Cristina. "Izquierda y 'nueva izquierda' en la Argentina. El caso del Partido Comunista”. Cuadernos del CISH. N 6, 1999, pp. 221-232.
} 
Partido había abordado la política de Illia en los comienzos de su gobierno. Se contraponía, de este modo, la advertencia realizada por el XII ${ }^{\circ}$ Congreso sobre el posible giro derechista de los partidos burgueses con plataformas electorales progresistas, con la afirmación de la VII ${ }^{\circ}$ Conferencia de que el Partido tendría que haber apoyado las medidas progresistas de Illia a los fines de consolidar un gobierno democrático que satisficiera las reivindicaciones obreras y populares. La sugerencia retrospectiva sobre el gobierno de Illia, la oposición al onganiato a través del llamado a un frente democrático y patriótico y la militancia por un gobierno provisional que convocara una asamblea constituyente, así como el hecho de que no se expresara en los documentos partidarios la necesidad de la toma del poder, formaban parte de una crítica interna que tendía a hacer cada vez más visible la incapacidad del PCA para convertirse en la vanguardia revolucionaria de la clase obrera.

La crítica estaba estructurada fundamentalmente alrededor de la caracterización de las posiciones del CC como una "desviación oportunista" que había llevado al Partido a colocarse "a la cola de la burguesía liberal o nacionalista"117. Era esta política de seguidismo de la burguesía la que aparecía en la interpretación disidente como la responsable de haber conducido al PCA a posicionamientos claudicatorios de los principios comunistas, como el apoyo a los Azules en el conflicto militar de 1962, la confianza en las posibilidades de Illia de reorganizar su gobierno o la apuesta a la oposición a Onganía por parte de grupos de coroneles del Ejército. En términos más amplios, la desviación en la aplicación de la línea del XII ${ }^{\circ}$ Congreso era remitida a la postulación de la coexistencia pacífica como el objetivo estratégico del movimiento comunista internacional, la ubicación de la clase obrera como factor secundario del impulso democrático y antiimperialista de la burguesía argentina, y el otorgamiento de un carácter pacífico al proceso revolucionario a desarrollarse en Argentina. El modo en el cual los sectores disidentes sometían a discusión la vía pacífica al socialismo y se defendían de las acusaciones de proponer una sustitución del movimiento de masas por la lucha armada, era indicativo de que

117 “¿Por qué no se quiere discutir?”. Forjador. Revista bimestral del Comité Ejecutivo de la FJC, 1967, p. 5. 
la mayor tensión en los ámbitos partidarios se ubicaba en el problema de las vías de la revolución.

Precisamente, la denuncia del carácter desviado de la línea política aplicada por el CC y la advertencia sobre el carácter errático de sus posicionamientos en la coyuntura política argentina, dejaba entrever el florecimiento entre los sectores disidentes de una serie de lineamientos políticos alternativos a la vía democrática y pacífica al socialismo.

El más importante de ellos era el postulado de la necesidad de conducir a la clase obrera por un camino independiente de la burguesía y con objetivos revolucionarios. Se lo presentaba como la única línea política que habilitaba el acercamiento efectivo entre el partido y los trabajadores, así como la lucha contra los intentos burgueses de hegemonizar a la clase obrera. La conducción del proletariado por una senda independiente era postulada como el posicionamiento más seguro a los fines de combatir los golpes militares reaccionarios y evitar que éstos ocurrieran una vez restaurado el sistema democrático. Asimismo, este redireccionamiento de los objetivos políticos se articulaba con un énfasis en la necesidad de la autodefensa de las masas. Sobre la advertencia del escaso esfuerzo del partido por favorecer la organización de la clase obrera -adjudicado a "una insuficiente comprensión sobre el problema del poder"118-, los argumentos de los grupos disidentes se dirigían hacia la necesidad de crear condiciones para el desarrollo de una situación revolucionaria en Argentina.

El carácter programático de las formulaciones políticas de la disidencia partidaria se consolidó en 1968 a partir de la conformación del CNRR. Como anunciaba su "Declaración constitutiva", publicada en el número 1 de Nueva Hora, el PC y la FJC se enfrentaban a "la crisis más grave y profunda de su historia"119, cuyas causas eran adjudicadas al abandono por parte del partido de la tarea de dirección revolucionaria de la clase trabajadora y a la

${ }^{118}$ Comité Central de la Federación Juvenil Comunista. Hacia el ${ }^{\circ} X$ Congreso por la unidad y la defensa de la F.J.C. y el P.C. sobre la base de los principios leninistas. Octubre de 1967, p. 27.

${ }_{119}$ Partido Comunista Argentino-Comité Nacional de Recuperación Revolucionaria. "Declaración constitutiva del Comité Nacional de Recuperación Revolucionaria". Nueva Hora, $\mathrm{N}^{\circ} 1,12$ de febrero de 1968, p. 1. 
disminución de la influencia del comunismo entre el movimiento obrero y campesino. El CNRR se proponía como un instrumento de reencauce del partido en las sendas del marxismo-leninismo y como una expresión de los interrogantes que se habían desarrollado en el seno del partido desde mediados de la década de 1960. En relación a esto último, los argumentos recuperacionistas remarcaban especialmente preocupaciones en torno al por qué de la permanencia de la ideología de conciliación de clases entre los trabajadores, la ausencia de perspectiva revolucionaria del poder en los órganos partidarios, la separación política del partido de las masas, la incapacidad para captar a fracciones de la clase obrera influenciadas por el peronismo y la disminución de la combatividad de la militancia partidaria.

La constitución del CNRR implicó una demarcación más pronunciada frente a la vía pacífica al socialismo y una formulación explícita de la necesidad de adoptar la vía armada para la conquista del poder. La impugnación de la postergación de la lucha por la hegemonía de la clase obrera, fue dejando lugar a un tono más propositivo; de esta manera, los argumentos esgrimidos por el CNRR comenzaron a concentrarse cada vez más alrededor de los problemas relativos a la transformación revolucionaria a través de la vía armada. La necesidad de separarse del privilegio otorgado a los métodos pacíficos de lucha resultaba, en primer término, de una interpretación de la coyuntura argentina que tendía a enfatizar la agudización de la lucha de clases, el carácter crecientemente represivo del Estado, la presencia política de las Fuerzas Armadas y la intervención del imperialismo estadounidense. Esta necesidad remitía, asimismo, a un posicionamiento frente a la situación latinoamericana en el cual la valoración de la Revolución cubana aparecía desempeñando un rol preponderante. Concebido como elemento certificador de la practicabilidad del socialismo y de la verdad del marxismo-leninismo, el desarrollo del proceso revolucionario cubano operaba a modo de soporte de la postulación de la necesidad de coordinar y unir a las fuerzas revolucionarias del continente en un nuevo plano de solidaridad regional ${ }^{120}$.

${ }^{120}$ Los términos en los cuales los sectores juveniles recibían la posición del PCA frente al proceso cubano y la muerte de Guevara eran altamente indicativos de la brecha 
La propuesta de adopción de la vía armada y la posición favorable al guevarismo poseían, al momento de constitución del CNRR, una singularidad que debe ser destacada. Anclada en las tesis de enfrentamiento al oportunismo de derecha y al reformismo establecidas en la Conferencia de los 81 Partidos Comunistas y Obreros en 1960, la "Declaración constitutiva" del CNRR enfatizaba la necesidad de luchar contra las tendencias y prácticas que, en pos de combatir dichas desviaciones, se habían ubicado en un terreno igualmente ajeno al marxismo-leninismo. Se condicionaba la unidad del Movimiento Comunista Internacional a la derrota de las líneas de Mao y de la Liga Comunista de Yugoslavia, calificadas respectivamente de "nacionalista, antisoviética y divisionista" y "reformista y nacionalista", y a la superación de las posiciones de Debray, caracterizadas como "concepciones pequeñoburguesas" ${ }^{121}$. En este mismo sentido, en un artículo publicado en el número 6 de Nueva Hora, titulado "Las vías de la revolución", Rosendo Irusta [seudónimo de Otto Vargas] se esforzaba por asociar la opción por la vía armada con una interpretación de los procesos latinoamericanos en el marco de una situación revolucionaria general. El énfasis en la madurez de las condiciones para una insurrección armada operaba como argumento fortalecedor de la disociación entre la adopción de la vía armada propiciada por el CNRR y posiciones como el "putschismo aventurero" o el "guerrillerismo a ultranza desgajado de la lucha de clases" ${ }^{\prime 22}$. Se enfatizaba, por ello, la necesidad de apuntalar el accionar de los comandos obreros, a los cuales se les adjudicaba la tarea de enfrentar al aparato represivo del Estado, ganar a los

abierta en los espacios partidarios. En el artículo necrológico sobre Guevara publicado en Nuestra Palabra, se resaltaba con ironía la ausencia de la palabra "camarada" y la omisión del accionar de la guerrilla boliviana, por lo que el lector podía llegar a creer que Guevara "murió en un accidente automovilístico y no en un frente guerrillero". Y a modo de lamento, se hacía referencia a la "frialdad" con la que el partido se posicionó frente a la participación de militares argentinos en la búsqueda y captura de "nuestro héroe inmortal, el camarada Ernesto Guevara".

${ }^{121}$ Partido Comunista Argentino-Comité Nacional de Recuperación Revolucionaria. "Declaración constitutiva del Comité Nacional de Recuperación Revolucionaria". op. cit., p. 4.

${ }^{122}$ Irusta, Rosendo. "Las vías de la revolución”. Nueva Hora, № 6, Junio de 1968, pp. 2-3. 
trabajadores para la lucha contra la dictadura y preparar a la clase obrera para la insurrección armada.

Uno de los aspectos más destacables del esfuerzo en pos de la recuperación del carácter revolucionario del partido lo constituyó la articulación entre las tareas políticas y el trabajo teórico. Así como la formulación de una línea independiente de la clase obrera y la opción por la vía armada formaban parte de un programa de lucha política contra el seguidismo y el pacifismo de la vieja dirigencia comunista, el CNRR estableció como una de sus prioridades el desarrollo de una lucha contra los efectos del oportunismo en el terreno de la teoría. La disputa era cifrada fundamentalmente en términos de una superación de lo que era concebido como una tradición de análisis de la realidad argentina a través de las variables de una línea política prefijada. De este modo, la recuperación de la política revolucionaria se presentaba necesariamente asociada a una reformulación de las relaciones entre teoría y política, a partir de la cual la primera dejaría de ser únicamente el terreno sobre el cual se verificaban las verdades de la segunda.

La jerarquización del trabajo teórico y su conceptualización como un momento necesario de la práctica revolucionaria tuvieron un efecto concreto a principios de 1969 con la publicación del primer número de la revista Teoría y política. Como indicaba la "Presentación" a su edición inaugural, el CNRR le otorgaba a la revista el carácter de instrumento de producción de conocimientos que orientara permanentemente al partido en su accionar político. La creación de un espacio dedicado específicamente al trabajo teórico aparecía justificado por la necesidad de dejar atrás una "práctica teórica distorsionada" ${ }^{23}$, epíteto que refería a las operaciones de silenciamiento y tergiversación de datos de la realidad a los fines de legitimar la línea política partidaria. La manera en la cual se denunciaba la subestimación de los movimientos revolucionarios antiimperialistas y la justificación de los errores e imperfecciones del comunismo soviético daban cuenta del carácter conservador que los grupos disidentes le otorgaban a la distorsión entre teoría y política operada por la vieja dirigencia partidaria. A modo de contrapunto, el

123 “Presentación”. Teoría y Política, № 1, enero-febrero de 1969, p. 1. 
CNRR se proponía como una de sus tareas principales la realización de "un análisis teórico marxista-leninista de la estructura económico-social y de las superestructuras político e ideológica de la sociedad argentina" ${ }^{124}$. Solo a partir de este trabajo, se aseguraba, se podría abordar de una manera no dogmática los problemas planteados por las revoluciones latinoamericanas y el desarrollo del movimiento comunista internacional.

En el mismo primer número de Teoría y política, el articulista Andrés Marín introducía una serie de disquisiciones sobre la especificidad del trabajo teórico a desarrollar por los militantes comunistas. Su texto "Espontaneidad y conciencia de clase" daba cuenta de una problematización de la relación entre teoría y práctica revolucionaria que enfatizaba las tareas de esclarecimiento y demarcación entre la clase obrera. El tratamiento del problema del ocultamiento y la invisibilización de la realidad remitía tanto a El Capital como a su reactualización estructuralista -Maurice Godelier, en este caso- y la conceptualización de la conciencia obrera remarcaba permanentemente la importancia de la intervención del partido en tanto portador de la teoría. Para poder superar finalmente las posiciones espontaneístas, aseguraba Marín, era fundamental que los militantes comunistas desarrollaran una trabajo que fuera capaz de asegurar la "mediación científica" ${ }^{125}$ entre el interés objetivo y la conciencia de la clase revolucionaria. Este trabajo era cifrado en términos de una "práctica teórica" 126.

la plusvalía, como categoría científica, exige para su elaboración, el desocultamiento de la esencia del régimen capitalista, y por eso requiere un tipo de práctica que opere como negación teórica de la representaciones falsas elaboradas por el mismo obrero a partir de su inserción obligatoria (determinada por su cualidad de poseer solo su fuerza de trabajo) en el conjunto de las relaciones sociales articuladas por la presencia de la burguesía como clase dominante. ${ }^{127}$

\footnotetext{
124 Ibid., p. 2.

${ }^{125} / d$.

${ }^{126} / d$.

${ }^{127}$ Marín Andrés. "Espontaneidad y conciencia de clase". Teoría y Política, $\mathrm{N}^{\circ} 1$, enero-febrero de 1969, p. 4.
} 
En consonancia con el esfuerzo de superación de las limitaciones de la inserción del comunismo en la clase obrera, los objetivos particulares del trabajo teórico eran remitidos a la especificidad del contexto en el cual éste debía desarrollarse. Marín le asignaba a los militantes comunistas la tarea de explicitación de que en un país capitalista dependiente como Argentina, la contradicción entre burguesía y proletariado se expresaba en un enfrentamiento entre la oligarquía burguesa-terrateniente por un lado, y el proletariado y fracciones y clases aliadas por el otro. En ese sentido, la intervención militante en el interior de la clase obrera estaba condicionada a que la difusión de los aspectos doctrinales del marxismo se vinculara con un trabajo permanente de "explicación de cómo conquistar efectivamente el socialismo en ese país" ${ }^{128}$. La necesidad de subrayar que, en tanto país oprimido por la dominación imperialista, Argentina debía atravesar un proceso de liberación social y nacional, se correspondía con una reivindicación de la actividad propagandística. Sólo las tareas de propaganda, aseguraba Marín, permitía a los obreros "comprender teóricamente por qué en la Argentina, los campesinos pobres y medios y vastos sectores de las capas medias son sus aliados en esta fase de la revolución"129.

\subsection{Insurrección o guerrilla: el marxismo althusseriano y el debate acerca de la lucha armada}

Si bien presentes en el énfasis otorgado a la lucha teórica en la disputa contra el dogmatismo comunista, las tesis althusserianas ocuparán un lugar destacado en los debates desarrollados en el seno del CNRR en torno al carácter que debía adoptar la vía armada en el desarrollo del proceso revolucionario en Argentina. Como se percibía en el segundo número de la revista, un sector de la disidencia partidaria tendía a concebir la superación de las posiciones pacifistas y la adopción de la lucha armada en una clave

\footnotetext{
128 Ibid., p. 9.

${ }^{129}$ Ibid., p. 10.
} 
insurreccionalista ${ }^{130}$. La intervención que sistematizaba este posicionamiento, "Observaciones para el debate sobre la vía armada en Argentina" de Mariano Martin, postulaba como principal acción política del partido la preparación de una insurrección armada en las ciudades, quedando subordinado a ésta el accionar de las formaciones guerrilleras. Partiendo del supuesto de que sólo el trabajo teórico permite determinar las formas del proceso revolucionario, el trabajo de Martin consistía en un análisis económico, social y político de la realidad argentina que se coronaba con la delimitación de una estrategia de lucha para el contexto local. Así, en primer lugar, se hacía referencia a un país con un desarrollo capitalista dependiente, con zonas de concentración proletaria y espacios con relaciones pre-capitalistas, una clase obrera con tradición combativa aunque reformista, un campesinado poco numérico, un gran peso de la burguesía, y un estado fortalecido y con alta capacidad represiva. En consecuencia, se formulaba una estrategia centrada en el accionar político del partido y el apoyo de una fuerza clandestina que llevara a cabo acciones de propaganda armada, construyera la infraestructura para la insurrección y desarrollara un trabajo sistemático de inteligencia.

En un tenor argumentativo que evidenciaba la disputa con otras formulaciones programáticas, Martin se esforzaba en refutar aquellos posicionamientos que derivaban del análisis de la realidad argentina la necesidad de priorizar las acciones guerrilleras. Martin advertía sobre lo inadecuado que resultaba la adopción de la guerra popular prolongada en un país, como Argentina, en el que estaban ausentes las condiciones que tornaban necesaria dicha estrategia, como la composición social predominantemente campesina y el estado de crisis crónica. Igualmente forzado en el contexto local aparecía abordado el modelo de organización clandestina y profesionalizada centrado en la propaganda armada. Ejemplificado a través del caso de Tupamaros, se juzgaba de manera negativa el modo a través del cual, al no articular la actividad militar con el accionar

\footnotetext{
${ }^{130}$ Para una reconstrucción integral del debate sobre la vía armada en el CNRR, ver Lisandrello, Guido. "La discusión estratégica en la izquierda argentina en los años '70. Aproximación al debate entre guerrillerismo e insurreccionalismo en el nacimiento del Partido Comunista Revolucionario (PCR), 1967-1972". Andes, Vol. 23 N 1, 2015.
} 
político, este tipo de organizaciones veían menguadas sus capacidades de vinculación con la clase obrera y de incidencia en la coyuntura política. Si bien remarcaba el valor excepcional de la propaganda armada, Martin insistía en la distancia existente entre el accionar militar de una organización y su transformación en una fuerza socialmente proletaria.

En el mismo número de Teoría y Política, el texto "Ciencia y violencia" sistematizaba las posiciones de la línea a la que aludía críticamente el artículo de Martin. Esta tendencia estaba encabezada por Mauricio Malamud y Luis María Aguirre ${ }^{131}$ y era conocida como zaratismo por utilización por parte de aquellos de los seudónimos de Camilo y Gervasio Zárate. Como explicitaba el documento programático, el zaratismo postulaba como objetivo estratégico "conquistar Latinoamérica para el socialismo en un proceso de lucha armada inaugurado continentalmente por la Revolución Cubana"132. Uno de los elementos distintivos del posicionamiento zaratista lo constituía la articulación establecida entre las formulaciones guevaristas y el marxismo althusseriano. Como indicaba una nota ubicada al final del documento: "los conceptos teóricos que instrumentan este análisis, están tomados de la obra del intelectual marxista Louis Althusser"133. De manera divergente con las otras intervenciones sobre la vía armada reproducidas en la revista, el trabajo de Malamud y

\footnotetext{
${ }^{131}$ Mauricio Malamud había comenzado su militancia en el PCA en la década de 1930. Estuvo vinculado a la revista Propósitos que dirigió Leónidas Barletta y fue director de la Galería de Pintores Argentinos que funcionó durante la década de 1950 en el Teatro del Pueblo. En la primera mitad de la década de 1960 transitó por la Facultad de Filosofía y Letras de la UBA y por los grupos de estudios privados que florecieron por aquellos años. Habría tomado contacto por primera vez con la obra de Althusser a través del filósofo argentino Saúl Karsz. Karsz había viajado a París para realizar una tesis sobre Hegel con Jean Hyppolite, pero la irrupción del marxismo althusseriano lo había llevado a abandonar sus estudios sobre el hegelianismo y a abocarse al estudio de la obra de Althusser. Malamud habría recibido a través suyo ejemplares de Pour Marx y Lire Le Capital. Esta lectura tuvo efectos concretos en Malamud y en los grupos de estudios de los que formaba parte. Quienes participaban junto a él en el grupo de estudios de Raúl Sciarreta enfatizan el carácter disruptivo de las intervenciones en clav althusseriana realizadas por Malamud en las clases. El grupo que confluyó en el zaratismo estaba conformado por su hija Marina, su yerno Aguirre, Isaías Sokolowicz y la preja conformada por Susana del Carmen Giacché y Sergio Schneider.

132 Zárate, Camilo y Zárate, Gervasio. "Ciencia y violencia". Teoría y Política, № 2, marzo-abril de 1969, p. 33.

${ }^{133}$ Ibid., p. 55.
} 
Aguirre, si bien refería a los textos clásicos sobre dicho problema, como los de Clausewitz, Lenin, Mao y Giap, le otorgaba un rol destacado a los desarrollos teóricos del marxismo contemporáneo. Así, en un apartado específico de la bibliografía utilizada en el documento, se mencionaba como obras que habían resultado fundamentales en el establecimiento de una estrategia revolucionaria a La revolución teórica de Marx, el cuaderno La filosofía como arma de la revolución y Lire Le Capital ${ }^{134}$.

Dicha inscripción teórica redundaba, en primer lugar, en un esbozo de formalización del debate sobre la vía armada. En una inflexión que singularizaba su intervención, Malamud y Aguirre dedicaban un momento previo de la formulación de sus propias posiciones a un trabajo de presentación y encuadramiento de las diferentes variables inscriptas en la discusión sobre el carácter que debía asumir la vía armada en Argentina. De esta manera, se describía una situación en la que diversos sectores diferían de las posiciones pacifistas y oportunistas, invocaban al marxismo como principio fundamental en sus formulaciones programáticas, consideraban que sus planteos eran verdaderos porque estaban basados en la doctrina científica de Marx, y aún así, divergían entre ellos en relación a la táctica necesaria para el desarrollo de una estrategia revolucionaria. Se delimitaba entonces, a modo de diagrama, una "zona de acuerdo aparente", en la cual aparecía el marxismo como doctrina invocada y una América Latina socialista como objetivo estratégico, y una "zona de desacuerdos visibles" ${ }^{135}$ en la cual se ubicaban las formas de lucha armada.

Sobre este esquema se elaboraba una secuencia analítica destinada a una demarcación al interior de la tradición marxista. Malamud y Aguirre establecían como tarea primordial un ejercicio de comprobación si los desacuerdo a nivel táctico remitían a desacuerdos estratégicos, ya que la constatación de esta subsistencia sería indicativa de que los que estaba en contradicción no era solamente la forma de lucha sino el objetivo político. Por ello, se hacía un llamamiento a todos los sectores que participaban del debate

${ }^{134}$ Como hemos visto, la traducción castellana de Lire Le Capital será publicada unos meses después de la elaboración del documento de los Zárate.

${ }^{135}$ Ibid., p. 33. 
a que explicitaran "en qué consiste finalmente la teoría y método marxista que todos invocamos por igual", lo cual permitiría determinar "si efectivamente partimos de una base común igualmente entendida" ${ }^{136}$.

En este sentido, Malamud y Aguirre argumentaban que la única manera de garantizar que la forma de lucha sea la correcta radicaba en que el debate sobre la vía armada se desarrollara sobre una igualmente correcta concepción de las relaciones entre teoría y política. Al respecto, la base común de la que debía partir cualquier formulación sobre la estrategia revolucionaria consistía en la interiorización del siguiente encadenamiento: la guerra revolucionaria es una forma de lucha política-la lucha política es una forma de la lucha de clases-la lucha política revolucionaria tiene como objetivo la toma del poder-la práctica política está determinada por la teoría. Y era precisamente sobre este último eslabón que se realizaban las mayores precisiones conceptuales. El hecho de que la práctica política esté determinada por la teoría revolucionaria, implicaba que, en el marxismo, como en toda ciencia, la práctica está subordinada a un método que está producido a su vez por su teoría. Dichas disquisiciones intentaban despejar otras conceptualizaciones de las relaciones entre teoría y práctica, especialmente aquella que postulaba que la teoría se funda en la práctica espontánea. Enfatizando que la ciencia se constituye con la teoría de sus objeto, Malamud y Aguirre concluían con la sentencia "Marxismo quiere decir: Materialismo Histórico y Materialismo Dialéctico". Es decir, el marxismo es, por un lado,

Teoría de los modos de producción en cuanto formaciones sociales como un todo complejo de relaciones entre instancias o niveles distintos y articulados: el económico, el político, el ideológico; con autonomías relativas y con determinación en última instancia por el nivel económico ${ }^{137}$

Y por el otro,

Teoría de los "Modos de producciones racionales", en cuanto procesos de pensamiento; elaboración de los conceptos que,

\footnotetext{
${ }^{136}$ Ibid., p. 34.

${ }^{137} / d$.
} 
como instrumentos teóricos, permiten producir el efecto de conocimiento de cada realidad, existente, concreta, singular ${ }^{138}$

Al momento de delimitar las tareas que le correspondían al CNRR, en tanto órgano responsable de la recuperación del carácter revolucionario del PCA, el énfasis en la conceptualización del marxismo como Materialismo Histórico y Materialismo Dialéctico conducía, consecuentemente, a una equiparación del trabajo político con el trabajo teórico. Los argumentos del zaratismo tendían a remarcar que sólo se garantizaba la recuperación revolucionaria de la organización política si esta tarea estaba acompañada una recuperación de la teoría revolucionaria. Por esta razón, los esfuerzos de Malamud y Aguirre no estaban centrados tanto en la impugnación a la línea partidaria y su aplicación, sino en la problematización de lo que era denominado el "déficit teórico" del partido. En un sentido análogo a aquella caracterización de la "práctica teórica distorsionada" realizada en el primer número de Teoría y Política, se describía de manera negativa de qué manera el PCA había reemplazado el necesario "análisis científico marxista de cada situación local" por la adopción de un modelo revolucionario universalmente válido. La adjudicación de un carácter insustituible a la investigación científica de la realidad que se pretendía transformar, se anudaba tanto con un impulso a la apropiación del Materialismo Histórico por parte de los militantes comunistas como con una advertencia sobre el tenor a-científico del traslado a la realidad argentina de una solución adecuada para otro contexto. En suma, la recuperación de la teoría revolucionaria era la única garantía de que la lucha política fuera efectivamente revolucionaria:

si la guerra es una forma de lucha política, la guerra será revolucionaria siempre que, y sólo si, la política de la cual es su forma armada, sea política revolucionaria; y la práctica política será revolucionaria siempre que, y sólo si se funda en la Doctrina Científica de Marx ${ }^{139}$

\footnotetext{
${ }^{138}$ Ibid., p. 35.

${ }^{139} / d$.
} 
El énfasis en el carácter científico de la doctrina marxista implicaba que los esfuerzos de recuperación de la teoría revolucionaria se dirigieran hacia una jerarquización de la obra madura de Marx. Si la lucha política revolucionaria solo se garantizaba con una recuperación de la teoría revolucionaria, la única manera de asegurar que la teoría fuera realmente revolucionaria era una apropiación de la teoría y el método inaugurados en El Capital. La importancia de la circunscripción a esta obra radicaba, según Malamud y Aguirre, en que allí Marx realiza un ajuste de cuentas con su conciencia anterior, denuncia las formas ideológicas y no-científicas de dar cuenta de lo real y funda una ciencia en la cual lo económico se transforma en uno de los niveles de la estructura del modo de producción. El encuentro con la doctrina marxista debía desarrollarse, por ende, a partir del supuesto de que la obra madura de Marx opera una ruptura fundamental con las obras de su juventud:

en el acto mismo en que se constituye la Historia como Ciencia se produce la REVOLUCIÓN TEÓRICA DE MARX en que se liquida a la historia basada en las filosofías tradicionales rechazarse y reemplazarse todo el contexto de la vieja filosofía por la nueva filosofía de Marx: el Materialismo Dialéctico ${ }^{140}$

En tanto el Marx maduro era el único vector que posibilitaba la concurrencia entre práctica transformadora y teoría revolucionaria, el conocimiento de la filosofía fundada en El Capital era invocado como el elemento que permitía evitar las desviaciones recurrentes en el terreno de la política comunista. De este modo, aquellos anclajes en la obra de Marx caracterizados por la no interiorización de dicha revolución teórica eran exhibidos como posicionamientos teóricos que potencialmente podían desembocar en comportamientos políticos oportunistas o izquierdizantes. Por este camino, el establecimiento de una mediación científica con la obra de Marx adquiría un tono rupturista a través del cual se reivindicaba este conocimiento y aplicación de la doctrina marxista, a la vez que se denunciaban otras aproximaciones al texto marxista como invocaciones de tipo mágicas o religiosas. En consecuencia, una teoría efectivamente revolucionaria permitiría otorgarle una

${ }^{140}$ Ibid., p. 37. 
certificación científica al comportamiento político del militante comunista. De este modo, los problemas vinculados a la violencia revolucionaria y al internacionalismo proletario eran disociados de la voluntad o la valentía de la militancia comunista y direccionados hacia el cuerpo doctrinario del marxismo. A través de este movimiento, las acciones militantes en el terreno de la política comunista pasaban a ser conceptualizados como elementos "científicamente definibles"141.

El trabajo teórico era dotado de una especificidad insustituible: "hay una práctica económica, una práctica política y una práctica ideológica; pero hay también una práctica teórica científica" ${ }^{142}$. Si bien el zaratismo desarrollaba una serie de formulaciones programáticas en torno a la estrategia revolucionaria para la realidad argentina, consideraba urgente la conformación de comisiones de estudio que trabajaran en torno a las relaciones entre la teoría revolucionaria y la práctica política transformadora. Este trabajo teórico debía llevarse a cabo a partir del supuesto de que lo único permanente y válido es el método marxista, y no la estrategia revolucionaria -la cual precisamente debía ser el corolario del análisis sobre la situación concreta. A los fines de evitar la concepción de la estrategia como invariable, y la consecuente imitación de modelos revolucionarios válidos para otros contextos, Malamud y Aguirre le otorgaban al trabajo teórico una serie de exigencias metodológicas tendientes a resaltar el carácter insustituible del análisis científico de la realidad nacional. Al respecto, al destacar la concepción del materialismo histórico como "TEORÍA GENERAL" y de la teoría de los modos de producción como "TEORÍA PARTICULAR", enfatizaban la necesidad de elaboración de "TEORÍAS SINGULARES" para cada formación social y de "TEORÍAS REGIONALES" para cada una de sus instancias -económica, política e ideológica. Remarcando la idea de corte entre lo general y particular por un lado, y lo singular y regional por el otro, se privilegiaba a la formación económico-social como objeto analítico y -consecuentemente- se imponía la exigencia de teorizar las

\footnotetext{
${ }^{141}$ Ibid., p. 43.

${ }^{142}$ Ibid., p. 39.
} 
"impurezas" y "peculiaridades" 143 de las expresiones nacionales del modo de producción capitalista. Es decir, ni abstracción ni inmediatez en el conocimiento de lo real, sino conjunción entre elementos aportados por la teoría y datos contribuidos por la investigación sobre la realidad existente:

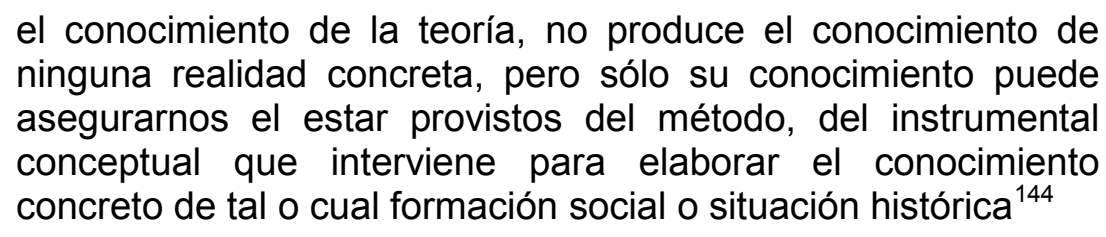

Si bien de manera provisoria, y con una serie de recaudos que remitían a la necesidad del trabajo en comisiones de estudio, Malamud y Aguirre finalmente esbozaban algunas formulaciones programáticas relacionadas con la estrategia revolucionaria. Refutadas las posiciones de la URSS y China, caracterizadas como resultado de la ausencia de una formulación positiva de la propia estrategia revolucionaria, y la de Yugoslavia, calificada de revisionista y subordinada al imperialismo, las valoraciones positivas del zaratismo se dirigían a las posiciones de Vietnam, Corea y Cuba. Aun destacando que estos posicionamientos no presentaban "un planteo teórico del rechazo y reemplazo" de las estrategias soviética y china, eran objeto de una ponderación en tanto poseían "una estrategia revolucionaria, real y actuante, desde la cual precisamente se diferencian de la posición de la URSS y PC reformistas, y China, y se ubican crítica y prácticamente en otra posición"145.

En consecuencia, un apartado del documento, que llevaba el título "Tesis a elaborar sobre la base de la carta del comandante Che al Secretariado de la OSPAAL (Abril de 1967) y los partidos no oportunistas o surgidos, como el nuestro, para la recuperación revolucionaria", estaba dedicado a la explicitación de un programa de continuación de las formulaciones guevaristas con la finalidad de delimitar la estrategia revolucionaria adecuada para la realidad argentina. Si bien la continuación con las tesis de Guevara era cifrada en términos positivos, fundamentalmente en relación a la impugnación de las

\footnotetext{
${ }^{143}$ Ibid., p. 40.

${ }^{144}$ Ibid., pp. 40-41.

${ }^{145}$ Ibid., p. 46.
} 
posiciones desviadas y a la prioridad otorgada a la situación concreta, este vínculo implicaba procesos de corrección y rectificación, especialmente en lo referido a la relación entre estrategia y táctica y al lugar del capitalismo desarrollado en la estrategia revolucionaria global.

Sobre este sustrato, el zaratismo establecía para la realidad argentina una estrategia de lucha armada con hegemonía de la clase obrera, en el marco de una estrategia continental y mundial contra el imperialismo y la recuperación del carácter revolucionario del movimiento comunista internacional. Al enfatizar la singularidad de la situación sobre la que se pretende intervenir, el contorno de la estrategia nacional se delineaba a partir de las peculiaridades de la Argentina de 1969. Aparecían destacados la diferencia entre zonas urbanas de gran concentración obrera y zonas de campesinado pobre, la inexistencia del desgaste del aparato estatal y el perfeccionamiento de los métodos de lo lucha policial, militar y paramilitar. Por ello, si bien se le adjudicaba a esta situación una forma de lucha insurreccional, se explicitaba la necesidad de plantear el problema de la insurrección desde unos marcos que no fueran los de la oposición entre lo político y lo militar y los de la ecuación proletariado = acción de masas / campesinado = lucha armada.

De manera análoga se procedía con la teoría del foco, sobre la que se enfatizaba la necesidad de no tergiversar la experiencia cubana y no intentar trasladarla mecánicamente a la realidad argentina. Se afirmaba que el foquismo no consistía en "el planteo trasnochado de un blanquismo" ni la revolución cubana había sido "el éxito feliz de aventureros" 146 , sino que el foco había sido un medio para crear las condiciones para el proceso revolucionario y había logrado captar a las masas antes de su irrupción y no solamente después. En último lugar, pero con el mismo tono refutador, aparecía la adopción de la estrategia terrorista, la cual era valorada como una forma de lucha que por sí sola no debilitaba al enemigo y que impedía la participación popular "por poner el acento en la técnica, en la relación hombre-arma" 147.

\footnotetext{
${ }^{146}$ Ibid., p. 53.

${ }^{147}$ Ibid., p. 55.
} 


\subsection{Organigramas para la revolución: althusserianismo y lucha armada en el nacimiento del PCR}

La fundación del PCR en 1969 trajo aparejado una homogeneización de la línea política. Su Primer Congreso, realizado en diciembre de aquel año, estableció un programa de revolución popular, agraria, antiimperialista, antimonopolista, de liberación social y nacional y delimitó una estrategia revolucionaria en la cual la violencia de las masas y el accionar militar del Partido quedaban subordinados a la tarea de preparación de una insurrección armada. El hecho de que las tensiones desarrolladas en el CNRR culminaran con la imposición de la tendencia insurreccionalista implicó que una porción importante de las formulaciones del naciente partido estuviera dirigida a la refutación de las posiciones sostenidas por los sectores derrotados. De este modo, el PCR insistía en la necesidad de una reorganización del partido que le permitiera a éste preparar un levantamiento insurreccional y llevar a cabo las tareas de liberación social y nacional. Direccionada dicha reorganización a la estructuración de un partido insurreccional, clandestino y centralista democrático, quedaba establecida como una de las principales tareas partidarias la liquidación de la idea de partido selecto. De allí que las formulaciones del "Informe del Comité Central" del PCR en su Primer Congreso giraran en torno a la insistencia en que todas las acciones violentas en contra de la dictadura se insertaran en la perspectiva de insurrección armada y en la diferenciación entre la lucha política y la lucha militar.

El "Balance de la actividad del partido" que acompañaba las resoluciones de su congreso fundacional, daba cuenta del conflictivo proceso que había culminado en la constitución del PCR. Al respecto, se caracterizaba retrospectivamente al CNRR como un espacio de confluencia de diversos sectores enfrentados al oportunismo del CC del PCA pero no lo suficientemente alejado de las "posiciones reformistas predominantes en el movimiento comunista y especialmente en el PCUS"148. Por ello, si bien se

${ }^{148}$ Partido Comunista Revolucionario. Primer Congreso del P.C.R. 11, 12, 13 y 14 de diciembre de 1969, p. 50 
destacaba que la convergencia de los grupos disidentes había permitido avanzar en la caracterización de una desviación seguidista en el PCA, la definición de la vía armada como la vía revolucionaria adecuada para Argentina y la definición del reformismo como el principal obstáculo en el movimiento comunista internacional, se advertía que el CNRR no había logrado estructurar una crítica radical a las posiciones del viejo PC ni formular una línea efectivamente revolucionaria para la situación argentina. La revisión habilitaba, entre otras cosas, la caracterización de la "Declaración constitutiva" del CNRR como una expresión atada al "reformismo internacionap"149, lastre adjudicado tanto a la composición social predominantemente pequeño-burguesa de dicho órgano como a la experiencia marcada por las posiciones oportunistas que arrastraban la mayor parte de sus militantes.

A modo de legitimación de la línea establecida en el Primer Congreso, el PCR postulaba el establecimiento de una política de hegemonía proletaria y una estrategia insurreccional como aquella instancia que había desencadenado la lucha entre los diversos grupos que conformaban el CNRR. La historización de la disputa desarrollada en el proceso de ruptura del PCA se detenía en el enfrentamiento entre la línea correcta y un conjunto de "desviaciones oportunistas de derecha y oportunistas de izquierda" ${ }^{150}$, al mismo tiempo que remarcaba la singularidad que había tenido esta lucha: "el embate se dio en línea, en tipo de partido, pero principalmente en teoría". Si bien el Balance dejaba asentado que la estrategia insurreccional había sido resistida por una cantidad significativa de grupos pertenecientes al CNRR, la mayor parte de las refutaciones eran dirigidas a aquellas tendencias que, según se afirmaba, había desarrollado luchas fraccionales: "el grupo Colman-Azúa de Rosario, y Zárate de la Capital'. Sobre el primero, se mencionaba sucintamente que había propiciado una desviación "política e ideológicamente trotsquizante", por la que habían sido "finalmente expulsados del partido"151. Sobre el segundo, en cambio, se desplegaban una serie de diatribas que habilitan tanto una complejización de los debates sostenidos en el seno del CNRR en los años

\footnotetext{
${ }^{149}$ Ibid., p. 51.

${ }^{150} / d$.

151 Ibid.,p. 54.
} 
previos como una aproximación a los modos a través de los cuales el PCR se legitimaba como órgano partidario a través de la derrota de las mencionadas tendencias.

Si bien los documentos fundacionales del PCR no se adentraban en la especificidad del "embate en teoría" desarrollado en el CNRR, las acusaciones que se proyectaban sobre el zaratismo permiten dar cuenta de la forma en la que era advertida la filiación marxista de la tendencia liderada por Malamud y Aguirre. Tal como vimos anteriormente, los momentos inmediatamente posteriores al Primer Congreso partidario estuvieron marcados por el señalamiento de la pervivencia de posiciones reformistas durante el período de funcionamiento del CNRR. De la misma manera, al referirse al accionar de los grupos acusados de fraccionalistas, se insistía sobre la continuidad de posiciones espontaneístas durante el proceso de recuperación del carácter revolucionario del PCA. Dicha insistencia, sin embargo, estaba acompañada por un esfuerzo en pos de desligar esta autocrítica de las acusaciones de espontaneísmo formuladas anteriormente por el zaratismo:

\footnotetext{
[EI CNRR] fue incapaz de destrozar las ideas escépticas sobre el estado de ánimo de las masas, las ideas doctrinarias, pedagógicas de construcción del partido, porque el informe y la práctica del Comité Nacional estaban fuertemente impregnados de espontaneísmo. No el espontaneísmo que nos adjudicó Zárate, para quien es espontaneísta compartir las teorías marxistas sobre el carácter de clase revolucionaria del proletariado, y que considera que el proletariado argentino nació a la lucha revolucionaria con la llegada de Zárate al marxismo. ${ }^{152}$
}

La pretendida inscripción refundacional del marxismo llevada a cabo por el zaratismo aparecía estrechamente vinculada con sus posicionamientos políticos, los cuales eran caracterizados como desviaciones, y su trabajo en el Partido, el que era catalogado de infiltración. De esta manera se sucedían afirmaciones condenatorias al zaratismo en lo relativo a su concepción del partido:

152 Ibid., pp. 54-55. 
El grupo Zárate distribuyó nacionalmente sus cuadros en casi todas las zonas del partido y realizó un activo trabajo de zapa, cuyo contenido político recién dio a luz varios meses después de abrirse la discusión para el Congreso. Entonces formuló abiertamente su teoría, que reemplaza al partido por un grupo militar: el 'Ejército Revolucionario'. Este 'Ejército Revolucionario', a través de la guerrilla urbana, realiza la revolución y 'luego' de la misma, ante la intervención imperialista, se despliega recogiendo en su seno a 'los sectores de la masa que hayan tenido organización y acción paramilitar previa, fundamentalmente comandos obreros', para enfrentar la intervención extranjera ${ }^{153}$

y a su estrategia revolucionaria:

Zárate confunde $-\mathrm{y}$ sus ideas penetraron relativamente en profundidad en el partido- el partido marxista-leninista, vanguardia de una clase social y estado mayor de la misma en la lucha revolucionaria, con ejército revolucionario, lo cual no es válido ni para la insurrección ni para la guerra campesina, de acuerdo con las tesis marxistas y la experiencia histórica de las revoluciones triunfantes. $Y$ formula una tesis pequeñoburguesa de la revolución, que en política termina en un frente policlasista revolucionario como apoyo logístico de grupos de guerrilla urbana ${ }^{154}$

El proceso de movilización obrera desarrollado durante 1969 y 1970, así como el rol en él desempeñado por dirigentes y militantes del partido, otorgaron nuevas dimensiones a los parámetros a través de los cuales el PCR abordaba las diversas expresiones teóricas y políticas de la izquierda argentina. En este sentido, la conflictividad obrera desplegada en los acontecimientos de Córdoba, el Chocón y fundamentalmente Perdriel -en los que el partido tuvo un rol preponderante- ${ }^{155}$ comenzaron a ser invocados como los indicadores de una

\footnotetext{
${ }^{153}$ Ibid., p. 56.

${ }^{154}$ Id.

${ }^{155}$ El 12 de mayo de 1970 se produjo la toma de la matricería Perdriel de IKA-Renault en la provincia de Córdoba. Los obreros enfrentaban el traslado de delegados gremiales clasistas pactado entre la empresa y la conducción del SMATA. El conflicto finalizó a los pocos días con un triunfo de los obreros, acontecimientos que contribuyó al fortalecimiento de los sectores liderados por René Salamanca. Para profundizar en la importancia de Perdriel en la consolidación de la línea insurreccionalista en el PCR, ver Lisandrello, Guido. "La toma de la fábrica Perdriel y la clarificación de la estrategia insurreccionalista en el Partido Comunista Revolucionario en los años 70". VII Jornadas de Trabajo de Historia Reciente. Buenos Aires, 2014.
} 
nueva etapa de la lucha de la clase obrera y, por lo tanto, como el espejo en el cual el resto de las organizaciones revolucionarias debían mirarse a los fines de advertir sus errores. La elevación en la conciencia de la clase obrera, deducida de fenómenos tales como la tendencia al enfrentamiento directo con la burguesía y las fuerzas del orden, la recurrencia de las ocupaciones de fábricas, las formas asamblearias de decisión política y el rebasamiento de los marcos gremiales, era invocada para evidenciar lo incorrecto del desarrollo de estrategias revolucionarias no insurreccionalistas.

Por tanto, la "Conferencia Permanente" de agosto de 1970 estará dedicada principalmente a rebatir los posicionamientos de las organizaciones armadas. En primer lugar, el PCR impugnaba las acciones realizadas por los grupos de origen marxista-leninista que habían girado hacia el populismo de izquierda, como las FAR. Sin embargo, el mayor esfuerzo argumentativo se depositaba sobre las organizaciones armadas que se proclamaban comunistas revolucionarias y que tenían planteos diferenciados del populismo de izquierda, fundamentalmente las FAL, de las cuales el zaratismo había sido uno de sus dos afluentes. Así como la sucesión de conflictos obreros era leída como un índice de la madurez de la clase obrera argentina, la estrategia centrada en las acciones de guerrilla urbana era exhibida como signo de la exterioridad de las organizaciones armadas con respecto a la lucha de las masas. La polémica entablada contra el zaratismo, si bien seguirá dando cuenta de las pretensiones refundacionales de su relectura de la tradición marxista, comenzará a centrarse cada vez más en el carácter teórico de dicha tarea. Por ello, a la sentencia ya esgrimida de que los Zárate "creen que el movimiento revolucionario de la clase obrera nace con ellos", se le agregará una caracterización peyorativa sobre la importancia otorgada por esta tendencia al trabajo teórico: "son incapaces de ser vanguardia de una clase obrera adulta a la que los vapores reformistas pueden haber desorientado largo rato pero no aletargado, como creen estos teóricos de biblioteca" ${ }^{156}$.

${ }^{156}$ Partido Comunista Revolucionario. Conferencia Permanente del P.C.R. 15 y 16 de agosto de 1970. p. 17. 
De esta manera, se estrecharán los vínculos entre la estrategia revolucionaria delimitada por el zaratismo y la corriente marxista en la cual se inscribían sus referentes. Amparado en el veredicto de que la forma que adquiere la lucha armada expresa los intereses de clase de quien la lleva adelante, el PCR catalogaba a las formaciones guerrilleras urbanas como expresiones políticas de la pequeña-burguesía. A modo de contraposición entre la inserción lograda por el partido en Perdriel y el secuestro del cónsul paraguayo Waldermar Sánchez -primera acción de las FAL-, el PCR forjará su contundente afirmación "vale más para hacer avanzar la conciencia de las masas obreras una lucha como la de Perdriel que cien secuestros" ${ }^{\text {"157. En }}$ un sentido análogo, el PCR reafirmaba la tesis de que la teoría es efectivamente revolucionaria cuando se desarrolla en los marcos del marxismoleninismo. Por tanto, las teorías marxistas percibidas como propiciatorias de una distorsión de las bases filosóficas del marxismo-leninismo eran señaladas como expresiones teóricas pequeño-burguesas. Quedaba establecida, de este modo, la asociación entre militarismo y teoricismo althusseriano:

En general los grupos partidarios del terrorismo urbano y
militaristas que se proclaman marxistas acostumbran
acompañar sus teorizaciones -que suelen ser organigramas
para la revolución- con referencias a un marco filosófico y de la
teoría del conocimiento supuestamente marxista-leninista; que
parte no de Marx sino generalmente de intérpretes de Marx,
como el filósofo del PC de Francia, Althousser [sic], al que a la
vez interpretan a gusto y paladar de ellos. Generalmente parten
de una ignorante o intencionada falsificación de la relación
conocimiento-práctica social, reemplazando a ésta por la
práctica de grupos aislados de acción directa 158

La forma en la cual se presentaba al marxismo althusseriano en el marco general de la impugnación de la guerrilla urbana permite delimitar la especificidad de la lectura de Althusser en el proceso de consolidación del

157 Ibid., p. 18 Las disquiciones alrededor de esta consigna permite asimismo advertir el modo a través del cual las FAL respondían a estas argumentaciones: "no pueden preguntarnos a nosotros ¿y después de Perdriel qué? Por cuanto ellos jamás construirán un Perdriel con esa línea", Id. En septiembre de 1970, el PCR sistematizará su crítica a la guerrilla urbana en el artículo "FAL: una línea equivocada para la revolución", firmado por Mariano Martin.

${ }^{158}$ Ibid., p. 19. 
PCR. En primer lugar, las objeciones al althusserianismo están estrictamente vinculadas con la torsión operada por esta corriente en la conceptualización de las relaciones entre teoría y práctica en la tradición marxista. En este sentido, la pertenencia de Althusser al PCF aparece únicamente como una referencia contextual a su trabajo como filósofo -valoración que se modificará radicalmente con la adhesión del PCR al maoísmo. Por otro lado, se evidencia una separación entre la obra de Althusser y la lectura que de ella hacían Malamud y Aguirre. La mención a una interpretación "a gusto y paladar de ellos" sugiere que lo que estaba en cuestión era, precisamente, la vinculación entre althusserianismo y guerrilla urbana, y no el marxismo althusseriano en sí. Tal como hemos visto, más allá de la singularidad del zaratismo, el althusserianismo había estado presente de manera significativa en las formulaciones relativas al trabajo de recuperación del carácter revolucionario del PCA.

Incluso el modo en el cual seguían siendo formuladas en las páginas de Teoría y Política las relaciones entre trabajo teórico y práctica política, permite dar cuenta de la pervivencia de las tesis althusserianas en el partido durante los primeros años de la década de 1970. Es decir, que al mismo tiempo que desde los materiales partidarios se lanzaban acusaciones hacia la articulación entre althusserianismo y lucha armada, aún gozaba de cierta legitimidad el tipo de intervención característico del momento de funcionamiento del CNRR: aquel centrado en la jerarquización del trabajo teórico y su concepción como momento necesario de la práctica revolucionaria. En este sentido, la nota dirigida a los lectores del número 4 de Teoría y política, a través del cual se retomaba la publicación de la revista, volverá a la explicitación de aquellos objetivos con los cuales había sido fundado el órgano de expresión teórica del partido. Reaparecerán, por tanto, el repaso crítico por las maneras en las cuales el PCA concebía la relación entre teoría y política -aplicación de juicios previos al estudio de la realidad concreta e investigación como demostración de tesis prefijadas- y el postulado sobre la ruptura teórica como la única garantía de que la separación política del reformismo sea efectivamente revolucionaria. Estas formulaciones tendrán, inclusive, una contundencia mayor 
que las desarrolladas en el proceso de conformación del CNRR: "no sólo en política debe haber dos comunismo, sino también en teoría... pensamos en suma, en la teoría como arma de la revolución"159.

Sin embargo, el texto se encargaba de destacar que la continuidad de la publicación, y por ende, el mantenimiento de un órgano de producción teórica en torno a los problemas nacionales y mundiales de la lucha revolucionaria, no eran criterios totalmente compartidos al interior del partido. Las lecciones que se pretendían extraer del ejemplo de Lenin dan cuenta tanto de un esfuerzo por legitimar la importancia del trabajo teórico como de las resistencias que estas concepciones despertaban en algunos sectores del partido. En primer lugar, se advertía sobre los peligros de que la mera invocación del dictum leninista "sin teoría revolucionaria no puede haber tampoco movimiento revolucionario" actuara como salvaguarda de una prolongación de las viejas concepciones sobre la relación entre teoría y política:

consideramos más ilustrativo atender a su actitud personal [la de Lenin]: al esfuerzo que dedicó al estudio del desarrollo del capitalismo en Rusia, a la teoría del imperialismo, al problema del Estado, a la lucha contra los empiriocriticistas, a la teoría del Partido, etc. Debemos aprender de Lenin, más que las frases que dedicó a la necesidad de la teoría revolucionaria, aquello [que] lo impulsó en determinados momentos a considerar la lucha teórica como lo fundamental, llegando incluso, según él mismo, a descuidar sus otras labores ${ }^{160}$

De la misma manera, se le señalaba al militante comunista que la asunción del ejemplo de Lenin implicaba la realización de un trabajo teórico concreto que debía trascender las declamaciones sobre la necesidad de la teoría revolucionaria:

repetir en mil lugares distintos que sin teoría revolucionaria no hay práctica revolucionaria, no tiene ni la milésima parte del valor que tiene la actitud del camarada que ante los problemas de su militancia diaria se dirige a los clásicos en búsqueda de los elementos teóricos que contribuyen a aclararle el

\footnotetext{
159 "A los lectores". Teoría y Política, N 4, 1971, pp. I-II.

160 Ibid., p. I.
} 
panorama, a elaborar una propuesta proletaria revolucionaria, a ganar a la clase obrera para el comunismo ${ }^{161}$

Dichas formulaciones adquirían un sentido bien definido a partir del análisis que se realizaba sobre la relación entre teoría y política en el PCR desde su fundación. Es decir, lo que a través del ejemplo leninista se afirmaba genéricamente para el militante comunista, se transformaba en señalamientos concretos al abordar de manera (auto)crítica la experiencia del partido durante los últimos años de la década de 1960 y los primeros de la de 1970. Por un lado, la defensa de la necesidad de que el partido contara con un órgano de producción y expresión teórica se acompañaba de una velada objeción a determinadas tendencias que propiciaban una subestimación del trabajo teórico. El hecho de que la revista no hubiese sido publicada durante 1970 por la dificultad de mantenerla económicamente era presentado como una evidencia de la importancia que el partido le prestaba a la lucha teórica. Por otro lado, el trabajo teórico era dotado de un carácter impostergable debido al destacado lugar que el PCR había adquirido en la coyuntura política argentina. Por tanto, se señalaba con preocupación que los significativos logros políticos adquiridos por el partido durante esos años -su participación en el desarrollo del sindicalismo clasista y en la movilizaciones estudiantiles- no hubiesen estado acompañadas por el necesario control teórico. Finalmente, la ausencia de un trabajo teórico sobre los hechos políticos quedaba estrechamente asociada a unas implicaciones para el presente y el futuro del partido que no podían ser sino desfavorables: "descuidar el conveniente tratamiento teórico de éstos puede acarrear consecuencias negativas en el futuro del PCR" 162 .

\subsection{El giro maoísta: antirrevisionismo y antialthusserianismo en el PCR}

La perceptible ambigüedad en las conceptualizaciones acerca de las relaciones entre teoría y política, y especialmente en las formulaciones sobre la necesidad del trabajo teórico, se despejará a partir del progresivo alineamiento

\footnotetext{
${ }^{161} / d$.

${ }^{162}$ Ibid., p. II.
} 
del PCR con el Partido Comunista Chino. En su Segundo Congreso, realizado en abril de 1972, el PCR ya identificaba la diferenciación desarrollada por el PCCh con respecto a la URSS como uno de los hitos fundamentales del proceso de reconstrucción revolucionaria del movimiento comunista internacional, y catalogaba a la República Popular China como "el destacamento más avanzado de las fuerzas que enfrentan antagónicamente al imperialismo y al revisionismo" ${ }^{163}$. Será, sin embargo, el Tercer Congreso partidario, realizado en marzo de 1974, el que terminará de ubicar al PCR en la senda del maoísmo. Se definirá una posición centrada en la contradicción entre las naciones oprimidas, por un lado, y el imperialismo y el socialimperialismo, por el otro. Al mismo tiempo, se hará un llamamiento a la creación de un Frente Popular de Liberación, en el cual convergerían las clases dominadas con intereses democráticos y revolucionarios, y un Ejército Popular de Liberación, el cual estaría integrado por milicias obreras y campesinas con mando operativo subordinado a consejos de fábrica y consejos populares revolucionarios. Todo ello contribuirá, en consecuencia, a una potenciación de la estrategia de insurrección popular armada y a un endurecimiento de las posiciones del partido frente a las organizaciones armadas, designadas peyorativamente como "formas organizativas de laboratorio"164. Finalmente, la Revolución Cultural Proletaria, saludada como continuación de la lucha de clases en las condiciones de la dictadura del proletariado y resolución de la batalla entre restauración burguesa y vía socialista, se transformará en el horizonte teórico y político del accionar del partido y en la vara privilegiada a partir de la cual eran juzgados los posicionamientos del resto de las organizaciones y partidos de la izquierda argentina.

Solo el despeje de las ambigüedades en torno a la práctica teórica operado por la contundencia del giro maoísta permite explicar el significativo lugar otorgado a la refutación de Althusser en las páginas del "Balance de la actividad del partido" que acompañaba las resoluciones del Tercer Congreso

${ }^{163}$ Partido Comunista Revolucionario. Segundo Congreso del PCR. 7, 8 y 9 de abril de 1972, p. 9.

${ }^{164}$ Partido Comunista Revolucionario. Tercer Congreso del PCR. 2 y 3 de marzo de 1974, p. 15. 
partidario. No deja de resultar llamativa la mención a un teórico marxista que no era Marx, Lenin o Mao en un texto partidario que trataba problemas tales como la construcción y el fortalecimiento del partido, la formación de cuadros, la vigilancia revolucionaria, la clandestinidad, la propaganda y las finanzas. El funcionamiento del partido bajo la consigna "no se puede ser marxista-leninista sin ser maoísta" implicaba necesariamente la abjuración de un pasado en el cual las concepciones sobre la relación entre teoría y política habían estado signadas indudablemente por las tesis althusserianas -de manera contundente en el caso del zaratismo y difusamente durante el funcionamiento del CNRR y los primeros años del PCR. Se relataba una lucha épica en la cual el marxismoleninismo-maoísmo había logrado "desentrañar los profundos lastres revisionistas en el plano teórico que aún subsistían en nuestro Partido". Si bien dichos lastres parecían referir ampliamente a desarrollos teóricos juzgados como revisionistas, el Balance dejaba en claro que la lucha tenía un blanco bien específico:

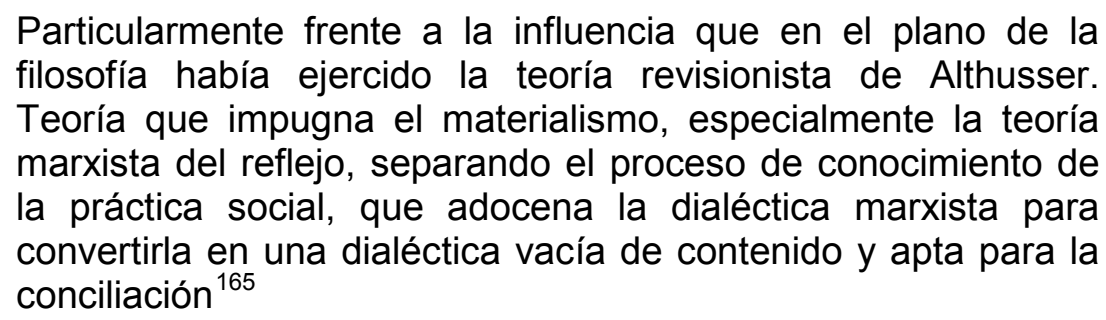

A partir de 1972, Teoría y política perderá el carácter de espacio de discusión teórica que había tenido anteriormente, disminuyendo los artículos publicados por número y priorizando la defensa de la línea del PCCh -con su consiguiente diatriba antisoviética- y los problemas de la coyuntura política argentina ${ }^{166}$. En este marco, la revista publicó en 1972 y 1973 dos artículos escritos por altos dirigentes del partido y destinados a la impugnación del althusserianismo y sus usos en el comunismo argentino: "Actualidad de la Revolución Cultural

\footnotetext{
${ }^{165}$ Ibid., p. 60.

${ }^{166}$ Cabe destacar que los primeros números de la revista -los correspondientes al período de funcionamiento del CNRR y los comienzos del PCR- habían estado integrados por una cantidad significativa de artículos dedicados al análisis histórico, socio-económico y teórico de problemas tanto nacional como mundiales.
} 
Proletaria China" de Irusta, en el número 9, y "Problemas actuales en la lucha ideológica”, de Lucas Figari [seudónimo de José Ratzer], en el número 10. Ambos textos, si bien más sofisticados que lo que se desprendía de las formulaciones antialthusserianas del "Balance" del Tercer Congreso partidario, participaban de los mismos impulsos que caracterizaron esta nueva etapa de la revista ${ }^{167}$. Las dos intervenciones ubicaban a Althusser como parte de un pasado revisionista finalmente abandonado, como una expresión teórica diametralmente opuesta al modelo propiciado por la Revolución Cultural China y como el responsable de determinados posicionamientos teóricos y políticos en el seno del comunismo argentino -los cuales eran signados como objetos de refutación a los fines de establecer una línea política realmente revolucionaria para la coyuntura argentina.

En la misma línea que los materiales partidarios, Irusta invocaba el alineamiento maoísta del PCR como el proceso que había permitido a los militantes del partido advertir el error de haber adherido "expresa o tácitamente, sin mayor rigor teórico y sin investigación concreta, a afirmaciones equivocadas e hipócritas como la del conocido teórico del PC revisionista francés, Althusser" ${ }^{168}$. En este mismo sentido, cargaba nuevamente contra "Zárate", al que describía como "un ilustrado defensor de la escuela 'althusseriana' en el país", al que acusaba de haber propuesto "impulsar la formación teórica y práctica' del PCR a partir de las teorías de Althusser", y al que consecuentemente responsabilizaba por haber convertido a Althusser en el "guía teórico de muchos militantes"169 del partido.

Sobre este sustrato se llevaba a cabo un repaso por las tesis centrales de Lire Le Capital, ejercicio que se realizaba a través de una contraposición entre éstas y los textos de Mao. De esta manera, Irusta intentaba evidenciar la raigambre revisionista y el carácter especulativo del althusserianismo a partir

\footnotetext{
167 Resulta indicativo, al respecto, que los textos formaban parte de números que traían solamente dos artículos: el de Irusta estaba acompañado de "Notas sobre los consejos obreros y el poder popular revolucionario en Argentina" de Andrés Marin y el de Figari por "La URSS: revolución y restauración" de Carlos Echagüe.

168 Irusta, Rosendo. "Actualidad de la Revolución Cultural Proletaria China". Teoría y Política, N 9, 1972, p. 14.

169 Ibid., p. 17.
} 
de lo que era percibido como una impugnación de la teoría del reflejo, un rechazo de la práctica social como criterio de verdad del conocimiento, una reducción de la política a la ideología y una separación del concreto real y el concreto del pensamiento. A su vez, una desmentida de la autocrítica realizada por Althusser en la Advertencia a la segunda edición francesa de Lire Le Capital pretendía dejar en evidencia una fusión entre materialismo e idealismo: no había sido la terminología de Althusser la que estaba próxima al estructuralismo, sino su contenido. Todo ello coronado con la postulación de la Revolución Cultural como guía para el militante maoísta argentino. Frente a ésta, Althusser como "el maestro por el ejemplo negativo", y los althusserianos, como comunistas que "no romperán jamás con el revisionismo moderno mientras no rompan con este filósofo del mismo" ${ }^{170}$.

La intervención de Figari también daba lugar a una historización de la presencia de Althusser entre los militantes del partido, la cual se inscribía asimismo en los parámetros delimitados por los documentos partidarios y el texto de Irusta. La articulación entre la renovación del marxismo propiciada por Althusser y la formulación de una estrategia centrada en la lucha armada era presentada retrospectivamente como un intento de hacer ingresar teorías no proletarias en el seno del PCR. En este sentido, la línea propuesta por el zaratismo era descripta como la combinación entre "la improvisación, la ligereza e inconstancia pequeñoburguesas con teorizaciones positivistas" ${ }^{171}$. Demostrado el carácter positivista del althusserianismo a partir de una lectura de sus postulados alrededor de las relaciones entre ciencia y filosofía, la intervención de Figari se dedicaba a la reconstrucción y explicación de la introducción de Althusser en el PCR. El althusserianismo aparecía como una corriente más que había disputado el espacio teórico del partido en los momentos en que éste aún no había delineado una clara línea proletaria. La presencia de Althusser, por tanto, era ubicada en una serie de la cual también formaban parte el existencialismo (Marcuse), la teoría del excedente económico (Paul Baran y Paul Sweezy), concepciones impulsivas

170 Ibid., p. 20.

${ }^{171}$ Figari, Lucas. "Problemas actuales de la lucha ideológica". Teoría y Política, № 10 , 1973, p. 7. 
(Luxemburgo) y el trotskismo (Nahuel Moreno). El resguardo y la seguridad que prometía la lectura de Marx realizada por Althusser habían sido, según Figari, los elementos posibilitadores de la difusión del althusserianismo en las filas del partido. En un contexto signado por la existencia de múltiples lecturas de Marx, Althusser le garantizaba al militante comunista una lectura correcta del texto marxista:

Frente a este tembladeral apareció la figura de Althusser. Su autosuficiencia trajo tranquilidad a los espíritus atormentados, quienes veían esfumarse una a una las verdades conquistadas por el marxismo. Los esquemas, las fórmulas con manejo de todas las letras del abecedario, prometían un poco de orden en el desorden que se había producido en la casa del marxismo. El supremo restaurador, Althusser, erigió un altar a El Capital, y en él encontró la Teoría (así, con mayúsculas). Para hacerlo demolió a Lenin (sin manejar su obra) y vilipendió a Engels, haciéndolo aparecer como un empirista grosero ${ }^{172}$

La historización realizada por Figari era la única que se adentraba en la especificidad de los efectos políticos generados por el althusserianismo. Si bien compartía el sustrato interpretativo que tendía a conceptualizar la obra de Althusser como una expresión teórica pequeñoburguesa, este análisis intentaba dar cuenta de las mediaciones establecidas entre los principales aspectos teóricos del althusserianismo y determinados posicionamientos políticos de la militancia comunista.

Los núcleos centrales a partir de los cuales Figari delimitaba dichas afinidades eran las formulaciones althusserianas en torno a la práctica teórica y la sobredeterminación. A su entender, las primeras tendían a escindir teoría y práctica, legitimando un modo de intervención centrada en el trabajo teórico. Es decir, a partir de la práctica teórica, Althusser "encerraba la obra marxista en un mundo impermeable a la sucia lucha cotidiana, lo que conviene mucho a los espíritus pequeñoburgueses, que no gustan de la contaminación, de los 'compromisos' de la política y que están por encima de las masas con sus conocimientos librescos"173. Las segundas dotaban de importancia a las

\footnotetext{
172 Ibid., p. 12

${ }^{173} / d$.
} 
contradicciones secundarias, haciendo más tolerable el advenimiento del proceso revolucionario. Por tanto, la sobredeterminación contribuía a "resolver la impaciencia pequeñoburguesa: las masas aprenden por su experiencia, pero como esto es muy largo y difícil, hace falta 'estimular', 'activar' a estas masas desde fuera de su lucha diaria." ${ }^{174}$. En suma, el althusserianismo colmaba las pretensiones militantes de una línea política que aún no era lo necesariamente proletaria. De allí que las tesis de Althusser sintonizaran con dos de los peligros que acechan a una línea efectivamente proletaria: el teoricismo y el izquierdismo. En palabras de Figari, con Althusser "las dos almas de la pequeñaburguesía están satisfechas. Se va a una torre de marfil 'marxista' o se va al terrorismo urbano o al foco rural que dan el puntapié inicial a las masas" $^{175}$.

\subsection{En defensa del marxismo-leninismo: los intelectuales comunistas y la modernización del marxismo}

Los modos de intervención de los cuadros intelectuales del PCA en el interior del corpus marxista durante la segunda mitad de la década de 1960 y los primeros años de la de 1970 estuvieron atravesados por los procesos de escisión desarrollados en el seno de la estructura partidaria. La ruptura pasadopresentista de 1963-1964 y la gran fractura de 1967-1968 condensaron los posicionamientos de la línea partidaria en el universo marxista y sedimentaron un discurso frente a los desarrollos innovadores del campo marxista que permanecerá en los círculos culturales del partido hasta entrada la década de 1970. La lucha política contra lo que era designado genéricamente como neoizquierdismo y la lectura de las nuevas corrientes marxistas desde un marxismo ortodoxo de factura soviética redundaron en una posición reactiva frente a los procesos de apertura y reformulación del marxismo, ya sea en su vertiente existencialista como en la estructuralista. Si bien en parte el althusserianismo fue leído desde estos marcos, la pertenencia

\footnotetext{
${ }^{174} / d$.

${ }^{175} / d$.
} 
de Althusser al comunismo partidario y la importancia otorgada por el PCA a las discusiones teóricas y políticas del PCF contribuyeron a ubicar al marxismo althusseriano en un espacio singular de las intervenciones de los intelectuales comunistas argentinos.

Una vez superada la crisis que condujo a la salida del grupo de Pasado y Presente de la estructura partidaria y dada por finalizada la discusión entre del Barco y Olivieri y Sciarreta ${ }^{176}$ en torno al problema de la objetividad en el marxismo ${ }^{177}$, Cuadernos de Cultura llevó a cabo una campaña contundente de refutación de las pretensiones modernizadoras del marxismo y de defensa frente a las acusaciones de esclerosamiento y envejecimiento del marxismoleninismo. El número 66, de principios de 1964, dedicado íntegramente a la "Afirmación militante del marxismo-leninismo", estaba integrado por intervenciones contundentes de los principales referentes intelectuales del partido, como Abel García Barceló, Miguel Lombardi, Mauricio Lebedinsky y Samuel Schneider ${ }^{178}$.

El editorial de este número especial, "En defensa del marxismoleninismo", impugnaba tanto las operaciones refundacionales del marxismo

\footnotetext{
176 Sciarreta estudió filosofía en la UBA. Durante la década de 1950 participó activamente de Cuadernos de Cultura y de las editoriales vinculadas al PCA. Tradujo Los intelectuales y la organización de la cultura de Gramsci y -como veremos en el capítulo 5- la obra de Galvano Della Volpe. Luego de finalizado el debate con del Barco, se alejó del PCA, distanciamiento coincidente con sus lecturas de Althusser. Para una ampliación de su trayectoria político-intelectual, ver la entrada correspondiente a Sciarreta en Tarcus, Horacio (dir.). Diccionario biográfico de la izquierda argentina. De los anarquistas a la "nueva izquierda" (1870-1976). Buenos Aires, Emecé, 2007, pp. 616-617.

177 En 1962, del Barco había publicado un artículo en el que la obra de Gramsci aparecía invocada contra toda concepción especulativa del problema de la objetividad. A través de una argumentación que, reproducida en las páginas de la revista no podía tener sino un carácter provocador, del Barco ubicaba en el historicismo gramsciano la clave para la superación de la creencia en la existencia objetiva del hombre. Dichas afirmaciones fueron rebatidas en los números siguientes por los miembros de la Comisión de Estudios Filósoficos del Partido Raúl Oliveri (bajo el seudónimo de Raúl Oliva) y Raúl Sciarreta (bajo el seudónimo de Raúl Sierra). Ambos ensayaron una férrea defensa de la objetividad y caracterizaron como idealistas las posiciones teóricas del joven filósofo cordobés. Este intercambio suele ser señalado como el antecedente directo de la salida del grupo de Pasado y Presente de las filas del partido.

${ }_{178}$ Cuadernos de Cultura, la revista mensual editada por la Comisión de Cultura del PCA, tuvo dos épocas. La primera, de 1950 a 1967. La segunda, coincidente con la crisis del Partido, de 1967 a 1976.
} 
como las críticas izquierdistas a la línea política del partido. Frente a las primeras, el PCA se auto-investía del mismo impulso que había llevado a Mariátegui a escribir su Defensa del marxismo, es decir, la necesidad de intervenir frente a los diagnósticos de esterilidad del marxismo y desfasaje de la teoría con una realidad diferente a la de los fundadores del materialismo histórico. Lo específico de esta nueva oleada de proyectos modernizadores del marxismo lo constituían, según la lectura partidaria, el despojamiento de todo sentido militante, su transformación en una filosofía universitaria, la amputación del leninismo y un tono marcadamente anti-comunista. Frente a las segundas, se imponía una lectura peyorativa de los impulsos vanguardistas e intelectualistas advertidos en los movimientos surgidos a la izquierda de la línea política del PCA. Dicha lectura estaba estructurada a partir de una censura de la vía insurreccional, acusada de sustituir la evolución política de las masas, y una refutación de las impugnaciones a la vía pacífica, la cual era disociada de factores claudicatorios y remitida a la organización constante de las masas con objetivos revolucionarios.

De todas las intervenciones de este número especial, la de García Barceló, "El marxismo-leninismo y la denominada 'totalización' del marxismo", lograba sistematizar la lectura comunista de los impulsos modernizadores del marxismo de la primera mitad de la década de 1960. Introducida la variable generacional en el debate que culminó con la salida del grupo pasadopresentista, la primera operación frente a las corrientes marxistas renovadoras consistía en la disociación entre la posición del viejo intelectual agorero, en la cual el antidogmatismo se asociaba irremediablemente al resentimiento anticomunista, y la de los jóvenes, cuya rebeldía y disconformismo eran caracterizadas como jalones de un camino que conducía inevitablemente a la esterilidad política. Si en el plano político las líneas izquierdistas eran confrontadas con la postulación del rol insustituible del Partido, en los aspectos filosóficos la modernización del marxismo era enfrentada a la posibilidad de establecer un programa de adecuación del marxismo-leninismo a la nueva etapa del movimiento comunista internacional. García Barceló impugnaba las operaciones de división del marxismo en su 
versión ortodoxa y en su vertiente creadora en tanto advertía que el único camino que proponían estas últimas consistía en la integración del marxismo con corrientes filosóficas idealistas, como el existencialismo y el neopositivismo y con disciplinas con tendencias antimaterialistas, como la sociología burguesa y el psicoanálisis.

Si la propagación del discurso renovador implicaba un desafío a la tradición marxista-leninista, el trabajo que se imponía consistía tanto en una detallada refutación de los núcleos teóricos del primero como un esfuerzo jearquizador de las bases filosóficas de la segunda. En una lectura que atendía las implicaciones de Crítica de la razón dialéctica de Sartre, y que remitía explícitamente a los debates en torno a Gramsci en el seno del comunismo argentino, García Barceló dedicaba el grueso de su intervención al tratamiento de aquellos núcleos del proceso de totalización del marxismo que se advertían como más problemáticos.

El primero de ellos correspondía a la concepción de que las corrientes filosóficas idealistas forman parte de la realidad y como tales deben ser englobadas en una teoría totalizadora. La confusión entre la existencia de una ideología y su aceptación teórica era cifrada en unos términos que guardan una estrecha similitud con aquellos a partir de los cuales el althusserianismo abordará al gramscianismo; a decir de García Barceló, “...las raíces de tan gratuita pretensión, residen en una concepción esquemáticamente historicista, que ignora las exigencias propias del conocimiento verdadero en la lucha ideológica" ${ }^{179}$.

El segundo problema estaba vinculado con la tendencia a identificar coincidencias temáticas entre el marxismo y las corrientes filosóficas idealistas. Sobre una aproximación general a las relaciones entre marxismo y fenomenología caracterizada por una valoración de Tran Duc Thao y JeanToussaint Desanti y una censura de Sartre, el problema de la coincidencia era abordado a partir de un esquema en el cual el idealismo aparecía acercándose al materialismo dialéctico, de lo cual se deriva el carácter verdadero de la

179 García Barceló, Abel. “El marxismo-leninismo y la denominada 'totalización' del marxismo". Cuadernos de Cultura, №66, enero-febrero de 1964, p. 18. 
filosofía marxista y la necesidad de que el marxismo se concentrara en aquellos problemas a los que el idealismo no había podido dar respuesta.

Por último era problematizada la cuestión de la existencia de lagunas en el marxismo-leninismo y la derivación programática que enfatizaba la posibilidad de que estas ausencias sean cubiertas a partir de la incorporación de investigaciones desarrolladas por corrientes no marxistas. Al respecto, García Barceló destacaba una corriente autocrítica en el marxismo-leninismo, de la cual el Roger Garaudy de Perspectives de l'homme aparecía como el caso paradigmático, que intentaba vislumbrar en qué casos la postergación del abordaje de problemas tales como la subjetividad, la libertad y la responsabilidad había estado condicionada por las necesidades de la lucha ideológica y en cuáles otros había obedecido a una lectura simplificadora de tradiciones filosóficas contemporáneas. ${ }^{180}$ En esta dirección, García Barceló se esforzaba por subrayar que del escaso tratamiento de estas temáticas por parte del marxismo no se desprendía necesariamente la existencia de lagunas en su interior y que, en tanto el marxismo-leninismo estaba lo suficientemente equipado para el abordaje de dichas problemáticas, de lo que se trataba era de profundizar el desarrollo de la propia filosofía marxista prescindiendo de la integración de elementos pertenecientes a filosofías idealistas.

La intervención de Lebedinsky, "Marxismo o marxismo-leninismo", apuntalaba la operación de defensa del marxismo-leninismo y refutación de las pretensiones modernizadoras de la tradición marxista. En su caso, el énfasis estaba puesto en la conformación de un mapa político-intelectual de lo que se designaba con un tono peyorativo como anti-dogmatismo creador. De este modo aparecían mencionadas las obras de Sartre, Henri Lefebvre, Jean-Yves Calvez y Erich Fromm en el contexto europeo, y las revistas Pasado y Presente, Cuestiones de Filosofía, Revista de Liberación y Nueva Izquierda en

\footnotetext{
${ }^{180}$ García Barceló resaltaba y hacía propio un argumento de Garaudy que permite destacar la importancia del gesto modernizador aún dentro de la ortodoxia comunista: "el marxismo no puede vivir y desarrollarse sino integrando y superando todo lo que la filosofía contemporánea tiene de vivo: el marxismo no sería marxismo, si se limitara a responder a Sartre con las objeciones que Marx hacía de Stirner, a Husserl por las refutaciones que hacía Lenin de las teorías de Ernesto Mach, a Desroches o a Teilhard de Chardin por la argumentación de Feuerbach", Ibid., p. 21.
} 
Argentina, a las cuales se les adjudicaba las operaciones de separación del marxismo del leninismo, transformación del marxismo en método sociológico de interpretación, priorización del problema de la alienación y conformación de un humanismo abstracto, separación de Marx y Engels y escisión entre la teoría y la práctica.

La lectura de las corrientes marxistas renovadoras realizada por Lebedinsky demuestra de modo contundente el lugar privilegiado que tenían las intervenciones de los filósofos comunistas franceses en las interpretaciones de los intelectuales comunistas argentinos y el modo en el que aquellas operaban a modo de mediación en el abordaje de los procesos de reformulación del marxismo desarrollados en Argentina. Así, al igual que García Barceló, Lebedinsky recurría a la palabra autorizada de Garaudy; en este caso, los planteos desarrollados en Perspectives de l'homme en contra al humanismo especulativo y a favor de una convergencia entre el problema de la alienación y la práctica política revolucionaria, eran retomados para refutar aquellas corrientes que “...tratan de convertir al marxismo en el movimiento puro de la alienación, en un humanismo etéreo, en una antropología humanista que se movería exclusivamente en el plano de la conciencia" ${ }^{181}$.

Del mismo modo se recurría a los primeros trabajos de Sève editados por el PCF, especialmente La différence, a los fines de ofrecer una caracterización general de los fenómenos de relectura del marxismo y de problematización de los vínculos entre el marxismo y el leninismo. De esta forma las corrientes renovadoras del marxismo aparecían representando una novedad en relación a otros momentos de replanteo del corpus marxista, como el correspondiente al revisionismo bernsteiniano, en tanto el núcleo de sus intervenciones no lo constituía el esfuerzo por revisar a Marx sino el intento de convertirse en los depositarios del verdadero marxismo. Asimismo, las derivas antidogmáticas del marxismo contemporáneo eran contrastadas con el itinerario de Lenin, quien viviendo una época de reacción política y filosófica, no

${ }^{181}$ Lebedinsky, Mauricio. "Marxismo o marxismo-leninismo". Cuadernos de Cultura, $\mathrm{N}^{\circ}$ 66, enero-febrero de 1966, p. 66. 
claudicó frente a las corrientes idealistas sino que había profundizado las bases del marxismo.

\subsection{La teoría enloquecida: el maoísmo francés visto por los comunistas argentinos}

Los primeros números de la nueva etapa de Cuadernos de Cultura, iniciada en 1967, estuvieron marcados, al igual que los de 1963-1964, por los avatares de un proceso de fraccionamiento en el seno de las estructuras partidarias. En este caso, los términos en los cuales los cuadros intelectuales del comunismo argentino procesaron la significativa escisión de fines de la década permiten inferir los parámetros de lectura sostenidos por el PCA frente a la estructura y las características del campo marxista durante esos años. Si durante la primera ruptura, el centro de las refutaciones de los intelectuales comunistas argentinos lo constituyeron aquellos fenómenos que eran percibidos como un anti-dogmatismo modernizador y una integración al marxismo de corrientes filosóficas idealistas, a lo largo del segundo proceso de escisión la atención se concentró en los procesos de radicalización política de los sectores juveniles y en la preponderancia alcanzada por el maoísmo.

Enmarcada en la necesidad de profundizar la convergencia de todas las fuerzas políticas progresistas para enfrentar a la dictadura de Onganía, el informe reproducido en Cuadernos de Cultura sobre el clima cismático en las estructuras partidarias adquiría la forma de un lamento. El informe en cuestión, "A propósito de una plataforma fraccional entre los jóvenes", publicado sin firma en el número 2 de la nueva época, vinculaba la caracterización del onganiato realizada por el partido -que enfatizaba la represión anticomunista y la censura cultural- con el señalamiento de lo desfavorable que resultaba, en un momento en el que se necesitaba la convergencia y no la división de la oposición a la dictadura, el surgimiento en el interior de la estructura partidaria de "una línea sectaria, donde el infantilismo de izquierda se entronca con las variantes del nacionalismo burgués, tras una plataforma política opuesta a la acción de 
masas y, por lo tanto, esencialmente antagónica a la línea del PC"182. En lo que respecta al modo en el cual se interpretaba la consolidación de la disidencia juvenil, el elemento causal sobre el cual se depositaban las variables explicativas era el llamado "giro a la izquierda de la juventud"183. Este era concebido como un fenómeno de radicalización problemático por estar protagonizado por un sujeto, como el estudiantil, proclive a las "vacilaciones ideológicas" ${ }^{184}$ y las "impaciencias políticas" ${ }^{185}$. En relación a las actitudes del comunismo frente a este giro a la izquierda, los sectores disidentes eran responsabilizados por haberse apartado del camino natural frente a un fenómeno de este tipo, es decir, aquel consistente en una acción ideológica contundente que posibilitara la difusión masiva de la línea partidaria logrando encauzar la radicalización en el partido de vanguardia, favoreciendo de este modo el aislamiento del PC de la juventud, la tergiversación de su línea política y la profundización del desamparo político entre los estudiantes.

En el análisis realizado sobre el surgimiento de una línea política disidente en el interior del PCA se destacaba la enumeración de los elementos pertenecientes a la dimensión teórica que conducían a lo que se percibía como efectos paralizadores en el terreno de la práctica política. Se alertaba, en primer lugar, sobre el establecimiento de la revolución agraria y antiimperialista como programa mínimo de lucha. La refutación de la necesidad del carácter democrático de la revolución agraria y antiimperialista pasaba a ser considerada como producto de una confusión entre el programa revolucionario del partido y el requerimiento de que sus bases se adecúen a la correlación de fuerzas de la situación nacional y a la urgencia de un frente antidictatorial conformado por fuerzas progresistas. Lo mismo ocurría con el ataque a la burguesía tout court, aprehendido como una posición clasista incapaz de diferenciar a los enemigos principales, como la oligarquía y el imperialismo, de aquellas clases que podrían formar parte, junto a la clase obrera, de un frente

\footnotetext{
182 "A propósito de una plataforma fraccional entre los jóvenes". Cuadernos de Cultura (nueva época), $\mathrm{N}^{\circ} 2$, noviembre-diciembre de 1967, p. 130.

${ }^{183} \mathrm{ld}$.

${ }^{184} / d$.

${ }^{185} / d$.
} 
democrático nacional. En conjunto, la descripción del proceso fraccional estaba atravesada por el señalamiento de los riesgos políticos que encubría el desarrollo de elementos teóricos reñidos con las bases filosóficas que guiaban la acción del partido. El surgimiento de nuevas teorizaciones en el interior de la estructura partidaria aparecía como el responsable de desviaciones gravísimas en el trabajo juvenil y cultural, tales como la obturación de la potencial participación en el frente antidictatorial de intelectuales de extracción burguesa -docentes, investigadores, profesionales, artistas- o la renuencia a establecer convergencias parciales con los sectores de la clase obrera influidos por el peronismo que aún no compartían totalmente el programa comunista.

El lugar ocupado por el desarrollo del maoísmo francés entre los intelectuales comunistas argentinos estaba directamente mediado por las descripciones realizadas de dicho fenómeno por los intelectuales del PCF. EI elemento más significativo de esta mediación lo constituyó la traducción y comentario, en la sección "De cada cual lo suyo", de dos artículos de Claude Prévost publicados entre 1967 y 1968 en La Nouvelle Critique. El primero de ellos, "Portrait robot du maoïsme en France", que ocupó las páginas del número 2 de Cuadernos de Cultura, consistía en una agudo retrato de las oposiciones de izquierda al interior del PCF vehiculizadas por los grupos maoístas; el otro, atendido en el número 10, correspondía a la respuesta a un lector de La Nouvelle Critique que había escrito una carta a la revista acusando a Prévost de esquivar las responsabilidades que le cabían a la ortodoxia del PCF en la salida de los jóvenes militantes de las filas partidarias. El modo en el cual se insertaban las intervenciones de Prévost en Cuadernos de Cultura reproducción de largos pasajes de los artículos, entre los cuales se intercalaban observaciones de un comentarista anónimo que refrendaba todas las afirmaciones de Prévost- dan cuenta tanto de la identificación entre la revista cultural del PCA y La Nouvelle Critique como de la coincidencia en los términos de la interpretación del "giro a la izquierda" realizada por el 
comunismo argentino y la de la lectura del gauchisme desarrollada por el comunismo francés ${ }^{186}$.

Resaltaba en las descripciones del intelectual comunista francés una sensación de asombro frente la preeminencia que adquiría la teoría por sobre la política entre los jóvenes maoístas enfrentados a la línea del PCF. Por un lado, Prévost advertía un fenómeno de inflación de la teoría en las nuevas generaciones de militantes comunistas. Uno de los elementos sobre los que se depositaba la atención era el privilegio otorgado a los aspectos teóricos del marxismo, fenómeno cuyas causas eran remitidas tanto a la relevancia del maoísmo en el movimiento comunista internacional como a la peculiaridad de la mirada francesa sobre la revolución china. Según sus palabras, se asistía en el París de aquellos días, "al espectáculo, burlesco o desolador, según el estado de ánimo, de la 'teoría' enloquecida" ${ }^{187}$. Si bien este fenómeno permitía avizorar ciertos avances en el interior de la tradición marxista, especialmente a partir del desarrollo inusitado de sus dimensiones teóricas, el hecho de que la preeminencia de la teoría implicara necesariamente un desbalance en detrimento de la práctica política, direccionaba su aprehensión hacia unos términos que no podían ser sino negativos. La mirada negativa se dirigía, asimismo, hacia lo que era percibido como una desviación en el modo de concebir la constitución de los elementos teóricos. Prévost enfatizaba las formas en las cuales ciertos desarrollos innovadores de la teoría marxista en Francia no eran resultados de una intervención crítica sobre lo existente sino que constituían meramente elementos justificatorios de las prácticas políticas de la revolución china. Así, por ejemplo, la jerarquización de los problemas en torno a la ideología en las discusiones marxistas aparecía como un producto de la necesidad del maoísmo francés por legitimar el accionar de los Guardias Rojos.

\footnotetext{
${ }^{186}$ Para una contextualización del posicionamiento de los intelectuales comunistas argentinos en el marco de la recepción argentina del mayo francés, ver Tarcus, Horacio. "El mayo argentino". Observatorio Social de América Latina. № 24, 2008, pp. 161-180.

187 "Modelo robot del maoísmo en Francia". Cuadernos de Cultura (nueva época), N2, noviembre-diciembre de 1967, p. 100.
} 
En un segundo plano, se advertía en la descripción de Prévost un esfuerzo por desnudar las implicaciones de la concepción de las ideas sostenida por el maoísmo y, especialmente, de la adjudicación a dicha dimensión de un desproporcionado potencial transformador. Al igual que ocurría con el desbalance entre la teoría y la práctica, la equiparación de la potencia de las ideas a la de la fuerza militar o la fuerza productiva era postulada como una distorsión del legado de Marx. La descalificación del pensamiento de Mao se dirigía tanto a la pretendida originalidad y radicalidad de sus tesis como a la forma idealista en la cual el maoísmo concebía la existencia de dicho pensamiento; a decir de Prévost, "[e]l pensamiento de un hombre (dejemos aparte el problema de su 'genio'), es dotado de este modo, de atribuciones mágicas". Del mismo modo, el anudamiento operado por el maoísmo entre la transformación de las ideas y la modificación de la realidad histórica era presentado en términos explicativos como las claves que permitían comprender el "moralismo maoísta" así como "los excesos terroristas que provoca" ${ }^{188}$. El repaso de estos elementos derivaba en una indagación sobre el modo en el cual el maoísmo se vinculaba con la tradición humanista del marxismo. Si bien Prévost destacaba el marcado anti-humanismo de las corrientes maoístas, se esforzaba por deducir la forma por la cual su contenido anti-humanista terminaba convirtiendo al maoísmo en una tradición sostenedora de un humanismo más cercano al creacionismo idealista que al marxismo. El hecho de dotar a las masas de un poder transformador ilimitado permitiría inferir cómo las tesis antihumanistas encubren una creencia en la omnipotencia de los hombres; en sus términos, "[s]u antihumanismo deliberado y provocador revela de rechazo, en un plano profundo, un hiperhumanismo idealista, que culmina en una verdadera idealización de La Humanidad" ${ }^{\prime 189}$.

La reproducción de los textos de Prévost hacía aparecer por primera vez al althusserianismo en las páginas de Cuadernos de Cultura. Escritos al calor del momento de mayor conflicto entre el PCF y el marxismo althusseriano, los artículos publicados en La Nouvelle Critique daban cuenta del modo en el cual

\footnotetext{
${ }^{188}$ Ibid., p. 103.

189 Ibid., p. 104.
} 
el comunismo francés leía, y hacía públicos, los efectos de la intervención de Althusser en los procesos de propagación de las corrientes maoístas y de la consiguiente fractura al interior de los órganos partidarios. Prévost expresaba esta lectura en dos planos. El primero de ellos remitía a la afinidad que existía entre las formulaciones de un marxismo renovador, sobre el cual no se mencionaba su filiación pero que, como bien dice Rancière ${ }^{190}$, no podía ser otro que el althusseriano, y los grupos disidentes del Partido que adscribían a la doctrina maoísta:

\begin{abstract}
En un primer momento algunos adoptaron por entusiasmo una lectura de Marx que privilegiaba el momento de la ruptura con la ideología anterior; sin embargo, era visible que izquierdizaban ese paso y lo llevaban al absurdo, que hacían del marxismo una especie de comienzo absoluto, la negación de toda la cultura pasada, con desprecio de cien textos de Marx y Lenin. Por lo contrario, les era necesario llevar a cabo un nuevo 'Gran Salto'. Entonces, el 'pensamiento de Mao', o por lo menos lo que se pone en primer plano en la actualidad, ofrecía su linealidad y esquematismo ${ }^{191}$
\end{abstract}

Los términos en los cuales Rancière retomaba en La lección de Althusser las afirmaciones de Prévost permiten advertir el ángulo a través del cual el PCF veía la articulación entre althusserianismo y maoísmo. Si bien no dejaba de remarcarse las afinidades existentes entre ambas expresiones, es evidente que se exculpaba al propio Althusser de las apropiaciones que hacían los grupos maoístas de su lectura novedosa de Marx. Mientras el althusserianismo era presentado en un tono neutro como un marxismo que direccionaba su interpretación de Marx en un sentido determinado, el anclaje teórico del maoísmo en el althusserianismo era caracterizado de manera negativa como un movimiento izquierdizante. Asimismo, la postulación del paso de los grupos disidentes hacia un maoísmo abierto y enfrentado con el Partido como un hecho inevitable y casi necesario, derivaba en una concepción del althuserianismo como una corriente marxista contenida en los lineamientos

\footnotetext{
${ }^{190}$ Rancière, Jacques. La lección de Althusser. Buenos Aires, Galerna, 1975, p. 99.

191 "Modelo robot del maoísmo en Francia". op. cit., p. 102.
} 
políticos y filosóficos del PCF ${ }^{192}$ El otro plano en el que se expresaba la lectura del comunismo francés sobre el althusserianismo avanzaba mucho más allá de la exculpación de Althusser. En su descripción crítica de las corrientes maoístas, Prévost se apoyaba en investigaciones sociológicas y en argumentaciones políticas de intelectuales del Partido. En el primer caso, el análisis realizado por Pierre Bourdieu y Jean-Claude Passeron en Los herederos. Los estudiantes y la cultura operaba como iluminador de la relación entre el izquierdismo y la extracción de clase burguesa. En el segundo, las intervenciones de Althusser, especialmente aquellas de la entrevista en L'Unitá, en torno a la necesidad de que los intelectuales lleven a cabo un largo proceso de reeducación para convertirse en dirigentes del proletariado, actuaban como fortalecedoras del leninismo y demarcadoras de la distancia que existía entre la militancia izquierdista y los problemas concretos de la clase obrera.

\subsection{Las ambivalencias del Marx estructural: lecturas de Althusser en Cuadernos de Cultura}

Atravesado por el proceso cismático de 1967 y condicionado por el carácter reaccionario y dictatorial del onganiato, el comienzo de la nueva época de Cuadernos de Cultura se caracterizó por la centralidad adquirida por un programa de renovación democrática de la cultura. Tal como lo formulaba Héctor Agosti en el informe presentado a la Tercera Reunión Nacional de Intelectuales Comunistas de 1967, y reproducido como artículo central del primer número de esta nueva etapa de la revista, la batalla por la hegemonía cultural en un contexto marcado por la consolidación de corrientes izquierdistas y la represión estatal implicaba simultáneamente un trabajo propiciatorio de una política de alianzas con las fuerzas progresistas enfrentadas a la dictadura y un proceso de discusión con dichas fuerzas, a los fines de "resguardar la

\footnotetext{
${ }^{192}$ Resulta por ello difícil de refrendar la afirmación de Rancière de que este pasaje constituye una "puesta en guardia contra los riesgos de izquierdización inherentes" a la conducta de Althusser. La lección de Althusser. op. cit., p. 100.
} 
individualidad del marxismo-leninismo"193. La especificidad de este programa democrático conllevaba el direccionamiento de la polémica con las otras fuerzas de izquierda hacia un trabajo de persuasión, tolerancia y construcción de soluciones concretas. Ahora bien, si por un lado Agosti insistía en la necesidad de evitar actitudes paternalistas y esquemáticas frente a las fuerzas políticas potencialmente aliadas, se mostraba inflexible con los sectores que se enfrentaban por izquierda a los lineamientos políticos del PCA. En sus palabras, le correspondía a los intelectuales comunistas "dialogar y accionar con todos, excepción hecha de los grupúsculos que tienen, como único 'objetivo de izquierda', la lucha contra el Partido Comunista"194.

En una versión actualizada de aquella "afirmación militante del marxismo-leninismo" de 1964, Agosti articulaba los elementos programáticos de la batalla por la hegemonía cultural con un mapeo actualizado de las nuevas corrientes marxistas que se pretendían modernizadoras. Lo más significativo de este abordaje panorámico del campo marxista de fines de la década de 1960 lo constituía la ausencia de referencias a la propuesta renovadora impulsada por el althusserianismo en Francia. En efecto, la intervención de Agosti que intentaba desarticular los desarrollos teóricos modernizadores, "El resguardo de la herencia ideológica de Marx" -transcripción de un discurso pronunciado en Moscú en 1968 durante las conmemoraciones por el aniversario del nacimiento de Marx- se detenía en varios de los núcleos problemáticos del marxismo sobre los cuales el althusserianismo intervenía generando innúmeras polémicas, como la relación entre ciencia e ideología o el vínculo entre el joven Marx y el Marx maduro, sin hacer referencia a los efectos de la incipiente tradición althusseriana en los debates del marxismo contemporáneo. Los elementos más nocivos de lo que se consideraba un proceso de desnaturalización de la herencia de Marx eran depositados fundamentalmente en las formulaciones de Marcuse, captadas como una interpretación del capitalismo contemporáneo propiciatoria de la disolución de los límites entre

\footnotetext{
${ }^{193}$ Agosti, Héctor. "Las nuevas condiciones de la batalla por la hegemonía cultural". Cuaderno de Cultura (nueva época). N ${ }^{\circ}$, septiembre-octubre de 1967, p. 17.

${ }^{194}$ Ibid., p. 19.
} 
burguesía y proletariado, y las de Fromm, acusadas de privilegiar una lectura humanista de Marx en pos de una articulación entre marxismo y cristianismo.

Si bien ausente en el panorama presentado por Agosti, la aparición del althusserianismo ocupó un lugar considerable en los primeros números de la nueva etapa de Cuadernos de Cultura. El trabajo de presentación de las características de la inflexión althusseriana en la tradición marxista, así como de exposición de una primera lectura codificada de la obra de Althusser, estuvo a cargo de Pablo Barcia, autor de la reseña de La revolución teórica de Marx, publicada en el número 2, y de "Marxismo y humanismo socialista", una intervención en el número 4 dedicada a defender al humanismo socialista de los ataques del antihumanismo althusseriano. El primer elemento al que atendía la introducción de Althusser en las páginas de la revista lo constituía la aclaración del lugar ocupado por sus tesis en los debates del comunismo francés. En este sentido, Barcia presentaba a Althusser como un filósofo comunista que venía desarrollando tesis singulares desde 1963. Por otro lado, que dichas formulaciones estaban vehiculizadas por un marxismo que abrevaba en la corriente estructuralista. En suma, se destacaba que la articulación entre marxismo y estructuralismo había merecido las críticas del referente intelectual del PCF, Garaudy, y que las implicaciones políticas del althusserianismo habían obligado al Comité Central del partido a convocar una reunión sobre problemas culturales e ideológicos -refiriéndose de este modo a la interpelación de la que había sido objeto Althusser por parte de sus camaradas.

En un movimiento que a simple vista podría parecer contradictorio, la enunciación de la dimensión problemática de la irrupción del althusserianismo daba lugar a una valoración positiva del tenor de la intervención de Althusser en el campo marxista contemporáneo y a un consecuente señalamiento de lo auspicioso que resultaba la llegada a la Argentina de las discusiones abiertas por dicha intervención. Esta valoración estaba asociada a la advertencia del carácter inusual de la propuesta renovadora impulsada por el althusserianismo. Los elementos que configuraban dicha singularidad eran remitidos por Barcia a dos dimensiones del marxismo althusseriano. El primero de ellos refería al 
camino a través del cual Althusser emprendía su relectura de Marx. El intelectual comunista argentino saludaba de este modo una reformulación del marxismo que esquivaba la tentación liquidacionista y el desarrollo de una filosofía crítica que no implicaba una renuncia al comunismo; destacaba por ello la elección de Althusser de colocarse en "la perspectiva del desarrollo teórico del marxismo como meta del trabajo intelectual de los investigadores comunistas, como cabal realización de su militancia en el plano de las ideas, superando el horizonte de un desnudo activismo político".

En un sentido convergente con el reconocimiento anterior, se dotaba de una valoración positiva la forma a través de la cual el aporte althusseriano a la filosofía marxista pretendía unos efectos más allá del campo teórico. Según Barcia, el modo en el cual Althusser articulaba los problemas de la filosofía marxista con los de la política comunista era indicativo de la prioridad que le otorgaba esta intervención marxista tanto a la obra científica de Marx como a la práctica política de los militantes comunistas. Se resaltaban así los esfuerzos del althusserianismo por evitar el desarrollo de "una 'filosofía' especulativa acerca del hombre, la economía, la historia o la objetividad en general, construida arbitrariamente a partir de una conjunción exterior de citas filosóficas" ${ }^{195}$.

El carácter valorativo de esta lectura derivaba en una presentación de las dimensiones cuestionables de la obra de Althusser que se desenvolvía sobre un sustrato en el cual dichos elementos eran concebidos como tendencias que conspiraban contra un auspicioso punto de partida y como errores aceptables por tratarse del trabajo de un filósofo comunista que, como tal, se encontraba "en el camino de la verdad relativa hacia el conocimiento infinito" ${ }^{196}$. En este marco eran repasadas someramente aquellas dimensiones del althusserianismo que se presentaban difícilmente integrables en las coordenadas filosóficas en las cuales se ubicaban los intelectuales del PCA: la relación entre ciencia e ideología, la concepción del materialismo dialéctico como epistemología del conocimiento científico, el lugar de la teoría como

${ }^{195}$ Barcia, Pablo. "La revolución teórica de Marx, por Louis Althusser". Cuadernos de Cultura (nueva época), $\mathrm{N}^{\circ} 2$, noviembre-diciembre de 1967, p. 118.

${ }^{196}$ Ibid., p. 121. 
trabajo de producción sobre objetos ideales, la tesis de un corte epistemológico en el pensamiento de Marx, la relación entre la dialéctica marxista y la dialéctica hegeliana, y la crítica al humanismo socialista. Fue esta última, sin embargo, la que generó un mayor afán refutativo en las páginas de Cuadernos de Cultura. Centrada en "Marxismo y humanismo", el texto fundamental sobre el tema incluido en La revolución teórica de Marx, la lectura de Barcia daba cuenta de los problemas teóricos y políticos de avanzar por un camino contrario al del humanismo. Principalmente, la insistencia en el carácter ideológico del humanismo socialista aparecía asociada al riesgo de perjudicar las alianzas con fuerzas políticas o sociales que abrevaban en la tradición humanista o de impedir de antemano el acercamiento al comunismo de militantes humanistas pertenecientes a corrientes no-marxistas. Barcia contraponía de este modo aquella aguda caracterización althusseriana del humanismo socialista como un jeu de mots [juego de palabras] indicativo de un équivoque vécue [equivoco vivido] y l'expression $d u$ vœu de la surmonter [la expresión de un deseo de sobrepasarlo] con la potencialidad del humanismo a los fines de establecer "una política de leal unidad con los antiimperialistas de otros sectores" 197.

La percepción de una vinculación evidente entre las críticas al humanismo socialista y el sectarismo político direccionaba la lectura de las tesis althusserianas hacia la problematización de las relaciones entre la obra de Althusser y los "pretéritos manejos dogmáticos". En el mismo sentido en el que desarollaba el conjunto de su interpretación, Barcia atendía una doble dimensión de dichas relaciones. Por un lado, certificaba que la concepción del humanismo socialista como ideológico y su agrupación junto a otros humanismos bajo el paraguas idealista, metafísico y subjetivante emparentaba inexorablemente al althusserianismo con el dogmatismo. Se advertía con preocupación la tendencia a conceptualizar el binomio humanismo socialista a partir de una concepción de la ideología y la ciencia en términos de una oposición recíproca, movimiento captado por Barcia como una operación valorativa que simultáneamente resaltaba el carácter científico del concepto de

197 Barcia, Pablo. "Marxismo y humanismo socialista". Cuadernos de Cultura (nueva época). $\mathrm{N}^{\circ} 4$, marzo-abril de 1968, p. 25. 
socialismo y condenaba al de humanismo al terreno de lo no-científico. Se evidenciaba, sin embargo, un esfuerzo por subrayar que la identificación entre las tesis de Althusser y el dogmatismo estaba puntualmente relacionado "con las conclusiones y no con la gratuidad del resultado conceptual" ${ }^{198}$. Es decir, que dicha afinidad se percibía en el plano de las consecuencias políticas de las tesis althusserianas y no en el de su fundamentación teórica, dimensión en la cual Barcia identificaba tanto elementos anti-dogmáticos -la valoración de la ciencia, la necesidad de una auténtica práctica teórica- como una complejidad divergente con el esquematismo característico del marxismo dogmático.

Por último, esta primera lectura de la obra de Althusser adquiría un tono de preocupación al analizar las implicaciones teóricas y políticas del anudamiento entre la concepción de la ideología en términos de relación imaginaria y la relectura de Marx en clave antihumanista. Para Barcia resultaba inconcebible que un filósofo marxista postulara la existencia de un mecanismo de producción genérico de las ideologías para todas las sociedades, soslayando de este modo la determinación de los fenómenos ideológicos por las estructuras sociales. Advertía especialmente que los problemas de la ideología en el socialismo, como los relativos al culto a la personalidad, debían analizarse a partir de la especificidad de la sociedad socialista y no a través de conceptualizaciones abstractas. La concepción althusseriana de la ideología aparecía como insuficiente en términos analíticos y potencialmente conservadora en términos políticos. Según Barcia, "para Althusser hay que resignarse a la atmósfera eterna de las relaciones imaginarias sin que puedan ser neutralizadas por la ciencia y el marxismo, convertidas en políticas del estado socialista" ${ }^{199}$.

La misma advertencia se dirigía hacia la propuesta de relevo de los conceptos del joven Marx -alienación, fetichismo, libertad, humanización- por los del Marx maduro -fuerzas productivas, relaciones de producción, superestructura-, inflexión a la que se le asignaba la tendencia a negar el rol del hombre en los procesos sociales e históricos. Al igual que ocurría con su

\footnotetext{
${ }^{198} / d$.

${ }^{199}$ Ibid., p. 32.
} 
singular aporte a la teoría marxista de la ideología, los efectos del antihumanismo althusseriano eran remitidos tanto a la dimensión interpretativa del marxismo -perjudicada en este caso por la anulación de la individualidad y la subjetividad- como a los problemas de la política comunista. Al respecto, la postulación del sujeto como portador de relaciones sociales no permitía, a decir de Barcia, concebir "la actuación crítico-práctica de los hombres que se agrupan en el partido revolucionario para lanzarse a la toma del poder y luego, desde la superestructura política condicionan la nueva articulación del sistema socialista y la emergencia de otras leyes económicas" 200.

\subsection{Contra la finalización del marxismo: Abel García Barceló y las lecturas de Althusser en la década de 1970}

Desde finales de la década de 1960 y hasta 1976, el althusserianismo ocupó un lugar destacado en las intervenciones de García Barceló, el intelectual que monopolizó durante la segunda mitad de la década de 1970 las discusiones sobre filosofía marxista en Cuadernos de Cultura. Los artículos de García Barceló resultan fundamentales a los fines de establecer las coordenadas del sustrato teórico del PCA a lo largo de esos años. En estos textos, la lectura de la obra de Althusser y sus efectos estuvo articulada con la problematización de dos núcleos centrales de la teoría marxista sobre los cuales los intelectuales comunistas argentinos pretendían ejercer una intervención efectiva. Por un lado, García Barceló sometía a discusión la relectura althusseriana de Marx en el contexto de los debates en torno a la relación hegelianismo y marxismo que se habían desarrollado en la década de 1960 y que se estaban actualizando hacia 1970 en ocasión del bicentenario del nacimiento de Hegel. Por el otro, el althusserianismo era problematizado -al igual que en las primeras lecturas- junto a otras tradiciones del marxismo contemporáneo en el marco del programa de defensa del marxismo-leninismo y de refutación de las corrientes modernizadoras. Sin embargo, ciertos desarrollos innovadores en el interior de la tradición marxista, entre los cuales

${ }^{200}$ Ibid., p. 37. 
determinados aportes de la obra de Althusser aparecía desempeñando un rol preponderante, tendieron a complejizar dicho programa direccionando las discusiones teóricas del comunismo hacia el problema de las negaciones de la filosofía marxista.

A modo de contrapunto con las lecturas del althusserianismo desarrolladas a fines de la década de 1960, las reflexiones de García Barceló se desenvolvían sobre un plano estrictamente filosófico. Será difícil de encontrar, de este modo, vinculaciones explícitas entre los desarrollos teóricos en torno a la ideología y el quietismo político o entre el programa antihumanismo y las posiciones sectarias. Sus intervenciones daban cuenta, sin embargo, de algunos procesos de circulación del althusserianismo en otros ámbitos partidarios; los textos fundamentales de García Barceló que atendían problemáticas teóricas abiertas por la obra de Althusser -"Hegel y el marxismo" del número 18 y "Las negaciones de la filosofía marxista" publicados en dos partes en los número 28 y 29- formaron parte de un "Curso de introducción a la filosofía marxista" dictado en el "Centro de Estudios Marxistas-leninistas Victorio Codovilla" y fueron publicados en 1971 por la editorial de dicho centro en un volumen titulado Hegel y la dialéctica científica de Marx.

Si bien el discurso de García Barceló mantenía en gran medida el tono impugnador de los procesos de apertura del marxismo a otras corrientes filosóficas contemporáneas, sus reflexiones de la primera mitad de la década de 1970 intervenían sobre un campo marxista que difería en algunos de sus elementos delineadores con aquel de mediados de la década de 1960. Declinado aquel impulso sesentista de lucha contra el izquierdismo de los sectores disidentes del partido, la concentración de la disputa en el campo de la teoría empujará aquel programa de resguardo de la individualidad del marxismo-leninismo hacia la refutación de las corrientes filosóficas finalizadoras del marxismo. En este sentido, el repaso crítico por los procedimientos teóricos instrumentados para "el suicidio filosófico del marxismo" 201 se anclaba en aquellos marxistas, como Sartre y Lefebvre, cuyos

${ }^{201}$ García Barceló, Abel. "Hegel y el marxismo". Cuadernos de Cultura (nueva época). $\mathrm{N}^{\circ} 18$, julio-agosto de 1970, p. 87. 
planteos aperturistas eran caracterizados como factores tendientes a la negación de los principios fundamentales del marxismo.

El énfasis de algunas corrientes del marxismo contemporáneo en problemas tales como la praxis existencial o la alienación de la esencia humana era conceptualizado como una renuncia abierta a los elementos singulares de la tradición marxista, especialmente aquel relacionado con la materialidad dialéctica del mundo natural y social. Si bien diferenciado de estas corrientes, especialmente por su desenvolvimiento en los marcos del marxismo-leninismo, el althusserianismo era interpretado como un esfuerzo trunco de oposición a las formulaciones finalizadoras:

Frente a los 'finalizadores', algunos marxistas valoran adecuadamente a la filosofía como teoría del conocimiento científico, pero incurriendo en otra distorsión inversa, la de desligar a la filosofía y a la teoría científica del marxismo de sus previos e indispensables condicionamientos sociales y políticos (Althusser, por ejemplo) $^{202}$

El otorgamiento de este lugar al marxismo althusseriano conllevará el sometimiento de la obra de Althusser y la de sus discípulos a una censura del mismo tenor que la operada sobre las filosofías negadoras del marxismo. La insistencia de García Barceló en la necesidad de que los filósofos comunistas avanzaran en el desarrollo de una teoría del individuo y de la alienación fundada sobre las bases de la economía política y el materialismo histórico, redundará en la formulación de un programa de lucha teórica estructurado a partir del combate en dos frentes. Por un lado, contra el humanismo especulativo, representado por Sartre y Lefebvre; por el otro, contra el antihumanismo teórico y práctico, representado por Althusser. El mismo tono se percibe en la ubicación del althusserianismo en las discusiones en torno a las relaciones entre Hegel y el marxismo. En un panorama estructurado a partir de la refutación de las operaciones teóricas tendientes a una mistificación de Hegel, así como de una consecuente postulación de la necesidad de afirmar la real continuidad de Hegel en el marxismo, la denuncia de las distorsiones

202 Ibid., p. 88. 
contemporáneas del legado hegeliano conllevaban una equiparación del althusserianismo con otras corrientes marxistas contemporáneas. Así, mientras se identificaba a Jean Hyppolite con la operación de un Marx hegeliano, a Lukacs con la de un Hegel marxista y a Marcuse con la de un Hegel sin Marx, Althusser aparecía representando la de un Marx sin Hegel. Por ello, el potencial antidialéctico del marxismo estructuralista era igual de combatido que las operaciones hegelianizantes:

\begin{abstract}
Al no aceptar la continuidad del núcleo racional hegeliano, continuidad que entraña al mismo tiempo transformación sustancial de la dialéctica idealista, Althusser, Godelier, Balivar [sic], etc., reemplazan a la dialéctica de la unidad y lucha de los opuestos en la contradicción, por las relaciones mecánicas entre estructuras; sustituyen a Hegel por Spinoza ${ }^{203}$
\end{abstract}

Hasta acá, el modo en el cual el althusserianismo intervenía en el corpus marxista articulando la práctica y la teoría era cifrado como un movimiento especular frente al desbalance entre estas dos dimensiones operado por las corrientes marxistas humanistas contemporáneas. Las afirmaciones de García Barceló no dejan lugar a dudas: la degeneración cientificista propiciada por Althusser, conducente a una hipertrofia de la teoría respecto a la práctica, era tan nociva como la degeneración practicista de Sartre, Lefebvre o Costas Axelos, responsable de una superposición entre la teoría y la práctica.

Ahora bien, si ambas tendencias aparecen como portadoras de un carácter regresivo en tanto contribuirían a la negación de aspectos fundamentales de la filosofía marxista, el pasaje a la problematización de la relación entre la filosofía y las ciencias implicará una modificación de la valoración de ambas directrices y, especialmente, la atemperación de la lectura convergente de las características del marxismo dogmático y las filosofías del hombre. En este sentido, los intérpretes estructuralistas del marxismo eran presentados como aquellos teóricos cuya insistencia en la cientificidad del marxismo permitía advertir los procedimientos desarrollados por las filosofías del hombre en pos de la conservación del carácter especulativo de las ciencias

${ }^{203}$ Ibid., p. 102. 
sociales y humanas. A pesar de la aclaración de que esta apreciación no implicaba "aceptar el punto de vista de los estructuralistas que niegan la existencia de una teoría filosófica sobre el humanismo en el marxismo", García Barceló destacaba el esfuerzo de Rancière y Pêcheux por evidenciar los mecanismos de traducción de los conceptos científicos a categorías filosóficas y por demostrar, de este modo, "la trasnochada supervivencia filosófica en el campo de las ciencias marxistas" 204 .

Esta valoración del althusserianismo, que incluía la transcripción de los diagramas reproducidos en los textos de Rancière y Pêcheux, se extendía asimismo a otras dimensiones teóricas abierta por la obra de Althusser. Si bien las proyecciones políticas del marxismo althusseriano no eran objeto de sus preocupaciones, García Barceló dejaba entrever cierta afinidad entre la lucha contra el lenguaje especulativo de las filosofías del hombre y el combate contra los movimientos izquierdistas cuyas formulaciones se mantenían aún en un terreno ideológico. Quedaban asociados, por lo tanto, el trabajo teórico consistente en la revelación de la pervivencia filosófica en la ciencia marxista y aquel dedicado a la constatación del carácter precientífico del discurso de los sectores otrora disidentes del partido. El repaso por las virtudes del cientificismo althusseriano se coronaba con una refutación de las pretensiones de las organizaciones izquierdistas, cuyos programas sustituían el análisis concreto de las fuerzas clasistas y la conciencia del proletariado por declaraciones vagas referidas a la violencia de los oprimidos o la inminente conquista de la esencia humana. Acompañando esta articulación entre dimensiones teóricas y políticas, García Barceló introducía una reflexión en torno a la actualización de las discusiones sobre la ideología a partir de la difusión de las formulaciones althusserianas. Si bien delineada a partir de un sustrato marxista-leninista que enfatizaba la imposibilidad de oponer teoría e ideología, la lectura de la concepción althusseriana de los procesos ideológicos

\footnotetext{
${ }^{204}$ García Barceló, Abel. "Las negaciones de la filosofía marxista desde las ciencias y las ideologías". Cuadernos de Cultura (nueva época). $\mathrm{N}^{\circ} 29$, p. 13 . El artículo de Rancière retomado por García Barceló era "Le concept de critique et la critique de l'economie politique dans les "Manuscrits de 1844", publicado en 1965 en La Pensée aquel incluido en la edición francesa de Lire Le Capital-. El de Pêcheux, "Les sciences humaines et le 'moment actuel'", publicado en La Pensée en 1969.
} 
estaba, aún advertida la subordinación de la ideología a la teoría, dotada de una valoración diferente a la de aquellas operaciones -como la sartreana o la gramsciana- tendientes a la subordinación de la teoría a la ideología. Sustentada en un seguimiento pormenorizado de la obra althusseriana, que incluía el conocimiento del texto aún inédito en castellano sobre los AIE, y de los debates por ella suscitados, especialmente aquel generado por Rancière presentado como "un discípulo de Althusser que pasó a posiciones de ultraizquierda" ${ }^{205}$-, la presentación de la concepción althusseriana atendía tanto la problematización de sus elementos más peligrosos -carácter transhistórico, representaciones imaginarias, nociones antropológicas- como la necesidad de que el marxismo-leninismo avanzara en la discusión teórica en torno al problema de la ideología -en qué consiste un proceso ideológico, con qué disciplina se lo estudia, etc ${ }^{206}$.

La lectura atenta del itinerario del marxismo althusseriano por parte de García Barceló estuvo acompañada por un seguimiento detallado de las innovaciones desarrolladas entre los intelectuales comunistas franceses a fines de la década de 1960 y comienzos de la de 1970. En este sentido, una parte considerable de la trayectoria de Cuadernos de Cultura durante su nueva

\footnotetext{
205 Ibid., p. 19.

${ }^{206}$ El lugar otorgado por García Barceló a las formulaciones althusserianas es perceptible en otras dos reflexiones desarrolladas en las páginas de Cuadernos de Cultura, que aún desde un espacio lateral y contingente, son altamente indicativas de la especificidad de sus marcos de lectura. Una de ellas la constituyó la reseña de El proceso ideológico editado por Eliseo Verón, publicada en el número 31. Si bien reticente a aceptar el privilegio otorgado al análisis de las formas lingüísticas de la ideología, García Barceló indicaba que dicha perspectiva de investigación no había sido aún desarrollada por el marxismo y que por lo tanto el trabajo realizado por Verón merecía la atención de los intelectuales comunistas. Valorando el camino abierto por la concepción althusseriana de la ideología pero despejando sus implicaciones antihumanistas, el análisis de los procesos ideológicos era direccionado hacia la investigación sobre las formas históricas de la individualidad, lo cual derivaba en la atención simultánea de los procesos ideológicos y de las relaciones de producción sobre las que ellos se desarrollan. La otra consistía en una apropiación de Althusser a los efectos de refutar las articulaciones entre marxismo y tercermundismo. En "La 'localización' de una 'vena idealista' en Marx", una reseña lapidaria de Ser social y tercer mundo de Norberto Wilner publicada en el número 15, García Barceló recurría a Lenin -como ejemplo de marxista clásico- y a Althusser -como ejemplo de marxista contemporáneo- para remarcar que cualquier abordaje del ser nacional realizado desde el marxismo debe -a efectos de no caer en el idealismo- tener como punto de partida el análisis de la interpenetración entre las formas que adquiere lo nacional y las especificidad de la formación económico-social en las que aquellas se desenvuelven.
} 
época coincidió con el enfrentamiento de Garaudy con la dirección del PCF y su consiguiente expulsión del partido, así como con el progresivo relevo de su figura por la de Sève y la posterior consolidación de éste último como principal referente intelectual del comunismo francés.

Hemos hecho referencia más arriba al modo en el cual las formulaciones marxistas-leninistas de Garaudy, ortodoxas y modernizadoras a la vez, actuaron a mediados de la década de 1960 a modo de ariete frente los procesos de integración del marxismo con corrientes filosóficas consideradas burguesas, como el existencialismo y el pensamiento católico. La importancia adquirida por Garaudy entre los intelectuales comunistas argentinos, que contribuyó al mencionado apoyo en la dureza de sus argumentaciones contra la disidencia política y teórica al marxismo-leninismo, pero también en aproximaciones sistemáticas a sus aportes a la filosofía marxista, en la apropiación de sus reflexiones en torno a problemas estéticos y en la interiorización de una lectura de la lucha de los estudiantes franceses y los episodios de mayo de $1968,{ }^{207}$ declinó abruptamente hacia finales de la década. Mauricio Lebedinsky fue el encargado de anunciar, en el número 14 (noviembre-diciembre 1969), la noticia inesperada: a través de su artículo "El 'antidogmatismo' de Roger Garaudy" comunicaba a los lectores de la revista que el por entonces referente intelectual del comunismo francés estaba incurriendo en actitudes desviacionistas. Una, política, concentrada en la crítica abierta a la URSS y al campo socialista debido a los sucesos de Checoslovaquia; la otra, teórica, consistente en la sorprendente asunción de la posición de la cual él había sido una de sus más firmes objetores, es decir, aquella de la necesidad de luchar contra el dogmatismo, propiciar la apertura del marxismo y favorecer su asimilación con otras corrientes filosóficas contemporáneas.

\footnotetext{
207 Ver respectivamente la reseña de Perspectivas del hombre escrita por Miguel Lombardi en el número 71 (noviembre-diciembre 1964), "La tesitura estética de Roger Garaudy" de Raúl Sciarretta en el número 74 (mayo-junio 1965) y la reproducción de su texto "La revuelta y la revolución" en el número 7 (septiembre-octubre 1968). Cabe destacar que el libro reseñado por Lombardi y al que hace referencia el artículo de Sciarretta, Hacia un realismo sin fronteras -del cual éste fue su traductor-, habían sido publicados por editoriales del partido, el primero por Lautaro y el segundo por Platina.
} 
Al año siguiente, y ya consumada su expulsión del partido, Cuadernos de Cultura publicó un dossier en su número 101 (mayo-junio 1970) sobre el caso Garaudy con un texto del comité de redacción de La nouvelle critique, el informe de Étienne Fajon -miembro del Comité Central del PCF- ante el XIX congreso partidario, un artículo del filósofo soviético Jachik Momdzhian y un texto de la redacción de Cuadernos de Cultura que establecía un paralelismo entre las tesis de Garaudy y las de Earl Browder. Una vez asimilado el giro revisionista de Garaudy, sus posiciones fueron presentadas como indicativas de la inconveniencia de contradecir públicamente la línea del partido -se citaban las notas del diario La Nación en las que aquel era presentado como un comunista sincero- y de la coincidencia entre los programas antidogmáticos surgidos a la derecha y a la izquierda del marxismo-leninismo -caducidad del rol de la clase obrera, negación del partido, aparición de un nuevo bloque histórico ${ }^{208}$.

Los efectos del caso Garaudy, especialmente en lo relativo a la vacancia del espacio de referencia intelectual del comunismo francés, así como la progresiva importancia adquirida por las interpretaciones marxistas de Sève, ancladas en el marxismo-leninismo pero propiciadoras de una serie de remarcables innovaciones al interior de dicha tradición, contribuyeron a que algunas de sus tesis fueran retomadas en el discurso de los intelectuales comunistas argentinos, que algunos de sus textos fueran reproducidos en Cuadernos de Cultura y que sus trabajos más importantes fueran promovidos en reseñas y comentarios críticos en las páginas de la revista. $\mathrm{Si}$, como bien vimos anteriormente, las tesis de Sève ya había sido referenciadas por los comunistas argentinos junto a las de Garaudy en aquella "afirmación militante del marxismo-leninismo" de mediados de la década de 1960, durante la primera mitad de la de 1970 éstas ocuparán un lugar central en las reflexiones filosóficas desarrolladas en el marco del PCA. Este movimiento, evidentemente

208 En 1974, la editorial Cartago editará el volumen El comunismo científico: su falsificación por Garaudy-Fischer y otros preparado por el Instituto de de Marxismoleninismo. Será anunciado en las contratapas de los números de la revista como "un valioso trabajo que destruye las teorías revisionistas de Garaudy y Fischer" y "entrega ricos antecedentes teóricos respecto al papel dirigente de la clase obrera, el avance del socialismo real y la doctrina leninista del partido". 
impulsado por García Barceló y originado en el interés que en él concitaban las reflexiones de Sève en torno al problema del humanismo marxista, tuvo un desenvolvimiento signado por los avatares de la edición y traducción al castellano de su obra fundamental: Marxismo y teoría de la personalidad, publicada en francés en 1969.

En un primer momento fue traducido y publicado solamente el fragmento en el cual Sève problematizaba la interpretación althusseriana del marxismo. Así, el número 33 (enero-febrero 1973) reproducía la caracterización del althusserianismo como una corriente marxista que, al enfatizar la distinción entre el objeto de pensamiento y el objeto real, tendía a poner en duda la existencia objetiva de la esencia. Sobre esta base interpretativa, Sève identificaba negativamente aquellos elementos que a su entender estructuraban la interpretación althusseriana: la reducción de la dialéctica a una teoría de la sobredeterminación, la transformación del materialismo histórico en un antihumanismo teórico y la circunscripción de la epistemología al nivel específico de la teoría. Junto a la elección del fragmento reproducido, resulta relevante la inclusión de una brevísima nota introductoria al texto de Sève, sin firma pero seguramente escrita por García Barceló, que presentaba algunas directrices interpretativas a los fines de guiar la lectura del contenido publicado. Allí se afirmaba que la importancia de la obra de Sève radicaba en el privilegio otorgado por el filósofo francés a la esencia concreta y en su propuesta de construir una psicología fundada en el materialismo histórico y la economía política. La restauración de la originalidad de la epistemología marxista operada por Sève habilitaba, según el presentador anónimo, un camino alternativo al humanismo especulativo y al antihumanismo estructuralista.

La promoción de la interpretación de Sève terminó de consolidarse una vez que Marxismo y teoría de la personalidad fuera editado en castellano. En su número 40 (marzo-abril 1974), Cuadernos de Cultura publicó un comentario del libro escrito por García Barceló que, con el título "Un libro fundamental de nuestro tiempo", caracterizaba a la obra como una intervención destinada a reactivar la discusión que las corrientes marxistas hegemónicas habían logrado aplacar. La apropiación de las formulaciones de Sève permitía enfrentar al 
dogmatismo, en tanto éstas le restauraban al marxismo el carácter de programa descubridor de problemáticas y producción de nuevas concepciones, y a lo que se aludía como "ciertas concepciones erigidas muy apresuradamente para obtener patente de "marxismo científico creador", frente a las cuales el trabajo de Sève aparecía como posibilidad de desarrollar una investigación profunda y rigurosa en el interior de la tradición marxista sin que esto implicara necesariamente la introducción de elementos pertenecientes a corrientes no marxistas como el psicoanálisis, la lingüística, las matemáticas o la lógica. Si bien estas alusiones peyorativas referían veladamente a las formulaciones althusserianas, y el trabajo teórico amparado en los marcos de esta tradición era calificado como una “coctelera agitada en base a 'lecturas sintomáticas' de Marx" ${ }^{209}$, García Barceló destacaba que algunos elementos del programa de Sève en pos de una teoría científica del hombre y su personalidad -como aquel de las formas históricas de individualidad- habían sido originariamente postulados por Althusser. El mérito de Sève residía, a su entender, en haber desbloqueado el antihumanismo paralizante del althusserianismo y haber logrado despejar, en consecuencia, la tensión irresoluble entre la concepción humanista- del vínculo entre relaciones sociales e individuos en términos de identificación y aquella -estructuralista- que tendía a entenderla en el sentido de diferencia ${ }^{210}$.

\subsection{A modo de cierre}

La crisis abierta en el seno del PCA a mediados de la década de 1960 constituyó un fenómeno propicio para la incorporación de las tesis althusserianas en los discursos sostenidos por sus intelectuales. El proyecto de

\footnotetext{
${ }^{209}$ García Barceló, Abel. "Un libro fundamental de nuestro tiempo. Marxismo y teoría de la personalidad por Lucien Sève". Cuadernos de Cultura (nueva época). N 40, marzo-abril de 1974, p. 86

${ }^{210}$ El comentario de García Barceló permite advertir que la introducción de la obra de Sève entre los intelectuales comunistas argentinos no estuvo exenta de objeciones e impugnaciones. Al defenderla de ciertos ataques esquemáticos, aquel relataba que luego de haberse publicado en la revista el fragmento perteneciente a Marxismo $y$ teoría de la personalidad, "surgieron entre nosotros algunas voces que sin haber leído el libro calificaban de 'esencialista' al autor", Id.
} 
recuperación del carácter revolucionario del partido estuvo atravesado por una jerarquización del trabajo teórico. Convencidos de que el rumbo errático del comunismo argentino se debía tanto a una limitación política como a una teórica, algunos grupos disidentes comenzaron a postular la necesidad de sustentar la formulación de la línea partidaria en un estudio científico de la realidad argentina. Esta tarea, que tendía a equiparar las tareas teóricas con las del trabajo político, se pretendía superadora de los modos tradicionales a través de los cuales el partido había concebido la relación entre teoría y práctica. La referencia a dichos modos en términos de una práctica teórica distorsionada daba cuenta del esfuerzo por trascender una concepción de la teoría según la cual ésta operaba únicamente como legitimadora de una línea política fijada de antemano.

$\mathrm{Si}$ bien las formulaciones althusserianas permearon los discursos esbozados a lo largo del proceso de recuperación revolucionaria del partido, uno de los grupos que disputaban la dirección de dicha tarea se destacó por haber propiciado una articulación explícita entre el althusserianismo y una línea política alternativa a la sostenida por el CC. En este sentido analizamos la apelación realizada por el zaratismo a diversas tesis althusserianas con el objetivo de delimitar una estrategia de lucha armada para la coyuntura argentina de fines de la década de 1960. La derrota del zaratismo en el momento de fundación del PCR le otorgó al althusserianismo un derrotero singular en las discusiones teóricas y políticas establecidas por el partido. Vimos al respecto que un espacio significativo de los discursos de los cuadros partidarios estuvo ocupado por refutaciones de las tesis althusserianas. La condena a las formas organizativas que había propuesto el zaratismo conllevó un trabajo sistemático de crítica a la relectura del marxismo propuesta por Althusser. Advertimos, sin embargo, que junto a esta denuncia siguieron existiendo dentro del partido esfuerzos por dotar al trabajo político del necesario acompañamiento de las tareas teóricas. De este modo convivieron en los primeros años del partido una diatriba antialthusseriana con un discurso acerca del trabajo teórico que remitía precisamente a las propuestas del marxista francés. 
La pervivencia de formulaciones althusserianas declinó a la par de la ubicación del PCR en la órbita del comunismo chino. La profundización del enfrentamiento con las organizaciones armadas y la identificación del PCF como paradigma del revisionismo tendieron a reforzar el discurso antialthusseriano. Por un lado, la línea partidaria siguió encontrando legitimidad en la superación de aquella articulación entre marxismo althusseriano y lucha armada. Por el otro, identificando a Althusser como un filósofo que introducía elementos idealistas en el marxismo dada su participación en el partido comunista más revisionista de Europa. La contundencia del giro maoísta operado por el PCR permite comprender el lugar ocupado por Althusser en los textos escritos por los máximos dirigentes en la revista del partido. En el proceso de orientación hacia el maoísmo el althusserianismo constituyó un vector que permitía contraponer de manera efectiva, en el contexto mundial, la Revolución Cultural a la línea revisionista, y en el contexto nacional, la política del PCR con la de las organizaciones armadas.

En la segunda mitad de este capítulo nos ocupamos de los itinerarios del althusserianismo entre los intelectuales comunistas que permanecieron en el partido. A los fines de delimitar la especificidad del anclaje de estos intelectuales en el campo marxista contemporáneo, nos remontamos a las lecturas realizadas en la prensa partidaria de los procesos de apertura y modernización del marxismo. Los intelectuales comunistas argentinos cerraron filas en torno al marxismo-leninismo de matriz soviética caracterizando a las corrientes innovadoras de la década de 1960 como desviaciones idealistas. La crisis de 1967 reforzó aún más los ejercicios de defensa del marxismoleninismo. En este contexto, la prensa partidaria realizó un seguimiento del auge y desarrollo de las corrientes maoístas francesas. La relación ambivalente que Althusser mantenía con dicha tradición se reflejó en los textos publicados al respecto en Cuadernos de Cultura. Leído a través de las publicaciones análogas del comunismo francés, el marxismo althusseriano era presentado a la vez como un ejercicio de relectura de Marx realizado en los marcos partidarios como un tipo de trabajo teórico que sustentaba la crítica maoísta al PCF. 
Percibimos la misma ambivalencia en la recepción de Althusser en Cuadernos de Cultura una vez que fuera publicado en castellano Pour Marx. Los textos dedicados al marxismo althusseriano en la revista reconocían la productividad de un trabajo de relectura de Marx centrado en la dimensión teórica y la singularidad de una corriente renovadora del marxismo que no cedía a las tentaciones del idealismo. Identificamos un rechazo frontal de las nociones antihumanistas inherentes al proyecto althusseriano. El programa de convergencia con otras fuerzas políticas que el PCA impulsaba para enfrentar a la dictadura de Onganía encontraba en la crítica radical al humanismo un obstáculo que podría impedir tal política de alianzas. Vimos, sin embargo, que en la primera mitad de la década de 1970 las tesis althusserianas fueron incorporadas al discurso teórico del partido en el combate contra otras corrientes de pensamiento contemporáneas. Al respecto, si bien algunos aspectos del althusserianismo siguieron generando resistencia, como el cientificismo y en anti-hegelianismo, otros como la problematización de la ideología y la lucha contra el lastre de la filosofía en la ciencia marxista, recibieron la atención de García Barceló, el referente filosófico del partido. Finalmente reconstruimos el proceso a través del cual el althusserianismo comenzaba a perder interés a la par que Sève se convertía en la principal referencia de la teoría marxista francesa. En este sentido, analizamos cómo el trabajo de éste le permitía a García Barceló apostar a un marxismo que convergía en parte con los intereses del althusserianismo pero que no acarreaba elementos difíciles de traducir al contexto partidario, tales como el antihumanismo y la crítica interna al partido. 


\section{Capítulo 3}

\section{Entre el estructuralismo y el maoísmo: el Althusser de Los}

\section{Libros}

\subsection{Introducción}

En este capítulo analizamos el lugar ocupado por Althusser en la experiencia de la revista Los Libros. En primer lugar, nos detenemos en el rol desempeñado por el marxismo althusseriano junto a otras herramientas de raigambre estructuralista en el proceso de modernización de la crítica llevado a cabo por la revista. Delimitamos la importancia de los aportes althusserianos en el direccionamiento del trabajo crítico hacia el develamiento de los mecanismos ideológicos subyacente en los textos literarios. Luego analizamos la productividad específica que tuvo el althusserianimo en intervenciones de los colaboradores de la revista en relación a distintos ámbitos de la vida política e intelectual del país. Atendemos los efectos generados por la aplicación de variables althusserianas a los campos de la sociología, la ciencia, la filosofía y la política. Asimismo reconstruimos el examen al que el althusserianismo fue sometido a través de los mecanismos de control de las herramientas críticas implementados por la revista. Al respecto nos concentramos en el proceso de latinoamericanización de la revista a los fines de constatar las transformaciones en la interiorización de las herramientas propias del paradigma estructural.

A continuación analizamos el lugar del althusserianismo en la segunda etapa de la revista caracterizada por una crítica política de la cultura. Nos interesa destacar la existencia de una continuidad de los análisis de la cuestión ideológica deudora de la inscripción originaria de la revista en el paradigma estructural. En este sentido reconstruimos la pervivencia de las tesis althusserianas en el proceso de maoización de la revista. Para ello nos 
detenemos especialmente en los modos específicos a través de los cuales era procesada la relación entre práctica política y lucha cultural por los referentes de la publicación. Analizamos el rol preponderante adquirido por la ideología en la aproximación desarrollada por la revista a la situación de la educación argentina. También reconstruimos el proceso de relevo teórico que implicó un relegamiento del althusserianismo a favor de las concepciones gramscianas de la cultura popular. Finalmente, constatamos la relación entre la consolidación de Los Libros como expresión cultural de las corrientes maoístas y el marcado anti-althusserianismo que signó los últimos números de la revista.

\subsection{El paradigma estructural: crítica y crítica de la crítica}

Se ha señalado recurrentemente el afán fundacional con el que Los Libros irrumpió en el escenario intelectual argentino de fines de la década de $1960^{211}$. A diferencia del gesto rupturista que había caracterizado el nacimiento de otras revistas político-culturales de la izquierda argentina, Los Libros intentó singularizar su intervención a través de un vaciamiento del espacio en el cual pretendía inscribirse. La nota del primer número con la cual la revista se presentaba públicamente, "La creación de un espacio", apuntalaba material y textualmente dicha operación. Una página mayormente en blanco y un pequeño párrafo que comenzaba citando la frase que habría resonado en la

\footnotetext{
${ }^{211}$ Los Libros publicó cuarenta y cuatro números entre 1969 y 1976. La revista llevó los subtítulos "Un mes de publicaciones en Argentina y el mundo", desde el primer número (julio 1969) hasta el 7 (enero 1970); "Un mes de publicaciones en América Latina", desde el número 8 (mayo 1970) hasta el 21 (agosto 1971); "Para una crítica política de la cultura", desde el número 22 (septiembre 1971) hasta el 40 (marzo-abril 1975); y "Una política en la cultura", desde el número 41 (mayo-junio 1975) hasta el 44 (enerofebrero 1976). Cada una de las etapas coincidieron en gran medida con modificaciones en su equipo editorial: desde el primer número hasta el 7 fue dirigida por Héctor Schmucler y tuvo a Guillermo Schavelzon como editor responsable; a partir del número 8 se sumó Santiago Funes como secretario de redacción y se conformó un equipo de corresponsales en los países latinoamericanos; a partir del número 23 siguió siendo dirigida por Schmucler pero contó con un Consejo de dirección integrado por Carlos Altamirano, Ricardo Piglia y Beatriz Sarlo, al que luego se sumaron Miriam Chorne y Germán García; en el número 29 se fue Schmucler, Chorne y García y la revista pasó a ser dirigida por Altamirano, Piglia y Sarlo; a partir del número 31 dejó de tener corresponsales en América Latina; en el número 40 se fue Piglia y la revista fue dirigida hasta su último número por Altamirano y Sarlo.
} 
intelectualidad argentina a partir del proyecto de creación de la publicación: "la revista llenará un vacío" 212 .

La intervención específica que propiciaba la revista encontraba su legitimidad en la inexistencia de dispositivos críticos modernos: "la aventura de construirla -aunque densa de incertidumbre- había sido imaginada, en efecto, al estímulo de ausencias inquietantes" ${ }^{213}$. Al remitir los problemas de la constitución de un dispositivo novedoso a la determinación de sus impulsores, y no al condicionamiento de un ajuste de cuentas con formas pasadas de la crítica, dicha legitimidad era sometida a una operación de reforzamiento altamente efectiva: "las vacilaciones iniciales fueron de orden semántico: ¿cómo definir aquello que enuncia su inexistencia?”214. En suma, se delimitaba a la crítica como el terreno específico en el cual operaría la revista, se postulaba al establecimiento de los instrumentos de la crítica como la tarea fundamental a ser desarrollada por sus colaboradores y se distinguía a la ideología como el objeto primordial a ser abordado en dicha tarea crítica. Una concepción novedosa de los libros -"todo lenguaje está cargado de ideología"215 - convergía con una concepción novedosa de la crítica: "Los Libros no es una revista literaria, entre otras cosas porque condena la literatura en el papel de ilusionista que tantas veces se le asignara" ${ }^{216}$.

La puesta en marcha del aparato crítico delimitado daba cuenta que las pretensiones fundacionales de la revista estaban estructuradas a partir de una modernización de los instrumentos de la crítica anclada en los aportes de nuevos desarrollos teóricos, especialmente aquellos derivados del paradigma estructural. En la configuración de dicho aparato crítico, las variables analíticas del marxismo althusseriano operaron junto a las proporcionadas por otros saberes modernos, tales como el psicoanálisis lacaniano, la teoría semiológica y el análisis estructural. El modo en el cual los colaboradores de la revista se posicionaron frente a los libros de crítica literaria editados estuvo atravesado

212 "La creación de un espacio". Los Libros. Un mes de publicaciones en Argentina y el mundo, $\mathrm{N}^{\circ} 1$, Julio de 1969, p. 3.

${ }^{213} / d$.

${ }^{214} / d$.

${ }^{215} / d$.

${ }^{216} / d$. 
tanto por la legitimación y promoción de los abordajes estructurados a partir de la incorporación de dichas herramientas conceptuales como por la refutación y el desdén frente a las formas de la crítica ancladas en viejos paradigmas interpretativos ${ }^{217}$.

En este sentido resulta significativo que el artículo reproducido a continuación de la nota editorial del primer número haya sido un texto en el que Jorge Rivera sometía a examen el trabajo de Ernesto Sábato como crítico literario. Con el sugerente título "Sábato, custodio de las letras", Rivera llevaba a cabo una lectura de Tres aproximaciones a la literatura de nuestro tiempo (Robbe-Grillet, Borges, Sartre) ${ }^{218}$ en la cual el trabajo del escritor argentino era exhibido como ejemplo de una forma de la crítica tan obsoleta como conservadora. Contraponiendo la "reflexión orgánica" ${ }^{19}$ sobre la obra de Alain Robbe-Grillet realizada por Roland Barthes a la "difusa reflexión" 220 esbozada por Sábato, la aproximación del escritor argentino a la obra de autores europeos era descripta peyorativamente como la mirada de alguien "periférica y asincrónicamente ubicado frente al fenómeno que propone rebatir" 221 .

Junto a la desaprobación de una manera de posicionarse frente la literatura extranjera, Rivera presentaba a Sábato como el índice de una franja intelectual que reaccionaba frente a la proliferación de nuevas herramientas teóricas y metodológicas para la interpretación del hecho literario. De este modo, Sábato se convertía en el paradigma de una "inteligencia mitificadora"222, reactiva frente a los procedimientos precisamente desmitificadores de la crítica

\footnotetext{
217 José Luis de Diego ha destacado el carácter novedoso de esta crítica de control que mantenía actualizados los instrumentos analíticos. Esta operación de crítica de la crítica hacía que los colaboradores de la revista fueran "alternativamente sujeto y objeto del discurso crítico", ¿Quién de nosotros escribirá el Facundo? Intelectuales y escritores en Argentina (1970-1986). La Plata, Al Margen, 2013, p. 86. En esta misma clave, Fabio Espósito ha enfatizado la importancia de la reseña de textos críticos en tanto espacio posibilitador de la visibilización de estrategias de modernización de la crítica, "La crítica moderna en Argentina: la revista Los Libros (1969-1976)". Orbis Tertius. $\mathrm{N}^{\circ} 21,2015$, pp. 1-8.

${ }^{218}$ Santiago de Chile, Editorial Universitaria, 1968.

${ }^{219}$ Rivera, Jorge. "Sábato, custodio de las letras". Los Libros. Un mes de publicaciones en Argentina y el mundo, $\mathrm{N}^{\circ} 1$, Julio de 1969, p. 4.

${ }^{220} / d$.

${ }^{221} / d$.

$222 / d$.
} 
contemporánea, tales como la "desacralización de la ilusión referencial" y la "desfetichización de la concepción analógica del mundo"223. La lectura realizada por Rivera confirmaba la existencia del vacío al cual se hacía referencia en la nota editorial: la revista no podía anclarse en un campo intelectual en el que uno de sus referentes se esforzaba por "resguardar, en el meollo mismo de la crisis, la integridad de un código narrativo que se quiere incontaminado $y$ paradigmático" 224 .

Sobre estas mismas variables se desenvolvían las lecturas realizadas por Nicolás Rosa, cuyos artículos ocuparon un lugar significativo en los primeros números de la revista. En el primer número, una reseña de la compilación realizada por Jorge Lafforgue sobre la nueva novela latinoamericana ${ }^{225}$ operaba a modo de pretexto de una serie de preguntas alrededor de la existencia de una nueva generación de críticos en Argentina, el desarrollo de nuevos presupuestos teóricos y la aparición de nuevos objetos de estudio. El análisis de Rosa se caracterizaba por una demarcación entre un tipo de acercamiento a la obra mediado por instrumentos científicos y todo aquello que podía englobarse en "un registro no definido de naturalismo-idealismo, de lenguaje vago e impreciso y metalenguaje crítico no suficientemente elaborado, de oscura fenomenología y enclaves contenidistas" ${ }^{226 .}$

El esfuerzo por desligar el trabajo crítico de sus mitos más persistentes unidad de la obra, esencialidad, trasparencia del lenguaje- configuraba un escenario estructurado literalmente en dos lados. Por una parte, ingenuidad metodológica y buenas intenciones: sociologismo, generalizaciones, reivindicaciones estéticas, énfasis en los temas y el estilo. Por el otro, interpretación psicoanalítica y análisis dialéctico: revelación de las coyunturas estructurales que sustentan el discurso narrativo, centralidad de la escritura, captación de la obra en la totalidad de sus significaciones. Así se diagramaba un esquema de constatación de la existencia de una nueva generación de

\footnotetext{
${ }^{223} / d$

224 Id.

${ }^{225}$ Lafforgue, Jorge y otros. Nueva novela latinoamericana. Buenos Aires, Paidós, 1969.

${ }^{226}$ Rosa, Nicolás. "Nueva novela latinoamericana, ¿nueva crítica?”. Los Libros. Un mes de publicaciones en Argentina y el mundo, № 1, Julio de 1969, p. 6.
} 
críticos en el que elemento demarcador no era la declaración voluntarista de aquellos que impulsaban las nuevas interpretaciones sino la cientificidad del aparato crítico desplegado en sus análisis:

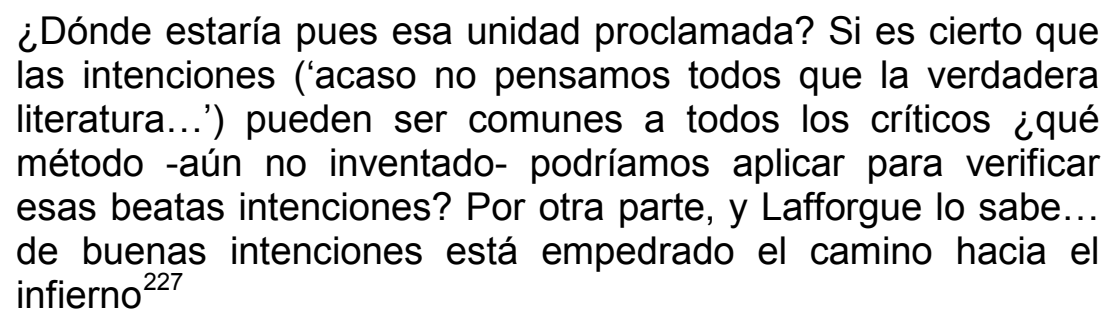

La operación consistente en la operativización de un esquema legitimador de aquellos textos que inscribían su aparato crítico en el nuevo paradigma interpretativo es claramente perceptible en la lectura que Rosa realizaba en el segundo número de la revista de Escrito sobre un cuerpo de Severo Sarduy ${ }^{228}$. En tanto innovador con respecto a los objetos analizados -Sade, Bataille, Lezama- y modernizador en cuanto a las herramientas teóricas y metodológicas utilizadas -Lacan, Jakobson, Barthes-, el libro de Sarduy era abordado a través de un registro que divergía de aquel puesto en juego en las lecturas de los textos atrapado en la trama de la vieja crítica.

En principio, la reseña desplegaba un repertorio de señalamientos y advertencias alrededor del trabajo crítico desarrollado por Sarduy, especialmente en lo relativo a los usos del estructuralismo realizados por el cubano: dialecto simbolizante y refractante, excesiva metaforización, circunscripción a una escritura jeroglífica, tendencia a la agramaticalidad. Sin embargo, el contrapunto establecido se desenvolvía sobre un reconocimiento del carácter progresivo del tipo de trabajo crítico implementado por Sarduy. En este sentido, el examen al que Rosa sometía al texto del cubano se realizaba sobre una serie de supuestos teóricos y metodológicos compartidos: "el inconsciente considerado como un lenguaje (Freud-Lacan), el 'fondo' de la obra

${ }^{227} / d$.

${ }^{228}$ Buenos Aires, Sudamericana, 1969. 
considerado como un vacío (el silencio: Mallarmé-Blanchot), o el 'contenido' como metáfora de la ausencia (Barthes) nos liberan de la tentación realista"229.

En este mismo número, Eduardo Romano desplegaba una operación análoga sobre la crítica de la obra de Roberto Arlt a propósito de la edición de los libros de David Maldavsky ${ }^{230}$ y Angel $\mathrm{Núñez}^{231}$. Un repaso por las principales lecturas sobre Arlt anclado en el espacio novedoso que la revista pretendía fundar, le permitía a Romano prolongar hacia la crítica de la obra del escritor argentino la misma constatación que Los Libros hacía sobre el conjunto de la crítica argentina; es decir, la existencia de un vacío. El repaso somero por las lecturas realizadas por Raúl Larra, Héctor Murena y Juan José Sebreli conducía a la aseveración de que la literatura arltiana aún no había sido objeto de una indagación crítica. Ni señalamiento de la falta de fe en el futuro de clase media -como en Larra-, ni énfasis en la independencia de la fantasía -como en Murena-, ni acento en la autonomía de la libertad -como en Sebreli-: la obra de Arlt debía ser estudiada a través de un análisis que priorizara la indagación sobre "aquello que su lenguaje revela"232.

En este sentido resulta relevante observar el modo en el cual aparecían contrapuestos los análisis de Maldavsky, cuyo trabajo introducía un enfoque psicoanalítico para el abordaje de la narrativa de Arlt, y los de Masotta, cuya aproximación al escritor argentino había sido realizada desde posiciones sartreanas. Al haber avanzado hacia un espacio donde cada vez eran menos importantes las preocupaciones éticas y cada vez más significativa la rigurosidad analítica, Maldavsky aparecía como aquel que había dado el paso necesario para la consolidación de una nueva crítica. De esta manera, Sexo y traición en Roberto Arlt de Masotta era ubicado por delante de la crítica

\footnotetext{
${ }^{229}$ Rosa, Nicolás. "La crítica como metáfora". Los Libros. Un mes de publicaciones en Argentina y el mundo, $\mathrm{N}^{\circ}$ 2, Agosto de 1969, p. 5. Sobre el lugar de Sade, Bataille y Blanchot en la revista, ver Bosteels, Wouter y Rodríguez Carranza, Luz. "El objeto Sade. Genealogía de un discurso crítico: de Babel, revista de libros (1989-1991) a Los Libros (1969-1971)". Roland Spiller (ed.). Culturas del Río de La Plata (1973-1995): transgresión e intercambio. Frankfurt, Vervuert Verlag, 1995, 313-338.

${ }^{230}$ La crisis en la narrativa de Roberto Arlt. Buenos Aires, Carlos Pérez, 1969.

${ }^{231}$ La obra narrativa de Roberto Arlt. Buenos Aires, Nova, 1968.

${ }^{232}$ Romano, Eduardo. "Arlt". Los Libros. Un mes de publicaciones en Argentina y el mundo, $\mathrm{N}^{\circ} 2$, Agosto de 1969, p. 7.
} 
realizada por el comunismo y Sur pero por detrás del deseable horizonte del análisis estructural. Según Romano, a diferencia de sus antecesores, Masotta había sido el primero en hacer una lectura de Arlt "desde tierra firme" ${ }^{233}$. Sólo le restaba, por lo tanto, completar el desembarco:

\begin{abstract}
Siguiendo el modelo del Saint Genet de Sartre, [Masotta] detecta las contradicciones configuradoras y cómo éstas reenvían a su vez, a las contorsiones de una conciencia apresada en las contradicciones de la sociedad efectiva. Lástima que a esa lúcida conexión de la subjetividad con el acto objetivo de escribir no le siga una cuidadosa especificación de las determinaciones de ambos procesos y sus transformaciones mutuas, ya que Masotta se circunscribe casi exclusivamente a esclarecer la estructura interpersonal (conducta) de los personajes en los términos de la fenomenología sartreana y la dialéctica hegeliana, adjudicándoles una interioridad psicológica de la que carecen, humanizándolos ${ }^{234}$
\end{abstract}

La impugnación de Romano a las formas de la crítica en el Masotta sartreano constituye un movimiento privilegiado a los fines de delimitar no solo las características de la crítica de la crítica desarrollada en Los Libros, sino también las especificidades de la crítica propiamente dicha llevada a cabo por los colaboradores de la revista: desplazamiento de postulados fenomenológicos y existencialistas, y consecuente centralidad de las determinaciones estructurales; alejamiento de interpretaciones humanistas e historicistas, y consiguiente apertura a los problemas del lenguaje y el inconsciente. Producto de la consolidación de una conceptualización de la tarea crítica como el esfuerzo por develar los mecanismos ideológicos subyacentes en la práctica literaria, las novedades de la literatura argentina y latinoamericana fueron procesadas en las páginas de la revista a través de una trama interpretativa que tendía a enfatizar el carácter interrogador y desmitificador del trabajo crítico. De esta manera, en el primer número,

\footnotetext{
${ }^{233}$ Ibid., p. 6.

${ }^{234}$ Id. Cabe destacar que Masotta ya se encontraba en ese tránsito al ser publicados los primeros números de Los Libros. Tal es así que la revista incluirá textos suyos en los números siguientes. Su libro Conciencia y estructura, editado unos meses antes del artículo de Romano, operaba a modo de correctivo de sus posiciones sartreanas. Tratamos específicamente este problema en el capítulo quinto.
} 
Santiago Funes leía Epitalámica de Murena ${ }^{235}$ como el efecto literario de un "pensamiento servil"236. En lugar de concebir al lenguaje en un sentido revolucionario, lo cual hubiese permitido interrumpir el orden y la lógica predominantes, Murena lo utilizaba como el instrumento de una "concepción representativa de la obra" ${ }^{237}$, movimiento que tendía a reproducir los parámetros culturales bajo los cuales la obra se desarrollaba ${ }^{238}$.

En el número siguiente, Schmucler realizaba una lectura de 62/Modelo para $\operatorname{armar}^{239}$ de Cortázar centrada en los significantes y las metáforas del texto. A modo de refutación categórica de las aproximaciones críticas que veían en dicho libro el conjunto de piezas de un rompecabezas o partes intercambiables, la obra de Cortázar era captada como un material "perfecta y unívocamente organizado" que se proponía "desnudar los ejes de cristalización para que cada uno imagine (lea) un resultado" ${ }^{240}$. Se desenvolvía, por tanto, una lectura atenta a las formas a través de las cuales el texto sugería un orden distinto a la existencia cotidiana de los personajes o el modo en el que sus acciones metaforizaban problemas relativos a las relaciones sociales. Si Rayuela había intentado "distanciarse del lector a fin de no engañarlo", con el objetivo de que éste se reencontrara "no en un falaz modelo existencial, sino en las profundas determinantes de los actos" ${ }^{241}$, lo central en 62/Modelo para armar era la conciencia de la autonomía del texto. En palabras de Schmucler: “el texto de 62 'dice' la verdad de sí mismo y no 'representa' al mundo exterior: participa de ese mundo y proclama -negándola- la ideología que lo piensa" ${ }^{242}$.

\footnotetext{
${ }^{235}$ Buenos Aires, Sudamericana, 1969.

${ }^{236}$ Funes, Santiago. "El peligro de las palabras". Los Libros. Un mes de publicaciones en Argentina y el mundo, $\mathrm{N}^{\circ} 1$, Julio de 1969, p. 10.

${ }^{237}$ Id.

${ }^{238}$ Cabe destacar el vínculo que se establecía entre este tipo de lectura y el abordaje valorativo de la obra. La crítica no se agotaba en el señalamiento de la inscripción ideológica del texto, sino que los aspectos vinculados a la calidad literaria de la obra eran remitidos precisamente a dicho anclaje. En este caso, Funes identificaba al carácter obediente y sumiso de la escritura de Murena como una de las razones de las "insuficiencias literarias" de su libro. Id.

${ }^{239}$ Buenos Aires, Sudamericana, 1968.

${ }^{240}$ Schmucler, Héctor. "Notas para una lectura de Cortázar". Los Libros. Un mes de publicaciones en Argentina y el mundo, N² 2, Agosto de 1969, p. 11.

${ }^{241}$ Id.

${ }^{242} / d$.
} 
En el número 11, una reseña múltiple de la obra de Silvina Bullrich le permitía a Germán García llevar a cabo un trabajo de lectura centrado en la delimitación de las características de una ideología de clase. A través de la distinción bachelardiana entre opinión y pensamiento, la literatura de Bullrich operaba como una cantera de la cual era posible extraer elementos ideológicos propios de una clase -la "poseedora" ${ }^{243}$ según García- que ya no era lo que había sido. La lectura consistía, por tanto, en un relevamiento de aquellas afirmaciones de Bullrich que se mantenían en el nivel de generalización propio de las opiniones. Frente a cada una de ellas, García formulaba las correspondientes afirmaciones fundadas en el conocimiento, oposición que tendía a evidenciar el carácter ideológico de los pensamientos que no estaban generados a partir de un saber. Asimismo, la lectura operaba una reconstrucción de los tópicos ideológicos que vertebraban la escritura de Bullrich: mi clase es el ser-la cultura es mi capital-el dinero es un premio moral-la escritura me convierte en Dios-mi clase es el mundo. Por último, García insinuaba un gesto analítico que trascendería el análisis interno de los textos y el de la relación entre ellos, y profundizaría en una clave psicoanalítica la relación entre literatura y lucha de clases:

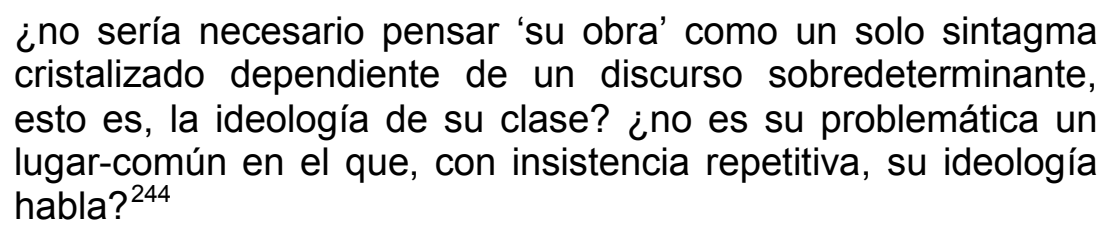

La narrativa de Eduardo Mallea fue igualmente abordada desde estos marcos analíticos. En el número 12, la lectura realizada por Beatriz Sarlo se estructuraba, al igual que la de García, en dos núcleos problemáticos. Por un lado, la delimitación ideológica de la práctica literaria examinada. El establecimiento de esta matriz analítica le permitía a Sarlo identificar los elementos ideológicos característicos de la narrativa de Mallea -individualismo e idealismo- y determinar de este modo la filiación ideológica de dicha práctica

${ }^{243}$ García, Germán. "Silvina Bullrich: las opiniones de una clase". Los Libros. Un mes de publicaciones en América Latina, №11, Septiembre de 1970, p. 9.

${ }^{244}$ Ibid., p. 10. 
literaria -ideología burguesa-. Una primera aproximación habilitaba, por tanto, la inscripción de la obra de Mallea en "la tradición escamoteadora de cierto pensamiento argentino" ${ }^{245}$; es decir, un modo de intervención que no elaboraba sus planteos a partir de las contradicciones concretas de la realidad argentina "dependiente"246 enfatizaba Sarlo- sino que acudía a las falsas opciones deudoras del mito civilización o barbarie, como la de pureza/corrupción o la de cultura/sentido material de la vida.

Por otro lado, la narrativa de Mallea era objeto de un segundo análisis, que si bien seguía dando cuenta del modo a través del cual la práctica literaria estaba sustentada en la ideología burguesa, se detenía particularmente en la especificidad de ese sustento. Al igual que las opiniones de Bullrich, captadas, según García, como la traducción de "la necesidad de una clase social que se resiste a ser desalojada de la escena" ${ }^{247}$, la literatura de Mallea era caracterizada por Sarlo como "una ideología personal de recambio" de algunos sectores de la burguesía, marginados del poder político. El abordaje de la obra desde la concurrencia de ambas matrices analíticas permitía dar cuenta de la inscripción ideológica de la práctica literaria considerada, al mismo tiempo que habilitaba un recorte de la singularidad de dicha inscripción -en el caso de Mallea, una literatura que, si bien mitificadora y encubridora, acarreaba una degradación y un empobrecimiento de la ideología de clase que la sustentaba.

Asimismo, la centralidad del análisis ideológico y la actualización teórica de la crítica en un sentido cientifizador se conjugaron en la primera etapa de la revista en la apertura hacia un trabajo de crítica y crítica de la crítica que trascendía las expresiones estrictamente literarias. En este sentido, la consolidación de un esquema interpretativo articulado alrededor de la tesis "todo lenguaje está cargado de ideología" conllevará una legitimación de aproximaciones analíticas a objetos de la cultura de masas ${ }^{248}$. Del mismo modo

245 Sarlo, Beatriz. "La retórica de Eduardo Mallea". Los Libros. Un mes de publicaciones en América Latina, №12, Octubre de 1970, p. 10.

${ }^{246} / d$.

${ }^{247}$ García, Germán. "Silvina Bullrich: las opiniones de una clase”. op. cit., p. 9.

${ }^{248}$ Tal como señala Jorge Panesi, la concepción de la cultura de masas como un terreno en el cual el poder de las clases dominantes se ejerce activamente a través de sutiles mecanismos ideológicos implicó naturalmente un ensanchamiento del radio de 
que ocurría con las novedades críticas y literarias, la formulación de un abordaje moderno y actualizado a este tipo de objetos extraía su potencia de un trabajo de impugnación y superación de las interpretaciones tradicionales que habían intentado -e intentaban- dar cuenta de los problemas de la cultura contemporánea.

Quizás ninguna intervención sea más paradigmática al respecto que la de Germán García en el número 18 a propósito de la edición de una serie libros sobre la juventud y la música beat ${ }^{249}$. García intentaba desmontar allí el pretendido carácter rebelde de la música beat refutando el sentido que sus impulsores y analistas le otorgaban a la relación entre ideología y política. Al sistematizar las concepciones de lo ideológico desplegadas en los relatos canónicos sobre la música beat, se advertía una asociación de la ideología con la política, movimiento por el cual la primera quedaba asociada negativamente al interés y la artificialidad: la música producto de una sensibilidad y no de una ideología-la falta de ideología como una ideología en sí misma. Las argumentaciones opuestas por García tendían a concebir estos razonamientos como la condensación de una serie de confusiones alrededor de la conceptualización del vínculo entre arte y política. Por un lado, se diagnosticaba una "ceguera ideológica" 250 que no permitía acceder a una interpretación científica de la ideología:

La ideología es el mal, la muerte, lo artificial: del otro lado está la vida (Kreimer) y la sensibilidad (Grinberg). Descubrimos, entonces, que los dos dicen lo mismo con signos cambiados. Porque lo que podemos llamar ideología es esa explicación de la apariencia por la apariencia mediante nociones vagas que tratan de cubrir la falta de una teoría científica de la ideología que dé cuenta de lo que aparece mediante la producción de un saber sobre las estructuras determinantes de los fenómenos ${ }^{251}$

intervención de la revista, "La crítica argentina y el discurso de la dependencia". Filología. Año XX, 1985, p. 177.

${ }^{249}$ Kreimer, Juan Carlos (comp.). ¡Agarrate! Buenos Aires, Galerna, 1970; Ono, Yoko. Pomelo. Buenos Aires, De la Flor, 1970; A.A.V.V. La música beat. Buenos Aires, Tiempo Contemporáneo, 1970.

${ }^{250}$ García, Germán. "Música Beat: los jóvenes en el espejo". Los Libros. Un mes de publicaciones en América Latina, № 18, Abril de 1971, p. 26.

${ }^{251} / d$. 
La lectura de García no sólo demostraba que los relatos alrededor de la música beat estaban cargados de ideología sino que, al depositar en la vitalidad -y no en la lucha de clases- el factor explicativo de los cambios sociales, dichas interpretaciones no hacían más que inscribir la pretendida subversión y rebeldía del género en la reproducción del orden social. Evidenciaba, asimismo, los mecanismos ideológicos a través de los cuales este tipo de abordaje de los fenómenos musicales aludía/eludía el lenguaje político. Las referencias a la rebelión de la imaginación o la dictadura del convencionalismo eran captadas como operaciones de desplazamiento en las cuales la mímesis del lenguaje político conllevaba un efecto despolitizador. Al ser arrastradas al nivel de la cultura, rebelión o dictadura perdían el sentido que tenían en el nivel político; la primera asociada a la lucha política revolucionaria y la segunda a la imposición de regímenes represivos. El trabajo reclamado por García, por tanto, era uno que permitiera despegar el análisis de la circularidad ideológica del objeto analizado y habilitara un espacio interrogador de los automatismos de "una cultura que se destruye en un parloteo luminoso, en los espejismo de una seducción lanzada a lo imaginario, al desconocimiento, a la impostura" ${ }^{252}$. Si la cultura de masas tendía a imantar los análisis sobre ella desarrollados hacia sus propias "ilusiones fantásticas que sirven para afianzar más la supremacía de lo Reap ${ }^{253}$, de lo que se trataba era precisamente de operar una ruptura que facilitara la advertencia sobre los modos a través de las cuales dichas ilusiones obturan los cambios sociales y la problematización sobre las estrategias necesarias para llevar a cabo dichas transformaciones.

\subsection{El dispositivo althusseriano: sociología, ciencia, filosofía, política}

En el trabajo de crítica y crítica de la crítica las formulaciones althusserianas operaban implícitamente e integradas con herramientas teóricas y metodológicas provenientes de otras expresiones inscriptas en el paradigma estructural. Mientras que en el abordaje de textos y problemas sociológicos,

\footnotetext{
${ }^{252}$ Ibid., p, 28.

${ }^{253} / d$.
} 
científicos, filosóficos y políticos el nombre de Althusser era invocado explícitamente y los parámetros interpretativos característicos del althusserianismo aparecían desempeñando un rol preponderante ${ }^{254}$.

Así ocurría, por ejemplo, con la explicación que la revista ofrecía de la sociología de la modernización. Leído por José Nun en el número 8, Sociología de la modernización de Gino Germani ${ }^{255}$ era objeto de una interpretación que inscribía a su autor y sus contenidos en el contexto ideológico propio del capitalismo contemporáneo. Anclado en la forma que adquiría la crítica en El Capital, Nun proponía un análisis de la sociología estadounidense y especialmente- del estructural-funcionalismo análogo al que Marx realizaba sobre los economistas clásicos. Es decir, una lectura que no estuviera centrada en la revelación de las intenciones de los autores, en la advertencia de sus intereses de clase ni en la certificación de la irrealidad de sus conceptos. De lo que se trataba era de aprehender estas formas de pensamiento como soportes de las relaciones de producción existentes; es decir, como conocimientos que en tanto expresiones de las condiciones de un régimen de producción, distorsionan lo real naturalizando y reproduciendo el orden social. Al respecto, afirmaba Nun remitiéndose a Pour Marx:

no hay astucia ni estratagema: como bien dice Althusser, la clase dominante no mantiene una relación exterior y lúcida con la ideología sino que es a través de ella que vive la realidad y que se constituye como dominante ${ }^{256}$

El despeje de aproximaciones subjetivistas y voluntaristas le permitía a Nun captar a la sociología germaniana como un elemento más de una respuesta teórica -el discurso de la modernización- a una contradicción económica países centrales y periféricos. Más allá de Germani, la sociología de la

${ }^{254}$ Dimensiones -cabe destacar- no transitadas en las investigaciones existentes sobre la revista. A diferencia de los artículos repasados anteriormente, los que analizamos a continuación no son siquiera mencionados en los estudios realizados sobre Los Libros -disparidad indicativa del predominio en dichos estudios de un interés por la especificidad del trabajo crítico desarrollado en esta experiencia político-cultural.

255 Sociología de la modernización: estudios teóricos, metodológicos y aplicados a América Latina. Buenos Aires, Paidón, 1969.

${ }^{256}$ Nun, José. "Gino Germani o la sociología de la modernización". Los Libros. Un mes de publicaciones en América Latina, N 8, Mayo de 1970, p. 4. 
modernización era interpretada como una construcción ideológica que transformaba al pasaje de lo tradicional a lo moderno como la única estrategia revolucionaria posible y convertía a la constatación de lo correcto de ese pasaje en el único modo legítimo de plantear el problema de la transición hacia otro sistema. Al centrarse en la forma en la cual la ideología constituía un sistema de codificación de la realidad, el discurso modernizador era abordado por Nun como un conjunto de interpretaciones que contrarrestaba el potencial de la política revolucionaria -reduciendo el significado del socialismo a su función modernizadora- y desdibujaba la interdependencia dialéctica entre economías centrales y periférica -reforzando el mito burgués de la igualdad de oportunidades. Asentada en este esquema interpretativo, la lectura de Nun también daba cuenta de los mecanismos ideológicos que le permitían a la sociología de la modernización integrar discursos impugnadores de sus núcleos argumentativos. De este modo se advertía, por ejemplo, la manera en la que, al tener que aludir necesariamente al problema de la dependencia, el libro de Germani desarrollaba una "técnica de la mención" ${ }^{257}$ a través de la cual una inclusión no conceptualizada de dicho fenómeno permitía mantener intactas las bases del discurso modernizador.

Puede ser igualmente ubicado en esta serie el modo en el cual la revista procesó el pensamiento de Marcuse. En una densa reseña titulada sugerentemente "Ideología de Marcuse" publicada en el número 3, Eliseo Verón abordaba los libros fundamentales de Marcuse enfatizando las preguntas sobre el lugar del filósofo alemán en la tradición marxista y los cuestionamientos acerca de las implicaciones políticas de su pensamiento ${ }^{258}$. La lectura que realizaba Verón se detenía sobre el marxismo marcusiano a los fines de delimitar la especificidad de sus concepciones sobre la dialéctica. La advertencia de un vacío teórico en la obra de Marcuse alrededor de la positividad justificatoria de la dialéctica hegeliana y el señalamiento de la necesidad de operar una reformulación del método dialéctico que le devolviera

\footnotetext{
257 Ibid., p. 5.

${ }^{258}$ Los libros reseñados eran Razón y revolución, El marxismo soviético, El hombre unidimensional, Eros y civilización, La sociedad industrial y el marxismo, El fin de la utopía y La sociedad carnívora.
} 
a éste su potencial crítico, conducían a una pregunta retórica: "ante la realidad del capitalismo posindustrial, ¿Es Marcuse el nuevo capitán del pensamiento negativo, de la reflexión crítica?" 259 .

En la perspectiva de Verón, el marxismo capaz de llevar a cabo dicha operación de relevo debía ser uno que priorizara la problematización de la singularidad de la relación Hegel-Marx: "la cuestión central (recientemente actualizada por Althusser en un contexto teórico muy distinto), es pues en qué consiste la diferencia entre la dialéctica marxista y la dialéctica hegeliana"260. El hecho de que la obra de Marcuse extrajera del análisis de dicho problema una conclusión diferente a la de la existencia de una ruptura epistemológica, es decir una lectura de Marx centrada en la diferencia entre la filosofía y la ciencia, tornaba improbable que el marxismo marcusiano pudiera encarnar las tareas de relevo contemporáneo del método dialéctico.

Ahora bien, Verón divergía de Marcuse acerca de las características del trabajo de actualización del método dialéctico, y en consecuencia, de las implicaciones que dichas operaciones tenían en la reformulación de la tradición marxista. Si Marx fundó la ciencia de la historia y esta ciencia generó una práctica transformadora de la realidad, las formulaciones perceptibles en la obra de Marcuse en torno a una potencia del método dialéctico detenida por el peso de los hechos, transformaban al marxismo marcusiano en un pensamiento negativo cuyo núcleo estaba constituido por una "lectura realista de la realidad" 261 . Verón calificaba de esta manera a la obra de Marcuse como portadora de un pensamiento cerrado y pesimista. Asimismo, su singular inscripción en la tradición marxista lo tornaba propiciatorio de una integración entre la teoría revolucionaria y principios metafísicos (el Eros), y entre práctica transformadora y objetivos extra-sociales (desublimación de la cultura). Pero por sobre todas las cosas, el pensamiento de Marcuse era presentado como una contra-ideología; es decir, como un pensamiento que sólo podía expresar las contradicciones sociales, siendo incapaz de volverlas inteligibles y -menos

\footnotetext{
${ }^{259}$ Verón, Eliseo. "Ideología de Marcuse". Los Libros. Un mes de publicaciones en Argentina y el mundo, $\mathrm{N}^{\circ} 3$, Septiembre de 1969, p. 10.

${ }^{260} \mathrm{ld}$.

${ }^{261}$ Ibid., p. 12.
} 
aún- de producir una apertura política. Todo ello era indicativo, en la lectura de Verón, de los problemas propios de aquellas relecturas de Marx que, en lugar de enfatizar -y profundizar- la cientificidad del marxismo, operaban un regreso a Hegel:

\begin{abstract}
Marcuse prueba una vez más que ser hegeliano por querer ser post-marxista, después de la crítica de Marx a Hegel (y la consiguiente transformación del concepto de racionalidad, que pasa de la filosofía a la ciencia), es emprender una recorrida a contrapelo de la historia, que sólo puede hacerse "neuróticamente", vale decir, al precio de un resurgimiento de lo irracional social disfrazado de naturaleza, irracionalidad que a medida que se pone de manifiesto la imposibilidad del esfuerzo, escapa a la represión ${ }^{262}$
\end{abstract}

Junto a las lecturas de la sociología de la modernización y el marcusianismo, dos intervenciones realizadas en esta primera etapa de la revista se destacaban tanto por la inscripción de sus posiciones polémicas en los marcos del pensamiento althusseriano como por tener como autores a referentes del althusserianismo en Argentina.

En el número 10, Malamud fue el encargado de comentar Ciencia, política y cientificismo de Oscar Varsavsky ${ }^{263}$. Objeto privilegiado para el despliegue de argumentaciones estructuradas en base al programa althusseriano, el debate abierto por el llamamiento de Varsavsky a una politización de la ciencia y la constitución de una ciencia rebelde, fue enfrentado por Malamud con una intervención centrada en la refutación de los presupuestos alrededor de los cuales giraban los argumentos esgrimidos. A la propuesta de Varsavsky solo se le reconocía haber abierto una discusión sobre las relaciones entre ciencia y política, y puesto en evidencia que la intelectualidad argentina estaba atravesada por la tendencia dicotómica entre un cientificismo sin política y un politicismo sin ciencia. En este sentido, la posición de Malamud convergía necesariamente en la necesidad de someter a crítica el paradigma cientificista. Sin embargo, a diferencia del análisis de Varsavsky, que enfatizaba la adaptación al mercado, la desvinculación de los

${ }^{262} / d$.

${ }^{263}$ Buenos Aires, Centro Editor de América Latina, 1969. 
problemas políticos y la dependencia social y cultural, Malamud direccionaba la aprehensión del cientificismo en un sentido ideológico. Este paradigma se presentaba como un elemento determinado por la ideología de las clases dominantes, conceptualización que permitía explicar el no cuestionamiento del sistema y la legitimación de su pervivencia.

Para Malamud, la propuesta de Varsavksy se trataba del abordaje de "un problema justo, pero mal planteado" ${ }^{264}$. La postulación de una ciencia nueva como condición para la creación de un nuevo sistema social, y la consecuente definición de la revolución científica como antecesora y posibilitadora de la revolución política, eran captados como elementos indicativos de una incorrecta concepción de la ciencia y como factores propiciatorios de una confusión alrededor de las relaciones entre la ciencia y la política. Si de lo que se trataba era de encontrar un reemplazo para el cientificismo que se rechazaba, Varsavsky fracasaba en la tarea, en tanto su propuesta de una ciencia al servicio del cambio social implicaba un esfuerzo de superación del paradigma cientificista a través de fundamentos no-científicos. Según Malamud, la lucha contra el cientificismo requería necesariamente un trabajo consistente en la demarcación de elementos ideológicos y científicos en el interior del conjunto de prácticas y enunciados definidos como ciencia. De esta manera, la posición rebelde defendida por Varsavsky en el sistema científico era equiparada por Malamud a aquellas posiciones que Ciencia, política $y$ cientificismo pretendía combatir: la fósil, la totalitaria y la reformista. En tanto prisionera de una concepción tradicional de lo científico, la propuesta de una ciencia nacional formaba parte de la misma matriz ideológica en la que se inscribían los programas científicos conservador, stalinista y modernizador. Frente a estas cuatro posiciones juzgadas como equivalentes, Malamud postulaba una quinta: "el intento de redefinir las ciencias y determinar si existe o no, ciencia fundada respecto del cambio social"265. Tal posición conllevaba una tarea de replanteo radical de las preguntas alrededor de la definición de la ciencia y su relación con la política:

\footnotetext{
${ }^{264}$ Malamud, Mauricio. "Ciencia y política". Los Libros. Un mes de publicaciones en América Latina, №10, Agosto de 1970, p. 31. ${ }^{265} / d$.
} 
Pregunta: ¿Se teoriza respecto de las ciencias desde una racionalidad revolucionada, o se vuelve y se sigue haciendo filosofía de LA CIENCIA? La estructura, constitución y funcionamiento de esa LA CIENCIA, viejo personaje creado por la filosofía vieja, queda definida por el autor [Varsavsky] con lo que él llama 'la cadena completa de la actividad científica; descripción, explicación, predicción, decisión'.

Problema: La rebeldía se consuma entonces en la inversión del orden de los eslabones. Es la rebeldía máxima, pero prisionera al fin, encadenada a la cadena academicista y empirista a la que denuncia, pero no rompe. Paradojalmente la reafirma, la confirma en el acto de inversión mismo ${ }^{266}$

Al mantenerse en un registro en el cual la ciencia era definida desde los dogmas filosóficos, los esfuerzos por vincular a la ciencia con la política quedarían atrapados en las categorías ideológicas que la filosofía genera a partir de los conceptos de la ciencia. Por lo tanto, la asunción de una posición rebelde en esta misma estructura ideológica ni contribuía a una redefinición de la ciencia ni propiciaba la vinculación entre ciencia y política. Al contrario, al refrendar, a través de la rebeldía, la transformación de conceptos de la ciencia en categorías filosóficas, no se hacía más que reproducir la represión de la política operada por la ideología. Se revelaba, de esta manera, la falsedad de la disyuntiva planteada por Varsavsky entre cientificismo y politización.

A modo de contrapunto, el abordaje de Malamud de las relaciones entre ciencia y política era remitido, en primer lugar, a la pregunta alrededor del carácter científico de la Ciencia de la Historia inaugurada por Marx. Si la teoría de los modos de producción es científica, el debate alrededor de la "politización" de la ciencia necesariamente debía ser abordado desde el materialismo histórico: "una correcta definición de la relación entre las ciencias y la política, o se formula desde la ciencia pertinente al fenómeno social (Materialismo Histórico) o se vuelve a confundir la cosa" ${ }^{267}$. Anclado en las formulaciones de la epistemología francesa, especialmente la de la necesidad de una revolución epistemológica -un Bachelard leído por Althusser- y en la actualización althusseriana del concepto de formación económico-social, el

\footnotetext{
${ }^{266} / d$.
}

${ }^{267} / d$. 
pensamiento acerca de las relaciones entre ciencia y política no podía ser sino disociado de problemas tales como la "sensibilidad social" o las "necesidades del pueblo". Dicha filiación conducía a Malamud a la explicitación de un programa centrado en el análisis de la inscripción de la ciencia y de los trabajadores intelectuales "en el único ámbito en que existen" ${ }^{268}$; es decir, en el interior de sociedades singulares, en las cuales la ciencia constituye una instancia determinada por las instancias económica, política e ideológica.

El énfasis en la ruptura epistemológica dejaba al descubierto la superficialidad de la politización y la rebeldía postulada por Varsavsky. A partir del ejemplo de la relación entre la alquimia y la química, Malamud desacreditaba las problematizaciones alrededor de la ciencia centrada en el problema de lo nacional:

\footnotetext{
Una sociología alquimista, por argentina que fuese, dejaría intacto el sistema, con la sola novedad del registro de un nuevo modelo que quizá funcione, y resulte aprovechable para explicar o interpretar con otros criterios nuevos, la realidad nacional. Pero no para transformarla revolucionariamente, siendo que era eso lo que se querría demostrar 269
}

A los fines de avanzar en una discusión efectiva acerca de todos los problemas que se desprendían de la intervención de Varsavsky, Malamud formulaba desde las páginas de la revista una propuesta de creación de un "Centro Argentino de Estudios Sociales Científicos", espacio que aglutinaría a los intelectuales argentinos y operaría como una plataforma de definición del status político y los deberes y obligaciones de los agentes de producción en el ámbito de las ciencias.

En el número 15-16, Raúl Sciarreta fue el encargado de llevar a cabo un balance del itinerario filosófico de Carlos Astrada a propósito de su muerte ocurrida a fines de 1970. Una caracterización de Astrada como "filósofo militante" ${ }^{270}$ conducía a una valoración de su trayectoria político-intelectual

\footnotetext{
${ }^{268} / d$.

269 Id.

270 Sciarreta, Raúl. "Carlos Astrada, un filósofo militante". Los Libros. Un mes de publicaciones en América Latina, №15-16, Enero/Febrero de 1971, p. 52.
} 
centrada en la apertura a la tradición marxista, el desarrollo de una obra alejada de las posiciones dogmáticas, y la explicitación de sus opciones políticas. La totalidad de la obra filosófica de Astrada era escrutada por Sciarreta a través de una sugerente división entre los trabajos de su juventud y los de su madurez. Por un lado, aquellos caracterizados por la influencia de Scheller y la profundización de la fenomenología husserliana y heideggeriana; por el otro, los de la consolidación en el terreno marxista, la crítica antiheideggeriana y la importancia concedida a Hegel. El primer énfasis, por tanto, estaba puesto en las obras astradianas en las cuales dicha ruptura era perceptible: El marxismo y las escatologías y Fenomenología y praxis. Ajuste de cuentas con antiguas posiciones fenomenológicas, crítica al irracionalismo y advertencia de la mitologización del ser implícita en la filosofía heideggeriana, eran captados por Sciarreta como operaciones fundamentales para un pasaje definitivo a la filosofía marxista y una necesaria problematización del carácter de la herencia hegeliana.

El prisma althusseriano a través del cual Sciarreta leía el itinerario filosófico de Astrada implicaba el señalamiento de que el movimiento de ruptura con la fenomenología y de asunción de posiciones marxistas, si bien progresivo, no había sido completo. El pormenorizado análisis al que eran sujetas las formulaciones críticas desarrolladas por Astrada daba cuenta de la limitación de llevar a cabo el mencionado movimiento rupturista a través de un énfasis en la praxis de la razón dialéctica. Al priorizar a la razón dialéctica como lugar de constitución del ser en su historicidad, la filosofía de Astrada se habría alejado de las posiciones fenomenológicas para caer en el -igual de problemático- terreno del historicismo. El repaso de Sciarreta ponía en primer lugar "la diferencia entre la teoría de la historia (el concepto de razón dialéctica, objeto instrumento de conocimiento) y la historia real" ${ }^{271}$ y la consecuente advertencia sobre su superposición: "la identificación de ambos, reduce el problema a una interpretación historicista" 272 . Por otro lado, al reproducir de manera acrítica la pervivencia en Marx del monismo hegeliano del sujeto-

\footnotetext{
${ }^{271} / d$.
}

${ }^{272} / d$. 
sustancia, el acercamiento de Astrada a la filosofía marxista se habría realizado sobre un sustrato en el cual se debilitaba el tenor rupturista de la relación Hegel-Marx menoscabándose, por tanto, el carácter científico del marxismo. La contraposición operada por Sciarreta se filiaba en El Capital y enfatizaba el modo a través del cual Marx había revolucionado la categoría de materia al concebirla como sistema complejo de relaciones económico-sociales. La categoría de sustancia en Marx, por tanto, no remitía ni a las cualidades sensibles de la cosa aislada ni al conjunto de relaciones fenomenales, quedando disociada tanto del sustancialismo como del relacionismo. Sciarreta explicitaba de esta manera cuál era a su entender la lectura correcta de Marx "Desde Marx -como sostiene Althusser- no vale ya un monismo, ni cabe sustituirlo por un pluralismo positivista" ${ }^{273}$ - y qué esquema debía ser adoptado a los fines de evitar los errores perceptibles en la filosofía de Astrada:

\begin{abstract}
El concepto de modo de producción permite pensar un todo complejo articulado de instancias (económica, política, ideológica) con dominancia en última instancia de la economía. Esa estructura le permite a Marx definir la historia como la sucesión discontinua de los modos de producción. Con el sustancialismo ha caducado el monismo ${ }^{274}$
\end{abstract}

El mayor esfuerzo de Sciarreta estaba centrado en la delimitación de las concepciones de Astrada sobre la dialéctica. Al haberse instalado en un terreno decididamente marxista, la filosofía de Astrada había comenzado a operar con el implícito de la especificidad y la novedad de la dialéctica materialista. Sciarreta no dejaba de advertir el carácter incompleto de un pasaje a la filosofía marxista que no problematizara aquel implícito sobre la dialéctica materialista. La relectura de Marx propiciada por Althusser se presentaba en las argumentaciones de Sciarreta como un marco que posibilitaba el cuestionamiento de la inscripción de la filosofía de Astrada en la concepción tradicional de la dialéctica marxista como inversión de la dialéctica hegeliana. En primer lugar, Sciarreta prevenía contra una lectura literal de Marx. Tal era, a su entender, el modo de obrar de Astrada, quien no le oponía mediaciones a su

${ }^{273}$ Ibid., p. 53.
${ }^{274} /$. 
lectura de las afirmaciones del propio Marx acerca de la inversión de la dialéctica hegeliana. La lectura sintomática althusseriana dejaba en evidencia la ingenuidad de esos modos de leer: "Althusser enseña que sólo una lectura ingenua puede quedarse en lo que 'se dice', críticamente hace falta reconstruir los contenidos teóricos de lo manifiesto"275. Por otro lado, una lectura de la obra de Marx en clave de ruptura epistemológica actuaba como relevo de un marxismo que, a entender de Sciarreta, nunca se había podido despegar totalmente de Hegel. Mientras la preocupación de Astrada había sido la determinación de la especificidad de la dialéctica hegeliana, Althusser era mentado como un marxista que extraía conclusiones diferentes sobre el problema de la relación Hegel-Marx. De este modo, la agenda althusseriana le permitía a Sciarreta delimitar unas tareas para el marxismo frente a las cuales la obra de Astrada no podía quedar sino obsoleta. Se trataba, por un lado, de consolidar un Marx anti-hegeliano: todo marxista debería plantearse "si la diferencia de forma consiste simplemente en 'sustraer' el núcleo racional y 'suprimir' su forma mística o si es una nueva dialéctica la que Marx ha producido" 276 . Por el otro, de llevar cabo un trabajo, por sobre todas las cosas, teórico: "hace falta elaborar la teoría de la estructura productiva del conocimiento científico que Marx dejó indicada y abierta como posibilidad"277.

Por último, algunas de las problemáticas abiertas por el althusserianismo estuvieron presentes en la polémica sobre la relación entre intelectuales y política desarrollada en la revista a partir del "caso Padilla" ${ }^{278}$. Una vez

\footnotetext{
${ }^{275} / d$.

${ }^{276}$ Ibid, p. 54.

277 ld.

${ }^{278}$ A fines de 1967, el escritor cubano Heberto Padilla protagonizó una polémica en la revista El Caimán Barbudo con Lisandro Otero, también escritor y por entonces vicepresidente del Consejo de Cultura cubano. Padilla había criticado la novela de Otero Pasión de Urbino y elogiado el libro Tres tristes tigres de Guillermo Cabrera Infante, escritor que se encontraba alejado del proceso revolucionario cubano y que al poco tiempo haría públicas sus críticas al gobierno de la isla. En 1968, un libro de poesía de Padilla fuertemente criticado por el aparato cultural cubano, Fuera de juego, resultó ganador del concurso literario de la Unión Nacional de Escritores y Artistas de Cuba. En 1971, Padilla fue detenido acusado de actividades contrarrevolucionarias. Al ser liberado, leyó un discurso autocrítico de neto contenido antiintelectualista en el cual denunciaba sus veleidades como escritor, censuraba sus actividades contrarrevolucionarias, reconocía su ingratitud con el gobierno de Castro y llamaba a
} 
conocido el debate generado a partir de la detención y la autocrítica del escritor cubano, Los Libros suspendió el plan original de dedicar su número 20 a la movilización obrera y estudiantil en Córdoba, y preparó una edición especial con el título "Cuba/cultura/revolución" en la cual se reprodujeron una serie de materiales referidos al "caso Padilla" ${ }^{279}$. Lo más significativo, sin embargo, era la inclusión de dos documentos en los que la revista explicitaba su posicionamiento frente a las discusiones sobre la relación entre cultura y revolución. Uno de ellos, "Puntos de partida para una discusión", presentaba las formulaciones en las que habían coincidido los colaboradores de la revista en discusiones previas a la salida del número especial. Se desarrollaba allí una crítica al posicionamiento de los intelectuales europeos y latinoamericanos que denunciaban al gobierno cubano. Si aquel grupo de intelectuales había reaccionado de tal manera frente a un acontecimiento como el de Padilla, quedaba en evidencia para la revista que el apoyo que aquellos expresaban

los escritores cubanos a replantear su lugar como intelectuales en una sociedad socialista. El "caso Padilla" precipitó una serie de acciones y discusiones en el seno de los intelectuales latinoamericanos y europeos comprometidos con la revolución cubana. Mientras el Primer Congreso Nacional de Educación y Cultura cubano especialmente el discurso de clausura de Castro- refrendaba los términos de la "autocrítica" de Padilla, un grupo de intelectuales -entre los que se encontraban entre otros Jean-Paul Sartre, Simone de Beauvoir, Carlos Fuentes, Lucio Magri, Pier Paolo Pasolini, Juan Rulfo y Mario Vargas Llosa- escribieron una carta a Castro en el que acusaban de stalinista al gobierno cubano. Para una reconstrucción de los debates alrededor del "caso Padilla" en las revistas político-culturales latinoamericanas, ver Gilman, Claudia. Entre la pluma y el fusil. Debates y dilemas del escritor revolucionario en América Latina. Buenos Aires, Siglo XXI, 2003, pp. 233-263.

${ }^{279}$ El número 20 estaba compuesto por la "Autocrítica" de Padilla, la "Carta de los 61 intelectuales", el poema "Policrítica a la hora de los chacales" de Julio Cortázar, la renuncia de Vargas Llosa al comité de Casa de las Américas y la respuesta de Haydée Santamaría, el discurso de Castro en el Primer Congreso Nacional de Educación y Cultura, un documento con extractos de discursos de Castro sobre la relación entre cultura y revolución, un informe sobre la cultura en Cuba realizado por Lisandro Otero y una crítica de James Petras al libro Cuba, ¿es socialista? del francés René Dumont. Resulta llamativa la ausencia en la reconstrucción realizada por Gilman del lugar ocupado por el "caso Padilla" en Los Libros. Cabe destacar que la revista había publicado tempranamente una reseña sobre Fuera de juego escrita por Juan Gelman en la que se llamaba la atención sobre las críticas de las cuales había sido objeto la obra de Padilla, ver "Poesía y revolución". Los Libros. Un mes de publicaciones en Argentina y el mundo, $\mathrm{N}^{\circ} 2$, Agosto de 1969, p. 3. Para un abordaje integral del "caso Padilla" en Los Libros, ver Zarowsky, Mariano. "Praxis editorialista y proyecto intelectual en el itinerario de Héctor Schmucler". VIII Jornadas de Sociología de la UNLP, 3 al 5 de diciembre de 2015. 
por la revolución cubana había sido más el "efecto ambiguo de una adhesión moral" 280 que "el producto de una elaboración política"281. Se revelaba de esta manera una representación del intelectual como dueño de la teoría y crítico del proceso histórico, y se sometía dicha ideología a una operación que intentaba evidenciar que el rol del intelectual cifrado en clave de negatividad descansaba sobre valores para nada revolucionarios -dignidad humana, libertad de creación, respeto del individuo. Asimismo, se leía al modelo de intelectual sustentado por el populismo como el reverso de la ideología del intelectual como poseedor del saber y crítico absoluto. Si en la carta de los 61 intelectuales se percibía una sobrevaloración del intelectual, en intervenciones como las de García Márquez o Rodolfo Walsh se podía advertir una negación de la teoría en nombre del sentido común.

Frente a ambos modelos, Los Libros introducía una concepción del intelectual en la cual las funciones de éste último perdían el carácter de negatividad absoluta sin resignar la especificidad de su trabajo. La función del intelectual en una sociedad socialista como la cubana, coincidían los colaboradores de la revista, era la del cuestionamiento permanente de los procesos de elaboración intelectual y la problematización de la propia categoría de "intelectual". Según estos puntos de partida para la discusión, el problema no radicaba en la formulación de una política cultural revolucionaria ni en la autocrítica de un intelectual que se pretendía revolucionario. Los problemas culturales que atravesaba el socialismo cubano tenían su origen en la desatención de los procesos de transformación en los modos de producción intelectual y, sobre todo, en la ausencia de las masas en dichos procesos correctivos.

En esta misma senda se desarrollaba la "Carta a Libre", una breve nota de Schmucler dirigida a Juan Goytisolo en el cual aquel declinaba la invitación de éste a participar en la mencionada revista ${ }^{282}$. El director de Los Libros

280 "Puntos de partida para una discusión". Los Libros. Un mes de publicaciones en América Latina, $\mathrm{N}^{\circ} 20$, Junio de 1971, p. 4.

${ }^{281} / d$.

${ }^{282}$ La revista literaria Libre fue creada en 1971 en París por un grupo de escritores latinoamericanos entre los que se encontraban Julio Cortázar, Mario Vargas Llosa, Juan Goytisolo, Carlos Fuentes, Octavio Paz y Severo Sarduy. Consolidada a partir de 
justificaba la negativa a integrarse a la novel revista a partir de una caracterización implacable del modelo de intelectual que Libre propiciaba: escamoteo de la política en un proyecto cultural que se pretendía político -el conjunto "intelectuales latinoamericanos" encubría la dicotomía fundamental entre los intelectuales revolucionarios y aquellos que no lo eran-, legitimidad adquirida por la consagración otorgada a los escritores por el mercado -toda intervención en la revista, por más revolucionaria que fuera, quedaría asociada a dicho sustrato- y ausencia de una articulación entre una teoría revolucionaria y una práctica política transformadora -las declaraciones y objetivos, por más radicales que fuesen, perdían sentido al no tener como referencia las realidades latinoamericanas concretas ${ }^{283}$.

Dos números después de la edición especial sobre cultura y revolución en Cuba, Los Libros publicó una réplica de Oscar del Barco al documento que habían consensuado los colaboradores de la revista. Al respecto, resulta de sumo interés el modo a través del cual las críticas esbozadas por el colaborador díscolo al posicionamiento de la revista frente al "caso Padilla" estaban apuntaladas por formulaciones althusserianas. La oposición desarrollada por del Barco frente a los "Puntos de partida para una discusión", y también frente a la "Carta a Libre", estaba configurada a partir de una concepción de la sociedad como un todo estructurado en distintos niveles, los cuales a su vez eran postulados como productos de diversas prácticas y poseedores de diferentes temporalidades, y cuyas relaciones de dominancia eran cifradas en términos históricos siendo la economía determinante en última instancia. Esta concepción se oponía a la idea de la sociedad como un todo homogéneo, a la cual del Barco calificaba de hegeliana -"como lo ha

los debates del "caso Padilla", la revista centró la discusión acerca de la relación entre escritores y política en el postulado de la libertad de creación y en la figura del intelectual crítico, ver Gilman, Claudia. op. cit., pp. 278-306.

${ }^{283}$ El proyecto de creación de Libre había sido anteriormente objeto de impugnaciones desde las páginas de Los Libros. En el número 12, Santiago Funes había enfatizado que se trataba de un proyecto iluminista -un grupo de intelectuales escribiendo desde París sobre la revolución latinoamericana- y respondía a las demandas del mercado un discurso adaptado a los procesos de mercantilización de la literatura-, "Mercado, ideología". Los Libros. Un mes de publicaciones en América Latina, $\mathrm{N}^{\circ} 12$, Octubre de 1970, pp. 30-31. 
demostrado Althusser" 284 - y señalaba como una fuente de confusiones y malentendidos alrededor de las relaciones entre política y cultura -y consecuentemente, de una interpretación errónea del "caso Padilla". En primer lugar, dicha concepción le permitía a del Barco cuestionar la distinción que la revista hacía entre adhesión política y adhesión moral a la revolución en su interpretación del posicionamiento de los intelectuales críticos. A su entender, el menosprecio hacia una práctica política revolucionaria que no tiene como correlato una teoría revolucionaria era una actitud indicativa de una creencia en una sociedad homogénea en cuyo vértice se encuentra la teoría y los dirigentes políticos encargados de aplicarla. Así, la jerarquización de la adhesión política al proceso revolucionario y el otorgamiento de un sentido negativo a la adhesión moral serían la consecuencia de una "idea unidimensional de la revolución" ${ }^{285}$, en la cual la transformación revolucionaria se sitúa únicamente en el plano de la política y los dirigentes revolucionarios aparecen como depositarios del sentido de la revolución. Sólo la superación de la concepción de la sociedad como un todo homogéneo permitiría evitar la confusión en los niveles de análisis:

Si no se considera a la sociedad como un todo estructurado a distintos niveles que exigen distintas prácticas destructivas, es imposible explicar que quienes hacen la revolución sean grandes masas de hombres que carecen de una teoría revolucionaria: hay una práctica política que no tiene como correlato indispensable una teoría política, y este reconocimiento no implica un menosprecio de la teoría, ya que el paso de lo ideológico a lo teórico es uno de los objetivos principales del movimiento revolucionario. Quiero decir que un escritor, lo mismo que un campesino o un obrero, puede ser revolucionario por razones éticas y no teóricas, sin que esto implique 'fragilidad' desde el punto de vista revolucionario: la mayoría de los muertos en la revolución son hombres que mueren sin conocer la teoría 286

El cuestionamiento de la idea unidimensional de la revolución conllevaba la problematización acerca de lo político como el espacio donde la revolución se

${ }^{284}$ Del Barco, Oscar. "Respuesta a 'Puntos de partida para la discusión"”. Los Libros. Para una crítica política de la cultura, N $^{\circ} 22$, Septiembre de 1971, pp. 32.

${ }^{285} / d$.

${ }^{286} / d$. 
presenta plena de sentido y como el nivel desde el cual la transformación revolucionaria se derrama hacia el resto de las prácticas. Al poner en duda que el índice del carácter revolucionario de las prácticas no estrictamente políticas debía ser el de la remisión al sentido pleno de la revolución, es decir, al de la revolución política, del Barco iba más allá de los posicionamientos de los otros colaboradores de la revista. El problema ya no era el de la necesidad de reformulación de los modos de producción intelectual, sino que lo que se trataba era de repensar el lugar de la cultura como un nivel al servicio de la revolución política. De esta manera, la contraposición con la idea de sociedad como un todo homogéneo tornaba más palpable las implicaciones de aquella afirmación sobre la exigencia de distintas prácticas destructivas. Afirmaba del Barco en un pasaje de marcado tono propositivo:

la revolución política no es LA revolución. En todo caso, si se pudiera hablar de LA revolución, ésta sería la suma de las distintas revoluciones, política, económica, ética, teórica... La sociedad trabaja a distintos niveles, constituye con sus distintas prácticas la estructura escalonada que es una formación económico-social determinada. Por consiguiente la lucha revolucionaria debe darse en todos esos niveles (cuya autonomía es relativa, pero cuyas mediaciones aún permanecen en el campo de lo no-conocido; siendo el marxismo, el psicoanálisis y la lingüística, fundamentales en el proceso de su reducción), en el espacio que esos niveles implican: hay una lucha de clases en la economía, en la política, en el arte, en el sistema de transmisión del saber, etc.; y es en su campo específico donde el escritor lleva adelante su lucha contra la burguesía 287

Una lectura del "caso Padilla" en términos de una sociedad estructurada en niveles específicos de realidad y constituida por diferentes prácticas conllevaba la justificación del cuestionamiento por parte del gobierno revolucionario de la categoría de intelectual pero también la advertencia de que los dirigentes revolucionarios debían reconocer su incompetencia en el orden literario o científico. De esta manera, del Barco representaba un modo de concebir las relaciones entre política y cultura que divergía tanto de los intelectuales críticos, para quienes la separación entre las esferas se justificaba por la libertad de

${ }^{287} / d$. 
creación, como de los que defendían la continuidad entre actos políticos y actos culturales, quienes subordinaban a la política la especificidad de los otros niveles. Quedaba así legitimada una tesis de la discontinuidad entre política y cultura en la cual la distinción de niveles no consistía en un valor a ser defendido en nombre de la autonomía intelectual ni en una brecha a ser salvada por el accionar de los dirigentes revolucionarios. Advertencia del carácter burgués de la posición intelectual crítica y señalamiento del tenor contrarrevolucionario de la subordinación de la cultura a la política: en las formulaciones de del Barco operaba, sin lugar a dudas, una radicalización de las concepciones sobre la revolución realmente existentes.

\section{4. ¿Qué es el estructuralismo? Difusión y control de un programa renovador de las ciencias humanas}

La consolidación por parte de Los Libros de un dispositivo crítico modernizador estuvo acompañada en sus primeros números por un trabajo de problematización de los nuevos saberes que nutrían aquella nueva forma de la crítica. En este sentido, los comentarios de libros desarrollados en las secciones "Filosofía", "Psicoanálisis", "Lingüística" o "Antropología" operaron en dos sentidos. Por un lado, actuaron como un espacio que permitió la recepción de obras recientemente editadas en el seno de dichas disciplinas -trabajo que transformó a la revista en un vehículo privilegiado de la difusión del pensamiento de Althusser, Levi-Strauss y Lacan. Por otro lado, dichas reseñas constituyeron una zona de Los Libros en la que era posible someter a discusión las implicaciones de las herramientas teóricas y metodológicas instrumentalizadas en la crítica de textos literarios y críticos. En tanto estos comentarios fueron encargados a intelectuales referentes en la recepción y difusión del estructuralismo en Argentina, las lecturas realizadas sobre los libros recién editados tendieron preponderantemente a precisar las especificidades y contornos de aquel conjunto de discursos teóricos percibido como el nuevo paradigma de las ciencias humanas. 
Resultan sumamente significativos, al respecto, los textos en los cuales José Sazbón modulaba un examen crítico de la consolidación del estructuralismo como tradición intelectual a través de la introducción de la obra de Levi-Strauss. Con la publicación de un comentario sobre Antropología estructura ${ }^{288}$, la revista intervino en la polémica alrededor del antihistoricismo estructuralista sentando una posición caracterizada por un afán aclaratorio y complejizador. En dicho texto, publicado en el número 2 y titulado precisamente "Estructuralismo e historia", Sazbón advertía sobre la multiplicidad de usos de la noción de estructura en las ciencias sociales. Aparecían así diferenciados aquellos usos de la noción de estructura como propiedad real de las relaciones humanas, en los que la estructura remitía a un elemento existente en el marco de las relaciones sociales, de sus usos como modelo construido a partir de la realidad, en los que la estructura estaba asociada a la formalización de un esquema interpretativo. Ubicada por Sazbón entre estos últimos, la antropología levistraussiana era caracterizada como una corriente inscripta en la estela del estudio estructural de los hechos sociales inaugurada por Saussure a principios del siglo XX. Según su descripción, el estructuralismo debía ser cifrado como un esfuerzo por trascender el estudio de los fenómenos conscientes y concentrarse en el análisis de la infraestructura inconsciente. Así la atención prestada por la antropología estructural a las reglas matrimoniales, los ritos y las formas de organización social, implicaban el desplazamiento del análisis "desde el marco vivido y sabido por los actores hacia la base inconsciente que sostiene la complicada red de sus relaciones y sus conductas" $^{\prime 289}$.

Resulta evidente que uno de los mayores intereses de Sazbón radicaba en la refutación de las lecturas sobre el estructuralismo que tendían a identificar en dicha corriente una analogía entre estructura orgánica y estructura social. Aludiendo a la obra de Alfred Radcliffe-Brown, intentaba demostrar que aún en los cultores del concepto de estructura como propiedad real de las relaciones humanas, el análisis estructural se desplegaba en el mismo nivel de las

\footnotetext{
${ }^{288}$ Buenos Aires, Eudeba, 1968.

${ }^{289}$ Sazbón, José. "Estructuralismo e historia". Los Libros. Un mes de publicaciones en Argentina y el mundo, $\mathrm{N}^{\circ}$ 2, Agosto de 1969, p. 15.
} 
relaciones sociales. Mucho menos le cabía dicha acusación, por tanto, a LeviStrauss, en cuyo trabajo la estructura operaba como modelo de análisis de la realidad social y servía de herramienta para la comparación externa entre sociedades. Sazbón articulaba dicha precisión con una reflexión acerca de las relaciones entre estructuralismo e historia. El núcleo de sus consideraciones alrededor de este vínculo lo constituía la delimitación de la especificidad del lugar de la historia en la obra de Levi-Strauss. Al respecto, Sazbón no podía más que dar cuenta de los elementos que se desprendían de Antropología estructural: mientras que la historia organiza sus datos a partir de las experiencias conscientes de la vida social, la etnología los organiza en base a las condiciones inconscientes. Resultaba, por tanto, innegable que la historicidad era desplazada a un lugar secundario y que el tiempo histórico era captado únicamente como el espacio en el que despliegan las invariantes estructurales.

Sin embargo, Sazbón avanzaba sobre el problema del antihistoricismo estructuralista completando la lectura en la que podía converger con las críticas a la obra de Levi-Strauss. En este sentido, la pregunta "¿Debemos concluir que para Levi-Strauss es imposible un estudio diacrónico de lo social que conserve el rigor estructural?"290 conducía a una problematización de los lugares comunes acerca del lugar de la historia en la corriente estructuralista. Sazbón se encargaba de remarcar que el análisis sincrónico no implicaba necesariamente la anulación de una perspectiva diacrónica y que el estructuralismo no desvalorizaba la historia sino que remarcaba el carácter mítico del esfuerzo por explicar el sentido del tiempo vivido por los hombres. De esta manera, la revista se transformaba en un espacio desde el cual se aludía críticamente a aquellas lecturas que veían en el estructuralismo una anulación de la historia strictu sensu. A través de los agudos comentarios de Sazbón, Los Libros hacía propias una serie de afirmaciones contundentes que tendían a legitimar y complejizar la renovación propuesta por el programa estructuralista. Por ejemplo, que "el hombre debe ser consciente de que su existencia histórica

${ }^{290} / d$ 
es un mito, sin que por ello renuncie a vivirla" ${ }^{291}$ o que "la inteligibilidad inmediata del proceso histórico es una ilusión, quizás necesaria para los fines de la acción, pero que no puede reivindicar el absoluto de una verdad total" 292 293.

Ahora bien, al mismo tiempo que se matizaban y corregían ciertos lugares comunes configurados alrededor de las principales formulaciones estructuralistas, la revista comenzará a ejercer cierto control sobre la recepción y apropiación del estructuralismo como paradigma de las ciencias humanas. El primer esbozo sistemático en este sentido también le correspondió a Sazbón, quien en el número 6 lanzó la pregunta acerca de la existencia de un estructuralismo a propósito de la edición de una serie de trabajos dedicados al concepto de "estructura" y al estructuralismo como corriente teórica ${ }^{294}$. Al haberse transformado en un -ismo más, afirmaba Sazbón, el estructuralismo corría el riesgo de convertirse en una moda, lo que lo volvería irremediablemente objeto tanto de operaciones ideológicas como de lecturas extremas. La edición de libros como los de Roger Bastide, Jean-Marie Auzias y Jean Fages aparecía como un elemento indicativo de que dicha conversión se había puesto en marcha.

Por un lado, la idea del estructuralismo como tradición era resultado de operaciones interpretativas realizadas por divulgadores con autonomía de los debates desarrollados entre los propios autores caracterizados como estructuralistas. Al dar cuenta de la importancia del formato libro en estas operaciones de divulgación, Sazbón sentenciaba que la unidad del estructuralismo "lejos de ser un resultado de los contactos directos entre quienes aplican métodos estructurales, es creada artificialmente desde fuera

${ }^{291} / d$.

${ }^{293}$ Cabe destacar que el número 2 traía, además del texto de Sazbón, un comentario de Mitológicas I. Lo crudo y lo cocido escrito por el antropólogo Héctor Lahitte, quien trabajaría posteriormente con el propio Levi-Strauss en Francia, y una entrevista realizada por Lahitte a Anne Chapman, discípula de Levi-Strauss que había trabajado sobre los indios onas en Tierra del Fuego.

${ }^{294}$ Bastide, Roger (comp.) Sentidos y usos del término estructura en las ciencias del hombre. Buenos Aires, Paidós, 1968; Auzias, Jean-Marie. El estructuralismo. Madrid, Alianza, 1969; Fages, J.B. Para comprender el estructuralismo. Buenos Aires, Galerna, 1968. 
por obra de los órganos de difusión"295.Por otro lado, el estructuralismo generaba lecturas que lo repudiaban como la nueva ortodoxia de las ciencias humanas y otras que adherían de manera entusiasta al incipiente paradigma sin problematizar la unidad de los elementos que lo conformaban. Según Sazbón, el carácter polisémico no podía ser sino desfavorable para un esfuerzo teórico que se pretendía renovador: "productiva y fecunda en el lenguaje literario, la polisemia es letal en un contexto, como el científico, que acepta tácitamente la necesidad de conceptos univocos"296.

Sazbón remitía a la lectura de Michel Serres y daba cuenta de lo problemático que había resultado la extensión del análisis estructural desde la fonología, la disciplina en la que este había sido definido con precisión y en el que había alcanzado grandes logros, hacia otros campos del saber, como la antropología, el psicoanálisis y la literatura. En este sentido, la posición de Sazbón participaba de la idea acerca de la vinculación entre la extensión de la noción de estructura y su debilitamiento como concepto. El señalamiento de ciertos límites en el desarrollo de la tradición estructuralista a partir de formulaciones -como las de Serres- inscriptas en la misma corriente teórica, permite advertir el funcionamiento en la revista de un mecanismo que se volverá fundamental posteriormente: la crítica al estructuralismo desde los propios marcos del pensamiento estructuralista ${ }^{297}$. Sin embargo, en este primer momento, dicho mecanismo convivía con la caracterización del programa estructuralista como un movimiento progresivo en el terreno de las ciencias humanas.

Al respecto, la lectura de Sazbón explicaba las reacciones generadas por el estructuralismo a partir del peso que por entonces tenían los hábitos

\footnotetext{
${ }^{295}$ Sazbón, José. "Qué es el estructuralismo". Los Libros. Un mes de publicaciones en Argentina y el mundo, №6, Diciembre de 1969, p. 20.

${ }^{296}$ ld.

${ }^{297}$ Si bien la referencia no era explícita, podemos afirmar que Sazbón remitía al primer libro de la serie Hermès de Serres, La Communication. París, Editions du Minuit, 1968. La posición de Serres en la tradición estructuralista, deudora del trabajo epistemológico de Jean Cavaillès y Georges Canguilhem, se caracterizó por enfatizar el origen matemático de la noción de estructura y problematizar el lugar de la fonología y la lingüística como disciplinas nucleares del estructuralismo, ver Dosse, François. History of Structuralism, Voume I. The Rising Sign, 1945-1966. Minneapolis, University of Minnesota Press, 1998, pp. 88-90.
} 
analíticos que aquel pretendía corregir. Si el estructuralismo era polémico, se debía a que éste enfrentaba las principales limitaciones de las ciencias humanas, como "cierta morosidad descriptiva que apenas roza la superficie de los fenómenos" 298 o "una inflación desmedida que hace del sujeto (individual o colectivo) la fuente de un sentido traslúcido"299. El futuro de la tradición estaba, por entonces, abierto. Por un lado, un conjunto de esfuerzos teóricos por operar un descentramiento del acontecimiento, de la historia, de lo vivido y del ser. Por el otro, unas consecuencias que aún no podían calcularse: el hecho de que el estructuralismo pretendiera impugnar el discurso totalizador de las ciencias humanas y disolver sus supuestos epistemológicos, tornaba imposible un balance que se desenvolviera al interior de una conciencia filosófica tradicional.

Ya en el número 3, la revista había dado cuenta del lugar que ocupaban algunas formulaciones provenientes de la obra de Althusser en los debates teóricos contemporáneos. En un texto publicado en la sección "Filosofía" dedicado a analizar la figura de Sartre a partir de una serie de lecturas críticas sobre su legado, Sazbón repasaba algunas impugnaciones de las que era y había sido objeto el sartreanismo. Aparecía, en primer lugar, el ataque levistraussiano a la razón dialéctica en nombre de un programa de disolución del hombre. Luego, entre las críticas realizadas desde el marxismo, Sazbón mencionaba a "los althusserianos" 300 , quienes advertían en la Crítica de la razón dialéctica "las aborrecidas figuras hegelianas"301 así como "un retorno al joven Marx" 302 .

Sin embargo, será en el número 4 en el que el althusserianismo aparecerá con una presencia significativa en las páginas de las revista. Como anunciaba la tapa del mencionado número, aquella edición de la revista estaba dedicaba a dos grandes temas. Por un lado, "Arquitectura", con su correspondiente serie de libros reseñados y un trabajo bibliográfico sobre la

\footnotetext{
$298 / d$.

${ }^{299} / d$.

${ }^{300}$ Sazbón, José. "Marx y Sartre". Los Libros. Un mes de publicaciones en Argentina y el mundo, $\mathrm{N}^{\circ} 3$ Septiembre de 1969, p. 13.

${ }^{301} / d$.

${ }^{302} / d$.
} 
temática. Por el otro, "Althusser", objeto abordado a partir de un dossier de reseñas de sus principales obras y compilaciones de trabajos en los que aparecían textos de su autoría: La revolución teórica de Marx, Para leer El Capital, La filosofía como arma de la revolución, Materialismo histórico y materialismo dialéctico y Cristianos y marxistas: los problemas de un diálogo ${ }^{303}$. Y como también indicaba la tapa -Arquitectura y Althusser aparecían relacionados a partir de la "A" con la que comenzaban ambas palabras-, el althusserianismo era abordado, al igual que la arquitectura, como un objeto de la contemporaneidad que debía ser sometido a un análisis riguroso ${ }^{304}$. En este sentido, el lugar ocupado por Althusser puede pensarse en sintonía con aquel que la revista le había reservado a Levi-Strauss en los números anteriores. Al mismo tiempo que en las mencionadas intervenciones de Nun, Verón y -sobre todo- Malamud, Sciarreta y Del Barco, el althusserianismo operaba como dispositivo en intervenciones políticas, científicas y filosóficas, la aproximación a Althusser en tanto objeto teórico y político se caracterizará por la delimitación de la especificidad del althusserianismo y la problematización sobre las implicaciones de su operativización como herramienta analítica e interpretativa. La discusión alrededor de Althusser, sin embargo, diferirá en cierto sentido de la lectura a la que Sazbón sometía a Levi-Strauss. Si bien la problematización de las aristas antihistoricista y antihumanista perceptibles en el althusserianismo estará presente en las lecturas desarrolladas en la revista, la pertenencia de Althusser a la tradición marxista y su participación en el PCF, así como la asignación de los comentarios a intelectuales argentinos provenientes -igualmente- del marxismo y el comunismo, le otorgará a este

${ }^{303}$ La revolución teórica de Marx y Para leer El Capital correspondían a las traducciones publicadas por Siglo XXI. La filosofía como arma de la revolución y Materialismo histórico y materialismo dialéctico habían sido publicadas respectivamente en los Cuadernos de Pasado y Presente número 4 y 8 , ver el capítulo siguiente. Cristianos y marxistas: los problemas de un diálogo había sido editado en España por Alianza en 1968 a instancias del teólogo Jesús Aguirre. La compilación incluía textos de intelectuales católicos -Karl Rahner, Giulio Girardi, Johann Baptist Metz y José Aranguren- y marxistas -Lucio Lombardo Radice, Milan Machovec, Gilbert Murry, Manuel Sacristán y el propio Althusser.

${ }^{304}$ Ver apéndice de imágenes. 
dossier un carácter mucho más político que el que se podía desprender del debate alrededor de la obra de Levi-Strauss.

Las posiciones tomadas por los colaboradores de Los Libros frente a Althusser dan cuenta de un abanico de lecturas de la obra althusseriana que iba desde apreciaciones impugnatorias hasta consideraciones apologéticas. Entre las primeras cabe destacar la intervención de Terán, titulada de manera contundente "Límites de un pensamiento". Si bien esbozaba algunas valoraciones positivas de la obra de Althusser -la rigurosidad en el planteo de los problemas filosóficos- y explicitaba algunos atenuantes -el hecho de que se trataba de un pensamiento en formación-, la lectura realizada por Terán estaba guiada por el propósito de evidenciar las limitaciones teóricas del althusserianismo y demostrar lo desfavorable que podrían resultar a la política revolucionaria. La limitación más seria que advertía era la concepción de la ideología como "velo" o "robo a la realidad". La postulación de la ideología como "el mundo más alejado de las realidades efectivas de la historia" 305 implicaba, según Terán, un divorcio del concreto real y el concreto de pensamiento, lo cual dificultaba la dilucidación de las condiciones de posibilidad del surgimiento de una nueva problemática, y una negación del instinto de clase proletario, lo cual bloqueaba la posibilidad de que el proletariado negara la estructura social en la que es explotado. Asimismo señalaba, en contraposición a Althusser, que la ideología no es un todo homogéneo, y que cuando Marx ve la plusvalía y el proletariado niega la estructura, lo hacen "no solo a pesar de la ideología de las clases dominantes sino también sobre la base de un 'conocimiento' que se alberga en algunos sectores de la ideología de las clases subalternas" ${ }^{306}$.

El corte radical entre ciencia e ideología postulado por el althusserianismo bloquearía el acceso a un verdadero concepto de "mediación". De este modo, explicaba Terán, Althusser recurría a elementos mágicos para explicar el pasaje del terreno ideológico al científico -"un paso antes estamos en el dominio de la ideología, pero se puede franquear esa

\footnotetext{
${ }^{305}$ Terán, Oscar. "Límites de un pensamiento". Los Libros. Un mes de publicaciones en Argentina y el mundo, $\mathrm{N}^{\circ}$ 4, Octubre de 1969, p. 22. ${ }^{306}$ ld.
} 
frontera 'y penetrar en el dominio de la realidad' y 'hete aquí solo frente a tu objeto real"307- y psicologistas para explicar el surgimiento de una nueva problemática -"la voluntad feroz de Marx de liberarse de los mitos" ${ }^{308}$. La advertencia de una tendencia cientificista en Althusser se complementaba con una crítica al anti-historicismo, sobre el que se enfatizaba que no permitía explicar el cambio social, y al anti-humanismo, sobre el que se señalaba que no habilitaba una distinción entre un humanismo de derecha -de raigambre liberal y deudor de la noción de "persona humana"- y uno de izquierda -propiciatorio de los "incentivos morales" o la "revolución cultural". Señalamientos, cabe destacar, que aparecían vinculados a la pertenencia de Althusser al PCF, "uno de los partidos más revisionistas del mundo" 309 a decir de su lector argentino. En suma, una serie de objeciones frontales que llevaban a Terán a utilizar al althusserianismo como evidencia de la necesidad de dar prioridad a las formulaciones de problemas teóricos en espacios que atravesaban procesos revolucionarios: "El marxismo, también como teoría, no sólo está detrás sino también por hacerse, en aquellos ámbitos del llamado Tercer Mundo donde hoy se plantea más radicalmente la 'práctica política' revolucionaria" ${ }^{310}$.

En las antípodas de las acusaciones de Terán se encontraban las intervenciones de Sciarreta y Juan Carlos Indart, tituladas respectivamente "Leer El Capital" y "Lectura de la lectura". Como se desprende de dichas nominaciones, el carácter auspicioso de la lectura realizada por ambos comentaristas estaba originado en la percepción del althusserianismo como una corriente modernizadora del marxismo. La propuesta althusseriana de problematizar la práctica de la lectura, a partir de la cual el abordaje de El Capital ya no constituiría el acceso a un "libro abierto" 11 o a un "espejo transparente" ${ }^{\prime 12}$ sino que sería una práctica caracterizada por la ambivalencia, llevaba a Sciarreta a ubicar a Althusser en el linaje Marx-Nietszche-Freud, a

\footnotetext{
${ }^{307}$ Ibid., p. 23.

${ }^{308} / d$.

${ }^{309} / d$.

${ }^{310} / d$.

${ }^{311}$ Sciarreta, Raúl. "Leer El Capital". Los Libros. Un mes de publicaciones en Argentina y el mundo, $\mathrm{N}^{\circ} 4$, Octubre de 1969, p. 23.

${ }^{312} / d$.
} 
partir del cual se habría vuelto indispensable teorizar aquellas acciones que, como el hacer y el decir, se habrían transformado en fetiches de la práctica social. Cerca de Spinoza y lejos de Feuerbach, el Marx de los Manuscritos económicos-filosóficos y Sartre, Althusser habría dado el paso de negarse a fundar la ciencia y la filosofía en el humanismo, lo cual permitía evitar "la circularidad reiterativa de la experiencia sensible y de lo imaginario"313 y explicitar la existencia de una práctica inmanente a la teoría. La constatación althusseriana de que no hay lectura inmediata de los fenómenos históricos y que lo que se necesita es un medio teórico para generar conocimiento formal concreto desde el sistema formal abstracto permitía, según Sciarreta, evitar las distorsiones que se habrían hecho de la relación entre teoría y práctica y orientar la especificidad de dicha unidad.

Así, el replanteo de Althusser de la relación Hegel-Marx demostraría que, lejos de operar en dicho pasaje la conservación del método dialéctico extraído de un sistema impugnado, la fundación del materialismo histórico implica un pasaje de la pre-ciencia a la ciencia, a partir del cual se constituye una nueva organización conceptual como producción reglada de un objeto de conocimiento. La lectura de Sciarreta percibía en Althusser una "reformulación y rigurosa legitimación de la práctica teórica" ${ }^{314}$, lo cual no implicaba una desviación cientificista, en tanto se reinscribiría dicho proceso en una nueva práctica de la filosofía, de inspiración leninista, en la cual existía una clara delimitación entre la ciencia y la ideología y la ciencia y la política. Era precisamente, según Sciarreta, su carácter rupturista e innovador lo que le otorgaba al althusserianismo la fortaleza para ignorar las críticas teóricas y políticas que se habían levantado en su contra: "pensamos recordando a Bachelard, que la teoría siempre opera rupturas con su pasado, esa es su misma condición, la práctica teórica y la práctica filosófica están bajo el signo de la juventud"315.

En un sentido análogo intervenía Indart, quien clarificaba y precisaba algunas tesis althusserianas a la vez que problematizaba algunas lecturas

\footnotetext{
${ }^{313} / d$.

314 Ibid., p. 24.

315 Id.
} 
realizadas sobre la obra de Althusser. A su entender, el aporte fundamental de Althusser era la explicitación del problema de la lectura teórica de Marx, dimensión que según su mirada no había sido suficientemente problematizada -de lo cual daba cuenta el énfasis instrumental en la traducción al español de Lire Le Capital como Para leer El Capital- pero que poseía una radicalidad tal que podía modificar las concepciones de lectura de los lectores de textos marxistas. Según Indart, la obra althusseriana no debía ser abordada ni como sustitutiva de la obra de Marx ni como un esfuerzo de despejar el camino a la pureza de los textos marxistas, sino que la clave radicaría en "una lectura que encuentra su fundamento en la opacidad constitutiva de los textos" ${ }^{316}$. De las discusiones y malentendidos alrededor de su obra también habría sido responsable el propio Althusser, se afirmaba, en tanto sus recortes y aumentos en las ediciones de sus obras impedía replegar su obra sobre sí misma y aplicarle los mismos principios que a la lectura de Marx, y su intención de distinguir claramente su proyecto del estructuralismo oscurecía el rol que pudo haber tenido el estructuralismo en su reformulación del marxismo.

En la lectura de Indart, el peligro alrededor de estas ambivalencias radicaba en que el althusserianismo, más allá de los aspectos más innovadores de su proyecto, no pudiera evitar el vicio marxista de denunciar el carácter ideológico de las ciencias sociales ignorando a su vez sus fructíferos avances teóricos, lo cual resultaría en una "inflación de la teoría marxista y una incapacidad de desarrollar la ciencia fundada por Marx" ${ }^{317}$. Más allá de las discusiones generadas en torno a aspectos problemáticos de su teoría, el althusserianismo demostraba a los lectores marxistas el largo camino por recorrer para lograr una cabal comprensión de la teoría a la cual pretendían acceder. En suma, Indart no escatimaba elogios sobre el tenor rupturista del marxismo althusseriano: "el lector también debe hacer su interpretación y considerar que no se trata de ser anti-althusseriano o post-althusseriano, sino de saber que se es fundamentalmente pre-marxista" ${ }^{318}$.

\footnotetext{
${ }^{316}$ Indart, Juan Carlos. "Lectura de la lectura". Los Libros. Un mes de publicaciones en Argentina y el mundo, $\mathrm{N}^{\circ} 4$, Octubre de 1969, p. 26.

${ }^{317}$ ld.

${ }^{318} / d$.
} 
La lectura de Aricó se caracterizaba -tal como profundizamos en el próximo capítulo- por una destacable singularidad. Más permeable al althusserianismo que la de Terán pero más cautelosa que las de Sciarreta e Indart, su intervención, titulada "El marxismo antihumanista", procedía a un balance de los aportes de Althusser al marxismo a partir de su contextualización en las tendencias internacionales de la teoría marxista y del movimiento obrero. A partir de la confrontación con aquellas intervenciones que postulaban la muerte del marxismo debido a las múltiples fragmentaciones del movimiento comunista internacional, Aricó postulaba a la situación permanente de crisis como el modus vivendi natural del marxismo, en tanto éste, a diferencia de otras teorías, no sólo quiere interpretar el mundo, sino que lo hace para poder transformarlo. El hecho de que la situación de desconcierto y confusión por la que estaba atravesando el movimiento obrero internacional estuviese acompañada por una marcada influencia del marxismo en la cultura contemporánea, tampoco debía sorprender, afirmaba Aricó, ya que el marxismo mantiene su autonomía frente a los hechos políticos y su fuerza no depende exclusivamente de ellos. Dicha situación de desconcierto y confusión implicaba, por lo tanto, que al mismo tiempo que se desenvolvía un proceso de universalización del marxismo -"el marxismo participa del Saber de nuestra época y todos somos, de una manera u otra, "marxistas" 319 - se producía una merma de su potencial crítico por querer explicarlo todo -"el marxismo se ha convertido en algo tan vago que incluye obras dispares como el programa del PCUS, el Libro Rojo de Mao o el Testamento de Togliatti' ${ }^{320}$.

Aricó proclamaba que la única manera de que el marxismo pudiera volver a responder las preguntas que le planteaba la realidad política era llevando a cabo un proceso de autocuestionamiento, replanteo de sus orígenes e identificación de aquello que lo define como teoría y como ciencia. Era por lo tanto la situación de crisis política del socialismo la que posibilitaba una etapa de desarrollo y maduración de la teoría marxista, dentro de la cual, según Aricó, debía ser ubicada la obra de Althusser. En la lectura de Aricó, el intento

\footnotetext{
${ }^{319}$ Aricó, José. "El marxismo antihumanista". Los Libros. Un mes de publicaciones en Argentina y el mundo, $\mathrm{N}^{\circ} 4$, Octubre de 1969, p. 20. ${ }^{320}$ ld.
} 
de redescubrir los orígenes del marxismo, el replanteo de la diferencia con la filosofía clásica alemana y de la relación Hegel-Marx, y la interrogación del significado de la crítica marxista que estaban implícitos en las elaboraciones teóricas del althusserianismo, hacian de éste un canal fundamental a través del cual se intentaba "fundar teóricamente la especificidad irreductible del marxismo" ${ }^{321}$. Se desprendía de esta lectura una valoración positiva del esfuerzo de Althusser por la postulación del marxismo como saber objetivo, la ubicación del materialismo dialéctico como base de la constitución teórica del conocimiento científico y el sometimiento del marxismo a la aplicación de principios marxistas de investigación, en tanto éstos constituían un avance en la epistemología marxista y proporcionaban herramientas para polemizar con el historicismo, la concepción del conocimiento como reflejo, el pragmatismo, el humanismo y el estructuralismo. A través de una calificación que adelanta la discusión planteada en el próximo capítulo, la polémica entablada por el althusserianismo contra dichas tendencias -entre las que debe ser destacado el humanismo- era adjetivada por Aricó como "eficaz y brillante" 322.

Esta apreciación, indicativa de la ambivalencia de Aricó que tratamos más adelante, aparecía matizada por el señalamiento de elementos problemáticos al interior del althusserianismo. Siguiendo a Alain Badiou, Aricó prevenía al lector que aceptar la noción de ciencia de Althusser, implicaba necesariamente la extensión a las ciencias sociales de la especificidad del conocimiento científico en las ciencias físicas y matemáticas y la exclusión del hombre de la estructura teórica de las ciencias humanas. A partir de las críticas del filósofo italiano Massimo Barale, aparecía la acusación de teoricista a Althusser por privilegiar a la experiencia gnoseológica como única vía de acceso a la realidad -movimiento que acarreaba el peligro de introducir una ideología implícita- y por definir a la filosofía como teoría de la práctica teórica concepción que soslayaría la relación entre filosofía y política ${ }^{323}$. Estas "lagunas

\footnotetext{
${ }^{321} / d$..

${ }^{322}$ Ibid., p, 21.

${ }^{323}$ El texto de Barale aludido por Aricó era "Sul rapporto di scienza e ideologia in Althusser", publicado en el número 111 de la revista Aut-Aut.
} 
$y$ espacios" 324 del althusserianismo eran utilizadas por Aricó para calificar de dogmático a Althusser y señalar críticamente su adhesión al PCF: "Quizás sean esos vacíos conceptuales los que lo impulsan a adherir tan acríticamente al accionar político del Partido Comunista Francés del cual es hoy su filósofo oficial $^{325}$.

El proceso de latinoamericanización de la revista operado a partir del número 8 implicará un desplazamiento en los parámetros a través de los cuales Los Libros difundía y problematizaba los saberes que le otorgaban a su trabajo crítico un carácter riguroso y modernizador. El auspicio de la revista por parte de editoriales latinoamericanas (Fondo de Cultura Económica, Losada, Monte Avila, Siglo XXI y Editorial Universitaria de Chile), su distribución hacia América Latina, Estados Unidos y España, la contratación de corresponsales en diversos países del continente y la incorporación de discusiones generadas a partir de libros editados por las editoriales latinoamericanas, estará acompañada de un proceso de corrección de los posicionamientos teóricos asumidos por la revista durante su primer año de vida. En efecto, el "Editorial" del número en el cual se anunciaba la apertura hacia América Latina, publicado en mayo de 1970, operó a modo de plataforma desde la cual se enfrentaron las críticas de las que había sido objeto la singular intervención de la revista y sobre todo- se reconocieron errores derivados del despliegue de las herramientas teóricas asumidas por sus colaboradores. Así, mientras Los Libros se defendía de las acusaciones de "crípitica, elitista, extranjerizante y estructuralista" 326 enfatizando la necesidad de la especificidad del discurso y la rigurosidad del método para la consecución de un trabajo centrado en la búsqueda de estructuras reales y el develamiento de los mecanismos ideológicos, admitía el error de haber incurrido en un lenguaje demasiado técnico que podía haber restringido el acceso de los lectores a los contenidos de los artículos. Por ello, al mismo tiempo que se reforzaba el programa de

\footnotetext{
${ }^{324}$ Aricó, José. "El marxismo antihumanista”. op. cit., p. 22.

325 ld.

326 "Etapa". Los Libros. Un mes de publicaciones en América Latina. № 8, Mayo de 1970 , p. 3.
} 
lucha teórica contra la crítica "terrorista de intereses o de grupos" ${ }^{227}$ y las ideas "cristalizadas de la ideología"328, se anunciaba una tarea de replanteo del lenguaje utilizado por la revista y de reconocimiento de que ésta se dirigía a un público que no era necesariamente especialista.

A partir del proceso de latinoamericanización, aquella forma de vinculación con el estructuralismo caracterizada por la corrección de aproximaciones superficiales y la complejización de sus formulaciones teóricas más polémicas, irá perdiendo terreno frente a las operaciones de control sobre la recepción y apropiación del estructuralismo como nuevo paradigma de las ciencias humanas. El relevo entre una lectura como la que había realizado Sazbón sobre la Antropología estructural y aquella que él mismo había realizado sobre los divulgadores del estructuralismo, no se hizo esperar: el número que le siguió al que anunciaba la apertura hacia América Latina y la corrección de errores cometidos durante la primera etapa, llevaba como primer título de tapa "La moda del estructuralismo", a la vez que desplegaba en su interior análisis críticos sobre los procesos de edición, circulación y consumo de libros inscriptos en la corriente estructuralista.

Por un lado, Verón atendía la traducción al español de Las estructuras elementales del parentesco ${ }^{329}$ indagando las razones por las cuales un libro largo, mayormente técnico y escrito en pleno auge existencialista, se había convertido rápidamente en un clásico consumido por la intelectualidad latinoamericana de fines de la década de 1960. Aparecían destacados, en este sentido, los desajustes entre los procesos de producción y consumo de las obras, y la tendencia al consumo ostentoso de producciones teóricas de los países centrales por parte de los intelectuales de los países dependientes ${ }^{330}$.

Carlos Sastre, por su parte, se detenía en la edición de Psicoanálisis, existencialismo y estructuralismo ${ }^{331}$, una compilación de textos de MerleauPonty, Lagache, Althusser y Foucault, resaltando la difícil convivencia en un

\footnotetext{
${ }^{327} / d$.

328 Id.

${ }^{329}$ Barcelona, Paidós, 1969.

${ }^{330}$ Verón, Eliseo. "Actualidad de un clásico. La moda del estructuralismo". Los Libros. Un mes de publicaciones en América Latina. N 9, Julio de 1970, pp. 16-18.

${ }^{331}$ Buenos Aires, Papiro, 1969.
} 
mismo volumen de trabajos como "Fascinación de la conciencia por el yo" de Lagache -un texto fenomenológico cargado de conceptualizaciones acerca de la conciencia y el yo- y el "Freud y Lacan" de Althusser -precisamente una refutación palmaria de posiciones como la asumida por Lagache ${ }^{332}$. Al igual que Verón, para Sastre dicho fenómeno sólo era comprensible a partir de un análisis que inscribiera el negocio editorial en el marco de los procesos de reproducción ideológica.

La profundización del control sobre la recepción y apropiación de las herramientas teóricas que constituían el aparato crítico de la revista, implicó asimismo la consolidación de un gesto singular que ya habíamos visto insinuado en las primeras lecturas desarrolladas en sus páginas: el del abordaje de los fenómenos de difusión y expansión del método estructural a partir de esquemas analíticos proporcionados por la propia constelación estructuralista. Al igual que Sazbón remitía a Serres a fines de certificar un debilitamiento del concepto de estructura en el proceso de divulgación del estructuralismo, la operación de conceptualización del estructuralismo como "moda" característica de este momento de la revista, encontraba su potencia en las formulaciones althusserianas sobre la ideología.

En el caso de Verón, la distinción entre ciencia e ideología desempeñaba un rol fundamental en la explicación sobre el desajuste entre los procesos de producción y consumo de las obras. A su entender, la transformación de Las estructuras elementales del parentesco en un clásico a fines de la década de 1960 obedecía al desfasaje entre el tiempo de la práctica científica y el tiempo de su expansión ideológica. Al ser mucho más lento el tiempo de la primera que el de la segunda, lo que se conocía por "estructuralismo" no era más que un conjunto de elementos ideológicos surgidos de la práctica científica desarrollada por los estructuralistas. Junto a este desajuste de tipo temporal, el análisis de Verón se dirigía a un desfasaje geográfico. Al estar situada en un contexto dependiente, la intelectualidad argentina solamente accedía a textos secundarios sobre el estructuralismo,

${ }^{332}$ Sastre, Carlos. "El negocio editorial al servicio de la ideología". Los Libros. Un mes de publicaciones en América Latina. № 9, Julio de 1970, pp. 20-22. 
razón por la cual el método estructural quedaba asociado a un discurso especulativo de segundo orden. A esta diferencia espacial le adjudicaba Verón el hecho de que cuando una obra de primer orden era traducida en América Latina, al no contar con el campo específico en el cual el trabajo fue generado la sociología del parentesco en el caso del libro de Levi-Strauss-, lo que finalmente era consumido eran los desprendimientos ideológicos de la práctica científica desarrollada en los países centrales. La constatación de este doble desfasaje le permitía a Verón ubicar el proceso de expansión del estructuralismo dentro del campo de la ideología: "la invasión 'estructuralista' de nuestro contexto intelectual es un fenómeno puramente ideológico" ${ }^{333}$.

Sastre también enfatizaba el carácter ideológico de la difusión del estructuralismo, aunque en su caso, el análisis del libro comentado se dirigía hacia la vinculación entre las reglas del mercado editorial y la reproducción de la ideología dominante. Si la edición de Psicoanálisis, existencialismo y estructuralismo había sido posible, las razones debían encontrarse en el consumo de un libro prestigiado por el nombre de sus autores y la filiación de algunos de ellos en las tendencias teóricas predominantes en la época. Asimismo, el éxito de un libro que agrupaba tipos disímiles de saberes y tradiciones teóricas diametralmente opuestas, solo era comprensible remitiéndose a la potencia integracionista de la ideología. De este modo, la convivencia de Lagache y Althusser en un mismo volumen se convertía en el resultado de una concepción ideológica según la cual todos los elementos son integrables a través de operaciones de suma.

\subsection{Una crítica política de la cultura: Mao y Althusser}

Como ha sido reiteradamente señalado, hacia 1971 la revista atravesó un proceso de transformación que derivó en una reestructuración significativa tanto de su colectivo editorial como de sus modos de intervención políticocultural. En un movimiento análogo a la autocrítica operada en el proceso de latinoamericanización, el pasaje desde una posición centrada en la crítica de

${ }^{333}$ Verón, Eliseo. “Actualidad de un clásico. La moda del estructuralismo”. op cit., p. 16. 
libros hacia una anclada en la crítica política de la cultura conllevó una corrección de las formas anteriores de articulación entre las tareas políticas y las tareas culturales. El número 21, que anunciaba la desvinculación de la editorial Galerna y el comienzo de un autofinanciamiento, asumía el carácter acotado que había tenido la intervención de la revista en tanto órgano que se posicionaba frente a las condiciones políticas y culturales de América Latina a través de la crítica de libros. Adjudicada al carácter dependiente de los contextos en los cuales los intelectuales latinoamericanos desarrollaban su práctica específica, la reducción del trabajo crítico a la discusión de novedades editoriales aparecía como una etapa de la intervención de la revista que, si bien progresiva, debía ser finalmente trascendida. Lamentando no haber podido dar cuenta de discusiones políticas desde sus comienzos pero valorando la apertura operada con el proceso de latinoamericanización, Los Libros anunciaba su desplazamiento hacia la crítica de aquellos textos que se encontraban más allá del registro escritural; es decir, los que "constituyen los hechos históricos sociales" 334335.

Dicho desplazamiento, cabe destacar, poseía una singularidad que resiste lecturas apresuradas sobre una politización anuladora de la especificidad del trabajo teórico. Tal como explicitaba el texto programático incluido en el número 21 , el direccionamiento de la crítica hacia problemáticas sociales y políticas no implicaba el abandono de los presupuestos teóricos que habían guiado el trabajo crítico de la revista desde sus comienzos. En primer lugar, éste seguiría siendo un trabajo de lectura centrado en el análisis ideológico: "Estas formas de la cultura exigen también una lectura que los

334 "En este número". Los Libros. Un mes de publicaciones en América Latina. № 21, Agosto de 1971, p. 3.

${ }_{335}$ Desplazamiento que implicará la agudización de las tensiones dentro del colectivo editorial entre los posicionamientos que tendían a priorizar el trabajo crítico y los más proclives a dar lugar a los problemas políticos de la coyuntura. Para una lectura del itinerario de la revista que dé cuenta de este problema, ver Peller, Diego. "Crítica literaria, crítica cultural y política en la revista Los Libros (1969-1976). IV Jornadas de Historia de las Izquierdas "Prensa política, revistas culturales y emprendimientos editoriales de las izquierdas latinoamericanas". Buenos Aires, Noviembre de 2007 y Cousido, Diego. "Actualización teórica, lucha ideológica, en el caso de Los Libros". Cuadernos críticos de comunicación y cultura. $\mathrm{N}^{\circ} 4$, primavera-verano de 2008, pp. 107-127. 
decodifique para destacar su significado, el mundo ideológico en que se insertan"336. Una tarea que no renunciaría a la perspectiva analítica proporcionada por el paradigma estructural: "Requieren ser ordenados a partir de un pensamiento que los observe como síntomas de una estructura que se ofrece opaca y que es preciso develar para modificarla" ${ }^{337}$. Finalmente, una forma de la crítica que anudaba las formas modernas de la teoría con una pulsión política de corte revolucionaria: "Se trata, en última instancia, de contribuir al cambio de las condiciones en que se produce la cultura" ${ }^{338}$.

La convergencia entre la formulación del programa de crítica política de la cultura y el protagonismo adquirido en la dirección de la revista por Ricardo Piglia -vinculado a VC- y Carlos Altamirano -vinculado al PCR-, redundó en el posicionamiento de la revista bajo unos parámetros teórico-políticos explícitamente maoístas ${ }^{339}$. Ya en el número 23 , dedicado a la temática

${ }^{336} / d$.
${ }^{337} / d$.
${ }^{338} / d$.

${ }^{339}$ El señalamiento de una confluencia entre la "politización" de la revista y el lugar ocupado en la dirección por los intelectuales más vinculados a la experiencia maoísta se enmarca en una aproximación historiográfica a dicho fenómeno -la única, finalmente, capaz de dar cuenta de la historicidad de la transformación de la revista. No participa, por lo tanto, del sentido que le han intentado otorgar sus propios protagonistas, quienes en el afán de abjurar de un pasado vergonzante, ridiculizan dicha convergencia reduciéndola a un episodio meramente contingente. Como afirmaba recientemente Piglia a propósito de la edición facsimilar de la revista: "En la época en que se va Galerna, pasa una cosa divertida para llamarla de algún modo: Toto Schmucler se vuelve maoísta durante quince días más o menos (risas). En esos quince días, como yo también era maoísta, decidimos darle esa orientación a la revista. Y entonces yo digo 'invitémoslo a Altamirano', que también era maoísta. Por eso en el Consejo aparecemos los tres, porque hay un acuerdo político, no de partido ni de grupo, sino que estábamos de acuerdo en darle a la revista una orientación maoísta". Somoza, Patricia y Vinelli, Elena. "Para una historia de Los Libros". Los Libros. Edición Facsimilar. Buenos Aires, Biblioteca Nacional, 2011, p. 15. Lo que se tornaría "risible" -por llamarlo de algún modo- sería la subsunción de la complejidad de los últimos veinte números de la revista a este tipo de explicaciones configuradas a partir de la memoria y el testimonio. Es evidente que la historia de las políticas culturales del maoísmo argentino está aún por realizarse. El avance más significativo en relación a lo que aquí nos interesa ha sido, sin dudas, "Althusser's Reception in Argentina: The Case of Los Libros (1969-1976)". Popovitch, Anna. In the Shadow of Althusser: Politics and Culture in Late Twentieth-Century Argentina. op. cit. pp. 106157. Sobre el maoísmo de Piglia, ver Bosteels, Bruno. "In the Shadow of Mao: Ricardo Piglia's 'Homenaje a Roberto Arlt'”. Journal of Latin American Cultural Studies, Vol. 12, $\mathrm{N}^{\circ} 2$, 2003, pp. 229-259. Sobre la presencia del maoísmo y el lugar de sus prácticas editoriales en la cultura de izquierdas argentina, ver Celentano, Adrián. "El maoísmo 
"Universidad y lucha de clases", en Los Libros se daba cuenta de las transformaciones operadas en las universidades chinas a partir del proceso de la RCPCh. La introducción de la experiencia china se realizaba a través de la reproducción de una entrevista publicada por la revista estadounidense Movement a Chris Milton, un joven que había estudiado en China y que describía las implicaciones del proceso revolucionario chino en el sistema universitario. La referencia más significativa al modelo de la Revolución Cultural se produjo, sin embargo, con el número 35, de mediados de 1974. Íntegramente dedicado a la temática "China después de la revolución cultural", enfatizaba la importancia del modelo revolucionario chino en tanto ruptura radical con la dominación imperialista y proceso de liberación nacional protagonizado por las masas. El contenido de los textos publicados en dicho número nos permite advertir la atracción que generaba entre los intelectuales maoístas argentinos la importancia otorgada por los revolucionarios chinos a la lucha ideológica en el proceso revolucionario. De este modo, además de un texto del economista maoísta argentino Horacio Ciafardini sobre la organización industrial china ${ }^{340}$ y del sinólogo francés Jean Daubier sobre el problema del poder en el seno de la revolución ${ }^{341}$, la revista reproducía textos que abordaban problemas relativos a la psiquiatría, la educación y la cultura en el marco de la Revolución Cultural ${ }^{342}$.

argentino entre 1963 y 1976. Libros, revistas y periódicos para una práctica política". Políticas de la Memoria. Anuario de investigación e información del CEDINCl. № 14 , Verano 2013/2014, pp. 151-165.

${ }^{340}$ Ciafardini reseñaba Revolución cultural y organización industrial en China de Charles Betteheim, economista maoísta francés con quien había estudiado en París. El libro de Bettelheim había sido editado en Francia por François Maspero en 1973 y publicado en español por Siglo XXI en 1974. Cabe destacar que Bettelheim había formado parte del círculo althusseriano y su análisis de una restauración del modo de producción capitalista en la Unión Soviética se realizaba a través de un marxismo estructural de orientación netamente althusseriana, ver Resch, Robert Paul. Althusser and the Renewal of Marxist Social Theory. Berkeley, University of California Press, 1992, pp. 75-76. Para una semblanza político-intelectual de Ciafardini, ver la entrada correspondiente en Tarcus, Horacio (dir.). Diccionario biográfico de la izquierda argentina. De los anarquistas a la "nueva izquierda" (1870-1976). op. cit., pp. 133-135.

${ }^{341}$ Daubier había contribuido de manera significativa a la difusión de la Revolución Cultural en Francia con su libro Histoire de la Révolution Culturelle Prolétarienne en Chine, publicado por François Maspero en 1970.

342 "Curar a los enfermos para la revolución", tomado de la revista francesa Cinétique; "Educación y lucha de clases en China", tomado de la publicación de la Asociación de 
Se publicará, asimismo, en el número 40, un larguísimo artículo del francés André Pommier sobre la restauración capitalista en la URSS en el que se insistía en el carácter revisionista del PCF y se contraponía el desenvolvimiento del proceso revolucionario en la URSS y en China ${ }^{343}$. Ciafardini y el también economista maoísta Eugenio Gastiazoro publicarán varios artículos sobre el carácter dependiente de la economía argentina y sobre el socialimperialismo soviético ${ }^{344}$. Cabe destacar, finalmente, los comentarios realizados por Santiago Más de libros que abordaban problemas vinculados, de una manera u otra, con la tradición maoísta ${ }^{345}$.

Durante esta última etapa, la revista se constituirá en un espacio atravesado por la formulación de las posiciones de las organizaciones maoístas frente a la coyuntura política argentina. Ahora bien, como también hemos dicho, la forma que adquirían algunos de estos posicionamientos, permite caracterizar al proceso de maoización de Los Libros como un fenómeno que integra un paso explícito hacia la política y una continuidad en la valoración del trabajo teórico. Esta dimensión es claramente perceptible en el texto de Altamirano sobre el GAN publicado en el número 27. Por un lado, se delineaba allí un posicionamiento frente al proceso político argentino que remitía a la línea

Amistad Franco-China -dirigida por entonces por Bettelheim-; y "Reflexiones sobre la Revolución Cultural" de Giovanni Blumer, tomado de la revista italiana Quindici. Se reproducía, asimismo, "Notas sobre el materialismo dialéctico", un texto inédito de Mao.

${ }^{343}$ Pommier André. "La restauración del capitalismo en la URSS". Los Libros. Para una crítica política de la cultura. Marzo-abril de 1975, N 40, pp. 27-38.

${ }^{344}$ Ciafardini fue un colaborador asiduo de la revista desde 1971: en el número 27 comentó Proyectos nacionales. Planteo y estudios de viabilidad de Varsavsky, en el número 29 publicó su artículo "Argentina: desarrollo capitalista dependiente y discurso ideológico", en el número 33 fue uno de los que respondió a la encuesta "Economía: liberación o dependencia", en el número 37 comentó dos libros sobre el feudalismo y en el número 39 comentó El otro imperialismo. Del socialismo al socialimperialismo del dirigente maoísta Carlos Echagüe. Gastiazoro, por su parte, publicó los textos "Acumulación y centralización en la industria argentina" en el número 30, "La industrialización dependiente" en el número 41 y "La cuestión agraria" en el número 43.

${ }^{345}$ Schlesinger, Rudolf. La Internacional Comunista y el problema nacional (Córdoba, Pasado y Presente, 1974) en el número 36; Mandel, Ernest. Autogestión, control obrero, consejos obreros (Buenos Aires, La ciudad futura, 1973) y AAVV. Consejos obreros y democracia socialista (Buenos Aires, Pasado y Presente, 1972) en el número 36; y Schram Stuart y Carrère D'Encausse, Hèlene. El marxismo y Asia (Buenos Aires, Siglo XXI, 1974) en el número 40. 
establecida por el PCR. Pero por otro lado, se analizaban en el texto algunas problemáticas de la realidad política argentina a través de herramientas teóricas provenientes de los saberes operativizados, difundidos y controlados durante la primera etapa de la revista. Así, por ejemplo, Altamirano introducía un análisis del participacionismo sindical configurado a partir de los conceptos althusserianos de ideología y AIE:

\begin{abstract}
El participacionismo constituye la forma ideológicamente dominante del conjunto de la jerarquía sindical. Su predominio manifiesta los efectos de la ideología burguesa sobre el aparato gremial argentino, pero no de cualquier variante de esa ideología sino de aquella que traduce la necesidad que tienen el capitalismo y su estado de integrar a los organismos sindicales dentro de su estrategia para convertirlos en instancias de mediación económica, política e ideológica ante el proletariado 346347
\end{abstract}

Nos interesa destacar aquí, sin embargo, aquellas intervenciones que retomaban desde un espacio explícitamente maoísta la problemática que había singularizado a la experiencia de Los Libros; es decir, la relación entre lucha política y práctica cultural. Al respecto, resultan sumamente significativos dos textos de Piglia que anclaban esta discusión en el pensamiento de Mao y en el proceso de la Revolución Cultural: "Mao Tse Tung. Práctica estética y lucha de clases", publicado en el número 25; y "La lucha ideológica y la construcción socialista", publicado en el número 35. Especialmente porque el trabajo de

\footnotetext{
${ }^{346}$ Altamirano, Carlos. "El Gran Acuerdo Nacional". Los Libros. Para una crítica política de la cultura. $\mathrm{N}^{\circ} 27$, Julio de 1972, p. 10. Que la confluencia señalada sea percibida en el texto la torna aún más relevante, en tanto ésta fue la primera intervención política sobre la coyuntura argentina realizada por la revista, y como tal, la que condujo al alejamiento de los miembros del Consejo de Dirección Miriam Chorne, Germán García y Héctor Schmucler. Como ha sido señalado en reiteradas oportunidades, la revista no solo operó como un terreno de explicitación de las posiciones políticas del maoísmo argentino, sino también como un espacio de confrontación entre las diferentes líneas partidarias formuladas dentro de esta tradición. Puede verse, al respecto, el intercambio en el número 40 entre Altamirano y Sarlo, por un lado, y Piglia, por el otro, acerca de la caracterización del gobierno de Isabel Perón -diferencia que derivó en el alejamiento de Piglia de la revista.

${ }^{347}$ Para profundizar el posicionamiento de la revista de cara a la coyuntura política de comienzos de la década de 1970, ver Celentano, Adrián. "Insurrección obrera y compromiso intelectual. Los Libros y Cristianismo y Revolución frente al Cordobazo y el Viborazo". Archivos de historia del movimiento obrero y la izquierda. $\mathrm{N}^{\circ} 4$, Marzo de 2014, pp. 53-75.
} 
inscripción en el pensamiento de Mao realizado por Piglia permite constatar la convergencia implícita entre el maoísmo asumido por Los Libros y las posiciones althusserianas presentes en la revista desde sus comienzos. Se ha insistido, con razón, en la importancia de Tel Quel en la configuración del dispositivo conceptual sobre las relaciones entre política y cultura que acompañó el itinerario de Los Libros $^{348}$. Sin negar en absoluto dicha filiación, cabe destacar, sin embargo, que la problematización de las relaciones entre lucha de clases y práctica cultural en la revista se realizaba en los mismos términos que los que resultaban por entonces de la confluencia entre althusserianismo y maoísmo. El dictum maoísta "no hay arte por encima de las clases" funcionaba en las formulaciones de Piglia como un elemento vertebrador de una concepción de la producción artística como una demanda social nacida en el seno de la lucha de clases. En esta dirección, el análisis de todos los elementos vinculados al proceso estético -significación ideológica, modo de producción, formas de distribución y consumo, materiales y herramientas de trabajo- a partir de su determinación por los intereses de clase, habilitaba, además de una rotunda refutación de la estética idealista, una jerarquización del trabajo de investigación sobre la especificidad de la relación entre la práctica estética y las condiciones de su producción. Cobraba relevancia, de esta manera, aquella concepción de los libros como el producto de una práctica específica que, si bien articulada con otras prácticas sociales, debía ser analizada a partir de su singularidad. La explicitación de la necesidad de constituir una teoría específica de la práctica estética y la remisión de la tarea a una lectura científica de Marx hacian participar a Piglia de un impulso

\footnotetext{
${ }^{348}$ Wolff, Jorge. Telquelismos latinoamericanos. La teoría crítica francesa en el entrelugar de los trópicos. Buenos Aires, Grumo, 2009. La convergencia entre ambas revistas es evidente: al igual que Los Libros, Tel Quel fue un emprendimiento políticocultural producto de la ruptura de sus miembros con el Partido Comunista, constituyó un foco de irradiación del paradigma estructural, dedicó varios de sus números a China, sus referentes realizaron viajes a este país, publicó un número especial sobre la Revolución Cultural, difundió textos de Mao y sostuvo posiciones marcadamente antiburocráticas, ver Dosse, François. History of Structuralism, Voume I. The Rising Sign, 1945-1966. op. cit., pp. 276-278 y Xu, Kefei. "Le maoïsme de Tel Quel autour de Mai 1968". Transtext(e)s Transcultures. Journal of Global Cultural Studies. N 6, 2011.
} 
que no podía sino remitir a los efectos del althusserianismo en el terreno de la crítica:

hay que 'aplicar el punto de vista del marxismo en la observación del arte y la literatura', utilizar lo que Mao llama 'la ciencia del arte' para fundar una teoría de la producción literaria que, a partir de la ciencia establecida por Marx en El Capital, estudie las leyes de la práctica estética, sus condiciones materiales, el objeto y los instrumentos de trabajo, la historia de los pasajes de un sistema de producción literario a otro 349350

El otorgamiento de un carácter diferencial a la práctica estética se correspondía, en un plano netamente programático, con una singularización de la lucha cultural. Si toda producción artística debía ser captada en su especificidad, el planteo de las características que debía adoptar la lucha en el terreno de la cultura estaba atravesado por el efecto característico de una concepción de lo social como un todo complejo estructurado. Así, las valoraciones de Piglia se dirigían sobre todo hacia la concepción maoísta de la lucha cultural como una tarea con sus métodos específicos; esto es, métodos

${ }^{349}$ Piglia, Ricardo. "Mao Tse-Tung. Práctica estética y lucha de clases". Los Libros. Para una crítica política de la cultura. N $^{\circ} 25$, Marzo de 1972, p. 22.

${ }^{350}$ Resulta significativo que Piglia le otorgara a la tarea que le correspondía al marxismo en el análisis de la práctica estética el título de la obra que simbolizó los efectos del althusserianismo en la crítica literaria: Para una teoría de la producción literaria de Pierre Macherey. El libro de Macherey había sido editado en 1966 en la colección que Althusser dirigía para François Maspero y sería publicado en español por la Universidad Central de Venezuela en 1974, dos años después de las intervenciones de Piglia. Sobre Macherey y el althusserianismo, ver Bennet, Tonny. Formalism and Marxism. Nueva York, Methuen, 1979 y Dosse, François, History of Structuralism, Voume I. The Rising Sign, 1945-1966. op. cit., passim. Igualmente relevante resulta el hecho de que ese mismo año, uno de los textos de Piglia publicado en Los Libros -"Mao Tse-Tung. Práctica estética y lucha de clases"- haya sido reeditado en el volumen Literatura y sociedad junto a textos de Macherey -"Lenin, crítico de Tolstoi-, Althusser -"El conocimiento del arte y la ideología"- y Badiou -"La autonomía del proceso estético". La compilación, que llevaba como autores a "Louis Althusser, Alain Badiou y otros" fue editada por Tiempo Contemporáneo. La constatación de esta filiación teórica de Piglia nos parece sumamente relevante, en tanto Althusser no aparece mencionado explícitamente en sus artículos. En ellos, la referencia más importante al marxismo occidental es Bertolt Brecht, el cual sin dudas también desempeña un rol destacado en sus reflexiones acerca de la práctica estética. Sobre el vínculo Piglia-Brecht, ver García, Luis Ignacio. "Ricardo Piglia entre la radicalización y la barbarie: Brecht y Benjamin en los '70". La crítica entre culturas. Estética, política, recepción. Santiago de Chile, Universidad de Chile, 2011, pp. 135185. 
necesariamente diferenciados de los de la práctica política. La potencia revolucionaria de la producción artística no radicaba, por tanto, en el grado de subsunción a una única lucha política revolucionaria, sino en el modo en el cual se resolvía la política proletaria en ese nivel específico. Las concepciones estéticas del maoísmo se revelaban, de esta manera, como un pensamiento que permitía legitimar la no reducción del arte a la política:

\begin{abstract}
Al no reducir la producción estética (ni tampoco la crítica) a la política o a la ideología, Mao le reconoce toda su eficacia a partir de la forma específica y de su inteligibilidad propia y le estructura un espacio singular en el conjunto de su teoría sobre la articulación de la práctica social ${ }^{351}$
\end{abstract}

El planteo de las relaciones entre política y cultura en términos de una práctica específica que mantiene vínculos con la política y la ideología sin reducirse a ella, volvía altamente eficaz el combate contra las concepciones de estas relaciones derivadas del realismo socialista y del compromiso sartreano. El alejamiento de los modos tradicionales de concebir la relación entre práctica estética y práctica política implicaba, sin embargo, la pérdida de los parámetros tradicionales utilizados para certificar el carácter revolucionario de determinada producción cultural.

El hecho de que los objetivos revolucionarios de un producto cultural no pudieran estar garantizados por el voluntarismo del sujeto-artista ni por el vínculo entre el sentido de la obra y el origen de clase del autor, conducía a un replanteo de los vínculos entre autor, práctica estética y política revolucionaria. Al respecto, regresaba en Piglia la misma pregunta nodal que había atravesado a la revista a propósito del "caso Padilla”: “¿dónde encontrar la instancia que decida la eficacia revolucionaria de una práctica específica?” ${ }^{352}$. La respuesta a esta disyuntiva -más nítida que en aquella ocasión- remitía a una dimensión de la cultura marxista de la época en la cual también tendían a converger althusserianismo y maoísmo: la de la posición de clase. El énfasis puesto en el espacio a partir del cual se define toda práctica operaba un descentramiento de

\footnotetext{
${ }^{351}$ Piglia, Ricardo. "Mao Tse-Tung. Práctica estética y lucha de clases". op. cit., p. 22. 352 Ibid., p. 23.
} 
las relaciones entre ideología, proceso estético y lucha de clases que redundaba en el traslado de la discusión acerca de la garantía revolucionaria de toda práctica estética hacia las condiciones de su producción. Así, el rechazo de índices tales como la voluntad del autor o la clase a la cual pertenece encontraba su respaldo en la formulación de una tarea para el intelectual revolucionario: el pasaje hacia las posiciones de la clase obrera a través de un trabajo de educación en el seno del pueblo y en la ciencia del marxismo-leninismo.

Junto a la evidente articulación con las posiciones políticas maoístas, el althusserianismo siguió operando de manera significativa en intervenciones que mantenían cierta autonomía del impulso que convirtió a la revista en un órgano de crítica política de la cultura. Así ocurría, por ejemplo, en la polémica que enfrentó entre los números 26 y 28 a Nicolás Rosa con Blas Matamoro a propósito del tópico "Borges y la crítica". En sintonía con aquellas lecturas desarrolladas en los primeros números de Los Libros, Rosa procesaba el libro de Matamoro sobre Borges ${ }^{353}$ a través de un corpus crítico diagramado en base al paradigma estructural. Leída desde la matriz cientifizadora característica de dicho corpus, una aproximación a la literatura borgeana realizada desde los marcos de la izquierda nacional no podía ser sino objeto de refutación y descrédito. Según Rosa, el esfuerzo trunco de Matamoro por dar cuenta del significado de la obra de Borges podía enmarcarse en la imposibilidad más general de cierto pensamiento de izquierda por trascender una lectura meramente ideológica del "objeto Borges". Y como bien se esforzaba por dejar en evidencia, el problema con este tipo de lecturas no radicaba en que operaban desde un espacio definidamente político. Lejos de una valorización per se de la autonomía del trabajo crítico, la lectura de Rosa enfatizaba la dificultad de los críticos por operar una ruptura en la circulación de significaciones ideológicas entre la crítica y la obra:

La crítica de la izquierda nacional, de gran valor político -y éste es un referente no desdeñable dentro de una problemática de la literatura- elabora generalmente una crítica de oposición

${ }^{353}$ Jorge Luis Borges o el juego trascendente. Buenos Aires, Peña Lillo, 1971. 
ideológica, característica que tal vez sea, significativamente, su mayor falencia histórica; como trabajo crítico no opera una verdadera ruptura; es decir, no crea una verdadera crítica de ruptura que posibilite una lectura 'real' de Borges ${ }^{354}$

Al igual que Piglia, para Rosa la consecuencia más grave de la crítica centrada en la oposición ideológica era la imposibilidad de conceptualizar a la literatura como una práctica específica. En un repaso por las lecturas sobre Borges en el que también aparecían destacados los abordajes de Adolfo Prieto ${ }^{355}$ y David Viñas ${ }^{356}$, Rosa advertía una tendencia recurrente en la crítica argentina hacia una aproximación sociológica del objeto literario, la cual, al desplazar el significado de la obra hacia otros niveles sociales -el político sobre todo-, oscurecía la especificidad de la práctica que lo producía. El quiebre con la inercia ideológica de la lectura sobre Borges sólo se produciría, a juzgar de Rosa, a través de una "sistematización científica de la crítica" ${ }^{357}$. Por un lado, se debía desarrollar un proceso de síntesis de los aportes científicos contemporáneos -marxismo y psicoanálisis fundamentalmente. Una vez operada la ruptura con las concepciones ideológicas sobre la literatura, debía llevarse a cabo en el terreno de la práctica crítica un trabajo de verificación del carácter efectivamente científico de dicha ruptura. Un paso más allá de la explicitación del programa de análisis estructural, Rosa advertía ciertas dificultades inherentes al proceso de ruptura epistemológica, lo cual no hacía más que poner en evidencia el retraso teórico de lecturas como las de Matamoro. Así, en el mismo sentido del Badiou de "El recomienzo del materialismo dialéctico", Rosa señalaba el peligro de que las nuevas prácticas surgidas de la ruptura encubrieran elementos ideológicos y que, por tanto, la ruptura no fuese más que una reinscripción ideológica de la ciencia.

Asimismo, la lectura de Rosa se trasladaba al propio campo desde el cual Matamoro ejercía la crítica, con el fin de demostrar que ni siquiera cumplía con las exigencias de sus propios modelos teóricos. De este modo,

\footnotetext{
${ }^{354}$ Rosa Nicolás. "Borges y la crítica". Los Libros. Para una crítica política de la cultura. $\mathrm{N}^{\circ}$ 26, Mayo de 1972, p. 19.

${ }^{355}$ Borges y la nueva generación. Buenos Aires, Letras Universitarias, 1954.

${ }^{356}$ Literatura argentina y realidad política. Buenos Aires, Siglo Veinte, 1971.

${ }^{357}$ Rosa, Nicolás. "Borges y la crítica”. op. cit., p. 20.
} 
evidenciaba el modo en el cual Matamoro degradaba al marxismo sartreano al oponerlo a un difuso "estructuralismo". Mientras los llamados "estructuralistas" desarrollaban mecanismos de control teórico sobre sus propias formulaciones, las acusaciones que se les lanzaba desde posiciones como las de Matamoro, lejos de proceder de manera análoga con sus propios postulados, actuaban por simple oposición creando una entidad fantasmática llamada "estructuralismo". Es decir, una aproximación al objeto que distaba significativamente de los procedimientos de la metodología sartreana. Rosa destacaba igualmente la degradación a la que Matamoro sometía a la teoría freudiana. Evidentemente leído desde el Freud de Althusser y Lacan, un uso de Freud reducido a la constatación de una analogía entre vida y obra -un Borges castrado y mutiladono podía ser sino catalogado como pre-científico. Es decir, un Freud desprovisto de sus descubrimientos más significativos, tales como la elaboración onírica y el trabajo del inconsciente. El diagnóstico de Rosa, al respecto, era categórico: "Hay una utilización ideológica de la cientificidad freudiana hecha a mansalva" ${ }^{358}$.

Resulta relevante destacar, por último, que los argumentos de Rosa no solo daban cuenta de la vinculación entre el tipo de utilización de los modelos teóricos y el carácter dependiente de la cultura argentina, sino que terminaban disputando desde una posición cientifizadora el significado de la dependencia que se desprendía de un trabajo crítico como el de Matamoro. La brutal utilización ideológica de los modelos científicos utilizados por la crítica argentina era explicada por Rosa a través de un proceso en el cual participaban el propio modelo teórico, la operación de traducción y la aplicación a una práctica concreta. Al ser incorporado en una cultura dependiente, el modelo objeto de apropiación se desplazaba hacia un espacio ideológico que resultaba incompatible con los resultados de la ruptura epistemológica producida en origen. Al encubrir fenómenos de reproducción ideológica, la traducción de modelos teóricos a una realidad dependiente producía efectos más allá de la voluntad de los críticos -tal como Matamoros incorporando todos aquellos elementos ideológicos de los que renegaba explícitamente.

${ }^{358} / d$ 
La respuesta de Matamoro reproducida por la revista constituye un objeto privilegiado a los fines de constatar la forma en la cual eran percibidas formulaciones como las de Rosa desde las posiciones teóricas y políticas objetadas por la revista. En primer lugar, Matamoro llamaba la atención sobre el potencial cientificista que entrañaba el programa crítico esbozado por Rosa:

\begin{abstract}
Atención, entonces, no vayamos a poner a la Ciencia (la ciencia de la escritura, por ejemplo, la gramatología, o la semiótica, o cualquier tentativa parecida) en el lugar de dios y le vayamos a conceder la falaz plenipotencia gnoseológica como para que dé cuenta de objetos que están en la historia, donde todo es vaivén e inconclusión ${ }^{359}$
\end{abstract}

Alertaba sobre el sesgo anti-historicista de sus concepciones de la ideología:

contra la opinión de Rosa, entiendo legítimo entrar a saco en un texto en busca de la manifestación de ideologías, pero no de lo que Rosa llama ideología, o sea la regla combinatoria formal, el procedimiento técnico de que se vale el escritor para componer su texto, sino de las pautas de pensamiento necesariamente escritas, en alguna instancia- que están inscriptas en los materiales de que vale para componer (idea de lo verosímil o de lo inverosímil, lengua, género, permisiones, prohibiciones, convenciones codificadas, etc. $)^{360}$

Reivindicaba el potencial de intervención política que entrañaban los abordajes sociológicos e historiográficos a la obra literaria:

Es claro que mi aporte no apunta a la crítica literaria, sino a la sociología y a la historia de la cultura. Y es voluntarista, ideológico y militante, si querés, y el diablo me guarde de que no lo sea. Porque la sociedad que estudia la sociología y la historia que estudia la historiografía son cosas que estamos haciendo todos los días, ideológicamente, todos los hombres ${ }^{361}$

Y evidenciaba, en consecuencia, el carácter conservador de la crítica estructural:

359 Matamoro, Blas. "Borges y la crítica. Respuesta de Blas Matamoro". Los Libros. Para una crítica política de la cultura. № 28, Septiembre de 1972, p. 19.

${ }^{360} / d$.

${ }^{361}$ Ibid., p. 20. 
La alternativa es de hierro. ¿Qué hacer? O caer de rodillas ante la realidad o poner la oreja sobre su flujo para oír las voces del ser que misteriosamente se acerca a la percepción, y entonces hacer lo que Rosa propone [...] o afiliarse al Partido de la oposición a lo real y acercarse al saber por el negativo camino de la praxis transformadora ${ }^{362}$

Igual de ilustrativa se presenta la contracrítica de Rosa, en tanto las impugnaciones formuladas por Matamoro llevaron a aquel a precisar los fundamentos de su crítica. No quedaban dudas, desde el comienzo del texto, el sustrato teórico sobre el cual se asentaban sus argumentaciones: Rosa utilizaba como epígrafe el pasaje de Para leer El Capital en el cual Althusser remitía a Freud la posibilidad de trascender una lectura inocente ${ }^{363}$. Y cuanto más explícitas se hacían las apoyaturas teóricas de sus formulaciones, más contundentes se volvían sus objeciones a Matamoro. Al especificar, al amparo de la tesis althusseriana, los procedimientos inherentes a la lectura de un texto, Rosa operaba un distanciamiento extremo del trabajo objetado. Afirmaba, en este sentido, que "cuando Matamoro habla de texto y de escritura está claro que no entiende bien lo que quiere decir"364. Matamoro no llegaba a advertir que para llevar a cabo una lectura efectiva de un texto, la producción formalizada que implica toda escritura debía ser abordada a través de una formalización necesariamente abstracta regida por sus propias leyes -y no de una inocente creencia en la realidad de sus contenidos. $Y$ frente al requerimiento -juzgado urgente por Rosa- de establecer líneas de demarcación entre lecturas verdaderas y lecturas falsas, la lectura inocente era descripta como una forma de aproximación al texto netamente ideológica. Al creer en lo que "el texto dice", este tipo de lecturas no podían sino contribuir a la circularidad ideológica entre la obra y el lector. Toda lectura que se mantuviera

\footnotetext{
${ }^{362} / d$.

${ }^{363}$ La cita en cuestión: "A partir de Freud comenzamos a sospechar lo que quiere decir escuchar, por lo tanto, lo que quiere decir hablar (y callarse); comenzamos a sospechar que ese 'quiere decir' del hablar y del escuchar descubre, bajo la inocencia de la palabra hablada y escuchada, la profundidad de un segundo discurso, completamente distinto, el discurso del inconsciente".

${ }^{364}$ Rosa, Nicolás. "Contracrítica por Nicolás Rosa". Los Libros. Para una crítica política de la cultura. $\mathrm{N}^{\circ} 28$, Septiembre de 1972, p. 21.
} 
en un registro ideológico sólo sería capaz de dar cuenta del contenido manifiesto del texto. Es decir, no podría revelar el contenido latente del texto ni contribuir al fin último del trabajo crítico; esto es, dar cuenta de los sentidos ideológicos que lo estructuran.

En este sentido, el registro propio de la contracrítica nos permite advertir que lo que estaba en cuestión era precisamente la posibilidad de fundar científicamente la práctica crítica:

\begin{abstract}
No está suficientemente elaborado todavía el análisis del proceso de la producción estética dentro de una perspectiva marxista. Las posibilidades son más claras con respecto a la crítica que, en cuanto tal, se inscribe como una práctica significante específica que sobrepasa la mera valoración, descripción, ubicación, de las obras-productos para instaurarse en la producción de conocimiento a la par de cualquier otra actividad crítica, es decir paralelamente a la práctica teóricocientífica. Como práctica social está sumergida en la ideología y produce ideología, como práctica teórica tiene como función política desarmar la ideología para contribuir al conocimiento del saber: es fundamentalmente histórica pues no agota el saber, es fundamentalmente científica pues produce saber, es fundamentalmente política pues debe producir el saber real que contribuya a la ruptura de las ideologías que sustentan, confirman y legitiman el control de los medios de producción en la sociedad capitalista ${ }^{365}$
\end{abstract}

El otorgamiento de un carácter condicionante de la efectividad revolucionaria de la práctica política a la cientificidad de la lectura de lo real le permitía a Rosa no solo esquivar aquella alternativa de hierro formulada por Matamoro, sino también evidenciar el carácter conservador de toda contraposición entre práctica teórica y práctica transformadora. En verdad, el obstáculo más importante para que la crítica facilitara una práctica política efectivamente transformadora lo constituía la permanencia del trabajo crítico dentro del círculo ideológico:

Matamoro debe entender, pues esto está suficientemente claro, que la ideología no puede liberar a la ideología. Suponer una ideología que se presupone crítica a otra realizada en un texto no conduce a nada más que una negación voluntarista y sin

${ }^{365}$ Ibid., p. 22. 
consecuencias: es un gesto ético antes que una acción política $^{366}$

\subsection{El aparato ideológico escolar: educación e ideología en Argentina}

La concepción althusseriana de la ideología fue, precisamente, uno de los presupuestos teóricos originarios de la revista con más presencia en el proceso de apertura hacia nuevos campos implicado en el giro hacia una crítica política de la cultura. Junto al debate alrededor de la relación entre psicoanálisis y política que analizaremos en el capítulo quinto, el otro gran núcleo sobre el cual giró la intervención de la revista a lo largo de esta etapa fue la discusión sobre la educación ${ }^{367}$. En el marco del proceso de movilización y organización sindical que culminó en la conformación de la CTERA, la revista dedicó dos números a la temática del vínculo entre educación e ideología en Argentina. En el abordaje del problema, la prioridad otorgada a la ideología operaba a modo de garantía de un análisis efectivamente científico de los mecanismos de reproducción del sistema educativo y de una práctica efectivamente revolucionaria por parte de las organizaciones de trabajadores de la educación. Como afirmaba el "Editorial" del número 31, el surgimiento de "una alternativa de nuevo tipo, popular y revolucionaria" ${ }^{368}$ en el interior del movimiento docente obligaba a la revista a profundizar los análisis sobre la ideología dominante en el proceso educativo, los mecanismos de reproducción ideológicos en las instituciones escolares y las contradicciones en el seno del

\footnotetext{
${ }^{366}$ Ibid., p. 24.

${ }^{367}$ El althusserianismo tuvo una presencia significativa en las reflexiones sobre la problemática educativa argentina desarrolladas en la primera mitad de la década de 1970. El espacio privilegiado de este proceso de recepción lo constituyó la Revista de Ciencias de la Educación, publicación dirigida por Juan Carlos Tedesco en cuyas páginas Guillermo García, Tomás Vasconi, Julia Silber, Rafael Roncagliolo y el propio Tedesco desarrollaron abordajes de cuestiones educativas desde los parámetros analíticos abiertos por Althusser, ver Suasnábar, Claudio. Universidad e intelectuales. Educación y política en la Argentina (1955-1976). Buenos Aires, Manantial, 2004, pp. 210-219 y Gómez, Sebastián. "El recorrido de la Revista de Ciencias de la Educación (1970-1975). Desde la ausencia original de Gramsci ¿a la articulación u oposición con el legador althusseriano?". VII ${ }^{\circ}$ Encuentro Nacional y $\mathrm{VI}^{\circ}$ Latinoamericano "La Universidad como objeto de investigación". San Luis, 29 al 31 de Agosto de 2013.

368 "Editorial". Los Libros. Para una crítica política de la cultura. $\mathrm{N}^{\circ} 31$, AgostoSeptiembre de 1973, p. 3.
} 
aparato educativo. De este modo se reproducía una serie de trabajos realizados por referentes del campo de las ciencias de la educación y del movimiento sindical docente, los cuales eran presentados como investigaciones tendientes a un "desmontaje crítico de los discursos ideológicos elaborados por las clases dominantes en Argentina" ${ }^{669}$ y a la formulación de "propuestas de ruptura" ${ }^{370}$ en el marco del sistema educativo.

Entre los análisis publicados, las notas de investigación de Juan Carlos Tedesco sobre educación e ideología en Argentina se destacaban por la centralidad otorgada al concepto de ideología en el abordaje de los problemas educativos. Invocada como posibilitadora de una concepción de la educación como engranaje fundamental del proceso de imposición de la ideología dominante, la revitalización del concepto de ideología producida a comienzos de la década de 1970 aparecía como un desarrollo teórico que permitiría avanzar en el análisis de las formas concretas de la reproducción. Remitiéndose explícitamente a Ideología y aparatos ideológicos de Estado de Althusser y La reproduction de Bourdieu y Passeron, Tedesco destacaba la potencialidad de estas sistematizaciones teóricas a los fines de analizar los aspectos vinculados a la práctica escolar concreta -regulación de las relaciones docente-alumno, promoción y sanción de conductas, organización del aprendizaje, distribución social del conocimiento- y los modos a través de los cuales éstos eran representados y codificados en la teoría pedagógica. En esta dirección, el texto de Tedesco reproducía algunas hipótesis de trabajo alrededor de la relación entre educación e ideología desarrolladas por el equipo de trabajo por él liderado en la Facultad de Humanidades y Ciencias de la Educación de la Universidad Nacional de La Plata ${ }^{371}$. Allí se repasaba el contenido ideológico de los libros de lectura utilizados en la escuela primaria durante la primera mitad del siglo XX -personajes e instituciones y el modo en el que estos eran representados- y la carga ideológica de las teorías

\footnotetext{
$369 / d$.

$370 / d$.

${ }^{371}$ Este trabajo se realizaba en el marco de la cátedra Historia de la Educación Argentina y Latinoamericana de la mencionada Facultad, y contaba con la participación de, entre otros, Julia Silber, Gerardo Sánchez y Ana Bemon.
} 
pedagógicas que habían marcado la historia del sistema educativo argentino positivismo, espiritualismo antipositivista y la ideología pedagógica del justicialismo ${ }^{372}$.

Junto a los avances en una problematización general de la relación entre educación e ideología, la revista dio también lugar a un análisis de la ideología implícita en el discurso educativo de la dictadura de Onganía. A través de una lectura de los documentos programáticos de la Revolución Argentina y de los discursos pronunciados por sus referentes, Horacio Cuello y Fernando Mateo resaltaban las operaciones ideológicas a través de las cuales la dictadura de Onganía sustraía el problema de la educación de la lucha de clases y del imperialismo: la presentación de su proyecto como la única alternativa viable para solucionar la crisis orgánica del país, la integración de la totalidad de la población en la recuperación de la grandeza de la Nación y la transferencia del sentimiento de frustración de las clases dominantes hacia el resto de las clases sociales $^{373}$.

En este mismo sentido se le dio lugar a intervenciones destinadas a calibrar el status de las disciplinas vinculadas con el campo de la educación. Tal es el caso de un documento firmado por Reina Cheja, Betriz Grego y el equipo de la cátedra de Psicología Educacional de la Universidad de Buenos Aires en el que se formulaba un programa de transformación radical de la psicología de los procesos educativos. En dicho programa, la constelación althusseriana operaba de manera evidente en la advertencia del carácter ideológico de la psicología educacional y en la redefinición del objeto de la disciplina. Por una parte, la diferenciación entre el objeto real y el objeto de conocimiento permitían caracterizar como empirista la definición de la psicología educacional como una disciplina que estudia el fenómeno

\footnotetext{
372 Tedesco, Juan Carlos. "Educación e ideología en Argentina. Notas para una investigación". Los Libros. Para una crítica política de la cultura. N ${ }^{\circ} 31$, AgostoSeptiembre de 1973, pp. 4-11.

373 Cuello, Horacio y Mateo, Fernando. "Un discurso ideológico transaccional: los objetivos de la política educacional de la 'Revolución Argentina'”. Los Libros. Para una crítica política de la cultura. $\mathrm{N}^{\circ} 31$, Agosto-Septiembre de 1973, pp. 13-18. Cabe destacar que en 1975 Fernando Mateo publicó en coautoría con Esteban Pardo el volumen Argentina, educación y capitalismo dependiente: esbozos críticos para una investigación en la editorial Tiempo Contemporáneo.
} 
"educación". Remitiendo al Badiou de "El (re) comienzo del materialismo dialéctico", este documento proponía una certificación de la cientificidad de la disciplina a partir de la conceptualización althusseriana del efecto de conocimiento. Es decir, si la ciencia produce el conocimiento de un objeto cuya existencia está indicada por una región determinada de la ideología, la psicología educacional no podía seguir siendo caracterizada con una disciplina dedicada al fenómeno de la educación. Se reforzaba de esta manera la concepción del efecto de conocimiento como resultado de la producción de un objeto diferenciado del objeto real: "subrayemos: [la existencia del objeto de la ciencia] está indicada por esa región, pero no es esa región de la ideología"374. La reformulación del objeto de la disciplina conducía simultáneamente a una caracterización de la psicología educacional como ciencia dedicada a estudiar los procesos de interpelación educativa y a una concepción de la "educación" como uno de los AIE:

\begin{abstract}
No es desde la psicología que se podrá ubicar teóricamente el fenómeno 'educación'. Es Marx quien produce el concepto. Ubicando la educación dentro del continente específico del materialismo histórico, la definiremos siguiendo a Althusser, como uno de los aparatos ideológicos del Estado que operan e influencian con la ideología, por medio de la influencia ideológica ejercida sobre los sujetos, que quedarán así constituidos como tales ${ }^{375}$
\end{abstract}

Uno de los aspectos más significativos de las intervenciones de la revista sobre el campo de la educación lo constituyeron aquellas dimensiones vinculadas con el segundo propósito que se proponía Los Libros con la edición de los dos número dedicados a la temática, es decir, aquel centrado en la detección de las contradicciones al interior del aparato ideológico educativo y la formulación de propuestas de ruptura revolucionaria al interior de dicho aparato. En tanto la dimensión programática del abordaje del problema educativo conllevaba una serie de especificaciones acerca de las tareas necesarias para la consecución

${ }^{374}$ Cheja, Reina; Grego, Beatriz y equipo de la cátedra de Psicología Educacional de la U.N.B.A. "Apuntes para una teoría de la inserción social en el proceso educativo". Los Libros. Para una crítica política de la cultura. $N^{\circ} 31$, Agosto-Septiembre de 1973, p. 25. ${ }^{375} / d$. 
de la mencionada ruptura, los pasajes prescriptivos de los textos reproducidos constituyen objetos privilegiados a los fines de constatar las prolongaciones de las categorías de ideología, AIE e interpelación hacia la práctica concreta del trabajador docente al interior del aparato educativo. Al respecto, para el caso de la psicología educacional, Cheja y Grego enfatizaban la importancia del imaginario en las operaciones de control ideológico, los efectos de desconocimiento en el aparato educativo y las condiciones de producción de la cultura popular. El documento proponía, en este sentido, un trabajo sobre la subjetividad educativa enfocado en las identificaciones imaginarias -las decisiones y responsabilidades del sujeto educativo como ilusiones que aseguran el funcionamiento y la subsistencia del orden social-, un abordaje diferenciado de los obstáculos al conocimiento en los ámbitos educativos condiciones psicológicas que perpetúan al individuo en las operaciones de control y dominación, perturbaciones en los procesos de producción de conocimiento, factores histórico-personales y orgánicos- y una indagación sobre los factores que condicionan la cultura popular -técnicas de reconocimiento del sujeto en las historias que lo constituyen, de ruptura de los obstáculos al conocimiento y de contribución a la producción de la cultura popular.

Las argumentaciones desarrolladas en este documento se revelan como significativas al reflejar también una dimensión de la utilización de los conceptos althusserianos por parte de los intelectuales argentinos a comienzos de la década de 1970: la necesidad de justificar la utilización de conceptos producidos en el contexto europeo para la delimitación de prácticas tendientes a transformar la realidad de un país dependiente. Al finalizar un desarrollo argumental cargado de referencias y citas de Althusser y Badiou, aparecía una pregunta retórica de profundas implicaciones políticas e intelectuales: "¿Puede esta bibliografía ayudar a producir un conocimiento que nos entregue un poder de transformación de nuestra realidad?" ${ }^{376}$. La respuesta, igualmente categórica, tendía a descentrar la disyuntiva saber latinoamericano/saber extranjero a favor de la contraposición ciencia/ideología: "El problema no es

${ }^{376}$ Ibid., p. 27. 
entonces el que cita más autores de los países dependientes, sino lograr la producción de conocimiento" 377.

A partir de un esquema argumental que nos remite al posicionamiento de la revista sobre el problema del conocimiento en un contexto dependiente, la intervención en el campo de la educación postulaba la centralidad de la apropiación real de los medios de producción de conocimiento. En un sentido análogo a las formulaciones de Malamud en el campo de la ciencia y de Rosa en el terreno de la crítica literaria, Cheja y Grego procedían a decretar la ingenuidad de las postulaciones alrededor de la necesidad de una ciencia nacional y la esterilidad del debate acerca del cientificismo. Mas allá del carácter nacional o extranjero de aquel que producía el conocimiento, lo que resultaba fundamental era que aquella producción fuera efectiva, es decir, que operara una transformación en la ideología. $Y$ al igual que los otros posicionamientos en el seno de la revista que daban cuenta de esta problemática, la de Cheja y Grego no sólo no evitaba la cuestión de la politización del campo en el se producía la intervención, sino que disputaba con las posiciones impugnadas el sentido que debía tener ese proceso de radicalización. Frente a la necesidad de apuntalar los procesos tendientes a la consecución de un efecto de conocimiento que permitiera trascender los saberes ideológicos, el rechazo de los desarrollos teóricos extranjeros por no haber sido producidos en un contexto dependiente, se revelaba como un posicionamiento conservador. La reivindicación de la literatura nacional y el repudio a los saberes extranjeros no hacían, en sus palabras, "más que hacerle el juego a los opresores, creando una autorrestricción espontánea que se suma a las ya padecidas" ${ }^{378}$.

Finalmente, el seguimiento realizado por la revista del proceso de movilización docente nos permite advertir las vinculaciones entre el terreno teórico en el cual se llevaba a cabo el análisis del aparato educativo y los posicionamientos políticos concretos desarrollados en el seno de los sindicatos de trabajadores de la educación. El número 32, que completaba los análisis

\footnotetext{
${ }^{377} / d$.

${ }^{378}$ Id.
} 
alrededor del vínculo entre educación e ideología y -sobre todo- atendía los avatares del proceso de sindicalización docente, reproducía una serie de materiales acerca de la disputa en el interior del movimiento sindical de trabajadores de la educación. Si bien la revista llevaba a cabo un repaso general del proceso de unificación de los sindicatos docentes, los documentos más destacados eran aquellos que daban cuenta de un posicionamiento antiburocrático, clasista y combativo frente al desarrollo de dicho proceso. En estos últimos materiales, la conceptualización de la educación como AIE aparecía vinculada tanto a la afirmación de la imposibilidad de transformación de la escuela en el marco de una sociedad capitalista como la consecuente impugnación de las lecturas reformista y populista de la cuestión escolar. Así, en un repaso del sindicalismo docente en Argentina, Lisandro Leiva afirmaba que el sostenimiento de una alternativa clasista y revolucionaria en el campo de la educación implicaba la militancia en pos de una escuela científica, democrática y popular. Esta escuela sólo podría desarrollarse en el marco de una democracia popular revolucionaria, por lo que el programa de lucha a sostener bajo el sistema capitalista era el de la exigencia constante de sus postulados -mayor cantidad de escuelas rurales, comedores escolares, becas. La concepción de la esuela como un aparato ideológico y el programa de escuela científica, democrática y popular, se presentaban contrapuestos a las consignas de "escuela abierta al pueblo" -calificada de idealista por reclamar el acceso masivo de los hijos de los sectores populares a la burguesa- y "escuela liberadora" -caracterizada como utopista por suponer que el Estado entregaría "el fundamental aparato ideológico que es la escuela" para que en su interior se desarrollara una práctica revolucionaria ${ }^{379}$.

En un sentido análogo se presentaba una declaración de la agrupación docente "18 de Noviembre": el aparato escolar está determinado por las clases dominantes del sistema capitalista y no existe posibilidad de lograr en el marco de esta sociedad una educación al servicio de las masas. La lucha en el terreno de la educación debía tener como horizonte el modelo de escuela

${ }^{379}$ Leiva, Lisandro. "Argentina 1973, movimiento docente”. Los Libros. Para una crítica política de la cultura. $\mathrm{N}^{\circ} 32$, Octubre-Noviembre de 1973, p. 19. 
científica, democrática y popular, posicionamiento que era cifrado en términos de una militancia concreta a favor de las reivindicaciones de los trabajadores docentes y de enfrentamiento con los programas que favorecían la reconciliación entre las clases, como el de "la educación al servicio de las necesidades del hombre argentino" o el de "la escuela como formadora de conciencia" 380381.

\subsection{La interferencia cultural: del Gramsci althusseriano al potencial de la cultura popular}

Junto a los análisis de los vínculos entre ideología y educación y los materiales relativos al proceso de sindicalización y movilización docente, Los Libros publicó en el número 32 un texto altamente indicativo del anclaje teórico de la revista durante su etapa de crítica política de la cultura: "Gramsci y la cuestión escolar" de Christine Glucksmann. Si bien dedicado a analizar el lugar ocupado por la escuela en los escritos de Gramsci, en este texto se daba cuenta de uno de los debates más significativos del marxismo europeo de la época: el del vínculo entre althusserianismo y gramscianismo. Tal como veremos en el capítulo siguiente, el rol desempeñado por Glucksmann en la discusión abierta por la lectura althusseriana de Gramsci correspondía a aquella franja del marxismo francés que rechazaba tanto la liquidación de la tradición gramsciana en nombre de un marxismo anti-humanista y antihistoricista como la reivindicación del humanismo y el historicismo frente a una lectura estructuralista de Marx. En el mismo sentido que su intervención en el debate sobre el concepto de "formación económico-social" como en la sistematización de su libro Gramsci et l' Etat: pour une théorie matérialiste de la

380 "Declaración de la Agrupación Docente 18 de Noviembre". Los Libros. Para una crítica política de la cultura. $\mathrm{N}^{\circ} 32$, Octubre-Noviembre de 1973, pp. 22-23.

${ }^{381}$ Para un abordaje del lugar del trabajador de la educación en la revista, ver Celentano, Adrián. "La historia del sistema educativo argentino y el concepto de 'trabajadores de la educación' en la revista Los Libros". Jornadas Interescuelas/Departamentos de Historia. Catamarca, 2011. 
philosophie ${ }^{382}$, en este texto Glucksmann abordaba la relación entre el althusserianismo y el gramscianismo a través de una operación que tendía a explorar la productividad de un vínculo recíproco entre ambas tradiciones marxistas $^{383}$.

Ya desde el comienzo de su artículo, Glucksmann daba cuenta de los problemas de inscribir la discusión alrededor de la cuestión educativa en el pensamiento de Gramsci, en tanto el lugar de dicho pensamiento en la tradición marxista estaba atravesando un momento de señalamientos e impugnaciones. Sin nombrar a Althusser pero haciéndose eco del debate por él generado, la francesa llamaba a atenuar algunas de las críticas formuladas por el althusserianismo enfatizando la historicidad del marxismo gramsciano:

\begin{abstract}
Estas notas no apuntan sino a instaurar un recorrido de los textos, centrado sobre la cuestión escolar. Por ello no entramos en la discusión de las interpretaciones actualmente en curso. Por lo menos frontalmente... Nos parece necesario operar una doble lectura que no separe la teoría de sus relaciones con la historia y con la política ${ }^{384}$
\end{abstract}

Sin embargo, el resto del trabajo de delimitación del problema educativo en la obra de Gramsci estaba atravesado por la lectura althusseriana, de la cual Glucksmann extraía la posibilidad de una tarea de corrección y revitalización de los elementos teóricos estructurantes de la tradición gramsciana. La especificidad de esta mediación era perceptible, en primer lugar, en la indagación acerca del concepto de "intelectual" en el itinerario teórico de Gramsci. Al detenerse en este problema, Glucksmann insistía en la trasformación operada en el pensamiento del marxista italiano que lo había conducido al "abandono de una definición humanista y tradicional de los

\footnotetext{
${ }^{382}$ París, Fayard, 1975. Este libro fue publicado en castellano por Siglo XXI España en 1978.

${ }^{383}$ Sobre la articulación entre althusserianismo y gramscianismo en el campo de la educación a partir del trabajo de Glucksmann, ver Gómez, Sebastián. "El derrotero de Los Libros (1969-1976) y su crítica pedgógica. La interpretación de Antonio Gramsci a través de Christine Buci-Glucksmann". Izquierdas. Una mirada histórica desde América Latina. $\mathrm{N}^{\circ} 28$, Julio de 2016, pp. 292-314.

${ }^{384}$ Glucksmann, Christine. "Gramsci y la cuestión escolar". Los Libros. Para una crítica política de la cultura. $N^{\circ} 32$, Octubre-Noviembre de 1973, p. 4.
} 
intelectuales" ${ }^{385}$ y al comienzo de una investigación centrada en la función de dichos sujetos. En este mismo sentido, el recorrido por el problema de la cuestión educativa en la obra de Gramsci enfatizaba el lugar que éste le adjudicaba a la escuela como uno de los organismos de hegemonía que reproducen la dominación de una clase sobre las otras. La importancia otorgada por Glucksmann a los organismos de hegemonía en el pensamiento de Gramsci en un momento en el cual la escuela era conceptualizada por el althusserianismo como uno de los AIE, no podía sino redundar en una compatibilización entre ambos conceptos:

A propósito de los 'organismos de hegemonía' no puede aquí
dejarse de señalar la relación entre el análisis de Gramsci y el
propuesto por Althusser [...] Quizás porque el análisis de
Althusser se sitúa sobre el terreno explorado por Gramsci:
análisis de las formas de persuasión, de conquista de las
masas en el nivel institucional ${ }^{386}$

No debe pasarse por alto que la vinculación establecida por Glucksmann entre el concepto de organismo de hegemonía y el de AIE también daba cuenta de una serie de diferencias entre los desarrollos teóricos de Althusser y los de Gramsci. Al respecto, Glucksmann destacaba el hecho de que en Gramsci el problema de la hegemonía no se agota con el análisis del Estado, sino que remite a la sociedad civil y a la dirección de una clase sobre el resto de la sociedad. Asimismo, aclaraba que en Gramsci el vínculo entre Estado y sociedad civil no se reduce a la diferenciación entre aparato coercitivo y aparato ideológico, por lo que el análisis del nivel ideológico debe operar junto a los análisis de los otros niveles de la sociedad. Debe insistirse, sin embargo, en que dichos matices se delimitaban sobre un sustrato teórico que no solo priorizaba la compatibilidad entre el análisis althusseriano y el gramsciano, sino que también blindaba al concepto de organismo de hegemonía y al de AIE de las críticas que suscitaban tanto la conceptualización althusseriana de la ideología como la relectura del problema de la hegemonía a la luz de dicha conceptualización. En sus propios términos, este tipo de aproximación analítica

\footnotetext{
385 Ibid., p. 5.

${ }^{386}$ Ibid., p. 7.
} 
"nada tiene que ver con una interpretación funcionalista o instrumental, que relacione mecánicamente las instituciones con las clases o el Estado"387.

La filiación teórica perceptible en la intervención de Glucksmann cobra especial relevancia al constatarse que el pasaje operado en Los Libros a partir de 1973 desde una posición de crítica política de la cultura hacia una de formulación de una política en la cultura conllevó un relevo progresivo del dispositivo teórico althusseriano por el gramsciano. Al tratarse de una operación teórica gradual, el direccionamiento de la intervención de la revista hacia los problemas de la hegemonía de las clases dominante y la especificidad de la cultura popular, se realizará sobre un sustrato de articulación productiva entre la tradición althusseriana y la gramsciana. Como evidencia el texto programático de esta nueva etapa de la revista, "Acerca de política y cultura en la Argentina" de Altamirano y Sarlo, la apertura hacia el análisis de la organización cultural de las clases dominantes y los componentes democráticos y populares de la cultura de las clases subalternas implicó la pervivencia de la lectura del problema de la dominación en clave de la ideología y los Aparatos Ideológicos de Estado. De este modo, la forma en la cual Altamirano y Sarlo abordaban teóricamente la organización de la cultura por parte de la clase dominante, estaba dirigida especialmente hacia el problema de la transmisión y asimilación de elementos ideológicos -valores, contenidos, códigos de comportamiento- por parte de las clases dominadas. Por ello, la dimensión analítica de su intervención se caracterizaba por la indagación acerca de la función de los aparatos ideológico-culturales -escuela, medios de comunicación, industria cultural- como reproductores del orden social. En una investigación de implicaciones significativas para el momento en el cual escribían, Altamirano y Sarlo se detenían en la cultura popular del primer peronismo a los fines de constatar la efectividad de aquellos aparatos en la trasmisión de una ideología de conciliación de clases ${ }^{388}$.

\footnotetext{
${ }^{387}$ Ibid., p. 6.

${ }^{388}$ Altamirano, Carlos y Sarlo Sabajanes, Beatriz. "Acerca de política y cultura en la Argentina". Los Libros. Para una crítica política de la cultura. $N^{\circ} 33$, Enero-Febrero de 1974, pp. 18-24.
} 
Sin embargo, un rastreo de las posiciones gramscianas asumidas por la revista a partir de 1974 nos permite constatar la desvinculación de la problemática ideológica del análisis sobre la organización de la cultura de las clases dominantes y las expresiones culturales de la clase subalterna. La ruptura de los vínculos de solidaridad y compatibilidad entre el marxismo althusseriano y el marxismo gramsciano puede apreciarse en los modos a través de los cuales fue operativizado el concepto de hegemonía en los campos privilegiados por la revista durante sus últimos números: el folklore y el cine. Con respecto al primero de ellos, el número 39 reproducía un artículo del antropólogo italiano Luigi Lombardi Satriani en el que la atención prestada por Gramsci a la cultura popular aparecía como un elemento posibilitador de un abordaje de la cultura de las clases subalternas que trascendiera su concepción como mera falsa conciencia. En tanto cantera ambivalente de elementos legitimadores e impugnadores de la organización de la cultura de las clases dominantes, la cultura popular era postulada como un espacio necesario a explorar en la tarea del favorecimiento de la toma de conciencia política de las clases subalternas. De este modo se privilegiaba una interpretación de la dominación entre las clases que, si bien daba cuenta de la función reproductiva de la cultura popular, enfatizaba por sobre todas las cosas el potencial revolucionario de las expresiones de las clases subalternas ${ }^{389}$.

El mismo desplazamiento desde el énfasis en la reproducción hacia el interés por las dimensiones subversivas de la cultura popular se verifica en el abordaje realizado por la revista de las diversas expresiones del cine argentino de la primera mitad de la década de 1970. En sendos artículos publicados en los números 39 y 41 , Sarlo se apoyaba en Gramsci para afirmar el carácter contradictorio de la cultura de las clases subalternas y justificar un análisis del carácter impugnador de la cultura popular "en el sentido de descubrir sus núcleos de verdad y luego [...] establecer los momentos de ruptura y los momentos de conservación y superación" ${ }^{390}$. Este programa de lectura le

\footnotetext{
${ }^{389}$ Lombardi Satriani, Luigi M. "Folklore y cultura popular". Los Libros. Para una crítica política en la cultura. $\mathrm{N}^{\circ} 39$, Enero-Febrero de 1975, pp. 3-9.

${ }^{390}$ Sarlo, Beatriz. "Nazareno Cruz y el lobo". Los Libros. Una política en la cultura. $\mathrm{N}^{\circ}$ 41, Mayo-Junio de 1975, pp. 24-25. El otro artículo de Sarlo es "Cine argentino. De
} 
permitía a Sarlo diferenciar las producciones cinematográficas comerciales de las verdaderamente populares. Así, en un primer momento, las películas de Leopoldo Torre Nilsson o de Daniel Tinayre eran captadas como producciones que se apropiaban de contenidos populares en un sentido puramente comercial, lo cual hacía que el vínculo con la cultura de las clases subalternas operara únicamente en un sentido de circularidad. Diferente atención merecía la obra de Leonardo Favio, en tanto producciones como Juan Moreira o Nazareno Cruz y el lobo se relacionaban con los contenidos populares desde el punto de vista de la propia identidad de las clases subalternas. Si bien se asentaba que estas expresiones eran limitadas en tanto la resolución de las contradicciones sociales se resolvían en el plano del populismo, se afirmaba que era sobre estos productos de la cultura popular donde debía focalizarse la mirada a los fines de favorecer la expresión de contenidos efectivamente impugnadores del orden social en el seno de las clases dominadas.

A partir de este relevo por un marxismo de matriz gramsciana, el althusserianismo no sólo dejará de operar como un dispositivo fundamental en el análisis de los problemas relativos a la dominación, sino que se convertirá en un objeto fuertemente impugnado y refutado en las páginas de la revista. En sintonía con la campaña anti-althusseriana desarrollada en Francia por los intelectuales maoístas y a modo de prolongación del anti-althusserianismo codificado por el PCR, Los Libros publicará durante los años 1974 y 1975 una serie de artículos dedicados a un ajuste de cuentas con un pasado marcado por el althusserianismo. La intervención más destacada en este sentido fue "El último Althusser", un texto de Altamirano publicado en el número 36 a propósito de la edición de Para una crítica de la práctica teórica. Respuesta a John Lewis. Casi en los mismos términos que por entonces utilizaban sus camaradas Rosendo Irusta y Lucas Figari para atacar a Althusser en la revista partidaria Teoría y Política, Altamirano explicaba la importancia que el althusserianismo había tenido entre los intelectuales argentinos a fines de la década de 1960 a partir de las afinidades existentes entre esta expresión del

Juan Moreira a La Tregua". Los Libros. Para una crítica política de la cultura. $\mathrm{N}^{\circ} 39$, Enero-Febrero de 1975, pp. 11-14 
marxismo contemporáneo y los elementos ideológicos propios de las clases medias. De este modo, insistía sobre las vinculaciones entre la práctica teórica y las ambiciones intelectuales de la pequeña-burguesía:

\begin{abstract}
la concepción althusseriana de la autonomía y la especificidad irreductible de la 'práctica teórica' marxista, esto es sin referencias a condiciones, indispensables, de posibilidad, condiciones sociales, ideológicas y políticas de clase, se anuda orgánicamente con las aspiraciones hegemónicas del intelectual pequeño-burgués que, al consagrar la autonomía del 'saber' no hace sino consagrar su predominio ${ }^{391}$
\end{abstract}

Así como la relación entre la diferenciación entre ciencia e ideología y la justificación de prácticas políticas oportunistas:

podría examinarse cómo funcionó la tesis sobre la oposición entre ciencia e ideología (cualquier ciencia, cualquier ideología) que proporcionó razones 'marxistas' para que algunos pudieran titularse marxistas 'desde el punto de vista teórico' y practicar el más amplio oportunismo 'desde el punto de vista ideológico' (y político, por supuesto) ${ }^{392}$

Una vez delimitados los lineamientos de la (auto)crítica sobre los usos de Althusser por parte de los intelectuales marxistas argentinos, Altamirano repasaba los elementos centrales del proceso de rectificación del otrora referente, con el objetivo de reforzar la caracterización del althusserianismo como un discurso especulativo en el interior del revisionismo. En tanto las tesis que Althusser le oponía a John Lewis eran precisamente aquellas en las cuales la intervención althusseriana tendía a converger con el maoísmo -"las masas hacen la historia", "la filosofía como lucha de clases en la teoría"-, la lectura de Altamirano se dirigía hacia el escudriñamiento de las vinculaciones entre Althusser y el revisionismo. En este sentido, se dotaba de una valoración negativa a aquella característica del althusserianismo que más productiva le había resultado a las corrientes maoístas cuando disputaban el sentido de la política comunista dentro de los aparatos partidarios: el planteo de los

\footnotetext{
${ }^{391}$ Altamirano, Carlos. "El último Althusser". Los Libros. Para una crítica política de la cultura. $\mathrm{N}^{\circ} 36$, Julio-Agosto de 1974, p. 26.

${ }^{392} / d$.
} 
problemas políticos del movimiento comunista internacional desde un plano fundamentalmente teórico. Una vez producido el divorcio definitivo entre las organizaciones maoístas y el marxismo althusseriano, Altamirano se detenía en los núcleos del althusserianismo -antihumanismo teórico, oposición entre ciencia e ideología- para constatar cuán lejos se encontraban de los problemas políticos concretos de la política comunista, como el de las vías de la revolución o el de la dictadura del proletariado.

Este marcado tono anti-althusseriano estuvo presente, asimismo, en otras intervenciones de los últimos números de la revista. Por ejemplo, en el número 39, al comentar el volumen Las clases sociales en América Latina ${ }^{393}$, Cecilio Molas [seudónimo de Emilio De Ípola] realizaba una concesión a las críticas anti-althusserianas a Poulantzas desarrolladas por Fernando Henrique Cardoso en su texto “¿Althusserianismo o marxismo? A propósito del concepto de clases en Poulantzas". Al tomar como base el postulado de que cualquier expresión teórica del marxismo debía hacer referencia a los problemas de la lucha de clases en América Latina, Molas juzgaba "loable y necesaria" la tarea de Cardoso en pos de "un enjuiciamiento global de la moda althusseriana" ${ }^{394}$. Sobre todo en los países latinoamericanos, añadía, "donde dicha moda hizo estragos" ${ }^{395}$. Asimismo, en el número 43, al reseñar dos ediciones de Ludwig Feuerbach y el fin de la filosofía clásica alemana de Engels publicadas en $1975^{396}$, Altamirano se refería de manera peyorativa a las revisiones contemporáneas del vínculo entre el marxismo y Hegel. Entre estas, la lectura anti-hegeliana propiciada por Althusser ejemplificaba como ninguna otra las tentativas de liquidación de la dialéctica dentro de la tradición marxista: "tal vez el caso extremo lo constituya el althusserianismo, para el cual lo que Marx

\footnotetext{
${ }^{393}$ México D.F., Siglo XXI, 1973.

${ }^{394}$ Molas, Cecilio. "Las clases sociales en América Latina". Los Libros. Para una crítica política de la cultura. $\mathrm{N}^{\circ} 39$, Enero-Febrero de 1975, p. 30. ${ }^{395}$ ld.

396 Buenos Aires, La Rosa Blindada, 1975 y Córdoba, Cuadernos de Pasado y Presente, 1975.
} 
habría tomado de Hegel sería una supuesta visión de la historia como 'proceso sin sujeto" 397 .

Finalmente, la impugnación hacia Althusser y el althusserianismo tuvo lugar en un particular espacio de la revista cuyas características han sido oportunamente señaladas por José Luis De Diego: las páginas finales dedicadas a mencionar y comentar brevemente los libros publicados y distribuidos en Buenos Aires ${ }^{398}$. Tal como De Diego ha destacado en su trabajo, estos breves comentarios anónimos constituyen elementos privilegiados a los fines de delimitar los posicionamientos de la revista, en tanto adquirían la forma de sentencias brutales contra aquellas publicaciones de las cuales la revista buscaba distanciarse. Estas invectivas, que en el campo de la literatura fueron dirigidas por ejemplo a Marcos Aguinis -"médico, joven, amante esposo, golfista"- y a Abel Posse -"versión masculina de Silvina Bullrich"-, también fueron esbozadas durante los último números de Los Libros para el campo de la teoría. En el caso de los libros inscriptos en la constelación althusseriana, la agudeza del comentario estaba dirigida principalmente a operar una separación entre Althusser y el marxismo.

En este sentido, en el número 38 se afirmaba sobre Ensayo sobre la posición de Lenin en la filosofía de Dominique Lecourt:

Lecourt desarrolla varias tesis muy discutibles acerca de la
teoría del reflejo, especialmente vinculadas con los últimos
desarrollos del 'marxismo' althusseriano sobre 'la historia como
proceso sin sujeto'. Así, la tesis de que en Lenin el reflejo es un
reflejo sin espejo aparece vinculada a la última operación de
esta corriente filosófica francesa, más próxima al
estructuralismo que al marxismo ${ }^{399}$

Y en el número 44, sobre la compilación Dialéctica marxista y pensamiento estructural. Mesas redondas acerca de los trabajos de Althusser.

397 "Reseñas". Los Libros. Una política en la cultura. $N^{\circ} 43$, Septiembre-Octubre de 1975 , p. 27.

${ }^{398}$ De Diego, José Luis. ¿Quién de nosotros escribirá el Facundo? Intelectuales y escritores en Argentina (1970-1986). op. cit., p. 103.

${ }^{399}$ Los Libros. Para una crítica política de la cultura. $\mathrm{N}^{\circ} 38$, Noviembre-Diciembre de 1974 , p. 33. 
Anacrónico intento de los editores de seguir rescatando a Althusser, precisamente en uno de los campos en que su teoría demostró su esterilidad productiva y su alejamiento radical de las concepciones marxistas ${ }^{400}$

El tenor de estos comentarios contrasta notablemente con los publicados durante las primeras etapas de la revista sobre textos pertenecientes al universo althusseriano. Sobre Para leer El Capital del propio Althusser: "Entendiendo que 'la filosofía representa la lucha de clases en la teoría', el pensador francés propone librar un 'combate filosófico entre palabras' contra las desviaciones del humanismo y del economicismo" 401 ; sobre Los conceptos elementales del materialismo histórico de Harnecker: "Una chilena discípula de Althusser expone didácticamente la teoría marxista de la historia y selecciona varios textos clásicos" ${ }^{402}$; sobre Clases sociales y poder político en el estado capitalista de Poulantzas: "Si en Hegemonía y dominación en el Estado moderno, Poulantzas nos presenta los hitos de su paso del historicismo gramsciano al 'rigor' althusseriano, ahora nos hallamos frente a la culminación de ese esfuerzo por la construcción de una ciencia política desde la perspectiva del materialismo histórico" ${ }^{403}$; sobre El marxismo ante las sociedades "primitivas" de Emmanuel Terray: "Bajo la inspiración de las investigaciones teóricas de Louis Althusser, Terray se propone una confrontación del marxismo con algunas de las últimas adquisiciones de la antropología" ${ }^{404}$.

Los comentarios críticos fueron las últimas menciones a Althusser en Los Libros: el golpe de Estado producido al mes siguiente de la publicación del número 44 implicó el cierre de la revista.

\subsection{A modo de cierre}

\footnotetext{
400 Los Libros. Una política en la cultura. N 44, Enero-Febrero de 1976, p. 29.

${ }^{401}$ Los Libros. Un mes de publicaciones en Argentina y el mundo. $\mathrm{N}^{\circ} 3$, Septiembre de 1969, p. 29.

402 Los Libros. Un mes de publicaciones en Argentina y el mundo. № 4, Octubre de 1969 , p. 29.

${ }^{403}$ Los Libros. Un mes de publicaciones en Argentina y el mundo. $\mathrm{N}^{\circ} 6$, Diciembre de 1969 , p. 31.

${ }^{404}$ Los Libros. Para una crítica política de la cultura. N 6, Noviembre de 1971, p. 29.
} 
La aparición de Los Libros en 1969 contribuyó a imponer en el campo de la cultura argentina un aparato crítico configurado a partir de los desarrollos teóricos del estructuralismo. En dicho aparato, los aportes propiciados por la obra de Althusser se conjuraron con otras renovaciones de la teoría contemporánea, tales como la semiología y el psicoanálisis lacaniano. Puestos en juego en la consideración de la crítica literaria desarrollada en nuestro país, estos esquemas propiciaron una impugnación de perspectivas sociológicas o contenidistas y la legitimación de abordajes cientifizadores y desmitificadores. Aplicados a la propia producción literaria, implicaron un direccionamiento de la mirada hacia los mecanismos ideológicos subyacentes a la obra. Asimismo, el privilegio analítico otorgado la ideología conllevó la expansión de la crítica más allá de los textos literarios. La concepción de todo lenguaje como portador de ideología le permitió a los colabores de la revista desarrollar una aproximación tan legítima como productiva a los fenómenos de la cultura de masas.

Junto a esta presencia en la renovación de la crítica mediada por el estructuralismo, los aportes althusserianos desempeñaron un rol destacado en la lectura realizada por la revista de problemas teóricos y políticos. El encargo del comentario de libros de sociología, ciencia y filosofía a algunos de los principales lectores argentinos de Althusser redundó en la operativización de la tesis del marxista francés en un conjunto de problemas altamente relevantes de la cultura política de izquierda de la década de 1970. Al respecto constatamos la productividad del concepto de ideología, de la tesis de separación entre ciencia e ideología, la afirmación de una ruptura epistemológica en la obra de Marx y la representación de lo social como un todo complejo estructurado, en el abordaje de problemas tales como la sociología de la modernización, la propuesta de una ciencia nacional, el marxismo historicista y los vínculos del intelectual con la política.

Nos detuvimos luego en los procesos de difusión y control del propio paradigma estructural llevado a cabo por los colaboradores de la revista. Las lecturas realizadas por la revista de las novedades teóricas permitían difundir a los autores inscriptos en dicho paradigma a la vez que discutir las implicaciones de su pensamiento. En este sentido, un trabajo significativo lo constituyó la 
matización y corrección de algunos sentidos comunes generados a partir de la consolidación del estructuralismo. En este marco Althusser fue objeto de una aproximación colectiva en la cual colaboradores de la revista sometieron a discusión las principales dimensiones teóricas y políticas de su obra. Vimos asimismo que el proceso de latinoamericanización atravesado por la revista reforzó los mecanismos de control teórico. De este modo el estructuralismo comenzó a ser abordado en tanto moda cobrando relevancia el análisis de su difusión en clave ideológica. Aproximaciones que dan cuenta de un examen del estructuralismo a través de las propias herramientas teóricas y metodológicas proporcionadas por dicho paradigma.

Si bien el desplazamiento de Los Libros hacia un espacio de crítica política de la cultura marcó una torsión significativa en los vínculos que la revista mantenía con el registro teórico, enfatizamos la pervivencia tanto del althusserianismo como del paradigma estructural. Al respecto destacamos que la mentada politización de la revista no implicó la anulación del trabajo teórico. Revelamos, por un lado, que el abordaje de ciertos tópicos de la coyuntura política fue realizado a partir de variables analíticas althusserianas. De la misma manera advertimos la presencia de las tesis althusserianas en las concepciones de los referentes de la nueva etapa de la revista alrededor de la relación entre práctica política y lucha cultural. Por otro lado vimos que junto al pasaje hacia el análisis de problemas estrictamente políticos, la revista siguió dando lugar al trabajo crítico que había predominado en los primeros números. Al respecto, la polémica establecida por Rosa contra Matamoro nos permitió evidenciar la continuidad de un aparato crítico configurado a partir de impulsos cientifizadores y desmitificadores.

En este mismo sentido, la concepción althusseriana de la ideología fue el insumo teórico fundamental a través del cual la revista se acercó a la cuestión educativa en Argentina. Resultado del interés que comenzó a concitar en esta nueva etapa los problemas de la coyuntura, Los Libros dedicó un espacio significativo al análisis de los mecanismos de reproducción en el sistema educativo y al planteo de prácticas revolucionarias por parte de los trabajadores de la educación. Encargados a intelectuales pertenecientes al 
campo de las ciencias de la educación y a referentes del sindicalismo docente, las aproximaciones al problema del vínculo entre educación y cultura dan cuenta de la productividad que por entonces tenía el concepto de AIE. La interpretación althusseriana de la ideología permitía captar la funcionalidad de la práctica escolar así como su codificación en el campo de la teoría educativa. Leída en clave de aparato ideológico, la escuela se presentaba como un ámbito necesario de la reproducción de las relaciones de producción capitalista. En el plano de las aproximaciones analíticas, esta caracterización redundaba en el abordaje pormenorizado de los efectos de desconocimiento y las operaciones de control ideológico inherentes al ámbito educativo. En el plano de la práctica política, conllevaba la refutación de los planteos acerca de la posibilidad de transformar la escuela en el marco de una sociedad capitalista.

Finalmente, el recorrido por los últimos números de la revista evidenció dos operaciones teóricas y políticas que implicaron el declive de la presencia althusseriana en sus páginas. Vimos al respecto que la importancia otorgada a los análisis de Glucksmann representó la legitimidad de una perspectiva teórica en la cual la hegemonía gramsciana convivía con la ideología althusseriana. En este sentido, la mayor presencia que fueron adquiriendo las concepciones gramscianas conllevó un progresivo abandono de las formulaciones althusserianas. A medida que los intereses de la revista giraban hacia el problema de la cultura popular, sus referentes comenzaron a atender más las posibilidades disruptivas que los mecanismos de reproducción. Por otro lado, las lecturas realizadas de diversos aspectos del althusserianismo reflejaron las posiciones que frente él había desarrollado el maoísmo partidario. Al respecto, la ubicación de la revista como expresión cultural del PCR implicó un abordaje de Althusser y el althusserianismo atravesado por la diatriba antirrevisionista. De este modo vimos que las críticas esbozadas desde la revista replicaron las acusaciones de idealismo realizadas por los referentes políticos del partido. 


\section{Capítulo 4}

\section{Más allá del principio de exclusión: el Althusser de Pasado y Presente}

\subsection{Introducción}

En este capítulo reconstruimos el lugar ocupado por Althusser en la experiencia poltico-intelectual de Pasado y Presente. El análisis propuesto está estructurado a partir de una discusión con las interpretaciones canónicas sobre dicho fenómeno. En este sentido comenzamos con un repaso por las afirmaciones que cimentaron tales interpretaciones. Delineadas por un contexto hostil al marxismo althusseriano, las indagaciones sobre el lugar de Gramsci en la cultura de izquierdas latinoamericana tendieron a extremar algunas de las relaciones establecidas en las décadas de 1960 y 1970 entre ambas tradiciones del marxismo contemporáneo. Una delimitación del lugar de Althusser en la experiencia de Pasado y Presente nos permitirá matizar este sentido común así como proponer conclusiones alternativas.

Luego de este estado de la cuestión específico, nos adentramos en la particularidad del anclaje marxista desarrollado en la primera etapa de la revista. Al respecto, destacamos la raigambre humanista e historicista de las posiciones marxistas asumidas en ella a los fines de evidenciar el potencial anti-althusseriano de esta experiencia. Por otro lado, recorremos aquellas dimensiones de la revista que se presentaban propicias para una incorporación de las formulaciones althusserianas. Su pretensión modernizadora nos permitirá contextualizar el lugar otorgado por sus referentes a corrientes marxistas cientifizadoras, tales como la propiciada por Galvano della Volpe, y a desarrollos teóricos no-marxistas, tales como el estructuralismo. 
A continuación reconstruimos el lugar del marxismo althusseriano en los Cuadernos de Pasado y Presente. Expresión del agotamiento de la intervención desarrollada en la primera mitad de la década de 1960, los Cuadernos constituyeron una experiencia original de expansión del corpus marxista. La delimitación de un conjunto de Cuadernos dedicados a la tradición althusseriana nos permitirá adentrarnos en la especificidad de este proceso de recepción. En esta sección repasamos las primeras lecturas de Althusser, que replicaron en gran parte las aproximaciones realizadas en la primera etapa de la revista; el interés concitado por la lectura althusseriana de Gramsci, que habilitó una corrección de las aproximaciones clásicas al marxista italiano; el seguimiento del debate alrededor del concepto de formación económico-social, que permitió conjugar elementos propios de las tradiciones althusseriana y gramsciana; y la difusión de los primeros textos de Poulantzas, que daban cuenta del pasaje desde un marxismo historicista hacia uno de cariz estructural.

Finalmente nos concentramos en la segunda etapa de Pasado y Presente. Reconstruimos allí el anclaje de la revista en la coyuntura abierta por el regreso de Perón y el acercamiento a las expresiones de la izquierda peronista. Veremos que el gramscianismo consejista con el que revista acompañó dicha intervención conllevó una refutación de las expresiones vanguardistas e intelectualistas de la izquierda argentina. Leído desde este marco, el althusserianismo fue objeto de un conjunto de refutaciones en lo relativo a la forma en que esta tradición concebía la intervención política. Veremos asimismo que durante esta segunda etapa consumó una separación de los vínculos que habían unido al marxismo althusseriano y gramsciano en los años anteriores. Al respecto analizamos los intentos evidentes de diferenciar las aproximaciones gramscianas a los problemas de la hegemonía, el Estado y la ideología de las propiciadas por el althusserianismo.

\subsection{Althusser y Gramsci en América Latina: límites de una historización}


La delimitación del lugar ocupado por el althusserianismo en el proceso de relectura del corpus marxista llevado a cabo por el colectivo de Pasado y Presente ha estado en gran medida condicionada por una variable interpretativa que postula una necesaria incompatibilidad y exclusión entre las tradiciones gramsciana y althusseriana. Las intervenciones producidas en las décadas de 1980 y 1990 en pos de reconstruir el itinerario del gramscianismo en América Latina establecieron un sentido común en torno a la relación entre la circulación de la obra de Gramsci y la de Althusser en la izquierda latinoamericana: el auge del althusserianismo durante la segunda mitad de la década de 1960 habría bloqueado la difusión de la obra gramsciana y le habría otorgado a ésta la marca del prejuicio althusseriano; al mismo tiempo, el gramscianismo habría comenzado a ser hegemónico a medida que el althusserianismo perdía su interés a mediados de la década de 1970.

Esta perspectiva, que estuvo presente en la mayor parte de los esfuerzos de los intelectuales de filiación gramsciana por pensar el pasado y el presente de dicha tradición en América Latina, se cristalizó en tres momentos altamente indicativos de las marcas epocales que la delinearon: el seminario internacional "Las transformaciones políticas de América Latina: presencia de Gramsci en la cultura latinoamericana" organizado por el Instituto Gramsci en Ferrara en 1985, en el cual participaron Aricó, Portantiero, Néstor García Canclini, el mexicano Arnaldo Córdova y los brasileños Carlos Nelson Coutinho y Marco Aurélio Nogueira; el suplemento "Gramsci en América Latina del número 6 de la revista La Ciudad Futura, que incluía artículos de Aricó, Portantiero, Waldo Ansaldi, Coutinho y el boliviano Fernando Calderón ; y el número 115 de la revista Nueva Sociedad. Democracia y política en América Latina, dedicado a Gramsci y América Latina publicado en 1991, que reunía algunas de las intervenciones mencionadas y textos de los chilenos Enzo Faletto y Osvaldo Fernández Díaz y el mexicano Francisco Gómez Hinojosa.

El primero en sistematizar este sentido común fue Córdova, quien dedicaba una gran parte de su intervención a señalar la particularidad de la difusión de Gramsci en América Latina debido a que este proceso estuvo mediado por la imposición de la obra de Althusser en el continente. La forma en 
la cual la izquierda latinoamericana conoció a Gramsci ocurrió, según el mexicano, "del modo más lamentable" ${ }^{405}$, en tanto la rápida y masiva difusión del althusserianismo estructuró una aproximación a Gramsci en la cual éste aparecía vinculado a las tradiciones croceana, historicista y reformista. Sí fue saludable, para Córdova, el declive del althusserianismo en América Latina y la importancia adquirida por la obra de Gramsci, ya que los conceptos y preocupaciones que ésta última proveía -sociedad civil, sociedad política, hegemonía, bloque histórico, reforma moral e intelectual- hicieron proliferar los estudios sobre la realidad mexicana, especialmente aquellos que intentaban redefinir la historia del país y el rol del Estado.

Siguiendo a Córdova, Aricó afirmaba que la relación entre la difusión de Althusser y Gramsci en América Latina había sido paradójica, en tanto la ausencia de traducciones castellanas de Gramsci durante las décadas de 1960 y 1970 hizo que los lectores argentinos, chilenos y mexicanos conocieran la obra de Gramsci a través de las críticas althusserianas, lo cual puso de moda a Gamsci pero anticipó una lectura que asociaba estrechamente a Gramsci a la tradición idealista italiana. El posterior relevo de Althusser por Gramsci en los marcos teóricos de la izquierda latinoamericana implicó, según Aricó, un desplazamiento productivo, en tanto la preocupación gramsciana por lograr una organización de las clases subalternas capaz de estructurar sobre bases consensuales una voluntad nacional-popular contra hegemónica, era la misma que atribulaba a la izquierda de los países latinoamericanos en la década de $1980^{406}$

En este mismo sentido, Marco Aurélio Nogueira advertía que las traducciones de Gramsci realizadas en Brasil en la segunda mitad de la década de 1960 tuvieron poco impacto en el país debido a que su intelectualidad

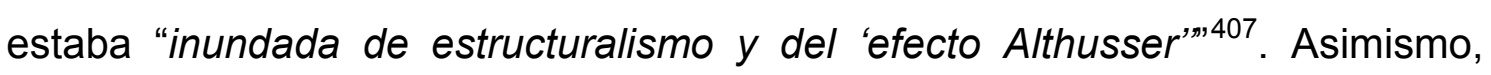

\footnotetext{
${ }^{405}$ Córdova, Arnaldo. "Gramsci y la izquierda mexicana". Nueva Sociedad. Democracia y política en América Latina. № 115, 1991, 151.

${ }^{406}$ Aricó, José. La cola del diablo. Itinerario de Gramsci en América Latina. Buenos Aires, Siglo XXI, 2005, p. 132.

407 "encharcada de estruturalismo e do "efeito Althusser", Nogueira, Marco Aurélio. "Gramsci, a questão democratica e a esquerda no Brasil". Carlos Nelson Coutinho y
} 
advertía el rol progresivo que desempeñó la obra de Gramsci en Brasil, en tanto ésta permitió a los intelectuales de izquierda desarrollar un trabajo de renovación del marxismo, a través del cual pudieron dejar de pensar el Estado, el socialismo y el Partido desde el marxismo-leninismo y recuperar el valor de la autonomía relativa de la política. Según Nogueira, tanto el declive del althusserianismo como el auge del gramscianismo, habilitaron a los intelectuales marxistas a incorporar herramientas de análisis relacionadas con los procesos de transformación capitalista y formación de la nacionalidad, y así, encontrar al Brasil moderno, industrial y de masas que siempre habían tenido delante de los ojos y que el marxismo ortodoxo les había impedido ver.

Carlos Nelson Coutinho, por su parte, daba cuenta de un silenciamiento impuesto a la obra de Gramsci en Brasil durante la segunda mitad de la década de 1960 debido a la preponderancia alcanzada en la izquierda brasileña por la combinación entre las formulaciones de Althusser, Marcuse, Mao y Debray. La importancia adquirida por la lucha armada como forma privilegiada de lucha contra la dictadura implicó, según Coutinho, que el gramscianismo haya sido catalogado como una expresión del etapismo y la claudicación política. Un marcado tono anti-althusseriano campea en el análisis del brasileño, quien afirmaba que la nueva izquierda de Brasil sucumbió a "la supuestamente radical 'revolución epistemológica' de Althusser" ${ }^{408}$, lo cual se expresó en el hecho de que mientras las traducciones de Althusser eran constantemente reeditadas, las de Gramsci "encallaran, terminando por ser vendidas en los estantes de oferta" ${ }^{409}$. Fue a mediados de la década de 1970 cuando la izquierda brasileña, según Coutinho, descubrió a Gramsci, fenómeno favorecido tanto por pérdida de interés en el cientificismo anti-ideológico althusseriano y el irracionalismo marcusiano como por la autocrítica de la

Marco Aurélio Nogueira (orgs.). Gramsci e a América Latina. Río de Janeiro, Paz e Terra, 1988, p. 132.

${ }^{408}$ Coutinho, Carlos Nelson. "Brasil y Gramsci: variadas lecturas de un pensamiento". Nueva Sociedad. Democracia y política en América Latina, N 115, 1991, p. 108.

${ }^{409}$ Ibid., p. 109. 
estrategia de lucha armada y la interpretación de Brasil como sociedad compleja y occidental ${ }^{410}$.

Este sentido común cristalizado hacia fines de la década de 1980 y comienzos de la de 1990 es perceptible en reconstrucciones más recientes del itinerario de Gramsci en América Latina. El trabajo de Jaime Massardo, que sirve de introducción a la edición castellana del libro de Antonio Santucci sobre Gramsci, no solo reproducía esta línea interpretativa sino que extremaba algunos de sus postulados. A fines de dar cuenta de la postergación de la apropiación de Gramsci en América Latina, Massardo remitía a factores condicionantes de la izquierda latinoamericana que resultaron hostiles a la tradición gramsciana. Uno de ellos, estructural, lo constituía la pervivencia del socialismo científico en el marxismo latinoamericano; otro, coyuntural pero deudor del primero, estaba relacionado con la importante circulación de los textos de Althusser en el continente. El impacto de Althusser era postulado por Massardo como un fenómeno que frustró las potencialidades del gramscianismo para la izquierda latinoamericana. La reconstrucción de Massardo adquiere tonos épicos y responsabiliza al cientificismo althusseriano por haber obturado la advertencia de la proximidad ética y política existente entre Gramsci y Guevara y la valoración de la afinidad entre la filosofía de la praxis gramsciana y los fundamentos de la Teología de la Liberación ${ }^{411}$.

${ }^{410}$ Como vimos en el primer capítulo, Coutinho había sido uno de los principales impugnadores brasileños del estructuralismo y, especialmente, de la obra de Althusser. Su libro $O$ estruturalismo e a miséria da razão tuvo amplia difusión en América Latina gracias a la traducción y edición por la editorial mexicana Era en 1973. En 2010 fue reeditado en Brasil por la editorial Expressão Popular con un prólogo del autor; puede verse allí una contextualización de la primera edición del libro. En Argentina la obra de Coutinho es conocida en gran medida por los trabajos de Néstor Kohan, quien reivindica al brasileño como uno de los pilares del marxismo humanista latinoamericano, ver Kohan, Néstor. De Ingenieros al Che. Ensayos sobre el marxismo argentino y latinoamericano. Buenos Aires, Biblos, 2000 e Introducción al pensamiento marxista. Buenos Aires, La Rosa Blindada-Universidad Popular Madres de Plaza de Mayo, 2003.

${ }^{411}$ Una referencia indicativa del tono de la reconstrucción; para significar el peso del anti-historicismo althusseriano sobre el gramscianismo, el chileno cita al Cassirer de Las ciencias de la cultura y asegura: "nos cuesta mucho trabajo dejar de pensar aquí en Vico [Gramsci] sosteniendo con energía contra Descartes [Althusser] el valor del método propio del conocimiento histórico", Massardo, Jaime. "La recepción de Gramsci en América Latina. Algunos problemas teóricos y políticos". Antonio Santucci. Gramsci. Santiago de Chile, Bravo y Allende Editores, 2001, p. 8. 
Los elementos característicos del sentido común en torno a la incompatibilidad entre las tradiciones gramsciana y althusseriana se estructuraron en un momento en el que la izquierda latinoamericana llevaba a cabo un proceso de deconstrucción del marxismo posclásico y formulación de un corpus marxista adecuado a los nuevos tiempos. Este proceso, que implicó tanto una revisión de la experiencia de las formaciones de la nueva izquierda latinoamericana como de las corrientes del marxismo que se articularon con ellas, redundó en una historización de la tradición marxista caracterizada por el otorgamiento de valoraciones positivas a las corrientes que podían ser traducidas a la nueva gramática teórica de la década de 1980 y la hostilidad frente a aquellas que se presentaban como intraducibles a ese presente.

La articulación entre una relectura de Gramsci y la deriva democrática de la izquierda latinoamericana estuvo acompañada por una revisión del corpus marxista explícitamente reactiva al althusserianismo, lo cual se manifestó en una historización que absolutizaba las diferencias entre las tradiciones gramsciana y althusseriana, silenciaba la especificidad de sus divergencias y obturaba la visibilización de las relaciones de compatibilidad e intercambio entre ellas. Aún obviando sus enunciados más reñidos con una reconstrucción histórica crítica, como los lamentos de Córdova o las elucubraciones contrafácticas de Massardo, el sentido común sedimentado por la bibliografía de fines de la década de 1980 en torno a los itinerarios de Gramsci y Althusser en América Latina es portador de una linealidad y un esquematismo que, por lo menos para el caso de Pasado y Presente, resulta difícilmente sostenible ${ }^{412}$.

\footnotetext{
${ }^{412} \mathrm{Si}$ bien el siguiente análisis se detiene en una experiencia particular del marxismo latinoamericano, cabe destacar que el trabajo de conexión entre las tradiciones althusseriana y gramsciana se desarrolla actualmente en múltiples direcciones. Puede mencionarse, al respecto, la importancia que ha tenido en la reversión del mencionado prejuicio el análisis retrospectivo sobre las obras de -entre otros- Glucksmann, Poulantzas, Stuart Hall y Ernesto Laclau. Asimismo, la articulación entre Gramsci y Althusser es evidente en el trabajo teórico de marxistas europeos como Vittorio Morfino, Fabio Frosini y Peter Thomas. Ver respectivamente El materialismo de Althusser. Santiago de Chile, Palinodia, 2014; Da Gramsci a Marx. Ideologia, verità e politica. Roma, Derive Approdi, 2009 y The Gramscian Moment. Philosophy, Hegemony and Marxism. Leiden, Brill, 2009. Para un análisis de estos movimientos, ver Morfino, Vittorio. "Lire Gramsci après Althusser". Décalages. An Althusser Studies Journal. Vol. 1, $\mathrm{N}^{\circ}$ 2, 2014 y la introdución al dossier "Althusser-Gramsci" publicado recientemente en la misma revista, Frosini, Fabio y Morfino, Vittorio. "Introduzione".
} 


\subsection{La reflexión del hombre sobre el hombre: un marxismo humanista e historicista para la cultura argentina}

Resulta innegable que los elementos fundamentales del marxismo sustentado por la experiencia pasadopresentista a partir de su escisión del comunismo partidario constituyen instancias potencialmente reactivas al althusserianismo ${ }^{413}$. La principal intervención de la revista que da cuenta de dichos elementos, "Pasado y presente", escrito por Aricó para el primer número a modo de manifiesto, nos permite advertir la estructuración de un marxismo configurado a partir de las bases historicista y humanista de la tradición marxista. Si bien la experiencia pasadopresentista comparte con la corriente althusseriana el gesto radicalizador del comunismo pos-estalinista, el impulso renovador de la política comunista generado por Pasado y Presente está vehiculizado por un marxismo de matriz gramsciana que, a simple vista, aparece como impermeable a una relectura antihumanista y antihistoricista de Marx como la propiciada por el althusserianismo.

Los argumentos rupturistas esbozados por Aricó enfatizan la concepción del marxismo como filosofía de la praxis. La búsqueda en el pasado de las causas por las cuales no se había concretado en Argentina una voluntad colectiva revolucionaria aparecía asociada a una problematización de los

Décalages. An Althusser Studies Journal. Vol. 2, $\mathrm{N}^{\circ} 1,2016$. Hemos intentado delimitar las condiciones y la productividad de la conexión entre Althusser y Gramsci en las corrientes marxistas actuales en Starcenbaum, Marcelo. "Gramsci y Althusser: intersecciones del marxismo contemporáneo". Actas del Coloquio Internacional '50 años de Lire Le Capital'. La Plata, Facultad de Humanidades y Ciencias de la Educación (en prensa).

${ }^{413}$ Pasado y Presente tuvo dos etapas. En la primera, entre 1963 y 1965, en la que llevó el subtítulo "Revista trimestral de ideología y cultura", fueron editados nueve números. El primer número tuvo como directores a Oscar del Barco y Aníbal Arcondo. En el número 2-3 se sumó Héctor Schmucler como secretario de redacción. A partir del número 5-6 contó con un consejo de redacción integrado por Del Barco, Aricó, Samuel Kieczkovsky, Juan Carlos Torre, Arcondo, César Guiñazú, Carlos Assadourian y Francisco Delich. En la segunda, acotada al año 1973, con el subtítulo de "Revista trimestral", fueron publicados dos números. Esta etapa tuvo como editor a Aricó. Entre ambas etapas, comenzaron a ser editados los Cuadernos de Pasado y Presente. Entre 1968 y 1983 fueron publicados noventa y ocho cuadernos dedicados a diversos aspectos de la tradición marxista. 
impedimentos que tuvo el marxismo para introducirse en el interior del proletariado del país. Al respecto, Aricó le asignaba a la nueva generación de intelectuales la obligación de evitar el error de la vieja vanguardia política de desligar la dinámica partidaria de los procesos de conciencia que atraviesa la clase obrera. En este sentido, la dificultad en la concreción de una ligazón efectiva entre marxismo y proletariado no era remitida a la incapacidad de la clase obrera $\mathrm{o}$ a la hostilidad del contexto, sino que era vinculada específicamente con el modo equivocado a través del cual el comunismo partidario concebía la tarea de adecuación interpretativa del marxismo y la forma de su inserción en la práctica revolucionaria. Frente a estas concepciones obsoletas aparecía postulada como necesaria la reflexión sobre la propia práctica y el énfasis en la concepción de la filosofía como toma de conciencia y autoreflexión a la que se somete a la praxis.

El acento puesto por Aricó en la filosofía de la praxis estaba acompañado por un repaso crítico de las instancias del comunismo partidario en las cuales el marxismo se había inclinado hacia posiciones teoricistas. En referencia a la lectura que el comunismo partidario realizaba de las transformaciones modernizadoras que atravesaba por ese entonces la sociedad cordobesa, la intervención pasadopresentista advertía una expresión de las dificultades tradicionales de la izquierda por superar las polaridades entre ideología y ciencia, conocimiento histórico y metodología científica y totalidad y empirismo. El marxismo que le permitiría a la nueva izquierda evitar dichos dilemas era sistematizado por Aricó como un aparato cognoscitivo capaz de trascender la escisión entre teoría y práctica. Denunciadas la consideración de la teoría como justificadora de la práctica política y la concepción de la práctica política en tanto ejemplificación de la teoría como manifestaciones ideológicas de un distanciamiento entre intelectuales y pueblo, la identidad entre teoría y práctica aparecía postulada como el elemento que le aseguraba a la organización revolucionaria el establecimiento de la unión entre la dirección y las bases, lo que permite al partido, por lo tanto, convertirse en un verdadero intelectual colectivo. Es esta identificación de las inclinaciones teoricistas del comunismo partidario lo que habilita a Aricó a refutar la idea de 
la inadecuación del marxismo para la comprensión y la intervención en las sociedades modernas. A decir del cordobés, lo que se hallaba en situación de crisis en ese momento no era el marxismo como tradición, sino que lo que estaba entrando en una fase terminal eran sus expresiones dogmáticas.

El núcleo problemático de la sociedad moderna sobre el cual Aricó depositaba la tarea fundamental de la investigación marxista contemporánea era el de la alienación. Movimiento derivado explícitamente de la atención que concitaba para el colectivo de Pasado y Presente las transformaciones acaecidas en el interior de la clase obrera cordobesa y especialmente el surgimiento de un nuevo tipo humano, aquel configurado a partir de la experiencia del trabajo en los complejos industriales modernos, la conceptualización de la función del marxismo era traccionada hacia la tarea de negación de una sociedad alienada en la que está impedida toda posibilidad de realización de lo humano. El problema de la alienación aparece permeando el pormenorizado análisis realizado por Aricó de la situación de las fábricas cordobesas. Introducción de técnicas de racionalización del trabajo y disminución de la importancia individual del trabajador eran, de este modo, analizadas como procesos de desnaturalización del contenido humano del trabajo y estructuración de un trabajador de tipo colectivo, fenómenos a los cuales se les asignaba tanto un efecto negativo de intensificación de la alienación como una posibilidad de apertura de un terreno para una acción ideológica efectiva de la clase obrera.

Si para Aricó el problema de la alienación y la subjetividad constituía un elemento de prioridad en la agenda de la investigación marxista, la evaluación que éste realizaba del desarrollo del marxismo en relación a dichas temáticas conllevaba la advertencia de un déficit. La importancia de los escritos del joven Marx, especialmente los Manuscritos económico-filosóficos de 1844, y la necesidad de que la investigación marxista analizara las formas del capitalismo contemporáneo desde categorías como las de trabajo alienado, exteriorización y reificación, eran contrapuestos al retraso en el desarrollo de lecturas antropológicas de El Capital y al reparo que generaba este tipo de análisis entre los marxistas debido al halo hegeliano del concepto de alienación y de los 
Manuscritos en general. La propuesta esbozada por Aricó no da lugar a dudas; si lo que se pretendía era devolverle al marxismo su potencialidad explicativa y militante, la investigación marxista debía dirigirse hacia la problemática abierta por el joven Marx:

\begin{abstract}
No siempre los continuadores de Marx supieron comprender la riqueza actual, el profundo valor cognoscitivo de trabajos como los Manuscritos económico-filosóficos de 1844 y otros escritos 'juveniles, durante mucho tiempo reducidos a la cómoda y no comprometedora categoría de obras 'premarxistas' y por lo tanto hegelianizantes. Es hoy más necesario que nunca que el marxismo retome el discurso del genio de Tréveris y lo desarrolle en forma creadora profundizando el aspecto antropológico o humanista de una doctrina que nunca perdió en sus fundadores el sentido de una reflexión del hombre sobre el hombre ${ }^{414} 415$
\end{abstract}

La prioridad otorgada al problema de la alienación y el énfasis en las dimensiones humanistas de la doctrina marxista estuvieron presentes a lo largo de la primera etapa de la revista, especialmente a través de la inclusión de artículos escritos por colaboradores y textos tomados de publicaciones

414 "Pasado y Presente". Pasado y Presente. Revista trimestral de ideología y cultura. $N^{\circ}$ 1, abril-junio de 1963, p. 14.

${ }^{415}$ A modo de refuerzo de dicho direccionamiento, el primer número de la revista contenía, en la sección de notas y comentarios, una reseña escrita por Del Barco de las dos ediciones en castellano de los Manuscritos realizadas en 1962; la de Grijalbo, traducida por Wenceslao Roces, y la de Fondo de Cultura Económica, acompañada por el texto introductorio de Fromm "Marx y su concepto del hombre". La lectura demarcada en dicha reseña refutaba las aproximaciones a los Manuscritos que negaban la validez de dicha obra por pertenecer al período de juventud de Marx o que tendían a concebirla como parte de un camino hacia las obras de su madurez. Sin embargo, Del Barco también criticaba aquellas lecturas, como la de Fromm, que recurrían a textos como los Manuscritos para configurar una interpretación ética de Marx. Frente a este abanico de protocolos de lectura juzgados como insuficientes, las aproximaciones más fértiles aparecían vinculadas, más allá de la referencia a Gramsci, con autores pertenecientes al marxismo fenomenológico, como Sartre, Merleau-Ponty, Tran-Duc-Thao y Enzo Paci. Un dato resulta relevante del tenor rupturista que adquirirá la intervención althusseriana y de la potencial desconfianza que podía generar una lectura de Marx como la propuesta por Althusser: al problematizar las interpretaciones que identificaban un hiato entre las obras de juventud de Marx y sus obras de madurez, Del Barco vislumbraba que era "cada vez menos viable" la aproximación que tiende a negar al joven Marx en provecho del Marx maduro pero remarcaba que no debía olvidarse el hecho de que "durante largos años la llamada 'ortodoxia' marxista ni mencionó los Manuscritos", "Carlos Marx y los Manuscritos económico-filosóficos de 1844" Pasado y Presente. Revista trimestral de ideología y cultura. $\mathrm{N}^{\circ} 1$, abril-junio de 1963, p. 102. 
extranjeras y traducidos al español. ${ }^{416}$ Sin embargo, la expresión más significativa de este direccionamiento dentro del corpus marxista la constituyó, por su carácter concreto y su pretensión de incidencia en los problemas de la clase obrera, la publicación del "Informe preliminar sobre el conflicto de Fiat" en el número 9 de la revista. Dicho informe, que reunía datos relativos al conflicto desarrollado en la fábrica cordobesa en 1965 -datos de la empresa, cronología de la huelga, organización sindical, estrategia obrera- se presentaba como un intento de sistematización de la información a los fines de promover una discusión entre la dirección de la revista y los dirigentes que formaron parte del conflicto. La presentación de Aricó al informe, "Algunas consideraciones preliminares sobre la condición obrera", encuadraba el trabajo realizado sobre la huelga de Fiat desde una perspectiva en la cual se articulaban elementos provenientes de los desarrollos teóricos en torno al neocapitalismo, como los de la revista Quaderni Rossi en Italia y André Gorz y Serge Mallet en Francia, con un incisivo juicio retrospectivo de las posiciones del PCA frente a la clase obrera, especialmente en lo referente a la unilateralidad de la ortodoxia marxista frente al proletariado y la consecuente inadvertencia de las transformaciones acaecidas en el mundo industrial ${ }^{417}$.

De dicha articulación se derivaba un reforzamiento de las directrices marxistas sistematizadas por Aricó en el primer número de la revista. En primer lugar, la convicción de que el concepto de clase obrera no puede ser producto de una deducción filosófica operada solamente a nivel teórico, sino que debe ser extraído de los datos reales de la situación concreta sobre la cual se

\footnotetext{
${ }^{416}$ Entre los primeros cabe destacar "Trabajo, símbolo y evolución humana" del cordobés Enrique Revol, publicado en el número 2-3. Entre los segundos, "Verdad y libertad" del italiano Luporini, publicado en el número 1 y "Marxismo, técnica y alienación" del brasileño Arthur Gianotti, publicado en el número 5-6. Resulta relevante la inclusión de un texto de éste último, en tanto el brasileño será en 1968 el autor del célebre artículo "Contra Althusser", publicado en la revista paulista Teoría e prática.

${ }^{417}$ Junto al informe y la introducción de Aricó, el número 9 de la revista traía un artículo de Darío Lanzardo, "Intervención socialista en la lucha obrera", publicado en Quaderni Rossi y traducido por Aricó, y "La encuentra obrera de 1880" de Marx. Sobre la relación de Pasado y Presente con las expresiones políticas e intelectuales del obrerismo europeo, ver Petra, Adriana. "En la zona de contacto: Pasado y Presente y la formación de un grupo cultural". Ana Clarisa Agüero y Diego García (eds.). Culturas interiores. Córdoba en la geografía nacional e internacional de la cultura. La Plata, Al Margen, 2010, 213-239.
} 
pretende intervenir. De este modo, Pasado y Presente se proponía como una empresa marxista centrada en el análisis del obrero argentino, concreto y real, operación que permitía legitimar las preocupaciones por la situación de los trabajadores de las nuevas empresas capitalistas al mismo tiempo que subrayar las diferencias con los marxismos que absorbían las particularidades de la clase obrera en la estrechez de sus posturas doctrinarias y desligaban la figura del obrero de las relaciones de trabajo específicas en las que estaba inserto. La centralidad otorgada a las transformaciones del mundo industrial y la situación de los trabajadores en las grandes fábricas expresaba, por lo tanto, un esfuerzo por construir una política de unidad entre intelectuales y clase obrera no desde actitudes principistas y declaracionistas, sino sobre la base de un trabajo concreto de investigación y militancia. De allí que Aricó intentara zanjar la discusión sobre el espontaneísmo y el vanguardismo a través de la elaboración de un programa concentrado en el problema de la alienación y enfocado en contrarrestar los elementos ideológicos burgueses que racionalizaban y mistificaban la maximización de ganancias. La respuesta a su pregunta, fundamental y urgente, sobre “¿cuál es la posibilidad que se le ofrece al joven intelectual proveniente de las capas medias de fundirse con la clase obrera?" ${ }^{418}$, se expresaba en dos planos tan indicativos de lo que se pretendía dejar atrás como del dispositivo militante que se buscaba consolidar. Denunciada la posición doctrinalista sostenida históricamente por el PCA como dogmática y caracterizado el intento vanguardista de conducir la lucha política revolucionaria desde fuera de la fábrica como "la tragedia de la izquierda argentina" ${ }^{419}$, Aricó postulaba la necesidad de una política revolucionaria focalizada en la alienación sufrida por el trabajador en el proceso productivo, capaz de potenciar el componente anticapitalista presente en la lucha sindical y cuyo objetivo principal sea el contribuir a que la clase obrera obtenga una autonomía política, ideológica y organizativa.

${ }^{418}$ Aricó, José. "Algunas consideraciones preliminares sobre la condición obrera". Pasado y Presente. Revista trimestral de ideología y cultura. $\mathrm{N}^{\circ}$ 9, abril-septiembre de 1965 , p. 55.

${ }^{419} / d$. 


\subsection{Las tensiones de la modernización: marxismo y estructuralismo}

Sin embargo, otras dimensiones implícitas en el desarrollo de la experiencia de Pasado y Presente nos permiten dar cuenta de cierta permeabilidad frente a la renovación propuesta por el althusserianismo. Fundamentalmente porque el establecimiento de un horizonte marxista marcadamente gramsciano no implicaba una irradiación opresiva de la matriz humanista e historicista hacia todas las dimensiones de la intervención pasadopresentista. El propio manifiesto escrito por Aricó daba cuenta de la apuesta por constituir un marxismo que escapara de las trampas del dogmatismo y que estuviera dotado de una predisposición a la apertura teórica. Enmarcada en un proyecto de creación de un nuevo tipo de cultura y modificación de la relación tradicional entre elites intelectuales y masas, dicha apertura era remitida a la necesidad de una difusión efectiva de las verdades del marxismo entre el proletariado. De este modo, la revista se planteaba como una plataforma que permitiría a los lectores acercarse a traducciones de textos vinculados con los debates contemporáneos del marxismo y como un espacio abierto a corrientes marxistas que, aún sin converger con las líneas directrices de la revista, abordaran los mismos núcleos problemáticos que movilizaban la intervención del colectivo de Pasado y Presente.

Una expresión relevante de esta tendencia aperturista lo constituyó la traducción y edición en el primer número de la revista de una serie de textos pertenecientes al debate generado al interior del marxismo italiano a partir de la obra de Galvano Della Volpe. ${ }^{420}$ Con el título "A propósito del carácter del

${ }^{420}$ Como bien demuestra Petra, la recepción argentina de Della Volpe se produjo especialmente en el terreno de la estética, siendo Sciarreta su principal impulsor, quien editó Crisis de la estética romántica por Jorge Alvarez en 1964 y Claves de la dialéctica histórica por Proteo en 1965, el cual también tradujo, "En la zona de contacto: Pasado y Presente y la formación de un grupo cultural". op. cit. En el caso específico de Pasado y Presente, con el antecedente inmediato de Realismo y realidad en la narrativa argentina, el libro de Portantiero editado 1961 cuyo aparato analítico incorporaba la perspectiva dellavolpeana, la dimensión estética del marxismo de Della Volpe está presente en dos artículos de Schmucler. El más relevante, "La cuestión del realismo y la novela testimonial argentina", del primer número de la revista, proponía una discusión en torno al problema del realismo en la cual se impugnaban las concepciones románticas e idealistas del arte y procedía a un análisis 
historicismo marxista", el dossier reproducía un conjunto de intervenciones de filósofos marxistas italianos publicadas en Rinascita en 1962: "La relación Hegel-Marx" de Lucio Colletti, "La realidad objetiva de la contradicción" de Nicola Badaloni, "Sobre la realidad objetiva de la contradicción" de Paci, "Sobre la dialéctica (una respuesta a los compañeros y a los otros)" de Della Volpe, "El círculo concreto-abstracto-concreto" de Luporini, y "Para un desarrollo unitario de los estudios marxistas" de Alessandro Natta. Dichas intervenciones estaban acompañadas por una introducción del propio Luporini, "Apuntes sobre una discusión entre filósofos marxistas en Italia", dedicada a establecer las coordenadas fundamentales de la querella abierta en el marxismo italiano por la interpretación de Marx postulada por el dellavolpismo. En ella, Luporini afirmaba que la obra de Della Volpe acentuaba marcadamente la contraposición entre la dialéctica marxista y la dialéctica hegeliana, formaba parte de un intento deliberado de liquidar de la cultura filosófica italiana la herencia de pensadores idealistas como Giordano Bruno y Vico, priorizaba la concepción del marxismo como metodología en detrimento de su adopción como concepción del mundo, y direccionaba la lectura de El Capital en un sentido contrario a una deseable aproximación antropológica.

Como puede apreciarse, el modo a través del cual eran presentados por Luporini los elementos configuradores del marxismo dellavolpeano guarda una estrecha similitud con la forma en la cual será recibida años después la interpretación de Marx realizada por Althusser. De la misma manera que ocurrirá con la irrupción del althusserianismo, el debate alrededor de las tesis del dellavolpismo girará en torno a una serie de argumentos, a favor y en contra, de un marxismo que leía la obra de Marx a partir del prisma de la cientificidad y el antihegelianismo. Mientras Della Volpe y Colletti objetaban el marxismo humanista en nombre de la riqueza de la obra madura de Marx y llamaban a superar la mentalidad marxista ochocentista, hegelianizante y evolucionista, sus críticos se esforzaban por llamar la atención sobre los

de la literatura argentina en el cual el dellavolpismo aparecía desplazando a la teoría lukacsiana. En "Hacia una nueva estética", del número 5-6, Schmucler realizaba una despiadada reseña de la edición de Crisis de la estética romántica preparada por Sciarreta, a quien le reprochaba una aproximación a la obra de Della Volpe realizada desde los marcos del dogmatismo partidario. 
peligros de las operaciones de transformación del marxismo en una ciencia y destacaban las virtudes y la productividad de un marxismo historicista. Así Badaloni defendía la concepción del marxismo como filosofía de la praxis y describía críticamente las pretensiones científicas del dellavolpsimo, Paci remitía sus argumentaciones a las tesis sartreanas y postulaba una concepción de la filosofía como reflexión sobre la praxis, y Luporini acusaba al dellavolpismo de propiciar un marxismo sectario e intelectualista, que impedía la reflexión sobre problemas como la historia y el hombre, que no daba cuenta del pasaje de la teoría a la práctica revolucionaria y que hacía decir a Marx lo contrario de lo que éste quería decir. ${ }^{421}$ De este modo, la circulación de los términos en los cuales se desarrolló el debate italiano puso en contacto tempranamente al grupo de Pasado y Presente con un repertorio de juicios valorativos frente al desarrollo de un marxismo cientificista y antihegeliano, operando de esta forma como antecedente de la querella abierta posteriormente por la irrupción del althusserianismo ${ }^{422}$.

El mismo tenor aperturista que estuvo presente en las discusiones en el interior del universo marxista, se expresaba asimismo en las posiciones sostenidas frente a las relaciones entre el marxismo $y$ otras corrientes intelectuales contemporáneas. El postulado gramsciano de la creación de un nuevo tipo de cultura se presentaba como inseparable de la necesidad de que el marxismo entablara un diálogo con los desarrollos teóricos más novedosos del campo de las ciencias sociales. Así como el manifiesto de Aricó llamaba a dar lugar a corrientes marxistas no necesariamente compatibles con el historicismo y el humanismo gramsciano, la revista también propugnaba la apertura hacia innovaciones teóricas no marxistas. En este marco, la lucha por

${ }^{421}$ Sobre este mismo elemento, el de "hacer hablar a Marx", se apoyará André Glucksmann para acusar a Althusser de propiciar un "estructuralismo ventrílocuo", Althusser: un estructuralismo ventrílocuo. Barcelona, Anagrama Barcelona, 1971.

${ }^{422}$ Del hecho de que una polémica tan relevante como la del dellavolpismo no haya continuado en el marxismo argentino, y de un itinerario como el de Sciarreta, desde el marxismo dellavolpeano hacia el althusserianismo, Petra ha derivado la interesante sugerencia de que, debido a las afinidades existentes entre ambas corrientes marxistas, es probable que la llegada del estructuralismo y la obra de Althusser a la Argentina haya desplazado el interés que por entonces concitaba la obra de Della Volpe, "En la zona de contacto: Pasado y Presente y la formación de un grupo cultural". op. cit. 
convertir al marxismo en la filosofía de las masas implicaba el abandono del lastre de las oposiciones principistas del marxismo frente a otras doctrinas teóricas. Frente a estas posiciones, advertidas como dogmáticas y estériles, Pasado y Presente se proponía como un espacio que contribuyera a la edificación de un marxismo capaz de confrontar otras concepciones del mundo reconociendo en ellas contradicciones y errores pero también identificando sus verdades y potencialidades.

Esta concepción esbozada por Aricó en el manifiesto pasadopresentista se expresó, quizás como ningún otro caso, en la atención prestada por la revista al desarrollo incipiente del estructuralismo francés. El artículo de del Barco, "Metodología histórica y concepción del mundo (acerca del problema de la larga duración)", del número 2-3 y su nota bibliográfica sobre El pensamiento salvaje de Levi-Strauss del número 7-8, constituyen un atento seguimiento del desarrollo de la obra levi-straussiana, de sus proyecciones hacia el campo de las ciencias sociales y especialmente de las discusiones abiertas en torno a las relaciones entre el estructuralismo y el marxismo. En el primero de ellos, una respuesta a un artículo de Tulio Halperín Donghi publicado en Cuestiones de Filosofía en 1962 en el que éste planteaba el problema de la larga duración en la historiografía a partir de una lectura crítica de la relación entre marxismo y conocimiento histórico, del Barco presentaba el panorama de las ciencias sociales de fines de la década de 1950 y comienzos de la de 1960 deteniéndose en aquellos esfuerzos, como los de Fernand Braudel y LeviStrauss, por trascender los límites de sus respectivas disciplinas y alcanzar una integración totalizadora de las ciencias. El modo en el cual Del Barco procesaba la tendencia hacia el análisis estructural implícita en la historiografía braudeliana y la antropología levi-straussiana se oponía a la interpretación de Halperín Donghi, estructurada a partir de una contraposición entre el marxismo, al cual le asignaba la enfatización de la creatividad humana, y la larga duración, perspectiva a la cual le otorgaba implicancias pesimistas. del Barco se detenía en las referencias a la obra marxiana presentes en Antropología estructural ofreciendo una lectura que priorizaba las afinidades entre Levi-Strauss y Marx en torno a la identificación de estructuras a-temporales y que adscribía a una 
interpretación de la obra levi-straussiana en la cual el análisis estructural no implicaba necesariamente la anulación de la creatividad humana ${ }^{423}$.

La atención prestada por Pasado y Presente a la obra de Levi-Strauss alcanzó su punto más alto con la densa reseña de El pensamiento salvaje escrita por Del Barco para el número publicado a principios de 1965. Dedicada especialmente a desentrañar los elementos nucleares de la empresa levistraussiana, la lectura de del Barco estaba estructurada en base a una indagación incisiva tanto del sustrato teórico sobre el cual se edificaban las tesis de Levi-Strauss como de los efectos que éstas podían tener sobre los impulsos más productivos del pensamiento filosófico. Así, un análisis de la lingüística saussereana permitía advertir que los postulados levi-straussianos se desarrollaban sobre un trasfondo epistemológico que privilegiaba el nivel inconsciente y a-histórico de la realidad humana. Asimismo, el abordaje del esfuerzo de Levi-Strauss por iluminar a través del análisis estructural los elementos que actúan a modo de intermediarios entre la naturaleza y el hombre era dotado de una valoración negativa. Remitida la igualación de todos los puntos de vista a una visión plana del mundo y asociada la búsqueda de una estructura trascendental a la construcción de una visión omnicomprensiva de la realidad, del Barco concluía su lectura de la obra levi-straussiana afirmando que ésta se caracterizaba principalmente por operar una extensión ilegítima de sus descubrimientos científicos al terreno filosófico y propiciar así un esquematismo comparable con el trascendental abstracto del pensamiento kantiano.

Los modos a través de los cuales Del Barco analizaba las polémicas abiertas en Europa a partir de la publicación de El pensamiento salvaje constituyen elementos indicativos del lugar del estructuralismo en la experiencia de Pasado y Presente. En primer lugar, del Barco abordaba el

\footnotetext{
${ }^{423}$ Una primera referencia a la polémica Halperín Donghi-del Barco puede encontrarse en Terán, Oscar. Nuestros años sesentas. La formación de la nueva izquierda intelectual argentina. op. cit. Para una reconstrucción de dicha discusión en el marco de la recepción de Braudel en Argentina, ver García, Diego. "La renovación historiográfica en Córdoba. Un recorrido". Ana Clarisa Agüero y Diego García (eds.). Culturas interiores. Córdoba en la geografía nacional e internacional de la cultura. op. cit., p. p. 165-184.
} 
embate de Levi-Strauss contra Sartre a través de una mediación argumental que terciaba claramente a favor de éste último. Si Sartre se negaba a reconocer la existencia de una naturaleza humana, esto se debía, según el cordobés, a que el sartreanismo formaba parte de una tradición filosófica que, aun aceptando la importancia de las invariantes estructurales, está interesada en problematizar las formas en la cuales el hombre puede trascender las estructuras a través de una praxis liberadora. Por ello, mientras del Barco destacaba la atención prestada por Sartre a la contingencia de cada cultura particular, acusaba a Levi-Strauss de absolutizar su propia cultura al amparo de la postulación de la posibilidad de una comprensión transhistórica.

Asimismo, del Barco demarcaba una lectura de las primeras discusiones sobre la relación entre marxismo y estructuralismo. La referencia a Marxismo y estructuralismo de Lucien Sebag, especialmente su insistencia en que el estructuralismo no niega que el hombre es el productor de todo lo humano, opera en los argumentos de del Barco a modo de separación de lecturas superficiales de la corriente estructuralista, como aquella que podía concebir al estructuralismo como una teoría postuladora de las estructuras como dadoras de sentido -las estructuras como creadora de las lenguas, los mitos, las religiones, etc ${ }^{424}$. Cifrada la encrucijada de la filosofía de mediados de la década de 1960 en la disyuntiva entre sometimiento de las estructuras y libertad del hombre, la opción por el análisis estructural aparecía en el texto de del Barco como condicionada a que dicha perspectiva atendiera de modo

\footnotetext{
${ }^{424}$ La obra de Sebag, de 1964, no había sido aún traducida al castellano. Será editada en 1968 por Siglo XXI España. Sebag, de formación en filosofía, realizó trabajos de antropología bajo la influencia de Levi-Strauss, de quien había sido alumno. Marxista y vinculado con grupos de extrema izquierda, fue expulsado del PCF en 1955. Su único libro, Marxismo y estructuralismo, generó en los círculos marxistas parisinos un debate que anticipó el que ocurriría posteriormente con la obra althusseriana. Como es harto conocido, Sebag era paciente de Lacan y pareja de su hija Judith, y se suicidó en enero de 1965 a los 31 años. Uno de los pasajes célebres de El porvenir es largo relata la visita de Lacan a Althussser luego de su suicidio. Pueden encontrarse referencias al itinerario político intelectual de Sebag en Dosse, François. History of Structuralism, Voume I. The Rising Sign, 1945-1966. op. cit., pp. 88-89; Roudinesco, Elisabeth. La batalla de cien años. Historia del psicoanálisis en Francia. Tomo 3. 19251985. Madrid, Fundamentos, 1993, pp. 17-18 y en el obituario escrito por Jean-Paul y Marie-Claire Boons para Les Temps Modernes en 1965 y reproducido en la edición española de Marxismo y estructuralismo.
} 
equivalente los problemas relativos a la praxis y la historicidad. Valorado el análisis estructural, la precaución se dirigía a un potencial desbalance entre los elementos invariantes y la contingencia histórica:

\begin{abstract}
Estamos con el estructuralismo cuando sostiene que existen niveles de la realidad que sólo pueden ser pensados en términos lógicos y no históricos concretos, y esto de hecho y no de derecho, pero nos negamos a considerar como central y excluyente al nivel estructural, viéndolo en cambio, englobado dentro de una dialéctica de la totalidad, en la cual la estructura aparece como la parte más pesada y casi inmóvil ${ }^{425}$
\end{abstract}

Finalmente, en un movimiento que nos retrotrae a las referencias sobre el lugar del estructuralismo en Argentina problematizadas en el primer capítulo, del Barco reforzaba las oposiciones abstractas a El pensamiento salvaje con una disquisición en torno a la relación entre el estructuralismo levi-straussiano y la historia concreta de los pueblos a lo largo del siglo XX. El cordobés oponía las afirmaciones anti-humanistas más contundentes de Levi-Strauss, especialmente aquellas que referían a un escepticismo sobre la liberación del hombre y a la convicción de un progresivo sometimiento al determinismo natural, a los esfuerzos realizados por los pueblos en pos de liberarse de los condicionamientos naturales y afirmar su voluntad sobre la fatalidad de las estructuras. $Y$ afirmaba que si bien la lucha por la liberación del hombre no es un proceso simple y transparente, sino que está cargado de contradicciones y desgarramientos, la ponderación del nivel estructural de Levi-Strauss no sólo no contribuía a pensar el problema de la construcción de un mundo desalienado, sino que terminaba ubicándose en un espacio divergente de la lucha de los pueblos por liberarse de los determinismo materiales y sociales.

El seguimiento realizado por del Barco del itinerario teórico del estructuralismo levi-straussiano, receptivo del momento correspondiente a Antropología estructural y reactivo frente al avance propuesto en El pensamiento salvaje, convivió en la revista con intervenciones escritas por

${ }^{425}$ Del Barco, Oscar. "El pensamiento salvaje de Claude Levi-Strauss". Pasado y Presente. Revista trimestral de ideología y cultura. $\mathrm{N}^{\circ} 7-8$, octubre de 1964-marzo de 1965, p. 229. 
colaboradores pertenecientes a la expresión argentina de la tradición estructuralista. En el marco del impulso aperturista de Pasado y Presente y su programa de integración de los desarrollos teóricos más novedosos de las ciencias sociales, la revista incluyó los artículos "Infraestructura y superestructura en el análisis de la acción social” de Verón, publicado en el número 7-8, y "Jacques Lacan o el inconsciente en los fundamentos de la filosofía" de Masotta, publicado en el número 9. En sintonía con la primera lectura realizada por del Barco de la obra de Levi-Strauss y en clara divergencia con la segunda, los textos de Verón y Masotta constituían, más allá de sus singularidades, intervenciones caracterizadas tanto por la permeabilidad a las innovaciones propiciadas por los teóricos estructuralistas europeos como por el direccionamiento de los programas de investigación de sus autores bajo el influjo del paradigma estructural.

Si el texto de Masotta problematizaba la relación entre fenomenología, estructuralismo y psicoanálisis ${ }^{426}$, en el de Verón se enunciaba un programa de análisis de los fenómenos superestructurales que integraba los desarrollos teóricos de Levi-Strauss, Barthes, Jakobson y Piaget y que se pretendía superador de las limitaciones de la teoría de la acción parsoniana. Definida la superestructura como un complejo proceso de circulación de mensajes y resaltados los mecanismos de emisión, transmisión y recepción, la propuesta de Verón giraba en torno a un pasaje desde la concepción representacional de la significación hacia una operacional, lo cual implicaba consecuentemente el relevo de las nociones de idea y orientación por las de signo y comunicación. De este modo, el análisis de los procesos ideológicos aparecía disociado de las concepciones funcionalistas de la dimensión normativa de la cultura y direccionado hacia el estudio de los mecanismos metacomunicacionales y los efectos normativos que operan a nivel inconsciente. Presentados los sociólogos de la acción como apresados en una perspectiva subjetivista y conciencialista, la intervención de Verón constituía un llamado a trascender el énfasis en la dimensión institucionalizada de la norma y constituir una teoría de la ideología capaz de atender las operaciones connotativas de la ideología.

${ }^{426}$ Analizamos en detalle esta intervención de Masotta en el capítulo siguiente. 
En un agrupamiento que da cuenta de ambas dimensiones repasadas, es decir la apertura del marxismo pasadopresentista pero también las tensiones que generaba una corriente como la estructuralista, el artículo de Verón integraba un apartado preparado específicamente para el número de principios de 1965 sobre la temática "Marxismo y sociología" junto a un texto de Fernando Henrique Cardoso titulado "El método dialéctico". Si bien la intervención de Cardoso se situaba al igual que la de Verón en el núcleo problemático de las relaciones entre marxismo, funcionalismo y estructuralismo, la triangulación entre dichos elementos por él operada divergía sustancialmente con la que se desprendía de la propuesta del argentino.

Como vimos en el primer capítulo, Cardoso había sido uno de los impugnadores de las tesis althusserianas en Brasil. A diferencia del programa teórico diagramado por Verón, en el cual una relectura estructuralista de Marx habilitaba una superación del funcionalismo, los postulados de Cardoso daban cuenta de una posición que buscaba blindar al marxismo frente a los desarrollos del funcionalismo y el estructuralismo a través de un reforzamiento del método dialéctico. Desde una lectura de Marx mediada por la interpretación lukacsiana, Cardoso intentaba mostrar cuán lejos del análisis estructural marxista se encontraba el enfoque estructuralista, principalmente en su vertiente levi-straussiana. Así, mientras el primero era descripto como un procedimiento totalizador que sintetizaba determinaciones generales y determinaciones particulares, y que por lo tanto permitía explicar tanto lo que permanece como lo que se transforma, el segundo era captado como un constructor de modelos vacíos de contenido cuyos patrones eran aplicados indistintamente a los fenómenos sociales concretos. En este sentido, la diferencia radical entre marxismo y estructuralismo era cifrada por Cardoso como una expresión del contrapunto entre las interpretaciones que conciben a la historia como la realización de la actividad humana colectiva y aquellas que tienden a explicar los procesos sociales como confirmaciones de condiciones y fines ya dados.

\subsection{Los cuadernos althusserianos}


Clausurada la experiencia de la primera etapa de la revista, la intervención del colectivo de Pasado y Presente se orientó hacia el trabajo editorial. Si bien el grupo había tenido un papel relevante en emprendimientos editoriales de la ciudad de Córdoba, la fundación en 1968 de la Editorial Pasado y Presente por Aricó, del Barco, Varas y Funes operó a modo de prolongación de la especificidad de la intervención político-intelectual desarrollada en la revista ${ }^{427}$. En este sentido, la publicación de los Cuadernos implicó un trabajo de lectura, traducción y edición de textos dotado de un impulso heterodoxo en relación a la vinculación con el corpus marxista, así como un esfuerzo de promoción de la apertura del marxismo hacia los desarrollos innovadores de las ciencias sociales. La inscripción anti-dogmática del grupo redundó principalmente en la publicación de textos provenientes de diversas corrientes del marxismo contemporáneo, con la obvia excepción de la ortodoxia soviética, pero también de textos pertenecientes a corrientes intelectuales no-marxistas con las cuales el marxismo podía establecer un diálogo o aquellas que representaban un desafío a sus premisas teóricas ${ }^{428}$.

Si bien las referencias al lugar ocupado por el althusserianismo en esta experiencia editorial se sitúan más allá de las posiciones anti-althusserianas del gramscianismo ochentista, algunos de sus supuestos aún perviven en las interpretaciones más recientes de los Cuadernos. La lectura realizada por Burgos da cuenta de la importancia del althusserianismo en los primeros cuadernos editados destacando que "Pasado y Presente no dejaba de expresar una fuerte simpatía por los textos de Althusser"429. Sin embargo, ubicaba dicha simpatía en el marco del proyecto general de los Cuadernos de difusión de

\footnotetext{
${ }^{427}$ Para una reconstrucción del trabajo editorial del grupo antes de la edición de los Cuadernos, ver Barbeito, Ignacio. "Aportes para una historia del circuito editorial en la Córdoba de los '60 y primeros '70s. Ediciones Nagelkop, Aula Vallejo e Igitur'. Políticas de la Memoria. Anuario de investigación e información del CEDINCI, $\mathrm{N}^{\circ}$ 10/11/12, 2011-2012, pp. 143-148.

${ }^{428}$ Resulta, al respecto, sumamente sugestivo que mientras el primer cuaderno editado correspondió a la largamente anunciada Introducción general a la crítica de la economía política, el segundo lo constituyó Elogio de la antropología de Levi-Strauss. ${ }^{429}$ Burgos, Raúl. Los gramscianos argentinos. Cultura y política en la experiencia de Pasado y Presente. Buenos Aires, Siglo XXI, 2004, p. 189.
} 
autores marxistas heterodoxos advirtiendo que el althusserianismo fue un elemento "contingente" ${ }^{430}$ en la experiencia pasadopresentista en tanto su marca registrada estaba vinculada estrechamente a los conceptos gramscianos. La reconstrucción realizada por Crespo, si bien atiende una serie de variables generalmente desatendidas en la historización de la experiencia pasadopresentista -especialmente la convergencia teórica y política con el maoísmo-, presenta un agrupamiento de los problemas y los autores difundidos en los Cuadernos en el cual están ausentes tanto Althusser como las discusiones teóricas y políticas abiertas por el althusserianismo. A su entender, el marxismo althusseriano estuvo presente en la experiencia de los Cuadernos únicamente en la importancia otorgada por Aricó al trabajo al interior de la teoría marxista, representando de este modo el althusserianismo una "contaminación" $" 31$ en el itinerario marxista de Pasado y Presente.

\subsubsection{La parcialidad del pensador francés: primeras lecturas de Althusser}

En los últimos años de la década de 1960, el colectivo editorial de Pasado y Presente publicó en Córdoba dos Cuadernos que contenían traducciones de textos que formaban parte de la constelación de debates abiertos por la obra althusseriana en Europa. Estos fueron el Cuaderno número 4, La filosofía como arma de la revolución de Althusser, editado en 1968 y el Cuaderno número 8, Materialismo histórico y materialismo dialéctico de Althusser y Badiou, editado en 1969.

El Cuaderno número 4 contenía "La filosofía como arma de la revolución", la entrevista de Macciocchi a Althusser realizada para L'Unità en febrero de 1968, traducida por del Barco; "Práctica teórica y lucha ideológica", el texto publicado en Casa de las Américas al que hicimos alusión en el primer capítulo; y "Sobre el trabajo teórico", publicado por primera vez en La Pensée en abril de 1967, con traducción de Del Barco.

\footnotetext{
${ }^{430}$ Ibid., p. 191.

${ }^{431}$ Crespo, Horacio. "En torno a Cuadernos de Pasado y Presente, 1968-1983". Claudia Hilb (comp.). El político y el científico. Ensayos en homenaje a Juan Carlos Portantiero. Buenos Aires, Siglo XXI, 2009, p. 193.
} 
La "Advertencia" a La filosofía como arma de la revolución constituye la primera aproximación sistemática al althusserianismo explicitada por el colectivo Pasado y Presente. Se refleja en esta aproximación una lectura cautelosa de la figura de Althusser, tanto en lo relativo a su propuesta renovadora del marxismo como a las proyecciones políticas de su obra. Aricó presentaba los textos de Althusser publicados en el Cuaderno como ensayos que expresaban problemas ya abordados en La revolución teórica de Marx y Lire Le Capital y que daban cuenta de un trabajo sistemático de establecimiento de las coordenadas fundamentales de la filosofía marxista ${ }^{432}$. En tanto recortada a un intento de constitución de la filosofía marxista, la obra de Althusser era caracterizada como un trabajo de tipo epistemológico que proponía una lectura rupturista de Marx, a partir de la cual el texto marxiano dejaba de ser concebido como una obra transparente y comenzaba a ser considerado como un discurso que inaugura una nueva problemática con conceptos todavía inadecuados. Asimismo, la presentación de Aricó daba cuenta de la incorporación por parte de Althusser, en su esfuerzo por llevar a cabo esta lectura sintomática de la obra de Marx, de recursos de la lingüística jakobsoniana, la antropología estructural levi-straussiana y el psicoanálisis lacaniano.

La introducción de Aricó presentaba un panorama del impacto de las tesis de Althusser en el campo marxista en el cual se remarcaba que, a pesar de constituir un proyecto en elaboración, el althusserianismo había tenido "enormes efectos positivos" ${ }^{333}$ en los debates marxistas contemporáneos. La presentación a los textos del Cuaderno daba cuenta de la influencia que las formulaciones althusserianas estaban comenzando a tener en diversos campos de investigación, y por ende, del lugar que estaba adquiriendo el althusserianismo en la cultura francesa y europea. El núcleo de la "Advertencia" se dirigía, sin embargo, a las proyecciones políticas de la obra de Althusser. Al dar cuenta del entusiasmo que el althusserianismo concitaba en espacios de la

${ }^{432}$ Cabe destacar que para el momento en el que fue escrita esta Advertencia, sólo estaba traducido al español La revolución teórica de Marx. Como hemos visto, Para leer El Capital será editado al año siguiente.

433 "Advertencia". Althusser, Louis. La filosofía como arma de la revolución. Córdoba, Pasado y Presente, 1968, p. 8. 
nueva izquierda, Aricó advertía que el hecho de que el desarrollo de una corriente marxista que descansaba sobre dimensiones epistemológicas conllevara importantes efectos políticos se presentaba "superficialmente como un hecho bastante paradójico" ${ }^{34}$. Es por ello que señalaba que el lector no debería sorprenderse de la profusa circulación que la obra de Althusser tenía en Cuba ni del reconocimiento que a ella le otorgaban los aparatos culturales del estado cubano.

La politicidad del althusserianismo era cifrada por Aricó en una clave leninista anti-espontaneísta y distanciada de la tradición stalinista. Las coordenadas interpretativas a partir de las cuales Aricó presentaba a Althusser en este primer momento estaban nutridas por fuentes diversas. La primera era "The Structure of Capital", la reseña de Pour Marx y Lire Le Capital realizada por Eric Hobsbawm para Times Literary Supplement en $1966 .{ }^{435}$ El comentario de Hobsbawm consistía en una lectura equilibrada de la obra de Althusser. En ella se pronosticaba una proyección productiva del althusserianismo en tanto propuesta radical de relectura de la obra de Marx al mismo tiempo que se advertía sobre algunos de sus núcleos problemáticos, especialmente el énfasis epistemológico, el distanciamiento de lo concreto y la dificultad para dar cuenta del cambio histórico. Hobsbawm situaba el factor explicativo del ascenso del althusserianismo en la oportunidad de su surgimiento: la dureza de la obra de Althusser establecía una afinidad con la juventud rebelde parisina que el marxismo humanista de Sartre o Lefebvre y el oportunismo de Rochet y Garaudy estaban lejos de alcanzar. Era a esta explicación a la que recurría Aricó en su presentación para prevenir al lector de que los textos de Althusser no debían ser leídos como expresiones de un marxismo neo-stalinista, sino

\footnotetext{
${ }^{434} / d$.

${ }^{435}$ El texto fue publicado de forma anónima, de allí que Aricó hiciera referencia a "un artículo que le dedicara [a Louis Althusser] el Suplemento Literario del Times" y no mencionara la autoría de Hobsbawm. En su descripción del Cuaderno, Burgos afirma que Aricó recurre a un artículo del Times y aclara que no hay referencias de la cita. El texto de Hobsbawm fue reeditado en 1973, ya con su firma, en el volumen Revolucionarios. Ensayos contemporáneos. Asimismo, Elliott lo incluyó en 1994 en Althusser: A Critical Reader, una compilación de lecturas clásicas y contemporáneas sobre Althusser.
} 
como indicadores de un resurgimiento del leninismo opuesto al espontaneísmo del comunismo francés ${ }^{436}$.

La otra era una intervención de Cesare Luporini publicada en 1967 en el número 4 de la revista francesa L'homme et la société. Luporini, por entonces uno de los lectores italianos más entusiastas de Althusser, fue uno de los principales introductores de su obra en Italia. El texto al que se refería Aricó era la traducción francesa de la nota introductoria a Per Marx, la edición italiana de Pour Marx, que había sido traducida por Madonia y editada por Riuniti, la editorial del $\mathrm{PCl}^{437}$ En este texto, Luporini introducía a los lectores italianos en las principales dimensiones de la obra de Althusser y dedicaba gran parte del recorrido a prevenirlos de lo incorrecto de algunas de las acusaciones esgrimidas contra Althusser en Francia, especialmente aquellas que enfatizaban lo descaminado de sus posiciones anti-humanistas y antihistoricistas. La lectura de Luporini avanzaba sobre los debates en torno a estos tópicos y prefería centrarse en lo que, a su juicio, representaba la mayor riqueza del althusserianismo: la fidelidad a la crítica leninista de toda concepción espontaneísta. El italiano daba cuenta de este modo del carácter progresivo del althusserianismo en tanto propiciador de una elaboración teórica de la visión de clase revolucionaria e impugnador de las posiciones que depositaban una confianza mística en una conciencia de clase preexistente. Aricó seguía literalmente a Luporini al afirmar que si bien las consecuencias políticas del althusserianismo debían ser aún exploradas, el hecho de que Althusser representara una salida leninista frente al empantanamiento del

\footnotetext{
${ }^{436}$ En la cita que hace del texto de Hobsbawm, Aricó excluye, por alguna razón, la siguiente frase: "Es muy característico que, pese a ser miembro de Partido Comunista, [Louis Althusser] eligiera como editor de sus obras a François Maspero, portavoz de la ultraizquierda".

${ }^{437}$ Sobre Luporini como introductor de Althusser en Italia y la recepción del althusserianismo en dicho país, ver Lo lacono, Cristian. Althusser en Italia. Saggio bibliografico (1959-2009). Milán, Mimesis, 2009 e Izzo, Francesca. "Althusser and Italy: a Two-Fold Challenge to Gramsci and Della Volpe". International Critical Thought. Vol. $5, \mathrm{~N}^{\circ}$ 2, 2015, pp. 200-210. Como evidencia la correspondencia de Althusser con Madonia, la edición de Per Marx constituyó un delicado proceso en tanto con dicha iniciativa editorial el $\mathrm{PCl}$ daba legitimidad a un proyecto teórico-político, como el althusserianismo, que estaba en los límites de lo tolerado por el PCF, Althusser, Louis. Lettres à Franca (1961-1973). París, Stock/IMEC, 1998.
} 
espontaneísmo "justifica plenamente que hayamos decidido presentar estos escritos" ${ }^{438}$.

El texto de Luporini que mediaba el primer acercamiento a Althusser hacía lugar a una reflexión que será fundamental para el itinerario posterior del althusserianismo en la experiencia de Pasado y Presente. El italiano se mostraba interesado en las premisas althusserianas y anunciaba que éstas estaban destinadas a impregnar la filosofía italiana, ya que la obra de Althusser representaba una novedad para un espacio nacional donde la tradición historicista tenía un peso notable. Anunciaba, por ello, que "la discusión sobre 'historicismo y marxismo' puede ser considerada abierta para nosotros" ${ }^{439}$. Efectivamente, en 1968 el marxismo italiano se vio sacudido por una importante discusión en torno a las relaciones entre marxismo e historicismo generada a partir de un intercambio entre Althusser y los filósofos comunistas. Un comentario crítico de Rino Dal Sasso sobre "El marxismo no es un humanismo" publicado en diciembre de 1967 en el semanario comunista Rinascita dio lugar a una respuesta de Althusser y a un debate que se extendió en el semanario durante todo el año siguiente y en el cual intervinieron Badaloni, Luciano Gruppi, Lucio Lombardo Radice y Della Volpe.

El Cuaderno número 8 retomaba la discusión italiana y presentaba intervenciones que daban cuenta del desarrollo de la tradición althusseriana en Francia. Materialismo histórico y materialismo dialéctico contenía los textos del debate llevado a cabo en los números 11, 13 y 14 de Rinascita, "La filosofía, la política y la ciencia" y "Respuesta a Antonio Pesenti sobre 'Leer El Capital"' de Althusser, "Método de lectura" de Dal Sasso, "La tarea del filósofo" de Badaloni, "La relación hombre-naturaleza" de Gruppi, "Sí, para nuestra suerte" de Radice y “Un planteo 'estructural"” de Della Volpe, todos ellos traducidos por Aricó. Asimismo reproducía "El (re) comienzo del materialismo dialéctico" de Badiou, publicado en Critique en mayo de 1967, con traducción de Nora Rosenfeld de Pasternac; "Materialismo histórico y materialismo dialéctico" de Althusser, un

\footnotetext{
438 "Advertencia". Althusser, Louis. La filosofía como arma de la revolución. op. cit., p. 9.

439 "la discussione su 'storicismo e marxismo' si può considerare aperta anche da noi", "Nota introduttiva". Althusser, Louis. Per Marx. Roma, Riuniti, 1967, p. XXVI.
} 
artículo publicado en abril de 1966 en Cahiers marxistes-leninistes, traducido por Aricó; y el Prólogo a la segunda edición francesa de Lire Le Capital, editado en 1968, con traducción de Santiago Funes.

Si bien ambos conjuntos de textos pueden ser concebidos como elementos pertenecientes a una gran discusión sobre la irrupción del althusserianismo en Europa, cada uno de ellos derivaba de debates centrados en problemas específicos. Las intervenciones de Althusser y Badiou problematizaban las relaciones entre materialismo histórico y materialismo dialéctico y la vinculación entre althusserianismo y estructuralismo. En su texto de 1966, Althusser procedía a una historización de la distinción entre materialismo histórico y materialismo dialéctico de la cual se derivaba tanto una programa de constitución de la filosofía marxista como una dura crítica a las posiciones marxistas que a su entender habían negado o alterado dicha distinción. Si la tarea que se imponía era la de plantear el problema de la naturaleza de la filosofía marxista a partir de un riguroso trabajo de crítica sobre el texto marxista, las concepciones de la filosofía marxista sostenidas por Labriola, el joven Lukács y Gramsci aparecían como operaciones de reducción del materialismo dialéctico al materialismo histórico. La asimilación de la ciencia de la historia a la filosofía implicaba, en el recorrido propuesto por Althusser, la asunción del marxismo como radicalización del historicismo hegeliano y el consecuente peligro de caer en posiciones especulativas o empiristas.

El texto de Badiou, que como bien afirma Bosteels, constituye "muy sorprendente reseña de libro" ${ }^{440}$, contenía una densa lectura de Pour Marx y Lire Le Capital y un incisivo seguimiento de "Matérialisme historique et matérialisme dialectique". El carácter extraordinario del texto de Badiou implicó que la figura del discípulo de Althusser se superpusiera a la de su maestro y que sus comentarios fuesen considerados al mismo nivel que los textos de Althusser. Según explicaba Aricó en la presentación a la compilación, "el otro texto analizado por Badiou es el que se incluye aquí con el título 'Materialismo

440 "a quite astonishing book review", "Alain Badiou's Theory of the Subject: Part I. The Recommencement of Dialectic Materialism". Pli: The Warwick Journal of Philosophy, $\mathrm{N}^{\circ} 12,2001$, pp. 203-204. 
histórico y materialismo dialéctico" ${ }^{441}$. La intervención badiouana consistía en una propuesta de radicalización de las tesis althusserianas enmarcada en un programa general de (re)comienzo del materialismo dialéctico. Contextualizado en una coyuntura signada por el silencio teórico de los Partidos Comunistas occidentales, el althusserianismo era saludado por Badiou como un marxismo que permitía tanto combatir al idealismo fenomenológico como diagramar una salida de las operaciones de supresión y yuxtaposición entre el materialismo histórico y materialismo dialéctico que caracterizaban a las diferentes vertientes de marxismo vulgar predominantes durante el proceso de desestalinización.

Badiou se detenía en lo que consideraba los núcleos del programa althusseriano, las diferencias entre ciencia e ideología y entre práctica determinante y práctica dominante, a las cuales suscribía aún planteando algunas reservas. La crítica badiouana se centraba así en las dificultades del althusserianismo para discernir qué distingue la reanudación filosófica producida por la ruptura científica de la reinscripción ideológica de la ciencia y para producir un concepto colectivizante de las prácticas. Esta posición, que adelanta desarrollos posteriores de la obra de Badiou, especialmente la propuesta de una disciplina formal previa, a la que llamaba teoría de los conjuntos históricos, esquivaba las críticas recurrentes al althusserianismo y propiciaba, en sentido contrario a éstas, una aproximación a la obra de Althusser consistente en un repliegue sobre sí misma, es decir que no describiera sus argumentos ni la opusiera a otras corrientes teóricas, sino que le aplicara los conceptos metateóricos que ella misma producía. La lectura badiouana de Althusser no pretendía cuestionar el proyecto de su obra en sí, sino que apuntaba a suturar las lagunas de los textos a través de la introducción de los problemas que dichos espacios están indicando.

La "Advertencia a la segunda edición francesa de "Leer El Capital" indicaba, al igual que la intervención de Badiou, un trabajo de corrección sobre algunas tesis ya esbozadas por el althusserianismo a mediados de la década de 1960, en esta ocasión realizado por el propio Althusser. Si bien allí se

\footnotetext{
441 "Advertencia". Althusser, Louis y Badiou, Alain. Materialismo histórico y materialismo dialéctico. Córdoba, Pasado y Presente, 1969, p. 7.
} 
realizaban aclaraciones de formato sobre la nueva edición, como la supresión de las contribuciones de Rancière, Macherey y Establet, el núcleo del texto estaba estructurado en torno a un ejercicio autocrítico. Se evidenciaba en el texto el intento de Althusser por desvincular su obra de la tradición estructuralista. La reacción frente a las críticas al althusserianismo en tanto corriente marxista permeada por el estructuralismo adquiría la forma de la asunción de la responsabilidad por haber empleado una terminología demasiado cercana a las corrientes estructuralistas. Asimismo, la nueva edición de Lire Le Capital traía aparejada una rectificación de la definición, dada en este libro y en Pour Marx, de la filosofía como teoría de la práctica teórica. En lo que era denunciado como una tendencia teoricista, Althusser advertía a los lectores que la mencionada definición de la filosofía había sido un error de concepción, sobre el cual era necesario avanzar para evitar caer en posiciones teóricas y políticas especulativas o positivistas.

El intercambio entre Althusser y los comunistas italianos se ubicaba, en cambio, en un espacio en el cual las formulaciones althusserianas eran rebatidas desde posiciones gramscianas. El marcado anti-historicismo de la intervención de Althusser se expresaba en la aseveración de que si bien Gramsci se había esforzado en pensar una de las dos determinaciones de la filosofía, la relación entre filosofía y política, no había dedicado la misma energía a pensar la otra determinación, la relación entre filosofía y ciencia. Este desfasaje explicaba, según los argumentos althusserianos, la supresión del término materialismo dialéctico y la importancia otorgada a la filosofía de la praxis en la obra de Gramsci. Asimismo, Althusser se esforzaba en asentar que la existencia de un pensamiento concreto no puede servir a modo de evidencia de que el equívoco teórico ha sido corregido. Así se contestaba el argumento de Dal Sasso, y del gramscianisno en general, de que los problemas derivados de la obra de Gramsci, como el déficit en la problematización de las relaciones entre filosofía y ciencia, eran disipados por el lugar que había tenido el pensamiento concreto en el itinerario del marxista italiano.

Las respuestas de los italianos, más allá de los matices particulares, apuntaban al cientificismo althusseriano y realizaban una encendida defensa 
del historicismo gramsciano. Dal Sasso replicaba postulando las limitaciones del método de lectura althusseriano, al cual le adjudicaba el error de asociar el historicismo gramsciano con el historicismo croceano, y advirtiendo sobre los peligros de la teorización de la ciencia, operación que vinculaba con las aberraciones científicas del stalinismo. Badaloni justificaba el marxismo historicista y remitía las diferencias entre Althusser y Gramsci a una divergencia política, en la cual el primero aparecía sustentando una concepción de la revolución como hecho espontáneo irrefrenable y el segundo una idea más acorde a las sociedades modernas, en la cual la revolución es pensada a partir de la construcción de un bloque histórico dirigido hacia un nuevo orden social. Gruppi acusaba a Althusser de propiciar una restauración especulativa de la filosofía, operación que era vista de forma negativa en tanto separaba a la filosofía de la praxis y reducía a la política a la ideología. Radice, con su "sí, para nuestra suerte", celebraba que el comunismo italiano, bajo la guía de Gramsci y Togliatti, se hubiese caracterizado por priorizar el pensamiento sobre la relación entre filosofía y política y concebir al marxismo como la doctrina política de la clase obrera, en tanto de este modo había podido reunir en el seno del $\mathrm{PCl}$ a todos los militantes revolucionarios independientemente de las filosofías particulares por ellos sostenidas. Della Volpe, por su parte, llamaba la atención sobre las dificultades de las aproximaciones estructurales de la filosofía marxista.

La Advertencia del Cuaderno da cuenta de la doble dimensión de la proyección althusseriana atendida en la compilación. Los textos provenientes de Francia, el de Badiou y los del propio Althusser, permitían, según Aricó, constatar que el pensamiento de Althusser seguía desarrollándose y complementar con textos menores la lectura de lo que a su entender es su opus magna, Lire Le Capital. Los textos del debate entre Althusser y los italianos eran presentados como indicativos de la relación problemática entre las posiciones althusserianas y las elaboraciones de Gramsci, quien era considerado uno de los teóricos que más había renovado el pensamiento marxista en el siglo XX. Las reacciones de los marxistas italianos frente a las impugnaciones althusserianas de las posiciones gramscianas debían ser 
leídas, según Aricó, como una advertencia de que éstas "no pueden ser estudiadas con la parcialidad con que lo hace el pensador francés" ${ }^{442}$.

\subsection{2. ¿Gramscianos vergonzantes? Althusser y las posibilidades de una lectura renovada de Gramsci}

En 1970 fue editado el Cuaderno número 19, titulado Gramsci y las ciencias sociales, el cual se proponía como una continuación de las discusiones en torno a la lectura althusseriana de Gramsci retomadas en Materialismo histórico y materialismo dialéctico. En este sentido, el cuaderno reproducía los textos "Gramsci y las ciencias sociales" de Luciano Gallino y "Sobre el método de Gramsci" de Alessandro Pizzorno, publicados en Quaderni di Sociologia en 1967, con la traducción de José Aricó; "Notas críticas sobre una tentativa de 'Ensayo popular de sociología'” de Gramsci, originariamente publicado en El materialismo histórico y la filosofía de Benedetto Croce por la editorial Lautaro en 1958 con la traducción de Isidoro Flaumbaum; y "Notas sobre Gramsci" de Debray, un artículo publicado en /l Manifesto en 1969 y traducido por Aricó.

Gallino y Pizzorno proponían en sus artículos un examen de las lecturas clásicas de la tradición gramsciana y una apertura a nuevas aproximaciones a la obra del marxista italiano desde una perspectiva sociológica. Gallino concordaba con algunas de las objeciones al historicismo gramsciano propiciadas por el althusserianismo, aunque explicitaba los peligros que implicaba una metodología de lectura como la propuesta por Althusser. Procedía, del mismo modo, a una historización de las concepciones de Gramsci en relación a la ciencia, en la cual la aversión gramsciana a lo científico era explicada por el temor de Gramsci de coincidir con las posiciones groseras del positivismo italiano. Por su parte, Pizzorno describía el carácter rupturista de la lectura althusseriana de Gramsci y advertía un declive del gramscianismo estructurado en la década de 1950. Este relevo interpretativo era presentado en términos positivos ya que si bien las lecturas anteriores de

${ }^{442}$ Ibid., p. 8. 
Gramsci habían permitido resistir la ortodoxia partidaria, reivindicar un rol específico para los intelectuales y estimular la investigación de la realidad italiana, aquellas habían obstaculizado el alejamiento definitivo de la tradición croceana y la vinculación con una metodología rigurosa de las ciencias sociales.

El texto de Gramsci reproducido en el cuaderno era aquel en el cual el italiano discutía las implicaciones del manual de Bujarin La teoría del materialismo histórico. La lectura del materialismo bujarinista por parte de Gramsci daba cuenta de un esfuerzo por combatir las corrientes del marxismo que reducen la filosofía de la praxis a una sociología. De este modo, el gramscianismo aparecía como un marxismo que permitía defender el núcleo dialéctico de los ataques de las vulgarizaciones que reducen la concepción del mundo a formulaciones mecanicistas. En este mismo sentido, en las notas sobre Gramsci escritas desde la cárcel boliviana de Camiri, Debray se centraba en el combate entablado por el italiano contra el mecanicismo bujarinista y postulaba que el mayor mérito del gramscianismo había sido la soldadura entre teoría y práctica. La reacción gramsciana frente a los corrientes marxistas que propiciaban un desbalance en la relación entre historia y filosofía era señalada por Debray como lo que le había permitido al gramscianismo proyectarse hacia la militancia revolucionaria de la década de 1970. Sin embargo, dicha reacción era también concebida como aquello que podía favorecer el desvío historicista de considerar a la historia como un problema auto-resolutorio.

La Advertencia al cuaderno refleja una concepción de Aricó del althusserianismo como parteaguas en la historia de la interpretación de la obra de Gramsci. Allí se planteaba a la compilación como la expresión de la confrontación entre dos vertientes del marxismo europeo, la francesa, en la cual predominaba el marxismo estructuralista de Althusser y sus discípulos, y la italiana, dominada por el marxismo historicista de los comunistas gramscianos. Sin embargo, a diferencia del posicionamiento sustentado en el cuaderno 8, la postulación althusserianiana del historicismo gramsciano como una operación de disolución de la teoría en la praxis y bloqueo de sus posibilidades científicas era presentada como una lectura que habilitaba una aproximación 
contemporánea a la tradición gramsciana, es decir ya no mediada por el combate contra el dogmatismo soviético. Así, según Aricó, las críticas de Althusser:

marcan el punto más alto de un período de reexamen crítico del pensamiento de Gramsci, tras el gran impulso de entusiasmo que sus escritos tuvieron en el movimiento socialista desde mediados de la década del 50 , cuando los análisis de Gramsci aparecían como una de las pocas vertientes que la dureza del stalinismo no había secado en treinta años de monotonía dogmática ${ }^{443}$

Si bien Gramsci y las ciencias sociales se presentaba como una compilación en torno a la obra del marxista italiano, es evidente que la edición de dicho cuaderno estaba motorizada por lo oportuno y ajustado de algunos de los desafíos planteados al historicismo gramsciano desde la escuela althusseriana. Tanto la postulación de la continuidad con la discusión sobre al intercambio entre Althusser y los filósofos italianos como la traducción de lecturas modernas de Gramsci y la inclusión del texto sobre Bujarin y el comentario de Debray, permiten advertir una necesidad de dar lugar a un replanteo de los problemas del historicismo gramsciano a la luz de las críticas esbozadas por el althusserianismo. Si bien se percibe que Aricó advierte que la radicalidad del anti-historicismo althusseriano entraña los mismos peligros que Althusser señala en el historicismo absoluto gramsciano, también puede apreciarse en sus argumentos la certeza de que el problema del historicismo al interior del marxismo ya no podía pensarse de la misma forma que se lo pensaba antes de la obra de Althusser ${ }^{444}$.

443 "Advertencia". Pizzorno, Alessandro; Gallino, Luciano; Debray, Regis; Gramsci, Antonio. Gramsci y las ciencias sociales. Córdoba, Pasado y Presente, 1970, p. 5.

${ }^{444}$ Es interesante, al respecto, la discordancia entre la tapa y la contratapa del cuaderno. Si la tapa llevaba el nombre de Gramsci y anunciaba la traducción y edición de textos de la constelación gramsciana, la contratapa reproducía un pasaje del texto de Gallino dando cuenta de que el cuaderno número 19, al igual que el número 8, estaba motorizado por la irrupción del althusserianismo: "Si todo lo que se haya dicho o hecho un sujeto histórico es remisible totalmente a la situación en la que actuaba, el sujeto desaparece como ente autónomo; su actividad aparece determinada completamente por la situación, y el estudio del sujeto pierde interés. Louis Althusser ha demostrado que el propio Gramsci se hace a veces culpable de tal achatamiento de niveles. Al identificar teoría y política, la teoría de la historia cae inexorablemente en la 
La postulación del althusserianismo como correctivo de las lecturas clásicas del marxismo gramsciano implícita en Gramsci y las ciencias sociales dio lugar a discusiones con apropiaciones de la obra gramsciana realizadas desde otros espacios político-intelectuales de la izquierda argentina. En 1972 y en el marco del enfrentamiento entre las Cátedras Marxistas y las Cátedras Nacionales, un grupo de estas últimas editó El príncipe moderno y la voluntad nacional-popular, un volumen que compilaba textos de Gramsci. El príncipe moderno y la voluntad nacional-popular se proponía actuar a modo de contrapeso de la articulación entre althusserianismo y gramscianismo advertida en Cuaderno número 19 , de lo cual dan cuenta una serie de elementos vinculados a la edición de dicho volumen. En primer lugar, el libro no era más que la reproducción de Notas sobre Maquiavelo, la política y el Estado moderno, que había sido editado por Lautaro en 1962 con traducción de Aricó. Por otra parte, fue publicado por una editorial creada únicamente para editar dicho libro, llamada Puentealsina. Finalmente, su única innovación era el prólogo de Horacio González, en el cual se demarcaba una lectura de Gramsci opuesta explícitamente a la que se desprendía de Gramsci y las ciencias sociales ${ }^{445}$.

En el prólogo, que llevaba como título "Para nosotros, Antonio Gramsci", González sentenciaba que toda lectura de los Cuadernos de la Cárcel debía ser realizada desde el supuesto de que allí se encuentra el delineamiento de una estrategia orgánica para la toma del poder y que las aproximaciones a la figura de Gramsci debían partir de una concepción del italiano como un teórico que vincula la revolución a las voluntades nacionales y populares. En este sentido, reaccionaba frente a las lecturas que, a su entender, encasillaban la obra de Gramsci y achataban su original inflexión en la tradición marxista. González se detenía en tres de estas operaciones. Una era la traducción

historia del hecho; el objeto es confundido con el objeto real. Pero Althusser parece haberse abstenido en este caso de su intento de leer a Gramsci más allá de las palabras, porque si se sigue este camino es difícil sustraerse a la conclusión de que el esfuerzo de conceptualización de Gramsci, es si no autónomo respecto de la historia, por lo menos más constante que las situaciones de las que emergió."

${ }_{445}$ Para una reconstrucción de esta edición, en base al testimonio de González, ver Burgos, Raúl. Burgos, Raúl. Los gramscianos argentinos. Cultura y política en la experiencia de Pasado y Presente. op. cit., p. 193-199. 
política togliattiana, que había transformado al gramscianismo en el soporte teórico de estrategias neo-reformistas. Otra era la lectura sociológica, que hacía de Gramsci un pensador que podía servir a modo de guía para la comprensión de fenómenos de la sociedad moderna como la "autonomía del Estado". La tercera remitía claramente a la lectura althusseriana de Gramsci: González denunciaba al gramscianismo que condicionaba la productividad de Gramsci a la revisión de los equívocos metodológicos y conceptuales presentes en su obra y que postulaba como un error a ser subsanado "la negativa gramsciana de constituir una ciencia de estructuras al margen del proceso histórico en que se forma la hegemonía del "moderno príncipe" 446.

La intervención de González contenía una descripción de la aproximación althusseriana a Gramsci que daba cuenta de una visión negativa tanto de la corriente estructuralista como de los esfuerzos por corregir en su nombre ciertos errores del marxismo humanista e historicista. Dicha visión se expresaba en un repaso, a través una serie de metáforas ácidas, de diversas dimensiones de la lectura de Gramsci realizada desde el althusserianismo. Así, en algunos casos, catalogaba a esta lectura como la actitud de aquel que perdona a otro por sus pecados; por ejemplo en la forma en la cual era conceptualizada la relación de Gramsci con Croce y Sorel. En otros casos, la vislumbraba como el esfuerzo por digerir un alimento indeseable; por ejemplo, en el modo en el cual era leída la postulación gramsciana de la Revolución rusa como una "revolución contra El Capital". Si estas actitudes aparecían como incomprensibles, más extraño aún le resultaba a González el intento del althusserianismo por acercarse al gramscianismo y establecer una articulación entre ambas tradiciones. González se esforzaba en remarcar que el althusserianismo y el gramscianismo constituían dos corrientes del marxismo contemporáneo caracterizadas por la mutua incompatibilidad y exclusión. Se mostraba así incrédulo frente a la persistencia del althusserianismo en "entablar polémicas con quien -como él- [Antonio Gramsci] cerraba terminantemente la posibilidad de justificar una 'práctica teórica' o una ciencia

${ }^{446}$ González, Horacio. "Para nosotros, Antonio Gramsci”. Gramsci, Antonio. El príncipe moderno y la voluntad nacional-popular. Buenos Aires, Puentealsina, 1972, p. 4. 
estructural de la revolución, al margen de la práctica total de la revolución, empeñada por el intelectual colectivo y la voluntad nacional-popular" ${ }^{447}$.

El otro aspecto atendido por el prólogo de González estaba vinculado con las proyecciones de estas discusiones entre los intelectuales de izquierda en Argentina. Una gran parte del texto estaba dedicada a desmontar las conclusiones del artículo de Pizzorno, editado en Gramsci y las ciencias sociales, el cual era considerado como paradigmático de las lecturas sociológicas del marxista italiano que amputaban el núcleo duro de la intervención gramsciana: el desarrollo de una estrategia para la toma del poder por parte de las clases populares. Estas operaciones, de las cuales resultaría un Gramsci sometido a la sociología neo-reformista y a la política socialdemócrata, eran remitidas por González al gramscianismo pasadopresentista. Al igual que sus pares transatlánticos, los integrantes del colectivo Pasado y Presente eran catalogados de "hormiguitas sociológicas" ${ }^{448}$, en tanto habrían realizado un sinuoso recorrido a fines de obtener prestadas categorías pertenecientes a la tradición gramsciana. Así González intentaba desnudar al marxismo propiciado por los Cuadernos de Pasado y Presente concibiendo a sus editores como "gramscianos vergonzantes" y afirmando que éstos "en definitiva están de acuerdo con el intento althusseriano de convertir a Gramsci en la prehistoria del estructuralismo" ${ }^{449}$.

En tanto González y su grupo estaban inscriptos en las inflexiones humanistas e historicistas del marxismo, los ataques realizados desde el althusserianismo a las posiciones gramscianas eran concebidos como un acto de mezquindad. Del mismo modo, el énfasis en las relaciones entre filosofía y ciencia propiciado por el althusserianismo y la advertencia de su ausencia en las formulaciones gramscianas, transformaban a aquellos que hacían lugar a las tesis althusserianas en cientificistas responsables de oscurecer las dimensiones más productivas del legado marxiano. En palabras de González:

\footnotetext{
${ }^{447}$ Ibid., p. 11.

448 Ibid., p. 16.

${ }^{449}$ ld.
} 
no se debe dejar de señalar el empeño mezquino de quienes, desde sus Cuadernos de laboratorio [Cuadernos de Pasado y Presente], atacan a los Cuadernos de la Cárcel por su escasa cientificidad y su excesivo apego a los aforismos de las tesis sobre Feuerbach: el lado activo del conocimiento, desarrollado hasta el momento sólo por el idealismo. Pero si ésta es, precisamente, la veta prometedora y fecunda que puede desarrollarse desde Marx ${ }^{450}$

\subsubsection{Gramsci o Althusser, una falsa disyuntiva. El debate en torno al concepto de formación económico-social}

En 1973 el colectivo de Pasado y Presente llevó a cabo un proceso de traducción y edición de los debates generados en Francia e Italia a partir de la activación por parte de Althusser y sus discípulos, especialmente Balibar, del concepto de formación económico-social.

Enmarcada en el proyecto general de relectura de la obra de Marx, la problematización althusseriana de la formación económico-social implicaba su definición como un concepto abstracto que reemplazara la noción ideológica de sociedad y su designación como el objeto del materialismo histórico en tanto totalidad de instancias articuladas sobre la base de un modo de producción determinado. Asimismo, las ambigüedades advertidas por el althusserianismo en El Capital, las cuales permitirían concebir al término de formación económico-social como un concepto abstracto pero también como un concepto empírico, fueron direccionadas hacia la advertencia del peligro que entrañaba postular al objeto teórico de una ciencia abstracta como modelo de realidades existentes. La insuficiente elaboración de los conceptos que designan la articulación de las instancias de la formación económico-social en la obra de Marx era retomada por el althusserianismo en una propuesta de análisis de formaciones económico-sociales concretas y estudio de las leyes de coexistencia y jerarquía que operan en la combinación de los elementos de diferentes modos de producción.

El Cuaderno número 39, titulado El concepto de "formación económicosocial", reproducía una serie de artículos que formaban parte de una discusión

${ }^{450}$ Ibid., p. 17. 
desarrollada alrededor del concepto de formación económico-social en la revista italiana Critica marxista y en la francesa La Pensée. Una parte del cuaderno estaba compuesta por dos textos de Luporini publicados en Critica marxista; "Dialéctica marxista e historicismo" ${ }^{451}$, de 1966, traducido por Aricó, y "Marx según Marx", de 1972, traducido por Celina Manzoni; y uno de Emilio Sereni, "La categoría de 'formación económico-social'", publicado en la misma revista en 1970, con traducción de Oscar Landi. La otra parte estaba integrada por los artículos de un número especial de La Pensée de 1971 dedicado al tema; "Modo de producción, formación económico-social, teoría de la transición a propósito de Lenin" de Christine Glucksmann, "Contra el fetichismo" de René Gallissot, "La formación económico-social como combinación de modos de producción" de Guy Dhoquois, "Desacuerdo sobre la definición de los conceptos" de Jacques Texier, "El punto de vista de un economista" de Pierre Herzog, "Estatuto del concepto de economía" de Pierre Gruet y "Cuatro observaciones sobre los conceptos de modo de producción y de formación económica de la sociedad" de Georges Labica, todos ellos traducidos por Irene Agoff ${ }^{452}$.

Resulta relevante la traducción y edición del texto de Luporini de 1966 que introducía el cuaderno, en tanto éste constituía una intervención en torno al concepto de formación económico-social realizada en el interior del marxismo italiano de modo simultáneo a las formulaciones althusserianas y convergente con algunas de ellas en sus principales variables interpretativas. Luporini avanzaba sobre el problema de la relación entre realidad y modelos abstractos en el marxismo desde una posición que enfatizaba el modelo científico construido en El Capital y objetaba explícitamente las corrientes historicistas de la tradición marxista. En este marco era postulado el concepto de formación económico-social como un modelo teórico que tiene una función interpretativa

${ }^{451}$ Este texto, cuyo título original era "Realtà e storicità: economia e dialettica nel marxismo" ["Realidad e historicidad: economía y dialéctica en el marxismo"], había sido editado de forma independiente en 1969 en el Cuaderno número 11.

${ }^{452}$ Dicho número de La Pensée contenía también un texto que no fue incluido en la edición del cuaderno: “¿Qu'est-ce que definir une 'formation éconómique et sociale? L'exemple des Incas" [“¿Qué es lo que define a una 'formación económico-social? El ejemplo de los Incas"] de Maurice Godelier. 
respecto al ámbito que delimita, que es poseedor de una capacidad de periodización en sentido historiográfico y que se constituye en la oposición entre leyes generales de la producción y las leyes que definen una formación económico-social determinada.

La intervención del italiano remarcaba la posición subordinada que le corresponde al momento histórico-genético frente al momento genético-formal y que dicha subordinación no implica una disolución de la historia sino que, al contrario, es la única forma relacional que permite la disponibilidad teórica del modelo para su aplicación a realidades distintas de la que ha servido como base para su construcción. En un análisis que reivindicaba a Lenin y desacreditaba a Labriola, Luporini advertía que la desatención del carácter subordinado de lo histórico frente a lo sistémico conlleva siempre la posibilidad de caer en dogmatizaciones mecanicistas, las cuales ejemplificaba a partir de las operaciones stalinistas que permitieron la imposición de los esquemas del feudalismo occidental a los pueblos orientales y de la política etapista para los países dependientes del capitalismo occidental. Si bien aparecía en una nota al pie del texto de Luporini, no quedaban dudas de las implicaciones políticas de esta definición del concepto de formación económico-social y la consecuente concepción de la relación entre ciencia e historia en el marxismo: "en este sentido, no aparece universalmente necesario el pasaje a través de una fase democrático-burguesa para alcanzar el socialismo" 453454.

La discusión sobre el concepto de formación económico-social se abrió cuatro años después con una intervención de Sereni que abordaba los problemas relativos a dicho concepto en una dirección divergente a la del texto

453 "Dialéctica marxista e historicismo". El concepto de "formación económico-social". Buenos Aires, Pasado y Presente, 1973, p. 221

${ }^{454}$ Cabe destacar que si bien la intervención de Luporini consistía básicamente en la asunción sin ambages de una posición anti-historicista, en alguno de sus pasajes advertía los peligros que entrañaban las formulaciones estructuralistas. En este sentido, Luporini entablaba un diálogo con el texto de Rancière "Le concept de critique et la critique de l'economie politique des manuscrits de 1844 au Capital" ["El concepto de crítica y la crítica de la economía política de los Manuscritos de 1844 a El Capital"]. Dicho texto le servía a Luporini para ejemplificar la importancia de mantener la noción de subordinación del momento histórico-genético al momento genético-formal, ya no para evitar el peligro del historicismo sino para evadir los problemas del estructuralismo, en tanto, a su entender, Rancière tendía a anular la historia y absorber todo elemento histórico-genético en lo genético-formal. 
de Luporini. Sereni daba cuenta de una lectura de la obra de Marx y Lenin en la cual la categoría de formación económico-social estaba asociada a la dinámica del proceso histórico y no a la construcción de modelos teóricos. En los términos de Sereni, posiciones como las de Luporini, que otorgaban un rol predominante al momento genético-formal, contribuían a acortar las distancias entre el marxismo y aquellas corrientes sociologistas que tendían a considerar de forma Sutra-histórica o a-histórica las relaciones y los procesos sociales. Subyacía en esta intervención la propuesta de que la única forma de que el concepto de formación-económico social resultara operativo tanto en el plano historiográfico como en el político era que sus dimensiones sistémica e histórica estuvieran integradas en el mismo nivel en una unidad analítica.

El texto de Sereni no esquivaba la explicitación del terreno en el cual se desarrollaban sus objeciones. Si el contrapunto en relación a todos los aspectos problematizados se realizaba con el artículo de Luporini, el señalamiento de la necesidad de un abordaje dinámico y no estático del concepto de formación económico-social tenía unos destinatarios más allá de los Alpes. Según Sereni, el énfasis en la caracterización de toda formación económico-social como proceso era fundamental en el marco de la contraposición entre las lecturas anti-historicistas y anti-humanistas de Marx como las de Althusser y Balibar, y las historicistas y humanistas como las de Labriola y Gramsci. En una operación que integraba los debates marxistas italiano y francés, Sereni rescataba a Labriola de las acusaciones de mecanicismo esgrimidas por Luporini y retomaba las críticas de aquel a las interpretaciones esquemáticas y sociologizantes del desarrollo histórico para oponerlas al estructuralismo y al althusserianismo, al cual, a pesar de su descripción como una de las lecturas más refinadas e inteligentes de Marx, catalogaba como una expresión del sociologismo idealista.

En el marco del marxismo italiano siguió desarrollándose la discusión alrededor del concepto de formación económico-social, de lo cual da cuenta la respuesta de Luporini a Sereni que también se incluía en el cuaderno ${ }^{455}$. Sin

455 Dicha discusión ocupó un importante espacio en los números de Critica marxista editados en 1972. Además del mencionado "Marx según Marx" de Luporini, las 
embargo, la polémica abierta por la intervención de Sereni tuvo un impacto significativo especialmente entre los intelectuales marxistas franceses. En 1971, las posiciones que propiciaba dicha intervención fueron discutidas en el Centre d'Etudes et de Recherches marxistes del PCF. En el marco de estas discusiones, el texto de Sereni fue traducido al francés por dos de los referentes del Centre, Texier y Nicolas Pasquarelli. Finalmente, tanto la traducción del texto de Sereni como las lecturas críticas desarrolladas por los marxistas franceses fueron publicadas en el número 159 de La Pensée.

Si bien al igual de la discusión generada en Italia, el debate francés sobre el concepto de formación económico-social estuvo fracturado por las formulaciones althusserianas y dividió a aquellos que propiciaban un marxismo humanista e historicista de los que combatían dichas posiciones desde un esquema estructurado a partir de la obra de Althusser, otras intervenciones pretendían esquivar dichas dicotomías y relativizar la incompatibilidad entre ambas tradiciones. En este sentido se destacaba el texto de Glucksmann, en el cual se le reconocía a Sereni la reevaluación del concepto de formación económico-social pero divergía con aquel en el direccionamiento de esta rehabilitación en el interior de la tradición marxista. Esta lectura operaba a modo de defensa de las acusaciones de sociologismo a la tradición althusseriana, así como matizando la oposición global entre Althusser y Labriola, Gramsci y Lenin. Glucksmann clarificaba la distinción entre niveles de abstracción teórica inscripta en las formulaciones althusserianas y enfatizaba la importancia de la diferenciación entre conceptos teóricos y conceptos empíricos a los fines de poder precisar la relación entre modo de producción y formación económico-social. Asimismo postulaba a la concepción althusseriana de la formación económico-social como la única continuadora de las tesis

intervenciones más significativos fueron "Formazione sociale e società de transizione" ["Formación social y sociedad de transición"] de Gerratana, "Concetto lógico e concetto storico di "formazione economico-sociale"' ["Concepto lógico y concepto histórico de 'formación económico-social'"] de Giuseppe Prestipino y "Modo di produzione, rapporti di produzione e formazione economico-sociale" ["Modo de producción, relaciones de producción y formación económico-social"] de Gianfranco La Grassa. Para una reconstrucción integral de este debate, ver Simoni, Nicola. Tra Marx e Lenin. La discussione sul concetto di formazione economico-sociale. Napoles, La Cittá del Sole, 2008. 
leninistas, tanto en lo relativo a la prioridad otorgada a las relaciones de combinación, coexistencia y dominancia entre los elementos de cada formación como en lo vinculado a la distinción entre las diferentes historicidades del todo complejo estructurado en instancias.

El resto de las intervenciones de los marxistas franceses coincidían con Glucksmann en la necesidad de aclarar, matizar y problematizar las principales aseveraciones del texto de Sereni. Aunque no realizaban dichas operaciones desde posiciones plenamente althusserianas, los franceses daban cuenta de la importancia adquirida por la concepción althusseriana de la formación económico-social y de la necesidad de complejizar las interpretaciones historicistas y humanistas. Esto era evidente, por ejemplo, en la lectura realizada por Gallissot, quien advertía los peligros que engendraban las interpretaciones estructuralistas pero responsabilizaba del avance de esta corriente a los pobres abordajes contemporáneos del concepto de formación económico-social. En esta misma línea interpretativa, Gallissot afirmaba que el retraso de la investigación sobre formaciones económico-sociales en el campo de los estudios marxistas había posibilitado la introducción entre los intelectuales comunistas de un economicismo que bloqueaba la comprensión de fenómenos superestructurales, una concepción de la ideología que dividía todo lo existente entre el error burgués y la verdad proletaria y una práctica política que no podía incorporar las preocupaciones por la cuestión nacional.

La Advertencia al Cuaderno que reproducía los debates italiano y francés abordaba directamente el conjunto de problemas abiertos por la concepción althusseriana de la formación económico-social. Allí, Aricó se esforzaba por remarcar que las discusiones que se desarrollaron en Critica marxista y La Pensée daban cuenta de la importancia que tenía el concepto de formación económico-social en el campo del marxismo y que tal importancia estaba relacionada con el hecho de que la disputa por la definición del concepto abarcaba una gran cantidad de temas y niveles de análisis que iban desde problemas epistemológicos hasta los de la práctica política. Por ello, la Advertencia se dirigía a una contextualización de los debates mantenidos en el marco del marxismo europeo y a la estructuración de un esquema que operara 
a modo de plataforma para articular dichas discusiones con las necesidades de la izquierda de los países dependientes.

La lectura de la reactivación europea del concepto de formación económico-social realizada por Aricó se detenía en la relevancia teórica y política que el concepto tenía para establecer la dirección de la práctica política del proletariado en la lucha revolucionaria. En sus términos, el núcleo de la discusión en torno al concepto de formación económico-social lo constituía el problema de la relación entre economía y política, lo cual habilitaba a considerar a dicho debate como una expresión de la necesidad de abordar este problema nodal más allá del economicismo y el mecanicismo. En este sentido, Aricó advertía los peligros que entrañaban las posiciones estructuralistas; a su entender, se corría el riesgo de que el proletariado, frente al formalismo estructuralista, se encontrara en una situación crítica similar a la que se enfrentó en el contexto ideológico positivista de la Segunda Internacional. Sin embargo, establecía que las relecturas contemporáneas del concepto de formación económico-social eran fundamentales para un replanteo de los problemas relativos a la construcción de la hegemonía proletaria en los países dependientes y a la conformación de la dictadura del proletariado en la transición hacia la sociedad sin clases, en tanto las interpretaciones economicistas y sus proyecciones políticas reformistas habían dado signos de agotamiento.

El dato más relevante de la Advertencia a El concepto de "formación económico-social" lo constituye el modo en la cual Aricó abordaba la contraposición advertida en las discusiones reproducidas entre las tradiciones historicista y estructuralista del marxismo. Aricó describía las discusiones entre los intelectuales marxistas de la época como un espacio en el cual los problemas tradicionales abordado por la crítica marxista, como la determinación económica, la lucha política, la ideología, la voluntad, la reproducción "tienden a presentarse, como términos escindidos $y$ excluyentes en la antinomia protagonizada por la polémica entre las interpretaciones historicistas y estructuralistas del marxismo, que ha marcado muchas de las investigaciones y de los debates de los últimos años en el 
marxismo" 456 . En este sentido aseguraba que la reactivación del concepto de formación económico-social implicaba una oportunidad para restituirle al marxismo el potencial revolucionario perdido por el rol predominante del concepto de modo de producción y por las consecuentes posiciones políticas etapistas. Según Aricó, la restitución no sería alcanzada mientras el marxismo gramsciano y el althusseriano fuesen concebidos en términos de exclusión e incompatibilidad. Allí radicaba, por lo tanto, según el cordobés, la riqueza de las discusiones reproducidas en el cuaderno:

\begin{abstract}
el trabajo de reconstrucción del significado del concepto de "formación económico-social" en los clásicos del marxismo se plantea como un requisito insustituible para avanzar en la superación de la falsa disyuntiva señalada [entre las interpretaciones humanistas y estructuralistas del marxismo] y con ello para lograr una reinscripción práctica del materialismo histórico en toda su dimensión y eficacia revolucionaria ${ }^{457}$
\end{abstract}

\title{
4.5.4. La revolución que tuvo lugar: Nicos Poulantzas entre el historicismo y el estructuralismo
}

La discusión en el colectivo de Pasado y Presente en torno a las relaciones entre las tradiciones gramsciana y althusseriana adquirió una mayor complejidad durante 1973 a partir de la circulación de la obra de Poulantzas. El hito principal de dicha recepción lo constituyó la edición del Cuaderno $N^{\circ} 48$, titulado Hegemonía y dominación en el Estado Moderno. Este cuaderno contenía una serie de textos tempranos de Poulantzas que constituían

\footnotetext{
456 "Advertencia". El concepto de "formación económico-social". op. cit., pp. 7-8, resaltado nuestro.

${ }^{457}$ Ibid., p. 8, resaltado nuestro. Cabe destacar que el debate sobre el concepto de formación económico-social en América Latina no se circunscribió a la experiencia de Pasado y Presente. Tal como han indagado Leonardo Pérez Leyva y Jaime Ortega, pueden encontrarse inflexiones en los trabajos del boliviano René Zavaleta Mercado, el venezolano José Rafael Núñez Tenorio y el chileno Tomás Vascono, ver Núñez Tenorio, José Rafael. "La teoría de las formaciones socioeconómicas y el pensamiento marxista latinoamericana: originalidad y autenticidad". Pablo Guadarrama (dir.). Despojados de todo fetiche: autenticidad del pensamiento marxista en América Latina. Bogotá, Universidad Central de las Villas, 1999, pp. 137-168 y Ortega, Jaime. "El cerebro de una pasión: Althusser en tres revistas mexicanas". op. cit.
} 
intervenciones previas a la publicación sus obras principales. ${ }^{458}$ Los artículos que integraban la compilación eran "La teoría marxista del Estado y del derecho y el problema de la 'alternativa'", que había sido publicado en Les Temps Modernes en 1964; "Introducción al estudio de la hegemonía en el Estado", publicado en la misma revista en 1965; "La teoría política marxista en Gran Bretaña", editado por New Left Review en 1967; y "Marx y el derecho moderno", que había formado parte en 1967 de un número especial sobre el tema de Archives de philosophie du droit, todos ellos traducidos por María Teresa Poyrazián.

Uno de los elementos más destacables de Hegemonía y dominación en el Estado Moderno lo constituía la inclusión de un prefacio escrito especialmente por el propio Poulantzas dirigido a los lectores latinoamericanos. Este texto contenía una contextualización de la escritura de los artículos compilados así como un recorrido por los itinerarios teóricos y políticos del autor. En ambas dimensiones atendidas en estas notas introductorias, el althusserianismo tenía un lugar destacado. En la presentación de los artículos, Poulantzas remarcaba que éstos no poseían una unidad de problemática teórica. Aclaraba, en consecuencia, que presentaban una unidad en lo relativo a su objeto, el cual estaba vinculado con la investigación sobre el Estado y el derecho en la teoría marxista. Asimismo, ofrecía un repaso sobre el lugar del análisis de la superestructura jurídico-política y de lo político en los textos marxistas en el cual se destacaba la postulación de una ausencia de un nivel de sistematicidad teórica. Las obras políticas del marxismo aparecían como poseedoras de conocimiento en estado práctico, en tanto su elaboración había estado tradicionalmente sometida a la necesidad de guiar la acción política o intervenir en la lucha ideológica. Esta evaluación se coronaba con la

\footnotetext{
458 Estas eran Pouvoir politique et clases sociales de l'etat capitaliste de 1968, Fascisme et dictature: la IIle Internationale face au fascisme de 1970 y Les classes sociales dans le capitalisme aujourd'hui de 1974, todas editadas por François Maspero. Cabe destacar que al momento de ser editado el cuaderno, habían sido publicadas por Siglo XXI México las traducciones de dos de las obras de Poulantzas, Poder político y clases sociales en el Estado capitalismo en 1969 y Fascismo y dictadura en 1971, a las cuales se sumaba su intervención en el Seminario de Mérida reproducida en el volumen Las clases sociales en América Latina de 1973. El libro Las clases sociales en el capitalismo actual será editado en 1976.
} 
caracterización de los trabajos recopilados como una serie de esfuerzos en pos de constituir una teoría marxista de la superestructura del Estado.

La descripción de la coyuntura política y teórica en la cual habían sido escritos sus textos también estaba marcada por la irrupción del althusserianismo. En este caso, Poulantzas destacaba el modo a través del cual la renovación de la teoría marxista propiciada por Althusser había operado a modo de correctivo de sus tempranas posiciones humanistas e historicistas. Así, aparecía diagramado un mapa del marxismo europeo de los primeros años de la década de 1960 en el cual era valorada la riqueza de los autores italianos, como Della Volpe, Umberto Cerroni, Lucio Colletti y Mario Rossi, frente a los franceses, entre los cuales ubicaba a Sartre y los marxistas nucleados alrededor de la revista Arguments, como Henri Lefebvre, Kostas Axelos, Claude Lefort, Pierre Fougeyrollas y Lucien Goldmann. Poulantzas describía sus primeras búsquedas teóricas en el interior del corpus marxista como un camino transitado junto a las formulaciones sartreanas y gramscianas, apropiaciones que eran adjudicadas tanto a la pobreza del marxismo oficial como a su situación de clase pequeñoburguesa.

Reconstruía, luego, un momento de crisis teórica, en el cual habían convergido tanto la consolidación del marxismo althusseriano como una advertencia propia de las limitaciones de las inflexiones humanistas e historicistas del marxismo para pensar las relaciones entre Marx y Hegel, el sujeto de la historia, la ciencia y la ideología, y la génesis de las estructuras. Era por ello que, según su descripción de los artículos publicados, se podía advertir un estadio de sus formulaciones teóricas en las cuales las posiciones humanistas e historicistas habían entrado en crisis, aunque como en todo momento de ruptura, algunos de sus elementos aún convivían con las nuevas posiciones teóricas. Finalmente daba cuenta del espacio ocupado en el terreno marxista al momento de escribir el prefacio, en el cual sus inflexiones humanistas e historicistas eran concebidas retrospectivamente como errores necesarios en el descubrimiento del camino justo, el cual era identificado precisamente con la brecha abierta por Althusser en el campo del marxismo. Poulantzas anunciaba a los lectores latinoamericanos que el pasaje desde las 
posiciones gramscianas y sartreanas hacia las althusserianas había tenido, para él, un tenor revolucionario: "el itinerario teórico de estos artículos presenta, en forma condensada y en un terreno particularmente propicio, la evolución actual del pensamiento marxista: es el reflejo de la revolución que tuvo lugar" 459 .

La disposición cronológica de los textos reproducidos en Hegemonía y dominación en el Estado Moderno le permitía al lector, efectivamente, acompañar el itinerario teórico descripto por Poulantzas. Sus primeros trabajos constituían esbozos de un análisis marxista del derecho y el Estado en las sociedades modernas occidentales, estructurados en base a una problematización de las concepciones marxistas clásicas sobre el nivel jurídico y estatal. Entre éstas, la atención de Poulantzas se centraba en las formulaciones de Michael Reisner y Andrey Vyshinsky sobre el derecho como conjunto de normas emitidas por el Estado que refrendan la explotación entre las clases, y las de Peter Stuchka y Evgeny Pashukanis sobre el derecho como sistema y orden de relaciones sociales ratificado por el Estado. En un primer momento, Poulantzas refutaba estas concepciones a través de argumentos historicistas. A su entender, el marxismo soviético no podía captar que todo conjunto de normas implica una cristalización de valores a partir de los cuales se estructura el orden normativo. En este sentido, le oponía a dichas concepciones la tesis de que los dominios superestructurales, entre los cuales se ubican el derecho y el Estado, están genéticamente estructurados y deben ser captados en base a los valores históricos que le otorgan su especificidad.

En un segundo momento, si bien la intervención poulantziana se mantenía en un sustrato historicista, sus bases gramscianas comenzaban a convivir con problematizaciones de inspiración althusseriana. A partir de este movimiento, las concepciones sobre el derecho y el Estado sustentadas por el marxismo soviético eran consideradas como inflexiones que, al identificar al orden estatal únicamente con la violencia represiva, propician abordajes idealistas y voluntaristas del Estado. Desde esta posición, Poulantzas calificaba

459 "Prefacio". Poulantzas, Nicos. Hegemonía y dominación en el Estado moderno. Córdoba, Pasado y Presente, 1973, p. 10. 
a las nociones marxistas tradicionales sobre el orden jurídico y estatal como concepciones opuestas a un análisis marxista científico del Estado. La lectura poulantziana se detenía en los modos en los cuales dichos abordajes concebían la relación entre los dominios estructurales y superestructurales a fines de advertir los peligros que entrañaba la introducción de elementos voluntaristas y el economicistas en el análisis marxista. Era precisamente frente a estas matrices teóricas que aparecía delineado un programa de análisis en el cual las relaciones entre estructuras y prácticas eran concebidas como elementos constitutivos de un sistema con niveles específicos de realidad. Así, Poulantzas introducía el concepto de formación económico-social en su acepción althusseriana, destacaba el modo en el que éste complejizaba el problema de la temporalidad y remitía a su productividad la posibilidad de superar las concepciones unilineales de la sucesión de los modos de producción. Asimismo, ingresaba en la discusión en torno al concepto de hegemonía en la tradición marxista a través de un movimiento que operaba una demarcación frente a las perspectivas subjetivistas. Para ello, Poulantzas se apoyaba en las formulaciones althusserianas sobre la ideología, las cuales actuaban a modo de base para refutar aquellos enunciados teóricos, como los de Goldmann, Adorno y Marcuse, que tendían a problematizar lo ideológico a partir del problema de la alienación. Como contraparte, la ideología entendida en clave althusseriana se presentaba desempeñando un rol fundamental a los fines de integrar en una perspectiva marxista científica una concepción de lo ideológico como un nivel específico de realidad.

La matriz althusseriana de la intervención de Poulantzas aparece definitivamente consolidada en el texto publicado en New Left Review, el cual constituía una respuesta a las tesis de Anderson y Tom Nairn sobre la hegemonía de la aristocracia terrateniente en la evolución del capitalismo en Gran Bretaña. La oposición planteada frente a los marxistas ingleses adquiría un tono rupturista, en tanto éstos eran presentados como sostenedores de una perspectiva historicista y subjetivista que los conducía a abordar los problemas relativos a las clases, las superestructuras, la hegemonía y la ideología desde un aparato conceptual disociado del análisis marxista científico. Poulantzas 
calificaba a Anderson y Nairn de continuadores de la tradicional concepción de la formación económico-social como una totalidad funcionalista, circular y compuesta por elementos equivalentes, poseedora de una instancia central dadora de sentido y cuyo desarrollo se adjudica al devenir unilateral de dicha instancia, ya sea en su vertiente economicista o voluntarista. De modo divergente con estas tendencias interpretativas, Poulantzas postulaba una concepción de la formación económico-social como un complejo estructurado en niveles específicos con predominio en última instancia de la economía y cuyo sentido está dado por la articulación de los niveles a partir de un modo de producción determinado. El abandono de la perspectiva historicista y subjetivista y la adopción de un punto de vista althusseriano le permitía a Poulantzas fundamentar el análisis de las formaciones sociales en las que existe un desajuste entre la clase políticamente dominante y las estructuras objetivas del Estado. De este modo, la atención prestada a la articulación de los diferentes niveles con sus correspondientes historicidades tornaba inteligible una formación económico-social como la británica, en la cual el carácter feudal de la estructuras del Estado no implicaba necesariamente la hegemonía política de la aristocracia.

Resulta relevante el modo en el cual la sucesión de textos de Poulantzas reflejaba que la consolidación del aparato conceptual althusseriano no implicaba necesariamente el abandono de la tradición gramsciana. Al contrario, el progresivo desplazamiento entre ambas tradiciones estaba acompañado por una reinterpretación de las tesis gramscianas, a través de las cuales éstas eran disociadas de aproximaciones subjetivistas y voluntaristas y traccionadas hacia una lectura estructural. Esta relectura era particularmente evidente en la forma en la cual aparecía problematizado el concepto de hegemonía. Al desmontar la estrecha asociación operada en las tesis de Anderson y Nairn entre la constitución del proletariado como clase hegemónica y la conciencia de clase, Poulantzas intentaba separar el problema de la hegemonía de las concepciones humanistas y voluntaristas de la lucha proletaria. De este modo, aparecía historizada la discusión en torno al concepto de hegemonía en la tradición marxista y se destacaba lo problemático que 
había resultado la interpretación de la cuestión de la alianza entre el proletariado y las otras clases dominadas. En este sentido, la inflexión poulantziana direccionaba el problema de la hegemonía proletaria hacia las coordenadas objetivas de la formación social capitalista, lo cual se traducía en una concepción de la hegemonía en tanto interiorización de las contradicciones entre el proletariado y las clases dominadas y constitución política de los intereses específicos de la clase obrera en interés general de todos los trabajadores.

\subsection{Partir de la fábrica: intelectuales y partido en la conformación de una fuerza revolucionaria}

Durante la segunda etapa de Pasado y Presente se consolidó definitivamente la orientación obrerista esbozada antes de la finalización de la primera etapa de la revista. El texto programático con el que el colectivo pasadopresentista se presentaba luego de ocho años de un trabajo orientado hacia la labor editorial, "La 'larga marcha' al socialismo en la Argentina", articulaba una mirada retrospectiva de la coyuntura pos-Cordobazo con un programa militante centrado en la conquista de la autonomía de la clase obrera. Sobre un sustrato marcadamente antiimperialista, las discusiones en torno a la instauración de un poder revolucionario eran trasladadas desde las concepciones de dicho fenómeno como resultado de la toma del poder hacia la convicción de que la revolución constituye un largo y amplio proceso de lucha anticapitalista. En el marco del direccionamiento conceptual de la revolución como resultado de una larga marcha, la lucha por la constitución de un poder obrero autónomo en la fábrica aparecía priorizado como el elemento capaz de unificar a las masas en un movimiento auténticamente anticapitalista. De este modo volvía a ser delimitado, para la elaboración de una estrategia socialista, el imperativo de partir de la fábrica. Era el enfoque del trabajo militante en la realidad fabril lo que habilitaba, según el editorial pasadoprensentista, pensar desde el interior de la propia clase y lograr así una correcta articulación entre la 
estructura de clase, las relaciones de producción y el programa de lucha obrera $^{460}$.

La orientación obrerista de esta nueva etapa de la revista estaba acompañada, al igual que a mediados de la década de 1965, por lecturas críticas de los impulsos varguardistas de la izquierda argentina. El partir de la fábrica era así postulado como un factor facilitador de la superación definitiva de las posiciones intelectualistas que tendían a definir la situación de la clase obrera únicamente desde una filosofía de la historia y los valores propios de una vanguardia iluminada. La necesidad de derivar las formas organizativas y de lucha de la propia experiencia de la clase obrera, volvía a aparecer como la única forma de articulación entre el marxismo y la clase revolucionaria capaz de sortear los errores dogmáticos de la izquierda argentina.

Lo que sí se presentaba como novedoso en este nuevo momento de intervención de la revista, era el modo en el cual el problema de la autonomía de la clase obrera aparecía vinculado a la cuestión peronista. El análisis desarrollado a lo largo del editorial pasadopresentista, escrito al calor del triunfo del FREJULI, estaba estructurado en base al argumento de que si, a los fines de evitar posiciones vanguardistas, era necesario que la militancia revolucionaria atendiera los condicionamientos históricos y sociales del contexto en el que ésta se desarrollaba, el camino a seguir para la izquierda argentina era el de una articulación entre movimiento de masas y práctica socialista que diera cuenta de la adhesión al peronismo de los sectores populares del país. Un análisis del peronismo que esquivara las trampas de concebirlo como astucia burguesa o como reformismo tradeunionista implicaba, por lo tanto, una problematización de las concepciones clásicas en torno a la conciencia de la clase, la espontaneidad, la vanguardia y los movimientos nacionales. En sus propios términos, todos estos problemas hacían que en este momento se planteara:

\footnotetext{
${ }^{460}$ Si bien el obrerismo se manifiesta explícitamente en 1973, Aricó venía llevando a cabo un trabajo de investigación sobre el claisismo cordobés desde comienzos de la década de 1970, ver Schmucler, Héctor; Malecki, Sebastián; Gordillo, Mónica. El obrerismo de Pasado y Presente. Documentos para un dossier (no publicado) sobre SITRAC-SITRAM. Buenos Aires, AI Margen, 2009.
} 
como objetivo básico de PASADO Y PRESENTE, la necesidad de analizar la originalidad del proceso de constitución de una fuerza socialista de masas en Argentina, como un caso en que la relación 'conciencia-espontaneidad' se muestra 'impura', en el que, por lo tanto, es necesario impulsar el desarrollo de una conciencia socialista a partir de las luchas de una clase políticamente situada en el interior de un movimiento nacionalpopular $^{461} 462$

La demarcación del mencionado horizonte político estaba articulada con la consolidación de un viraje en la lectura del corpus gramsciano. A modo de punto de llegada de las discusiones en torno al humanismo y al historicismo gramscianos, que expresaban el agotamiento de las lecturas clásicas de Gramsci, y de la decisión política de entroncar la experiencia pasadopresentista con las luchas del peronismo revolucionario, reveladora de una apuesta por la intervención militante concreta, la segunda etapa de la revista estuvo marcada por un direccionamiento hacia el Gramsci de L'Ordine Nuovo y la experiencia de los consejos de fábricas. Resulta indicativo en este sentido la compilación de textos del Gramsci ordinovista reproducida en el primer número de la nueva etapa con el título "Democracia obrera y socialismo". Dicha selección daba cuenta de los esfuerzos gramscianos por demostrar tanto las virtudes de la experiencia consiliar como los problemas derivados del otorgamiento de una centralidad excluyente al Partido. Adquirían relevancia, por ende, argumentos relativos a la necesidad de favorecer y articular las actividades e instituciones propias de la vida social de la clase obrera, al sistema de la democracia obrera como generador privilegiado de experiencia política para los trabajadores y de preparación para el ejercicio del poder, al consejo de fábrica como modelo del estado proletario en tanto instancia de organización, solidaridad y colaboración entre los trabajadores, y a la inconveniencia de que el partido y los sindicatos

\footnotetext{
461 "La 'larga marcha' al socialismo en la Argentina". Pasado y Presente. № 1 nueva serie, abril-junio de 1973, p. 20.

${ }^{462}$ Sobre la cuestión peronista en la segunda etapa de la revista, ver Casco, José. "Ser o no ser. Qué hacer con Perón y el peronismo". Prismas. Revista de historia intelectual. $\mathrm{N}^{\circ} 18,2014$, pp. 217-220.
} 
se ubiquen como tutores o conductores de la experiencia política de los consejos de fábrica ${ }^{463}$.

La selección de textos gramscianos estaba acompañada por una introducción de Aricó, que llevaba el título "Espontaneidad y dirección conciente en el pensamiento de Gramsci" y se ofrecía como delimitadora de los parámetros de lectura de los artículos reproducidos. Allí, Aricó contextualizaba la experiencia de los consejos de fábrica desarrollados en Turín durante el bienio rojo de 1919-1920, destacando la iniciativa de L'Ordine Nuovo y caracterizando a Gramsci como el traductor más original del leninismo a la realidad italiana de la posguerra. En relación a la especificidad del movimiento consiliar, se valoraba el modo en el cual los consejos habían constituido instancias que permitieron que la vanguardia deje de ser un elemento externo al proletariado. De esta forma, según Aricó, los trabajadores habían podido vincularse con la vanguardia a partir de la singularidad de su experiencia, apuntando en este sentido a revertir la relación pedagógica y abstracta entre Partido y clase obrera. Las postulaciones gramscianas de la revolución como un proceso a través del cual el proletariado se expresa a través de sus propios órganos de lucha eran leída por Aricó como indicativas de los vínculos de la teoría gramsciana con las formulaciones de Luxemburgo, del Lenin de las tesis de Abril y de Mao. Denunciados el espontaneísmo y el vanguardismo como las dos caras de un mismo problema, la conceptualización del proceso revolucionario era direccionada hacia la articulación entre la lucha en los lugares de trabajo y las luchas desarrolladas en el seno de las otras contradicciones del sistema capitalista.

En consonancia con la importancia otorgada a las formulaciones del Gramsci consejista, en la segunda etapa de la revista tendrán un lugar destacado las discusiones abiertas por André Gorz sobre el problema del control obrero. El rol desempeñado por los desarrollos teóricos gorzianos son especialmente perceptibles en el número $2 / 3$ de la segunda etapa de la revista,

463 Para una reconstrucción ampliada del ordinovismo en la revista, ver Ouviña, Hernán. "De la Petrogrado italiana a la Turín argentina. La recepción del joven Gramsci por el grupo Pasado y Presente". Estudios latinoamericanos. $\mathrm{N}^{\circ} 33$, enerojunio 2014, pp. 15-65. 
cuyo dossier sobre "Problemas del movimiento obrero" incluía el texto del francés titulado "Táctica y estrategia del control obrero". La intervención de Gorz, enmarcada en el contexto de luchas obreras europeas y el programa general de conquista del proceso de trabajo por parte de los trabajadores, intentaba dar cuenta de lo desfasado que se encontraban los sindicatos tradicionales frente a las transformaciones en las formas de producción del capitalismo contemporáneo. La propuesta de control obrero se presentaba, en este sentido, como la forma más adecuada de lucha frente a los procesos de predeterminación de las condiciones de trabajo y de globalización de la política gerencial. Así, el direccionamiento de la acción de los trabajadores hacia el control obrero aparecía delimitado por un riguroso diagnóstico de la experiencia de la clase obrera, en este caso atravesada por procesos de modificación de los tiempos de producción, de las calificaciones y los salarios. La no adecuación de los sindicatos tradicionales a esta nueva situación de la clase obrera hacía que en la perspectiva de Gorz dichos espacios fueran concebidos como instituciones conservadoras en tanto expresaban solamente demandas realistas y condicionan la lucha de los trabajadores dentro de los convenios establecidos con la patronal.

La intervención de Nun que acompañaba el texto de Gorz, "El control obrero y el problema de la organización”, abordaba el problema de la estrategia de lucha obrera desde un marco teórico que convergía con las orientaciones gorzianas. Los argumentos desarrollados por Nun en torno a la organización estaban marcados por la vinculación entre los problemas relativos a la consigna de control obrero, como la autoempancipación del proletariado y la concepción de la revolución como largo proceso social, y las posiciones políticas derivadas de la asunción de un marxismo mecanicista, como el vanguardismo y el intelectualismo. La postulación de la fábrica como espacio paradigmático de la lucha en pos de la conquista de la autonomía obrera era contrapuesta por Nun a aquellas concepciones sobre la emancipación del proletariado estructuradas en base al rol desempeñado por el partido y la ciencia. Así se desarrollan sucesivamente oposiciones entre la consigna del control obrero y la concepción del proletariado como "mero soporte o portador 
de estructuras que se reproducen más o menos mecánicamente"464, posición acusada de ignorar las relaciones dialécticas entre sujeto y objeto, y actividad humana y realidad social, y la de los intelectuales radicalizados como "arcángeles del progreso científico" ${ }^{465}$, desviación atribuida a la idea errónea de que la conciencia proletaria puede ser determinada por una conciencia externa a la clase obrera. En consecuencia, el vanguardismo, el iluminismo y el cientificismo eran integrados por Nun en una crítica general de aquellos marxismos que tienden a fetichizar la estructura partidaria y la acción de sus intelectuales:

no puede extrañar, entonces, que este lugar de encuentro entre el proletariado y su conciencia externa [EL PARTIDO] pase a ser casi naturalmente el verdadero sujeto del discurso revolucionario y que el papel, la estructura y el funcionamiento de la organización se consideren susceptibles de una teorización autónoma y universalmente válida ${ }^{466} 467$

\subsection{Una diferencia necesaria: estado, política e ideología entre Gramsci y} Althusser

Sobre el sustrato teórico delineado por la apropiación del Gramsci consejista, la adopción de los desarrollos teóricos contemporáneos sobre el control obrero y la consecuente posición anti-vanguardista, los análisis coyunturales de la realidad argentina y latinoamericana aparecidos en la

\footnotetext{
${ }^{464}$ Nun, José. "El control obrero y el problema de la organización". Pasado y Presente. $\mathrm{N}^{\circ} 2$ nueva serie, julio-dicimebre de 1973, p. 208.

465 Ibid., p. 209.

${ }^{466} / d$.

${ }^{467}$ En consonancia con la publicación del texto de Gorz y el análisis desarrollado por Nun, el dossier "Problemas del movimiento obrero" incluía un denso artículo de Antonio Carlo sobre "La concepción del partido revolucionario en Lenin". La aproximación a la obra de Lenin allí delimitada conllevaba una intención aperturista en torno a la interpretación de las formulaciones leninistas en torno a la relación entre vanguardia y masas. La exégesis realizada por Carlo constituía un esfuerzo por demostrar que lo que se entendía por "concepción leninista del partido" correspondía únicamente al momento del Qué hacer y a la lectura particular desarrollada posteriormente por el stalinismo. Remarcaba, de este modo, que durante el período revolucionario y especialmente a partir de la consigna "todo el poder a los soviets", las concepciones de Lenin sobre la relación partido-masas conllevaban una corrección de las tesis vanguardistas e idealistas sostenidas a comienzos de siglo.
} 
segunda etapa de la revista estaban dotados de un explícito tenor antialthusseriano. Esta lectura reactiva del marxismo althusseriano se expresa especialmente en el texto "Clases dominantes y crisis política en la Argentina actual" de Portantiero, así como en "La pequeña burguesía y el problema del poder: el caso chileno" del colaborador brasileño Rui Mauro Marini, ambos publicados en el primer número de la nueva etapa. En ambas intervenciones se deslizaban advertencias sobre la difusión y apropiación de dimensiones teóricas y analíticas de raigambre althusseriana, como la concepción estructural del modo de producción, la interpretación poulantziana de la hegemonía, la torsión anti-humanista y anti-historicista del corpus marxista, y la concepción del Estado y la ideología cifrada en el concepto de AIE.

El análisis de Portantiero intentaba dar cuenta de las relaciones de fuerza de la Argentina de 1973 a partir de un repaso de las transformaciones iniciadas en el país con el golpe de Estado de 1966. Con el objetivo político de contribuir al desarrollo de un bloque social de poder alternativo y con la prioridad analítica otorgada a la relación entre las contradicciones económicas y las contradicciones políticas, Portantiero explicitaba un marco interpretativo de dichas contradicciones que atendía alguno de los núcleos revitalizados por el althusserianismo pero que se revelaba hostil frente a algunas inflexiones del marxismo estructuralista. El principal supuesto que guiaba este análisis de la coyuntura argentina estaba vinculado con la relación entre las contradicciones económicas y las contradicciones políticas y consistía particularmente en la postulación de la existencia de temporalidades específicas en cada uno de los mencionados niveles. Este supuesto implicaba la noción de que las contradicciones en el nivel político no pueden ser concebidas a modo de despliegue o proyección de las contradicciones en el nivel económico. Asimismo, esta conceptualización de la relación entre las diferentes contradicciones conllevaba un condicionamiento de la fusión de las diversas temporalidades a la elaboración de una estrategia revolucionaria correcta en tanto ésta permitiría alcanzar el único proceso capaz de lograr dicha coincidencia, es decir, la revolución. 
En la lectura de Portantiero eran priorizadas las categorías gramscianas de alianza de clases y bloque de fuerzas. La primera remitía a posiciones estructurales en tanto era definida como la articulación de clases y fracciones de clases establecida al margen de la voluntad de los actores y a través de la cual se les adjudica intereses objetivos de acuerdo a la especificidad de las contradicciones económicas. La segunda divergía de la interpretación poulantziana de Gramsci en tanto era concebida como el proceso de constitución política de las clases sociales en el cual desarrollan un rol fundamental la conciencia y la voluntad de los actores. De este modo, las fuerzas sociales eran remitidas a la interacción entre objetividad y experiencia, estructura y superestructura, y posición subjetiva y organización voluntaria.

Asimismo, Portantiero explicitaba un punto de partida analítico que daba cuenta de la existencia de contradicciones al interior de la alianza de clases y el bloque de fuerzas y de relaciones de tipo asimétricas entre sus componentes. Era precisamente el énfasis en la dimensión asincrónica de la contradicción el que habilitaba el análisis de la coyuntura argentina en clave de empate hegemónico, a través de la cual la situación era caracterizada como una fase de no correspondencia entre la nueva dominación económica y la nueva dominación política, en la cual ninguna de las clases que lideraba los polos de la contradicción principales, es decir capital monopolista y proletariado industrial, había logrado hegemonizar un bloque de fuerzas sociales.

Para Portantiero, un análisis como el llevado a cabo en este artículo requería una serie de precisiones en torno a las coordenadas desde las cuales era realizado. En tanto los objetos abordados y las aproximaciones analíticas por él priorizados coincidían con los del marxismo estructuralista y las lecturas de la coyuntura inspiradas en dicho marco interpretativo, aparecía postulada como necesaria la explicitación de que su intervención no formaba parte del conjunto de estudios desarrollados a partir de la inflexión de dicha corriente del marxismo contemporáneo. En primer lugar, Portantiero remarcaba que su análisis partía de una posición marxista que concebía a la sociedad como un entretejido de relaciones sociales, el cual era remitido a los comportamientos de los actores sociales y disociado de la concepción de la sociedad como 
yuxtaposición de niveles estructurales. Asimismo, remitía la necesidad de enfatizar esta diferencia a la importancia adquirida por ciertas expresiones del marxismo estructuralista: "Parecería redundante recordarlo, pero ante la ola de nominalismo estructuralista que tiende -al menos en su uso vulgar- a fetichizar los instrumentos analíticos como si fueran estructuras concretas, la reiteración no es inútir ${ }^{468}$. De este modo, el uso de distinciones analíticas y diferenciaciones entre niveles de la realidad social era condicionado al mantenimiento de un sustrato marxista que concibiera a la sociedad como el producto de la actividad de los hombres y que entendiera a las categorías analíticas como elementos que permiten comprender la relación entre estructuras concretas. Era la autonomización del análisis estructural de dicho sustrato lo que producía, según Portantiero, una reificación de las categorías analíticas y la configuración de un marxismo "según el cual la historia sería 'producto' de las estructuras, mientras la acción humana, la voluntad, la experiencia, quedan reducidas a un rol subordinado" 469 .

Al igual que en la intervención de Portantiero, el althusserianismo ocupaba en el texto de Marini el lugar de oposición frente a las propios argumentos sustentados. En este caso, la circulación de las innovaciones propiciadas por el marxismo althusseriano era articulada con las discusiones desarrolladas alrededor de la vía chilena al socialismo. En el marco de la actualización generada por el proceso chileno de los debates en torno a la relación entre la toma del poder político y la transformación del modo de producción, el análisis de Marini jerarquizaba las conceptualizaciones que tendían a priorizar las dimensiones coercitivas del aparato de Estado. En este sentido aparecía como privilegiada la distinción entre el Estado, entendido como la cima del sistema de dominación, y el sistema de dominación en sí, definido como el conjunto de elementos sobre los que una clase basa su poder. En consecuencia, el análisis del caso chileno enfatizaba la separación entre los problemas de la conquista del aparato de Estado y los del poder proletario, y destacaba la posibilidad que le ofrecía la posesión del poder del Estado al

468 Portantiero, Juan Carlos. "Clases dominantes y crisis política en la Argentina actual". Pasado y Presente. $N^{\circ} 1$ nueva serie, abril-junio de 1973, p. 33.

469 Ibid., p. 34. 
proletariado de establecer alianzas con las demás clases explotadas y modificar así la correlación de fuerzas en pos de la construcción del socialismo. Frente a esta posición, las formulaciones de Althusser sobre los AIE y su problematización por parte de Poulantzas eran señalados por Marini como expresiones de un marxismo que tendía a borrar los límites del Estado hasta hacerlo coincidir con el sistema de dominación. En la lectura realizada por Marini del marxismo althusseriano aparecía se destacaba la validez de un análisis en clave de AIE para regímenes excepcionales, como los fascistas, pero también advertida la dificultad que tiene este tipo de perspectivas para abordar la complejidad de las relaciones entre el Estado e instituciones como los sindicatos en sociedades como las latinoamericanas.

\subsection{A modo de cierre}

La representación tradicional acerca de las lecturas de Althusser en el marco de la experiencia de Pasado y Presente estuvo mediada por una marcada hostilidad al corpus althusseriano. Explicable a partir de la traducción de Gramsci a la realidad política de la década de 1980, la hostilidad redundó en una historización particular de la difusión de la obra de Althusser en las décadas de 1960 y 1970. Esta interpretación estableció un sentido común acerca de la necesaria incompatibilidad entre las tradiciones gramscianas y althusseriana. Aplicada a la experiencia de recepción de Gramsci en América Latina, este sentido común propició un solapamiento de las relaciones de compatibilidad e intercambio entre el gramscianismo y el althusserianismo. Un recorrido por la experiencia de Pasado y Presente atenta a las particularidades de su gestación y las torsiones de su itinerario nos ha permitido resaltar un conjunto de proposiciones políticas y teóricas en las cuales los aportes de Gramsci y Althusser se articularon de manera productiva.

Si bien desarrolladas en marcos nacionales diferentes, la experiencia de Pasado y Presente y el althusserianismo comparten el malestar con la política comunista stalinista y el afán renovador del corpus marxista. La mediación gramsciana de la salida de Pasado y Presente de la órbita del comunismo 
partidario le otorgó a esta experiencia una marcada tendencia humanista e historicista. El seguimiento que los miembros de la revista realizaron de las transformaciones de la clase obrera en la década de 1960 estuvo fuertemente signada por el problema de la alienación. Asimismo la lectura de los Manuscritos de 1844 y la atención prestada a las expresiones del marxismo fenomenológico sedimentaron un posicionamiento hostil a la apertura del marxismo a la corriente estructuralista. Sin embargo, al convivir con un esfuerzo por superar el dogmatismo de la cultura comunista argentina, el marxismo de Pasado y Presente fue permeable al desarrollo de corrientes marxistas cientifizadoras y a tradiciones teóricas no-marxistas. En este sentido analizamos el lugar que la revista le otorgó a la renovación propuesta por Della Volpe, crítica del historicismo gramsciano, y a análisis inscriptos en el paradigma estructural, como los de Verón y Masotta.

Sobre este sustrato se llevaron a cabo las primeras lecturas de Althusser desarrolladas por Aricó. Receptiva de las pretensiones renovadoras de su obra, pero cautelosa en cuanto a sus consecuencias políticas, esta aproximación se centró principalmente en las impugnaciones althusserianas al marxismo gramsciano. Las lecturas subsiguientes, sin embargo, dan cuenta de una incorporación productiva de las formulaciones althusserianas. En este sentido, analizamos los efectos de la crítica althusseriana a Gramsci en una aproximación renovada al marxista italiano. El repaso por el modo en el cual esta lectura fue vista por otros espacios de recepción de Gramsci nos permitió calibrar el tenor de la presencia de Althusser en este ejercicio modernizador. Por otra parte el seguimiento realizado del debate acerca del concepto de formación económico-social nos permitió dar cuenta de la articulación entre las proposiciones gramscianas y althusserianas. Captadas en términos de una falsa disyuntiva, dichas proposiciones fueron procesadas a través de un esquema de lectura estructurado en torno a las relaciones de solidaridad e intercambio entre Gramsci y Althusser. Finalmente la edición de un cuaderno dedicado especialmente a Poulantzas da cuenta de la atención concitada por un pasaje desde el marxismo historicista hacia el marxismo estructural. La compilación de los primeros textos de Poulantzas reflejaba tanto el carácter 
correctivo que la lectura de Althusser había tenido sobre las aproximaciones a Gramsci como la productividad de un ejercicio teórico en el cual convergían ambas tradiciones del marxismo contemporáneo.

De manera alternativa a las afirmaciones inscriptas en el sentido común con el cual iniciamos el capítulo, el repaso de la segunda etapa de la revista nos permitió evidenciar que la hostilidad hacia el althusserianismo provino de un giro específico en la experiencia de la revista. De cara a la coyuntura de 1973, Pasado y Presente acompañó su acercamiento al peronismo revolucionario con una recepción del Gramsci consejista. La importancia que sus miembros le otorgaron al espacio fabril y a la autonomía obrera redundó en una refutación de las corrientes marxistas proclives a priorizar la forma partido y las tareas de vanguardia de los intelectuales. Por otra parte los análisis de la coyuntura que siguieron operando a partir del concepto de formación económico-social, como los de Portantiero, se caracterizaron por un esfuerzo de desligar las categorías gramscianas de sus acepciones estructuralistas. En este sentido advertimos los esfuerzos en separar los conceptos de hegemonía, Estado e ideología de los significados que le había otorgado las propias formulaciones althusserianas o los ejercicios de articulación entre Gramsci y Althusser como los de Poulantzas. 


\section{Capítulo 5}

\section{Entre Lacan y el freudomarxismo: el Althusser de los psicoanalistas argentinos}

\subsection{Introducción}

En este capítul se reconstruyen las lecturas de Althusser desarrolladas en el campo psicoanalítico argentino. La primera parte está dedicada a analizar el lugar de las tesis althusserianas en el itinerario de Oscar Masotta. Nos detenemos en primer lugar en el año 1965 en tanto momento clave de su pasaje desde la fenomenología hacia el estructuralismo. En base a este quiebre nos remontamos a la primera mitad de la década de 1960 a los fines de delimitar la especificidad de la estación fenomenológica de su trayecto intelectual. Al respecto reconstruimos los efectos de la lectura sartreana en la delimitación de los vínculos entre marxismo y psicoanálisis. En este sentido nos concentramos en la coloración particular que el marco fenomenológico le otorgó a sus primeras lecturas de Lacan. Veremos que durante un tiempo el estructuralismo convivió con la tradición fenomenológica teniendo como resultado la articulación entre Lacan y la psicología concreta. Comenzamos luego a dar cuenta de los efectos de la lectura de Althusser en el desplazamiento hacia un terreno estructuralista y el consecuente abandono de la reflexión fenomenológica. Leídos desde estos marcos, la polémica entablada por Masotta con Sebreli -a propósito de la discusión que éste mantuvo con Verón- nos permitirá evidenciar la productividad de la jerarquización althusseriana del trabajo teórico. Luego nos detenemos en la particularidad de la estación estructuralista de su itinerario. Al respecto destacamos la importancia de la lectura de Althusser en el programa de un regreso científico a Freud. Así analizamos los efectos de dicho programa en el debate que enfrentó a Masotta con Emilio Rodrigué. Por último nos detenemos en los ejercicios de 
rectificación de sus primeras lecturas de Lacan llevados a cabo en la década de 1970. Nos interesa especialmente destacar la importancia de Althusser en la corrección de antiguas aproximaciones fenomenológicas a la propuesta teórica del psicoanalista francés.

En la segunda parte nos focalizamos en las concepciones sobre el vínculo entre marxismo y psicoanálisis sostenidas por los grupos que protagonizaron la ruptura de la APA. Veremos al respecto que los modos predominantes de representar dicha relación se filiaban en la tradición freudomarxista. Constataremos que si bien distintos aspectos propios del althusserianismo estuvieron presentes en los posicionamientos delimitados, las operaciones de aproximación entre marxismo y psicoanálisis se cifraban en términos de analogía. Nos concentramos luego en la particularidad de los posicionamientos que en el contexto de crisis de la APA acudían a las formulaciones althusserianas. Nos interesa indagar especialmente en el carácter anti-lacaniano de las lecturas de Althusser desarrolladas en el proceso de escisión de la institución psicoanalítica. Veremos que los textos que representaron dichas lecturas se pretendían equidistantes del freudomarxismo y el lacanismo. Finalmente nos detenemos en el trabajo llevado a cabo en la primera mitad de la década de 1970 por Gregorio Baremblitt, el psicoanalista que había propiciado a fines de la década de 1960 el posicionamiento estructurado alrededor de las tesis althusserianas. Nos interesa analizar tanto la profundización de las críticas al freudomarxismo y al lacanismo como la introducción de la problemática de la ideología y los AIE.

La última parte del capítulo está dedicada a calibrar los efectos de las lecturas de Althusser llevadas a cabo por el lacanismo y el freudomarxismo. En primer lugar nos concentramos en la obra de León Rozitchner a los fines de delimitar un freudomaxismo anti-althusseriano. Un repaso por el trabajo desarrollado alrededor del problema de la subjetividad en la primera mitad de la década de 1960 nos permitirá comprender el carácter reactivo de su lectura del anti-humanismo althusseriano. Pasamos luego al otro lado del campo psicoanalítico argentino con el objetivo de delimitar una lectura lacaniana que no podía procesar el althusserianismo anti-lacaniano difundido a lo largo del 
proceso de crisis de la APA. En este sentido analizamos el debate desarrollado en Los Libros entre Baremblitt, quien defendía un Althusser sin Lacan, y Miriam Chorne y Germán García, propiciadores de una articulación entre ambos corpus teóricos.

\subsection{5, annus mirabilis}

Comencemos destacando una convergencia significativa: el momento de la irrupción de Althusser en el escenario político-intelectual europeo coincidió con una de las principales torsiones del itinerario teórico de Masotta. En 1965, la editorial Jorge Alvarez publicó en formato libro una serie de textos que Masotta había escrito a fines de la década de 1950. El volumen en cuestión, Sexo y traición en Roberto Arlt, daba cuenta de una aproximación a la obra del escritor argentino realizada desde los marcos de la fenomenología e inspirada en gran medida en Saint Genet de Sartre. Fiel a su estilo de intervención, Masotta utilizó este acontecimiento editorial para difundir un relato sobre su trayectoria en el campo intelectual argentino entre fines de la década de 1950 y mediados de la de 1960.

En la comunicación leída en la presentación del libro, titulada "Roberto Arlt, yo mismo", contextualizaba la escritura de los textos en un momento de su vida en el que se encontraba fuertemente influenciado por Sartre y MerleauPonty, al mismo tiempo que le advertía a la audiencia que el momento fenomenológico de su producción intelectual estaba llegando a su fin. En un sentido retrospectivo, el vínculo establecido con los referentes de la fenomenología francesa aparecía en términos de apasionamiento y hasta de superposición. En dicho relato, Masotta se volvía prescindente y su lectura de Arlt adquiría la forma de un despliegue de las intuiciones cifradas en Saint Genet: "Después de leer a Sartre [...] mi libro sobre Arlt ya estaba escrito [...] cualquier que hubiera leído a Sartre podía haber escrito ese libro" ${ }^{470}$.

\footnotetext{
${ }^{470}$ Masotta, Oscar. "Roberto Arlt, yo mismo". Sexo y traición en Roberto Arlt. Buenos Aires, Jorge Alvarez, 1965, p. 88.
} 
El despegue progresivo de la plataforma teórica que había conducido a Masotta hacia aquella lectura de Arlt se vinculaba con dos elementos centrales de su biografía. Uno de ellos, de índole personal: la muerte de su padre. Este acontecimiento era invocado como un factor condicionante de un replanteo de los modos a través de los cuales este intelectual se representaba a sí mismo y de una consecuente apertura al psicoanálisis: "me tuve que olvidar de golpe de Merleau-Ponty y Sartre [...] del 'compromiso' y de las ideas que había forjado sobre mí mismo. Tuve entonces que buscarme un psicoanalista" ${ }^{\text {"171. }}$. El otro, relacionado con ciertos movimientos de relevo operados en la filosofía contemporánea. La inminente consolidación del paradigma estructural actuaba en el discurso de Masotta como un elemento que permitiría prontamente un replanteo de los problemas del marxismo. El declive de la fenomenología y la creciente importancia de las investigaciones sobre el lenguaje, las estructuras y el inconsciente justificaban un cuestionamiento de las antiguas posiciones sartreanas y una lectura negativa de las relaciones entre marxismo y fenomenología: "Recién hoy comienzo a comprender que el marxismo no es, en absoluto, una filosofía de la conciencia; y que por lo mismo, y de manera radical, excluye a la fenomenología"472.

Debe destacarse que la comunicación leída en ocasión de la edición de Sexo y traición en Roberto Arlt da cuenta de un momento del itinerario de Masotta en el cual el debilitamiento de la perspectiva fenomenológica no se correspondía necesariamente con una legitimidad del análisis estructural. Como afirmaba Masotta en su citadísima respuesta a la pregunta ¿conciencia o estructura?, la decidida opción por la segunda estaba atada a una preocupación por la consecuente prescindencia de la primera ${ }^{473}$. Es decir, si bien el desarrollo de los saberes modernos abría la posibilidad de una actualización de la filosofía marxista, la superación de la fenomenología podía conllevar una liquidación de la potencialidad política que entrañaban las

\footnotetext{
${ }^{471}$ Ibid., p. 94.

${ }^{472}$ Ibid., p. 98.

473 "A la alternativa: ¿o conciencia o estructura?, hay que contestar, pienso, optando por la estructura. Pero no es tan fácil, y es preciso al mismo tiempo no rescindir de la conciencia (esto es, del fundamento del acto moral y del compromiso histórico y político)". Id.
} 
posiciones teóricas centradas en la conciencia. Si bien evidente en el texto leído ante la audiencia, poco se ha indagado en los modos a través de los cuales la materialidad del libro editado por Jorge Alvarez permite constatar la persistencia de postulados fenomenológicos. En primer lugar, los textos escritos a fines de la década de 1950 que Masotta aceptaba publicar en 1965, propiciaban una reactualización de la filiación sartreana en la lectura de textos literarios. Es decir, al mismo tiempo que se optaba por la estructura, se reeditaba un trabajo en el cual la obra literaria era pensada en términos de una dialéctica entre profundidad y mundo, en el que se indagaba en la humillación, el silencio y la angustia de los personajes, y en la que los individuos eran captados como aquello que los otros habían decidido que fueran. Lo más significativo se encontraba, sin embargo, en los elementos anexados al texto de 1958 y preparados especialmente para la edición de mediados de la década de 1960. Por un lado, un epígrafe con una cita de Crítica de la razón dialéctica reforzaba aquel rechazo de Masotta a una prescindencia absoluta de la conciencia ${ }^{474}$. Por el otro, un prólogo en el cual la literatura de Arlt era ligada estrechamente a la problemática marxista de la alienación. Leída a través del prisma de los Manuscritos económico-filosóficos, la preocupación de Marx acerca del carácter alienante del trabajo en la sociedad capitalista era puesta en sintonía con la centralidad de la masificación y el anonimato del individuo en los textos de Arlt. Al respecto, resulta sumamente llamativo que dicha sintonización alcanzaba tal densidad que llevaba a Masotta a afirmar que la obra de Arlt constituía "un cierto y preciso comentario" ${ }^{\text {"45 }}$ de las palabras de Marx acerca del hombre como absolutamente libre $y$ absolutamente determinado.

\subsection{El momento fenomenológico: marxismo, fenomenología y estructuralismo en los tempranos 1960}

\footnotetext{
${ }^{474}$ La cita en cuestión: "La subjetividad que aparece entonces, en toda su abstracción, como la condenación que nos obliga a realizar libremente y por nosotros mismos la sentencia que una sociedad 'en curso' ha dictado sobre nosotros y que nos define a priori en nuestro ser. Es a este nivel que encontraremos lo práctico-inerte". Sexo y traición en Roberto Arlt. Buenos Aires, Jorge Alvarez, 1965, p. 8.

475 Ibid., p. 14.
} 
Un breve repaso por las mediaciones teóricas a través de las cuales Masotta intervino en la cultura argentina desde fines de la década de 1950 hasta mediados de la de 1960 permite precisar la singularidad de aquel momento fenomenológico denunciado en ocasión de la publicación de Sexo y traición en Roberto Arlt y delimitar, por lo tanto, las características del sustrato intelectual sobre el cual se producirá su encuentro con Althusser a partir de $1965^{476}$.

Una de las intervenciones que habilita dicha tarea es el comentario realizado por Masotta a propósito de Un dios cotidiano, la novela de David Viñas publicada en 1957. Esta lectura, realizada de manera contemporánea a la escritura de los textos sobre Arlt, se filiaba en las interpretaciones francesas de Hegel realizadas en la década de 1950, fundamentalmente la de Jean Hyppolite, e intentaba delimitar la especificidad de la dialéctica de reconocimiento establecida entre los personajes de la novela. En este sentido, Masotta reconocía en la escritura de Viñas un esfuerzo por iluminar el momento en el que el hombre toma conciencia de que es un ser encarnado y que no existe un yo aislado. Le reclamaba, sin embargo, no haber propiciado una profundización de ese reconocimiento, a través del cual el hombre podría avanzar hacia un trabajo de desalienación que le permitiera diferenciar su propio yo con respecto al yo de los otros. Es este marco, la trascendencia del hombre, problema a través del cual Masotta se identificaba con Viñas, era cifrada en términos de una recuperación de la totalidad de lo humano ${ }^{477}$.

Resulta sumamente relevante analizar el modo en el que las primeras lecturas de Lacan desarrolladas por Masotta se realizaron desde la misma matriz fenomenológica que delineó los mencionados abordajes de la obra de

\footnotetext{
${ }^{476}$ Para un abordaje integral de esta etapa de Masotta, ver Scholten, Hernán. Oscar Masotta y la fenomenología. Un problema en la historia del psicoanálisis. Buenos Aires, Atuel, 2001. Para una lectura centrada en la importancia de Sartre, ver Piglia, Ricardo. "Improvisaciones sobre un tema de Oscar Masotta". AAVV. Oscar Masotta. Lecturas críticas. Buenos Aires, Atuel-Anáfora, 2000, pp. 120-132. Para un análisis de la recepción de Merleau-Ponty, ver Testa, Adriana. "El duro banco del objeto". Ibid., pp. 87-97.

${ }^{477}$ Masotta, Oscar. "Explicación de Un dios cotidiano". Comentario. Publicación del Instituto Judío-Argentino de Cultura e Información. Año 5, N² 2, 1958, p. 7.
} 
Arlt y de Viñas. Como ha sido ampliamente señalado, la primera mención de Masotta a Lacan se encuentra en su artículo "La fenomenología de Sartre y un trabajo de Daniel Lagache", publicado en 1959 en la revista Centro a modo de introducción a las traducciones de "La trascendencia del ego" de Sartre y "Fascinación de la conciencia por el yo" de Lagache ${ }^{478}$. En aquella ocasión, Masotta destacaba que la publicación de ambos trabajos permitía advertir "Ios efectos positivos de la investigación fenomenológica sobre la estructura de la relación de la conciencia con el mundo", ingresaba en el debate entre MerleauPonty y Sartre a propósito de la filosofía de la conciencia -terciando a favor de este último- y utilizaba el texto de Lagache a los fines de advertir la especificidad de los vínculos entre fenomenología y psicoanálisis. Así, la primera referencia de Masotta al psicoanálisis lacaniano se desarrollaba sobre un contexto teórico que enfatizaba la importancia de Sartre en la definición del yo como objeto trascendente y de la relación de la conciencia con el yo como una relación de objeto, y que refrendaba la formulaciones de Lagache acerca de la objetivación del yo como la principal tarea del psicoanálisis.

En términos específicos, al remitir la publicación de Lagache a la SFP, Masotta mencionaba la importancia adquirida por "el recelado Jacques Lacan"479 y el grupo de psicoanalistas separados de dicha institución a partir de una crisis interna. Al respecto, Masotta explicaba con un inocultable interés la forma a través de la cual los lacanianos cuestionaban la teoría y la práctica psicoanalítica defendidas por la API. Por un lado, la advertencia sobre la transformación del psicoanálisis en una institución y la consecuente pérdida del rol cuestionador que le había otorgado el fundador de la disciplina. De este modo, Masotta daba cuenta de la disputa establecida por los lacanianos alrededor de las condiciones y características de la institución dedicada a la formación del psicoanalista. Por el otro, la lucha contra la pasividad del psicoanálisis francés ante la penetración del culturalismo estadounidense, a través de un trabajo de regreso a Freud guiado por formulaciones filosóficas

${ }^{478}$ El texto de Sartre había sido publicado en Recherches philosophiques en 19361937 y el de Lagache en La Psychanalyse, la revista de la SFP, en 1957. La traducción del primero había estado a cargo del propio Masotta.

${ }^{479}$ Masotta, Oscar. "La fenomenología de Sartre y un trabajo de Daniel Lagache". Centro. N13, Tercer Trimestre 1959, p. 80. 
contemporáneas como los de Hegel, Heidegger y Husserl. Así, Masotta destacaba el modo en el que Lacan procedía a una revitalización del psicoanálisis a partir de una confluencia entre la relectura de Freud y el desarrollo de la tradición fenomenológica.

Por otro lado, el comentario de Crítica de la razón dialéctica escrito por Masotta para el semanario uruguayo Marcha al año siguiente de la publicación del texto sobre Lagache, permite advertir la forma en la cual este intelectual argentino concebía la relación entre marxismo y psicoanálisis a comienzos de la década de 1960. El caluroso recibimiento de la obra sartreana por parte de Masotta implicaba tanto una valoración positiva de la discusión acerca del vínculo entre marxismo y existencialismo como una contundente refutación de los esquemas interpretativos de los referentes del marxismo ortodoxo. La inscripción marxista de Sartre se oponía, en este sentido, a la de figuras como Garaudy y Lukács, a las cuales se les adjudicaba un sistema de correspondencia entre universales abstractos y una tendencia a inscribir todo acontecimiento en un mecanismo de esquemas predeterminados ${ }^{480}$. Este diagnóstico de la situación del marxismo contemporáneo tendía a vincular el empobrecimiento de la tradición teórica inaugurada por Marx con la renuencia de los principales teóricos de dicha corriente a problematizar las mediaciones existentes entre los individuos en un determinado contexto socio-económico. Parafraseando a Sartre, Masotta afirmaba que el marxismo contemporáneo no podía dar cuenta del proceso de constitución de una persona en el seno de un proceso histórico porque carecía de "una jerarquía de las mediaciones" ${ }^{481}$. Así se formulaba un programa de vinculación entre marxismo y psicoanálisis en el que el nexo entre ambas tradiciones se cifraba en términos de asimilación. Para Masotta, el psicoanálisis constituía una herramienta que debía ser integrada por el marxismo a los fines de que éste pudiera dar cuenta finalmente

480 La crítica a Lukács daba lugar, asimismo, a un cuestionamiento del antiheideggerianismo contemporáneo. Contra la interpretación lukácsiana, Masotta mencionaba las lecturas conjuntas de Marx y Heidegger realizadas en Alemania e Italia, la relectura de Hegel realizada por Alexandre Kojève en Francia y la obra de Lucien Goldmann. Sobre Masotta lector de Goldmann, ver Scholten, Hernán. op. cit., p. 198.

${ }^{481}$ Masotta, Oscar. "Destrucción y promoción del marxismo contemporáneo". Marcha. Octubre de 1960. 
de la emergencia de las historias individuales en el marco de la totalidad histórica ${ }^{482}$.

El año 1964 nos muestra a un Masotta ya instalado en el campo teórico abierto por Lacan y decidido a avanzar en la problematización de los vínculos entre marxismo, estructuralismo y psicoanálisis, pero aún atado a algunos postulados de la tradición fenomenológica. Al respecto, resulta clave su primera aproximación integral al psicoanálisis lacaniano, el texto "Jacques Lacan o el inconsciente en los fundamentos de la filosofía", leído en el Instituto Pichón Rivière de Psiquiatría Social en marzo de aquel año y -tal como mencionamos en el capítulo 4- publicado en 1965 en el número 9 de Pasado y Presente.

Allí Masotta llevaba a cabo un trabajo de demarcación de la empresa lacaniana, a la cual concebía como un esfuerzo del psicoanálisis francés por revertir el predominio del culturalismo estadounidense y el psicoanálisis anglosajón. De este modo, los elementos del lacanismo más atendidos y valorados por Masotta eran la oposición a "todo idealismo de la conciencia o del yo" y la crítica a toda concepción de la terapia "en términos de 'fortalecimiento' del yo" ${ }^{483}$. En un sentido divergente con aquella primera lectura de Lacan y en sintonía con lo esbozado en "Roberto Arlt, yo mismo", el regreso a Freud propiciado por Lacan era diferenciado de los abordajes fenomenológicos de los problemas del inconsciente. Su posicionamiento al respecto era contundente: "ya no se trata de justificar la noción de inconsciente dentro de los límites estrechos de la fenomenología, sino de rescatar, más bien, los derechos del inconsciente frente a una crítica hecha desde una perspectiva fenomenológica" ${ }^{484}$. Así comenzaba a configurarse un espacio

\footnotetext{
${ }^{482}$ La evaluación de la situación del marxismo contemporáneo a través de los parámetros sartreanos es también evidente en la crítica de Masotta al diálogo entre cristianos y marxistas. En una polémica entablada en 1963 contra Jean Yves Calvez y Conrado Eggers Lan, Masotta caracterizaba al marxismo como la única filosofía concreta de la época. En este sentido, lo defendía de la acusación cristiana acerca de la ausencia de una noción de trascendencia en la filosofía marxista y afirmaba la potencialidad de una perspectiva materialista centrada en la alienación frente a una teoría del pasaje entre el individuo histórico concreto y la universalidad del espíritu, "Cristianismo, catolicismo, marxismo". Discusión. № 2, Mayo de 1963.

${ }^{483}$ Masotta, Oscar. "Jacques Lacan o el inconsciente en los fundamentos de la filosofía”. Pasado y Presente. Año III, N 9, Abril-Septiembre de 1965, p. 2.

${ }^{484}$ Ibid., p. 4.
} 
teórico en el que los elementos predominantes eran el inconsciente estructurado como lenguaje, el sujeto sujetado por la palabra, los mecanismos de condensación y desplazamiento, y la importancia de las fantasías, la imaginación y los símbolos.

Cabe destacar, sin embargo, que por entonces el énfasis de Masotta en la propuesta lacaniana de disolución del yo era compatible con el programa de psicología concreta establecido por Georges Politzer. Dado el evidente conocimiento que Masotta tenía de la comunicación que Jean Laplanche y Serge Leclaire habían presentado en el Coloquio de Bonneval en 1961, a través de la cual el lacanismo había reconocido el lugar de Politzer en la historia del psicoanálisis en Francia, no resulta totalmente sorprendente la asociación que aquel establecía entre el psicoanálisis lacaniano y la psicología politzeriana $^{485}{ }^{486}$. En términos específicos, la localización de Lacan en el

${ }^{485}$ El Coloquio de Bonneval fue organizado por Henry Ey y tuvo como expositores a André Green, René Diatkine, Serge Lebovici, Conrad Stein, Jean-Bertrand Pontalis, François Perrier, Paul Ricœur, Maurice Merleau-Ponty, Henri Lefebvre y Jean Hyppolite, además del propio Lacan y los mencionados Laplanche y Leclaire. Dedicado a "la naturaleza del inconsciente", el Coloquio actuó como un espacio en el que se sometió a discusión la relación entre fenomenología y marxismo. La edición castellana de las actas fue realizada por Siglo XXI México recién en 1970. A juzgar por las notas de su artículo, Masotta conocía las discusiones de Bonneval a través de la publicación de algunas de las intervenciones en Les Temps Modernes. Sobre el Coloquio, ver Roudinesco, Elizabeth. La batalla de cien años. Historia del Psicoanálisis en Francia. Tomo 3 (1925-1985). Madrid, Fundamentos, 1993, pp. 301-310 y Viguera, Ariel. "Tres tesis acerca del inconciente en el Coloquio de Bonneval de 1960: Lacan, Laplanche, Politzer". Revista de Psicología-Segunda época. N 12, 2012, pp. 41-53.

${ }^{486}$ Junto a la referencia al Coloquio de Bonneval, la coexistencia entre Lacan y Politzar debe entenderse en el marco del prestigio que éste último gozaba en el campo psicoanalítico argentino. Como afirma Vezzetti, "en pocos años, tanto esa visión del marxismo como el proyecto demasiado genérico de la psicología concreta caerán bajo la impugnación demoledora de la nueva doxa althusseriana. Sin embargo, en esos años la posición de Politzer como un héroe indiscutido de la izquierda intelectual se mostraba compatible con la primera recepción de Lacan", "Los comienzos de la psicología como disciplina universitaria y profesional. Debates, herencias y proyecciones sobre la sociedad". Neiburg, Federico y Plotkin, Mariano (comps.). Intelectuales y expertos. La constitución del conocimiento social en la Argentina. Buenos Aires, Paidós, 2004, p. 298. En este mismo sentido, Plotkin y Visacovsky han advertido que la imagen de un pasaje abrupto entre la fenemonología y el estructuralismo obedece en gran parte a un mito de origen creado por el propio Masotta acerca de la difusión de Lacan en Argentina: "el antiguo sartreano se convirtió, así, en el nuevo lacaniano. Desde luego, la transición fue mucho menos brusca de lo que él mismo se encargó de hacer creer luego", "Los psicoanalistas y la crisis, la crisis del psicoanálisis". Cuadernos LIRICO. $N^{\circ} 4,2008$, p. 153. Sobre el mito 
interior de la tradición psicoanalítica francesa operaba a través de dos variables. En primer lugar, una sintonización entre las irrupciones de Lacan y Politzer en el campo psicoanalítico, las cuales eran recortadas a sus dimensiones críticas: "existe un paralelismo posible entre la crítica politzeriana a la reificación del inconsciente [...] con la oposición de Lacan a todo intento de reificación del yo" ${ }^{487}$. Por otro lado, un englobamiento de dichas expresiones en una tradición teórica de largo alcance, en la que los referentes de la fenomenología ocupaban un rol preponderante: "una [la crítica de Politzer] y otra [la crítica de Lacan] se enlazan, desde hace más de treinta años [...] con la crítica que Sartre y Merleau-Ponty realizarían de la noción de Sustancia tal como aparece formulada a partir de Descartes" ${ }^{\prime 48}$. Es decir, en los modos a través de los cuales Masotta introducía a Lacan en Argentina al filo de 1965 se advierte el mismo carácter progresivo del relevo de la fenomenología por el estructuralismo que percibíamos en Sexo y traición en Roberto Arlt. Quizás nada evidencia mejor la singularidad de este momento que la siguiente que frase que Masotta deslizaba al finalizar su texto: "fenomenología, estructuralismo, marxismo, psicoanálisis, convergen en Lacan y esto al nivel más inmanente de su obra y de su enseñanza" ${ }^{489}$.

\subsection{El desplazamiento estructural: entre el saber marxista y la práctica teórica}

de origen del lacanismo, ver también Visacovsky, Sergio. El Lanús. Memoria y política en la construcción de una tradición psiquiátrica y psicoanalítica argentina. Buenos Aires, Alianza, 2002 y "Origins stories, Invention of Genealogies and the Early Diffusion of Lacanian Psychoanalysis in Argentina and Spain (1960-1980)". Damousi, Joy y Plotkin, Mariano (eds.). The Transnational Unconcious. Essays in the History of Psychoanalysis and Transnationalism. Londres, Palgrave Macmillan, 2007, pp. 227256.

${ }^{487}$ Masotta, Oscar. "Jacques Lacan o el inconsciente en los fundamentos de la filosofía”. op. cit., p. 4. ${ }^{488} / d$.

${ }^{489} \mathrm{Ibid}$., p. 15. Si bien progresivo, el mencionado relevo entre paradigmas no dejaba de incomodar a aquellos politzerianos que observaban una recolocación de su referente en el incipiente campo estructural. Al respecto, Marcela Borinsky hace referencia al desconcierto de José Bleger al escuchar la comunicación leída por Masotta en el Instituto Pichón Rivière, "Entre Bleger y Masotta: Georges Politzer o la búsqueda de un héroe". Julio César Ríos, Ricardo Ruiz, Juan Carlos Stagnaro, Patricia Waissman (comps.). Psiquiatría, Psicología y Psicoanálisis. Historia y Memoria. Buenos Aires, Polemos, 2000, pp. 130-140. 
La respuesta dada por Masotta en 1966 a una encuesta sobre literatura preparada por la revista Ensayo Cultural, permite constatar de qué manera aquella compatibilidad entre la fenomenología y el estructuralismo se iba resolviendo a favor de este último paradigma. En primer lugar, Masotta contestaba con cierto desdén preguntas acerca de la influencia de la literatura en el hombre corriente y la toma de conciencia de la realidad. Frente a éstas, respondía solicitando mayor precisión conceptual y rigurosidad analítica en el abordaje de los vínculos entre literatura y sociedad. También planteaba reparos a la pregunta acerca de sus maestros intelectuales. Sin embargo, accedía finalmente a responder $y$ aquel enunciando propiciaba un significativo desbalanceo en el conjunto de sus referentes: "efectivamente, tengo mis autoridades: Sartre (aunque hoy menos), Lévi-Strauss, Barthes, Bateson, en fin, Freud y Jacques Lacan" ${ }^{\prime 90}$. Por último, frente al requerimiento de cuáles habían sido, a su entender, los ensayos fundamentales publicados en Argentina en los últimos diez años, Masotta mencionaba Orden y progreso de David Viñas, Persona y comunidad de León Rozitcher y el sartreano Buenos Aires, vida cotidiana y alienación de Sebreli. Elogioso con los dos primeros, se desmarcaba claramente del tipo de trabajo intelectual que se reflejaba en el tercero: "El caso de Sebreli, en fin, es difícil. De su libro debo decir que cada vez me gusta menos: pero no se puede quitarle relevancia" ${ }^{491}$.

Será precisamente a propósito de una discusión generada por el libro de Sebreli que Masotta desplegará por primera vez un repertorio argumental de matriz althusseriana. El debate en cuestión fue aquel centrado en las relaciones entre marxismo y estructuralismo que enfrentó entre 1966 y 1967 a Masotta y Verón, quienes tenían una posición favorable al acercamiento entre ambas tradiciones, con Sebreli, quien resistía la apertura del marxismo al análisis estructura ${ }^{492}$. El enfrentamiento, que se desarrolló en las páginas del

\footnotetext{
490 "La literatura y el 'hombre corriente"'. Ensayo Cultural. Buenos Aires, 1966. $491 / d$.

${ }^{492}$ Para un abordaje integral de la polémica, ver Sarlo, Beatriz. La batalla de las ideas (1943-1973). Buenos Aires, Ariel, 2001, pp. 94-98. Para una lectura centrada en las transformaciones de la crítica literaria, ver Tuset Mayoral Vicenç. "La polémica Verón, Sebreli, Masotta y la problematización de la literatura como objeto crítico". VIII
} 
semanario uruguayo Marcha, se había iniciado con una intervención de Verón en la que la obra de Sebreli -el mencionado Buenos Aires, vida cotidiana y alienación y Eva Perón ¿aventurera o militante?- era presentada como un ejemplo de la institucionalización del mito del análisis marxista. Amparado en el análisis de los mensajes sociales y la cultura de masas, Verón se esforzaba por demostrar no solo que las interpretaciones de Sebreli no cumplían con los requisitos del análisis marxista, sino que el éxito que aquellas tenían en segmentos de la sociedad argentina debía explicarse a partir de transformaciones en las pautas de consumo en las clases media y alta. Al abordar los elementos míticos de la sociedad argentina -Buenos Aires, Eva Perón- a través de proposiciones autoevidentes y carentes de verificación empírica, así como saberes superficiales ajenos a las operaciones teóricas básicas, Sebreli quedaba encerrado en las trampas de la identificación entre el objeto y su análisis. En este contexto, el concepto althusseriano de práctica teórica permitía desmontar las pretensiones desmitificadoras del análisis de Sebreli. En sus libros, aseguraba Verón, "la destrucción está presente como significación, pero desaparece como praxis teórica" ${ }^{493}$. Es decir, al no producir de manera independiente un análisis crítico del material del mito, Sebreli terminaba hablando del objeto en el mismo lenguaje ideológico que pretendía destruir -identificación que solo podía conducir a una aceptación y absorción del marxismo en los marcos de la cultura dominante del capitalismo argentino.

Quebrada ya toda posibilidad de diálogo entre un marxismo de corte existencial y uno abierto a la modernización estructural, Sebreli había respondido a Verón con todo el repertorio anti-estructuralista de la época: "terrorismo analítico", "perspectiva cientificista y neopositivista", "ciencia de

Congreso Internacional de Teoría y Crítica Literaria "Orbis Tertius". La Plata, 7 al 9 de Mayo de 2012. Para una aproximación al intercambio atenta a la recepción de la teoría crítica por parte de Sebreli, ver García, Luis. "La modernidad en disputa. La Escuela de Frankfurt en la Argentina". Hugo Biagini y Arturo Roig (dirs.). El pensamiento alternativo en la Argentina del siglo XX. Tomo II. Obrerismo, vanguardia, justicia social (1930-1940). Buenos Aires, Biblos, 2006, pp. 111-140.

${ }^{493}$ Verón, Eliseo. "Muerte y transfiguración del análisis marxista". Marcha. N 1309, 24 de Junio de 1966. 
gabinete", "jerga tecnicista", "nostalgia por el orden lógico-matemático" ${ }^{494}$. Observada desde una posición sartreana, la introducción del concepto de estructura en el marxismo adquiría un sentido puramente negativo. En tanto la estructura era asimilada a un círculo cerrado y un elemento autosuficiente, dicho movimiento era percibido como la apertura del marxismo a un esquema analítico que minaría sus bases fundamentales: la idea de unidad de la historia, el pensamiento dialéctico y la concepción del hombre como sujeto de la historia. En esta dirección, el marxismo estructural era presentado como una tendencia centrada en aspectos puramente programáticos y metodológicos, incapaz de avanzar hacia análisis concretos de la realidad y obturadora del desarrollo de una práctica política transformadora.

La respuesta de Masotta propiciaba una jearquización entre Verón y Sebreli amparada en el vínculo que cada uno de ellos había establecido con los saberes del paradigma estructural. A su entender, la discusión mantenida entre ambos no podía ser aprehendida como un debate alrededor de los vínculos entre marxismo y estructuralismo, en tanto uno de los contendientes -Veróncomprendía las implicancias de dicha relación mientras el otro -Sebreli- las desconocía. Una vez establecida la afinidad intelectual con Verón, Masotta procedía a desglosar el desconocimiento teórico de Sebreli. Se trataba, en primer lugar, de una carencia: "Sebreli carece de toda experiencia teórica de los problemas metodológicos que la lingüística estructural y la antropología estructural han planteado o ayudado a plantear al pensamiento contemporáneo" ${ }^{495}$. Este desconocimiento consistía, por otro lado, en una simple ignorancia: "Sebreli ignora el sentido y no sé si la distinción misma entre lengua y habla, entre código y mensaje, entre sistema y proceso, entre estructura y acontecimiento" ${ }^{496}$. De este modo, la ausencia en Sebreli de los elementos teóricos necesarios para una intervención en torno a la relación

\footnotetext{
${ }^{494}$ Sebreli, Juan José. "Verón: la ciencia oficial contra el marxismo”. Marcha. N 1312 , 15 de Julio de 1966.

495 Masotta, Oscar. "Anotación para un psicoanálisis de Sebreli". Conciencia y estructura. Buenos Aires, Jorge Alvarez, 1968, pp. 196-197. La intervención de Masotta fue preparada para Marcha pero no fue publicada debido a que el gobierno de Onganía prohibió la venta del semanario en Buenos Aires.

${ }^{496}$ Ibid., p. 197.
} 
entre marxismo y estructuralismo, conducía a una deslegitimación de su defensa de la primera tradición frente a la segunda y de su caracterización del estructuralismo como ciencia "oficial".

El problema de la legitimidad intelectual era el otro gran núcleo que estructuraba la intervención de Masotta en el debate. Al respecto, lo que se convertía en objeto de análisis para Masotta era la operación a través de la cual Sebreli esquivaba la discusión teórica, lugar en el que no podía más que evidenciar su deshonestidad, y se deslizaba hacia lo real, espacio en el cual lograba encontrar finalmente su legitimidad. Es decir, que lo que Masotta enfrentaba era el postulado de la reducción del trabajo teórico a las necesidades de la práctica política. Allí la crítica althusseriana a la definición del marxismo como filosofía de la praxis operaba como desarticuladora de las posiciones de Sebreli: "Sebreli legitima su deshonestidad y su poca seriedad intelectual mediante lo que él entiende que constituye su praxis política. Estructura de conducta que se halla, por detrás, como nos recuerda Althusser, del 'estancamiento' del marxismo teórico contemporáneo"497. A favor de Verón y en contra de Sebreli, la lectura retrospectiva de la tradición marxista realizada por Althusser prevenía a Masotta de la tentación política de legitimar los posicionamientos teóricos por los posicionamientos políticos. Si bien Masotta desplegaba dicha prevención entre el conjunto de los intelectuales de izquierda argentinos, para el caso de Sebreli se reservaba una observación complementaria. Si en el caso de un intelectual de izquierda la tentación política era censurable pero comprensible, en el caso de Sebreli aquella desviación era más aguda en tanto se trataba de un intelectual que carecía de raigambre política: "si él intenta justificar su liviandad teórica por las exigencias de la política, no está en cambio afiliado al partido comunista ni milita en grupo ni partido de izquierda alguno" ${ }^{\text {"998 }}$.

Ahora bien, semejante afirmación no podía pasar por alto el hecho de que, en lo relativo a la relación entre la teoría y la política, Masotta y Verón compartían dicha ilegitimidad con Sebreli. Si bien pertenecientes a tradiciones

${ }^{497}$ Ibid., p. 198.

${ }^{498}$ Id. 
teóricas a esta altura incompatibles, los tres eran intelectuales sin una militancia política concreta. En consecuencia, la refutación de la posición de Sebreli realizada desde los marcos althusserianos no implicaba automáticamente su caracterización como un intelectual no-marxista: "una vez demostrado [...] que Sebreli no cumple con las exigencias del 'análisis marxista', y que ignora el sentido profundo de la noción althusseriana de 'praxis teórica', no se podría decir, sin más, que Sebreli no es marxista"499. En este marco, Masotta afirmaba que tanto él como Verón le debían a Althusser una advertencia simétrica a la de la tentación política. Es decir, que en la crítica a Sebreli estaba también implícita la prevención frente la tentación teórica, aquella que lleva a legitimar las posiciones políticas por las posiciones intelectuales. En este sentido, era la práctica teórica althusseriana la que habilitaba la diferenciación con Sebreli dentro de una ilegitimidad intelectual que les era común. $Y$ aquí volvía a desempeñar un rol preponderante el desconocimiento de Sebreli: mientras éste asumía la ilegitimidad intelectual y le otorgaba un valor positivo a través de una intervención delineada por la figura sartreana del bastardo, Masotta y Verón conocían "lo que hay de profundo en Althusser" ${ }^{500}$. Es decir, habían logrado advertir que entre la práctica política y la práctica teórica hay puntos de unión, líneas de separación, dependencias relativas y legitimidad de sus autonomías. Por ello, mientras Sebreli permanecía fiel a la ilegitimidad, Masotta y Verón intentaban curarse de ella a través del trabajo teórico:

\begin{abstract}
Hay una diferencia: que mientras es probable tal vez 'curarse' de esa ilegitimidad al nivel del 'trabajo' intelectual, por un control teórico de las operaciones teóricas de un saber 'Saber' difícil, como el marxista, puesto que aspira a dar cuenta de la 'totalidad', Sebreli ha elegido en cambio un camino equívoco y que consistiría en sumirse, en todos los niveles de su acción, en esa ilegitimidad ${ }^{501}$
\end{abstract}

499 Ibid., p. 199. El hecho de que tanto Masotta como Verón hablaran de "praxis teórica" y no de "práctica teórica" seguramente obedezca a una traducción propia del concepto leído en la edición francesa de Lire Le Capital. Una vez que éste sea publicado en español, se impondrá en nuestro medio la segunda forma de referir al concepto.

${ }^{500} / d$.

${ }^{501} / d$. 


\subsection{Leer a Freud: marxismo, estructuralismo y psicoanálisis}

Con la publicación de Conciencia y estructura en 1968, Masotta confirmará el alejamiento definitivo de la tradición fenomenológica y el asentamiento en los marcos del paradigma estructural. Al igual que había ocurrido en 1965 con la edición de Sexo y traición en Roberto Arlt, la publicación de un volumen con los textos que había escrito entre 1956 y 1967 fue utilizada por Masotta para explicitar las derivas de su itinerario intelectual y dar a conocer la singularidad de la estación teórica a la que había arribado. Y del mismo modo en que habían sido realizadas en el libro de 1965, las operaciones de enunciación autorreferencial desarrolladas en Conciencia $y$ estructura se llevaban a cabo principalmente en el espacio paratextual. En primer lugar, Masotta elegía como epígrafe del libro un pasaje de un texto de Bernard Pingaud en el que se describía la evolución del campo intelectual francés entre las décadas de 1940 y 1960. En dicho texto, la introducción a un número especial de la revista L'Arc dedicado a Sartre, Pingaud relataba en un registro impresionista el relevo de nombres, palabras y referencias que se había producido en la reflexión teórica contemporánea. De aquella descripción, Masotta elegía un fragmento en el que enfatizaba el desplazamiento de la filosofía por las ciencias humanas y la aparición de un nuevo vocabulario. "Ya no se habla de 'conciencia' o de 'sujeto', sino de 'reglas', de 'códigos', de 'sistemas'; ya no se dice que 'el hombre hace el sentido, sino que el sentido 'adviene al hombre'; no es más existencialista, se es estructuralista”" 502.

Por otro lado, Masotta incluía un prólogo a la compilación, fechado en abril de 1967, en el que se esforzaba por legitimar la asunción de un marxismo estructural. En tanto se incluían en Conciencia y estructura sus trabajos relativos al pop-art, la historieta y los happenings, Masotta aprovechaba para presentar su itinerario intelectual como un proceso de complejización y enriquecimiento de sus anteriores inscripciones en la tradición marxista: "Yo no he evolucionado desde el marxismo al arte 'pop'; ni ocupándome de las obras

${ }^{502}$ Conciencia y estructura. op cit., p. 10. 
de los artistas 'pop' traiciono, ni desdigo, ni abandono el marxismo de antaño... Al revés, al ocuparme de esa nueva tendencia [...] entiendo permanecer fiel a los vacíos, a las exigencias y a las necesidades de la teoría marxista" ${ }^{503}$. Asimismo, Masotta anudaba la recolocación de su posicionamiento marxista con una nueva representación de la intervención intelectual. Del mismo modo que se intentaba legitimar la apertura del marxismo al análisis de objetos de la cultura de masas, se insistía en la necesidad de que el intelectual jerarquizara el trabajo teórico. Así, a modo de prolongación de aquella cura contra la ilegitimidad recetada a Sebreli, Masotta ubicaba a la práctica teórica como un elemento que permitiría una revitalización de la intervención intelectual marxista:

\begin{abstract}
Mis posiciones generales -básicas- con respecto a la lucha de clases, al papel del proletariado en la historia, a la necesidad de la revolución, son las mismas hoy que hace quince años atrás. Lo que ha cambiado tal vez es la manera de entender el rol del intelectual en el proceso histórico: cada vez comprendo más hasta qué punto ese rol tiene que ser teórico; esto es, que si uno se ha dado la tarea de pensar, no hay otra salida que tratar de hacerlo lo más profundamente, lo más correctamente posible ${ }^{504}$
\end{abstract}

Entre julio y agosto de 1969 Masotta dará una serie de lecciones en el Instituto Di Tella en torno al seminario de Lacan sobre "La carta robada" de Edgar Allan Poe. Estas sesiones, que llevaron como título "Psicoanálisis y estructuralismo", fueron publicadas al año siguiente en el volumen Introducción a la lectura de Jacques Lacan. Las referencias bibliográficas consignadas en cada una de las sesiones permite indagar cuáles eran, además de Para leer El Capital, las fuentes a través de las que Masotta había leído a Althusser. En primer lugar, al referir al problema de la historia en el psicoanálisis, Masotta afirmaba que la doctrina freudiana se ubicaba más allá de la discusión entre Sartre y LeviStrauss sobre la relación entre el sujeto y la estructura. A modo de apuntalamiento de dicha afirmación, indicaba "Véase el inteligente artículo de

\footnotetext{
${ }^{503}$ Ibid., p. 11.

${ }^{504}$ Ibid., pp. 11-12.
} 
Poulantzas, 'Vers une théorie marxiste" ${ }^{m 05}$. Es interesante destacar que el artículo que citaba Masotta no trataba sobre Freud, Sartre ni Levi-Strauss, sino que era precisamente la reseña de La revolución teórica de Marx que Poulantzas había escrito para Les Temps Modernes en 1966. En ella, se realizaba una presentación general del marxismo althusseriano y se destacaba la importancia de un trabajo renovador como el desarrollado por Althusser en tanto vehiculizado por un intelectual que reunía en sí la condición de filósofo marxista y la de militante comunista. Junto a un relato de tipo descriptivo sobre los principales conceptos althusserianos -ruptura epistemológica, sobredeterminación, práctica teórica- Poulantzas problematizaba el lugar de Althusser en las discusiones acerca de la relación entre estructura e historia. Allí Althusser aparecía como el representante de un trabajo teórico que permitía advertir la pertenencia del historicismo sartreano y el estructuralismo levi-straussiano a una misma problemática. Según Poulantzas, más allá de las diferencias entre la historicidad del sujeto y la hipostatasión de las estructuras, los postulados de Sartre y Levi-Strauss compartían la misma concepción acerca de la especificidad objetiva de la historia y la estructura, y la misma creencia acerca de la existencia de una relación entre ambas. Frente al historicismo y al estructuralismo, Althusser era presentado por Poulantzas como aquel que proporcionaba herramientas para avanzar en una ruptura epistemológica con concepciones ideológicas. En este sentido, el texto daba cuenta de la potencialidad de la tarea de re-descubrimiento de Marx a los fines de otorgarle un nuevo contenido a los conceptos de historia y estructura, y de la importancia de la concepción de "estructura con dominante" para plantear de otro modo las relaciones entre ambos conceptos ${ }^{506}$.

Si bien la referencia al texto de Poulantzas daba cuenta de una vinculación indirecta entre Althusser y la doctrina freudiana, otros textos utilizados por Masotta en sus lecciones nos permiten poner en sintonía el

\footnotetext{
505 Masotta, Oscar. "Psicoanálisis y estructuralismo". Introducción a la lectura de Jacques Lacan. Buenos Aires, Proteo, 1970, p. 113.

${ }^{506}$ Poulantzas, Nicos. "Vers une théorie maxiste". Les Temps Modernes. № 240, 1966, pp. 1952-1982. Un fragmento de este texto había sido publicado con el título "Sartre y Levi-Strauss: una problemática común" en el volumen Sartre y el estructuralismo compilado por José Sazbón en 1968 para la editorial Quintaria.
} 
itinerario del intelectual argentino con las experiencias concretas de articulación entre althusserianismo y psicoanálisis. Al mencionar el concepto de sutura en relación a la lectura lacaniana de Poe, Masotta remitía la discusión acerca de dicho concepto a dos textos publicados en la revista francesa Cahiers pour l'analyse: "La suture" de Jacques-Alain Miller y "Manque et marque: à propos du Zéro" de Alain Badiou. La revista a la que aludía Masotta era la publicación del Círculo de Epistemología de la ENS, colectivo conformado por discípulos de Althusser y Lacan. Como tal, la revista constituía la principal experiencia de articulación entre althusserianismo y lacanismo en la Francia de la segunda mitad de la década de 1960. Con colaboraciones de los propios Althusser y Lacan, pero especialmente sostenida por el trabajo de Miller, Jean-Claude Milner, Badiou, Michel Pêcheux y François Regnault, Cahier pour l'analyse era una publicación en la que predominaban la formalización conceptual y la rigurosidad científica, y en la que se vincularon de manera productiva las tradiciones estructuralista y psicoanalítica ${ }^{507}$. La discusión a la que aludía Masotta estaba centrada particularmente en las relaciones entre ciencia y sujeto. Estructurando la explicación de la causación del sujeto alrededor del concepto de sutura, Miller describía la relación entre sujeto y significante a través de la mediación de Frege y la teoría de los números ${ }^{508}$. En su réplica, Badiou caracterizaba a la lógica del significante como metafísica y se apartaba de Miller incorporando a sus propias formulaciones la referencia lacaniana al teorema de Gödel. A los fines de delimitar la relevancia de la lectura de este texto por parte de Masotta, cabe destacar que la objeción de Badiou a Miller se desarrollaba sobre un sustrato marcadamente althusseriano, en el cual el

\footnotetext{
507 Ver Dosse, François. History of Structuralism. Volume 1. The Rising Sign, 19451966. op. cit., p. 291; Peden, Knox. "The Fate of the Concept". Peter Hallward y Knox Peden. Concept and Form. Volume 2. Interviews and Essays on Cahiers pour l'analyse. Londres, Verso, 2012, pp. 1-14.

${ }^{508}$ Miller, Jacques-Alain. "La suture (elements de la logique du signifiant). Cahiers pour l'analyse. $\mathrm{N}^{\circ} 1$, Febrero de 1966, pp. 37-49. Traducción castellana: "La sutura. Elementos de la lógica del significante". Matemas II. Buenos Aires, Manantial, 1988, pp. 53-65.
} 
concepto de ruptura epistemológica y la distinción entre ciencia e ideología cumplían un rol preponderante ${ }^{509}$.

Si bien significativas, las lecturas de Poulantzas y Badiou estaban acompañadas por una referencia que será clave en el itinerario psicoanalítico de Masotta: el artículo "Freud y Lacan" de Althusser. En una de las lecciones dadas en el Di Tella, la problematización acerca del lugar del dinero en el contrato psicoanalítico derivaba en la explicitación del problema del status social del psicoanalista:

\begin{abstract}
esa ambigüedad que envuelve o corroe la práctica psicoanalítica en las sociedades de hecho no es ajena al enriquecimiento de muchos de sus oficiantes, y que este define el status social del psicoanalista, la corporación de los médicos, como dice Althusser, y que esa corporación, a la que se suman las alianzas, las complicidades, las 'confidencias' de los grupos, no podría ser ajena del todo a los avatares de la teoría (¿no viene Lacan a recordarnos lo que ha sido de la teoría freudiana en la historia del psicoanálisis?) ni, lo que sería más grave, a la formación de los jóvenes y de los prácticos ${ }^{510}$
\end{abstract}

De esta manera, Masotta introducía en el medio psicoanalítico local la discusión acerca de la relación entre la práctica psicoanalítica, y la institucionalización del psicoanálisis y las condiciones socio-económicas en la que la práctica psicoanalítica es ejercida. El énfasis que Masotta ponía en el

${ }^{509}$ Badiou, Alain. "Manque et marque: à propos du Zéro". Cahiers pour l'analyse. $\mathrm{N}^{\circ}$ 10, Invierno de 1969, pp. 150-172. Traducción castellana: "Marca y carencia: a propósito del cero". El concepto de modelo. Bases para una epistemología materialista de las matemáticas. Buenos Aires, Siglo XXI, 1972, pp. 94-110. Para una contextualización de este artículo en el itinerario de Badiou, ver Gillespie, Sam. "Giving Form to Its Own Existence: Anxiety and the Subject of Truth". Paul Ashton, A.J. Bartlett y Justin Clemens. The Praxis of Alain Badiou. Melbourne, re.press, 2006, pp. 180-209 y Feltham, Oliver. Alain Badiou: Live Theory. Londres, Continuum, 2008, pp. 14-22. Para una lectura retrospectiva del propio Badiou, ver Tho, Tzuchien. "The Concept of Model: Forty Years Later: An Interview with Alain Badiou". Alain Badiou. The Concept of Model. An Introduction to the Materialist Epistemology of Mathematics. Melbourne, re.press, 2007, pp. 79-106; "Prefacio de la nueva edición". Alain Badiou. El concepto de modelo. Introducción a una epistemología materialista de las matemáticas. Buenos Aires, La Bestia Equilátera, 2009, pp. 9-33 y "'Theory from Structure to Subject:': An Interview with Alain Badiou". Peter Hallward y Knox Peden. Concept and Form. Volume 2. Interviews and Essays on Cahiers pour l'analyse. op. cit.

510 Masotta, Oscar. "Psicoanálisis y estructuralismo". Introducción a la lectura de Jacques Lacan. op. cit., p. 50. 
problema de la corporación médica nos permite inferir que uno de los elementos más destacados del "Freud y Lacan" era precisamente la problematización de la tríada teoría psicoanalítica-condiciones de aparición histórica-condiciones sociales de aplicación. En este sentido, Althusser le permitía a Masotta una interrogación acerca de la repercusión de los orígenes históricos y las condiciones económicas y sociales del ejercicio del psicoanálisis en la teoría y la técnica analíticas.

Si bien el planteo acerca de la corporación médica se encontraba entre los temas que Althusser enunciaba como parte de una agenda de investigación futura abierta por la lectura lacaniana de Freud, la explicitación del problema tenía unas implicaciones radicales. Como se desprende de la referencia de Masotta, el "Freud y Lacan" habilitaba un estrechamiento de los problemas relativos al status del psicoanalista y a la teoría psicoanalítica. En aquel texto que Masotta citaba en sus lecciones, Althusser esbozaba la pregunta acerca del modo en el cual el silencio teórico sobre las condiciones sociales y políticas del ejercicio del psicoanálisis -"la inhibición teórica"511, "el hecho de no haber pensado estos problemas" ${ }^{512}$ - afectaban el contenido de la teoría y la técnica analíticas.

Si bien evidente en la referencia realizada en las lecciones, la productividad de la lectura del "Freud y Lacan" se desplegará de manera contundente en la polémica entablada por Masotta contra Emilio Rodrigué. La importancia que Masotta le otorgaba a Althusser se manifestaba en la primera oración que aquel elegía para iniciar el debate con Rodrigué: "Es Althusser quien lee a Marx no sin haber leído a Lacan- el que nos sugiere el sentido y el alcance de la tarea: leer a Freud"513. Si bien la mayor parte de las referencias que se han hecho a este pasaje dan cuenta de la importancia de Althusser entre las referencias teóricas de Masotta, no se ha destacado suficientemente el lugar preponderante que esta referencia ocupaba en el programa de regreso

${ }^{511}$ Althusser, Louis. "Freud y Lacan". Escritos sobre psicoanálisis. Freud y Lacan. México D.F., Siglo XXI, 1996, p. 46.

${ }^{512}$ Ibid., p. 41.

${ }^{513}$ Masotta, Oscar. "Leer a Freud". Revista Argentina de Psicología. N 1, Septiembre de 1969, p. 19. 
a Freud ${ }^{514}$. Es decir, no puede ser soslayado que para Masotta -y aquí la lectura del "Freud y Lacan" se revela fundamental-, el que sugiere el sentido y el alcance de la tarea de leer a Freud, no es tanto Lacan como Althusser. Si bien semejante afirmación no deja lugar a dudas, la nota al pie que acompañaba dicha frase nos permite refrendar la primacía de Althusser en esta inscripción de Masotta en el trabajo de re-lectura de Freud y de replanteo de la tradición psicoanalítica. En una significativa aclaración, nunca mencionada en las investigaciones específicas sobre Masotta $\mathrm{ni}$ en las historias del psicoanálisis argentino, aquel afirmaba: "La obra de Lacan, que induce una interpretación precisa y una lectura dura de los textos de Freud, al concederle su verdadera dimensión, y si facilita el proyecto, no resuelve la tarea" ${ }^{515}$.

Era tal el alcance de la resolución por parte de Althusser de la tarea de leer a Freud que Masotta se sentía en condiciones de oponerle a Rodrigué un discurso en el cual se integraban un diagnóstico de la situación actual del psicoanálisis, un cuestionamiento de la historia del psicoanálisis y un programa para el futuro de la disciplina. En primer lugar, Masotta se retrotraía a los tiempos de Freud para demostrar hasta qué punto había sido desvalorado el lugar de la teoría en la tradición psicoanalítica. En contraste con una época en la cual el momento de la construcción de la teoría ocupaba un lugar privilegiado, el psicoanálisis de fines de la década de 1960 se reducía a la transmisión de una técnica y a la formalización de una teoría. El hecho de que ningún psicoanalista se preocupara por los fundamentos y alcances de la teoría formalizada aparecía estrechamente vinculado a la institucionalización del psicoanálisis. Si la jerarquización de la teoría se correspondía con una noinstitucionalización del psicoanálisis, la desatención de las dimensiones teóricas de la disciplina obedecía al confinamiento del saber a los espacios de poder de las asociaciones profesionales: "si ella [la teoría] existe en la cabeza

\footnotetext{
${ }^{514}$ Más allá del objetivo específico de delimitar el lugar ocupado por Althusser, debe destacarse la potencia concentrada de la frase. Como afirma Vezzetti, "si puede hablarse allí de un capital simbólico, hay que reconcer que está hecho sobre todo de lecturas y de citas". "Los comienzos de la psicología como disciplina universitaria y profesional. Debates, herencias y proyecciones sobre la sociedad". op. cit., p. 323. Como señalan Plotkin y Visacovsky, "cuatro autoridades (y lecturas) en una oración no es poco...", "Los psicoanalistas y la crisis, la crisis del psicoanálisis". op. cit., p. 154. 515 ld.
} 
de nuestros 'gigantes de sillón', es porque el Poder fundametará el Saber" 516. Asimismo, la advertencia sobre el lugar ocupado en la actualidad por la teoría psicoanalítica conllevaba una problematización de los relatos tradicionales sobre la historia de la disciplina. Aquí Masotta identificaba una historia "inscrita en el 'Establishment' psicoanalítico" ${ }^{517}$, a la cual identificaba institucionalmente con la APA y personalmente con Rodrigué. El foco de atención sobre el proceso de configuración de dicha historia lo constituía la operación represiva a la que había sido sometido Freud. De esta manera, el distanciamiento del psicoanálisis argentino con el freudismo era dotado de un tenor rupturista:

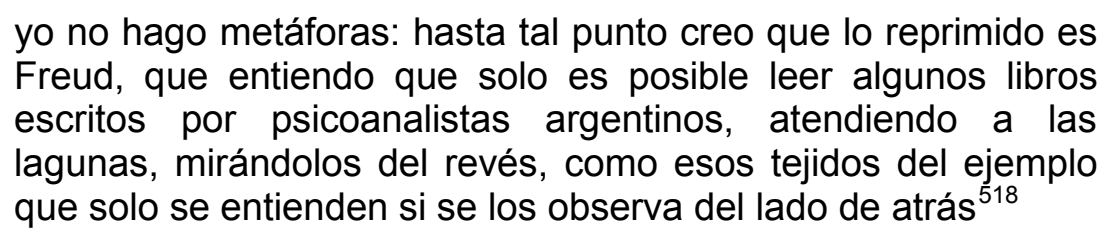

En este sentido, Masotta tomaba como ejemplo los textos de Rodrigué a los fines de evidenciar cuán lejos se encontraba su interpretación de Freud de los requisitos de la tarea de lectura esbozada por Lacan y apuntalada por Althusser. Fundamentalmente identificaba en los trabajos del referente de la APA una sustitución del necesario análisis psicoanalítico del significante por un conductismo de la significación, a través de la cual la teoría del significante era desvirtuada y reducida a los problemas del simbolismo. El enfrentamiento con el freudismo de Rodrigué hacía emerger la productividad que entrañaba el "Freud y Lacan" para una inscripción crítica en el campo psicoanalítico argentino de fines de la década de 1960. Por un lado, el alejamiento del psicoanálisis de toda antropología y la insistencia en el carácter científico de la disciplina. Dicha recolocación implicaba necesariamente un direccionamiento de la teoría psicoanalítica en un sentido estrictamente anti-humanista: "para el psicoanálisis, o en el psicoanálisis, no hay hombre, sino 'sujeto', o bien 'sobrevivientes', como nos recuerda Althusser'519. De este modo, Masotta

\footnotetext{
${ }^{516}$ Ibid., p. 20.

${ }^{517}$ Ibid., p. 22.

518 Ibid., p. 23.

519 Ibid., p. 25.
} 
anunciaba a la comunidad psicoanalítica argentina que la tarea más urgente era la deconstrucción del mito freudiano y la construcción de los hechos de la teoría de Freud. Por otro lado, la afirmación tan simple como categórica de que el objeto del psicoanálisis lleva el nombre del inconsciente. De manera análoga a la apertura de su impugnación a Rodrigué, en la cual se destacaba la importancia de Althusser en la necesaria tarea de regreso a Freud, Masotta elegía para cerrar su texto la descripción althusseriana del inconsciente como objeto del psicoanálisis. Inscripción anti-humanista en la tradición psicoanalítica y afirmación del inconsciente como objeto del psicoanálisis cobraban sentido en un final en el cual Masotta fusionaba sus palabras con aquel pasaje en el cual Althusser daba cuenta de la soledad teórica de Freud al momento de expresar en forma de conceptos abstractos su gran descubrimiento:

\begin{abstract}
Descubriremos entonces que la verdad del sujeto sin hombre se confunde con el objeto del psicoanálisis: ese paisaje lunar hecho de sonidos escuchados, de imágenes atisbadas y de escenas fantasmáticas, de inscripciones y marcas, de traducciones de esas marcas, de huellas y de pistas, de caminos transitados una y otra vez por un sentido que es sentido y fuerza a la vez, significación y energía. Ese 'rebus', en fin, arqueológico y geológico que encierra el secreto de ese 'redundante pescado del inconsciente que los hombres llaman mudo porque habla aun cuando duermen, 520
\end{abstract}

\title{
5.6. La mediación althusseriana: lecturas de Lacan en la década de 1970
}

Resulta sumamente relevante destacar la importancia de la mediación althusseriana en las operaciones de relectura de Lacan y recolocación del lacanismo desarrolladas por Masotta a principios de la década de 1970. En diversos textos escritos por Masotta en aquellos años, pueden percibirse los efectos de la lectura del "Freud y Lacan" en la revisión de las variables interpretativas a través de las cuales aquel se había aproximado originariamente al psicoanálisis lacaniano. Por ejemplo, en el prólogo escrito para Las formaciones del inconsciente, Masotta aprovechaba un repaso sobre las ediciones en castellano de los textos de Lacan para destacar la relevancia

${ }^{520}$ Ibid., p. 26. 
del artículo de Althusser y ajustar cuentas con su viejo texto "La fenomenología de Sartre y un trabajo de Daniel Lagache". En dicho repaso, se detenía en la importancia que había tenido para la difusión de Lacan en castellano el volumen Psicoanálisis, existencialismo, estructuralismo, publicado por Papiro en 1969 con textos de Althusser, Merleau-Ponty, Foucault y Lagache. Al respecto, Masotta hacía referencia al carácter excepcional del "Freud y Lacan": "Sobre el trabajo de Althusser, nada que decir" ${ }^{221}$. A su entender, se trataba de una inusual aproximación marxista al psicoanálisis que al mismo tiempo atendía dimensiones poco problematizadas de la tradición psicoanalítica: "el marxista francés no sólo muestra un conocimiento adecuado de los textos de Lacan, señalando algunos puntos jamás discutidos por la comunidad profesionap ${ }^{522}$. Entre estas, Masotta remarcaba aquella vinculación entre la teoría y la práctica psicoanalítica y las condiciones de surgimiento y ejercicio del psicoanálisis: "el término de Althusser no es tal vez irónico, sino sociológicamente descriptivo: la 'corporación' de los psicoanalistas" ${ }^{253}$. Por otro lado, Althusser demostraba que se podía recurrir a su relectura de Marx a los fines de alcanzar una mayor comprensión de los elementos constituyentes del psicoanálisis: "sino que alude además a qué puntos de su propia teoría habría que recurrir para pensar y discutir el estatuto de la práctica, la técnica y la teoría psicoanalítica y sus relaciones de implicación recíprocas". A través de una sugerente lectura retrospectiva de aquella compilación, Masotta lamentaba que el texto de Althusser hubiese circulado junto a los de Merleau-Ponty y Lagache, en tanto estos propiciaban aproximaciones a Lacan divergentes a las que auspiciaba el "Freud y Lacan" ${ }^{24}$. En este sentido, Masotta procedía a rectificar las afirmaciones de aquel texto de 1959 en el cual tendía a inscribir al psicoanálisis lacaniano en la problemática de la fenomenología sartreana:

\footnotetext{
${ }^{521}$ Masotta, Oscar. "Prólogo". Jacques Lacan. Las formaciones del inconsciente. Buenos Aires, Nueva Visión, 1970, p. 3.

${ }^{522}$ Ibid., p. 5.

${ }_{523}^{523}$ Ibid., p. 6.

${ }^{524}$ Tal como lo analizamos en el capítulo 3, Masotta objetaba el mismo volumen que desde las páginas de Los Libros impugnaba Carlos Sastre, también desde posiciones althusserianas.
} 
Entonces yo ignoraba a Freud y creí percibir en la reflexión de Lagache una conexión válida entre un yo soporte de objetivaciones e identificaciones (el yo psicoanalítico según Lagache) y el Ego trascendente a la conciencia, objeto intramundano y que la conciencia debería intencionar, según Sartre ${ }^{525}$

Así como en ocasión de la publicación de Las formaciones del inconsciente, Masotta corrigió la contextualización de Lacan esbozada en "La fenomenología de Sartre y un trabajo de Daniel Lagache", la compilación de sus textos en el volumen Ensayos lacanianos fue aprovechada para llevar a cabo una rectificación de su artículo "Jacques Lacan o el inconsciente en los fundamentos de la filosofía". En el prólogo preparado para dicho volumen, escrito en Londres en marzo de 1976, Masotta le comunicaba al lector que el artículo de 1964 debía ser considerado de manera diferente al resto de los textos compilados -producidos entre 1971 y 1975 - y abordado como un texto histórico ${ }^{526}$. En esta dirección, el primer análisis sistemático de Lacan aparecía sustentado en una serie de referencias que Masotta daba "por abandonadas" 527 . Por un lado, el planteo de las relaciones entre marxismo y psicoanálisis en términos de conexión y de unión. Por el otro, la integración del existencialismo, la fenomenología y el estructuralismo en una misma problemática. El texto era presentado por Masotta de una manera tal que le permitía contextualizar aquella lectura de Lacan a la vez que anunciar su superación definitiva. Así, mientras el acercamiento a Lacan desarrollado a mediados de la década de 1960 era descripto como un esfuerzo en pos de

\footnotetext{
525 Ibid., p. 7. Asimismo, en una conferencia dictada en 1970 en el Hospital de niños de La Plata, Masotta asociaba la crítica althusseriana a la "corporación de los médicos" con la recuperación de la subversión freudiana propiciada por Lacan a través de la colocación del inconsciente como objeto del psicoanálisis. Un resumen de la conferencia, con el título "Aclaraciones en torno a Jacques Lacan", fue recuperado en el volumen Métodos de investigación en Psicología y Psicopatología compilado por David Ziziemsky y publicado al año siguiente por Nueva Visión.

${ }^{526}$ Masotta se había exiliado en Europa en 1974. Luego de su estadía en Londres, se intalará en Barcelona, en donde tendrá un rol clave en la difusión de Lacan en España. Sobre esta etapa de su itinerario, ver Druet, Anne-Cécile. "Ecos socioculturales de la introducción del lacanismo en España". Cuadernos LIRICO. N ${ }^{\circ} 4,2006$, pp. 165-174 y Visacovsky, Sergio. "Origins stories, Invention of Genealogies and the Early Diffusion of Lacanian Psychoanalysis in Argentina and Spain (1960-1980)". op. cit.

${ }^{527}$ Masotta, Oscar. "Prólogo". Ensayos lacanianos. Barcelona, Anagrama, 1976, p. 10.
} 
liberarse del "impacto y la influencia ejercida sobre nosotros por la fenomenología francesa" ${ }^{28}$, la mediación fenomenológica en la aproximación al psicoanálisis lacaniano era refutada de manera contundente: "Preferiríamos hoy cerrar ese capítulo: el 'análisis existencial' es pre-freudiano" ${ }^{29}$. De la misma manera era abordado el vínculo establecido en aquel texto entre el psicoanálisis lacaniano y la psicología concreta. Masotta explicaba que la referencia a Politzer debía ser comprendida como la utilización de un caballo de batalla en la necesaria tarea de introducción del problema del inconsciente. Si la consecución de este objetivo justificaba retrospectivamente la referencia a la psicología concreta, aquella mediación también debía ser rectificaba. En este sentido, Masotta afirmaba que "Politzer debe ser revisado o su crítica refinada" ${ }^{530}$.

\subsection{La veta freudomarxista: marxismo y psicoanálisis en la crisis de la} APA

En 1971, la APA atravesó un proceso de crisis que derivó en la renuncia de una gran parte de sus jóvenes candidatos y miembros asociados. Dicho acontecimiento constituyó el corolario de un malestar que se venía gestando en el interior de la institución desde finales de la década de 1960. La extensión de las posiciones críticas había obedecido tanto a la oposición a la estructura jerárquica de la institución y a la proliferación de nuevas teorías y prácticas psicoanalíticas como al creciente proceso de radicalización política e intelectual experimentado a nivel nacional e internacional. La intransigencia de los sectores más conservadores de la APA frente a estas transformaciones, ejemplificada en la reacción frente a la solidaridad de algunos miembros con la huelga por la represión policial en Córdoba en 1969 y en la negativa a publicar un artículo de Marie Langer en la revista institucional, condujo a la renuncia masiva de los psicoanalistas a la institución y consecuentemente a la desafiliación de todos ellos de la API.

\footnotetext{
${ }^{528}$ Ibid., p. 11.

${ }^{529}$ ld.

${ }^{530} / d$.
} 
Si bien los dos agrupamientos que nuclearon a los psicoanalistas disidentes, el grupo Plataforma y el grupo Documento, compartían la mayor parte de las posiciones críticas frente a la APA, cada uno de ellos enfatizaba determinados aspectos de la estructura institucional y de la teoría y la práctica psicoanalítica. En el texto con el cual se dieron a conocer públicamente, una declaración dirigida a los trabajadores de la salud mental publicada en el número 25 de Los Libros, los miembros del grupo Plataforma ${ }^{531}$ acusaban a la APA de haber propiciado una distorsión y una paralización del pensamiento psicoanalítico. Al adjudicar dicho proceso a la estratificación jerárquica de la institución, se destacaba fundamentalmente el vínculo establecido entre la estructura institucional y la ideología de la clase dominante. En este sentido, se advertía negativamente sobre el relegamiento de las acciones necesarias para la evolución teórica y técnica del psicoanálisis -profundización de los conceptos, intercambios con otras ciencias, apertura de los campos de aplicación, ensayo de formas novedosa de docencia- por la búsqueda de prestigio, status y beneficios económicos. En contraposición a la inscripción institucional de la disciplina, Plataforma se presentaba como un grupo de psicoanalistas que buscaban poner el conocimiento al servicio de las ideologías políticas cuestionadoras del sistema. Al enfatizar la necesidad de que el psicoanálisis retomara la senda de la innovación y el desarrollo a través de la contribución de otras ciencias y de una explícita inscripción social, los miembros del grupo se presentaban como científicos comprometidos con los sectores combativos de la población que luchaban por la liberación nacional y el advenimiento de la patria socialista ${ }^{532}$.

Por su parte, los integrantes del grupo Documento ${ }^{533}$ intentaban evidenciar los vínculos entre la estructura institucional de la APA y la

531 Firmaron aquella declaración Armando Bauleo, Fanny Barenblit de Salzberg, Gregorio Barenblit, Carlos G. Bigliani, Lea Nuss de Bigliani, Manuel B. Braslavsky, Luis María Esmerado, Andrés Gallegos, Diego García Reinoso, Hernán Kesselman, Marie Langer, Miguel Matrajt, Guido Angel Narváez, Eduardo Pavlovsky, José Rafael Paz, Emilio Rodrigué y Juan Carlos Volnovich.

532 "Declaración del Grupo Plataforma". Los Libros. Para una crítica política de la cultura. $\mathrm{N}^{\circ}$ 25, Marzo 1972, pp. 5-6.

${ }^{533}$ Diana Etinger de Alvarez, Hugo Bellagamba, Marcos Bernard, Hugo Bleichmar, Emilce Dio de Bleichmar, Santiago Dubcovsky, Carlos Kaplan, Raquel Kielmanowicz, 
instrumentación ideológica del psicoanálisis al servicio de las clases dominantes. La concentración del poder político de la institución por parte de una minoría era analizada en términos de la creación de condiciones que dificultaban el cuestionamiento de los supuestos básicos de la teoría y la práctica psicoanalítica. De acuerdo a la historización realizada por el grupo, a los psicoanalistas argentinos les había resultado menos riesgoso refrendar las líneas teóricas ya establecidas que exponerse a las consecuencias de la marginación dentro de la institución. En pos de logar el ascenso en la pirámide burocrática de la APA, el trabajo científico realizado en el seno de la institución no hacía más que acatar y legitimar el empobrecimiento teórico de la tradición psicoanalítica: deformación epistemológica, desvinculación del resto de las disciplinas científicas, bloqueo de la elaboración de nuevos instrumentos terapéuticos. En contra de esta paralización de la disciplina, Documento rechazaba la neutralidad de la práctica científica y postulaba la necesidad de que la disciplina se insertara en la realidad de los países dependientes y que pusiera sus herramientas al servicio de la impugnación del orden existente. ${ }^{534}$

Los discursos teóricos sedimentados durante el proceso de escisión de la APA y consolidación de los grupos Plataforma y Documento dan cuenta de la convivencia entre los psicoanalistas argentinos entre una conceptualización de las relaciones entre marxismo y psicoanálisis sustentada en las premisas del freudomarxismo y otra configurada a partir de las formulaciones althusserianas. Los textos en los cuales los miembros de los sectores disidentes ampliaron y profundizaron los supuestos establecidos en sus declaraciones constitutivas, nos permiten advertir que la forma preponderante a través de la cual se precisaban los vínculos entre marxismo y psicoanálisis correspondía más bien a la primera de las conceptualizaciones mencionadas. Dicha primacía es claramente perceptible en las compilaciones tituladas Cuestionamos, publicadas en 1971 y 1973, las cuales reproducían una serie de documentos

Ignacio Maldonado, Julio Marotta, Aldo Melillo, Lea Rivella de Paz, Aída Dora Romaros, Jorge Rovatti, Leopoldo Salvarezza, Fanny Elman de Schutt, Jaime P. Schust, Horacio Scornik, Gilberto Simoes, Raquel Kozicki de Simoes y Fernando Ulloa.

534 "Declaración del Grupo Documento". Los Libros. Para una crítica política de la cultura. $\mathrm{N}^{\circ} 25$, Marzo 1972, pp. 6-7. 
en los que los miembros de Plataforma y Documento sometían a discusión los elementos fundamentales de la teoría y la práctica psicoanalítica.

En el primero de ellos, un epígrafe en negritas de Marie Langer, compiladora del volumen, establecía los parámetros a través de los cuales debían comprenderse las relaciones entre marxismo y psicoanálisis: "Freud y Marx han descubierto por igual, detrás de una realidad aparente, las fuerzas verdaderas que nos gobiernan: Freud, el inconsciente; Marx, la lucha de clases" ${ }^{535}$. Debe mencionarse que en el prólogo a la compilación, Langer deslizaba una serie de afirmaciones que permiten inferir cierta presencia de variables de lectura althusserianas: la importancia de Sciarreta en el aprendizaje de la lectura de Freud y $\operatorname{Marx}^{536}$, la necesidad de priorizar el Freud científico frente al Freud ideológico ${ }^{537}$. Sin embargo, la caracterización de las limitaciones actuales del psicoanálisis realizada por Langer nos permite advertir que el sentido que se pretendía otorgar a la vinculación entre marxismo y psicoanálisis divergía del propuesto por el althusserianismo. En sus propios términos, el psicoanálisis institucionalizado había ocultado la influencia que ejerce la estructura de la sociedad capitalista en la causación de la neurosis del paciente y en la conformación de criterios de curación en el psicoanalista. Asimismo, la diferenciación entre lo científico y lo ideológico en Freud era cifrada en términos de una oposición entre la advertencia sobre el modo en cual la ideología de la clase dominante se transmite entre generaciones volviendo lerdo al hombre en su capacidad de cambio y la perspectiva que toma a la sociedad como dada y al hombre como inmodificable. En consecuencia, el trabajo teórico que se asignaba para los psicoanalistas apartados de la APA era el del replanteo y enriquecimiento del psicoanálisis a través de la incorporación de investigaciones realizadas desde una perspectiva

\footnotetext{
${ }^{535}$ Langer, Marie. "Prólogo". Cuestionamos. Documentos de crítica a la ubicación actual del psicoanálisis. Buenos Aires, Granica, 1971, p. 11.

536 "Raúl Sciarretta, el gran amigo, cuya 'lectura' de Freud y de Marx nos ha enseñado mucho", Ibid., p, 14. El entrecomillado en la palabra que designa la acción de leer obedece, sin dudas, al cuestionamiento de Althusser a las formas tradicionales de lectura. Tal como vimos en el capítulo 3, esta era una de las dimensiones del althusserianismo más valoradas por Sciarreta.

537 "No cuestionamos al Freud científico [...] pero cuestionamos al Freud ideológico", Ibid., p. 14-15.
} 
marxista y el de la indagación en las "analogías y puntos de contacto importantísimos" ${ }^{\prime 33}$ existentes entre ambas tradiciones.

Por otra parte, el desarrollo de una corriente cuestionadora en el seno del psicoanálisis argentino era remitido explícitamente al surgimiento y la expansión de luchas políticas de liberación en los países latinoamericanos. De acuerdo a la historización de Langer, el cuestionamiento a la institucionalización del psicoanálisis, al pacto con las clases dominantes, a la práctica elitista y adaptacionista, al aislamiento de las instituciones psicoanalíticas y al verticalismo de la organización institucional, debía ser captado como una consecuencia directa de acontecimientos concretos de la coyuntura política latinoamericana. En el caso de los psicoanalistas argentinos, el acontecimiento en cuestión era el Cordobazo. En el caso de los psicoanalistas uruguayos, algunos de los cuales participaban en Cuestionamos, había sido el asesinato del estudiante Líber Arce ${ }^{539}$. Si hasta acá puede afirmarse que Langer circunscribía las transformaciones operadas en la teoría y la práctica psicoanalítica al contexto de politización desarrollado en América Latina, resulta relevante destacar el modo a través del cual la experiencia cuestionadora del psicoanálisis argentino se filiaba en la experiencia del freudomarxismo. Al repasar el momento del despertar de los psicoanalistas argentinos, Langer afirmaba: "Leyendo a Wilhelm Reich descubrí la similitud de los hechos que llevan a los psicoanalistas a asumirse políticamente" 540 . De esta manera se establecía una continuidad entre el relato de Reich en el cual una huelga ocurrida en Viena era invocada como el elemento propiciatorio de una instrumentación del saber psicoanalítico al servicio de las luchas de liberación, y el proceso argentino y latinoamericano

\footnotetext{
${ }^{538}$ Ibid., p 14.

${ }^{539}$ El carácter situado de la intervención aparecía de manera evidente en el fechado del prólogo. Allí Langer realizaba una operación a través de la cual repetía, corregía y ampliaba en negritas:
}

\section{Buenos Aires, octubre de 1971}

Poner fecha y lugar a este prólogo no significa cumplir con un formalismo. Importa esta ubicación. Por eso repito y amplío: Buenos Aires, Argentina, Montevideo, Uruguay, Latinoamérica, 1971

${ }^{540}$ Ibid., p. 15. 
del cual Cuestionamos era uno de sus efectos. Por último, y para advertir el tenor de la aproximación a los referentes teóricos del trabajo de articulación entre marxismo y psicoanálisis, Langer aseguraba que Reich no era el único psicoanalista que había tomado "una posición ideológica definida y de izquierda" pero que sí era "el más absoluto y concreto". No era el único, porque también existían otros referentes del mencionado trabajo de articulación, como Otto Fenichel, Fritz Sternberg y Siegfried Bernfeld. Sin embargo éstos -se encargaba de aclarar Langer- a diferencia de Reich, se habían limitado al trabajo teórico ${ }^{541}$.

La mayor parte de las intervenciones de Cuestionamos se inscribían dentro de los parámetros establecidos por Langer. Por ejemplo, el grupo de psicoanalistas uruguayos argumentaba que la sociedad constituye el objeto común del paciente y el analista, y que el devenir histórico-social del país influye sobre ambos sujetos condicionando sus perspectivas de vida. En esta misma dirección, aseguraban que la vinculación del psicoanálisis con la realidad social conllevaba una ampliación espacial del campo analítico, movimiento que era caracterizado en términos de asunción de una responsabilidad social más allá de las paredes del consultorio y al cual se le adjudicaba la posibilidad de que se trataran episodios de la vida nacional en la propia sesión ${ }^{542}$. Gilberta Royer de García Reinoso, por su parte, resignificaba la libertad profesional del psicoanalista en términos de aislamiento frente a las perturbaciones sociales. A la representación del terapeuta como espectador de la realidad se le oponía la necesidad de que el psicoanálisis asumiera el problema de la responsabilidad y reflexionara acerca de los alcances de la acción y la inacción de la práctica profesional. En este marco, el problema de la realidad en el psicoanálisis era abordado a través de una articulación entre

\footnotetext{
${ }^{541}$ Cabe destacar que los dos volúmenes de Cuestionamos fueron editados en la colección "Izquierda freudiana" que Langer dirigía para la editorial Granica, y que en dicha colección habían sido editados, además de estas compilaciones, los volúmenes La izquierda freudiana de Paul Robinson y Marxismo, psicoanálisis y sexpol con textos de Erich Fromm, Otto Fenichel y Herbert Marcuse.

${ }^{542}$ Achard de Demaría, Laura; Pereda Valdés, Alberto; Casas de Pereda, Mirta; Pla, J. Carlos; Viñar, Marcelo; Ulrikse de Viñar, Maren. "Crisis social y situación analítica". Cuestionamos. Documentos de crítica a la ubicación actual del psicoanálisis. op. cit., pp. 43-52.
} 
Marx y Marcuse que redundaba en la centralidad de los procesos de deshumanización ${ }^{543}$.

De manera simultánea con el modo predominante de lectura del proceso de crisis institucional y con la impronta que Langer pretendía otorgarle al conjunto de los textos compilados, otras intervenciones reproducidas en Cuestionamos daban cuenta de un abordaje de los problemas de la teoría y la práctica psicoanalítica orientado por formulaciones althusserianas. Este era el caso, por ejemplo, del psicoanalista uruguayo Juan Carlos Pla, quien se apoyaba en el "Freud y Lacan" a los fines de ajustar una definición del objeto del psicoanálisis, una caracterización de la práctica específica de la disciplina y una delimitación de las tareas a realizar por parte de los psicoanalistas. Al igual que el resto de las descripciones del estado actual del psicoanálisis, Pla subrayaba el estancamiento teórico y la disociación entre el terapeuta y los conflictos sociales. Esbozaba, sin embargo, un programa de resolución de la crisis en el que el planteo acerca del carácter científico del psicoanálisis desempeñaba un rol preponderante: "De pleno acuerdo con Althusser: la vigencia irreductible del psicoanálisis se la da, como a toda ciencia, su objeto propio, en su caso, el inconsciente; posee una teoría y una técnica (método) que permiten el conocimiento y la transformación de su objeto en una práctica científica" ${ }^{544}$.

El lugar del inconsciente como objeto del psicoanálisis ponía en primer plano la existencia de las estructuras de desconocimiento al mismo tiempo que jerarquizaba el trabajo científico dedicado a su desentrañamiento. Quedaban anudados, de este modo, el problema del objeto del psicoanálisis y el de la cientificidad de la disciplina: "Es muy enriquecedor el enfoque lacaniano del inconsciente estructurado como lenguaje. Según Althusser, le da al psicoanálisis su fundamento teórico como ciencia" ${ }^{545}$. En esta misma dirección, la tarea de regreso a Freud conllevaba la advertencia acerca de las

${ }^{543}$ Royer de García Reinoso, Gilberta. “¿Violencia y agresión o bien violencia y represión?". Ibid., pp. 53-88.

${ }^{544} \mathrm{Pla}$, Juan C. "Sobre el inconsciente, la contratransferencia y otros temas también espinosos. Algunos problemas actuales del papel del analista". Cuestionamos. Documentos de crítica a la ubicación actual del psicoanálisis. op. cit., p. 187.

${ }^{545}$ Ibid., p. 189-190. 
implicaciones ideológicas de un diálogo con el padre del psicoanálisis mediado por la figura del genio. En un sentido contrario a los resultados que derivarían de una aproximación científica a Freud, el acercamiento a su obra a través del mito del genio obturaría la formulación de nuevas preguntas y la instrumentación de operaciones innovadoras sobre un pensamiento, como el freudiano, caracterizado precisamente por la ruptura y la renovación.

\subsection{Althusser sin Lacan: la singularidad de una lectura}

Eran, sin embargo, dos intervenciones del integrante de Plataforma Gregorio Baremblitt las que incorporaban de manera sistemática las formulaciones althusserianas y las que problematizaban explícitamente los problemas de su difusión en el proceso de descomposición de la APA y consolidación de corrientes psicoanalíticas disidentes. Una de ellas, el texto "El estudio de la obra de Freud", firmado junto a Miguel Matrajt, era una versión actualizada de un artículo escrito originariamente en 1969. Como indicaba su título, aquel texto constituía una indagación acerca de la especificidad de la lectura de la obra de Freud. Y como se desprende del contexto de su escritura y publicación, un texto que sometiera a discusión los modos de leer a Freud hacia fines de la década de 1960 no podía sino remitir a la actualización del problema propiciada por Althusser y Lacan. Efectivamente, Baremblitt y Matrajt llevaban a cabo un análisis que refrendaba la lectura cientifizadora de la obra de Freud. Frente a un repertorio de interpretaciones que iba desde el conductismo hasta la fenomenología, pasando por el existencialismo y el culturalismo, aquellos legitimaban una lectura que tendía a identificar el proceso de producción del conocimiento científico en Freud. Al respecto, describían de este modo la tarea de estudio de su obra:

un devanar la colosal urdimbre de ese todo, que partiendo de la observación de los hechos, datos, nociones y conceptos tomados de los más heterogéneos campos del comportamiento, ciencias e ideologías, la clínica psiquiátrica y psicoterapéutica, los errores cotidianos, el sueño, el juego, el chiste, el arte, el mito, las pautas de las comunidades primitivas, la historia, la física, la química, la neurofisiología, la 
zoología, etc., instaura su objeto formal abstracto de

conocimiento y sus operaciones de complejidad y explicatividad crecientes ${ }^{546}$

Ahora bien, las disquisiciones que Baremblitt y Matrajt realizaban acerca del problema del estudio de Freud nos permiten ver que, al mismo tiempo que interiorizaban determinadas dimensiones de la propuesta althusseriana, se mostraban reacios frente a algunos de sus potenciales efectos. Esta ambivalencia se presentaba de manera evidente al momento de determinar el posicionamiento frente a las lecturas de Freud que no priorizaban la variable cientifizadora. Es decir, de qué manera se procedía, una vez establecida una lectura correcta de Freud, con otros esfuerzos interpretativos que no compartían necesariamente los criterios de aquella. Tal como mencionamos anteriormente, aquel abanico de interpretaciones delimitado por los autores iba desde Melanie Klein hasta Merleau-Ponty pasando por Fromm y Politzer. Al respecto, Baremblitt y Matrajt operaban una intervención en la tradición teórica del psicoanálisis que conllevaba un distanciamiento del gesto althusseriano: aquellas lecturas debían seguir siendo estudiadas detenidamente y comparadas constantemente con la obra de Freud aún habiéndose advertido la obsolencia de sus premisas y "aunque algunos autores como Althusser parezcan tener definitivamente aclarado cuáles de estas combinaciones son progresos y cuáles amputaciones" ${ }^{547}$.

La forma en la cual Baremblitt y Matrajt describían la irrupción de Althusser en los debates teóricos del psicoanálisis contemporáneo nos permite advertir que los reparos que se le planteaban a algunos efectos de la lectura althusseriana estaban originados, en parte, en un posicionamiento reactivo frente a la figura de Lacan y a la difusión del psicoanálisis lacaniano entre los intelectuales argentinos. A través de una mención que no podía remitir sino a Masotta y a los círculos de psicoanalistas que alrededor de él se iban congregando, Baremblitt y Matrajt advertían que en el medio psicoanalítico

546 Baremblitt, Gregorio y Matrajt, Miguel. "El estudio de la obra de Freud". Cuestionamos. Documentos de crítica a la ubicación actual del psicoanálisis. op. cit., p. 124. Cabe destacar que las negritas corresponden exclusivamente al concepto althusseriano.

${ }^{547}$ Ibid., p. 123. 
argentino se estaba comenzando a desarrollar una corriente que estudiaba la obra de Freud mediante los aportes de la epistemología de Gaston Bachelard, la lingüística moderna, las ideas de Lacan, el estructuralismo y el marxismo althusseriano. En un sentido descriptivo, destacaban que la singularidad de dicha lectura radicaba en la lectura sintomal, caracterizada como la búsqueda de anomalías en el discurso científico del psicoanálisis para elucidar el valor y las falencias de la teoría, y en el recorte de las formas maduras de la obra de Freud, captado como la delimitación de la cientificidad del psicoanálisis a partir de la constitución de su objeto formal abstracto. Junto a la jerarquización de estos aspectos, que eran precisamente los que ellos incorporaban en su propia lectura de Freud, Baremblitt y Matrajt destacaban la potencialidad de la corriente descripta, la cual era adjudicada a "su rigor, su enfoque interdisciplinario y su raigambre marxista" ${ }^{548}$. La valoración de estas dimensiones, sin embargo, daba lugar inmediatamente a la advertencia sobre una serie de propiedades de esta corriente a las que se calificaba de inquietantes. Por un lado, la estricta separación entre una dimensión científica y una ideológica en la obra de Freud, la cual conllevaría la circunscripción de la lectura a algunos de sus textos y el abandono definitivo de otros. Por otro lado, el carácter esotérico de los escritos de Lacan y la necesaria erudición para su lectura, los cuales facilitarían el advenimiento de una nueva asociación aristocrática detentadora de prestigio, status y bienestar económico.

Resulta de gran interés destacar que Baremblitt y Matrajt no sólo operaban una separación entre Althusser y Lacan, sino que aquella disociación incluía una recurrencia a postulados althusserianos a los fines de delimitar críticamente la especificidad del psicoanálisis lacaniano. En primer lugar, la tesis althusseriana de que no hay lecturas inocentes y que todas las lecturas son culpables permitía una interpretación de la lectura de Lacan como una lectura situada. En este sentido, la culpabilidad de esa lectura la tornaba tan posible como legítima:

${ }^{548}$ Ibid., p. 140. 
Como muy bien lo han enfatizado Althusser y sus colaboradores, todas las lecturas son posibles y todas son culpables, incluso la de Althusser. Respetamos mucho (entre otras razones, porque no lo entendemos bien) el criterio de Lacan de ruptura con el lenguaje convencional y la recreación de palabras plenas y nuevas para nuevas realidades pero [...] cierto uso indebido nos preocupa ${ }^{549}$

Como se desprende del pasaje citado, la legitimidad de esa lectura no implicaba la aceptación de los parámetros a través de los cuales se pretendía volver a Freud. En sintonía con los reparos al lacanismo mencionados anteriormente, Baremblitt y Matrajt llamaban la atención sobre la propagación de una posición a la que denominaban cientificismo talmudista y a la que responsabilizaban por la difusión de aproximaciones cientificistas y memorísticas de Freud. A diferencia de las posiciones que tendían a agrupar a Althusser y Lacan contra la institucionalización del psicoanálisis, en este caso la oposición al cientificismo redundaba en una ruptura de aquel agrupamiento teórico. En este sentido, el afán cientifizador del althusserianismo era disociado del cientificismo de la corriente lacaniana en un movimiento que conllevaba tanto una jerarquización de Althusser como una analogía entre lacanismo y psicoanálisis institucional. Es decir, que mientras el althusserianismo aparecía como un pensamiento que posibilitaba la conexión entre el trabajo teórico y la práctica política, el lacanismo era percibido como una corriente que ponía la producción de conocimientos al servicio de la constitución de una nueva corporación de psicoanalistas:

si a lo que se aspira es a formar investigadores en psicoanálisis (esa es nuestra aspiración y la exigencia de muchos), si lo que se desea es preparar intelectuales 'productores de conocimientos', como dice Althusser, que tengan su vida comprometida en la cultura y que integren el saber de su campo con todos los otros en el activo y urgente propósito de transformar el mundo, no es así como debe obligárseles a insumir muchos años del período más fértil y potencialmente práctico de su vida ${ }^{550}$

\footnotetext{
549 Ibid., p. 139.

${ }^{550}$ Ibid., p. 133.
} 
En esta dirección, Baremblitt y Matrajt aseguraban que la única manera de evitar una inscripción institucional del psicoanálisis disidente era la conformación de un núcleo marxista de formación psicoanalítica. Como evidencia de dicha necesidad se invocaba la capacidad de la institución psicoanalítica de incorporar los discursos teóricos impugnadores de su poder y su estructura. Era tal la importancia que estos psicoanalistas le otorgaban a los usos liberales del pensamiento marxista que, en ocasión de la publicación del texto en Cuestionamos, creyeron necesario adjuntar un Post-Scriptum en el que se denunciara la neutralización institucional de la conjunción entre psicoanálisis y marxismo. Allí se lamentaba que la "interesante distinción althusseriana entre práctica científica, práctica política e ideología"551 hubiese sido apropiada por los sectores tradicionales de la institución psicoanalítica con el previsible resultado de su esterilización política. Cabe destacar, al respecto, que esta denuncia no implicaba una corrección de las posiciones asentadas en el texto de 1969, sino que perseguía el objetivo de diferenciarse de un uso de la valiosa distinción entre práctica científica y práctica política que tendía a procesarla en un sentido contrario al althusseriano. Es decir, postergando la segunda en beneficio de la primera y reduciendo la especificidad del trabajo teórico a la lógica mercantil de la enseñanza de la institución psicoanalítica ${ }^{552}$.

El despeje de los problemas relativos a la relación entre Althusser y Lacan y la neutralización de la potencia política del althusserianismo habilitaba una operativización plena de los parámetros althusserianos en la impugnación de las formas institucionales de la teoría y la práctica psicoanalítica. En este sentido se desenvolvían los argumentos de otro artículo de Baremblitt reproducido en Cuestionamos, "Psicología, ideología y política", un texto dedicado exclusivamente a refutar el documento "Corrientes actuales en el pensamiento psicoanalítico" de Madelaine y Willy Baranger, Alberto Campo y

\footnotetext{
${ }^{551}$ Ibid., p. 138.

${ }^{552}$ Baremblitt y Matrajt se referían a un efecto "tragicómico" de los usos de Althusser entre los círculos psicoanalíticos tradicionales, en tanto los alumnos aceptaban "más ciegamente" el hecho de tener que pagar por su aprendizaje debido al contenido revolucionario de las teorías que se les enseñaba, $I d$. Más allá de la inferencia sobre la inclusión de Althusser en la formación impartida por la APA luego de la ruptura de la institución, no hemos podido delimitar específicamente a qué instancias concretas se referían Baremblitt y Matrajt.
} 
Jorge Mom, en el cual se reflejaban las posiciones dominantes en la APA al momento de su ruptura ${ }^{553}$. En esta intervención, el documento oficial de la APA era utilizado como un material que permitía delimitar cuáles eran aquellos problemas teóricos y prácticos del medio psicoanalítico local que requerían un abordaje urgente. El primero sobre el cual se detenía el análisis de Baremblitt era el mismo que aparecía problematizado en el texto firmado junto a Matrajt: el del estudio de la obra de Freud. La centralidad otorgada a este problema se derivaba, a decir de Baremblitt, del hecho de que el modo a través del cual se lee a Freud constituye el elemento estructural sobre el cual se configura la concepción acerca de la relación entre el psicoanálisis y el contexto social en el cual éste se practica. En términos generales, la lectura del documento oficial tendía a evidenciar la existencia de presupuestos teóricos implícitos en planteos supuestamente neutrales acerca de la lectura de Freud. A un planteo nada problemático a simple vista como aquel que daba cuenta de la existencia de diferentes lecturas de Freud y del desarrollo de líneas divergentes en el pensamiento freudiano, se le oponía la afirmación categórica de que "ese modo de ver, es ya una toma de posición teórica con implicancias ideológicas por parte de los autores" ${ }^{554}$.

El sentido de dicha advertencia se prolongaba en el examen de los criterios valorativos que intervenían en las operaciones de jerarquización en el conjunto de lecturas de Freud. En primer lugar, Baremblitt delimitaba cuáles eran los criterios que determinaban la legitimación de algunas interpretaciones de Freud y la desaprobación de otras. El descarte de algunas de ellas -las de Carl Jung, Alfred Adler y Wilhelm Stekel por ejemplo- por el lapso transcurrido entre estas interpretaciones y las formas más novedosas de aproximación al corpus freudiano, así como la ponderación de otras -Klein principalmente- por los desarrollos ulteriores que aquellas lecturas posibilitaron, conllevaban la advertencia de que los criterios que imperaban en las valoraciones propiciadas por el psicoanálisis institucional eran los del tiempo y la apertura. La siguiente

553 Baremblitt aclaraba que si bien el artículo llevaba únicamente su firma, originariamente había sido firmado junto a Eduardo Pavlovsky y avalado por el Grupo Plataforma.

554 Baremblitt, Gregorio. "Psicoanálisis, ideología y política". Cuestionamos. Documentos de crítica a la ubicación actual del psicoanálisis. op. cit., p. 149. 
operación de lectura realizada por Baremblitt consistía en el desenmascaramiento de la naturaleza de dichos criterios. Aparentemente inocuos, estos criterios se revelaban como dispositivos que permitían evitar la confrontación con tendencias más productivas que aquellas que desempeñaban el rol dominante y promover de manera encubierta la legitimación de la lectura de Freud defendida por la institución. Una rearticulación de todos los elementos implicados en el problema de la interpretación de Freud, el encubrimiento de los criterios valorativos y el establecimiento de parámetros interpretativos arbitrarios eran invocados por Baremblitt como indicadores de la ausencia de un trabajo teórico acerca de la lectura:

lo que objetamos no es tener una preferencia teórico-técnica y propugnarla abiertamente fundamentando por qué es la mejor, sino la velada promoción institucional de una línea en base a criterios discrecionales, dando a entender que son los únicos, a falta de 'absolutos'. Lo que en rigor falta es una teoría de la lectura que determine los parámetros de productividad de la misma y permita entonces fundarla en un criterio de ruptura, ubicando históricamente cuál es 'buena' ${ }^{555}$

A través de la lectura del documento de la APA, Baremblitt también abordaba el problema de la relación entre ciencia, política e ideología. Al respecto, se detenía específicamente en las precauciones esbozadas por la institución acerca del vínculo entre epistemología y psicoanálisis -riesgo de intromisión de la primera en el segundo- y del establecimiento de un corpus conceptual básico para el psicoanálisis -peligro de clausura teórica sobre la disciplina. Frente a ellas, se esforzaba por evidenciar el carácter progresivo que tendría para el medio psicoanalítico local la introducción de los desarrollos contemporáneos de la epistemología. De este modo, el replanteo de problemas tales como la relación entre las ciencias, la constitución de la especificidad de cada una de ellas, el proceso de aplicación de sus términos teóricos, y -fundamentalmentela articulación entre práctica científica, práctica ideológica y práctica política, era presentado como un trabajo que le permitiría a los psicoanalistas

${ }^{555}$ Ibid., p. 153-154. 
argentinos el esclarecimiento de una serie de confusiones acerca del ejercicio de la práctica psicoanalítica. Por un lado, que la ciencia se define por un método, una técnica y la instauración de su objeto formal abstracto de conocimiento -conceptualización que evidenciaría lo incorrecto de los planteos sobre el psicoanálisis como ciencia a partir de su enfoque o su objeto empírico. Por otro lado, que la ciencia refiere a una práctica técnica específica transformadora del objeto real, la ideología al efecto de desconocimiento generado por el inconsciente y la lucha de clases, y la política a la lucha por la toma del poder por parte del proletariado -delimitación que demostraría el sesgo liberal de la amplitud conceptual en la definición de los problemas fundamentales del psicoanálisis.

El modo en el cual Baremblitt abordaba los planteos de la posición de la APA acerca de la relación entre práctica psicoanalítica y realidad social nos permite inferir la singularidad de su concepción sobre el vínculo entre marxismo y psicoanálisis. Con el mismo afán de rigurosidad que caracterizaba su delimitación entre la ciencia, la ideología y la política, el postulado sobre la necesidad de que el psicoanálisis se comprometiera con las luchas sociales era denunciado como abstracto y ambiguo. Es decir, las afirmaciones relativas al compromiso del psicoanálisis no daban cuenta de las contradicciones sobre las que se pretendía intervenir, las formas concretas a través de las cuales se lucharía y los objetivos que guiarían dicha intervención. Por lo tanto, aseguraba Baremblitt, estas posiciones expresaban una visión empírica de la realidad social y una concepción de la lucha de clases como "dimensión mítica, universal y casi intemporal"556. De seguir estos parámetros, la práctica psicoanalítica nunca podría operar una ruptura en la condición del paciente ni contribuir a la producción de una conciencia revolucionaria, en tanto se estaría intentando combatir un mito con otro mito. Según Baremblitt, aquella circularidad sólo podía ser quebrada a través de una intervención psicoanalítica que descansara sobre "una concepción científica" ${ }^{557}$ de la realidad social que

\footnotetext{
${ }^{556}$ Ibid., p. 164.

${ }^{557}$ Id.
} 
diera cuenta de la estructura clasista de la sociedad y del rol determinante en última instancia de la economía en la causación de los conflictos patológicos.

\subsection{Entre el lacanismo y el freudomarxismo: el Althusser de Gregorio Baremblitt}

El repertorio de problemas relativos al lugar del althusserianismo en la discusión sobre los vínculos entre marxismo y psicoanálisis fueron retomados por Baremblitt en 1974 en un extenso y denso artículo publicado en un volumen sobre el concepto de realidad en psicoanálisis ${ }^{558}$. Punto de llegada del itinerario teórico desarrollado en los marcos de los grupos escindidos de la APA y plataforma de despegue hacia otras estaciones del pensamiento psicoanalítico, aquella intervención retomaba las discusiones desarrolladas en los textos publicados en Cuestionamos con el afán de delimitar de la manera más acabada posible los problemas fundamentales de la teoría y la práctica psicoanalítica. En la misma dirección que las justificaciones esbozadas a lo largo del proceso de ruptura de la institución psicoanalítica, la necesidad de desarrollar una intervención crítica en la disciplina era remitida a la obligación de encontrar en el seno de la práctica profesional los efectos de la determinación del modo de producción capitalista, la ideología burguesa y la acción política de la clase dominante. Dicha tarea, sin embargo, era retomada en los marcos de un esfuerzo por delimitar la ubicación del psicoanálisis en una teoría general de las prácticas y teorizar las aplicaciones que operaban como prácticas técnicas en el seno de las instituciones de los AIE y las organizaciones revolucionarias. La atención simultánea prestada a las instancias reproductivas y a los movimientos disruptivos es indicativa de que la necesidad de un trabajo teórico sobre la inserción del psicoanálisis remitía a los procesos de incorporación de nuevas corrientes psicoanalíticas tanto en la

${ }^{558}$ Baremblitt, Gregorio. "Consideraciones en torno al problema de la realidad en psicoanálisis y del psicoanálisis en la realidad". Gregorio Baremblitt y otros. El concepto de realidad en psicoanálisis. Buenos Aires, Socioanálisis, 1974, pp. 13-86. Además del artículo de Baremblitt, aquel volumen traía textos de Sandor Ferenczy, Hans Loewald, Charlotte Bühler, Julián Wohl y Michel Tort. 
corporación profesional como en agrupamientos que se pretendían revolucionarios.

La definición de los conceptos básicos de la intervención evidenciaba de manera palmaria la raigambre althusseriana del instrumental teórico a través del cual se intentaba llevar a cabo aquel trabajo de delimitación y control. En un sentido análogo al reconocimiento que le propiciaba Langer en el prólogo al primer volumen de Cuestionamos, Baremblitt remitía a la enseñanza de Sciarreta muchas de las precisiones conceptuales esbozadas en su escrito ${ }^{559}$. Sin embargo, al contrario de lo que ocurría con aquella, en el caso de Baremblitt las enseñanzas del maestro se prolongaban efectivamente en el terreno de las definiciones conceptuales. De este modo, se definía a lo real como "la designación indeterminada compuesta de saber, desconocimiento y reconocimiento que las ideologías dan a sus objetos empíricos" ${ }^{560}$, a la ciencia como la práctica que accede "al conocimiento y transformación de los objetos de la realidad por la construcción y la instrumentación de sus propios y específicos objetos formales abstractos de conocimiento" 561 , a las prácticas como "las actividades que operando sobre una materia prima específica, con instrumentos específicos, por medio de un trabajo, la transforman en un producto específico históricamente determinable"562 y a la práctica social como "el conjunto articulado y jerarquizado de la totalidad de las prácticas" ${ }^{563}$. En este mismo marco se procesaban las grandes definiciones sobre las disciplinas que eran objeto de articulación. Por un lado, psicoanálisis remitía, en el mismo sentido que sus escritos anteriores, a una práctica social científica compuesta por una Teoría, un objeto formal abstracto, un método, una técnica y una situación experimental propia. Por otra parte, materialismo histórico remitía a la ciencia del modo de producción que divide su dominio en instancias y regiones que engloban la totalidad de las prácticas sociales.

\footnotetext{
559 "el autor reconoce su deuda con R. Sciarreta de cuyas enseñanzas se derivan las elementales puntualizaciones filosóficas que trata de desarrollar". "Agradecimientos". Gregorio Baremblitt y otros. El concepto de realidad en psicoanálisis. op. cit., p. 9.

560 Baremblitt, Gregorio. "Consideraciones en torno al problema de la realidad en psicoanálisis y del psicoanálisis en la realidad", op. cit., p. 16.

${ }^{561} / d$.

${ }^{562}$ Ibid., p. 16-17.

${ }^{563}$ Ibid., p. 17.
} 
Si el esquema analítico a través del cual operaba Baremblitt en la definición de los conceptos fundamentales del psicoanálisis constituía una prolongación de las interpretaciones esbozadas en sus escritos anteriores, el abordaje realizado en este momento de la función de la intervención psicoanalítica y de la organización institucional de los psicoanalistas daba cuenta de un énfasis en el problema de la ideología y de la incorporación del concepto de AIE.

Con respecto al primero de los problemas abordados, el rol del psicoanalista era captado a través de un esquema tripartito. El psicoanalista interviene, en primer lugar, como productor de las transformaciones necesarias para la producción y reproducción de los sujetos en las relaciones sociales de producción. Es decir, como agente de los procesos de ideologización y dominación. Por otra parte, ellos mismos actúan como sujetos ideológicos de la ideología de la clase dominantes, en tanto es la clase a la cual la mayor parte de los psicoanalistas pertenecen. Finalmente, los psicoanalistas son protagonistas del proceso político, tanto en lo que hace a las implicaciones políticas de su práctica específica como a su participación en los canales tradicionales de la política institucional. Es decir, en los efectos políticos de la propia práctica psicoanalítica y en la asunción de sus actos políticos. Con respecto al problema de la institucionalización del psicoanálisis, las sociedades psicoanalíticas eran concebidas como dispositivos de transmisión, promoción y control de los elementos relativos al ejercicio teórico y práctico de la profesión. En este sentido Baremblitt las calificaba como "instituciones y organizaciones del aparato ideológico de estado a la vez que corporaciones empresariales de prestaciones de servicios" 564 entendiendo por ello "instrumentos y ámbitos por medio de los cuales, y en los cuales, se reproduce el sistema de explotación y división de clases o de división sectorial intra-clase ${ }^{\text {"565 }}$.

En un plano de mayor precisión, el carácter reproductivo del psicoanálisis institucional en tanto AIE era remitido a tres elementos inherentes al funcionamiento de las sociedades psicoanalíticas. En primer lugar, la lucha

\footnotetext{
564 Ibid., p. 19.

${ }^{565} / d$.
} 
por el poder desarrollada en su seno. Al respecto, principios institucionales tales como la instauración de un rígido orden estamental, la selección política de los aspirantes, la regulación de las relaciones con la política estatal y el control sobre la conducta de sus miembros, eran concebidos como factores propiciatorios del mantenimiento del poder intrainstitucional y la evitación del conflicto con el Estado burgués y su aparato represivo. Por otro lado, los procesos de ideologización propios de la formación psicoanalítica. En este caso, las características que adquiría la enseñanza institucional, como la administración de una bibliografía parcial, los rituales de iniciación, las demoras en el ascenso, la autoridad como emblema y el recurso al deseo de la aceptación de los pares, eran explicadas a partir del objetivo de formar un ideal del Yo psicoanalítico en el cual se vincularan la ideología científica específica de la función psicoanalítica y una ideología funcional a la estructura institucional. Finalmente, el régimen económico de la institución. Con respecto a esta dimensión del funcionamiento de la sociedad psicoanalítica, la explotación de los candidatos por parte de los jerarcas, así como la explotación de un estamento extra-institucional por parte de los candidatos, se explicaba en términos de una práctica económica en un subsistema capitalista ${ }^{566}$.

\footnotetext{
566 Una disquisición explícitamente política resaltaba por sobre un registro preponderantemente teórico. Baremblitt remitía al régimen económico de la institución el proceso de ampliación del campo analítico. De acuerdo a su explicación, el desarrollo de las técnicas psicoanalíticas "de grupo", "de pareja", "de familia", "comunitaria", etc., obedecía al aumento de la tasa de ganancia en la exacción de los estamentos más bajos de la pirámide institucional. Eran los integrantes de aquellos estamentos los que, frente a la explotación a los que los sometían los miembros jerárquicos, expandían hacia nuevos terrenos el ejercicio de su práctica psicoanalítica. Si bien reconocía que el marxismo había denunciado justamente estas derivaciones, enfatizando su escasa cientificidad y su servicialidad política e ideológica, Baremblitt afirmaba que el hecho de que algunas de las nuevas técnicas formaran parte del repertorio de la intervención estatal obligaba a una mayor precisión conceptual en su impugnación. De allí se derivaba una advertencia sobre el potencial ideologizador del practicante de una psicoterapia nacional y popular: "Permítaseme esbozar la sospecha de que: desjerarquizado y mecanizado el médico por la asistencia mutual, sometido definitivamente el maestro por medio del terror económico durante la dictadura militar (porque aunque su salario no le alcanza ni para reproducir la fuerza de trabajo, su despido significaba el desclasamiento definitivo), el futuro agente de ideologización masiva puede llegar a ser el psicoterapeuta "nacional y popular". Ibid.,p . 78. Como veremos en el próximo capítulo, la psicoterapia nacional y popular será uno de los objetos privilegiados de impugnación por parte de los psicólogos althusserianos.
} 
La consolidación de la mediación althusseriana en la delimitación de los problemas fundamentales de la teoría y la práctica psicoanalítica redundó, asimismo, en una diferenciación explícita con la concepción de los vínculos entre marxismo y psicoanálisis delineada por el freudomarxismo. Si bien Baremblitt seguía insistiendo en la necesidad de estudiar cuidadosamente todas las lecturas de Freud y de evitar convertir a una de ellas en la única opción teórica, llevaba a cabo una aproximación sistemática al freudomarxismo cuyo objetivo fundamental era el establecimiento de los errores en su conceptualización del modo a través del cual el psicoanálisis debía articularse con el marxismo. De acuerdo con esta lectura, la equivocación fundamental de todos los autores inscriptos en la tradición freudomarxista era la de "mezclar o emparejar analógicamente" 567 el discurso del marxismo y el del psicoanálisis. Era precisamente esta subsunción entre ambas tradiciones teóricas la que generaba prácticas técnicas terapéuticas en las que se superponían objetivos y acciones propios de la práctica política, así como acciones ideológicas y políticas en las que se usaban empíricamente principios sexuales supuestamente promovidos por el psicoanálisis. De este modo, la ausencia de una caracterización de la ciencia, la ideología, las aplicaciones y la doctrina en el marxismo y el psicoanálisis era señalada como el factor propiciatorio de la reinscripción del vínculo entre ambas tradiciones en el marco de ideologías conciliadoras, utópicas, liberales o directamente reaccionarias. En este sentido se explayaba Baremblitt en un párrafo que merece ser citado in extenso:

Algunas de tales doctrinas imaginan la liberación psíquica y social como el retorno a un estado previo supuestamente tenido y perdido definido por una condición del ser (humano) o de la naturaleza (humana) especulativa y metafísicamente concebido. Su objetivo ideológico es románticamente libertario ('el vive como quieras'), el económico una superabundancia a lo ciencia-ficción o una reedición del modo de producción primitivo, el político un igualitarismo anarquista o un elitarismo 'socrático'. Su metodología psicoterapéutica es un adoctrinamiento en el sentido ideológico antes apuntado presentado interpretativamente, y su práctica política: o bien un movimiento anticostumbrista previsto, tolerado e incorporado por el sistema, o bien una revuelta sexopolítica donde no se

${ }^{567}$ Ibid., p. 42. 
discrimina con precisión cuánto y qué puede esperarse de esa lucha y de qué orden jerárquico determinante, autonomía de definición teórica, de tratamiento científico y de procesamiento histórico tienen los objetivos de una revolución socialista ${ }^{568}$

Si bien estos parámetros interpretativos dan cuenta de un uso productivo de Althusser en la impugnación de las corrientes freudomarxistas, Baremblitt se esforzaba por volver explícito el tenor de aquella productividad: "debemos a la corriente althusseriana la posibilidad teórica y aún el comienzo efectivo de la crítica y superación de las numerosas modalidades de freudo-marxismo" ${ }^{569}$. En términos retrospectivos, el proceso de apertura de un espacio teórico desde el cual había sido posible convertir al freudomarxismo en objeto de crítica y superación era remitido a la potencia de un esquema analítico estructurado en base a los conceptos de ruptura epistemológica, ideología, ciencia y realidad objetiva. El planteo del problema del vínculo entre marxismo y psicoanálisis a partir de elementos tales como el acto teórico constitutivo de una ciencia, el sistema de reconocimiento-desconocimiento de una estructura real, la práctica productora de conocimientos y el orden sobre el que todas las prácticas operan, se revelaba como fundamental en la advertencia sobre las operaciones de vinculación entre ambas tradiciones en un sentido de mezcla, superposición, reducción o correlación. En un terreno ya más propositivo, la productividad del althusserianismo era remitida a la posibilidad de concebir la relación entre marxismo y psicoanálisis en clave de una "articulación entre dos ciencias" "570. el psicoanálisis como ciencia de la estructura psíquica y el materialismo histórico como ciencia de la estructura social. Si bien Baremblitt daba cuenta, a través de una lectura de Michel Tort ${ }^{571}$, que esta articulación entre ciencias incluía

\footnotetext{
$568 / d$.

${ }^{569}$ Ibid., p. 43.

$570 / d$.

${ }^{571}$ Psicoanalista francés integrante del círculo althusseriano de la ENS. Conferencista en el curso sobre Lacan y los fundamentos del psicoanálisis organizado por Althusser a comienzos de la década de 1960, publicó una serie de artículos sobre la relación entre marxismo y psicoanálisis en clave althusseriana. Uno de ellos, "La psychanalyse dans le matérialisme historique", publicado en 1970 en la Nouvelle Revue de Psychanalyse, fue editado en Argentina en forma de libro por la editorial Noé en 1972. Es precisamente El psicoanálisis en el materialismo histórico el texto al que Baremblitt recurría a los fines de esbozar una conceptualización de la ubicación del psicoanálisis
} 
relaciones de presuposición (figuración de los resultados de una ciencia en otra) y de aplicación (constitución entre el objeto teórico y el objeto soporte que corresponde a la producción de un nuevo objeto teórico en las nuevas disciplinas), este tipo de vinculación era claramente disociada de expresiones como el psicoanálisis aplicado, que tendía a correlacionar el objeto teórico de una ciencia (el inconsciente con objetos empírico-ideológicos como la guerra o la miseria) o mecanismos como la relación imaginaria de constitución ideológica, el cual cifraba la presuposición de una ciencia en otra en un sentido reduccionista (el inconsciente es un lenguaje). De esta manera, el trabajo sobre la articulación entre el marxismo y el psicoanálisis era circunscripto, por sobre todas las cosas, a la demarcación epistemológica de las ideologías precientíficas de ambas tradiciones, a su ruptura, a la instauración de sus objetos específicos y a la inauguración de sus dominios.

Cabe destacar, finalmente, que el reconocimiento de la productividad althusseriana en la crítica del freudomarxismo no implicaba necesariamente una aceptación absoluta de los posicionamientos althusserianos. Si bien Baremblitt refrendaba aquella tarea de demarcación reconociéndole al althusserianismo la desmitificación de la conciliación freudomarxista y la superación definitiva del marxismo humanista, retomaba el tono cauteloso de sus escritos anteriores acerca de los usos y potenciales efectos de la corriente teórica inaugurada por Althusser. Lo novedoso de este balance radicaba, sin embargo, en que la evaluación del althusserianismo se realizaba ya sobre la trayectoria de una tradición político-intelectual y que las prevenciones acerca de su despliegue estaban configuradas a partir de nuevas referencias teóricas.

Así ocurría, por ejemplo, con la apoyatura en la obra de Robert Castel ${ }^{572}$ a los fines de calibrar la potencia de la articulación entre marxismo y

en el materialismo histórico. Como mencionamos anteriormente, el libro compilado por Baremblitt incluía otro texto de Tort, "El concepto freudiano de representante", publicado originariamente en 1972 en el número 5 de Cahiers pour l'Analyse. Sobre el itinerario intelectual de Tort, puede verse Roudinesco, Elisabeth, op. cit., passim.

572 Baremblitt citaba un libro titulado Le psychanalisme, processus d'ideologizacion specifique (sic), editado en Bruselas en 1971. No hemos podido encontrar referencias acerca de dicha edición, sin embargo los argumentos extraídos por Baremblitt de aquel texto nos permiten inferir que se trataría de una primera edición o una versión previa de su libro La psychanalisme. L'ordre psychanalytique et le pouvoir, editado en 
psicoanálisis. Si bien el althusserianismo había logrado desplazar el problema de la conciliación entre marxismo y psicoanálisis, nada garantizaba que esta corriente fuera capaz de superar definitivamente las aporías del freudomarxismo. De esta manera aparecía, en primer lugar, el riesgo de plantear el problema del vínculo en términos exclusivamente epistemológicos. Siguiendo a Castel, Baremblitt aseguraba que si bien el problema de la cientificidad era importante, también debía atenderse al psicoanálisis como un conjunto teórico y práctico que ocupa un lugar en la estructura social. Cobraban relevancia, en este sentido, problemas tales como las condiciones de emergencia del psicoanálisis, los principios de su funcionamiento, la lógica de su difusión y las funciones que asume en relación al conjunto de las otras prácticas. La prioridad otorgada al análisis de las instituciones de regulación y control social en las que los psicoanalistas ejercen su práctica redundaba en una resignificación de la crítica a la articulación entre althusserianismo y lacanismo. Si bien Baremblitt seguía insistiendo en la incapacidad autocrítica del althussero-lacanismo y su tendencia al terrorismo epistemológicoracionalista ${ }^{573}$, priorizaba el problema de la disociación entre la cientificidad de la teoría y la eficacia revolucionaria de la práctica. A través de un desplazamiento significativo, la garantía del carácter revolucionario de la práctica psicoanalítica era despegada del carácter científico de la teoría psicoanalítica y remitida a los problemas de la inscripción institucional del agente producto de la teoría: "es altamente frecuente en el país que althusserianos $y$ antialthusserianos sean reaccionarios, considerando su militancia política personal, su forma de vida burguesa o los empleos efectivos de sus discursos científico-filosóficos" ${ }^{\text {"574 }}$.

Asimismo, la lectura de Castel hacía ingresar en las reflexiones de Baremblitt una referencia que será fundamental en su posterior itinerario

Francia por François Maspero en 1973. Este texto fue editado en castellano recién en 1980 por Siglo XXI México.

${ }^{573} \mathrm{Si}$ en los textos anteriores inferíamos que el blanco de las impugnaciones de Baremblitt al althussero-lacanismo lo constituían los círculos nucleados alrededor de Masotta, en este caso el destinatario de la crítica era explícito: los textos de Carlos Sastre. Nos detenemos en ellos en el próximo capítulo.

${ }^{574}$ Baremblitt, Gregorio. "Consideraciones en torno al problema de la realidad en psicoanálisis y del psicoanálisis en la realidad”, op. cit., p. 63. 
psicoanalítico. Al destacar la importancia que Castel le otorgaba al estudio del lugar y las funciones de lo extraanalítico en lo analítico, y al valorar, en este sentido, una indagación sobre el modo en el cual el discurso psicoanalítico está infiltrado en sus niveles teóricos a partir de las condiciones socio-históricas de su surgimiento y desarrollo, Baremblitt refería que aquel se apoyaba especialmente en conceptos de Deleuze y Guattari ${ }^{575}$. Si bien por entonces se mostraba cauteloso acerca de las implicaciones de las propuestas de Deleuze y Guattari, Baremblitt daba cuenta de que el Anti Edipo establecía las bases de una nueva ciencia, el esquizoanálisis, el cual posibilitaría un análisis institucional absolutamente original. Pero fundamentalmente, esta primera inscripción en el espacio teórico abierto por Deleuze y Guattari habilitaba una superación conjunta del lacanismo y el althusserianismo. Superponiendo en su discurso una afirmación de Castel acerca del significativo aporte de Deleuze y Guattari, Baremblitt daba cuenta de la posibilidad de "transgredir esos 'dos momentos de legitimidad cultural en que se han convertido el freudismo bajo su forma lacaniana y el marxismo bajo su forma althusseriana" 576577.

\subsection{Un marxismo sin sujeto: el antialthusserianismo de León Rozitchner}

Las implicaciones de la lectura de Althusser realizada por Baremblitt pueden ser calibradas a través de un conjunto de discusiones desarrolladas en el medio psicoanalítico local a comienzos de la década de 1970. Por un lado, el trabajo de articulación entre marxismo y psicoanálisis llevado a cabo por León Rozitchner nos permite advertir de manera indirecta las tensiones a las que

\footnotetext{
575 Según aquellos que se han dedicado a rastrear la recepción de Deleuze en Argentina, esta mención de Baremblitt sería la primera referencia escrita a los autores de El Anti Edipo, Benyo, Javier; Churba, Daniel; García Viale, Verónica y Ragoni, Pablo. "Deleuze en la Argentina". Revista Lote. $N^{\circ} 82$, Mayo de 2004. Para una visión panorámica de su recepción en Argentina, ver el número especial de la revista Cuadernos de Campo sobre "Recepción y devenir del pensamiento de Deleuze y Guattari en la Argentina" (Año 2, N 5, Octubre de 2008).

${ }^{576}$ Baremblitt, Gregorio. "Consideraciones en torno al problema de la realidad en psicoanálisis y del psicoanálisis en la realidad", op. cit., p. 52.

577 Para una reconstrucción detallada de la recepción de las críticas al psicoanálisis oficial, ver Carpintero, Enrique y Vainer, Alejandro. Las huellas de la memoria. Psicoanálisis y salud mental en la Argentina de los '60 y '70. Tomo II: 1970-1983. Buenos Aires, Topía, 2005, pp. 127-137.
} 
estaba sometida una apropiación de Althusser en los marcos del freudomarxismo. Rozitchner venía desarrollando desde mediados de la década de 1960 un trabajo centrado en el problema de la subjetividad en la cultura revolucionaria. Frente a una izquierda que tendía a pensar la acción política mediante una racionalidad en la cual no tenían lugar los problemas relativos al sujeto revolucionario, Rozitchner enfatizaba la necesidad de priorizar el análisis de los procesos de desintegración de lo humano inherentes al sistema capitalista. En tanto la desintegración del individuo propiciada por el capitalismo forma parte de la objetivación del sistema, la resolución de las contradicciones no podía ser pensada a través de la racionalidad burguesa resultante de aquel proceso disolutivo. Por ello, la racionalidad política necesaria debía ser aquella que priorizara el descubrimiento por parte del sujeto revolucionario de la contradicción instaurada por la burguesía en su seno. Según Rozitchner, la izquierda sólo podía llevar a cabo una política efectivamente revolucionaria si afrontaba el problema fundamental de la escisión entre sujeto y cultura propiciada por el capitalismo. Centrado en la problemática de la alienación, el trabajo de Rozitchner operaba un replanteo de la teoría y la política revolucionaria en el sentido de la postulación del individuo como mediador entre la racionalidad teórica y la realidad sensible ${ }^{578}$.

A comienzos de la década de 1970, el tratamiento del problema de la subjetividad en la cultura revolucionaria se acopló en la obra de Rozitchner con una impugnación de Althusser y una advertencia en torno a su apropiación por parte de intelectuales de la izquierda argentina. Dicho movimiento es claramente perceptible en su libro Freud y los límites del individualismo burgués de 1972, en el cual Rozitchner leía El malestar en la cultura y Psicología de las masas y análisis del yo con el objetivo de comprender la distancia abierta por la burguesía en el sujeto revolucionario. Allí la adopción del althusserianismo entre los intelectuales argentinos era aprehendida como un ejercicio regresivo que reforzaba la tendencia de la izquierda argentina a pensar la política con una racionalidad sin sujeto. En este sentido, el trabajo

578 Rozitcher, León. "La izquierda sin sujeto". La rosa blindada. Año 2, N 9 , Septiembre de 1966, pp. 30-43. 
sobre los escritos de Freud realizado por Rozitchner era disociado de toda obra científica y postulado como un escrito con sujeto. Es decir, un texto asumido en primera persona en el que los problemas abordados no son solamente problemas de los otros, sino también de aquel que escribe. A través de dicha presentación Rozitchner intentaba contrarrestar los efectos de unos modos de intervención intelectuales centrados en la ciencia y el discurso, los cuales implicaban la ubicación del objeto de análisis fuera de sí mismo y el acrecentamiento de la distancia con el otro. La difusión del paradigma estructural entre los intelectuales argentinos propiciaba tanto la insistencia en el problema de la subjetividad como un nuevo impulso a la lucha contra una izquierda sin sujeto: "Este retorno sobre el sujeto se hace ahora más necesario que nunca; estructuralismo mediante, terminamos por no hablar sino por ser hablados. Nos disolvemos en lo impersonal que se piensa en nosotros como lugar anónimo de la significación y, por lo tanto, sin responsabilidad" 579.

Si de lo anterior se desprende que su crítica aludía genéricamente al estructuralismo, las formulaciones concretas elegidas para la oposición con una correcta articulación entre marxismo y psicoanálisis eran precisamente aquellas proporcionadas por el althusserianismo. De este modo, Rozitchner advertía que la concepción de la intervención intelectual en términos de práctica teórica implicaba una separación de la política y una negación del sujeto como núcleo de verdad histórica. En este mismo sentido, captaba al antihumanismo teórico como un postulado que tendía a abandonar los problemas de la estructura subjetiva del sujeto político. Así intentaba demostrar que bajo el objetivo explícito de negar la subjetividad burguesa, el althusserianismo dejaba abandonada "entre los trastos viejos de la burguesía"580 la contradicción esencial que el sujeto político debía asumir para llevar a cabo un movimiento efectivamente revolucionario. Rozitchner procesaba con agudeza la filiación teórico-política de Althusser -"resabios stalinistas" ${ }^{581}$-, su concepción del sujeto -"portador, siempre mensajero, changarín de una verdad ajena, y en última

${ }^{579}$ Rozitchner, León. Freud y los límites del individualismo burgués. Buenos Aires, Siglo XXI, 1972, p. 24.

580 Ibid., p. 27.

${ }^{581}$ Id. 
instancia, esclavo"582 - y la adopción de dichos postulados por parte de los intelectuales argentinos -"Althusser escribe en realista, y los nuestros repiten, sin rubor"583. En suma, el althusserianismo como relectura estructuralista de Marx que contribuía al ocultamiento de las contradicciones subjetivas inherentes al sistema capitalista, y los althusserianos argentinos como intelectuales seducidos por un saber con consecuencias contrarrevolucionarias:

Troncos de izquierda, despojados de lo más propio por la defoliación althusseriana, se quedan sin savia y sin hojas, sólo esqueletos de una espesura anterior o posible. Colonizados al fin por la moda de los centros europeos, de la que también toman su penúltimo grito, ¿qué mayor muestra de la sumisión colonizadora que este pedido ante el cual los humillados por el saber rinden lo más propio, la propia diferencia, el lugar más particularizado desde el cual podría ésta emerger: su propia subjetividad sometida? Porque es otra realidad la que allí grita y no la nuestra. Pero no por eso el pequeño burgués de cada uno que comenzó el tránsito lo terminó con la aceptación de la 'ciencia' marxista: lo negado abstractamente subsiste y, como nos enseña Freud, nos sigue determinando, sólo que ahora dedicando nuestras energías a que no aparezca. Meandros de la lógica represiva que ningún privilegio político podría anular ${ }^{584}$

\subsection{Althusser con Lacan: disputas en torno a una apropiación}

Si este pasaje de Freud y los límites del individualismo burgués da cuenta de una manera sumamente ilustrativa de la distancia existente entre los usos de Althusser desarrollados en los primeros textos de Baremblitt y el lugar que le cabía al althusserianismo en otros ejercicios contemporáneos de articulación entre marxismo y psicoanálisis, otro episodio de la vida intelectual argentina de comienzos de la década de 1970 nos permite advertir de forma explícita el vínculo conflictivo entre las apropiaciones de Althusser realizadas desde el freudomarxismo y las llevadas a cabo desde el lacanismo. Tal como habíamos anticipado al momento de analizar las intervenciones desarrolladas por los colaboradores de Los Libros sobre diversos problemas de la cultura argentina, durante el año 1972 la revista fue escenario de un debate a

\footnotetext{
${ }^{582} / d$.

$583 / d$.

${ }^{584}$ Ibid., p. 28.
} 
propósito de la conformación de los grupos Plataforma y Documento y la edición de los volúmenes Cuestionamos.

El número 25 de la revista, dedicado al tema "Psicoanálisis y política en la Argentina" -el cual se presentaba con una tapa en la que Freud y Marx aparecían juntos ${ }^{585}$ - incluía, además de los ya citados documentos fundacionales de los grupos y los materiales sobre el Centro de Docencia e Investigación, un artículo de la psicóloga Miriam Chorne y del sociólogo Juan Carlos Torre y otro del psicoanalista Germán García en los que se abordaba un conjunto de problemas relativos al proceso de ruptura de la APA. Como se afirmaba en la nota anónima en la que se presentaba el contenido del número, la intervención de la revista en el debate acerca del vínculo entre psicoanálisis y política perseguía el objetivo de refutar la concepción del proceso de politización de los psicoanalistas como advertencia del carácter apolítico del ejercicio de su profesión. Lo que este entendimiento ignoraba, de acuerdo al Consejo de dirección de la revista, es que toda actividad es política aunque el sentido de su inscripción no se manifieste en un plano consciente. En esta misma dirección, la lectura de los textos programáticos de Plataforma y Documento por parte de miembros de la revista se justificaba por la necesidad de evidenciar "la distancia de los hechos con la fantasía de sus protagonistas" ${ }^{586}$. Sin dudar de la franqueza ni de la legitimidad de las afirmaciones realizadas por los miembros de dichos grupos, Los Libros se esforzaba por visibilizar la dificultad que aquellos tenían para pensar la instalación de un sentido revolucionario en una práctica específica.

Sobre esta base común, Chorne y Torre se detenían en la pobreza de los contenidos de los programas de Plataforma y Documento. Según su perspectiva, una parte importante de esta falencia no se debía tanto a las limitaciones intrínsecas de los grupos como a las características de la institución de la que se separaban. No podía esperarse otra cosa de sujetos que provenían de un espacio autosuficiente en el que se había codificado la práctica analítica y se habían convertido los problemas relativos a su

\footnotetext{
${ }^{585}$ Ver apéndice de imágenes.

586 "En este número". Los Libros. Para una crítica política de la cultura. $\mathrm{N}^{\circ} 25$, Marzo 1972, p. 2.
} 
aprendizaje y ejercicio en una cuestión meramente administrativa. Haberse salido de un espacio con tales características no podía tener sino efectos positivos, especialmente en lo relativo a la recuperación de una capacidad crítica frente a una accionar ritualizado. Sin embargo, dicha separación no le proporcionaba ninguna herramienta al sujeto que buscaba pensar de otro modo los problemas fundamentales de la teoría y la práctica psicoanalítica. Al renunciar a las respuestas canonizadas de la institución, Plataforma y Documento se habían hecho cargo de un desafío, pero a los fines de afrontarlo no tenían "otras armas que las carencias del mundo que abandonan" ${ }^{57}$. Según Chorne y Torre, el lugar en el que más se evidenciaba esta falta era en el trabajo emprendido por los miembros de los grupos alrededor de una revisión teórica que permitiera confrontar con el esclerosado saber institucional. En base a una necesidad de incorporar conocimientos de otras ciencias y completar la formación parcializada impartida por la institución, los programas desarrollados por los grupos daban cuenta de un esfuerzo de apertura del psicoanálisis hacia otros saberes. El problema radicaba en que este movimiento aperturista no estaba acompañado por una reflexión acerca del modo en el cual se articulan los conocimientos provenientes de las diferentes ciencias. Se advertía así en las propuestas de Plataforma y Documento un eclecticismo que conducía a confundir los distintos niveles de realidad y yuxtaponer diferentes núcleos teóricos.

En esta misma dirección, Chorne y Torre percibían una confusión en los términos en los cuales las declaraciones de ambos grupos planteaban la relación entre psicoanálisis y política. Según su lectura, el afán politizador que aquellos documentos trasuntaba resultaría estéril de no mediar una reflexión acerca de los instrumentos necesarios para llevar a cabo una intervención política en el ámbito psicoanalítico. Los efectos negativos de dicha ausencia se percibían en una tendencia al declaracionismo en relación al programa político y a la vaguedad con respecto a los beneficiarios de la acción a llevarse a cabo. Si esta dimensión analítica conllevaba la advertencia de cierto intelectualismo

${ }^{587}$ Chorne, Miriam y Torre, Juan Carlos. "El porvenir de una ilusión". Los Libros. Para una crítica política de la cultura. $\mathrm{N}^{\circ} 25$, Marzo 1972, p. 3. 
en Plataforma y Documento, el cual les hacía suponer que la remisión al marxismo era suficiente para obtener una práctica revolucionaria, Chorne y Torre advertían una distorsión inversa en el modo en el cual se concebía la relación entre práctica política y práctica profesional. Es decir, pensar la politización en clave de vinculación entre el psicoanalista y las organizaciones políticas revolucionarias implicaba el desconocimiento de la existencia de un nivel específico de intervención del psicoanálisis sobre la sociedad. En esta lectura, el rescate de la especificidad de la intervención militante del psicoanalista operaba como una advertencia de que la participación política del psicoanalista no puede reemplazar a la "gestión profesional, políticamente orientada, en torno a los problemas de la salud mental en la sociedad"588. Frente a la pregunta sobre cuál es la intervención política que le corresponde a un profesional, Chorne y García intentaban disolver la oposición entre una politización que abandona el campo específico y un repliegue pesimista sobre la propia práctica profesional. Si la respuesta a aquella pregunta era la de una reestructuración del rol profesional en la que la práctica específica operaría un cuestionamiento permanente del ámbito institucional e ideológico en el cual ésta se lleva a cabo, la lectura de los modos en los cuales se relacionaba psicoanálisis y política en las declaraciones de Plataforma y Documento no podía tener sino un cariz negativo.

La intervención de García se detenía en los mismos puntos problemáticos que la lectura de Chorne y García. En primer lugar, en el problema de la práctica política como uno de los puntos ciegos de la práctica psicoanalítica. Al respecto, García repasaba los pasajes de los textos compilados en Cuestionamos en los que se mencionaba la cuestión del vínculo entre ciencia y revolución para concluir que lo allí afirmado era producto de "una voluntad teóricamente frágil y políticamente superficial" caracterización se sustentaba en un cuestionamiento particularmente incisivo de la aprehensión del proceso de politización en clave de toma de conciencia. El planteo del Cordobazo como episodio que había despertado a los

\footnotetext{
${ }^{588}$ Ibid., p. 4.

${ }^{589}$ García, Germán. "Cuestionamos, las aventuras del bien social”. Los Libros. Para una crítica política de la cultura. № 25, Marzo 1972, p. 12.
} 
psicoanalistas evidenciaba la concepción de que la problemática política no los había atravesado anteriormente. De esta manera, el pasaje desde un psicoanálisis sin política hacia una práctica profesional politizada era expresado en términos lacanianos como una protesta idealista contra el caos del mundo. Los miembros de Plataforma y Documento jamás alcanzarían una politización efectiva de continuar pensado lo social como un exterior a una práctica profesional que se desarrolla inevitablemente dentro de la sociedad. En este mismo sentido, García advertía la forma en la cual el vínculo deseado por aquellos psicoanalistas como "el marxismo" y "el psicoanálisis" aparecía como la apropiación de elementos ya dados y no como un trabajo necesario de construcción de saberes. Al igual que la palabra pan no da de comer, ironizaba, las declaraciones no sustituyen a las prácticas; al reemplazar unas por otras, los psicoanalistas no hacían más que reforzar "la ceguera teórica de su práctica científica" ${ }^{290}$. A los fines de evitar la tendencia voluntarista a creer que la inversión de la ideología de la neutralidad alcanza para lograr una ciencia comprometida, García postulaba la necesidad de un trabajo de articulación entre la práctica y la teoría analítica y la teoría política específica a la pretendía acceder.

Las lecturas desarrolladas por Chorne y Torre y García no podían pasar por alto que algunos de los artículos reproducidos en Cuestionamos escapaban en parte a las acusaciones lanzadas desde las páginas de Los Libros. Este problema aparecía de manera explícita en la intervención de García, quien frente a la necesidad de aclarar que algunos textos de la compilación daban cuenta de un reconocimiento de los problemas por él advertidos, creyó necesario adjuntar una nota al pie en la cual se daban mayores precisiones de dicha confluencia. Por un lado, García dejaba constancia que existían en el seno de Plataforma y Documentos reflexiones acerca de los vínculos entre psicoanálisis y política que no eran merecedoras de las caracterizaciones generales: "[el análisis] no hace justicia a los pocos textos de Cuestionamos que se plantean, sin anular los dos campos ni confundirlos, la relación entre la

${ }^{590}$ Ibid., p. 13. 
práctica y la teoría analítica y práctica y la teoría política" ${ }^{291}$. Sin embargo, dichos textos tampoco podían liberarse totalmente de las críticas generales impuestas a Cuestionamos, en tanto formaban parte de un conjunto de intervenciones que apuntaban mayoritariamente en un sentido contrario al que aquellos buscaban propiciar: "[n]o se trata de un descuido, sino de señalar que el contexto de la antología distorsiona, cuando no contradice abiertamente, la significación de esos textos" ${ }^{592}$.

Si la mención a la no superposición entre práctica profesional y práctica política podía hacer suponer que los textos aludidos por García eran precisamente los de Baremblitt, el número 27 de la revista vino a despejar toda duda. A modo de continuación de la discusión abierta en el número 25 , se reproducía allí una respuesta de Baremblitt al texto de Chorne y Torre y al de García. Los términos a través de los cuales Baremblitt enfrentaba las críticas lanzadas desde la revista permiten constatar de manera privilegiada tanto la distancia y la afinidad existente entre las formulaciones de Baremblitt y los otros miembros de Plataforma y Documento como la confluencia y la separación entre dichas formulaciones y la propuesta lacaniana. Con un epígrafe del pasaje de Lire Le Capital en el que Althusser refería al problema de la culpabilidad de toda lectura -"toda lectura es culpable"-, Baremblitt establecía un diálogo con sus críticos del que desligaba a los otros autores de Cuestionamos y al resto de los miembros de Plataforma y Documento. Resulta interesante destacar que su respuesta refrendaba varias de las advertencias realizadas por Chorne y Torre y García. Baremblitt coincidía en que los psicoanalistas salidos de la APA carecían de herramientas para consumar una alternativa teórica y práctica al psicoanálisis institucional. Asimismo, señalaba la justeza de caracterizar como una operación de simplificación y falsa homologación la asociación establecida entre el Cordobazo y la politización de los psicoanalistas. Finalmente, valoraba la impugnación de las posiciones humanistas predominantes en Cuestionamos así como el señalamiento de una

\footnotetext{
${ }^{591} / d$.
}

${ }^{592} / d$. 
tendencia declamatoria y voluntarista en el planteo de las relaciones entre psicoanálisis y política por parte de los miembros de Plataforma y Documento.

Pero al mismo tiempo que avalaba varias de las advertencias e impugnaciones realizadas por los miembros de la revista, Baremblitt se mostraba cauteloso frente a algunas de las implicaciones de las lecturas desarrollas por Chorne y Torre y, especialmente, García. A través de un contrapunto en el que resuenan otros debates en los cuales participaron intelectuales vinculados a Los Libros, Baremblitt les reprochaba a aquellos el sostenimiento de una aproximación meramente correctiva a Cuestionamos y el desconocimiento del esfuerzo desarrollado por Plataforma y Documento en pos de una intervención política concreta. Si bien el proceso de politización desplegado por aquellos grupos adolecía de una clarificación acerca de los vínculos entre teoría y práctica, no podía pasarse por alto el carácter progresivo de la delimitación de un proyecto alternativo al de la APA. Del mismo modo relativizaba Baremblitt el carácter absoluto de la carencia de conocimiento en los psicoanalistas salidos de la institución así como la tendencia hacia el eclecticismo en su propuesta de articulación de los diversos saberes. Tal como evidenciaban sus textos publicados en Cuestionamos, algunos de los miembros de Plataforma y Documento tenían un conocimiento sobre problemas de teoría y práctica psicoanalítica distinto al impartido y defendido por la institución. Asimismo, la propuesta allí delimitada consistente en la revisión del marxismo y el psicoanálisis a través de una lectura centrada en la ruptura operada en cada una de las tradiciones actuaba a modo de refutación de la supuesta carencia de criterios en el trabajo de apertura teórica. Si bien todos los participantes del debate compartían la necesidad de diferenciar práctica profesional y práctica política, el sentido que Baremblitt le otorgaba a dicha diferencia divergía claramente del de sus críticos:

es clarísimo que, para nosotros, los múltiples aspectos tales como revisar nuestra ciencia, buscar la correcta articulación con otras e indagar por nuevas formas de inserción política, son distinguidos entre sí. Se privilegia, claro está, la aplicación política pero eso no quiere decir que se omita la búsqueda de 
cientificidad. ¿Es eso confusión de niveles, yuxtaposición de núcleos teóricos? ${ }^{593}$

Los pasajes más explícitos a través de los cuales Baremblitt respondía las acusaciones de García dejaban en claro que su participación en el registro teórico inaugurado por Althusser estaba absolutamente condicionada a la disociación entre lacanismo y althusserianismo. Si los textos de Cuestionamos abordaban este problema pero mantenían velados a los destinatarios de la crítica, la polémica establecida con los intelectuales de Los Libros le permitió a Baremblitt confrontar directamente con aquellos que operaban una asociación entre ambas corrientes. Esta confrontación se desenvolvía, por un lado, en un plano recortado al interior de la obra de Lacan. Si bien Baremblitt valoraba determinados elementos implicados en relectura de Freud propiciada por Lacan, tales como la vinculación con la lingüística y la revalorización del deseo, advertía también sobre la necesidad de revisar aspectos problemáticos de su obra: "al Lacan reduccionista que hipostasia al deseo como la esencia de la naturaleza humana, al Lacan Hegeliano-Kantiano que afirma la incognoscibilidad de la único realmente existente, el inconsciente, al Lacan ‘lingüisticista' que sostiene a la lengua como la materialidad del psiquismo" 594. Junto a esta diferencia de índole teórica, Baremblitt regresaba al problema de las implicaciones político-intelectuales del lacanismo. En este caso, las críticas que le habían sido formuladas por García eran tomadas como ejemplo de las operaciones que debían ser evitadas a los fines de propiciar una articulación efectiva entre psicoanálisis y política. Por un lado, la tendencia a descalificar y distorsionar los argumentos criticados: "su metodología de selección discrecional de fragmentos para la crítica, la mordacidad de su estilo y el cientificismo neo-colonialista francés"595. Por el otro, las consecuencias conservadoras de una lectura cientificista con un objetivo meramente censor: "temo a una generación de Catones que munidos de buena información y 'carentes de culpa' instauren el neocientificismo psicoanalítico amparados en la

\footnotetext{
${ }^{593}$ Baremblitt, Gregorio. "El malestar en la cultura... y sus revistas". Los Libros. Para una crítica política de la cultura. $\mathrm{N}^{\circ} 27$, Julio 1972, p. 14.

${ }^{594}$ Ibid., p. 15.

${ }^{595}$ Ibid., p. 14.
} 
especificidad de las prácticas y el preciosismo galicista"596. Tal como hemos visto anteriormente, el lacanismo en Baremblitt no solo no era una inflexión progresiva en la tradición psicoanalítica, sino que representaba el peligro de una reconstitución del psicoanálisis institucional.

\subsection{A modo de cierre}

La reconstrucción de los itinerarios de Althusser en la trayectoria intelectual de Masotta y en los grupos que protagonizaron la crisis de la APA nos ha permitido delimitar dos modos diferenciados de recepción de las tesis del filósofo francés. En el caso de Masotta el althusserianismo constituyó un factor clave de su pasaje desde la fenomenología hacia el estructuralismo. Al respecto vimos que entre fines de la década de 1950 y comienzos de la de 1960 Masotta concebía en términos sartreanos tanto la especificidad del marxismo como su vínculo con el psicoanálisis. Si en relación al primero de los tópicos su lectura tendía a enfatizar el problema de la conciencia, en lo relativo al segundo sus reflexiones giraban alrededor de las relaciones de integración y asimilación. El anclaje fenomenológico de su producción teórica posibilitó una primera lectura de Lacan en la cual su propuesta renovadora en el campo del psicoanálisis convivía con las problemáticas teóricas de Sartre y Politzer. A mediados de la década de 1960 la lectura de Althusser acompañó a Masotta en su desplazamiento hacia el estructuralismo y la configuración de una nueva lectura de Lacan. Si en la primera de las operaciones el marxismo comenzó a ser asociado cada vez más a la importancia del trabajo teórico, en la segunda la relación entre marxismo y psicoanálisis se fue desplazando cada vez hacia el problema del inconsciente. En este sentido dimos cuenta de la productividad de la noción de práctica teórica en su rechazo de los posicionamientos intelectuales deudores del existencialistmo y de la lectura althusseriana de Freud en la refutación de las aproximaciones fenomenológicas a la tradición psicoanalítica. Al centrarnos particularmente en las intervenciones desarrolladas en el marco de las disputas acerca de la lectura de Freud, hemos

${ }^{596}$ Ibid., p. 15. 
visto los efectos del althusserianismo en la problematización de los vínculos entre la práctica psicoanalítica y su institucionalización. Asimismo al remitirnos a sus textos lacanianos de la primera mitad de la década de 1970 hemos certificado la importancia de Althusser en la corrección de sus antiguas lecturas fenomenológicas.

La otra lectura de Althusser delimitada en aquella realizada en los marcos de la crisis de la APA. El repaso por los textos fundamentales producidos en aquel contexto nos permitió certificar que los modos predominantes de concebir los vínculos entre marxismo y psicoanálisis abrevaban en la tradición freudomarxista. Entendida la relación entre ambos corpus teóricos en términos de analogía y la intevención política de los psicoanalistas en clave de compromiso, el sentido que los grupos Plataforma y Documento le otorgaban a su impugnación a la institución psicoanalítica estaba lejos del que podía desprenderse de un posicionamiento althusseriano. De allí la atención que han merecido las reflexiones realizadas en este contexto que acudían a formulaciones althusserianas. Al respecto analizamos las intervenciones de Baremblitt en tanto espacio de recepción de la propuesta althusseriana de lectura científica de Freud y de problematización de la relación entre teoría y política. Asimismo destacamos la singularidad de esta lectura en tanto la incorporación de formulaciones althusserianas estaba condicionada al rechazo frontal de las implicaciones teóricas y políticas del lacanismo. El seguimiento del itinerario de Baremblitt nos permitió constatar la pervivencia de sus críticas al freudomarxismo y al lacanismo así como analizar la introducción del problema de la ideología. Por último vimos cómo el althusserianismo comenzó a ser objeto de una reflexión crítica a medida que Baremblitt se acercaba a las discusiones abiertas por Deleuze y Guattari.

Finalmente el repaso por dos intervenciones alrededor de la relación entre marxismo y psicoanálisis nos permitió dar cuenta de los efectos que tuvieron en el campo psicoanalítico argentino las lecturas de Althusser realizadas en los marcos del lacanismo y el freudomarxismo. Con el repaso de la lectura de Althusser llevada a cabo por Rozitchner accedimos a una articulación entre marxismo y psicoanálisis hostil a la tendencia cientifizadora y 
anti-humanista del althusserianismo. Al insistir en la necesidad de una teorización de problema de la subjetividad, Rozitcher veía en las tesis althusserianas el índice de un posicionamiento políticamente regresivo. El debate entre Baremblitt y sus lectores lacanianos nos permitió indagar aún más en la singularidad de la lectura de Althusser desarrollada en el contexto de crisis de la APA. Si bien exceptuaba sus textos del freudomarxismo reinante en Plataforma y Documento, Chorne y García advertían en Baremblitt cierto apego a las confusiones propias de aquel modo de concebir las relaciones entre marxismo y psicoanálisis. En un sentido especular, Baremblitt suscribía las acusaciones lanzadas por el lacanismo a la vez que condicionaba la recepción de las tesis althusserianas a la reflexión acerca del potencial negativo del programa renovador propuesto por Lacan. Cercanas y lejanas al mismo tiempo, estos dos posicionamientos permiten dar cuenta de una compleja disputa por la apropiación de Althusser en el seno del psicoanálisis argentino.

\title{
Capítulo 6
}

\author{
Hacia la fundación científica de la psicología: Carlos Sastre y \\ Roberto Harari lectores de Althusser
}




\subsection{Introducción}

En este capítulo se analizan las lecturas de Althusser desarrolladas por dos psicólogos pertenecientes a las primeras camadas de egresados de la Facultad de Psicología de la UBA. En primer lugar recorremos el itinerario de Carlos Sastre. Veremos que sus primeras intervenciones en las discusiones de la disciplina consistieron en la disputa contra la psicoterapia breve. Allí reconstruimos los efectos de Althusser en la impugnación de la articulación establecida por Hernán Kesselman entre el rol político y el rol profesional del psicólogo. Nos detenemos luego en el trabajo de refutación desarrollado a comienzos de la década de 1970 que tuvo como objeto a la psicología de la conducta, la idea de alienación y la antipsiquiatría. Veremos cómo allí el althusserianismo operó proporcionando argumentos como el de la diferencia entre objeto real y objeto de conocimiento, el de la determinación estructural y el de la separación entre ciencia e ideología. Finalmente analizamos el desplazamiento hacia la epistemología propio de sus trabajos de mediados de los años setenta. Al respecto nos concentramos en la importancia del althusserianismo en la problematización de la fundación científica de la psicología y de los peligros de la ideología.

En segundo lugar analizamos la trayectoria de Roberto Harari. De manera análoga a Sastre, sus primeras intervenciones estuvieron dirigidas a polemizar con otros posicionamientos disciplinares contemporáneos. En su caso entabló discusiones con Juana Danis, quien propiciaba una práctica centrada en el ser humano en tratamiento, y con Hernán Kesselman y Antonio Caparrós, los cuales mantuvieron una discusión acerca de la relación entre psicoanálisis y antiimperialismo. Como veremos, Harari se impondrá antes dichas posiciones a través de un repertorio argumental deudor del althusserianismo, entre los cuales se destacaba la diferenciación entre los niveles científico y profesional, así como la postulación del inconsciente como el objeto de la práctica del psicólogo. Nos concentramos luego en sus 
desarrollos teóricos sobre el problema del rol del psicólogo. Al respecto analizamos los efectos de Althusser en el ajuste de cuentas con la psicología concreta de José Bleger y en el direccionamiento de las reflexiones sobre la práctica profesional hacia la problemática de los códigos inherentes a las formaciones ideológicas. Finalmente analizamos la operativización de variables tales como la reproducción de la formación social y el rol de los AIE en el trabajo desarrollado por Harari sobre la experiencia de la población villera.

\subsection{Un pensamiento falso: la polémica Carlos Sastre-Hernán Kesselman}

En el marco de las discusiones alrededor de la profesionalización del psicólogo y la difusión de nuevas teorías y prácticas psicoterapéuticas, un texto de Hernán Kesselman publicado en el primer número de la revista Cuadernos de Psicología Concreta establecía las bases de un programa para una psicoterapia "eficaz, popular, nacional e idónea" ${ }^{297}$. Una propuesta con tales características encontraba legitimación, en parte, en la propia trayectoria profesional y política de Kesselman: una persona que había sido formada en terapia psicoanalítica pero que había tenido que recurrir a otro tipo de asistencia psicológica al atender a una gran cantidad de pacientes que no podían recurrir a un tratamiento psicoanalítico. Alrededor de esta doble pertenencia se desplegaban una serie de preocupaciones relativas al vínculo entre las cuatro dimensiones que integraban el programa psicoterapéutico propuesto. En primer lugar, cómo desarrollar técnicas de duración limitada que permitieran llegar a la mayor cantidad de gente posible. En segundo término, cómo lograr que aquellas técnicas lograran efectivamente curar a la población. Por otra parte, cómo hacer para que dichas técnicas respondieran a las características regionales del país. Finalmente, cómo lograr que las técnicas utilizadas poseyeran una fundamentación científica. Dedicado a combatir la idea de que el psicoanálisis es caro pero eficaz y que las otras técnicas psicoterapéuticas pueden llegar a ser baratas pero son ineficaces, el trabajo de

\footnotetext{
${ }^{597}$ Kesselman, Hernán. "La responsabilidad social del psicoterapeuta". Cuadernos de Psicología Concreta. №1, 1969, p. 58.
} 
Kesselman introducía la afirmación de que una resolución de las cuestiones planteadas permitiría despejar el mencionado juicio valorativo sobre las psicoterapias que no se ajustaban a las prácticas psicoanalíticas legitimadas.

La propuesta de una psicoterapia eficaz, nacional, popular e idónea se alimentaba, asimismo, de un diagnóstico marcadamente negativo de los modos a través de los cuales los psicoterapeutas argentinos concebían tanto la posición frente a expresiones teóricas burgueses como la relación existente entre práctica profesional y contexto social. En relación al primer problema, Kesselman daba cuenta de la existencia de dos "extremismos peligrosos" 598 . Por un lado, el del desprecio por cualquier desarrollo teórico de origen burgués, lo cual conducía al rechazo sin más de conocimientos que podían ser utilizados poniéndolos al servicio de la transformación social. Por otro lado, el de la extrapolación directa de aquellos desarrollos teóricos a la realidad nacional, lo cual conllevaba la ausencia de un análisis de la incorporación del conocimiento mediado por los objetivos transformadores. En el caso del segundo problema discutido, lo que para el vínculo con las teorías burguesas aparecía en términos de actitudes extremas, aquí se presentaba como "soluciones puristas"599. Al respecto, Kesselman hablaba de dos formas de enfrentar la relación entre la práctica profesional del psicoterapeuta y la política. Por un lado, la defensa de la objetividad, la cual acarreaba la idea de que el trabajador de la salud mental debía mantener una neutralidad valorativa frente a la realidad observada. Por otro lado, la tendencia a mantenerse al margen de teorías y prácticas psicoterapéuticas supuestamente conservadoras, lo que producía profesionales incontaminados de elementos burgueses pero poco preocupados por la calidad de las bases que apuntalaban su práctica profesional. De acuerdo con Kesselman, el extremismo y el purismo eran los responsables de los elementos negativos que constituían a la psicoterapia en Argentina. De un lado, la pobreza de los desarrollos científicos, los cuales eran abandonados a la burguesía. Del otro, la mutilación profesional, la cual habilitaba la disociación entre práctica psicoterapéutica y rol social del trabajador de salud mental.

\footnotetext{
598 Ibid., p. 59.

${ }^{599}$ Ibid., p. 60.
} 
Frente a este panorama, un programa de psicoterapia eficaz, popular, nacional e idónea habilitaba un esfuerzo de superación de las soluciones existentes a los problemas del vínculo con la teoría burguesa y la relación entre práctica profesional y rol político del psicoterapeuta.

El texto de Kesselman fue procesado por Sastre a través de la delimitación de los principales núcleos problemáticos inscriptos en la propuesta de una psicoterapia eficaz, nacional, popular e idónea. El primero de ellos remitía a las implicaciones de una formulación programática de tales características. Sobre este nivel analítico, Sastre llevaba a cabo un conjunto de operaciones. Una de ella, de índole retórica, estructurada alrededor de la sugerencia de no poder abordar seriamente dicho programa debido a la "diversidad de campos semánticos" ${ }^{600}$ que se condesaban en la propuesta de una psicoterapia eficaz, nacional, popular e idónea. Es decir, de qué manera se podía establecer un diálogo con un programa que presentaba de manera indiferenciada adjetivos que remitían tanto al campo profesional como al campo político. Sin embargo, suspendido este señalamiento, su lectura se adentraba en la "relación de implicación" ${ }^{601}$ que se establecía entre dimensiones propias de la práctica terapéutica y aquellas pertenecientes a la ideología nacional y popular. Al respecto, Sastre atendía principalmente dos de las preocupaciones con las que Kesselman introducía su programa: la de cómo confeccionar técnicas de duración limitadas, a las cuales se les adjudicaba la garantía de que fueran efectivamente populares, y la de cómo lograr que estas técnicas partieran de las características regionales, condición que garantizaría que fueran efectivamente nacionales. Al respecto, Sastre advertía que, en los argumentos de Kesselman, los términos de origen político no eran traducidos al campo semántico de la psicología, sino que eran directamente trasladados. Al no mediar una operación de traducción, los sentidos que los términos poseían en su campo de origen quedaban inevitablemente perdidos en el movimiento de simple traslación. Así, lo "popular", que en el campo de la política tiene una connotación "anti-oligárquica", terminaba remitiendo a lo "masivo" en el campo

${ }^{600}$ Sastre, Carlos. "Acerca de 'Responsabilidad social del psicoterapeuta' de Hernán Kesselman”. Revista Argentina de Psicología. № 1, 1969, p. 92.

${ }^{601} / d$. 
de la psicología. Del mismo modo, lo "nacional", que en el campo de la política tiene una connotación "anti-imperialista", terminaba remitiendo a lo "local" en el campo de la psicología. Al no dar cuenta teóricamente de las relaciones entre los campos, la relación entre teoría política y práctica psicoterapéutica se revelaba como "un nexo solo aparente" ${ }^{002}$, en tanto no había ninguna garantía de que teorías y técnicas psicoterapéuticas locales y de consumo masivo fueran efectivamente revolucionarias. En este mismo sentido, la confusión en la que incurría Kesselman entre yuxtaposición e implicación lógica entre los campos tornaba estéril su esfuerzo por establecer un vínculo entre la práctica profesional y la realidad política. A través de la introducción de los términos popular y nacional, Kesselman satisfacía "su necesidad de vincular el quehacer psicológico a la vida del pueblo de nuestra patria" ${ }^{603}$. Sin embargo, el carácter directo de aquella operación de introducción hacía que el problema del vínculo permaneciera irresuelto. Para Sastre, el trabajo político en pos de una toma de conciencia nacional constituía un esfuerzo elogiable, el problema radicaba en que para que aquella fuera efectivamente productiva, "el planteo científico que establezca la relación [entre quehacer psicológico y vida del pueblo] debe ser verdadero" 604 .

Otro de los problemas recortados por Sastre remitía a la concepción de la relación entre rol profesional y rol político del psicoterapeuta inscripta en la propuesta de Kesselman. A su entender, la pregunta acerca de en qué medida la tarea profesional del psicoterapeuta contribuye a mantener o combatir el sistema social, era indicativa de la creencia en la posibilidad de combatir el sistema desde la propia práctica profesional. La lectura que Sastre hacía de este postulado de Kesselman era categórica: "la decisión de combatir el sistema desde la psicoterapia responde más a una fantasía que a una posibilidad de acción" ${ }^{\prime 605}$. Semejante caracterización se apoyaba en una refutación de la forma a través de la cual Kesselman concebía el trabajo intelectual. Según la mirada de Sastre, operaba allí una "idealización

\footnotetext{
${ }^{602} / d$.

${ }^{603}$ Ibid., p. 93.

604 Ibid., p. 94.

${ }^{605}$ ld.
} 
pequeñoburguesa de la tarea intelectual"606, en tanto se le adjudicaba la posibilidad de combatir al sistema a una sola de las prácticas insertas en el ciclo de producción y reproducción. Frente a dicha idealización, se esbozaba una explicación según la cual el psicólogo contribuye a la planificación de tareas políticas con sus conocimientos específicos, pudiendo integrarse a un proceso de combate al sistema a través de la vinculación con una organización política. Asimismo, Sastre revelaba cuál era la noción de totalidad que operaba en Kesselman posibilitando la creencia en la posibilidad de combatir el sistema desde la práctica profesional. A través de un especial detenimiento en los usos que se hacía en el texto de las enseñanzas de León Rozitchner, Sastre advertía otra confusión en los argumentos de Kesselman, aquella "entre el todo y las partes" ${ }^{607}$. Es decir, Kesselman concebía el vínculo entre el rol profesional y el rol político del psicoterapeuta bajo una noción de totalidad en la que la sustancia común del todo se expresa a través de diversas manifestaciones en cada una de las partes. Idea de totalidad que lo llevaba a asimilar la noción de unidad, en la cual la parte ocupa un lugar en una totalidad estructurada, y la de identidad, en la cual una parte contiene a todas las partes. Por ello, la palabra del psicoterapeuta era entendida como el esfuerzo en pos de que el sujeto tome conciencia de su relación con los otros, y no como un intento por nombrar el lugar que el sujeto ocupa en la sociedad y la determinación que dicho lugar le imprime a su visión del mundo. La concepción del sujeto como parte discontinua del todo social habilitaba una refutación de una noción de totalidad estructurada alrededor de la idea de una identidad de las partes. En el mismo sentido, la representación del psicoterapeuta como aquel que favorece en el sujeto una lectura correcta de la determinación social que lo habita, permitía

\footnotetext{
${ }^{606} / d$.

${ }^{607}$ Ibid., p. 95. Kesselman se referenciaba en un texto titulado "Niveles de experiencia", seguramente parte de los cursos sobre Marx y Freud dictados por Rozitcher en la Facultad de Filosofia y Letras de la Universidad de Buenos Aires a mediados de la década de 1960. Atravesadas por los efectos del momento fenomenológico y el impacto de los Manuscritos económico-filosóficos, las preocupaciones de Rozitchner se dirigían hacia el problema de la constitución del hombre en la cultura y el pasaje de lo individual a lo universal. Uno de los pasajes de Rozitchner más remarcado por Kesselman, y más impugnado por Sastre, afirmaba: "Decir 'uno' equivale a decir 'todos', cada uno es ejemplar respecto de los otros, por tanto los contiene a todos".
} 
una superación de aquella representación que lo piensa como quien contribuye a revelar la esencia común a todos los hombres. Al respecto, afirmaba Sastre con un dejo de ironía:

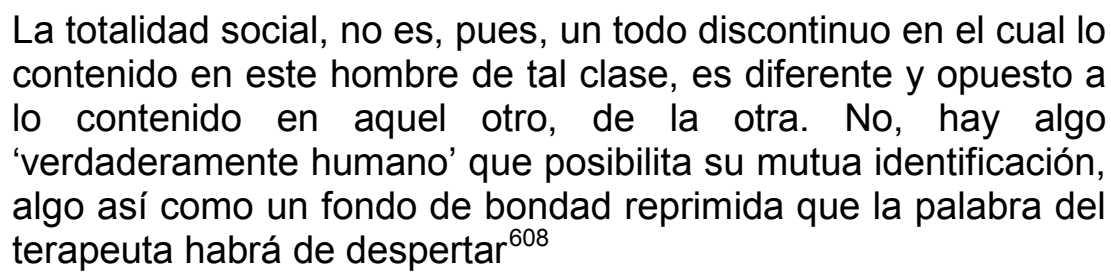

Por último, la lectura de Sastre se detenía en los modos a través de los cuales Kesselman abordaba el problema de la relación entre enfermedad mental y clase social. Para ello, apuntaba a algunos ejemplos utilizados por Kesselman con el fin de dar cuenta de las dificultades del sujeto para remitir sus conflictos individuales a problemas del sistema social. Con respecto a la burguesía, "Ios típicos e interminables reproches del paciente adolescente que se subleva e impugna con resentimiento las costumbres burguesas de sus padres" o "los angustiantes recuerdos de aquellos pacientes adultos que no perdonan el haberse sentido abandonados por padres que solo les dieron 'dinero $y$ cuidados materiales, pero nunca comprensión, interés o cariño". Y en relación a la clase obrera, "el rencor infantil e irreversible del hijo que frente a la melancolía brutal y alcoholizada de su padre obrero guardará la fuerza de su odio y su violencia para el recuerdo de las debilidades de su padre, o para desarrollar una campaña moral en la lucha contra el vicio". Frente a estos, Sastre desplegaba nuevamente el argumento del nexo aparente y la ausencia de traducción, en este caso entre patología y pertenencia de clase. De acuerdo a esta lectura, los ejemplos citados daban cuenta de una "excesiva comodidad epistemológica" ${ }^{009}$, la cual le permitía a su autor dar por sentada una correlación entre enfermedad mental y clase social que estaba lejos de ser probada. En parte, el problema de dicha correlación radicaba en la no contemplación de ejemplos que contradecían aquellas caracterizaciones, como padres burgueses cariñosos o padres obreros sobreprotectores. De este modo,

${ }^{608}$ Ibid., p. 96.

${ }^{609} / d$. 
las vinculaciones entre enfermedad mental y clase social resultaban de una hipótesis ad-hoc que no admitía contradicciones.

La lectura de Sastre, sin embargo, se volvía más escrutadora con otra dimensión del problema advertido en Kesselman: "la presentación de estos estereotipos míticos como si fueran hechos construidos por la ciencia" ${ }^{610}$. Es decir, que no sólo el análisis de la relación entre enfermedad mental y clase social estaba estructurado alrededor de representaciones estereotipadas, sino que éstas aparecían desempeñando el rol que le correspondía al conocimiento científico. Realizada tal advertencia y, por ende, liquidada toda posibilidad de establecer un diálogo con los postulados de Kesselman, la lectura de Sastre se deslizaba hacia una operación tan incisiva como indicativa del tenor del contrapunto entre ambos. Sastre construía un puente hacia la literatura dando a entender que, en su caracterización de la clase obrera, Kesselman se basaba más "en la literatura tremendista que producía hace treinta años el grupo de Boedo que en la investigación científica" ${ }^{11}$. Cobraba sentido, de esta manera, el epígrafe con el que Sastre abría su artículo, un pasaje del cuento "El niño proletario" de Osvaldo Lamborghini, en el cual se relata la vida de la clase obrera desde una mirada que lleva al extremo sus penurias y la violencia a la que es sometida por la burguesía ${ }^{612}$. Dichos jalones de la historia de la literatura argentina eran invocados para evidenciar cuán alejado se encontraba Kesselman del conocimiento de la situación concreta de la clase obrera del país hacia fines de la década de 1960. Si la literatura de Boedo ya era mítica en la Argentina de la década de 1930, en tanto sus representaciones de la vida obrera se alimentaban de las imágenes de los obreros ingleses durante la Revolución Industrial, resultaba "inconcebible encontrar los mismo mitos en

\footnotetext{
${ }^{610} / d$.

${ }^{611} / d$.

${ }^{612}$ El fragmento elegido por Sastre era el siguiente: "El padre borracho y siempre al borde de la desocupación, le pega a su niño con una cadena de pegar, y cuando le habla es sólo para inculcarle ideas asesinas. Desde niño, el niño proletario trabaja, saltando de tranvía en tranvía para vender sus periódicos, y en la escuela, que no termina, es diariamente humillado por sus compañeros ricos. En su hogar, ese antro repulsivo, asiste a la prostitución de su madre, que se deja trincar por los comerciantes del barrio para conservar el fiado".
} 
1969 y en un discurso aparentemente científico"613. El relato de Lamborghini, contemporáneo al debate, venía a dar el golpe de gracia a las caracterizaciones de Kesselman. Si "El niño proletario" ridiculizaba las operaciones de mitificación de la clase obrera al extremar sus estereotipos más recurrentes, éstos encontraban en Kesselman al "portavoz necesario para revivir e instalarse nada menos que en el plano de la discusión científica"614.

Resulta relevante destacar que, junto a esta lectura particularizada de los problemas que se desprendían de la propuesta psicoterapéutica de Kesselman, la mirada de Sastre también daba cuenta de una evaluación general de dicha propuesta en tanto pensamiento. Y lo que allí operaba era una disociación entre lo que tenían de real y lo que tenían de aparente las formulaciones de Kesselman. De este modo, parecía un interesante trabajo de articulación entre teoría política y teoría psicoanalítica, entre ideología marxista y política nacional y popular, cuando era el resultado de una yuxtaposición de elementos provenientes del marxismo y el psicoanálisis. Se presentaba como una perspectiva que pivotaba entre el subjetivismo y el realismo, cuando llevaba a cabo una traslación mecánica de elementos que pertenecían a distintos campos semánticos. Parecía un esfuerzo por vincular el rol profesional y el rol político del psicoterapeuta, cuando era una idealización de la tarea intelectual y el facilitador de una buena conciencia pequeño-burguesa. Se presentaba como un análisis científico de los vínculos entre enfermedad mental y clase obrera, cuando sus caracterizaciones estaban basadas en preconceptos y representaciones míticas. Tal contraposición entre realidad y apariencia hacía que el pensamiento de Kesselman se revelara, finalmente, "como un pensamiento falso" ${ }^{16}$. Y si era falso, ¿cómo se justificaba semejante esfuerzo deconstructivo sobre este pensamiento? El problema fundamental radicaba en que Kesselman abordaba aspectos nodales de la teoría y la práctica psicoterapéutica, como la relación entre práctica profesional y práctica política, el vínculo entre marxismo y psicoanálisis, el nexo entre enfermedad

\footnotetext{
${ }^{613}$ Ibid., p. 97.

${ }^{614}$ Ibid., p. 98.

${ }^{615} / d$.
} 
mental y clase social, pero los resolvía de manera incorrecta desorientando, por ello, a la nueva generación de jóvenes psicólogos.

\subsection{El despertar de un sueño: Althusser contra la psicología de la conducta, el hombre alienado y la antipsiquiatría}

Posteriormente a la impugnación de la articulación entre psicoterapia breve e ideología nacional y popular propuesta por Kesselman, Sastre publicó en la Revista Argentina de Psicología un conjunto de trabajos en los que sometía a discusión dos de las principales corrientes psicológicas contemporáneas. Una de ellas era la psicología de la conducta, cuyo procesamiento desde un prisma analítico althusseriano era evidente desde el comienzo del texto. Resulta significativo que Sastre eligiera dos epígrafes para introducir el análisis de los fundamentos de dicha corriente. Por un lado, un fragmento de Psicología de la conducta de Bleger en el que éste se refería a la concepción de la lectura que guiaba su trabajo: "aquí trato de aplicar mi convicción de que los libros no son para leerlos sino para pensarlos". Por el otro, el pasaje del "Prefacio" de Para leer El Capital en el cual Althusser postula la imposibilidad de lecturas inocentes: "plantear a toda lectura culpable, la pregunta que desenmascara su inocencia, la simple pregunta de su inocencia: ¿qué es leer?". Si bien esta contraposición permite dar cuenta de la importancia de Althusser en el trabajo de crítica y superación de la psicología de la conducta, Sastre era explícito al respecto. En términos formales, emprender una crítica del pensamiento de Bleger era someter a examen un corpus teórico que había tenido una gran importancia entre los psicólogos argentinos. Pero en un sentido generacional, dicha tarea implicaba revisar los propios marcos referenciales en los que una cantidad de psicólogos habían sido formados. Y esto remitía directamente al rol de Bleger como único marco al que podían remitirse la información fragmentaria proporcionada por la carrera de psicología. Si durante años el trabajo de Bleger había tenido un rol 
reparador de la "dispersión ecléctica" ${ }^{16}$ impartida por la institución formadora de psicólogos, aquella función se revelaba por entonces como "ilusoria" ${ }^{617} 618$.

Dicho carácter ilusorio estaba vinculado fundamentalmente a la creencia en la posibilidad de otorgarle "alguna coherencia que fuese científica" ${ }^{19}$ a las múltiples ideologías que por entonces dominaban el campo de la psicología. Recién a comienzos de la década de 1970 se podían entender las implicaciones de un trabajo de integración de los aportes del conductismo, el psicoanálisis y la psicología de la forma. Y el modo en el cual Sastre llevaba a cabo esta mirada retrospectiva da cuenta de que el ajuste de cuentas con la psicología de la conducta operaba tanto sobre Bleger como sobre Politzer ${ }^{620}$. Si la obra de este último había cumplido un importante rol como introductora del psicoanálisis para una generación de jóvenes franceses, la de Bleger había tenido un rol análogo entre los argentinos. En suma, se imponía un trabajo de evaluación sobre Bleger y Politzer en el cual el principal parámetro analítico era el del vínculo que aquella integración entre distintos aportes mantenía con la cientificidad del psicoanálisis. Al respecto, planteaba Sastre:

\begin{abstract}
La pregunta que debemos hacernos se refiere, entonces, a las condiciones de posibilidad para la integración entre escuelas. En otras palabras, ¿qué psicoanálisis es aquél susceptible de integrarse con el conductismo y la psicología de la forma? O sea, ¿cómo debemos recortar su teoría para producir esa unión? ¿qué contorsiones, qué esfuerzos le impone a la teoría el establecimiento de esas relaciones? Y el resultado de esas operaciones, ¿en qué medida supera, conserva o pierde la cientificidad del pensamiento de Freud? ${ }^{621}$
\end{abstract}

${ }^{616}$ Sastre, Carlos. "La psicología de la conducta: psicoanálisis y fenomenología". Revista Argentina de Psicología. № 4, junio 1970, p. 62.

${ }^{617}$ Ibid., p. 63

618 Sobre el rol de Bleger en la articulación entre marxismo y psicoanálisis en Argentina, ver Vezzetti, Hugo. Psiquiatría, psicoanálisis y cultura comunista en Argentina. Buenos Aires, Siglo XXI, 2016, pp. 195-230.

619 ld.

${ }^{620}$ Sobre Bleger como lector de Politzer, ver Plotkin. Freud en las pampas. Orígenes y desarrollo de una cultura psicoanalítica en Argentina (1910-1983). Buenos Aires, Sudamericana, 2003, pp. 176-183.

${ }^{621} / d$. 
La elección del parámetro de la cientificidad para la evaluación de la psicología de la conducta conducía la lectura de Sastre hacia los problemas del objeto y el método en psicología. En este sentido cobraban especial relevancia los postulados a través de los cuales Bleger procesaba la existencia de una diversidad de escuelas en psicología: "han aportado conocimientos fragmentarios de una única y misma totalidad [...] cuando cada una de ellas ha creído ver el todo en su segmento, han dado lugar a teorías erróneas, distorsionadas o exageradas [...] cada escuela o corriente refleja parte de la realidad [...] es necesario reencontrar y reubicar [cada parte de la realidad] en la totalidad y unidad original". A partir de ellos Sastre volvía visibles los presupuestos epistemológicos que guiaban a la psicología de la conducta. En primer lugar, la indiferenciación entre objeto de estudio y objeto de conocimiento, en tanto el conocimiento era concebido como la extracción de una parte de lo real. Por otra parte, la idea de que la articulación de los conceptos es homóloga a la ubicación de las partes de lo real, ya que sería posible remitir el conocimiento de cada escuela a una determinada parte de la realidad. Finalmente, la circunscripción del conocimiento a la acción de ver y el desinterés por lo no visto, en tanto no existía ninguna problematización sobre cómo se mira un objeto.

Medidos con el criterio de la cientificidad, la crítica a las concepciones del objeto y el método de la psicología de la conducta dejaba como saldo un conjunto de postulados que remitían explícitamente a Bachelard y Althusser. Por un lado, que el conocimiento debía ser concebido como producción y no como extracción: "el problema no es de segmentos de realidad reflejados en el conocimiento y exagerados o no sino de maneras de operar con el conocimiento, que deben ser entendidas como totalidades orgánicas cuya compatibilidad deberá ser discutida como la compatibilidad entre maneras de producir conocimiento"622. Por el otro, que la evaluación de cada escuela debía radicar en la constatación de si producía el efecto de conocimiento característico de la ciencia y no en cuál era su aporte a una supuesta totalidad original: "nuestra pregunta tampoco podrá referirse meramente a la

${ }^{622}$ Ibid., p. 65. 
compatibilidad entre los modos de producción que caracterizan a cada una de estas escuelas, sino que deberá llegar algo más lejos y cuestionarse la relación entre ellos y el modo de producción de conocimientos que es propio de la ciencia" ${ }^{623}$. Aplicados a la psicología de la conducta, estos postulados conducían a un esquema interpretativo en el cual se anudaban la integración del psicoanálisis a otras escuelas, su ideologización, el consecuente despojo de su cientificidad y la supresión del inconsciente:

\begin{abstract}
Trataremos de demostrar que la integración del psicoanálisis con las otras escuelas consideradas implica la necesidad de ideologizarlo, despojándolo de la cientificidad que le imprime su carácter de teoría de lo estructural, es decir, que para ejecutar esta operación es necesario suprimir el inconciente, y luego intentaremos mostrar que esa supresión encierra a la psicología de la conducta en contradicciones que no puede resolver, en lo tocante a la delimitación de su objeto de estudio ${ }^{624}$
\end{abstract}

En un momento en el que lo estaba en juego era precisamente "si el psicoanálisis es una teoría de la conducta o una teoría del inconciente"625, el trabajo crítico sobre la psicología de la conducta operaba como recordatorio de los problemas inherentes a toda lectura desarrollada desde el campo de la fenomenología. Problemas fundamentales en el terreno de la psicología, ya que la prioridad otorgada a lo fenoménico y la definición del inconsciente como desconocimiento, implicaba una toma de posición regresiva en aquella disyuntiva que atravesaba la discusión de la época. Pero también problemas, no menos graves, en lo relativo a los vínculos entre psicoanálisis y marxismo, en tanto una lectura fenomenológica de Marx acarreaba consecuencias igualmente adversas. En contraposición a una deseable lectura estructural, de la obra de Bleger se desprendía un Marx "fascinado por lo sensible y pensador de dicotomías formales que se resuelven en una tibieza sin muerte"626. Como podemos ver, esta proposición remitía, por un lado, al lugar ocupado por el mundo sensible en el marxismo sustentado por Bleger, énfasis que era visto

\footnotetext{
${ }^{623} / d$.

624 Id.

${ }^{625}$ Ibid., p. 67.

${ }^{626}$ Ibid., p. 69.
} 
por Sastre como una inversión de la inversión marxista, en tanto implicaría nada menos que un retorno al idealismo. $Y$ por otro lado, a la forma que adquiría la dialéctica en la psicología de la conducta. Con respecto a esto último, Sastre advertía que la contradicción que se percibía en la obra de Bleger era una contradicción simple, "esto es, no sobredeterminada" ${ }^{627}$. Constatación que tenía implicaciones significativas, en tanto si la noción de sobredeterminación había sido tomada de Freud a los fines de diferenciar la contradicción marxista de la contradicción hegeliana, la insistencia en una contradicción simple acercaba a Hegel y alejaba de Marx a quien la sustentara. Percibía, asimismo, una noción de la contradicción como separación de una esencia que tiene a reunirse en su desarrollo, lo cual lo llevaba a constatar la ausencia de la complejidad y heterogeneidad del movimiento real. Volviendo a la disyuntiva de la época, Sastre era explícito en lo relativo a la mediación a través de la cual la obra de Bleger era leída. Al hablar de las diversas concepciones que se desprendían de ella, apuntaba: "confróntese al respecto las obras de Althusser, Louis" ${ }^{628}$.

La otra corriente discutida por Sastre a comienzos de la década de 1970 era lo que él denominaba psicopatología del hombre alienado, un conjunto de desarrollos teóricos cuyo denominador común era ser resultantes de una vinculación entre marxismo y psicología a través de la teoría de la alienación. Y si en el caso de la psicología de la conducta Althusser era invocado como el facilitador de la crítica y el nombre del espacio en el que debían confrontarse los postulados a ser superados, para la teoría de la alienación esta invocación adquiría un tenor inusitado:

Lo que Althusser viene a decirnos resulta tan claro una vez producido que nos parece un sueño el oscuro panorama ideológico en el cual nos debatíamos antes de su lectura: si nos guardamos de proyectar la conciencia que habla en ciertos textos de Marx sobre la que habla en otros, o, si leemos a Marx como él enseñó a leer, la discontinuidad de su obra se

627 Ibid., p. 72 .
628 Ibid., p. 75 . 
manifiesta y la tarea epistemológica queda delimitada como la de articular esa ruptura con el conocimiento ${ }^{629}$

La representación de la lectura de Althusser como el despertar de un sueño nos permite dar cuenta de las dos dimensiones implícitas en el abordaje de la teoría de la alienación a través del pensamiento althusseriano. Como se desprende del pasaje citado, las tesis de Althusser permitían advertir el carácter oscuro e ideológico de las formas pretéritas de leer a Marx, es decir, aquellas recortadas a las obras de su juventud y poco preocupadas por los problemas relativos a la lectura. De este modo, quedaban confinados a un pasado de oscuridad e ideología los marxismos estructurados alrededor del joven Marx, sobre el que se constataba su pertenencia a la problemática de la filosofía clásica alemana, y cuyo objeto de conocimiento lo constituía el hombre alienado, sobre el cual se verificaba su disociación del discurso científico de Marx.

Ahora bien, así como Althusser permitía procesar como un sueño las discusiones previas a su irrupción en el escenario teórico, también aportaba los elementos para un presente que se vislumbraba tan luminoso como científico. El pasaje citado es sumamente ilustrativo al respecto. La tesis de la ruptura epistemológica en el interior de la propia obra de Marx y el postulado de la necesidad de articular dicha ruptura con el conocimiento, habilitaba un espacio de análisis y producción en el campo del marxismo claramente diferenciado de la teoría de la alienación. La asociación entre la lectura de Althusser y la posibilidad de despertar de un sueño da cuenta de los efectos disruptivos de la advertencia sobre la transformación del objeto de conocimiento y el modo de producción de conocimientos en la obra de Marx. Delimitado a partir de El Capital, el análisis marxista aparecía disociado del examen de la experiencia de un sujeto o de la reflexión sobre la esencia humana. La lectura de la obra de Marx debía ser realizada bajo el supuesto de que en ella se opera un pasaje "de la impugnación ética del movimiento aparente al análisis científico del

${ }^{629}$ Sastre, Carlos. "La psicopatología del hombre alienado: psicología y humanismo". Revista Argentina de Psicología. N 8, junio 1971, p. 51. 
movimiento real' 630 . Lo que se abría, por tanto, era un horizonte interpretativo en el cual la obra de Marx sería puesta al servicio del análisis de la estructura del sistema de producción.

La apertura de dicho espacio conllevaba el establecimiento de una dicotomía en los modos de operar el pasaje de la obra de Marx a la psicología. De un lado, la delimitación de la cientificidad en Marx se anudaba con una operación análoga impuesta a la obra de Freud, de lo cual resultaba un movimiento que estrechaba el análisis de la estructura con el del inconsciente. Recortada al plano de la ciencia, la vinculación entre ambos campos se presentaba dotada de cierta naturalidad:

\begin{abstract}
Cuando Marx, en El Capital, se ocupa por ejemplo del 'instrumento de trabajo que azota al obrero' y describe las reacciones de sublevación que las nuevas máquinas despiertan en los obreros, no hay allí reflexión alguna sobre la esencia humana ni sobre su negación, sino el análisis de un movimiento impersonal que arrastra, conjuga y opone a hombres y cosas por igual. Este obrero, pues, no está alienado, ya que no es determinado por su ser puesto fuera de sí, sino por un devenir que no se constituye a nivel de la vida individual. Si quisiéramos entonces, un análisis del sujeto epistemológicamente compatible con este Marx de la madurez, tendremos que buscar una ciencia del movimiento real, oculto y determinante de la subjetividad, que articule experiencia y estructura. Este análisis, sin duda, no está en Marx, sino en Freud ${ }^{631}$
\end{abstract}

Del otro lado se encontraban todos los ejercicios de vinculación que operaban en un sentido inverso. Es decir, aquellos que, en lugar de delimitar la cientificidad en ambos campos, propiciaban una articulación entre Marx y Freud a través de las dimensiones ideológicas de sus obras. Entre ellos, Sastre destacaba especialmente a aquellos desarrollados por autores pertenecientes a la tradición freudomarxista. De este modo, se detenía en las consideraciones de Fromm alrededor de la personalidad enajenada en su libro Psicoanálisis de la sociedad contemporánea a los fines de evidenciar los problemas implícitos en una conceptualización de los efectos del capitalismo en el individuo a través del concepto de alienación. Según Sastre, estos desarrollos no permitían

\footnotetext{
${ }^{630}$ Ibid., p. 53.

${ }^{631}$ Ibid., p. 55.
} 
distinguir ningún efecto específico del sistema social respecto de la función del yo como lugar de desconocimiento e ideología. Es decir, no podían dar cuenta de la relación entre los problemas del yo y la determinación del sistema capitalista. Asimismo, Sastre advertía un deslizamiento hacia la moral en el señalamiento de la incapacidad del hombre enajenado de "relacionarse productivamente" consigo mismo y con el mundo exterior. Leído desde el espacio teórico en el que se ubicaba Sastre, dicho señalamiento no podía ser sino interpelado con la pregunta acerca de los presupuestos que guiaban su formulación. Por este mismo camino, advertía lo ridículo de la idea de que el hombre enajenado se convierte en una suerte de esclavo de sus propios actos y las consecuencias que éstos generan. Atribuirle la determinación del yo a los propios actos y sus consecuencias implicaba una concepción del propio yo como determinante del yo, posición diametralmente opuesta a una idea de determinación centrada en los efectos de movimientos impersonales.

En esta misma dirección eran leídas las tesis de Marcuse, ubicadas también en el conjunto de articulaciones ideológicas entre Marx y Freud. Al igual que ocurría con el concepto de personalidad enajenada, Sastre seleccionaba algunos desarrollos de la obra de Marcuse para evidenciar la distancia que la separaba de una correcta vinculación entre marxismo y psicoanálisis. En este sentido era abordado el concepto de represión sobrante desarrollado en su libro Eros y civilización. En la lectura realizada por Sastre, la formulación de una noción que distinguía una forma de represión identificada con las restricciones provocadas por la dominación social debía ser "criticada desde el punto de vista científico"632. Dicho punto de vista implicaba, por un lado, la advertencia sobre la imposibilidad de delimitar empíricamente los montos de represión básica y represión sobrante, así como el señalamiento de una ausencia de articulación entre este concepto y otros de la teoría psicoanalítica. Se certificaba, de esta manera, un déficit de orden conceptual: "la noción en juego queda formulada como un término sin base empírica y sin articulación teórica, como abstracción indeterminada que sólo puede ostentar

${ }^{632}$ Ibid., p. 57. 
su capacidad de resonar como palabra, no como concepto" ${ }^{633}$. Por otro lado, este ángulo crítico permitía constatar el distanciamiento del tratamiento de la represión en tanto función. Alejado de este abordaje, Marcuse direccionaba su tratamiento en un sentido cuantitativo, lo cual era advertido en términos de introducción de un lenguaje de tipo matemático dentro de la teoría psicoanalítica. Ambos señalamientos se anudaban, finalmente, con la refutación de la tesis marcusiana de la pérdida de razón de ser de la represión en una sociedad con alto desarrollo tecnológico. De esta idea, que se estructuraba alrededor de la noción de cultura no represiva, Sastre derivaba el supuesto de la existencia de necesidades humanas, que debido a la escasez de medios para satisfacerlas, debían ser reprimidas. Dicho supuesto hacía que el distanciamiento de Marx y Freud se convirtiera en una traición a sus pensamientos: "Esta argumentación demuestra hasta qué punto Marcuse traiciona objetivamente tanto el pensamiento de Marx como el de Freud, para devolvernos al idealismo de la filosofía liberal"634. En el caso de Freud, porque no es la necesidad la que se reprime, sino el deseo. $Y$ en el caso de Marx, leído vía Althusser, porque las necesidades no están sometidas a una determinación antropológica, sino estructural. Al priorizar la definición antropológica de las necesidades, Marcuse se acercaba más a una antropología naturalista que al marxismo, el cual, a diferencia de aquella, parte de la ciencia del modo de producción con el objetivo de conocer la constitución del sujeto como consumidor.

En el abordaje de la obra de Marcuse, Sastre volvía a desplegar aquella estrategia discursiva empleada contra Kesselman, la de la suspensión del juicio sobre la falsedad de las bases del desarrollo teórico a la espera del encuentro con algún elemento válido a través del cual poder entablar un diálogo: "Quizás, ya que no podemos estar de acuerdo con las premisas, podamos acordar en la conclusión o, si se quiere, en la propuesta ideológica que formula, puesto que es sabido que razonando incorrectamente a partir de premisas falsas cabe la

${ }^{633}$ Ibid., p. 59.
${ }^{634}$ Ibid., p. 62. 
afortunada posibilidad de llegar a conclusiones verdaderas"635. Al igual que ocurría con Kesselman, dicha estrategia operaba como preámbulo de una liquidación de los argumentos del adversario ${ }^{636}$. En este caso, la pregunta acerca de su conclusión y la propuesta ideológica formulada remitía a la asociación entre libertad y ausencia de represión, así como al lamento por la pérdida de racionalidad y contenido de los derechos y libertades propios de la temprana sociedad industrial. De esta constatación se derivaba que el estado social deseado por Marcuse podía ser asimilado a la sociedad en la que creían los liberales del siglo XVIII. $Y$ al igual que con Kesselman, la lectura de Marcuse daba cuenta del carácter real y aparente de su pensamiento. En este caso, se presentaba como una ideología de avanzada cuando no era otra cosa que una actualización de la vieja utopía liberal. Menos contemplativo aún se mostraba Sastre con la postulación del amor y la libertad sexual como herramientas de transformación social. Era alrededor de este problema donde se evidenciaba la ausencia de un trabajo teórico articulado entre marxismo y psicoanálisis: "Debe aquí leerse nuestro rechazo científico y también ideológico a toda postura que busque en el amor y la libertad sexual la solución tanto de la psicopatología como de la explotación. A cada una le corresponde una teoría y una práctica específica, que deben ser profundizadas, no tiradas por la borda en una falsa integración" ${ }^{\prime 37}$.

Si bien los ejercicios de vinculación ideológica entre Marx y Freud eran recortados principalmente al trabajo de los autores inscriptos en la corriente freudomarxista, Sastre reservaba una parte de su análisis a la antipsiquiatría de David Cooper ${ }^{638}$. Caracterizada como "exageración caricaturesca" ${ }^{39}$ de la

\footnotetext{
635 Ibid., p. 65.

${ }^{636}$ Como afirma Vezzetti, las intervenciones de Sastre, y también de Harari, dan cuenta de la configuración de una figura del intelectual en la que su legitimidad descansa sobre la posesión de saberes legítimos: "cierta indicación condescendiente hacia el contrincante que exhibe en el otro la ausencia de libros, de autores y de lecturas; un plus que se agregaba a los argumentos y volvía como una autorreferencia en la construcción del propio lugar", "Los comienzos de la psicología como disciplina universitaria y profesional. Debates, herencias y proyecciones sobre la sociedad". op. cit., p. 323.

${ }^{637}$ Ibid., p. 68.

${ }^{638}$ Para una reconstrucción de la recepción de la antipsiquiatría en Argentina, ver Carpintero, Enrique y Vainer, Alejandro. Alejandro. Las huellas de la memoria.
} 
ideología freudomarxista debido a su postulación del enfermo como rebelde contra el sistema, la propuesta antipsiquiátrica era abordada en términos de una mera inversión de la clásica oposición entre razón y locura. Es decir, mientras la psiquiatría tradicional valoraba la razón en desmedro de la locura, la antipsiquiatría operaba en un sentido inverso valorando la locura por sobre la razón. En relación a este problema, la concepción althusseriana del pasaje de la ideología a la ciencia sustentaba un diagnóstico de entrampamiento teórico:

\begin{abstract}
Donde ella [la psiquiatría tradicional] leía mal, se proclama la presencia del bien, y viceversa. Toda vez que se acepte este planteo del problema, que a su vez acepta por antítesis a la ideología convencional, se habrá perdido la batalla de antemano. Como ha escrito Althusser, 'no se obtiene una ciencia invirtiendo una ideología', esto es, no se obtiene conocimiento verdadero valorando de otro modo los términos implicados en un falso planteo, puesto que se permanece entrampado en la manera de plantear ${ }^{640}$
\end{abstract}

La caracterización realizada por Sastre daba a entender que una lectura científica de Freud tornaba superflua una propuesta como la de la antipsiquiatría. Si el psicoanálisis era entendido como teoría de la estructura del inconsciente, se volvía innecesaria la elaboración de un programa alternativo, dado que, así concebida, la teoría psicoanalítica es en sí misma una antipsiquiatría. Es decir, es una teoría que pone en cuestión los planteos más básicos de la psiquiatría, uno de los cuales lo constituye la oposición entre razón y locura. Se establecía, de esta manera, una absoluta correlación entre la concepción del psicoanálisis como teoría del inconsciente y la prescindencia de la contradicción entre salud y enfermedad. Una lectura correcta de Freud no orientaba el trabajo a una toma de partido por los enfermos, sino precisamente a la teorización científica de la estructura de la psicosis y la neurosis. De allí que fuera posible abrir una brecha en la dicotomía planteada por la antipsiquiatría. Frente a la tesis de Cooper de la esquizofrenia como conducta

Psicoanálisis y salud mental en la Argentina de los '60 y '70. Tomo II: 1970-1983. op. cit., p. 166-180.

${ }^{639}$ Sastre, Carlos. "La psicopatología del hombre alienado: psicología y humanismo". op. cit., p. 70.

${ }^{640}$ Ibid., p. 72. 
política, se imponía un rechazo a la polarización entre razón y locura, así como la introducción de los elementos que quedaban fuera de la dicotomía. Y aquellos elementos que Sastre percibía ausentes en el discurso de Cooper eran precisamente los que remitían a una lectura científica de Freud y Marx. Por un lado, la teoría de las enfermedades; por el otro, la teoría del orden social y sus respectivas prácticas.

Al igual que en la polémica entablada contra Kesselman, el tratamiento de los desarrollos teóricos que daban cuenta de un pasaje ideológico de la psicología a la obra de Marx estaba recortado fundamentalmente a su dimensión impugnatoria. La única operación de lectura de la cual resultaban formulaciones enunciadas en un plano propositivo era aquella centrada en la pregunta acerca de si alguno de los problemas a los cuales este conjunto de ejercicios quería dar respuesta debía ser considerado desde una perspectiva científica. Este planteo conducía al problema del abordaje de las subjetividades de un punto de vista marxista. De igual modo que con la lectura de Kesselman, la indagación en torno a dicho tópico era justa y necesaria, el problema radicaba en que estaba mal planteado y resuelto. Trasladada al terreno de la práctica psicoterapéutica, aquellos ejercicios de vinculación entre psicoanálisis y marxismo implicaban un trabajo sobre el paciente direccionado hacia el esclarecimiento ideológico del sistema social a los fines de favorecer una práctica política transformadora.

La aproximación a estos desarrollos teóricos en clave de oposición se correspondía con un acercamiento de igual tipo a sus consecuencias prácticas. En este sentido, nada garantizaba aquel trabajo de esclarecimiento, ya que daba por supuesta una correlación entre ideología latente del paciente e ideología revolucionaria, así como entre interpretación del terapeuta del sistema social y análisis científico de la sociedad. Constatadas las deficiencias teóricas y prácticas, quedaba en suspenso la solución verdadera al problema de la lectura e interpretación de la ideología del paciente. En el marco de un esquema en el que el discurso del paciente es portador de efectos de reconocimiento-desconocimiento y en el que la práctica analítica persigue el objetivo de disolver la ideología, la preocupación de Sastre radicaba en cómo 
implementar una intervención que escapara de las trampas de la contratransferencia ideológica, la cual impide un procesamiento científico del material producido por el paciente. En este sentido, la posibilidad de alcanzar una lectura científica de la ideología del paciente era condicionada tanto a una lectura correcta de Freud como al desarrollo de una teoría de la contratransferencia que proporcionara conceptos adecuados para su control y que permitiera, por tanto, evitar la circularidad entre la ideología del paciente y la del analista. Sólo este desarrollo habilitaría calibrar nuevamente el objetivo de la práctica analítica, a decir: "disolver toda demanda ideológica específica en la universalidad del deseo, develando cómo esa alternativa ideológica particular, propuesta por un modo de producción es apropiada por el sujeto al servicio de la función yoica del ordenamiento del mundo"641. Es decir, revelar el modo mediante el cual el sujeto, al estar al servicio de su equilibro psíquico, se pone a su vez al servicio de la ideología, movimiento a través del cual pasa a ser hablado por una alternativa propuesta desde la dinámica impersonal del sistema.

\subsection{La psicología, red ideológica: ciencia e ideología en la conformación de un campo profesional}

Si bien centrados en el problema de la ideología, los textos producidos por Sastre en la primera mitad de la década de 1970 dan cuenta de un desplazamiento de sus preocupaciones hacia el terreno de la epistemología. En este sentido, los trabajos reunidos en su libro La psicología, red ideológica, publicado por la editorial Tiempo Contemporáneo en 1974, abordaban los problemas de la psicología contemporánea a través de una perspectiva que anudaba dos niveles analíticos.

El primero de ellos era netamente teórico. Amparados en un repertorio de referencias que remitía a la casi totalidad del espectro althusseriano Canguilhem, Bachelard, Badiou, Rancière, Pecheux y Fichant- estos textos se dedicaban a indagar en el problema del lugar ocupado por la ideología en las

${ }^{641} / d$. 
ciencias. Dicha indagación estaba guiada por una definición del concepto de ideología que enfatizaba el proceso de representación de lo real a través de lenguajes y discursos. Es decir, una concepción que entendía la vinculación con lo real como mediada por relaciones de desconocimiento (la ideología como ilusional e inversora) y por relaciones de reconocimiento (la ideología como perceptual y repoductora). Relaciones que constituian, a decir de Sastre, objetos privilegiados de análisis tanto para el marxismo, que reduce la ideología a la necesidad de cohesión social hegemonizada por las clases dominantes, como para el psicoanálisis, que la reduce a la necesidad del sujeto de una representación unitaria de sí. Junto a la coloración particular que le otorgaba al concepto de ideología, el althusserianismo aparecía en las explicaciones de Sastre como una corriente teórica superadora de los esquemas tradicionales con los cuales el marxismo había abordado los problemas vinculados a la ideología. Este era el caso, por ejemplo, del esfuerzo por disociar la ideología de un no-saber. Es decir, el énfasis en el reconocimiento direccionaba el abordaje del problema del vínculo con lo real en un sentido que excedía el mero desconocimiento. Aclaración de la que se derivaba la importancia de tener en cuenta el rol desempeñado por el reconocimiento ideológico tanto en la práctica política como en la práctica científica. En este mismo sentido debe pensarse la distinción entre diferentes formas de ideología, tales como la ideología en general, aquella representación de lo real dotada de un efecto de reconocimiento-desconocimiento que articula los efectos de la estructura social y la estructura del sujeto; las ideologías de clase, definidas como las representaciones de lo real dotadas de un efecto de reconocimientos-desconocimiento determinado por la estructura social del modo de producción capitalista; y las ideologías políticas, que remitían a las representaciones de las relaciones sociales institucionalizadas en la actualidad del proceso histórico de la estructura social. Distinción que evidencia, además de la complejización del entendimiento del fenómeno ideológico, una concepción anti-historicista según la cual el efecto de reconocimientodesconocimiento tiene un alcance universal singularizándose de acuerdo a las características de cada formación social. 
La preocupación por alcanzar una definición acabada del concepto de ideología obedecía a la necesidad de visibilizar la distancia que media entre lo real de la ideología y las estructuras que conocen las ciencias. En este sentido se expresaba Sastre en uno de los pasajes más iluminadores de su libro:

\begin{abstract}
El discurso ideológico se caracteriza por discurrir un saber que encuentra su verificación en la experiencia vivida. El mundo de la vida cotidiana, esas representaciones ilusorias en las cuales lo aparente se presenta como lo real, en las que los fenómenos manifiestos ocultan las estructuras latentes, serán las que, con el gozo del reconocimiento, se encontrarán en el texto. Las ciencias hablan, en cambio, de realidades que suenan ajenas a la experiencia, hablan un lenguaje más duro: el de la producción de conocimientos en ruptura con la experiencia y el sentido común. Descubren así que el espacio (euclídeo o no) no coincide con el de la representación intuitiva, que el salario no paga el trabajo, que el planeta gira en el espacio, que el relato dice más y otra cosa que el sujeto, que el tiempo no es uno, sino senderos que se bifurcan ${ }^{642}$
\end{abstract}

Si la ciencia se diferencia de la ideología por operar una ruptura con la experiencia vivida y el sentido común, ¿cuál es el proceso a través del cual el marxismo descubre que el salario no paga el trabajo y el psicoanálisis revela que el relato dice más que el sujeto? Al respecto, la explicación de Sastre se dirigía a la delimitación de algunas dimensiones ligadas al problema de la justificación, fundación e inscripción social de la ciencia. Resulta interesante destacar el esfuerzo de Sastre por despejar el malentendido que tendía a vincular la justificación de una ciencia con su puesta a prueba en la práctica política. Aquí se revelaba con total claridad los efectos del althusserianismo en la refutación las concepciones del marxismo como filosofía de la praxis. La política es una práctica que puede ser asistida por el conocimiento científico pero se diferencia de éste por estar dominada por un saber ideológico sobre la realidad. Lejos del terreno de la práctica política, la ciencia encuentra su justificación en investigaciones específicas, especialmente aquellas que analizan estructuras económicas y códigos ideológicos.

642 Sastre, Carlos. La psicología, red ideológica. Buenos Aires, Tiempo Contemporáneo, 1974, p. 22. 
Lo mismo puede ser dicho en relación a la fundación de la ciencia, tópico sobre el cual se advertía el modo a través del cual las ideologías anteceden pero también suceden a las ciencias. Alrededor de este punto, la productividad del althusserianismo puede ser pensada en los dos tópicos señalados. En lo que respectaba a la ideología como antecedente, Sastre remarcaba que la ciencia no solo responde a las ausencias del discurso científico, sino que también procesa aquello que está oculto en las presencias de dicho discurso. Y en lo relativo a la supervivencia de la ideología una vez constituida la ciencia, se detenía especialmente en las formas a través de las cuales la ideología asedia al conocimiento científico con el objetivo de revertir dicho proceso de constitución. En esta explicación desempeñaban un rol destacado las nociones de ideología seudocientífica, que remitía a las regiones diferenciadas de la ideología dominante que infiltran la ciencia con discursos ideológicos, y la de recaída, que daba cuenta de los efectos disolutivos del conocimiento científico una vez producida dicha infiltración. Explicaciones y nociones que eran ejemplificadas a partir del estado actual del marxismo y el psicoanálisis. Tanto uno como el otro eran invocados por Sastre a los fines de constatar el asedio al que era sometida la ciencia por parte de la ideología. En el caso del marxismo: "¿Cómo reconocer, siquiera, la obra de Marx en ese izquierdismo humanista, en esas disquisiciones políticas abstractas que pretenden derramarse desde su extracción liberal y pequeño-burguesa hasta la clase trabajadora bajo el nombre de marxismo?"643. Y en el caso del psicoanálisis: “¿Qué ha quedado de la obra de Freud en esa fenomenología moralista de la conducta que orienta las diversas prácticas pedagógicas y adaptacionistas que ejercen la mayor parte de los que se llaman psicoanalistas?" ${ }^{\prime 44}$.

Cabe destacar, finalmente, que este abordaje teórico de los problemas relativos al lugar de la ideología en la ciencia daba lugar a la problematización del vínculo entre práctica política y práctica científica. Si bien el tratamiento del problema de la justificación de la ciencia permitía advertir los parámetros a través de los cuales este problema era procesado, Sastre dedicaba una parte

\footnotetext{
${ }^{643}$ Ibid. p. 65.

${ }^{644}$ Id.
} 
significativa de su trabajo a la discusión sobre cómo debía pensarse el vínculo entre ciencia y política. Lo que en aquella crítica a la justificación del conocimiento científico por la práctica política se percibía como una advertencia sobre las operaciones ilegítimas de identificación entre ciencia y política, aquí era desplegado en términos de una crítica simétrica a las posiciones politicistas y cientificistas. Las primeras eran definidas como aquellas que intentan resolver los problemas de la práctica científica a través de recursos pertenecientes a la práctica política. Las segundas, como aquellas que proceden en sentido inverso, es decir, intentando resolver problemas de la práctica política a través de recursos pertinentes a la práctica científica. En conjunto, eran calificadas como formaciones ideológicas que propiciaban una enajenación de la práctica científica, ya sea en la política en el caso del politicismo o de la política en el caso del cientificismo. Frente a dichas posiciones, Sastre avanzaba en un tratamiento de la práctica científica que enfatizaba su irreductibilidad a la práctica política. Contra la condensación de las prácticas propiciadas por el politicismo y el cientificismo, debía afirmarse que las prácticas científicas "encuentran su inscripción política en la política científica que orienta la producción de conocimientos, y en el uso instrumental de los conocimientos científicos así producidos, dentro de la práctica social global' ${ }^{645} 646647$.

\footnotetext{
${ }^{645}$ Ibid. p. 76.

${ }^{646}$ Afirmación que, como hemos visto en su crítica a Kesselman, habilitaba una refutación de los programas de constitución de una "ciencia nacional". Estos, entre los que Sastre ubicaba a los trabajos de Gonzalo Cárdenas y "otros textos de lucha ideológica publicados por intelectuales peronistas, en especial en el período 19661970" (Ibid., p. 77), cometían el error de recortar el campo teórico según la representación política de lo real y creer que las particularidades del objeto real garantizan la producción científica. En el mismo sentido que había impugnado los postulados de Kesselman a fines de la década de 1970, Sastre aseguraba que la realidad nacional debía ser puesta en el plano del objeto de estudio y no como elemento generador de un supuesto conocimiento auténtico.

${ }^{647}$ Es interesante destacar que esta actualización de la crítica a la idea de una "ciencia nacional" estaba acompañada por una valoración del trabajo de Franz Fanon. Puede afirmarse, al respecto, que el pasaje de Sastre hacia Los condenados de la tierra y Piel negra, máscaras blancas eran tan intempestivo en el desarrollo argumental del texto como singular en lo relativo a la articulación con el registro predominantemente althusseriano. De dicha constatación, sin embargo, no puede derivarse que la incorporación de elementos provenientes de la obra de Fanon resultara disonantes con los argumentos desarrollados a lo largo del libro. Efectivamente, el esfuerzo de Fanon por llevar a cabo una impugnación ideológica de la realidad colonial era leído
} 
Junto a este nivel analítico, circunscripto al nivel de la teoría, los textos reunidos en La psicología, red ideológica propiciaban una operativización de las formulaciones acerca de la diferencia y articulación entre ciencia e ideología en el propio campo de la psicología. Cabe señalar, al respecto, que el resultado más significativo de dicho procedimiento lo constituía la caracterización de la psicología como paradigma de las ideologías seudocientíficas:

\begin{abstract}
La psicología, colección y entrecruzamiento de discursos que se contradicen, carente de un instrumental teórico y técnico unitario que delimite un objeto propio de conocimiento, dominada por el efecto de reconocimiento, siempre dispuesta a abrirse hacia todos los temas y a caer sobre innúmeros objetos reales señalados por el sentido común, dotada de lenguajes semánticamente vagos y peligrosamente seductores gracias a su familiaridad con las representaciones espontáneas de sus usuarios, constituye un paradigma de las ideologías seudocientíficas según las cuales la sociedad burguesa sistematizó el saber en el campo de las disciplinas destinadas al análisis de la vida humana ${ }^{648}$
\end{abstract}

Tal como se desprende del pasaje citado, el diagnóstico sobre el estado actual de la psicología anudaba todos los tópicos repasados alrededor del problema de la ideología: vinculación con lo real a través del efecto de reconocimiento, apego a la experiencia vivida y al sentido común, infiltración en las ciencias constituidas, forzamiento de recaídas. La aplicación de dichas variables al campo de la psicología y su consecuente evaluación como ideología

en clave de una transgresión revolucionaria de las ideologías dominante que favorecía la apertura de un espacio para la producción de las ciencias. Si bien se destacaba que los argumentos de Fanon no operaban en el campo de una ciencia constituida, se valoraba el trabajo de importación y aplicación de conceptos de ciencias que ya estaban constituidas. Junto a dicha ponderación, la aproximación a Fanon estaba mediada por un afán aclaratorio. Al respecto, Sastre aseguraba que algunos aspectos de su obra, especialmente aquellos que daban cuenta de sus concepciones sobre la ciencia, habían sido interpretados de manera errónea. De este modo, la crítica a la ciencia universal debía ser pensada como una crítica al cientificismo y no como una crítica a la ciencia. En este mismo sentido, la crítica a las concepciones de los psiquiatras franceses sobre los argelinos debía ser concebida como una crítica las ideologías seudocientíficas y no como una crítica al conocimiento científico. Para una visión panorámica de la recepción argentina de Fanon, ver De Oto, Alejandro. "Usos de Fanon. Un recorrido por tres lecturas argentinas". Cuyo. Anuario de Filosofía Argentina y Americana. Vol. 30, № 1, Junio 2013, pp. 35-60.

${ }^{648}$ Sastre, Carlos. La psicología, red ideológica. op. cit., p. 87. 
seudocientífica conducía al establecimiento de dos posibles tareas para el psicólogo de mediados de la década de 1970. Una de ellas, juzgada negativamente por Sastre, era la de seguir propiciando la integración entre las diferentes escuelas que conformaban la disciplina. Tal como habíamos señalado en relación a su crítica a Bleger, aquel esfuerzo integrador era denunciado por suponer de manera anticipada la existencia de una esencia común a todas las tradiciones y por confiar ingenuamente en la posibilidad de lograr una unificación entre ellas. Alejado de esta opción teleológica, que implicaba el recorte analítico sobre la unificación final de la psicología y la consecuente obturación del problema de su constitución como ciencia, Sastre proponía un trabajo de desarticulación conceptual de la disciplina. La relativización del vínculo entre constitución de la psicología e integración de diferentes escuelas posibilitaba la apertura de un juicio sobre la relación entre las distintas perspectivas y orientaciones.

Dicha operación implicará una torsión en los parámetros analíticos del problema de la integración desplegados a fines de la década de 1960. Si en aquellas críticas Sastre tendía a enfatizar el carácter ilusorio de una articulación entre perspectivas provenientes de distintas tradiciones, aquí buscaba demostrar que la heterogeneidad de los discursos era aparente y que todas las orientaciones integradas estaban unidas por una identidad esencial. Este desplazamiento tenía como resultado uno de los aportes más originales de la obra de Sastre: la caracterización de la psicología como red ideológica. Dicha nominación implicaba, en un primer nivel, la interpretación de la psicología como un tejido constituido por el entrecruzamiento de discursos. En un segundo, la identificación dentro de dicho tejido de un núcleo resistente que tendía a cohesionar el campo y que desempeñaba el rol de formación ideológica dominante. $Y$ en un tercer nivel, la advertencia de aquel núcleo como una condensación de recortes de la teoría psicoanalítica con la filosofía fenomenológica y el humanismo marxista. Era este desplazamiento hacia el abordaje de la psicología como red ideológica lo que le permitía a Sastre englobar aquellas impugnaciones realizadas de manera independiente unos años antes. Por un lado, la psicología de la conducta, nominada como "punto 
de intersección y condensación de una versión mutilada del psicoanálisis con el pensamiento fenomenológico" ${ }^{49}$. Y por el otro, la psicopatología del hombre alienado, descripta como "punto de intersección de la antropología filosófica feuerbachiana que orienta la lectura humanista de Marx, con varios recortes intencionados de la teoría psicoanalítica, ${ }^{350}$.

Finalmente, así como el abordaje de los problemas de la psicología contemporánea a través del problema de la relación entre ciencia e ideología posibilitaba la integración de diferentes corrientes teóricas dentro de una misma problemática, también favorecía la reevaluación conjunta de tendencias difundidas entre los psicólogos argentinos. Este era el caso de los discursos de la politización de la ideología y del psicólogo como agente de cambio social, los cuales pasaban a ser procesados como formaciones ideológicas que orientaban el accionar profesional pero que no alcanzaban el nivel de sistematización propio de la psicología de la conducta o la psicopatología del hombre alienado. Nominadas como ideologías de la profesión y catalogadas como simples mitos que guiaban la práctica profesional, estas formaciones eran interpretadas como un simple resultado del "lenguaje atado a las contradicciones de la experiencia del psicólogo" ${ }^{\prime 651}$. Al remitir su origen a una concepción errónea sobre la articulación entre las prácticas profesional, científica y política, estos discursos se presentaban a los ojos de Sastre como una conjunción de frases hechas, slogans y falsas presuposiciones. Así se actualizaba el examen sobre las preguntas acerca de cómo politizar el campo de la psicología y cuál es el rol social del psicólogo. Si bien Sastre conducía sus críticas a través de los tópicos de la redundancia y el equívoco -la psicología ya está politizada, el psicólogo ya interviene en la sociedad a través de su profesión-, esta revisión del problema estaba acompañada por el señalamiento del rol sustitutivo de las ideologías de la profesión. En el caso de la politización de la psicología, favoreciendo una "retórica politicista en sustitución de una crítica teórica". En el caso del psicólogo como agente de cambio social, fomentando un "orgullo profesional en sustitución de la práctica

\footnotetext{
${ }^{649}$ Ibid., p. 89.

${ }^{650} \mathrm{ld}$.

${ }^{651}$ Ibid., p. 180.
} 
política". Es decir, formaciones ideológicas que cumplían su cometido de desarticular en la práctica profesional avances que implicaran posicionamientos subversivos tanto en el orden de la ciencia como en el de la política.

Otro aspecto a través del cual se puede delimitar la especificidad de la intervención de Sastre en la primera mitad de la década de 1970 es la revisión de las clases dictadas por Omar Ipar en la cátedra de Psicohigiene de la carrera de Psicología de la UBA. Las movilizaciones estudiantiles de 1971 habían forzado a Ipar a renunciar a la cátedra de Psicohigiene y a la dirección de la carrera de Psicología ${ }^{652}$. Una vez producido el desplazamiento, la asamblea de alumnos de la cátedra le había encargado a un grupo de docentes liderados por Sastre una evaluación general del estado de la cátedra. En base a este pedido, Sastre y sus colaboradores, entre los que se encontraban Osvaldo Devries, Emma Costaguta, Beatriz Grego y Marta Satme, elaboraron un documento titulado "Crítica de una ideología en psicohigiene" en el cual se dedicaban a escrutan las clases teóricas dictadas por su titular. Dicho examen estaba estructurado en base a un conjunto de niveles analíticos. Estos eran su forma lógica (si el discurso poseía un orden lógico y no era tautológico ni contradictorio), su contenido empírico (si los términos denotaban con precisión a sus referentes), su instrumental teórico (si el discurso presenta una teoría general que abarca y explica los hechos), su pertenencia ideológica y los intereses sociales representados. Si la elección de estos niveles nos permite dar cuenta de cuáles eran los aspectos que debían ser analizados en todo discurso, el resultado de la evaluación de las clases de Ipar posibilita la advertencia de las dimensiones normativa del análisis desarrollado. A juzgar de Sastre, el discurso de Ipar era lógicamente defectuoso y semánticamente vago, calificaciones que se derivaban principalmente del examen del instrumental teórico puesto en juego. Era en este nivel en el que mayor atención ponía Sastre, señalando que las clases de Ipar combinaban opiniones de diversas

\footnotetext{
${ }^{652}$ Para una contextualización de la experiencia de la cátedra de Psicohigiene en el marco de las movilizaciones estudiantiles de los tempranos setentas, ver Bonavena, Pablo. "Apuntes para el análisis del 'doble poder' en la Facultad de Filosofía y Letras de la Universidad de Buenos Aires. Año 1971/1972". IV Jornadas de Estudio y Reflexión sobre el Movimiento Estudiantil Argentino y Latinoamericano. Luján, 6 y 7 de Septiembre de 2012.
} 
corrientes teóricas, anécdotas y datos sin relación, seudo-soluciones que respondían a problemas mal formulados y consejos técnicos para la manipulación de grupos humanos. Combinación que transformaba a las clases de Ipar en un discurso superficial y distorsionador en el tratamiento de las teorías, ecléctico en cuanto a la concepción de las relaciones entre ellas, anecdótico en el uso de datos y vacío en las soluciones propuestas.

\subsection{Confusiones epistemológicas: las polémicas de Roberto Harari con Juan Danis, Hernán Kesselman y Antonio Caparrós}

Al igual que el itinerario de Sastre, las primeras intervenciones de Roberto Harari en los debates de la psicología argentina estuvieron mediadas por un afán polémico. En su caso, dichas discusiones se desarrollaron alrededor de dos tópicos fundamentales. Por un lado, el problema del objeto de la psicología y el rol del psicólogo, a partir del cual estableció un debate con la psicóloga Juana Danis, cuyo trabajo representaba la prolongación de la obra de Bleger y la continuidad de la psicología concreta. Por el otro, el problema de la relación entre ciencia y política, el cual lo llevó a terciar en la polémica que mantuvieron Hernán Kesselman y Antonio Caparrós sobre los vínculos entre psicoanálisis y antiimperialismo. Como no podía ser de otra manera debido a la casi simultaneidad de las discusiones y al ámbito acotado en el cual se desarrollaban, ambas intervenciones estaban marcadas por los mismos problemas que atravesaban al campo de la psicología argentina a fines de la década de 1960 y principios de la de 1970. Sin embargo, un análisis particularizado de cada una de las polémicas en las cuales intervino Harari en aquellos años nos permite delimitar con precisión la especificidad de la mediación althusseriana en el abordaje de los tópicos mencionados.

El debate con Juana Danis se desarrolló entre los años 1969 y 1970 en la Revista Argentina de Psicología. El contrapunto con dicha psicóloga se inició a partir de la publicación de su artículo "El psicólogo y el psicoanálisis" en el primer número de la revista. Enmarcado en el proceso de profesionalización de la psicología en Argentina, la intervención de Danis constituía un esfuerzo por 
pensar el carácter diferencial del ejercicio de la disciplina frente a la tarea desarrollada durante años por los psicoanalistas. Al respecto, la propuesta de Danis se pretendía superadora de las posiciones recurrentes entre los psicólogos: el rechazo del psicoanálisis, apuntalado por cierto desconocimiento de la obra de Freud, y la indiferenciación con el trabajo psicoanalítico, muchas veces más proclamada que experimentada. Frente a estas opciones dicotómicas, Danis buscaba reforzar entre los psicólogos la identificación con una tarea profesional que es "afín y a la vez diferente de la labor psicoanalítica" ${ }^{653}$. El refuerzo identitario propiciado por Danis encontraba sustento en el perfilamiento del psicólogo ya no como un mero ayudante o un simple especialista en tests sino, fundamentalmente, como un profesional con una utilidad social. Fueron precisamente el procesamiento del vínculo entre el psicólogo y la sociedad en términos de utilidad, y la caracterización de dicha utilidad como la asistencia al cambio social, lo que otorgó un carácter singular a la propuesta de Danis en el campo de la psicología argentina de fines de la década de 1960:

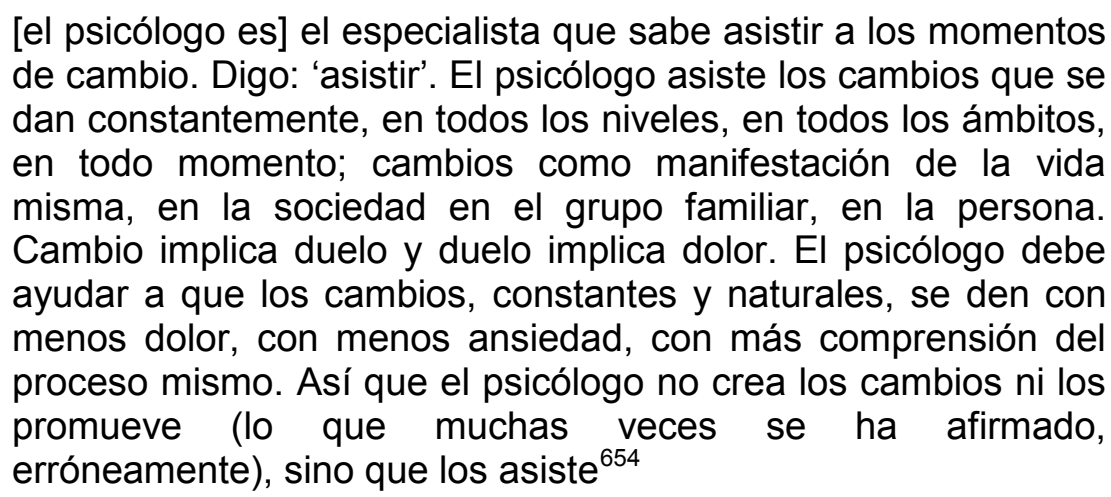

Este texto fue abordado por Harari en una intervención que operaba a modo de relevo de las referencias teóricas en las cuales las propuestas de Danis encontraban sustento. Apoyado en epígrafes del Marx de El Capital, LeviStrauss y Foucault, Harari desmontaba los argumentos centrales esbozados por Danis alrededor del problema del vínculo entre el psicólogo y el

${ }^{653}$ Danis, Juana. "El psicólogo y el psicoanálisis". Revista Argentina de Psicología. N 1 , septiembre 1969, p. 75.

${ }^{654}$ Ibid., p. 80. 
psicoanálisis, así como los relativos al objeto de psicología. En un gesto que guarda estrechas relaciones con las lecturas desarrolladas simultáneamente por Sastre, Harari escrutaba los propios términos a partir de los cuales Danis llevaba a cabo su análisis de las relaciones entre el psicoanálisis y la tarea profesional del psicólogo. De acuerdo a este examen, se desprendía que Danis equiparaba al psicólogo, término que refería a un trabajador que desarrollaba tareas en un campo específico -el de la salud y la enfermedad mental- con el psicoanálisis, expresión que refería conjuntamente a una teoría, una terapia y un método de investigación. Dicha asimilación llevaba al texto de Danis a ofrecer un contenido confuso desde sus propios supuestos: "deducimos, por tanto, que el campo semántico que barren los significantes 'psicólogo' y 'psicoanálisis' no son ni con mucho superponibles"

El esquema con el que Harari se aproximaba a los argumentos de Danis no se reducía a la constatación de esta superposición, sino que se prolongaba hacia la advertencia del sustrato epistemológico que favorecía las confusiones en las que incurría el texto. Del hecho de que en el artículo de Danis convivieran aclaraciones sobre la necesidad de evitar la confusión entre ciencia y profesión con numerosas menciones al psicoanálisis como labor profesional, Harari deducía que las superposiciones allí operadas trascendían las propias intenciones de la autora. Es decir que las confusiones conceptuales tenían un trasfondo de confusiones epistemológicas. De este modo se advertía una relación causal entre la conceptualización del psicoanálisis como profesión y una concepción empirista del conocimiento:

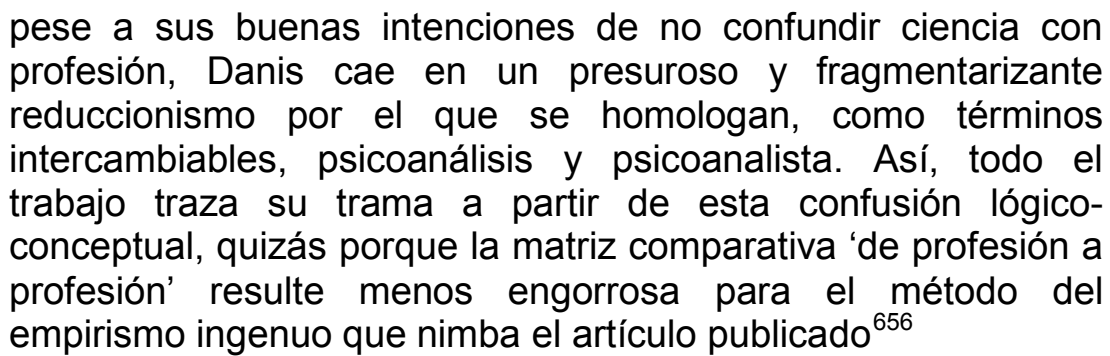

${ }^{655}$ Harari, Roberto. "El psicoanálisis y la profesionalización del psicólogo (a partir de 'El psicólogo y el psicoanálisis' de Juana Danis)". Revista Argentina de Psicología. N 3 , marzo 1970, p. 147. ${ }^{656}$ Ibid., p. 150. 
Resuenan de esta manera, en los argumentos de Harari, las acusaciones contra el empirismo formuladas por el estructuralismo. El direccionamiento del pensamiento hacia la indagación de lo "latente de la apariencia" conllevaba naturalmente la advertencia sobre la ingenuidad de las concepciones del conocimiento implícitas en el razonamiento de Danis. La potencia que entrañaba la renovación de las referencias teóricas se revela nítidamente en la resignificación a la que eran sometidos nada menos que los conceptos de psicólogo y ciencia. Los argumentos de Harari dejan entrever la creencia en que la prioridad otorgada a lo móvil, lo extrínseco y lo aparente -y el consecuente olvido de lo invariante, lo intrínseco y lo real- había conducido a un conjunto de naturalizaciones absurdas. Entre ellas, la nominación como psicólogos de quienes "sólo procuran el mero establecimiento de correspondencias descubiertas y públicas entre los sucesos" y como ciencia del simple "producto de literarias descripciones fenoménicas acerca de estados de ánimo" ${ }^{\prime 657}$. De este modo, las confusiones que habitaban el texto de Danis se revelaban como el efecto previsible de la imposibilidad de trascender la comprensión de lo manifiesto.

Así como el estructuralismo en tanto paradigma de las ciencias del hombre habilitaba una advertencia sobre el déficit científico de la propuesta de Danis, Althusser permitía un enjuiciamiento de las concepciones sobre el objeto del psicoanálisis que sustentaban sus afirmaciones. En primer lugar, la postulación del "ser humano en tratamiento" como objeto de la práctica profesional del psicólogo se revelaba como vacía por no estar apoyada en un trabajo de tipo teórico. Aquí, el "Freud y Lacan" de Althusser servía de apoyatura para la refutación de Danis en el sentido de que la delimitación de un objetivo para el psicoanálisis sólo es posible "si los conceptos que fundamentan su práctica han sido rigurosamente demostrados, en tanto, como cualquier ciencia, el psicoanálisis faculta el ejercicio de una práctica por la

657 Ibid., p. 151. La resignificación propiciada por la lectura estructuralista se revela asimismo en un guiño que el texto realizaba al lector; al mencionar estas concepciones naturalizadas del conocimiento, Harari le agregaba un signo de interrogación a la palabra ciencia: "aquellos otros que proceden a instituir como ciencia (?) el producto de literarias...., Id. 
existencia de una teoría, de la que aquella es un momento subordinado"658. Por otro lado, el esfuerzo de Danis por disociar en parte el trabajo del psicólogo del psicoanálisis era impugnado a partir de los términos en los cuales dicha separación era explicitada. Al respecto, el carácter científico que la lectura althusseriana de Lacan le otorgaba a la determinación del inconsciente como objeto del psicoanálisis, volvía extremadamente ingenua la sugerencia de Danis acerca de que la investigación del inconsciente resultaba una tentación de la que el psicólogo debía apartarse a los fines de no transformarse en psicoanalista. De acuerdo a Harari, resultaba insostenible que el problema del objeto del psicoanálisis dependiera de la voluntad del profesional: "original modalidad [la de Danis] de definir los términos de una práctica científica a través de la apelación a las apetencias y preferencias de los practicantes, imprecada moralmente" ${ }^{\prime 659}$.

Resulta relevante destacar dos aspectos de la lectura que Harari realizaba del "Freud y Lacan". El primero se relaciona con las refutaciones de Danis recién mencionadas. Así como Althusser permitía caracterizar como precientífico el postulado del "ser humano en tratamiento" como objeto de la práctica del psicólogo, también habilitaba algunas consideraciones positivas a partir de la delimitación de la investigación del inconsciente como objetivo del psicoanálisis. Desligada de cualquier criterio voluntarista, esta delimitación conducía a la postulación de la investigación del inconsciente como la condición que valida científicamente al psicoanálisis y, por lo tanto, autoriza su práctica. Validación que garantizaría la diferenciación entre el psicólogo y aquel que lo consulta. De esta manera el psicólogo efectivamente podría trascender la mera observación de los materiales construidos por el consultante. Si sólo se limitara a devolver a quien lo consulta lo mismo que éste ha construido, el rol del psicólogo se volvería redundante y prescindente. El segundo de los aspectos a destacar, que ya advertimos en el itinerario de Masotta, está vinculado con la convivencia entre las formulaciones de Althusser y las de Politzer. Es interesante destacar que, en este momento, la

\footnotetext{
${ }^{658} / d$.

${ }^{659}$ Ibid., p. 153.
} 
fuerza que cobraba la interpretación del inconsciente en la lectura que Harari realizaba de Danis estaba apuntalada tanto por la idea de captura del discurso inconsciente $y$ verbal en Althusser como por la idea de trascendencia de convencionalidad de la significación del relato en Politzer. Es decir que la definición del psicoanalista como aquel que traspasa el plano de la mera observación para interpretar el inconsciente se conjugaba con el interés por la inscripción de este último en el discurso relatado y significativo.

La intervención con la que Harari terció en la polémica entre Kesselman y Caparrós también estuvo atravesada por el problema del objeto del psicoanálisis, aunque en este caso dicho tópico se desplegó fundamentalmente alrededor de la cuestión de la relación entre ciencia y política. La polémica, que se desarrolló en las páginas de la revista Nuevo Hombre, se inició con un texto de Kesselman en el que se reseñaba favorablemente el proceso de constitución del agrupamiento Plataforma y se hacía un llamamiento al compromiso político de los psicoanalistas. En sintonía con los posicionamientos ya reseñados en ocasión del análisis de la lectura realizada por Sastre, Kesselman insistía en el hecho de que los psicoanalistas argentinos "se inscriben, lo sepan o no, les guste o no, en las reglas del juego que enmarcan las relaciones humanas en sociedades dependientes" ${ }^{660}$, inscripción por la cual el rol que les cabía era el de la oposición a la dependencia a través de una consecuente militancia antiimperialista. Por ello Kesselman destacaba el reconocimiento de los psicoanalistas de que "el meridiano de la lucha no pasaba fundamentalmente por las revueltas institucionales" ${ }^{\prime 61}$, toma de conciencia que les había permitido alejarse del intelectualismo para fundirse finalmente con los sectores más explotados de la sociedad. La respuesta de Caparrós enfatizaba la imposibilidad de que el psicoanálisis y el antiimperialismo se vincularan del modo propuesto por Kesselman. A juzgar por Caparrós, el programa postulado por Kesselman carecía de fundamentación, tanto en lo relativo a la relación entre profesión y política como a la ubicación del psicoanalista en el seno de las relaciones

${ }^{660}$ Kesselman, Hernán. "Psicoanálisis y antiimperialismo". Nuevo Hombre. № 6 , agosto 1971 , p. 10.

${ }^{661} / d$. 
humanas en las sociedades dependientes. Al no atender la necesaria diferencia entre el psicoanalista en tanto profesional y el psicoanalista en tanto militante político, Kesselman le otorgaba a la práctica psicoanalítica unos objetivos imposibles de cumplir. En tanto el psicoanálisis está "constituido y ligado indisolublemente sobre la base de premisas ideológicas falsas" ${ }^{\text {"62 }}$, la propuesta de Caparrós se dirigía hacia la elaboración de una teoría y práctica psicológica de tipo revolucionaria distinta del psicoanálisis.

Harari intervino en esta polémica con el objetivo de demostrar que si bien la lectura de Caparrós aparecía a simple vista como superadora de la de Kesselman, no era más que su imagen invertida. Esta operación se volvía posible por una distinción precisa entre los niveles científico y político de la totalidad social, así como por el énfasis en el inconsciente como objeto del psicoanálisis. El hecho de que tanto Kesselman como Caparrós plantearan sus argumentos alrededor del problema de la relación entre psicoanálisis y antiimperialismo hacía que ambos permanecieran en el mismo nivel analítico, aunque uno de ellos lo planteara en términos de conjunción y el otro en términos de exclusión. De acuerdo a Harari, los argumentos esbozados por Kesselman y Caparrós eran equívocos porque estaban construidos sobre presupuestos falsos:

\begin{abstract}
Parecen que dijeran todo lo contrario y sin embargo el planteo de fondo es el mismo: los dos suponen que estos términos [psicoanálisis y antiimperialismo] tienen por lo menos algo que ver, algo en común tal que haya justificado su relación, sea para darla por posible o no. Caparrós repite el planteo de Kesselman y lo invierte. No lo cambia de terreno, no rompe con él. La trampa ideológica a la que sucumben es una y la misma: es suponer que, en efecto, la relación mentada es posible ${ }^{663}$
\end{abstract}

Así como esta lectura del debate remitía a un problema específico del campo en el cual éste se desarrollaba, Harari pretendía dar lugar a una discusión que tensionara las bases que posibilitaban el planteo de una relación entre

${ }^{662}$ Caparrós, Antonio. "Psicoanálisis o antiimperialismo". Nuevo Hombre. № 10 , septiembre 1971, p. 10.

${ }^{663}$ Harari, Roberto. "Psicoanálisis/stalinismo". Nuevo Hombre. № 14, octubre 1971, p. 14. 
psicoanálisis y antiimperialismo. Es por ello que la intervención de Harari avanzaba sobre el problema general de los vínculos entre ciencia y política:

\begin{abstract}
Nosotros nos permitimos dudar y nos planteamos la cuestión de si dichos términos [psicoanálisis y antiimperialismo] son relacionables. Si un término que califica a una ciencia tiene algún sector en común con una práctica tendiente a romper la sujeción de las naciones dependientes -como la nuestra- a las naciones poderosas del orbe, tanto con las del primer mundo como con las del segundo. $Y$ respondemos por la negativa. Ambos términos se inscriben en dos universos del discurso articulados de tal manera que la inclusión de un término en el universo del otro se revela como manifiestamente no pertinente. Y si no, veremos cómo la no diferenciación de estas prácticas prostituye y pervierte a las dos: ni la ciencia llega a ser tal, ni la práctica política antiimperialista se cristaliza en un efecto eficaz, pertinente: político ${ }^{664}$
\end{abstract}

Por otra parte, el escudriñamiento de la discusión entre Kesselman y Caparrós desde el prisma de la insistencia en el inconsciente como objeto del psicoanálisis ensanchaba la base argumental necesaria para la equiparación entre dos posiciones que en apariencia resultaban absolutamente divergentes. Resulta interesante destacar, al respecto, que los argumentos de Harari no se dirigían tanto contra las tesis de Kesselman sino fundamentalmente contra las de Caparrós. La forma en la cual Harari interrogaba las afirmaciones de Caparrós desde esquemas althusserianos nos permite inferir que una parte importante de lo que se jugaba en esta polémica era la advertencia del agotamiento de la psicología concreta. De cara a su imposibilidad de trascender el plano de la experiencia vivida, Harari se interrogaba: “¿Tendrá esto que ver con la adscripción de Caparrós -en un momento ¿pasado?- al propósito de construir una 'psicología concreta' condenada a morir antes de nacer por no poder definir su objeto de estudio?"665. Frente a su llamado a construir una nueva teoría psicológica, Harari inquiría: “¿cuál es en esa teoría su objeto de conocimiento? ¿'lo concreto’ otra vez? No se entiende, en efecto,

\footnotetext{
${ }^{664} / d$.

$665 / d$
} 
qué elaboración teórica puede dar cuenta de las motivaciones profundas de un individuo sin apelar al concepto formal y abstracto de inconsciente"666.

Finalmente debemos mencionar que la advertencia del agotamiento de la psicología concreta se anudaba con un conjunto de consideraciones alrededor del problema de la ideología que se anclaban explícitamente en los trabajos de Althusser y Harnecker. La intervención de Caparrós en la polémica con Kesselman carecía de todo sustento porque daba por supuesta la posibilidad de percibir la realidad de manera transparente. Al respecto, Harari remitía al tratamiento otorgado por Harnecker al problema de lo ideológico, del cual se desprendía la afirmación de que la percepción de la realidad no se da sino bajo la acción deformadora de la ideología. En este sentido también era enfatizado el carácter universal de la ideología, lo cual llevaba a expandir ciertas problemáticas que en el debate aparecían vinculadas específicamente a las tareas del psicólogo: "[las transparencias] están al alcance de cualquier individuo sin necesidad de ser psicólogo ni de ser otra cosa que un portador de ideología" ${ }^{667}$. La atención prestada al problema de lo ideológico tenía su prolongación natural en una serie de consideraciones alrededor de la ciencia. En relación a este tópico, la idea del trabajo científico como aquel que desconfía del sentido común intuitivo y empirista, volvían equívocas la separación operada por Caparrós entre premisas ideológicas falsas -las del psicoanálisis- y premisas ideológicas verdaderas -las de la psicología por venir. De este modo Harari se esforzaba en demostrar lo descaminado que estaba Caparrós al postular como objetivo del trabajo del psicólogo la construcción de una teoría y una práctica diferentes al psicoanálisis. A estos fines, la correlación establecida por Althusser entre el carácter científico y el carácter

${ }^{666}$ Id. Si bien la refutación de Harari a Caparrós se desarrollaba en un plano netamente teórico, aquel deslizaba una crítica al rol docente de éste que permite inferir la asociación establecida entre el Caparrós psicólogo y el Caparrós militante del PCA: "así, habría que estudiar y practicar digamos por ejemplo a los psicólogos soviéticos para demostrar el ser revolucionario de un psicoterapeuta. Precisamente esa es la enseñanza que prodigó predominantemente Caparrós cuando ejercía la docencia universitaria en la UNBA", Id. Para profundizar en el itinerario de Caparrós y el lugar de la psicología soviética en Argentina, ver García, Luciano. La recepción de la psicología soviética en la Argentina. Lecturas y apropiaciones y la psicología, psiquiatría y psicoanálisis (1936-1991). Tesis doctoral, Universidad de Buenos Aires, 2012. ${ }^{667} / d$. 
revolucionario del psicoanálisis se volvía altamente eficaz: "Como bien indica Althusser, la ciencia es revolucionaria en sí, en tanto descentra el reconocimientos/desconocimiento al que estaban suturados los hombres antes de producirse la ruptura fundante de un territorio científico nuevo. Y un territorio nuevo es el que abrió al conocimiento Freud"668.

\subsection{Realismo, abstracción y formalismo: crítica de la psicología de la conducta y fundación científica de la disciplina}

Fueron precisamente los términos de la primera de las polémicas, aquella que lo enfrentó a Danis, los que se prolongaron en las producciones de Harari de los primeros años de la década de 1970. A lo largo de 1972 Harari se dedicó a ampliar algunos de los problemas transitados en el texto en el que refutaba a Danis, así como a rectificar ciertos sentidos allí expresados. Este trabajo, que fue publicado como aporte al volumen colectivo El rol del psicólogo, editado por Nueva Visión en 1973, operó a modo de sistematización de los tópicos abordados en sus primeros textos, tales como el objeto del psicoanálisis, la ideología y la especificidad del conocimiento científico. Sistematización claramente perceptible, por un lado, en la forma en la cual Harari refería al objetivo de su producción: "fundar para el psicólogo un operar encuadrable en los términos de una práctica científica estricta basada en la ontología y la epistemología materialista, desechando los discursos seductores y demagógicos con que nos tiende celadas por doquier la ideología dominante en nuestro medio profesional"669. Por el otro, en la nitidez con la que eran individualizadas las expresiones de la ideología dominante en el campo de la psicología: "el proyecto reaccionario del psicólogo 'acondicionante', que se invalida por sí solo" así como "aquellos otros que, imbuidos de ingenuidad y mesianismo, se han lanzado a pregonarse como los adalides de la integración

\footnotetext{
$668 / d$.

${ }^{669}$ Harari, Roberto. "El objeto de la operación del psicólogo". AAVV. El rol del psicólogo. Buenos Aires, Nueva Visión, 1973, p. 154.
} 
revolucionaria entre psicoanálisis y marxismo, desempeñándose, en verdad, en un ideologismo a ultranza" 670 .

Uno de los aspectos más significativo de este esfuerzo de sistematización radicó en el ajuste de cuentas con el trabajo de Bleger. Al respecto, una de las razones que permite explicar la tarea de ampliación y rectificación de la refutación de las tesis de Denis es la necesidad de explicitar una crítica abierta al lugar ocupado por el trabajo de Bleger entre los psicólogos argentinos. Es por ello que Harari llevaba a cabo una autocrítica por el lugar que le había otorgado en el texto de 1969 a las concepciones de Politzer explicitando que Bleger había actuado a modo de un "eslabón intermedio"671 entre aquel y Danis. De esta manera se revelaba que el verdadero destinatario de aquella refutación no era tanto Danis como Bleger. Ahora bien, ¿por qué entonces esta crítica no había sido explícita en su momento? Al igual que Sastre, Harari daba cuenta de la dificultad de romper totalmente con un tipo de trabajo que los había marcado en su formación y que había sido realmente significativo en cuanto al esfuerzo de vinculación entre marxismo y psicoanálisis. De este modo se refería Harari a la ausencia del nombre de Bleger:

\begin{abstract}
Nuestra única respuesta se inscribe en términos de la dificultad de someter a crítica una obra por la que fuimos altamente influidos y que concitaba nuestra adhesión intelectual, así como la de tantos otros colegas. Adhesión cifrada en la magnitud de la empresa acometida, consistente en una decidida 'integración' del psicoanálisis y del marxismo a partir de las pioneras posturas de Politzer ${ }^{672}$
\end{abstract}

La consolidación de Harari en un campo teórico predominantemente althusseriano permitía la configuración de un espacio de confrontación

\footnotetext{
${ }^{670} \mathrm{Ibid} ., \mathrm{p} .156$. La apropiación de los términos del althusserianismo operaba hasta en la forma en la que Harari nominaba el su evolución desde el texto de 1969 hasta el de 1972. A los fines de disculparse por cierta ausencia de sistematicidad en la lectura de Danis, Harari reproducía las consideraciones realizadas por Althusser en Lenin y la filosofía acerca de la práctica salvaje: "Práctica salvaje en el sentido en que Freud habla de un análisis salvaje, que no indica los títulos teóricos de sus operaciones... práctica salvaje, si se quiere, pero ¿quién no empezó por ser salvaje?”, Id.

${ }_{671}$ Ibid., p. 158.

${ }^{672}$ Ibid., p. 160.
} 
estructurado en torno a la tríada Politzer-Bleger-Danis. De este modo, el postulado del ser humano en tratamiento como objeto del trabajo del psicólogo que se desprendía del posicionamiento de Danis era puesto en sintonía con la afirmación del ser humano como objeto de la psicología que se derivaba del influyente Psicología de la conducta de Bleger. Frente a este anudamiento humanista cobraba aún más fuerza la postulación del inconsciente como objeto de la operación del psicólogo. Si en 1969 el tratamiento dado por Althusser al inconsciente pudo convivir con formulaciones politzerianas, en 1972 esta asociación era rotundamente interrumpida. Tener al inconsciente únicamente como el aura invisible -tal como aparecía en el texto de Danis- y no como el objeto específico y pertinente de una ciencia, acarreaba necesariamente el ingreso en el campo de la psicología de la ideología liberal que legitima el orden social capitalista. Así se consumaba el pasaje definitivo hacia una concepción del sujeto como soporte de estructuras. Es decir, no como el hombre libre que actúa en base a acciones proyectadas por su conciencia, sino como el sujeto sujetado a la doble determinación de la estructura del inconsciente y la estructura social.

El relevo del ser humano por el inconsciente como el objeto de la psicología implicaba un desplazamiento significativo desde el terreno de lo real y lo concreto hacia el de lo abstracto y lo formal. Es la magnitud de dicho movimiento lo que permite explicar el lugar que Harari le otorgaba a la refutación de eventuales impugnaciones a la postulación del inconsciente como el objeto científicamente verídico de la psicología. Al respecto, una parte importante de este trabajo ampliatorio y correctivo estuvo dedicado a sustentar la afirmación de que el inconsciente es al mismo tiempo real y construcción cognoscitiva. De esta manera Harari se adelantaba a las posibles impugnaciones humanistas a estos postulados a través de un trabajo argumentativo que le permitía sostener el carácter tanto ontológico como epistemológico de la colocación del inconsciente como objeto. Una vez legitimado este relevo, Harari podía asignarle un valor positivo al hecho de haber "incurrido en los tres pecados capitales que juzga condenatoriamente la 
psicología 'concreta': nuestra aseveración es realista, abstracta y formalista" 673 674

Una vez aseguradas las posiciones frente a la psicología concreta, el trabajo de Harari se concentró en la profundización de un conjunto de cuestiones relativas al problema de la ideología. El direccionamiento de sus preocupaciones estaba claramente mediado por el interés concitado por los requerimientos del conocimiento científico. Al respecto, Harari establecía como base del problema del conocimiento la distinción althusseriana entre objeto real y objeto de conocimiento. De esta manera cimentaba una concepción del acto cognoscitivo delineada por premisas tales como que es necesario poseer el objeto formal para hacer inteligible el objeto material, que las determinaciones de lo conocido sólo son otorgadas a través del objeto formal y que el conocimiento implica un trabajo específico en el que no participan ni la intuición ni el sentimiento.

Era a partir de la cimentación de estas premisas que el trabajo de Harari podía trascender la mera descripción de la concepción althusseriana de la ideología para ingresar en un terreno fundamentalmente crítico. Uno de los aspectos más interesantes para destacar de esta vinculación singular que Harari estableció con los aportes althusserianos radicó en la interrogación del problema de la ideología desde reflexiones apuntaladas desde el campo de la lingüística y la semiología. Así ocurría con el diálogo que el texto propiciaba entre la crítica de Althusser al empirismo epistemológico y las críticas de Saussure al empirismo lingüístico: mientras que las primeras evidencian la falsedad de la idea de que el conocimiento ya está presente en el objeto real a conocer, las segundas reducen al absurdo la creencia en que el mundo dicta a los hombres la idea que debe forjarse de él. En este mismo sentido se nos presenta el señalamiento de Harari acerca de cierto déficit en la concepción

${ }^{673}$ Ibid., p. 162.

${ }^{674}$ Una de las operaciones realizadas por Harari en relación a las concepciones de Bleger consistía en disociar el problema del inconsciente de la cuestión de los estímulos. Al ubicar la determinación del inconsciente en el deseo y no en el estímulo, la creencia del conductismo en la respuesta del inconsciente a estímulos exteriores aparecía como limitada: "la teorización conductista se revela cadenciada y deficitaria al no comprender que la eficacia del inconsciente no espera ni necesita del 'estímulo adecuado' para producir sus efecto", Ibid., p. 170. 
althusseriana del rol cumplido por los códigos en los procesos de sujeción. De acuerdo a su lectura, esta concepción permitía comprender la forma en la cual la estructura social tiene un efecto cohesivo sobre los sujetos, los cuales son provistos de un sistema de representaciones dotados de un papel histórico en una sociedad dada. Sin embargo, adolecía de una preocupación específica sobre el lugar ocupado por los códigos en el efecto deformador de la ideología:

\begin{abstract}
observamos que en realidad esta definición althusseriana de la ideología, que de ella estamos hablando, nos enfrenta con el efecto terminal de una estructura productiva, escotomizando los sistemas transformadores que las posibilitan: los códigos. Son éstos quienes instrumentan al sujeto para percibir-aceptarsoportar su mundo como el mundo mismo, sin que el sujetado cobre conciencia de ello, en pro de la armonía de la estructura social ${ }^{675}$
\end{abstract}

El tenor problematizador que Harari le imprimía a su lectura de Althusser daba lugar a una operación doble al interior de su propia producción intelectual. Por un lado, como hemos visto anteriormente, el trabajo sistematizador desarrollado en estos años acarreaba una revisión de sus primeras intervenciones. En relación al problema específico de la ideología, Harari abjuraba de una cita de Politzer invocada en el texto de refutación a Danis para dar cuenta de los problemas del objeto de la psicología: "el hecho psicológico no es un dato simple: como Objeto de conocimiento, es esencialmente construido". A fines de operar un relevo en las referencias teóricas, Harari replicaba a aquella afirmación con otra cita, en este caso proveniente de La formación del espíritu científico de Bachelard: "Nada va de suyo. Nada nos es dado. Todo es construido". Una vez constatado que todo es construido, que todo es significado, el problema de la construcción del hecho psicológico era objeto de una recolocación conceptual. Ya no importaba tanto la certificación de la construcción sino la indagación acerca del carácter científico o ideológico de la construcción. En sus palabras: “¿cuándo la estructura productiva de significaciones es ideológica y cuándo la estructura productiva de significados

${ }^{675}$ Ibid., p. 172. 
es científica? [...] ¿cómo el 'dato', el 'hecho', es construido ideológicamente y cómo es construido científicamente?"676.

Por otra parte, Harari ingresaba de lleno en las discusiones propias del espacio althusseriano. Es decir, que la certeza en la necesidad de avanzar en las conceptualizaciones althusserianas de la ideología a través de una profundización de la cuestión de los códigos y la significación, conducía a Harari a polemizar con otras lecturas del problema realizadas desde la propia órbita del althusserianismo. Así ocurría con la crítica a Althusser esbozada por Rancière, a la cual calificaba como "precipitada" ${ }^{677}$. Al respecto Harari consideraba que las acusaciones lanzadas por Rancière a los efectos políticos de la concepción althusseriana de la ideología pasaba por alto el problema fundamental señalado por Althusser, esto es, cómo los sujetos sólo reciben efectos metonímicos de la estructura social, los cuales los persuaden de la pertinencia y justicia de su ubicación en las relaciones de producción. En este mismo sentido Harari leía "El (re)comienzo del materialismo dialéctico" de Badiou. A su entender, el hecho de constituir el sujeto el lugar en el que entrelazan lo imaginario social y lo imaginario personal, volvía discutible el argumento de Badiou en torno al riesgo de que la articulación entre el marxismo y el status que el psicoanálisis le otorga a lo imaginario sea "provisionalmente inhallable" ${ }^{678}$. Era precisamente el contrapunto con el texto de Badiou el que le permitía a Harari introducir uno de los puntos más sobresalientes de su trabajo -el cual, como veremos más adelante, contará con la aprobación del propio Althusser. A diferencia del escepticismo de Badiou, Harari remarcaba que la articulación entre marxismo y psicoanálisis se cifraba en el carácter inconsciente de la ideología y en la estructura del inconsciente freudiano. Sin embargo, dicho punto no implicaba más que la constatación de la articulación. Ubicado en un espacio de trabajo futuro, Harari delimitaba como tarea la producción del concepto de esa articulación, aunque teniendo en cuenta que ella se encuentra en estado práctico en la obra de Freud.

\footnotetext{
${ }^{676} / d$.

${ }^{677}$ Ibid., p. 180.

${ }^{678}$ Ibid., p. 182.
} 
El hecho de orientar el problema de la ideología hacia la comprensión de la forma en la cual las representaciones producen un efecto de reconocimiento/desconocimiento llevaba a Harari a valorar más un trabajo como el de Harnecker que las lecturas críticas desarrolladas por Rancière y Badiou. Como hemos visto, la trasposición que Harnecker realizaba de la concepción althusseriana de la ideología era altamente valorada por Harari y utilizada recurrentemente en sus argumentaciones. En este caso, se trataba de una articulación entre la descripción harneckeriana de la ideología como depósito de elementos imaginarios y la introducción de la idea de sintagmas ideológicos cristalizados. Este movimiento de Harari debe ser resaltado, en tanto se trata de un modo de intervención en el campo del althusserianismo que tendrá como resultado el esbozo de contribución original. En lugar de una crítica política al maestro, como hacía Rancière, o la utilización de algunos de sus tópicos fundamentales para el inicio de un trayecto singular, tal el caso de Badiou, Harari se apoyaba en el trabajo de Althusser y el de la chilena para efectuar una profundización de uno de sus principales aportes. Harari retomaba el concepto de sintagmas cristalizados presente en Barthes, que refiere a las formas estereotipadas que restringen las posibilidades combinatorias de quien habla, para ubicarlo en el terreno específico de las representaciones ideológicas. De esta manera, los sintagmas ideológicos cristalizados aludían a formaciones configuradas por la ideología e incorporadas por los sujetos de una formación social dada. Como tales permitían inaugurar un desplazamiento fundamental en lo relativo al vínculo entre marxismo y psicoanálisis: "efectuamos el pasaje desde la consideración epistemológica de la ideología hacia su inserción en la materialidad de la subjetividad"679. Pasaje que tenía un conjunto de implicaciones en lo que respectaba a la comprensión del accionar de la ideología. En primer lugar, que la ideología se consolida en la subjetividad capturando al sujeto a través de sintagmas cristalizados. Por otra parte, que los sintagmas cristalizados pueden ser sustituidos por significantes corporales, logrando que la ideología se haga

${ }^{679}$ Ibid., p. 190. 
carne. Finalmente, que cuando se realiza dicha sustitución, el inconsciente muestra únicamente lo que el sintagma significa denotativamente ${ }^{680}$.

La vinculación que Harari establecía con la concepción althusseriana del conocimiento científico tenía la misma impronta que su intervención en los problemas de la ideología. Es decir, por un lado Harari operaba una lectura de las formulaciones acerca del conocimiento que se derivaban tanto de la obra de Althusser como de otros autores inscriptos en su órbita. Así se postulaba la centralidad de una epistemología materialista discontinuista, lo cual volvía protagonistas a las rupturas desarrolladas por la ciencia en relación las ideologías pre-científicas. Operaciones de las cuales actuaban a modo de apoyo las tesis del propio Althusser, y formulaciones tales como la de "corte científico" de Fichant y Pêcheux, y la de "ruptura" entre conocimiento científico y conocimiento sensible de Bachelard ${ }^{681}$. Resulta interesante destacar que al mismo tiempo que llevaba a cabo operaciones de lecturas dentro del propio campo del althusserianismo, Harari oponía las sistematizaciones resultantes a las concepciones epistemológicas que predominaron durante años en la psicología argentina. Enfatizaba al respecto: “Mal que les pese a los empiriopositivistas, habida cuenta de los de cuño fenomenológico como Bleger, no estamos nunca frente a los hechos, sino a las nociones que nos presta la ideología, y es únicamente por ruptura con ésta que es factible la construcción de una ciencia" ${ }^{682}$.

\footnotetext{
${ }^{680} \mathrm{Al}$ igual que en otros de los trayectos analizados, el texto sobre los AIE tendrá un marcado impacto en la producción de Harari. En tanto en "El objeto de la operación del psicólogo" se limitaba principalmente a glosar las tesis althusserianas, sólo nos interesa destacar el modo en el cual Harari enmarcaba el rol de los aparatos ideológicos en el problema de la materialidad de la ideología. Al respecto, Harari cifraba el aporte del concepto de AIE en la advertencia sobre la cristalización de prácticas y rituales descriptivos para los sujetos. Al mismo tiempo, consideraba pertinente la aclaración de que "cada AIE es un código materializado cuyas reglas de sustitución el sujeto conoce y observa, si bien es inconsciente de la excentricidad de las condiciones productivas del código", Ibid., p. 92.

${ }^{681}$ Cabe destacar que junto a los autores de la órbita althusseriana, Harari hacía participar de estas operaciones al trabajo del filósofo soviético Evald llénkov, cuyos desarrollos en torno a la dialéctica de lo abstracto y lo concreto coincidían con Althusser en sus críticas al empirismo. ${ }^{682}$ Ibid., p. 195.
} 
Al igual que ocurría con la cuestión de la ideología, las reflexiones de Harari alrededor del problema del conocimiento científico daban lugar a esbozos teóricos singulares. En este sentido, la primera tarea de Harari consistía en la consolidación de una concepción epistemológica diferenciada de las vertientes especulativa y empirista del idealismo. A diferencia de éstas, que operan distintas reducciones entre el ser y el conocimiento, Harari ubicaba en el horizonte de la tarea científica las premisas de la primacía del ser sobre su pensamiento y la distinción entre lo real y su conocimiento. Lo más interesante para resaltar, al respecto, es que en su trabajo Harari avanzaba algunos pasos en la concretización de aquel horizonte. Es decir, que sus reflexiones no sólo operaban en el campo althusseriano delimitando lecturas para luego volverlas efectivas en el campo de la psicología argentina, sino que estas lecturas también propiciaban acciones concretas en pos de la cientifización de la psicología. La primera de ellas consistía en la diagramación de un esquema relativo a la producción de conocimiento. Para ello, Harari adaptaba a los conceptos del psicoanálisis el esquema elaborado por Poulantzas para la teoría de lo político en el modo de producción capitalista. Utilizando como objeto la teoría de la racionalización yoica en la neurosis fóbica, Harari propiciaba un trabajo estructurado alrededor del esquema de generalidades althusseriano, es decir atravesado por el orden lógico que va de los conceptos más abstractos, relativos a los objetos formales, hacia los conceptos concretos, relativos a los objetos reales. La segunda correspondía a la fundamentación científica de la práctica técnica del psicólogo. Al respecto Harari elaboraba un diagrama en el cual se delimitaba la tarea de ruptura con las formas ideológicas. Harari asignaba un sentido doble a dicha ruptura. Por un lado, el psicólogo debía romper con las formas más reflexivas y sistematizadas, las cuales remitían a las ideologías pre-científicas. Por el otro, se fijaba para el psicólogo una acción rupturista en relación a formas difusas e irreflexivas, las cuales correspondían a la ideología del sujeto objeto de asistencia.

Destaquemos un conjunto de ampliaciones y rectificaciones que Harari agregaba a su trabajo a partir de la publicación de un apéndice a su texto "EI 
objeto de la operación del psicólogo". En primer lugar podemos advertir que así como la tarea del psicólogo era remitida a estas operaciones rupturistas, del mismo modo eran introducidos los peligros de una reinscripción ideológica de los conocimientos científicos. Al igual que Sastre, Harari estaba especialmente interesado en explicitar los riesgos de que, una vez producido el conocimiento científico, se produzcan movimientos regresivos originados en recaídas ideológicas. En este sentido es interesante dar cuenta de la forma en la cual esta cautela era aplicada al trabajo de lectura científica de la ideología del sujeto objeto de asistencia. Al momento de confrontar con los significantes corpóreos que sustituyen a los sintagmas ideológicos cristalizados, el psicólogo debía tener la precaución de evitar una "trasvación hipertrofiante" 683 de los conocimientos científicos a sectores de lo real que requieren la consideración de otros niveles de determinación. Es por ello que, de acuerdo a Harari, la constitución del principio de realidad del psicólogo debía estar también mediada por los conocimientos proporcionados por las ciencias afines, tales como la semiótica, la lingüística, el materialismo histórico y la antropología estructural ${ }^{684}$.

En segundo lugar, Harari proponía una reflexión acerca del rol ideológico cumplido por la psicología. En este sentido afirmaba que, revisando el texto por él escrito, había encontrado con sorpresa una coincidencia entre los distintos AIE y las distintas ramas de la psicología. En su ensayo, Althusser mencionaba a los aparatos religioso, escolar, familiar, jurídico, cultural. En el terreno de la disciplina se habían configurado especialidades tales como la psicología de la religión, educacional, familiar, jurídica, de la cultura. Ahora bien, si la psicología se ejercía en cada uno de los AIE, la cuestión a dilucidar era qué rol ocupaba la disciplina en cada uno de los aparatos. Al respecto Harari deslizaba que una de las tareas futuras debería ser el esclarecimiento sobre si ese ejercicio se realiza "no sólo porque se puede, sino porque se

\footnotetext{
${ }^{683}$ Ibid., p. 196.

${ }^{684}$ Harari presentaba la siguiente secuencia para ejemplificar una traslación ilegítima: el psicólogo trata a un paciente que tiene problemas con el dinero - el tratamiento lo ayuda a mejorar su vida - se extrae la conclusión de que sus problemas con el dinero derivan únicamente de problemas psíquicos (la culpa por ejemplo).
} 
debe" ${ }^{685}$. Es decir, si la división de la psicología en distintas ramas no obedecía a la necesidad del todo social de cohesionarse, actuando el psicólogo como agente de control en cada uno de los aparatos. Así como se imponía una dilucidación en el campo de la práctica del psicólogo, también correspondía un esclarecimiento en torno a la formulación de teorías específicas de la disciplina. Es decir, que si el criterio para la delimitación de las especialidades es ideológico, el desarrollo de teorías particulares propiciaría una disgregación favorable a la negación de la unidad teórica entre todas las ramas, esto es, la de tener como objeto al inconsciente.

Harari aprovechaba la inclusión del apéndice para llevar a cabo un ajuste de cuentas definitivo con ciertas lecturas de Sartre realizadas anteriormente. Si bien en el texto ampliatorio de la crítica a Danis las referencias a conceptualizaciones sartreanas eran ya marginales, Harari se sentía en la necesidad de rectificar esta inclusión. Como bien demuestra la forma en la cual se abjuraba de estas referencias, la renuncia a las nociones sartreanas tenía implicaciones que no remitían tanto al nivel de la teoría como al de la política. Dado el lugar protagónico que Sartre había tenido en las movilizaciones desarrolladas en Francia a fines de la década de 1960, Harari afirmaba que la refutación de los postulados sartreanos se hacían "muy a nuestro pesar porque admiramos su lucidez, su coraje intelectual coherente con la práctica política que viene desarrollando con particular combatividad, en especial en los últimos tiempos" ${ }^{\prime \prime 66}$. Las rectificaciones se desarrollaban, por un lado, en relación las concepciones epistemológicas que se desprendían de la obra de Sartre. Al respecto, Harari sentenciaba sin ambages que dichas concepciones eran portadoras de "las falacias de un empirismo humanista y relativista que, negando la autonomía relativa de la práctica teórica al diferenciarla de la técnica, sacrifica la universalidad de los conocimientos científicos y no discrimina al ser del conocimiento" ${ }^{687}$. El otro aspecto objeto de refutación era la noción de praxis, la cual era caracterizada como ideológica y contrapuesta a la de práctica en su acepción althusseriana. Aseguraba Harari

\footnotetext{
685 Ibid., p. 200.

${ }^{686} / d$.

${ }^{687}$ Ibid., p. 205.
} 
al respecto: "a diferencia de la totalidad estructural del concepto de 'práctica', [la noción de praxis] remite a los devaneos de un sujeto en el choque con lo real, quien le traspasa la sabiduría que es inherente" ${ }^{\text {n68 }}$. Si bien el ajuste de cuentas de Harari con Sartre puede enmarcarse en el relevo propiciado por el althusserianismo en diversos espacios del campo intelectual argentino, en este caso pareciera existir también otro aliciente: Harari mencionaba un texto de Bleger de 1971 en el que se le seguía otorgando actualidad a las concepciones objeto de refutación en este apéndice ${ }^{689}$.

Apuntemos, por último, que la secuencia iniciada con la crítica a Danis se coronará en 1976 con la publicación de "El objeto de la operación del psicólogo" en formato de libro por la editorial Nueva Visión. La reedición del artículo publicado originariamente en 1973 nos permite dar cuenta de un doble itinerario de los desarrollos teóricos esbozados por Harari en los primeros años de la década. El primero de ellos es la profundización de algunos elementos presentes en el texto compilado en el volumen El rol del psicólogo. Estas ampliaciones, que se reproducían en notas al pie preparadas especialmente para la edición del libro, apuntaban fundamentalmente al direccionamiento de su análisis hacia el campo de la semiótica. Al respecto Harari rectificaba algunos usos de Barthes desarrollados anteriormente. Las referencias a Julia Kristeva y Jean-François Lyotard eran indicativas de un desplazamiento hacia la semiótica en tanto ciencia autonomizada de la lingüística. Actualización que conllevaba el relevo de la concepción del hombre como ser de lenguaje por aquella que lo comprende como ser de semiosis. Resulta de interés destacar que dicha complejización reforzaba la disputa establecida por Harari en el interior del propio terreno del althusserianismo. En este caso, el objeto de discusión era el tratamiento otorgado por Saúl Karsz a los AIE en su libro Théorie et politique: Louis Althusser de 1974. La importancia que Harari le otorgaba a los códigos en el análisis de la ideología conducía a la percepción de que Karsz equiparaba a aquellos con otras instancias de la reproducción ideológica, tales como prácticas, actitudes, comportamientos y discursos. De

\footnotetext{
${ }^{688} / d$.

${ }^{689}$ Harari se refería al libro de Bleger Temas de psicología (entrevistas y grupos), publicado por Nueva Visión en 1971.
} 
acuerdo a su lectura, la desjerarquización de los códigos que se percibía en aquel análisis obedecía a la insuficiencia del "instrumental semióticolingüistico" ${ }^{690}$ de Karsz. Era precisamente esta carencia la que imposibilitaba comprender los elementos prioritarios que operaban en la configuración de todo AIE.

El segundo itinerario que nos interesa señalar está relacionado con un efecto singular logrado por el artículo de "El objeto de la operación del psicólogo". Antes de ser publicado en el volumen colectivo, Harari había enviado una copia del texto al propio Althusser. Tal como lo relatara posteriormente, Harari había recibido al poco tiempo una carta de Althusser en la que le manifestaba interés por sus desarrollos teóricos y le realizaba una serie de comentarios ${ }^{691}$. En ocasión de la publicación del artículo en formato de libro, la carta fue publicada al final del volumen a manera de epílogo. Si bien breve, el texto redactado por Althusser resulta relevante por, al menos, dos razones. En primer lugar, porque el francés validaba el trabajo desarrollado por Harari a través de una operación que lo llevaba a pronunciarse acerca de las discusiones teóricas de la psicología argentina. En este sentido le comunicaba Althusser: "Su análisis me ha interesado extremadamente. No conozco a Bleger, a quien usted critica, pero lo que dice de él (así como la comparación final con Sartre) permite hacerse una idea"692. En segundo lugar, porque Althusser reconocía de manera positiva la lectura que Harari realizaba del texto sobre los AIE: “usted ha 'visto' con mucha claridad que la mayor parte de los conceptos de dicho artículo se hallan 'dispuestos' para permitir un 'articulación' con los conceptos freudianos"693. Reconocimiento que implicaba, finalmente, un aliento a proseguir la investigación acerca de la relación entre lo ideológico

${ }^{690}$ Harari, Roberto. El objeto de la operación del psicólogo. Buenos Aires, Nueva Visión, 1976, p. 64.

${ }^{691}$ En el año 2001, Harari recordaba el episodio de la siguiente manera: "cuando hago este texto ['El objeto de la operación del psicólogo'], Carlos Espartaco, que en ese momento era librero en la Librería Santa Fe, me dice '¿por qué no lo traducís al francés y se lo mandas a Althusser?' Yo tenía 28 años, ¿le va a dar pelota a un sudaca? Hice la quijotada. Pagué de mi bolsillo un traductor. $Y$ se lo mandé a Althusser. Y fue generosísimo". Herreros, Gerardo. "Entrevista a Roberto Harari". Acheronta. Revista de psicoanálisis y cultura. №14, Diciembre 2001, p. 163.

${ }^{692}$ Harari, Roberto. El objeto de la operación del psicólogo. op. cit., p. 95.

${ }^{693} \mathrm{ld}$. 
y lo inconsciente: "lo que me ha interesado más en su tentativa es precisamente toda su reflexión sobre lo que denomina 'sintagmas ideológicos cristalizados' (y su 'sustitución por significantes corpóreos'). Creo que usted tiene ahí un punto muy importante de la teoría (aún por elaborar) entre la ideología y el inconsciente" ${ }^{\text {"994. }}$.

\subsection{Althusser en la villa: ideología y reproducción en comunidades marginales}

Junto a la circulación en el terreno de las discusiones teóricas de la psicología argentina, los esbozos desarrollados por Harari tuvieron efectos concretos en el tratamiento de distintos aspectos implicados en la experiencia de las comunidades marginales. Dicho tratamiento fue asentado en el informe de las acciones que Harari había realizado junto a un grupo de psicólogos en el marco del Plan de Erradicación de Villas de Emergencia ${ }^{695}$. Este material fue publicado en 1974 por Nueva Visión con el título Teoría y técnica psicológica de comunidades marginales. Compilado por Harari, el libro incluía los aportes de los miembros del grupo en relación a distintas dimensiones de la

${ }^{694} / d$.

${ }^{695}$ El Plan de Erradicación de Villas de Emergencias había sido establecido por ley en 1964 durante la presidencia de Arturo Illia. Sin embargo, se desarrolló fundamentalmente durante los últimos años de la década de 1960 y comienzos de la década de 1970. El Plan contemplaba la promoción de la participación y organización de los habitantes de las villas de emergencia en acciones de mejoramiento urbano y habitacional, la implementación de acciones en pos de detener el crecimiento de las villas y la erradicación de las villas con entrega de viviendas a sus habitantes. Fue precisamente este plan el que redundó en la creación de los núcleos habitacionales de General Belgrano, Lugano I y II, Ciudadela (conocido como "Fuerte Apache") y Soldati. En el marco del Plan, Harari coordinó el grupo de psicólogos integrado por Beatriz de Stancato, Virgina de Georgieff, Andea Piccini, Carlota de Vila, María Luisa de lorio, Diana Lerner, Eduardo Luxardo, Elisa Marino, Juan Carlos Nocetti, María Isabel de Tonelli, Leonardo Rodríguez, Marta Gonçalves Bórrega, Lucía Korol, Bernabé Bacci, Roberto Balada, Ana María Cervigni, María de las Mercedes Poccoroba, Silvia Loviscek. El único trabajo dedicado a indagar esta experiencia es Corvaglia Aguilar, Ana Morena y Landini, Pablo Fernando. "Primeras prácticas de psicología comunitaria en la Argentina: el caso del Programa de Erradicación de Villas de Emergencia". XIII Jornadas de Investigación y Segundo Encuentro de Investigadores en Psicología del Mercosur. Buenos Aires, Universidad de Buenos Aires, 2006. Sus autores analizan el trabajo del grupo de psicólogos en el Plan con la hipótesis de que se trataría de una experiencia de Psicología Comunitaria, discusión que excede los marcos de nuestro trabajo. 
experiencia villera, tales como las características de la familia, el vínculo de la población con la escuela y el acceso a la salud. La introducción de Harari al volumen, en el que establecía las líneas directrices del abordaje psicológico de la población villera y le otorgaba coherencia a los aportes de sus colaboradores, constituye un objeto privilegiado de análisis en tanto se retomaban allí varios de los problemas configurados en las polémicas de fines de la década de 1960 y luego sistematizados en su contribución al libro El rol del psicólogo.

Uno de los aportes principales de Harari lo constituía la revisión de las interpretaciones tradicionales sobre el surgimiento y permanencia de las villas miserias en Argentina. La primera de ellas era la que remitía dicho proceso al subdesarrollo del sub-continente. De acuerdo a esta interpretación, tanto las villas argentinas como las favelas brasileñas, las barriadas peruanas y las callampas chilenas, podían ser explicadas a través de la común experiencia subdesarrollada de los países latinoamericanos. En tanto para Harari las villas miserias constituían la expresión de estructuras sociales dadas, la interpretación basada en el subdesarrollo pasaba a ser considerada "un enunciado ideológico que, como tal, alude, elide e ilusiona"696. A través de una lectura que guarda estrecha similitud con la que José Nun realizaba en Los Libros de la sociología de la modernización germaniana, Harari aseguraba que esta explicación tendía a absolutizar el desarrollo económico de los países desarrollados y ocultar la relación dependiente entre países centrales y países periféricos. Por otro lado, Harari enfrentaba la interpretación que cifraba el crecimiento de las villas de emergencia en la migración de contingentes del interior del país hacia la zona metropolitana. Al respecto, si bien el fenómeno migratorio era un tópico considerado por Harari, se llamaba la atención acerca del riesgo de exagerar su rol en el crecimiento de la población villera "como si fuera un exponente original de un hecho aislado" ${ }^{697}$. Es decir que si bien no podía soslayarse la relación entre los movimientos de población, el déficit de vivienda y el auge de las villas de emergencia, el hecho de que la migración

${ }^{696}$ Harari, Roberto (comp.) Teoría y técnica psicológica de comunidades marginales. Buenos Aires, Nueva Visión, 1974, p. 8.

697 Ibid., p. 9. 
sea un fenómeno demográfico común y extendido hacía que su peso explicativo se relativizara.

Era precisamente frente a estas interpretaciones que Harari hacía ingresar el problema de la reproducción de la población villera. Ni en el marco de una región subdesarrollada ni en el de un país con una importante historia de migraciones, la vigencia de las villas de emergencia debía ser entendida a partir de "la tarea reproductiva de toda formación-social" ${ }^{398}$, problemática cuyo análisis debía ser necesariamente orientado por "la ciencia de la historia, es decir, por el materialismo histórico" ${ }^{699}$. Así la explicación de lugar ocupado por los villeros en la sociedad argentina quedaba indisociablemente ligada a la reproducción de los medios de producción, la fuerza de trabajo y las relaciones de producción. Si en un sentido amplio, la reproducción de toda formación económico-social debía ser analizada desde el materialismo histórico, a cada una de estas reproducciones específicas le correspondían distintas teorías regionales: la de la economía política en el caso de los medios de producción y la de la ideología en el caso de las relaciones de producción.

Ahora bien, ese Marx que leído a través de Althusser analizaba la reproducción de la familia proletaria como fuerza de trabajo, enfrentaba a Harari con un problema fundamental: ¿valía el análisis de Marx y Althusser para una población que no tenía las características de ese proletario inmerso en las relaciones de producción capitalistas? Es decir, el carácter científico del análisis marxista indicaba que el abordaje de la reproducción era válido para el conjunto de la formación económico-social, pero esa cientificidad podía relativizarse si la investigación estaba direccionada hacia la reproducción de la población desocupada o sub-ocupada. La forma en la cual Harari sorteaba este problema radicaba en un examen del concepto de "marginalidad". Así se remontaba hacia las primeras formulaciones del concepto a fines de poner en cuestión la colocación de los marginales por fuera de la sociedad global. A su entender, la postulación de los desocupados o sub-ocupados como un afuera de lo social era producto de un análisis realizado "desde un muy determinado

\footnotetext{
${ }^{698}$ Ibid., p. 12.

${ }^{699}$ Id.
} 
punto de vista, rayano en el empirismo de una generalidad ideológica ocular" ${ }^{700}$. Al no orientar el análisis del problema de la marginalidad hacia las determinaciones estructurales, el concepto tradicional de la marginalidad no podía captar el rol que desempeñaba la población desocupada y sub-ocupada en la depreciación de los salarios por constituir una mano de obra barata y abundante. Esta lectura advertía sobre el error de adjudicar la cantidad de hijos que tenían las familias villeras a factores tales como la ignorancia o la falta de educación. Un análisis centrado en la reproducción de la fuerza de trabajo colocaba al desconocimiento de pautas de planificación familiar como un efecto ideológico:

\begin{abstract}
Hay que buscar uno de los niveles de determinación más formidables en nuestra estructura económica capitalista dependiente, que necesita generar una masa marginal que actúa como potencial de recambio para los asalariados [...] No es de extrañar, ni mucho menos, en consecuencia, que los mecanismos invisibles, el movimiento real de las relaciones de producción, oculte, reprima e impida las ventajas de una planificación familiar para los marginales ${ }^{701}$
\end{abstract}

Leídos desde las líneas analíticas cifradas en "Freud y Lacan", los rasgos específicos que adquiría la familia villera eran capturados como los efectos resultantes de los procesos de subjetivación de los habitantes de las villas. Es decir, Harari se aproximaba al problema con una perspectiva que no se agotaba en la constatación del carácter patriarcal y exogámico de la familia occidental, sino que se prolongaba hacia la interrogación de las formaciones ideológicas que dominan la paternidad, la maternidad y la infancia. De allí que orientara los insumos provenientes del trabajo realizado en el marco del Plan hacia la dilucidación de las implicancias de ser padre, ser madre y ser hijo entre la población villera. Asimismo, abordado desde las conceptualizaciones desarrolladas en "Ideología y aparatos ideológicos de Estado", el vínculo que los niños de la villa establecían con el sistema escolar era visualizado como previsible. Es decir que lejos del sentido común que le otorgaba a la escuela

\footnotetext{
${ }^{700}$ Ibid., p. 13.

${ }^{701}$ Id.
} 
un rol integrador y nivelador de los distintos sectores sociales, su caracterización como AIE permitía constatar su accionar selectivo y discriminador. Así la valorada escuela pública, gratuita y laica se transformaba en un aparato que perpetuaba la marginación de los marginales. Acción reproductiva que operaba tanto a través de los contenidos impartidos, como las habilidades requeridas y las recompensas otorgadas. El hecho de que la escuela rechazara a los niños villeros no era un problema a solucionar, sino que constituía precisamente su razón de ser en tanto aparato ideológico. En consecuencia, esta constatación no se cruzaba con el accionar bienintencionado del trabajador de la educación que acogía e intentaba retener a los niños villeros. Es decir que la marginación se producía "más allá de las excelentes y honestas intenciones que ornan a tantos y tantos maestros, ya que el problema es indisoluble desde la iniciativa individual o aun colectiva de ciertos docentes, por ser estructural"702.

\subsection{A modo de cierre}

La reconstrucción de los itinerarios intelectuales de Sastre y Harari nos ha permitido dar cuenta de la presencia de Althusser en los debates de la psicología argentina entre fines de los años sesentas y mediados de los setentas. Al respecto, vimos que en las primeras intervenciones desarrolladas por estos intelectuales el althusserianismo constituyó el soporte teórico para la impugnación de distintas tendencias desarrolladas en la disciplina. En el caso de Sastre, el énfasis en la especificidad de los distintos niveles de la realidad social le permitió desmontar los argumentos alrededor del vínculo entre psicoterapia breve e ideología nacional y popular. En este mismo sentido, el repaso por los artículos escritos por Sastre para la RAP nos condujo a constatar el vínculo entre elementos teóricos provenientes de la tradición althusseriana y el abordaje crítico de corrientes disciplinarias con arraigo en nuestro país. De este modo analizamos la importancia de la separación entre ciencia e ideología en la refutación de la psicología de la conducta y la

702 Ibid., p. 20. 
antipsiquiatría, y de la lectura esctructural de Marx y Freud en la impugnación del concepto de alienación. Por último, analizamos las producciones de Sastre de mediados de la década de 1970 en términos de un desplazamiento hacia la dimensión epistemológica de la disciplina. Al respecto, vimos que el énfasis althusseriano en la potencia de la ideología jugó un rol clave en la nominación del campo disciplinar en términos de red ideológica.

La vinculación establecida por Harari con el corpus althusseriano puede ser enmarcada en la misma problemática en la que se inscribían las producciones de Sastre. En primer lugar, el althusserianismo operó como soporte de crítica las formulaciones de Danis acerca del ser humano en tratamiento como el objeto de la práctica del psicólogo y de la asistencia al cambio como el objetivo del rol profesional. Dicha filiación teórica le permitió esbozar una respuesta estructurada alrededor del inconsciente como objeto de la psicología. En este mismo sentido Harari se valió de argumentaciones deudoras de la obra de Althusser a los fines de intervenir en el debate entre Kesselman y Caparrós sobre psicoanálisis e antiimperialismo. La diferenciación de los niveles de la totalidad social le permitió acercar dos posiciones que a simple vista se presentaban como irreconciliables. Del mismo modo que Sastre, sus intervenciones de la primera mitad de la década de 1970 estuvieron marcadas por un afán sistematizador. En su abordaje de los problemas inherentes al rol del psicólogo, el vínculo con el althusserianismo fue productivo en dos sentidos. Por un lado, profundizando su crítica a las enseñanzas de Bleger, lo cual redundó en una operación de relevo de la idea de ser humano por el concepto de sujeto. Por otro lado, complejizando la interpretación de la ideología, lo que lo condujo a formular consideraciones originales sobre la temática, las cuales le valieron el reconocimiento del propio Althusser. Finalmente constatamos los usos de Althusser realizados por Harari en su trabajo sobre la experiencia de las llamadas comunidades marginales. Una concepción novedosa sobre la estructuración de la realidad social habilitaba un cuestionamiento de la tesis acerca del subdesarrollo así como un análisis de las vivencias villeras centrada en el rol de la ideología direccionaba la mirada hacia la reproducción de las poblaciones marginales. 


\section{Consideraciones finales}

En esta tesis nos propusimos analizar los itinerarios de Althusser en distintos espacios políticos e intelectuales de la Argentina de las décadas de 1960 y 1970. En tanto trabajo de historia intelectual, nuestra investigación estuvo animada por el objetivo de dar cuenta de los términos de las diferentes lecturas de Althusser realizadas y de tornarlas inteligibles a partir de los marcos contextuales en los que se llevaron cabo. Lejos de sancionar si estas lecturas fueron correctas e incorrectas, nos interesamos por comprender en qué sentido determinadas experiencias políticas e intelectuales legitimaban ciertas aproximaciones a un corpus teórico originado en un contexto distinto al de su recepción. Las herramientas metodológicas provenientes de la historia intelectual, así como las de la vertiente más específica de la circulación de ideas, nos han permitido enfrentar de manera desprejuiciada un objeto sometido a múltiples tensiones políticas y teóricas. Protagonista de una de las querellas del marxismo más importantes del siglo $X X$, el althusserianismo fue sometido a un conjunto de calificaciones que le otorgaron marcas indelebles. Vehiculizador de una intervención singular que expresaba su politicidad de manera estratégica y replegada sobre el terreno de la teoría, Althusser fue combatido tanto desde la izquierda reformista como desde las organizaciones revolucionarias. Soporte de proyectos políticos revolucionarios duramente derrotados, su recepción argentina y latinoamericana fue objeto de operaciones críticas por parte de varios de los que la habían protagonizado como de aquellos que observaron dicho proceso desde otras filiaciones teóricas.

Condensadoras de dichas operaciones, las referencias clásicas acerca de los itinerarios de Althusser en Argentina sedimentaron explicaciones tan esquemáticas como opuestas entre sí. Constatamos al respecto que algunas de ellas aseguraban que el althusserianismo había tenido grandes dificultades para ingresar en la cultura argentina dado que sus intelectuales estaban animados por una pulsión humanista y voluntarista configurada a partir de las 
tradiciones sartreana y guevarista. Al mismo tiempo, otras aseguraban que el althusserianismo se había convertido rápidamente en la corriente intelectual hegemónica de la nueva izquierda argentina favoreciendo una estrategia política armada de corte vanguardista. Apoyada en las escasas investigaciones contemporáneas sobre la recepción de Althusser en Argentina y en los cada vez más numerosos trabajos sobre su recepción en otros países latinoamericanos, nuestra investigación se propuso abordar el tema desde esquemas analíticos más desprejuiciados y comprensivos que aquellos sobre los que descasaban las interpretaciones codificadas en las décadas de 1980 y 1990. En esta dirección, un rastreo del campo intelectual y político argentino de los años sesentas y setentas orientado a la identificación de las lecturas de Althusser y sus productividades nos reveló un conjunto de sujetos y trayectorias que hicieron del althusserianismo un insumo clave para el desenvolvimiento de sus experiencias.

Las lecturas de Althusser más significativas se desarrollaron en parte en la cultura de izquierdas argentina. Tal como analizamos en el segundo capítulo, los intelectuales comunistas que intentaban modificar el rumbo político del partido encontraron en Althusser una certificación de que el estancamiento que atravesaba el movimiento comunista internacional tenía también causas teóricas. En este contexto, una de las tendencias que pugnaban por la recuperación revolucionaria del comunismo argentino se destacó por articular las formulaciones althusserianas y el programa guevarista. La derrota de este grupo por parte de los sectores que fundaron el PCR hizo del althusserianismo un objeto de refutación en los primeros años del nuevo partido. Una parte considerable de la crítica esbozada por el PCR a la lucha armada estuvo acompañada por un trabajo de refutación del marxismo althusseriano. El antialthusserianismo del PCR se agudizó una vez que el partido se ubicó en la senda del comunismo chino, volviéndose Althusser una variable destacada en las operaciones de diferenciación entre el revisionismo y el proceso revolucionario desarrollado en China.

También constatamos que el althusserianismo estuvo presente en las discusiones teóricas mantenidas por los intelectuales comunistas que 
permanecieron en el partido. El posicionamiento defensivo desarrollado por estos intelectuales frente a las corrientes modernizadoras del marxismo condujo a una aproximación ambivalente a la obra de Althusser. Por un lado, fue recibida como un sugerente ejercicio de relectura de Marx que no tenía como consecuencia el apartamiento del comunismo partidario. Sin embargo, las lecturas desarrolladas en los materiales partidarios fueron cautelosas tanto con la inflexión antihumanista en la tradición marxista como con las influencias que el althusserianismo tenía entre las corrientes maoístas francesas. Ya en la década de 1970, uno de los principales cuadros intelectuales del partido, García Barceló, incorporó a Althusser en sus intervenciones teóricas en Cuadernos de Cultura. Si bien algunas de las características del althusserianismo siguieron siendo objeto de críticas, como el antihegelianismo y el cientificismo, otras fueron articuladas en un impulso modernizador de la filosofía marxista, tales como la problematización de la ideología y la discusión acerca de la cientificidad del marxismo.

También fue importante la presencia de Althusser en la experiencia de la revista Los Libros. Tal como reconstruimos en el tercer capítulo, en la primera etapa de la publicación el althusserianismo fue objeto de dos operaciones. Por un lado, proporcionó elementos al programa renovador de la crítica impulsado bajo el influjo del estructuralismo. Asimismo constituyó el marco teórico preponderante a través del cual los colaboradores de la revista abordaron problemas de tipo políticos y epistemológicos. Por otro lado, el althusserianismo fue junto a los otros saberes que nutrían el trabajo crítico un objeto de indagación y reflexión. En este marco, el althusserianismo fue un insumo privilegiado en las reexaminaciones a las que fue sometido el paradigma estructural una vez producido el proceso de latinoamericanización de la revista. En la segunda etapa de la revista, caracterizada por el predominio de problemas políticos de la coyuntura, el althusserianismo siguió siendo operativo en tres sentidos. Por una parte, delineó el corpus teórico con el que algunos colaboradores de la revista siguieron abordando los problemas de la crítica. Por otra parte, coincidió con los esquemas maoístas a través de los cuales los referentes de esta nueva etapa calibraban la relación entre práctica 
política y lucha cultural. Finalmente, a través del tópico de la ideología y el concepto de AIE estuvo presente en los abordajes propiciados por la revista de los problemas del sistema educativo argentino. La relación que la revista había establecido desde sus inició sufrió un quiebre con su conversión en un órgano cultural de las organizaciones maoístas. En los últimos números Althusser fue duramente rebatido en el marco de la disputa sino-soviética mientras que las intervenciones de sus referentes comenzaban a filiarse cada vez más en concepciones gramscianas de la cultura popular.

Fue precisamente en los marcos de la relación entre Althusser y Gramsci que se llevó a cabo el otro proceso importante de recepción del althusserianismo en la izquierda argentina. La experiencia de Pasado $y$ Presente, tal como lo analizamos en el capítulo cuarto, mantuvo un vínculo complejo con el marxismo althusseriano. Configurada a partir de las dimensiones humanistas e historicistas de la tradición marxista, la publicación se mostró reactiva frente a la lectura estructural de Marx propiciada por Althusser. Sin embargo, los Cuadernos de Pasado y Presente dedicados al althusserianismo nos permitieron recortar su carácter productivo en el desarrollo de esta experiencia. Por un lado, la relectura althusseriana de Gramsci operó como un elemento correctivo y modernizador del gramscianismo codificado en la década de 1950. Por otro lado, la reactivación del concepto de formación económico-social habilitó un espacio en el que las tradiciones althusseriana y gramsciana se articularon de manera productiva. En tercer término, la recepción de los primeros textos de Poulantzas da cuenta de una lectura favorable del pasaje desde un esquema marxista historicista hacia uno estructural. El sentido común acerca de la incompatibilidad entre Gramsci y Althusser sí se ajusta a la segunda etapa de la revista. En los primeros años de la década de 1970, la recepción del Gramsci consejista tendió a ubicar al althusserianismo como un hito más del vanguardismo izquierdista. A su vez, la articulación entre althusserianismo y gramscianismo comenzó a dotarse de una actitud preventiva frente a las aproximaciones estructurales del Estado, la ideología y la hegemonía. 
Otra parte significativa de los itinerarios de Althusser se desarrolló en la cultura psicoanalítica argentina. Como se desprende del recorrido propuesto en el quinto capítulo, el althusserianismo estuvo presente en las dos tradiciones que cobraron relevancia al calor de la crisis del psicoanálisis institucional. En primer lugar, la obra de Althusser resultó clave en el apuntalamiento de la lectura científica de Freud que caracterizó a la corriente lacaniana. El caso de Masotta revela la productividad del althusserianismo en el pasaje desde una concepción fenomenológica del vínculo entre marxismo y psicoanálisis hacia una de corte estructural. Asimismo permite advertir la recolocación de la obra de Lacan desde su articulación con la psicología concreta hacia su asentamiento en el terreno del estructuralismo. Junto a la tradición lacaniana, el althusserianismo se articuló de diversas maneras con los grupos freudomarxistas que habían protagonizado la ruptura de la APA. Por un lado, si bien algunas dimensiones del althusserianismo permearon los discursos de los miembros de Plataforma y Documento, la vinculación entre marxismo y psicoanálisis derivada de los trabajo de Marcuse o Fromm era incompatible con la propuesta por Althusser. Por ello resulta tan singular el recorrido de Baremblitt, quien apelaba al althusserianismo en un contexto en el que predominaba la lectura freudomarxista. Distanciados del lacanismo, los trabajos de Barembliit se caracterizaron por un uso productivo de la lectura científica de Freud y de las conceptualizaciones althusserianas en torno a la relación entre teoría y política. Sus intervenciones de la primera mitad de los años setentas dan cuenta de una diferenciación abierta con el freudomarxismo y de una incorporación productiva de la noción althusseriana de ideología. La singularidad de la lectura de Baremblitt se nos reveló al dar cuenta de la importancia que por entonces tenían los posicionamientos freudomarxistas antialthusserianos, como el de Rozitchner, y las inflexiones lacanianas abiertamente críticas del freudomarxismo, como las de García y Chorne.

Junto a su difusión en los debates sostenidos por los psicoanalistas, el althusserianismo tuvo un rol destacado en las intervenciones desarrolladas por los psicólogos argentinos en el contexto de conformación del campo profesional. Tal como analizamos en el capítulo sexto, las trayectorias de 
Sastre y Harari se destacaron por articular distintos aspectos del corpus althusseriano con los problemas relativos al objeto de la psicología, el carácter científico de la disciplina y el rol profesional del psicólogo. Entre fines de los años sesentas y comienzos de los setentas, los usos de Althusser tuvieron como objetivo desmontar conceptualizaciones que pretendían incidir en la conformación del campo profesional de la psicología. En este marco, mientras que Sastre refutaba la psicoterapia breve, la psicología de la conducta y la antipsiquiatría, Harari atacaba la pervivencia de las tesis blegerianas que hacían del ser humano en tratamiento el objeto de la práctica profesional. A mediados de la década de 1970 las preocupaciones de ambos se dirigieron fundamentalmente al campo epistemológico, haciendo del althusserianismo el insumo fundamental para un trabajo en pos de la fundación científica de la psicología. En el caso de Sastre resulta significativa su caracterización de la psicología como red ideológica, lo cual le permitía advertir tanto los obstáculos para la fundación científica de la disciplina como los peligros que la acecharían una vez consumado dicho proceso. En el caso de Harari, el privilegio analítico otorgado al inconsciente como objeto de la teoría y la práctica del psicólogo lo condujo a profundizar en la importancia de los códigos en el funcionamiento de la ideología. Su programa de indagación alrededor de los sintagmas ideológicos lo llevó a situarse más allá de las formulaciones del propio Althusser, el cual se mostró interesado por las elaboraciones de uno de sus lectores argentinos.

Tal como afirmábamos en los inicios de la tesis, después de 1976 Althusser siguió siendo una referencia importante en los debates políticos y teóricos mantenidos por los intelectuales argentinos. Al igual que ocurrió con los fenómenos de recepción que aquí estudiamos, los itinerarios ulteriores de Althusser estuvieron condicionados por dos variables. Por un lado, las particularidades de los sucesivos contextos político-intelectuales de nuestro país. En este caso, el althusserianismo será objeto de apropiaciones diferenciadas bajo la transición a la democracia, el régimen neoliberal y el kirchnerismo. Por el otro, por las transformaciones operadas en el propio 
corpus althusseriano. Al respecto, el Althusser recepcionado será consecutivamente el de la crisis del marxismo, el de la filosofía del encuentro y el del materialismo de la coyuntura. Una indagación futura podría ser, por tanto, la delimitación de las lecturas de Althusser en las discusiones acerca de la crisis del socialismo real y las limitaciones de la reconstrucción del sistema democrático en la década de 1980. Otra podría analizar la imbricación de Althusser con el marxismo autonomista configurado contra el orden liberal en la década de 1990. Finalmente, otro trabajo podría ser el de examinar la recepción de Althusser en las discusiones acerca del lugar de la política en las experiencias posneoliberales.

Si nos atenemos a los itinerarios de Althusser en los sujetos analizados en la tesis, podemos afirmar que mientras algunos de ellos seguirán inscribiendo sus reflexiones en algún sentido en la tradición althusseriana, otros abandonarán definitivamente esta estación del pensamiento contemporáneo. Entre los intelectuales comunistas, Althusser no tendrá durante la década de 1980 el lugar de insumo teórico y objeto de reflexión que había tenido durante los años anteriores. Sí lo seguirá siendo para aquellos que se habían destacado como los principales difusores del filósofo francés en la cultura comunista argentina. En el caso de Sciarreta, si bien los resultados de sus lecturas de Althusser no fueron publicados, sí fueron difundidas en los grupos de estudios privados que coordinó durante aquellos años. Cada vez más instaladas en el espacio psicoanalítico, las lecturas de Sciarreta cruzaron epistemología y psicoanálisis a través de un althusserianismo conjugado con la tradición lacaniana ${ }^{703}$. En el caso de Malamud, el nombre de Althusser lo acompañó -como decía Aricó de su relación con Gramsci- como una sombra al cuerpo. Luego de la desaparición de sus hijas y sus yernos, y de haber estado él mismo detenido a disposición del Poder Ejecutivo, partió al exilio en 1977. Se asentó primero en París, donde se encontró con Althusser. Luego de un tiempo en la capital francesa, recaló en la ciudad mexicana de Morelia. Allí se

${ }^{703}$ La desgrabación de sus clases fueron publicadas en Sciarreta, Raúl. Escritos provisorios. Hacia un nuevo empirismo. Buenos Aires, Ediciones del Signo, 2000. Para un recuerdo de sus enseñanzas, puede la semblanza escrita nada menos que por Roberto Harari en ocasión de su muerte, "Sócrates vivió en Buenos Aires". Página 12. 23 de Septiembre de 1999. 
incorporó como docente en la Escuela de Filosofía de UMSNH. Contribuyó a la reestructuración de la carrera de Filosofía junto a Roberto Briceño Figueras, filósofo egresado de la UNAM, Hugo Sáez Arreceygor, psicólogo argentino exmilitante del PCR exiliado en Morelia, y el ya mencionado César Gálvez, filósofo y difusor de Althusser en Michoacán. En este marco propició la publicación por parte de la editorial universitaria de una serie de cuadernos temáticos sobre filosofía y metodología. En este mismo sentido organizó el dictado de seminarios dirigidos a la planta docente de la Facultad, entre los cuales coordinó uno sobre El Capital. A comienzos de la década de 1980, Malamud mantuvo una correspondencia con Althusser sobre temas personales, políticos y filosóficos. En una de ellas, Althusser lleva a cabo una evaluación global sobre su trabajo ${ }^{704}$. En Morelia Malamud conoció a Fernanda Navarro, la ya mencionada profesora de filosofía mexicana. En 1984, Malamud le encargó a Navarro, quien viajaba a París, la entrega de una carta a Althusser. Se inició de esta manera el vínculo entre Navarro y Althusser que culminó en 1988 con la publicación del libro Filosofía y marxismo. Entrevista por Fernanda Navarro. Durante su estadía mexicana, Malamud siguió el trabajo realizado por Althusser, lo cual se plasmó en un conjunto de ponencias y manuscritos ${ }^{705}$. Tras un regreso fallido a Buenos Aires, Malamud volvió a Morelia, donde falleció en $1989^{706}$.

Con respecto a los itinerarios de las revistas analizadas, cabe destacar que el grupo nucleado alrededor de Los Libros profundizará el desplazamiento culturalista característico de sus últimos números. Cuando hacia fines de la década de 1970 Sarlo, Piglia y Altamirano vuelvan a intervenir en el escenario intelectual argentino a través de la revista Punto de Vista, lo harán a través de una perspectiva teórica en la que se conjugaban la sociología de la cultura de

\footnotetext{
704 Althusser, Louis. "Letter to Mauricio Malamud". Philosophy of the Encounter: Later Writings, 1978-1987. Londres, Verso, 2006, pp. 209-214.

${ }^{705}$ Por ejemplo, "Las explicaciones materialistas e idealistas en filosofía y la filosofía marxista", presentado en el Tercer Coloquio Nacional de Filosofía, México, 1979; "Darle al arte la filosofía que se merece" (inédito, 1979); "En torno a la crisis actual del marxismo" (inédito, 1986) y "Filosofía de la historia" (inédito, 1987). Agradezco a Fernanda Navarro haberme facilitado copia de este material.

${ }^{706}$ Producto de una iniciativa de Navarro, la Biblioteca de la Facultad de Filosofía de la UMSNH lleva actualmente su nombre.
} 
matriz bourdiana y los estudios culturales de inspiración williamsiana. A modo de contrapunto con las derivas posteriores de Los Libros, los referentes de Pasado y Pasado seguirán manteniendo relaciones con el corpus althusseriano. Si bien algunos de ellos, como Portantiero, se desplazarán desde Gramsci hacia espacios teóricos no marxistas, como el weberiano, otros, como del Barco y Aricó, se mantendrán dentro de los esquemas marxistas, lo cual los llevará a dialogar de diversos modos con la tradición althusseriana. En el caso del primero, resulta relevante destacar su artículo "Althusser en su encrucijada", publicado en 1977 en la revista mexicana Dialéctica. El argumento de del Barco se dirigía a desmontar la pretendida autocrítica llevada a cabo por Althusser durante los años setenta y evidencias que seguían operando en su obra elementos regresivos para una política emancipatoria ${ }^{707}$. Del Barco llevaba a cabo un repaso crítico por la mayor parte de los tópicos del althusserianismo, como la lectura sintomática, la ruptura epistemológica y la práctica teórica, los cuales no eran adjudicados a una determinada orientación teórica, sino al posicionamiento de Althusser en tanto investigador científico, profesor universitario y militante comunista. Delegación de la política en el aparato partidario y delegación del saber en el dispositivo filosófico: el althusserianismo constituía en la lectura de del Barco un resabio leninista en la necesaria reformulación de una política revolucionaria desde las masas.

A diferencia de del Barco, la relación establecida por Aricó con el althusserianismo se caracteriza por un diálogo que se permite una serie de apropiaciones de elementos de dicha tradición, inflexión que parece estar condicionada tanto por el desplazamiento del lugar de Aricó en el interior del universo marxista como por la renovación propiciada por Althusser de sus presupuestos clásicos hacia fines de la década de 1970. En su libro Marx y América Latina de 1980, Aricó sancionaba aquellas formas de inscripción en la tradición marxista que remitían a los parámetros althusserianos clásicos, especialmente el teoricismo y la división de la obra de Marx en escritos mayores y menores ${ }^{708}$. Se mostraba entusiasta, sin embargo, con la tesis

${ }^{707}$ Del Barco, Oscar. "Althusser en su encrucijada”. Dialéctica, № 3, 1977, pp. 7-54.

${ }^{708}$ Aricó, José. Marx y América Latina. Lima, CEDEP, 1980. 
althusseriana, esbozada por primera vez en Venecia en 1977 y luego reflejada en el debate con filósofos italianos en 1978, del marxismo como teoría finita y limitada. Crítica de las tradiciones leninista y gramsciana, la postulación althusseriana del marxismo como teoría finita y limitada implicaba la apuesta por un marxismo limitado al análisis del modo de producción capitalista y de la tendencia contradictoria que posibilita la transición hacia otro momento histórico, y abierto a las tendencias contradictorias de la sociedad capitalista y a su porvenir aleatorio. En este sentido, el giro operado por Althusser era retomado por Aricó en diversas instancias de su argumentación en pos de un marxismo concebido como hecho terrenal e histórico; lo cual implicaba una apertura a la multiplicidad de tentativas y proyectos de las clases subalternas y un desplazamiento de la fe a la crítica que permitiera despegar definitivamente al marxismo de toda filosofía de la historia.

La contraposición entre lacanismo y freudomarxismo que contuvo la difusión de Althusser entre los psicoanalistas argentinos se diluyó con el golpe de Estado de 1976. La derrota de los proyectos revolucionarios forzó al exilio a varios de los psicoanalistas que habían formado parte de los grupos Plataforma y Documento. De la misma manera, una cierta clausura de los debates públicos contribuyó al repliegue institucional de los grupos lacanianos. Una mirada retrospectiva del vínculo que estas experiencias habían mantenido con la obra del filósofo francés nos permite constatar que en ambas el althusserianismo constituyó una plataforma de despegue hacia las estaciones teóricas que ya se esbozaban en la primera mitad de los setenta. En el caso de Masotta, tal como analizamos en el último apartado dedicado a su itinerario, una vez recolocado el lacanismo en espacio estructural, las referencias a Althusser desaparecerán de sus producciones. Exiliado en España, fue hasta su muerte en 1981 uno de los principales difusores de Lacan en este país europeo, labor que llevó a cabo a través de la enseñanza y publicaciones en revistas de orientación lacaniana. En el caso de Baremblitt también podemos percibir la prolongación de preocupaciones previas a la instalación de la dictadura. Como constatamos en los apartados dedicados a su trayectoria, sus reflexiones de los primeros años de la década de 1970 estuvieron orientadas a una problematización del 
psicoanálisis institucional. Estas líneas de trabajo, que lo acercaron a Castel y Deleuze, se profundizaron en su exilio brasileño. En 1978 organizó el Congreso de Psicoanálisis, Grupos e instituciones, al que asistieron Franco Basaglia, Castel y Guattari. Al año siguiente, fundó el Instituto Brasileño de Psicoanálisis, Grupos e Instituciones (IBRAPSI). Allí se convirtió en el referente del esquizoanálisis, la corriente fundada por Deleuze y Guattari que plantea prácticas e intervenciones diferenciadas del psicoanálisis. Asimismo publicó en aquellos años un conjunto de libros sobre dicha corriente. En la década del noventa fundó el Instituto Félix Guattari, desde el cual difundió el esquizodrama, el cual abrevaba en la obra del francés pero contenía marcas netamente personales. Actualmente Baremblitt goza de gran prestigio en ciertos ámbitos psicoanalíticos de Brasil y América Latina, fundamentalmente gracias a la técnica mencionada, la cual intenta detectar las resistencias y bloqueos en el sujeto de modo que se faciliten los procesos de intensificación de los flujos de deseo.

En el caso de los psicólogos que habían desarrollado apropiaciones de Althusser en el contexto de la conformación del campo disciplinar también se evidencia un desplazamiento hacia Lacan. Puede mencionarse al respecto, la trayectoria de Harari, quien se convirtió con el correr de los años en un destacado lacaniano con reconocimiento internacional. Sin embargo, el vínculo que la psicología argentina había mantenido con Althusser se prolongó en 1979 en un texto publicado por el psicólogo argentino Roberto Folla Ry en la revista mexicana Dialéctica. En sintonía con el trabajo de del Barco publicado en la misma revista, Folla Ry enjuiciaba determinadas concepciones de la relación entre ciencia y política que a su entender reproducían los principios de la sociedad burguesa ${ }^{709}$. Es decir que el autor participaba de la creencia según la cual lo que determina el carácter rupturista de una práctica no es el otorgamiento de un sentido revolucionario a la instancia en la cual se desenvuelve sino el cuestionamiento de la existencia misma de instancias diferenciadas. Desde estos marcos, los modos en los cuales los psicólogos

${ }^{709}$ Follari, Roberto. "Política y ciencia en psicología”. Dialéctica. № 6, Junio 1979, pp. 145-161. 
althusserianos habían planteado la relación entre ciencia y política se revelaban conservadores. Tomando a Sastre como paradigma de la inflexión althusseriana en el campo de la psicología, Folla Ry analizaba los problemas inherentes a la pretensión de circunscribir los problemas de la revolución al ámbito de lo científico. Esta perspectiva dotaba a los argumentos de Sastre de un alto contenido paradójico, en tanto se mostraban pertenecientes a un discurso altamente politizado cuando en realidad esquivaban el problema de la práctica política concreta. De esta manera Follari sometía a Sastre a la misma operación que éste sometía a Kesselman. Mientras el psicólogo althusseriano intentaba demostrar que, al contrario de lo que parecía, Kesselman y Caparrós compartían los mismos presupuestos, Follari intentaba evidenciar que el teoricismo de Sastre no era más que la imagen invertida del politicismo de Kesselman. Frente a los mecanismos simétricos de subsunción de la ciencia en la política y de la política en la ciencia, los argumentos de Follari se dirigían hacia la delimitación de una práctica profesional consistente en la crítica política de la práctica científica como práctica social burguesa y en la crítica epistemológica de las concepciones burguesas sobre la ciencia. 
Apéndice de imágenes 


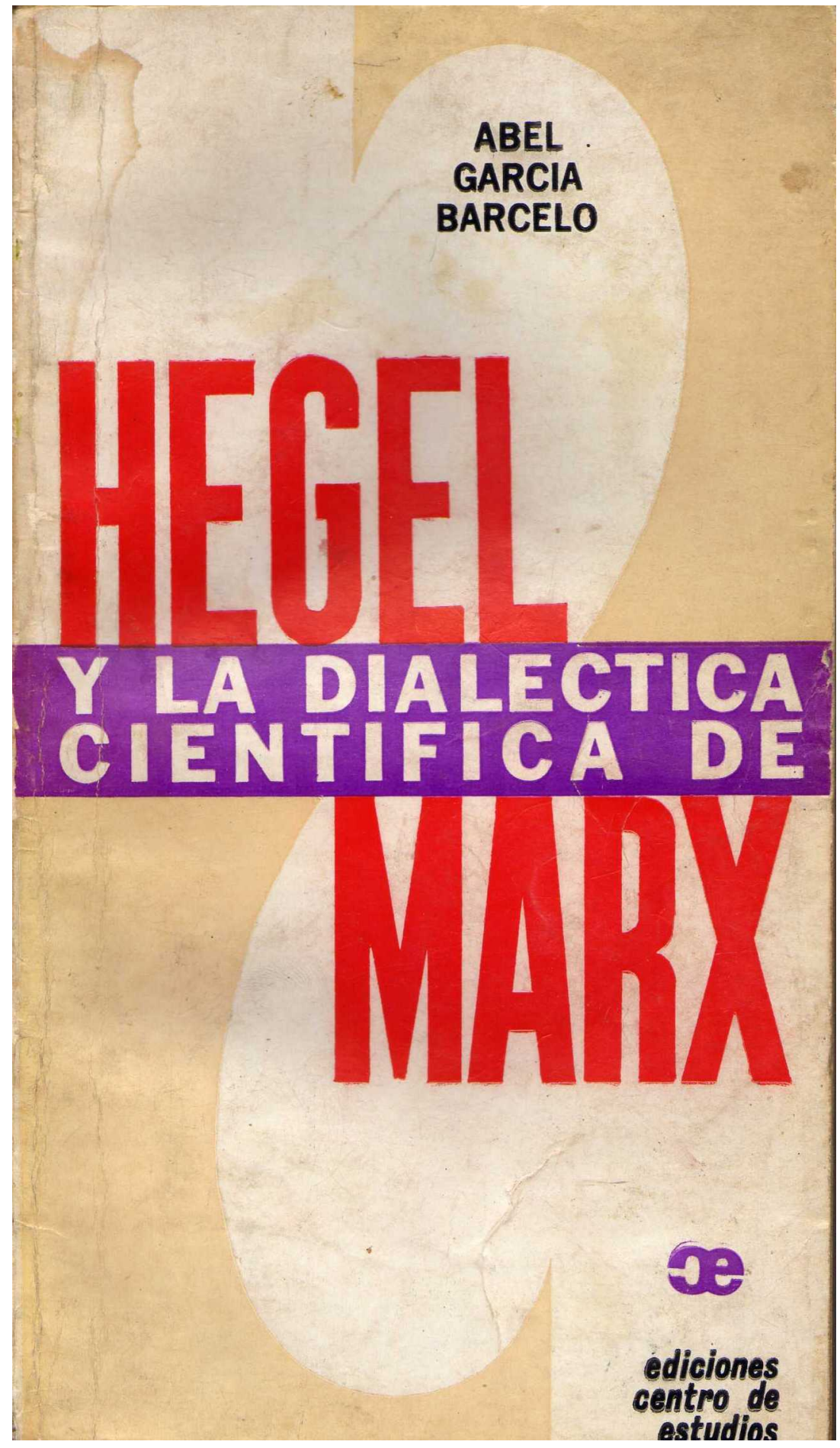

Imagen 1 


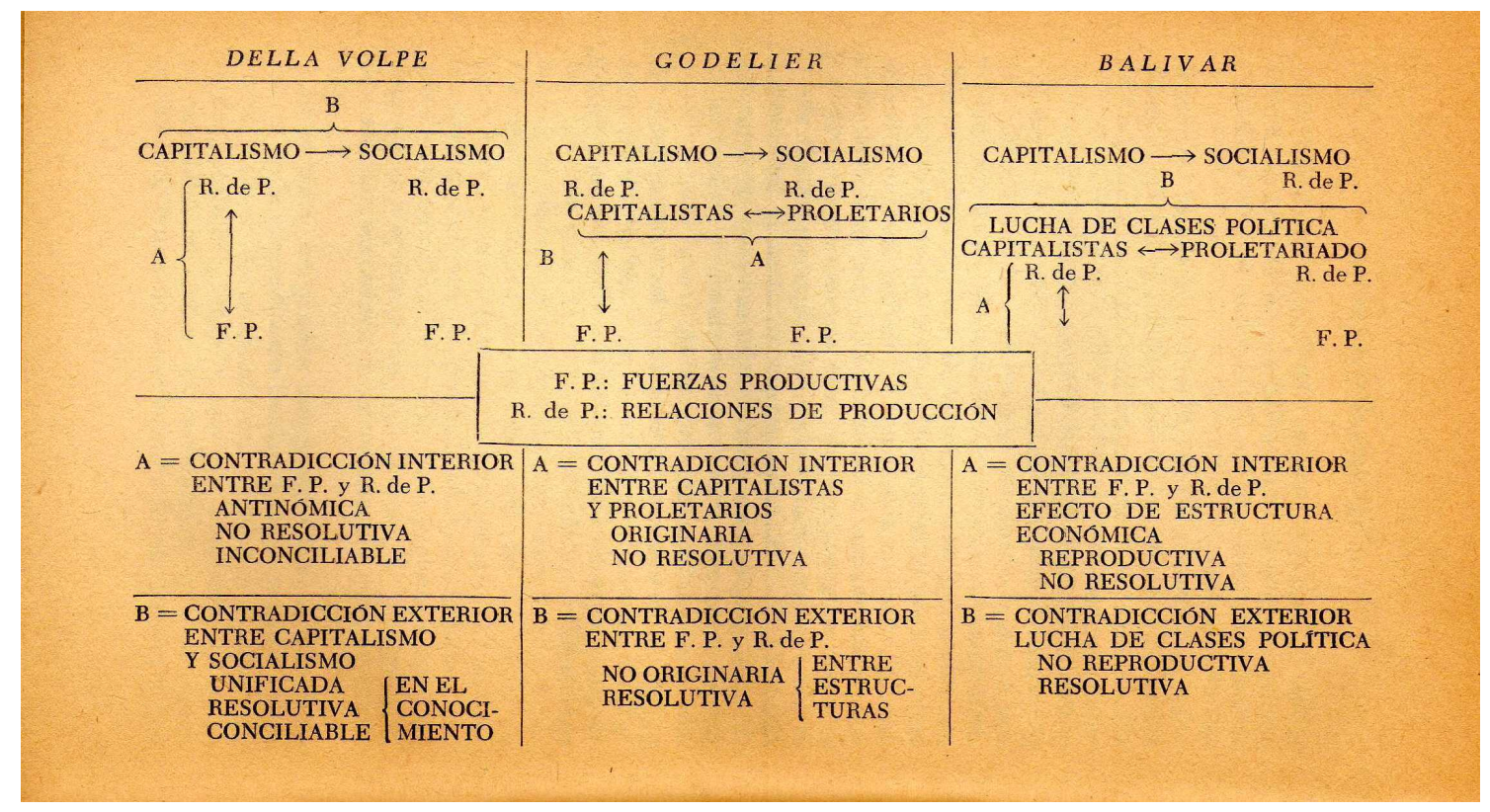

\section{Imagen 2}

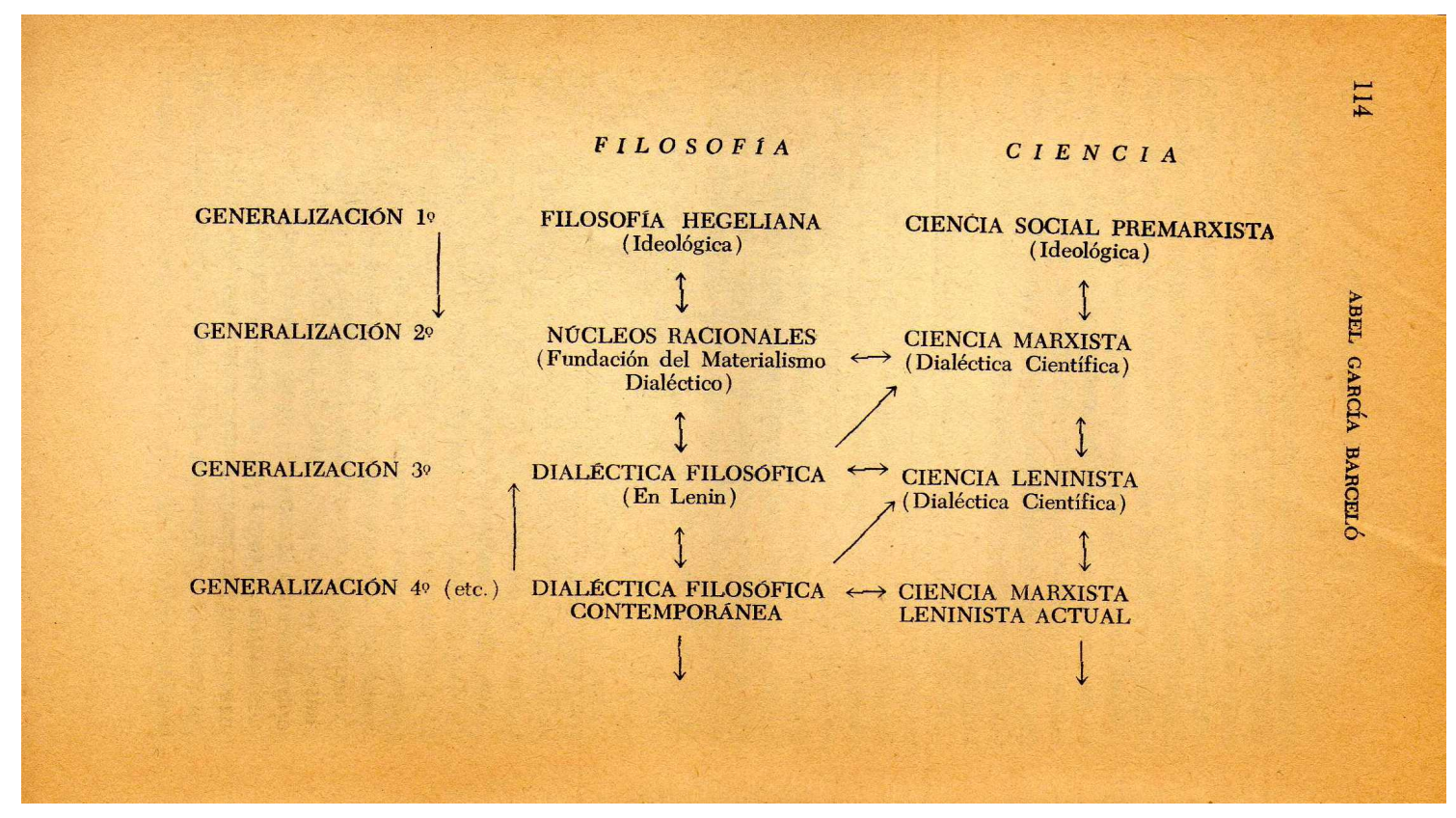

Imagen 3 


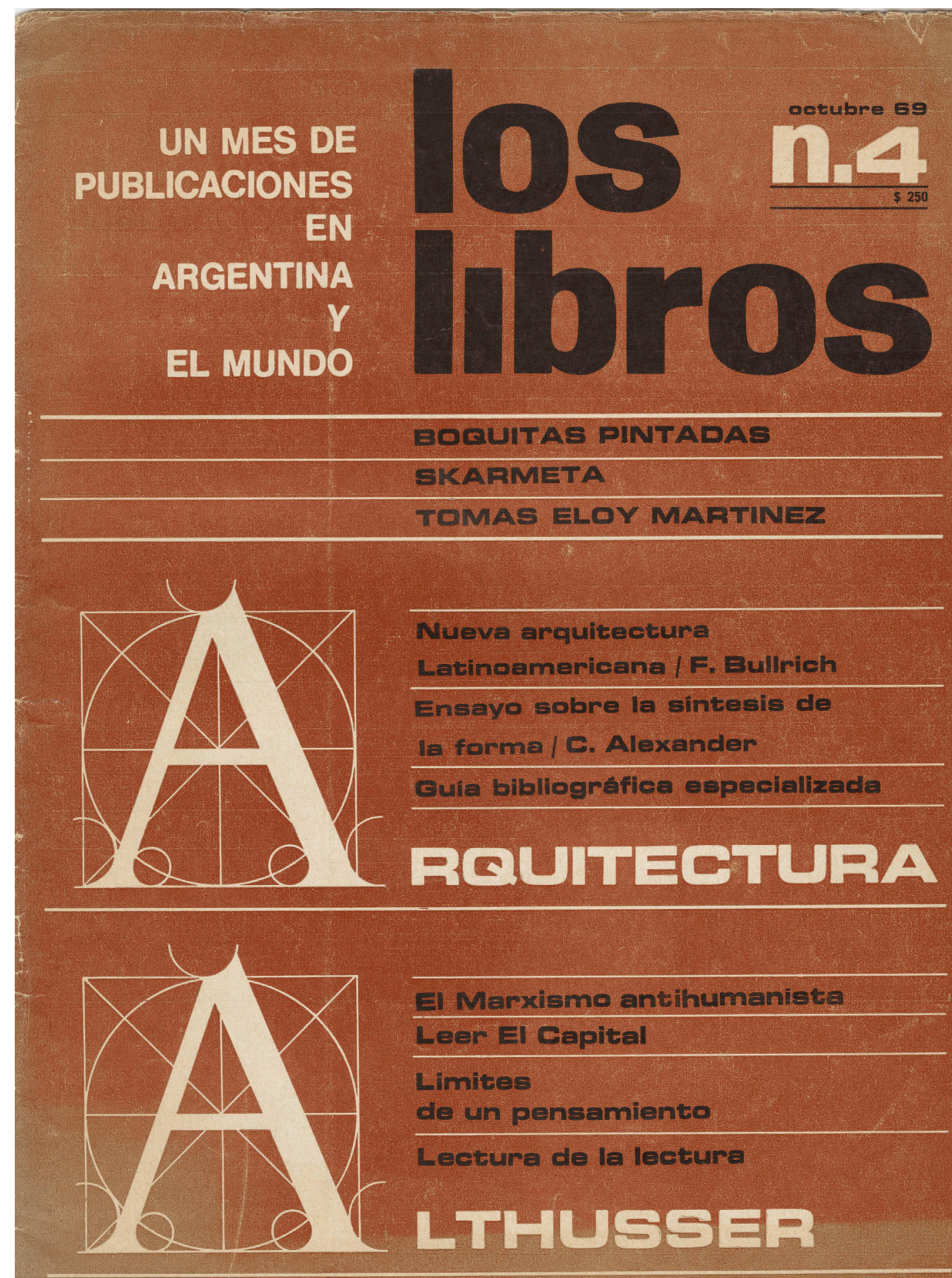

Imagen 4 

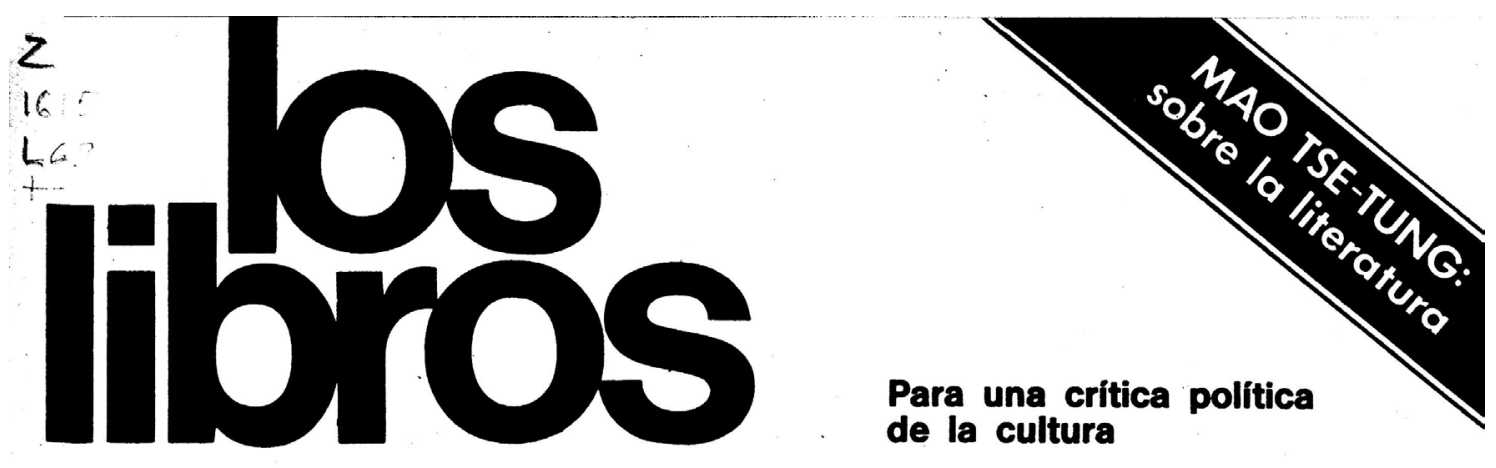
de la cultura

No 25 - Marzo 1972. Argentina. $\$ 300$.

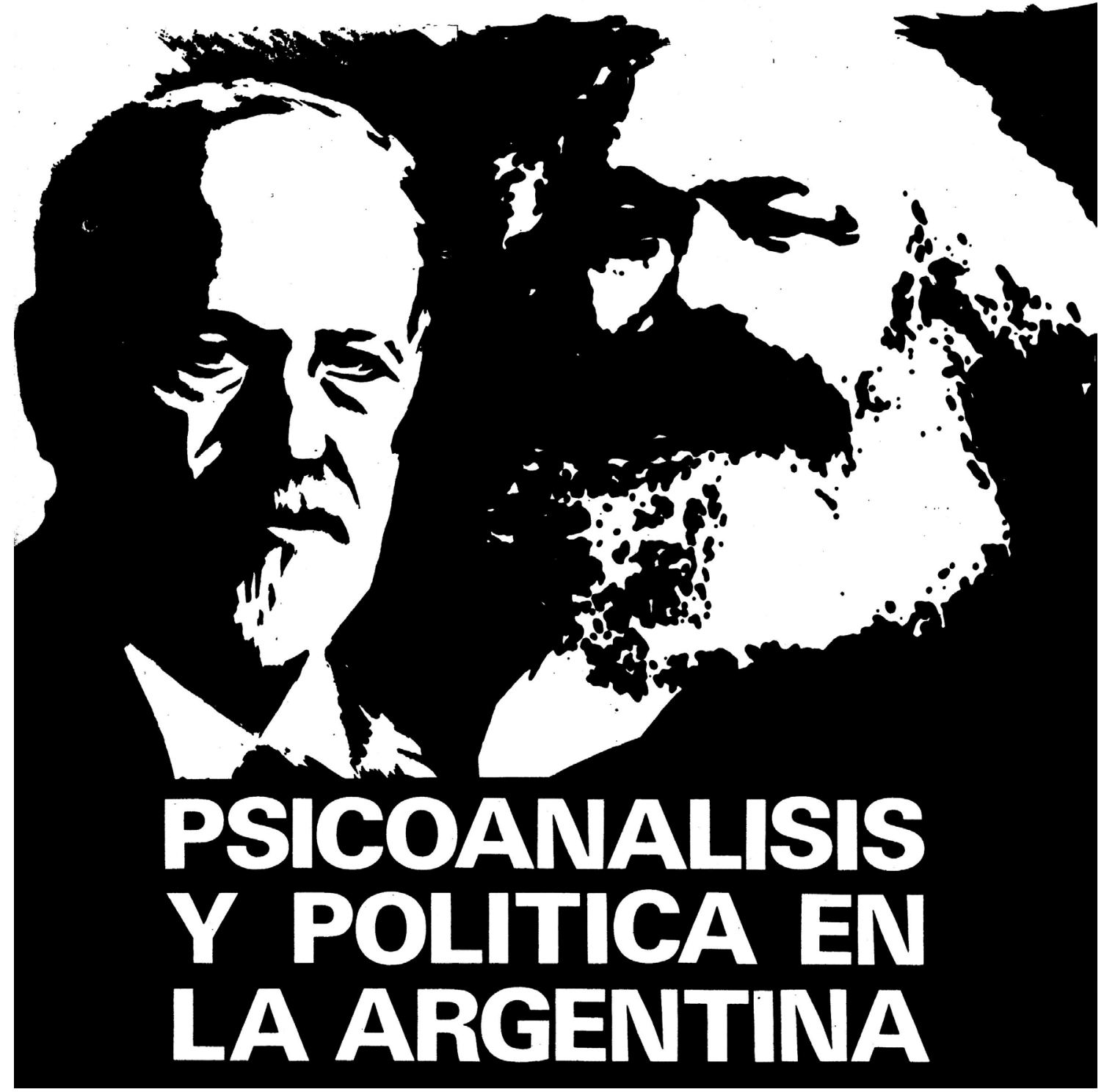

Imagen 5 

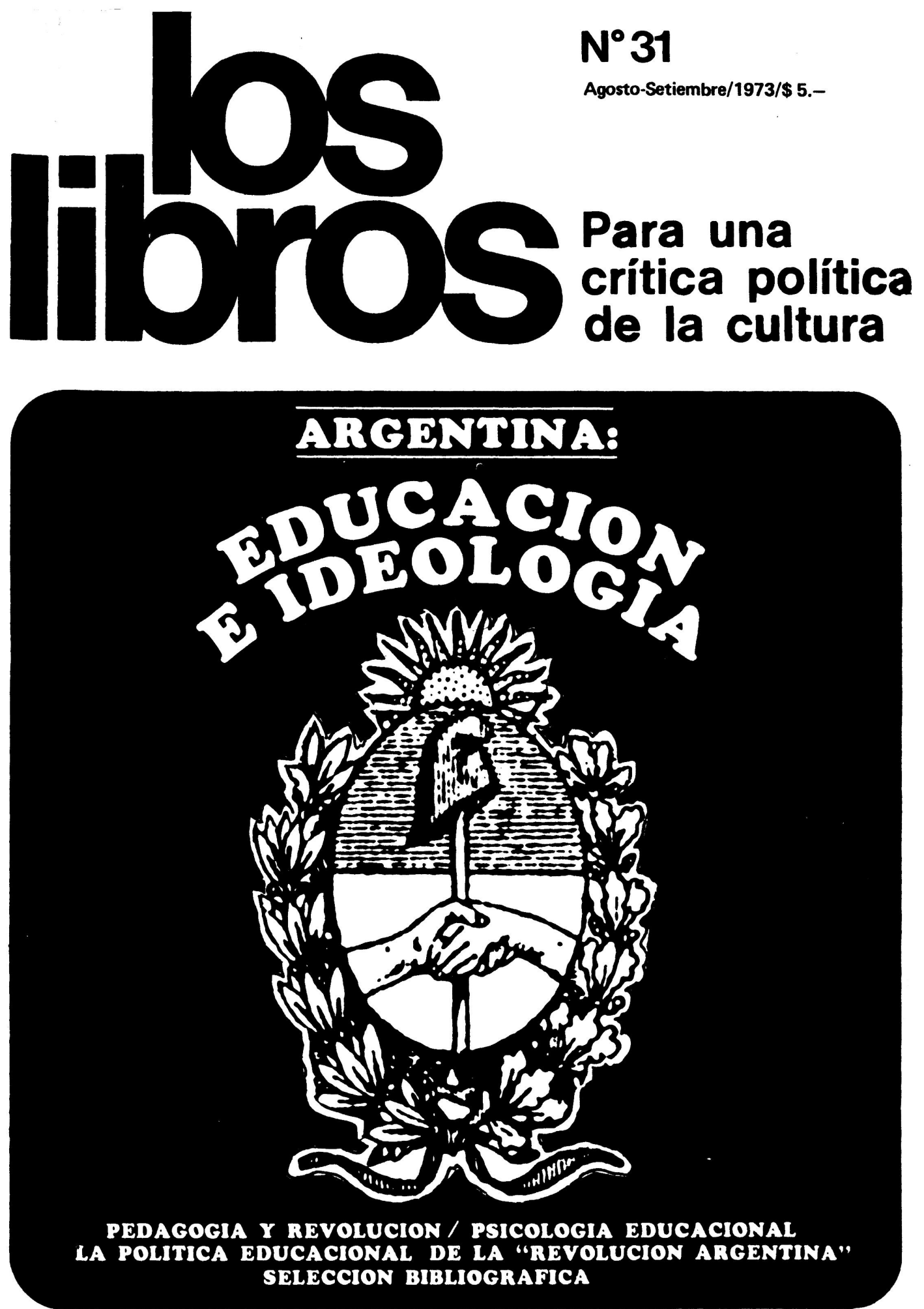

Imagen 6 


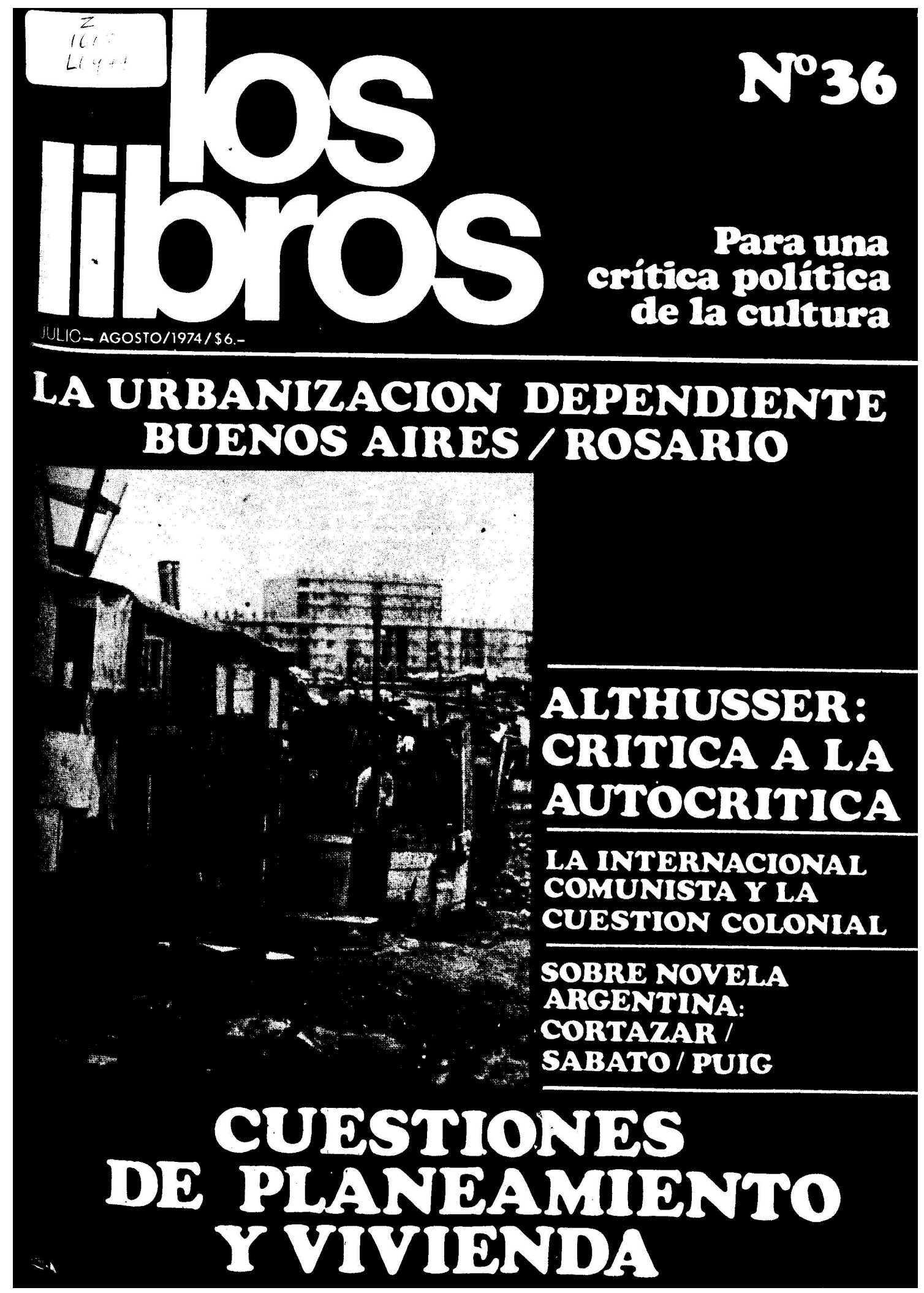

Imagen 7 


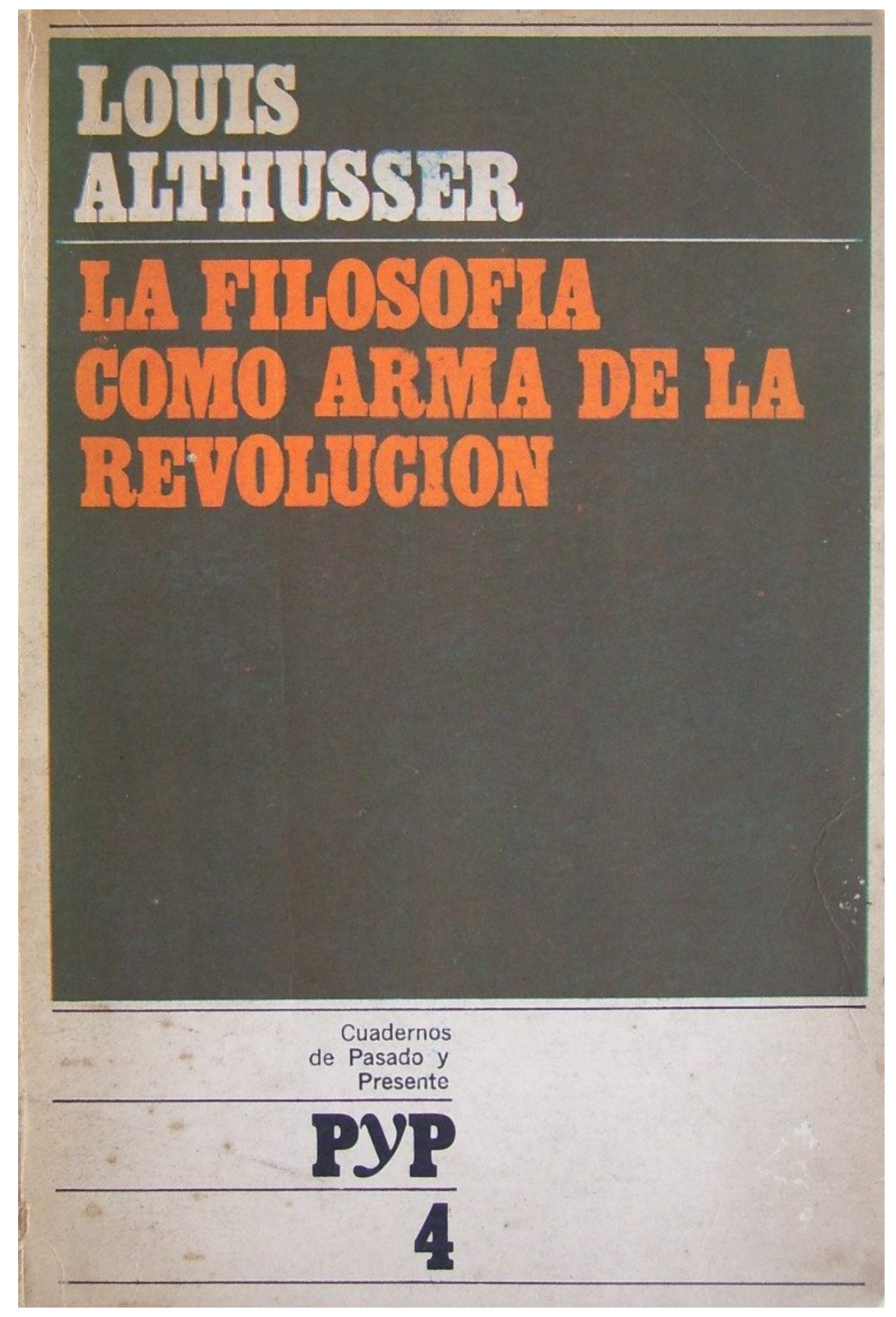

Imagen 8 


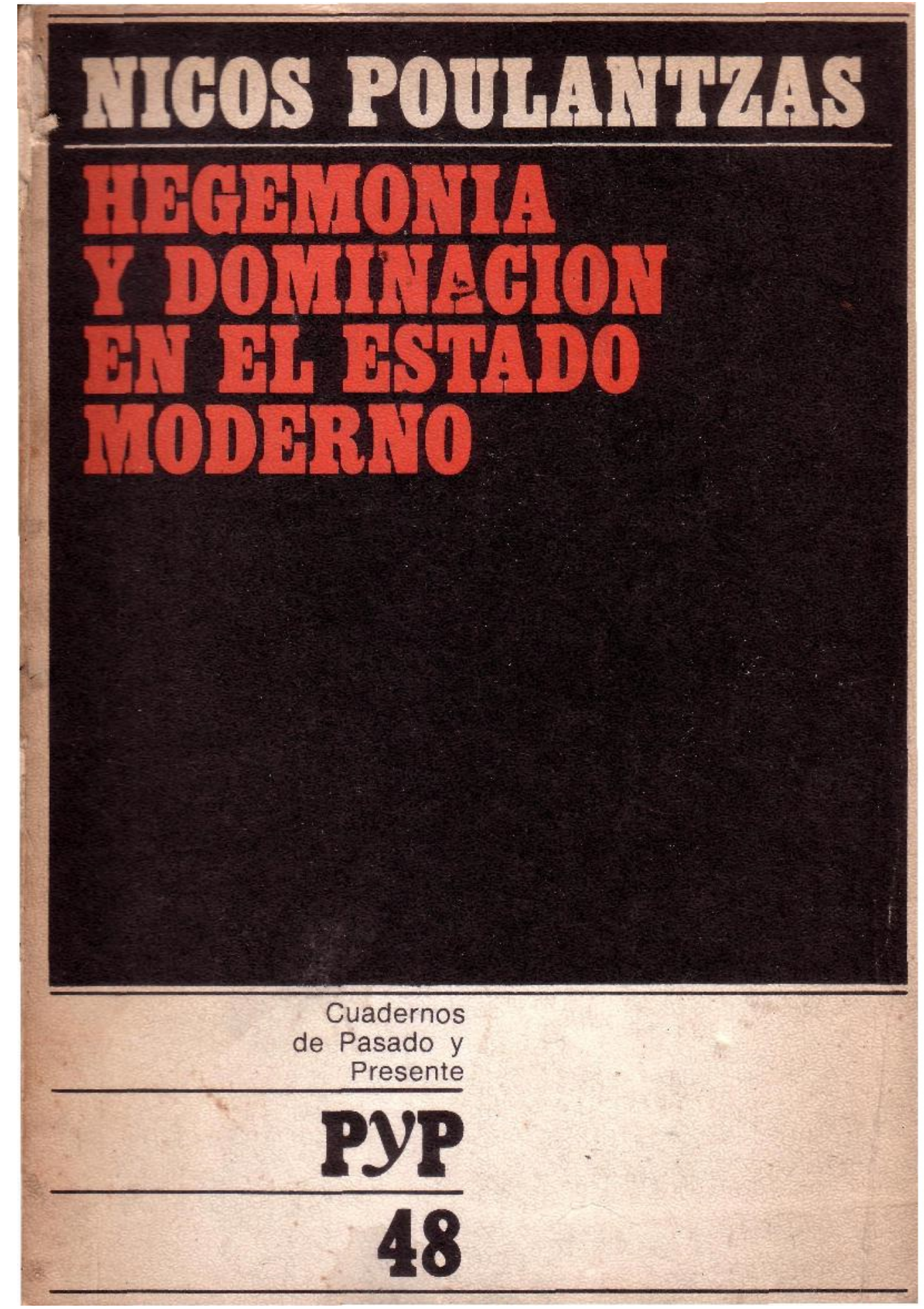

Imagen 9 


\section{Introducción a la lectura de Jacques Lacan}

Oscar Masotta

Biblioteca

Campo Freudiano Editorial

Proteo

Imagen 10 


\section{Oscar Masotta}

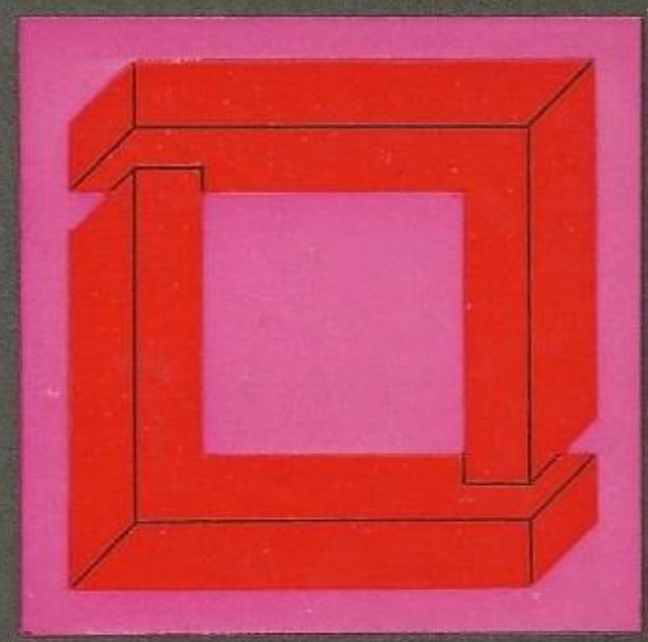

\section{Ensayos lacanianos}

\section{EDITORIAL ANAGRAMA}

Imagen 11 


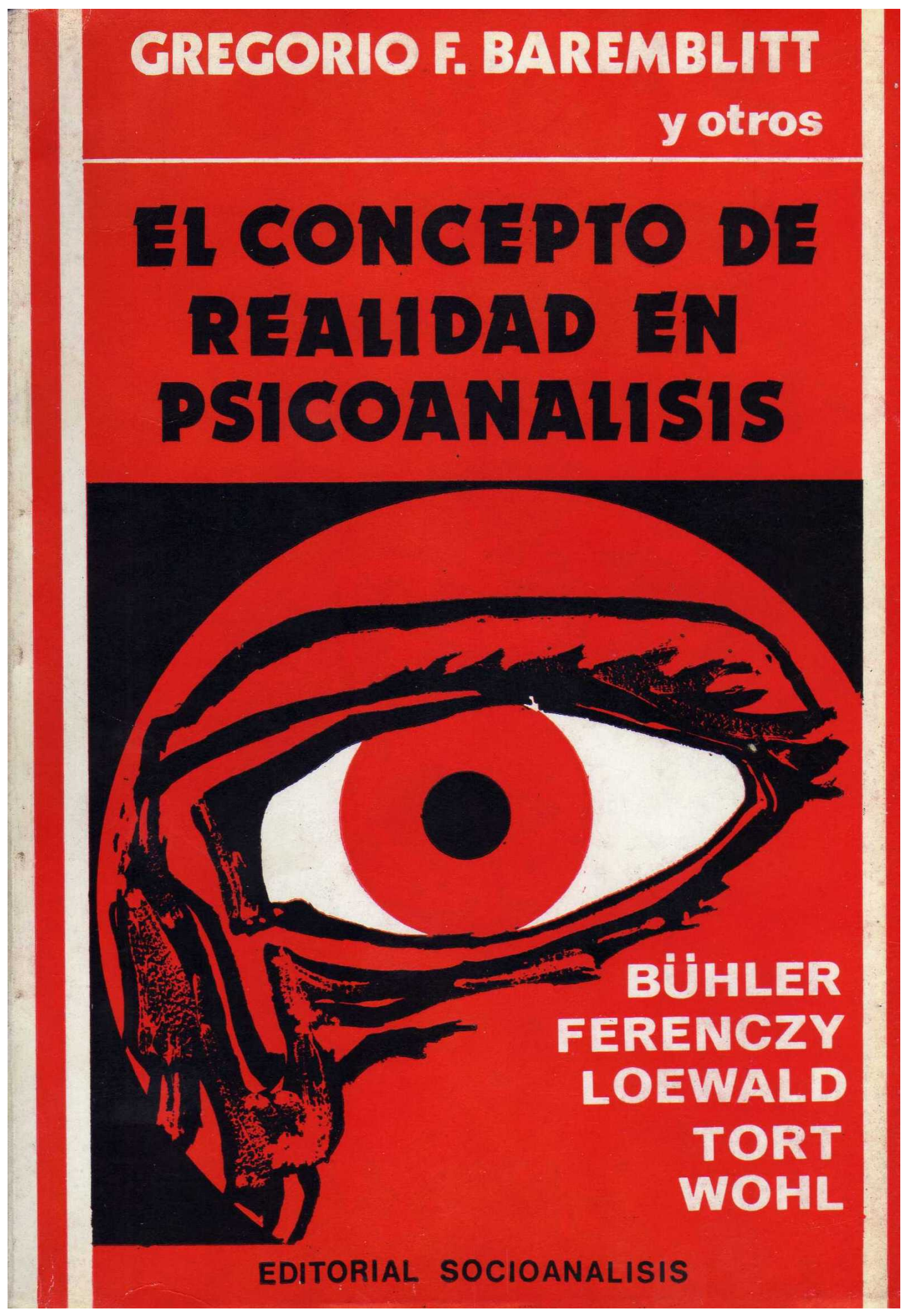

Imagen 12 

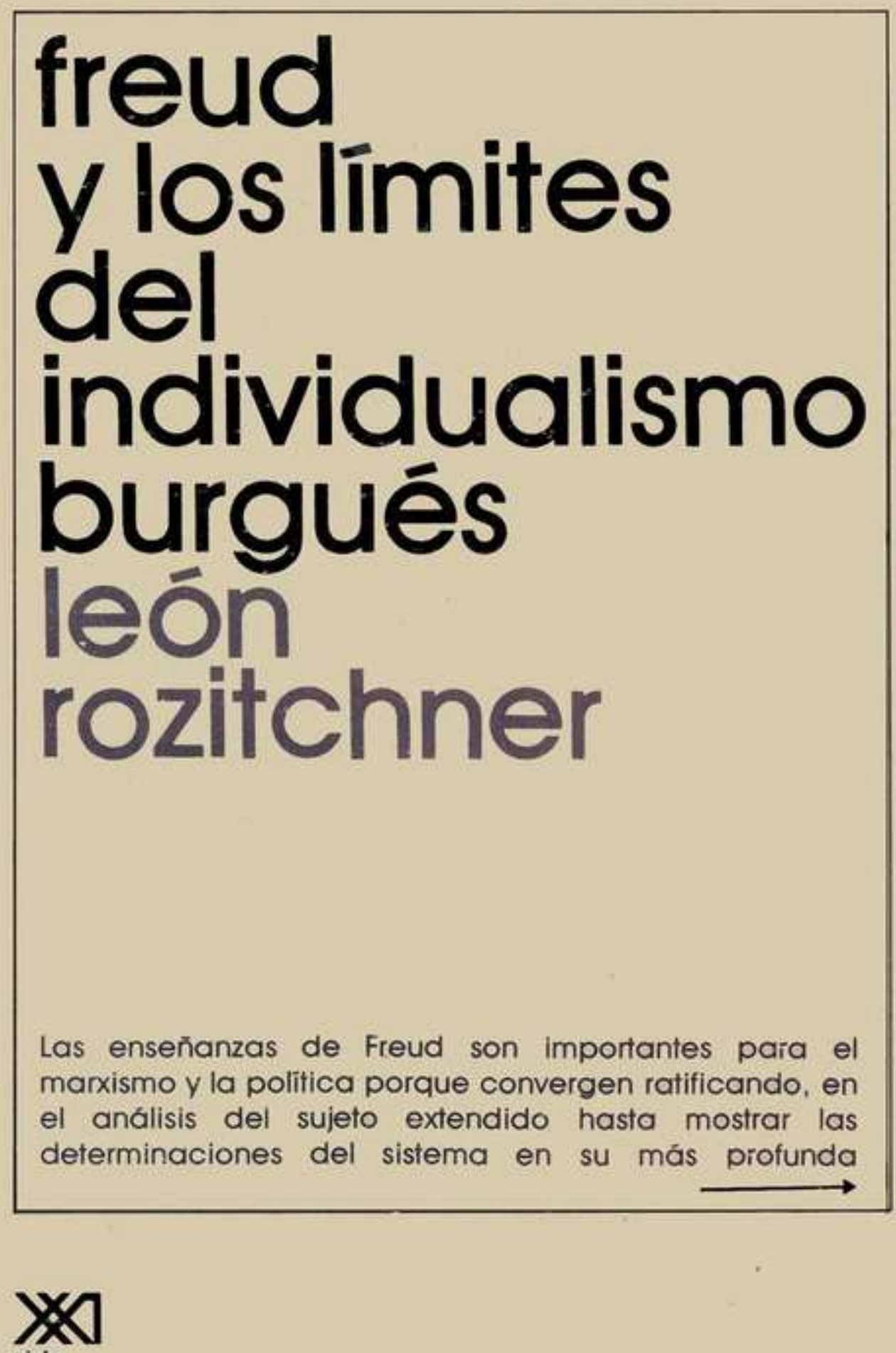


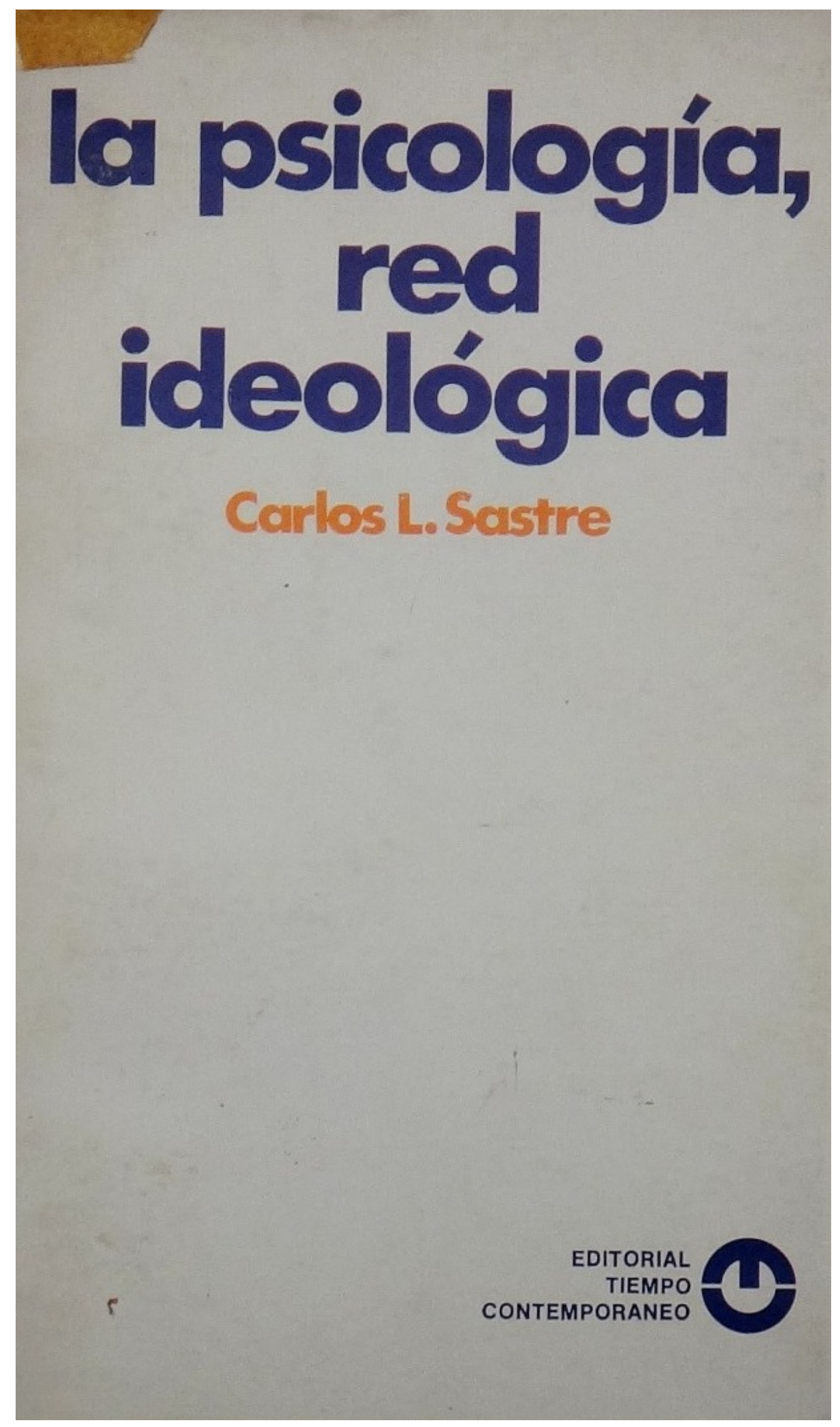

Imagen 14 


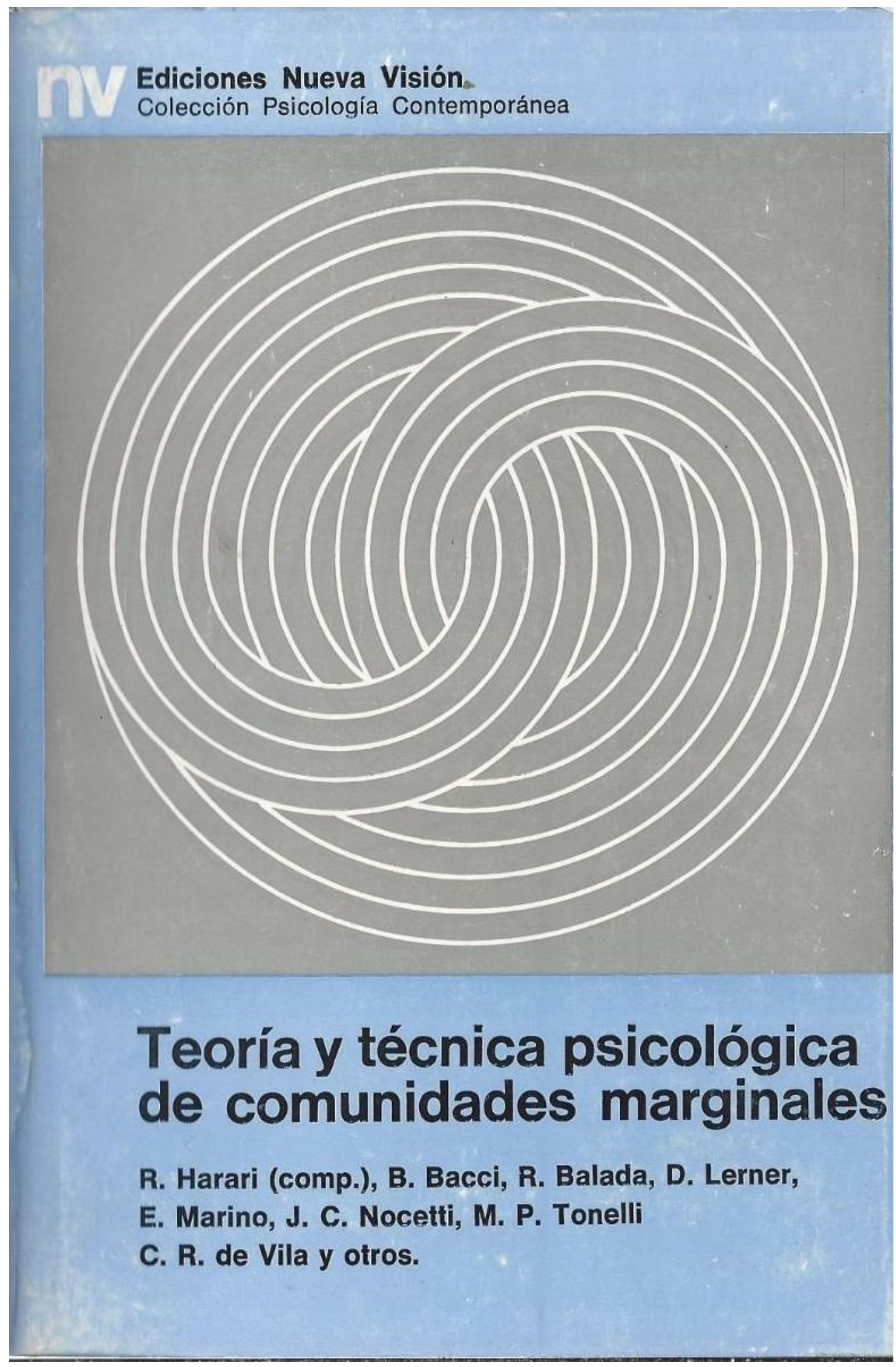

Imagen 15 


\section{Bibliografía}

\section{Fuentes}

\section{$\underline{\text { Publicaciones periódicas }}$}

Cuadernos de Cultura (1962-1976).

Cuadernos de Psicología Concreta (1969-1972).

Forjador. Revista bimestral del Comité Ejecutivo de la Federación Juvenil Comunista (1965-1970).

Los Libros (1969-1976).

Nueva Hora. Órgano del Partido Comunista Argentino-Comité Nacional de Recuperación Revolucionaria (1968-1973).

Pasado y Presente (1963-1965 / 1973).

Revista Argentina de Psicología (1969-1976).

Teoría y política (1969-1976).

\section{Artículos y libros}

A.A.V.V. El concepto de "formación económico-social". Buenos Aires, Pasado y Presente, 1973.

Althusser, Louis. "Carta a propósito de ¿Revolución en la revolución? (1967)”. Demarcaciones. Revista Latinoamericana de Estudios Althusserianos. $N^{\circ} 3$, Abril 2015, pp. 57-63 [primera edición: "Lettre à Régis Debray". Régis Debray. La critique des armes. París, Du Seuil, 1974, 262-269].

Althusser, Louis. La revolución teórica de Marx. México D.F., Siglo XXI, 1967 [primera edición: Pour Marx. Paris, François Maspero, 1965].

Althusser, Louis. La filosofía como arma de la revolución. Córdoba, Pasado y Presente, 1968.

Althusser, Louis y Badiou, Alain. Materialismo histórico y materialismo dialéctico. Córdoba, Pasado y Presente, 1969. 
Althusser, Louis. El porvenir es largo. Los hechos. Barcelona, Destino, 1992.

Althusser, Louis. Lettres à Franca (1961-1973). París, Stock/IMEC, 1998.

Althusser, Louis. "Carta ante la muerte del Che Guevara". Casa de las Americas. $\mathrm{N}^{\circ} 190$, enero-marzo 1993, pp. 61-64 [original fechado en marzo de 1967].

Aricó, José. Marx y América Latina. Lima, CEDEP, 1980.

Aricó, José. La cola del diablo. Itinerario de Gramsci en América Latina. Buenos Aires, Siglo XXI, 2005 [primera edición: Buenos Aires, Puntosur, 1988].

Badiou, Alain. El concepto de modelo. Bases para una epistemología materialista de las matemáticas. Buenos Aires, Siglo XXI, 1972 [primera edición: Le concept du modèle. Introduction à une epistemologie matérialiste des mathématiques. París, François Maspero, 1969].

Badiou, Alain. "Prefacio de la nueva edición". Alain Badiou. El concepto de modelo. Introducción a una epistemología materialista de las matemáticas. Buenos Aires, La Bestia Equilátera, 2009, pp. 9-33.

Baremblitt, Gregorio y otros. El concepto de realidad en psicoanálisis. Buenos Aires, Socioanálisis, 1974.

Castel, Robert. El psicoanalismo. El orden psicoanalítico y el poder. México D.F., Siglo XXI, 1980 [primera edición: La psychanalisme. L'ordre psychanalytique et le pouvoir. París, François Maspero, 1973].

Comité Central de la Federación Juvenil Comunista. Hacia el ${ }^{\circ} \mathrm{X}$ Congreso por la unidad y la defensa de la F.J.C. y el P.C. sobre la base de los principios leninistas. Octubre de 1967.

Debray, Régis. ¿Revolución en la revolución? Buenos Aires, Sandino, 1967.

De Ípola, Emilio. Ideología y discurso populista. Buenos Aires, Folios, 1983.

De Ípola, Emilio. Althusser, el infinito adiós. Buenos Aires, Siglo XXI, 2007.

Del Barco, Oscar. "Althusser en su encrucijada". Dialéctica, №3, 1977, pp. 754.

Fichant, Michel y Pécheux, Michel. Sobre la historia de las ciencias. Buenos Aires, Siglo XXI, 1971 [primera edición: Sur l'histoire des sciences. París, François Maspero, 1969]. 
Follari, Roberto. "Política y ciencia en psicología". Dialéctica. № 6, Junio 1979, pp. 145-161.

Fougeyrollas, Pierre. Contre Lévi-Strauss, Lacan et Althusser. Trois essais sur l'obscurantisme contemporaine. París, Editions de la Jouquère, 1976.

Gallino, Alessandro; Luciano; Debray, Regis; Gramsci, Antonio. Gramsci y las ciencias sociales. Córdoba, Pasado y Presente, 1970.

Garaudy, Roger. Marxisme du XXe siècle. París, La Palatine, 1966.

García Barceló, Abel. Hegel y la dialéctica científica de Marx. Buenos Aires, Centro de Estudios Marxistas-Leninistas Victorio Codovilla, 1971.

Glucksmann, André. Althusser: un estructuralismo ventrílocuo. Barcelona, Anagrama Barcelona, 1971 [primera edición: "Un structuralisme ventriloque". Les Temps Modernes, N²50, 1967, 1557-1598].

Goldmann, Lucien. Marxismo y ciencias humanas. Buenos Aires, Amorrortu 1975 [primera edición: Marxisme et sciences humaines. París, Gallimard, 1970].

Gramsci, Antonio. El príncipe moderno y la voluntad nacional-popular. Buenos Aires, Puentealsina, 1972.

Harari, Roberto (comp.). Teoría y técnica psicológica de comunidades marginales. Buenos Aires, Nueva Visión, 1974.

Harari, Roberto. El objeto de la operación del psicólogo. Buenos Aires, Nueva Visión, 1976.

Harari, Roberto. Márgenes interiores: epígrafes de un psicoanalista. Buenos Aires, Lumen, 2007.

Harnecker, Marta. Los conceptos elementales del materialismo histórico. México D.F., Siglo XXI, 1968.

Karsz, Saúl (comp.). Lectura de Althusser. Buenos Aires, Galerna, 1970.

Karsz, Saúl. Théorie et politique: Louis Althusser. París, Fayard, 1974

Kesselman, Hernán. Psicoterapia breve. Buenos Aires, Kargieman, 1970.

Langer, Marie (comp.). Cuestionamos. Documentos de crítica a la ubicación actual del psicoanálisis. Buenos Aires, Granica, 1971.

Langer, Marie (comp.). Cuestionamos 2. Psicoanálisis institucional y psicoanálisis sin instituciones. Buenos Aires, Granica, 1973. 
Lecourt, Dominique. Para una crítica de la epistemología. Buenos Aires, Siglo XXI, 1973 [primera edición: Pour une critique de l'épistémologie. París, François Maspero, 1972].

Lecourt, Dominique. Ensayo sobre la posición de Lenin en filosofía. Buenos Aires, Siglo XXI, 1974 [primera edición: Une crise et son enjeu (essai sur la position de Lenin en philosophie). París, François Maspero, 1973)].

Lefebvre, Henri. L’idéologie structuraliste. París, Du Seuil, 1971.

Lisbonne, Bernard. Phiosophie marxiste ou philosophie althussérienne. París, Anthropos, 1978.

Löwy, Michael. Dialectique et révolution. Essais de sociologie et d'histoire du marxisme. París, Anthropos, 1973.

Luporini, Cesare. "Nota introduttiva". Althusser, Louis. Per Marx. Roma, Riuniti, 1967, pp. V-XXVIII.

Masotta, Oscar. "Explicación de Un dios cotidiano". Comentario. Publicación del Instituto Judío-Argentino de Cultura e Información. Año 5, № 2, 1958.

Masotta, Oscar. "La fenomenología de Sartre y un trabajo de Daniel Lagache". Centro. $\mathrm{N}^{\circ} 13$, Tercer Trimestre 1959, pp. 71-83.

Masotta, Oscar. "Destrucción y promoción del marxismo contemporáneo". Marcha. Octubre de 1960.

Masotta, Oscar. "Cristianismo, catolicismo, marxismo". Discusión. N2, Mayo de 1963.

Masotta, Oscar. Sexo y traición en Roberto Arlt. Buenos Aires, Jorge Alvarez, 1965.

Masotta, Oscar. "La literatura y el 'hombre corriente"'. Ensayo Cultural. Buenos Aires, 1966.

Masotta, Oscar. Conciencia y estructura. Buenos Aires, Jorge Alvarez, 1968.

Masotta, Oscar. "Leer a Freud". Revista Argentina de Psicología. N ${ }^{\circ}$ 1, Septiembre de 1969, pp. 19-27.

Masotta, Oscar. Introducción a la lectura de Jacques Lacan. Buenos Aires, Proteo, 1970.

Masotta, Oscar. Ensayos lacanianos. Barcelona, Anagrama, 1976. 
Partido Comunista Revolucionario. Primer Congreso del P.C.R. 11, 12, 13 y 14 de diciembre de 1969.

Partido Comunista Revolucionario. Segundo Congreso del PCR. 7, 8 y 9 de abril de 1972.

Partido Comunista Revolucionario. Tercer Congreso del PCR. 2 y 3 de marzo de 1974.

Poulantzas, Nicos. Hegemonía y dominación en el Estado moderno. Córdoba, Pasado y Presente, 1973.

Sastre, Carlos. La psicología, red ideológica. Buenos Aires, Tiempo Contemporáneo, 1975.

Sebreli, Juan José. "Verón: la ciencia oficial contra el marxismo". Marcha. $\mathrm{N}^{\circ}$ 1312, 15 de Julio de 1966.

Rancière, Jacques. La lección de Althusser. Buenos Aires, Galerna, 1975 [primera edición: La leçon d’Althusser. París, Gallimard, 1974]

Rozitchner, León. "La izquierda sin sujeto". La rosa blindada. Año 2, N 9 , Septiembre de 1966, pp. 30-43.

Rozitchner, León. Freud y los límites del individualismo burgués. Buenos Aires, Siglo XXI, 1972.

Sciarreta, Raúl. Escritos provisorios. Hacia un nuevo empirismo. Buenos Aires, Ediciones del Signo, 2000.

Thompson, E.P. Miseria de la teoría. Barcelona, Crítica, 1981 [primera edición: Poverty of Theory \& Other Essays. Londres, Monthly Review Press, 1978].

Tort, Michel. El psicoanálisis en el materialismo histórico. Buenos Aires, Noé, 1972.

Verón, Eliseo. "Muerte y transfiguración del análisis marxista". Marcha. $\mathrm{N}^{\circ}$ 1309, 24 de Junio de 1966.

\section{Bibliografía consultada}

AAVV. Oscar Masotta. Lecturas críticas. Buenos Aires, Atuel-Anáfora, 2000.

Anderson, Perry. Teoría, política e historia. Un debate con E.P. Thompson. Madrid, Siglo XXI, 1985 [primera edición: Arguments within English Marxism. Londres, New Left Books, 1980]. 
Anderson, Perry. Tras las huellas del materialismo histórico. Madrid, Siglo XXI, 1986 [primera edición: In the Tracks of Historical Materialism. Londres, Verso, 1983].

Anderson, Perry. Consideraciones sobre el marxismo occidental. México D.F., Siglo XXI, 1987 [primera edición: Considerations on Western Marxism. Londres, New Left Books, 1976].

Aricó, José. Entrevistas, 1974-1991. Córdoba, Ediciones del Centro de Estudios Avanzados, 1999.

Artaraz, Kepa. Cuba y la nueva izquierda. Una relación que marcó los años 60. Buenos Aires, Capital Intelectual, 2011.

Arrúa, Néstor. "El marxismo en clave althusseriana de los trabajadores sociales brasileños en los años setenta". VIII Jornadas de Historia de las Izquierdas CeDINCI/UNSAM. 2015, pp. 315-332.

Balibar, Étienne. Escritos por Althusser. Buenos Aires, Nueva Visión, 2004 [primera edición: Ecrits pour Althusser. París, La Découverte, 1991].

Balibar, Étienne. "Althusser y la Rue d'Ulm”. New Left Review. №58, 2009, pp. 86-101.

Balibar, Étienne. "El infinito adiós al marxismo". Metapolítica. Septiembre de 2015.

Barbeito, Ignacio. "Aportes para una historia del circuito editorial en la Córdoba de los '60 y primeros '70s. Ediciones Nagelkop, Aula Vallejo e Igitur'. Políticas de la Memoria. Anuario de investigación e información del CEDINCI, $\mathrm{N}^{\circ}$ 10/11/12, 2001-2012, pp. 143-148.

Bennet, Tonny. Formalism and Marxism. Nueva York, Methuen, 1979.

Benton, Ted. The rise and fall of structural marxism: Althusser and his influence. Londres, Macmillan, 1984.

Benyo, Javier; Churba, Daniel; García Viale, Verónica y Ragoni, Pablo. “Deleuze en la Argentina". Revista Lote. N 82, Mayo de 2004.

Borinsky, Marcela. "Entre Bleger y Masotta: Georges Politzer o la búsqueda de un héroe". Julio César Ríos, Ricardo Ruiz, Juan Carlos Stagnaro, Patricia Waissman (comps.). Psiquiatría, Psicología y Psicoanálisis. Historia y Memoria. Buenos Aires, Polemos, 2000, pp. 130-140. 
Bosteels, Bruno. "Alain Badiou's Theory of the Subject: Part I. The Recommencement of Dialectic Materialism". Pli: The Warwick Journal of Philosophy, N²12, 2001, pp. 200-229.

Bosteels, Bruno. "Alain Badiou's Theory of the Subject: Part II. The Recommencement of Dialectic Materialism". Pli: The Warwick Journal of Philosophy, N 13, 2002, pp. 172-208.

Bosteels, Bruno. "In the Shadow of Mao: Ricardo Piglia's 'Homenaje a Roberto Arlt'”. Journal of Latin American Cultural Studies, N², 2003, pp. 229-259.

Bosteels, Bruno. Marx and Freud in Latin America: Politics, Psychoanalysis, and Religion in Times of Terror. Londres, Verso, 2012.

Bosteels, Wouter. "Análisis de un discurso enamorado. Barthes y Althusser en Los Libros". De Paepe, Christian; Lie, Nadia; Rodríguez-Carranza, Luz; Sanz Hermida, Rosa (eds.). Literatura y poder. Actas del Coloquio Internacional K.U.L. (Lovaina) / U.F.S.I.A. (Amberes). Lovaina, Leuven University Press, 1995, pp. 271-280.

Bosteels, Wouter y Rodríguez-Carranza, Luz. "El objeto Sade. Genealogía de un discurso crítico, de Babel, revista de libros (1989-1991) a Los Libros (19691971)". Spiller, Roland (coord.). Culturas del Río de la Plata (1973-1995). Frankfurt, Vervuert Verlagsgesellshaft, 1995, pp. 313-338.

Bourdieu, Pierre. "Las condiciones sociales de la circulación de las ideas". Intelectuales, política y poder. Buenos Aires, EUDEBA, 1999, pp. 159-170.

Bourg, Julian. "The Red Guards of Paris: French Student Maoism in the 1960's". History of European Ideas. N 4, 2005, pp. 472-490.

Burgos, Raúl. Los gramscianos argentinos. Cultura y política en la experiencia de Pasado y Presente. Buenos Aires, Siglo XXI, 2004.

Burke, Peter. "Context in Context". Common Knowledge. Vol. 8, № 1, 2002, pp. 152-177.

Burke, Peter. "La historia intelectual en la era del giro cultural". Prismas. Revista de historia intelectual. N¹1, 2007, pp. 159-164.

Callinicos, Alex. El marxismo de Althusser. México D.F., Premia, 1981 [primera edición: Althusser's Marxism. Londres, Pluto, 1978].

Canavese, Mariana. Los usos de Foucault en la Argentina. Recepción y circulación desde los años cincuenta hasta nuestros días. Buenos Aires, Siglo XXI, 2015. 
Carpintero, Enrique y Vainer, Alejandro. Las huellas de la memoria. Psicoanálisis y salud mental en la Argentina de los '60 y '70. Tomo I: 19571969. Buenos Aires, Topía, 2004.

Carpintero, Enrique y Vainer, Alejandro. Las huellas de la memoria. Psicoanálisis y salud mental en la Argentina de los '60 y '70. Tomo II: 19701983. Buenos Aires, Topía, 2005.

Casco, José. "Ser o no ser. Qué hacer con Perón y el peronismo". Prismas. Revista de historia intelectual. $\mathrm{N}^{\circ} 18,2014$, pp. 217-220.

Castañeda, Antonio y Quiroz, Sergio. "Marxismo y desafíos actuales. Entrevista a Marta Harnecker". Cuadernos de Marxismo. Noviembre de 2000, pp. 5-10.

Casullo, Nicolás. París 68. Las escrituras, el recuerdo y el olvido. Buenos Aires, Manantial, 1998.

Casullo, Nicolás. Sobre la marcha. Cultura y política en la Argentina: 19842004. Buenos Aires, Colihue, 2004.

Celentano, Adrián. "La historia del sistema educativo argentino y el concepto de 'trabajadores de la educación' en la revista Los Libros". Jornadas Interescuelas/Departamentos de Historia. Catamarca, 2011.

Celentano, Adrián. "El maoísmo argentino entre 1963 y 1976. Libros, revistas y periódicos para una práctica política". Políticas de la Memoria. Anuario de investigación e información del CEDINCI. N 14, Verano 2013/2014, pp. 151165.

Celentano, Adrián. "Althusser, el maoísmo y la revolución cultural". Políticas de la Memoria. Anuario de investigación e información del CEDINCl. $\mathrm{N}^{\circ} 15$, Verano 2015/2016, pp. 220-226.

Cernadas, Jorge. 'La 'vieja izquierda' en la encrucijada: Cuadernos de Cultura y la política cultural del Partido Comunista Argentino (1955-1963)". X’ Jornadas Interescuelas/Departamentos de Historia. Rosario, 2005.

Chartier, Roger. Cultura escrita, literatura e historia. México D.F., Fondo de Cultura Económica, 1999.

Chartier, Roger. Escribir las prácticas. Foucault, de Certeau, Marin. Buenos Aires, Manantial, 2006.

Córdova, Arnaldo. "Gramsci y la izquierda mexicana". Nueva Sociedad. Democracia y política en América Latina. N¹15, 1991, pp. 150-153.

Correas, Carlos. La operación Masotta. Cuando la muerte también fracasa. Buenos Aires, Catálogos, 1991. 
Cousido, Diego. "Actualización teórica, lucha ideológica, en el caso de Los Libros". Cuadernos críticos de comunicación y cultura. $\mathrm{N}^{\circ} 4$, primavera-verano de 2008, pp. 107-127.

Coutinho, Carlos Nelson. "Brasil y Gramsci: variadas lecturas de un pensamiento". Nueva Sociedad. Democracia y política en América Latina, $\mathrm{N}^{\circ}$ 115, 1991, pp. 104-113.

Crespo, Horacio. "Córdoba, Pasado y Presente y la obra de José Aricó". Prismas. Revista de historia intelectual. N¹, 1997, pp. 139-146.

Crespo, Horacio. "En torno a Cuadernos de Pasado y Presente, 1968-1983". Claudia Hilb (comp.). El político y el científico. Ensayos en homenaje a Juan Carlos Portantiero. Buenos Aires, Siglo XXI, 2009, pp. 169-196.

Crespo, Horacio. "El marxismo latinoamericano de Aricó. La búsqueda de la autonomía de lo político en la falla de Marx". José Aricó. Marx y América Latina. Buenos Aires, Fondo de Cultura Económica, 2010, pp. 9-48.

Cusset, François. French Theory. Foucault, Derrida, Deleuze \& Cia y las mutaciones de la vida intelectual en Estados Unidos. Barcelona, Melusina, 2005.

Dagfal, Alejandro. Entre París y Buenos Aires. La invención del psicólogo (1942-1966). Buenos Aires, Paidós, 2009.

Darnton, Robert. "Intellectual and Cultural History". Michael G. Kammen. The Past Before Us. Contemporary Historical Writing in the Unites States. Ithaca, Cornell University Press, 1980, pp. 327-354.

De Certeau, Michel. La invención de lo cotidiano. I. Artes de hacer. México D.F., Universidad Iberoamericana-ITESO, 2007.

De Diego, José Luis. ¿Quién de nosotros escribirá el Facundo? Intelectuales y escritores en Argentina (1970-1986). La Plata, Al Margen, 2003.

Diefenbach, Katja; Farris, Sara; Kirn, Gal; Thomas, Peter. Encountering Althusser. Politics and Materialism in Contemporary Radical Thought. Londres, Bloomsbury, 2012.

Dosse, François. History of Structuralism. Minneapolis, University of Minnesota Press, 1998.

Dosse, François. La marcha de las ideas. Historia de los intelectuales, historia intelectual. Valencia, Universitat de València, 2007 [primera edición: La marche des idées. Histoire des intellectuels, histoire intellectuel. París, La Découverte, 2003]. 
Druet, Anne-Cécile. "Ecos socioculturales de la introducción del lacanismo en España”. Cuadernos LIRICO. N4, 2008, pp. 165-174.

Eagleton, Terry. Ideología. Una introducción. Barcelona, Paidós, 2005 [primera edición: Ideology: An Introduction. Londres, Verso, 1991].

Elliott, Gregory (ed.). Althusser: A Critical Reader. Oxford, Blackwell, 1994.

Elliott, Gregory. Althusser: The Detour of Theory. Leiden, Brill, 2006 [primera edición: Londres, Verso, 1987].

Espósito, Fabio. "La crítica moderna en Argentina: la revista Los Libros (19691976)". Orbis Tertius. N²1, 2015, pp. 1-8.

Faletto, Enzo. “¿Qué pasó con Gramsci?”. Nueva Sociedad. Democracia y política en América Latina, N¹15, 1991, pp. 90-97.

Feltham, Oliver. Alain Badiou: Live Theory. Londres, Continuum, 2008.

Fernández Retamar, Roberto. "Presentación a Carta de Louis Althusser ante la muerte del Che Guevara". Casa de las Americas. N 190, enero-marzo 1993, pp. 59-60.

Ferretter, Luke. Althusser. Oxford, Routledge, 2005.

Fish, Stanley. Is there a text in this class? The authority of interpretative communities. Massachusetts, Harvard University Press, 1982.

Fornillo, Bruno y Lezama, Alejandro. Releer Althusser. Buenos Aires, Parusía, 2002.

Frosini, Fabio. Da Gramsci a Marx. Ideologia, verità e politica. Roma, Derive Approdi, 2009.

Frosini, Fabio y Morfino, Vittorio. "Introduzione". Décalages. An Althusser Studies Journal. Vol. 2, N 1, 2016.

García, Diego. "La renovación historiográfica en Córdoba. Un recorrido". Ana Clarisa Agüero y Diego García (eds.). Culturas interiores. Córdoba en la geografía nacional e internacional de la cultura. La Plata, Al Margen, 2010, pp. 165-184.

García, Diego. "Signos. Notas sobre un momento editorial". Políticas de la Memoria. Anuario de investigación e información del CEDINCI, N ${ }^{\circ}$ 10/11/12, 2011/2012, pp. 149-158. 
García, Germán. Oscar Masotta y el psicoanálisis en castellano. Barcelona, Argonauta. 1980.

García, Germán. Oscar Masotta. Los ecos de un nombre. Barcelona, Eolia, 1992.

García, Germán. El psicoanálisis y los debates culturales. Ejemplos argentinos. Buenos Aires, Paidós, 2005.

García, Luciano. La recepción de la psicología soviética en la Argentina. Lecturas y apropiaciones y la psicología, psiquiatría y psicoanálisis (19361991). Tesis doctoral, Universidad de Buenos Aires, 2012.

García, Luis. "La modernidad en disputa. La Escuela de Frankfurt en la Argentina". Hugo Biagini y Arturo Roig (dirs.). El pensamiento alternativo en la Argentina del siglo XX. Tomo II. Obrerismo, vanguardia, justicia social (19301940). Buenos Aires, Biblos, 2006, pp. 111-140.

García, Luis Ignacio. "Ricardo Piglia entre la radicalización y la barbarie: Brecht y Benjamin en los '70". La crítica entre culturas. Estética, política, recepción. Santiago de Chile, Universidad de Chile, 2011, pp. 135-185.

Gerratana, Valentino. "Althusser and Stalinism". New Left Review, No 120-121, 1977, pp. 110-121.

Ghioldi, Rodolfo. No puede haber revolución en la revolución. Buenos Aires, Anteo, 1967.

Gillespie, Sam. "Giving Form to Its Own Existence: Anxiety and the Subject of Truth". Paul Ashton, A.J. Bartlett y Justin Clemens. The Praxis of Alain Badiou. Melbourne, re.press, 2006, pp. 180-209.

Gillot, Pascale. Althusser y el psicoanálisis. Buenos Aires, Nueva Visión, 2010 [primera edición: Althusser et la psychanalyse. París, Presses Universitaire de France, 2009].

Gilman, Claudia. Entre la pluma y el fusil. Debates y dilemas del escritor revolucionario en América Latina. Buenos Aires, Siglo XXI, 2003.

Gómez, Sebastián. "El recorrido de la Revista de Ciencias de la Educación (1970-1975). Desde la ausencia original de Gramsci ¿a la articulación u oposición con el legador althusseriano?". VII' Encuentro Nacional y $\mathrm{VI}^{\circ}$ Latinoamericano "La Universidad como objeto de investigación". San Luis, 29 al 31 de Agosto de 2013.

Gómez, Sebastián. "El derrotero de Los Libros (1969-1976) y su crítica pedagógica. La interpretación de Antonio Gramsci a través de Christine Buci- 
Glucksmann". Izquierdas. Una mirada histórica desde América Latina. № 28, Julio de 2016, pp. 292-314.

González Canosa, Mora. "Políticas de construcción del peronismo. El discurso de las FAR en los albores de la década del setenta en Argentina". Tempo \& Argumento. Vol, 7, N¹4, 2015, pp. 180-216.

Goshgarian, G.M. "Introduction". Althusser, Louis. The Humanist Controversy and Other Writings. Londres, Verso, 2003, pp. XI-LXII.

Grafton, Anthony. "La historia de las ideas. Preceptos y prácticas, 1950-2000 y más allá". Prismas. Revista de historia intelectual. N 11, 2007, pp. 123-148.

Harari, Roberto. "Sócrates vivió en Buenos Aires". Página 12. 23 de Septiembre de 1999.

Hendler, Ariel. La guerrilla invisible. Historia de las Fuerzas Argentinas de Liberación (FAL). Buenos Aires, Vergara, 2010.

Herrero, Alejandro y Herrero, Fabián. "Oscar Terán". Las ideas y sus historiadores. Un fragmento del campo intelectual en los años noventa. Santa Fe, Centro de Publicaciones / Universidad Nacional del Litoral, 1996, pp. 153164.

Híjar Serrano, Alberto. “Althusser en Morelia”. Por esto! Mayo de 2012.

Hobsbawm, Eric. "La estructura del capital". Revolucionarios. Ensayos contemporáneos. Barcelona, Crítica, 2000 [primera edición: "The Structure of Capital". Times Literary Supplement, №3381, 1161-1163].

Izaguirre, Marcelo (comp.). Oscar Masotta: el revés de la trama. Buenos Aires, Atuel, 1999.

Izaguirre, Marcelo. Jacques Lacan: el anclaje de su enseñanza en la Argentina. Buenos Aires, Catálogos, 2009.

Izzo, Francesca. "Althusser and Italy: a Two-Fold Challenge to Gramsci and Della Volpe”. International Critical Thought. Vol. 5, N² 2, 2015, pp. 200-210.

Jay, Martin. "¿Debería la historia intelectual tomar un giro lingüístico? Reflexiones sobre el debate Habermas-Gadamer". Socialismo fin-de-siècle y otros ensayos. Buenos Aires, Nueva Visión, 1990, pp. 27-49 [primera edición: "Should Intellectual History Take a Lingüistic Turn? Reflection on the Habermas-Gadamer Debate". Dominick La Capra y Steven Kaplan. Modern European Intellectual History: Reappraisals and New Perspectives. Ithaca, Cornell University Press, 1982, pp. 86-110]. 
Jay, Martin. Campos de fuerza: entre la historia intelectual y la crítica cultural. Buenos Aires, Paidós, 2003 [primera edición: Force Fields: Between Intellectual History and Cultural Critique. Nueva York, Routledge, 1993].

Kohan, Néstor. De Ingenieros al Che. Ensayos sobre el marxismo argentino y latinoamericano. Buenos Aires, Biblos, 2000.

Kohan, Néstor. Marx en su (Tercer) Mundo. Hacia un socialismo no colonizado. La Habana, Centro de Investigación y Desarrollo de la Cultura Cubana Juan Marinello, 2003.

Kohan, Néstor. El Capital. Historia y método -Una introducción-. Buenos Aires, Universidad Popular Madres de Plaza de Mayo, 2003.

Kohan, Néstor. Introducción al pensamiento marxista. Buenos Aires, La Rosa Blindada-Universidad Popular Madres de Plaza de Mayo, 2003.

Lahire, Bernard, "Objectivation sociologique, critique sociale et disqualification". Mouvements des idées et des luttes. $\mathrm{N}^{\circ} 2$, noviembre-diciembre de 2002, pp. 46-52.

Lecourt, Dominique. Para una crítica de la epistemología. Buenos Aires, Siglo XXI, 1973 [primera edición: Pour une critique de l'épistémologie. París, François Maspero, 1972].

Lecourt, Dominique. Ensayo sobre la posición de Lenin en filosofía. Buenos Aires, Siglo XXI, 1974 [primera edición: Une crise et son enjeu (essai sur la position de Lenin en philosophie). París, François Maspero, 1973)].

Lewis, John. "The Althusser Case". Marxism Today, № 1, 1972, pp. 23-28.

Lisandrello, Guido. "La toma de la fábrica Perdriel y la clarificación de la estrategia insurreccionalista en el Partido Comunista Revolucionario en los años 70". VII Jornadas de Trabajo de Historia Reciente. Buenos Aires, 2014.

Lisandrello, Guido. "La discusión estratégica en la izquierda argentina en los años '70. Aproximación al debate entre guerrillerismo e insurreccionalismo en el nacimiento del Partido Comunista Revolucionario (PCR), 1967-1972". Andes, Vol. $23 \mathrm{~N}^{\circ}$ 1, 2015.

Lo lacono, Cristian. Althusser en Italia. Saggio bibliografico (1959-2009). Milán, Mimesis, 2009.

Longoni, Ana. "Oscar Masotta: vanguardia y revolución en los sesenta". Masotta, Oscar. Revolución en el arte. Pop art, happenings y arte de los medios. Buenos Aires, Edhasa, 2004, pp. 9-100. 
Löwy, Michael. "Notas sobre a recepção crítica ao althusserianismo no Brasil (anos 1960 e 1970)". Elide Rugai Bastos, Marcelo Ridenti y Denis Rolland. Intelectuais: sociedade e política. São Paulo, Cortez, 2003, pp. 213-223.

Luporini, Cesare. "Réflexions sur Louis Althusser". L'homme et la société, $\mathrm{N}^{\circ} 4$, 1967, pp. 23-35.

Luvecce, Cecilia. Las Fuerzas Armadas Peronistas y el Peronismo de Base. Buenos Aires, Centro Editor de América Latina, 1993.

Massardo, Jaime. "La recepción de Gramsci en América Latina. Algunos problemas teóricos y políticos". Antonio Santucci. Gramsci. Santiago de Chile, Bravo y Allende Editores, 2001.

Matheron, François. "Louis Althusser et Argenteuil : de la croisée de chemins au chemin de croix". Les Annales de la Société des Amis de Louis Aragon et Elsa Troilet. $\mathrm{N}^{\circ} 2$ 2, 2000, pp. 169-198.

Matheron, François. "Louis Althusser o la pureza impura del concepto". Demarcaciones. Revista Latinoamericana de Estudios Althusserianos. $\mathrm{N}^{\circ} 1$, Abril 2014, pp. 44-62 [primera edición : "Louis Althusser ou la impure pureté du concept". Jacques Bidet y Stathis Kouvelakis (dirs.). Diccionaire Marx contemporaine. París, Presses Universitaires de France, 2001, pp. 369-390].

Montag, Warren. Althusser and His Contemporaries. Philosophy's Pertetual War. Durham, Duke University Press, 2013.

Morales, Cesáreo. "El althusserismo en México". Dialéctica. № 14-15, 19831984, pp. 173-184.

Morfino, Vittorio. El materialismo de Althusser. Santiago de Chile, Palinodia, 2014.

Morfino, Vittorio. "Lire Gramsci après Althusser". Décalages. An Althusser Studies Journal. Vol. 1, N², 2014.

Motta, Luiz Eduardo. "Presentación a 'Carlos Henrique Escobar: “¿Quién tiene miedo de Louis Althusser? (1979)'”. Demarcaciones. Revista Latinoamericana de Estudios Althusserianos. $\mathrm{N}^{\circ} 1$, abril 2014, pp. 113-116.

Navarro, Fernanda. "La actualidad de las últimas reflexiones sobre la política de Louis Althusser". Youkali. Revista crítica de las artes y el pensamiento, № 3, 2007, pp. 5-13.

Nogueira, Marco Aurélio. "Gramsci, a questão democratica e a esquerda no Brasil". Carlos Nelson Coutinho y Marco Aurélio Nogueira (orgs.). Gramsci e a América Latina. Río de Janeiro, Paz e Terra, 1988, pp. 130-152. 
Nuñez, Manuel. Vuestros ochentas. Buenos Aires, Milena Caserola, 2009.

Núñez Tenorio, José Rafael. "La teoría de las formaciones socioeconómicas y el pensamiento marxista latinoamericana: originalidad y autenticidad". Pablo Guadarrama (dir.). Despojados de todo fetiche: autenticidad del pensamiento marxista en América Latina. Bogotá, Universidad Central de las Villas, 1999, pp. 137-168.

Ochoa Sandy, Gerardo y Beltrán del Río, Pascal. "Louis Althusser en México: la generación del 68 lo hizo suyo por radical y antidogmático". Proceso. 27 de octubre de 1990.

Ory, Pascal y Sirinelli, Jean- François. Les Intellectuels en France. De l'affaire Dreyfuss à nos jours. París, Armand Colin, 1986.

Ortega, Jaime. "El cerebro de la pasión: Althusser en tres revistas mexicanas". Izquierdas. Una mirada histórica desde América Latina. $\mathrm{N}^{\circ} 25$, octubre 2015, pp. 143-164.

Ortega, Jaime. "Incendiar el océano. Notas sobre la(s) recepción(es) de Althusser en Cuba". De Raíz Diversa. Revista Especializada en Estudios Latinoamericanos. Vol. 2, N4, julio-diciembre 2015, pp. 129-153.

Ortega, Jaime. "De Lecumberri a Lacandona: Louis Althusser y México". Rebelión. Agosto de 2016.

Ouviña, Hernán. "De la Petrogrado italiana a la Turín argentina. La recepción del joven Gramsci por el grupo Pasado y Presente". Estudios latinoamericanos. $N^{\circ} 33$, enero-junio 2014, pp. 15-65.

O'Neill, John. For Marx Against Althusser and Other Essays. Washington D.C., Center for Advanced Research in Phenomenology - University Press of America, 1982.

Panesi, Jorge. "La crítica argentina y el discurso de la dependencia". Filología. Año XX, 1985. pp. 171-195.

Palti, Elías. Verdades y saberes del marxismo. Reacciones de una tradición política frente a su "crisis". Buenos Aires, Fondo de Cultura Económica, 2005.

Peden, Knox. "The Fate of the Concept". Peter Hallward y Knox Peden. Concept and Form. Volume 2. Interviews and Essays on Cahiers pour l'analyse. Londres, Verso, 2012, pp. 1-14.

Peller, Diego. "Crítica literaria, crítica cultural y política en la revista Los Libros (1969-1976). IV Jornadas de Historia de las Izquierdas "Prensa política, revistas culturales y emprendimientos editoriales de las izquierdas latinoamericanas". Buenos Aires, Noviembre de 2007. 
Petra, Adriana. "En la zona de contacto: Pasado y Presente y la formación de un grupo cultural". Ana Clarisa Agüero y Diego García (eds.). Culturas interiores. Córdoba en la geografía nacional e internacional de la cultura. La Plata, Al Margen, 2010, pp. 213-239.

Plotkin, Mariano. Freud en las pampas. Orígenes y desarrollo de una cultura psicoanalítica en Argentina (1910-1983). Buenos Aires, Sudamericana, 2003.

Plotkin, Mariano y Visacovsky, Sergio. "Los psicoanalistas y la crisis, la crisis del psicoanálisis". Cuadernos LIRICO. N4, 2008, pp. 149-163.

Popovitch, Anna. In the shadow of Althusser: Culture and politics in late twentieth-century Argentina. Ann Arbor, UMI Dissertation Publishing, 2011.

Prochasson, Christophe. "Héritages et trahisons: la réception des œuvres". Mil neuf cent. Revue d'histoire intellectuel. Vol. 12, N 1, 1994, pp. 5-17.

Ramírez Castañeda, Santiago. "Althusser en México". Guillermo González Rivera y Carlos Torres (comps.). Sociología de la educación: corrientes contemporáneas. México D.F., Centro de Estudios Educativos, 1981, pp. 247262.

Resch, Robert Paul. Althusser and the renewal of marxist social theory. Berkeley, University of California Press, 1992.

Ridenti, Marcelo. "O romantismo revolucionário da Ação Popular: do cristianismo ao maoísmo". Latin American Studies Association. Chicago, 1998.

Robcis, Camille. "China in our Heads: Althusser, Maoism and Structuralism". Social Text. Vol. 30, N 110, 2012, pp. 51-69

Rochlitz, Rainer. "Traduire les sciences humaines”. Raisons Politiques. Etudes de pensée politique. $\mathrm{N}^{\circ} 2$, Mayo 2001, pp. 65-77.

Rodrigues de Andrade, Rosangela. Puzzle(s) Masotta. Oscar Masotta y lo imaginario (búsqueda teórica y búsqueda de imágenes matricies). Rosario, Homo Sapiens, 1997.

Rodríguez, Marcelo; Ramírez, José; Cortés, Cecilia. "Lecturas de Althusser en Chile (notas preliminares)". Ramal. Revista de filosofía y crítica. $\mathrm{N}^{\circ} 1$, Diciembre 2013, pp. 4-9.

Rot, Gabriel. "Notas para una historia de la lucha armada en Argentina. Las Fuerzas Argentinas de Liberación". Políticas de la memoria, № 4, 2003/2004 pp. 137-160. 
Roudinesco, Elisabeth. La batalla de cien años. Historia del psicoanálisis en Francia. Tomo 3. 1925-1985. Madrid, Fundamentos, 1993 [primera edición: La Bataille de Cent ans. Histoire de la psychanalyse en France. París, Du Seuil, 1986].

Roudinesco, Elisabeth y Plon, Michel. Diccionario de psicoanálisis. Buenos Aires, Paidós, 1998 [primera edición: Dictionnaire de la psychanalyse. París, Fayard, 1997].

Russo, Jane. "The Lacanian Movement in Argentina in Brazil: the Periphery Becomes the Center". Damousi, Joy y Plotkin, Mariano (eds.). The Transnational Unconcious. Essays in the History of Psychoanalysis and Transnationalism. Londres, Palgrave Macmillan, 2007, pp. 199-226.

Saes, Décio. "O impacto da teoría althusseriana da história na vida intelectual brasileira". João Quartim de Moraes (org.). História do marxismo no Brasil. Volume III. Teoria. Interpretações. São Paulo, Editora da UNICAMP, 1998, pp. 11-122.

Sáez Arreceygor, Hugo. "La tesis de filosofía del sub Marcos: una lectura de Althusser". Pacarina del Sur. Revista de Pensamiento Crítico Latinoamericano. Año 3, No 12, julio-septiembre 2012.

Sáez Arreceygor, Hugo. "Sobre líneas de demarcación trazadas por César Gálvez". Demarcaciones. Revista Latinoamericana de Estudios Althusserianos. $N^{\circ} 1$, abril 2014, pp. 97-101.

Scavino, Dardo. "Louis Althusser: ecos de una polémica. Un pensamiento renovador en la Argentina". Clarín. Suplemento Cultura y Nación. Jueves 4 de marzo de 1993, pp. 8-9.

Schaff, Adam. Structuralism and Marxism. Oxford, Pergamon Press, 1974.

Schmidt, Alfred. Historia y estructura. Crítica del estructuralismo marxista. Madrid, Alberto Corazón, 1973 [primera edición: Geschichte und Struktur. Fragen einer marxistischen Historik . Frankfurt, Hanser, 1971].

Schmucler, Héctor; Malecki, Sebastián; Gordillo, Mónica. El obrerismo de Pasado y Presente. Documentos para un dossier (no publicado) sobre SITRAC-SITRAM. Buenos Aires, AI Margen, 2009.

Scholten, Hernán. Oscar Masotta y la fenomenología. Un problema en la historia del psicoanálisis. Buenos Aires, Atuel, 2001.

Sève, Lucien. Marxismo y teoría de la personalidad. Buenos Aires, Amorrortu, 1973 [primera edición: Marxisme et théorie de la personnalité. París, Editions Sociales, 1969]. 
Sigal, Silvia. Intelectuales y poder en la década del sesenta. Buenos Aires, Puntosur, 1991.

Simoni, Nicola. Tra Marx e Lenin. La discussione sul concetto di formazione economico-sociale. Napoles, La Cittá del Sole, 2008.

Somoza, Patricia y Vinelli, Elena. "Para una historia de Los Libros". Los Libros. Edición Facsimilar. Buenos Aires, Biblioteca Nacional, 2011, pp. 9-19.

Sprinker, Michael. "Politics and Theory: Althusser and Sartre". Modern Language Notes, № 5, 1985, pp. 989-1011.

Starcenbaum, Marcelo. "El marxismo incómodo: Althusser en la experiencia de Pasado y Presente (1965-1983)". Izquierdas. Una mirada histórica desde América Latina, № 11, 2011, pp. 35-53.

Starcenbaum, Marcelo. "Ciencia y violencia: una lectura de Althusser en la nueva izquierda argentina". II $^{\circ}$ Jornadas "Espectros de Althusser: diálogos y debates en torno a un campo problemático”. Buenos Aires, 2011.

Starcenbaum, Marcelo. "Historia, política y responsabilidad. Oscar Terán y la autocrítica entre los intelectuales de izquierda en Argentina”. Temas de Nuestra América. Revista de Estudios Latinoamericanos, № 51-52, Julio-diciembre de 2012, pp. 143-160.

Starcenbaum, Marcelo. "La filosofía marxista entre Francia y América Latina: una lectura de la correspondencia entre Louis Althusser y Fernanda Navarro". Políticas de la Memoria. Anuario de Investigación del CeDInCl. № 15, Verano 2014/2015, pp. 107-121.

Starcenbaum, Marcelo. "Gramsci y Althusser: intersecciones del marxismo contemporáneo". Actas del Coloquio Internacional '50 años de Lire Le Capital'. La Plata, Facultad de Humanidades y Ciencias de la Educación (en prensa).

Suasnábar, Claudio. Universidad e intelectuales. Educación y política en la Argentina (1955-1976). Buenos Aires, Manantial, 2004.

Tarcus, Horacio. El marxismo olvidado en Argentina: Silvio Frondizi y Milcíades Peña. Buenos Aires, El Cielo por Asalto, 1996.

Tarcus, Horacio. "El corpus marxista". Susana Cella (dir.). Historia crítica de la literatura argentina. Volumen 10. La irrupción de la crítica. Buenos Aires, Emecé, 1999, pp. 465-500.

Tarcus, Horacio. Mariátegui en Argentina o las políticas culturales de Samuel Glusberg. Buenos Aires, El Cielo por Asalto, 2001. 
Tarcus, Horacio (dir.). Diccionario biográfico de la izquierda argentina. De los anarquistas a la "nueva izquierda". Buenos Aires, Emecé, 2007.

Tarcus, Horacio. Marx en Argentina. Sus primeros lectores obreros, intelectuales y científicos. Buenos Aires, Siglo XXI, 2007.

Tarcus, Horacio. "El mayo argentino". Observatorio Social de América Latina. $\mathrm{N}^{\circ} 24,2008$, pp. 161-180.

Terán, Oscar. Nuestros años sesentas. La formación de la nueva izquierda intelectual argentina, 1956-1966. Buenos Aires, El Cielo por Asalto, 1993 [primera edición: Buenos Aires, Puntosur, 1991].

Terán, Oscar (coord.). Ideas en el siglo. Intelectuales y cultura en el siglo XX latinoamericano. Buenos Aires, Siglo XXI, 2004.

Terán, Oscar. "Lectura en dos tiempos". Lucha Armada en la Argentina. $\mathrm{N}^{\circ} 1$, 2004, pp. 12-15.

Terán, Oscar. De utopías, catástrofes y esperanzas. Un camino intelectual. Buenos Aires, Siglo XXI, 2006.

Tho, Tzuchien. "The Concept of Model: Forty Years Later: An Interview with Alain Badiou". Alain Badiou. The Concept of Model. An Introduction to the Materialist Epistemology of Mathematics. Melbourne, re.press, 2007, pp. 79106.

Thomas, Peter. The Gramscian Moment. Philosophy, Hegemony and Marxism. Leiden, Brill, 2009.

Tortti, Cristina. "Izquierda y 'nueva izquierda' en la Argentina. El caso del Partido Comunista". Cuadernos del C/SH, 1999, pp. 221-232.

Tortti, Cristina. El "viejo" Partido Socialista y los orígenes de la "nueva izquierda". Buenos Aires, Prometeo, 2009.

Tosel, André. "The Development of Marxism: From the End of MarxismLeninism to a Thousand Marxisms -France-Italy, 1975-2005". Bidet, Jacques y Kouvelakis, Stathis (eds.). Critical Companion to Contemporary Marxism. Leiden, Brill, 2008, pp. 39-87.

Tuset Mayoral Vicenç. "La polémica Verón, Sebreli, Masotta y la problematización de la literatura como objeto crítico". VIII ${ }^{\circ}$ Congreso Internacional de Teoría y Crítica Literaria "Orbis Tertius". La Plata, 7 al 9 de Mayo de 2012. 
Valderrama, Miguel. "Althusser y el marxismo latinoamericano. Notas para una genealogía del (post)marxismo en América Latina". Mapocho. Revista de Humanidades y Ciencias Sociales. № 43, 1998, pp. 168-183.

Vezzetti, Hugo. "Los comienzos de la psicología como disciplina universitaria y profesional. Debates, herencias y proyecciones sobre la sociedad". Neiburg, Federico y Plotkin, Mariano (comps.). Intelectuales y expertos. La constitución del conocimiento social en la Argentina. Buenos Aires, Paidós, 2004, pp. 293326.

Vezzetti, Hugo. "Psicanálise e marxismo: a fratura da Associaçao Psicanalítica Argentina (1971)". Tempo social. Revista de sociologia da USP, № 2, 2009, pp. 61-85.

Vezzetti, Hugo. Psiquiatría, psicoanálisis y cultura comunista en Argentina. Buenos Aires, Siglo XXI, 2016.

Viguera, Ariel. "Tres tesis acerca del inconciente en el Coloquio de Bonneval de 1960: Lacan, Laplanche, Politzer". Revista de Psicología-Segunda época. № 12, 2012, pp. 41-53.

Vincent, Jean Marie et al. Contre Althusser. París, Union Génerale d' Editions, 1974.

Visacovsky, Sergio. El Lanús. Memoria y política en la construcción de una tradición psiquiátrica y psicoanalítica argentina. Buenos Aires, Alianza, 2002.

Visacovsky, Sergio. "Origins stories, Invention of Genealogies and the Early Diffusion of Lacanian Psychoanalysis in Argentina and Spain (1960-1980)". Damousi, Joy y Plotkin, Mariano (eds.). The Transnational Unconcious. Essays in the History of Psychoanalysis and Transnationalism. Londres, Palgrave Macmillan, 2007, pp. 227-256.

Wolff, Jorge. Telquelismos latinoamericanos. La teoría crítica francesa en el entre-lugar de los trópicos. Buenos Aires, Grumo, 2009.

Xu, Kefei. "Le maoïsme de Tel Quel autour de Mai 1968". Transtext(e)s Transcultures. Journal of Global Cultural Studies. № 6, 2011.

Zarowsky, Mariano. "Praxis editorialista y proyecto intelectual en el itinerario de Héctor Schmucler". VIII ${ }^{\circ}$ Jornadas de Sociología de la UNLP, 3 al 5 de diciembre de 2015.

\section{Entrevistas y comunicaciones personales}

Baremblitt, Gregorio; La Plata-Belo Horizonte, febrero de 2012. 
Funes, Santiago; La Plata-París, enero de 2012.

Follari, Roberto; Buenos Aires, julio de 2012.

Karsz, Saúl; La Plata, octubre de 2011.

Matrajt, Miguel; La Plata-México D.F, abril de 2012.

Navarro, Fernanda; Morelia, mayo de 2012 y México D.F., noviembre de 2014

Sáez Arreceygor, Hugo; Morelia, mayo de 2012. 